\title{
FLEXIBILIDADE PROCEDIMENTAL
}

(um novo enfoque para o estudo do procedimento em matéria processual)

\author{
TESE DE DOUTORADO
}

Orientador: Prof. Dr. Carlos Alberto Carmona

FACULDADE DE DIREITO DA USP

SÃO PAULO

2007 


\section{FERNANDO DA FONSECA GAJARDONI}

\section{FLEXIBILIDADE PROCEDIMENTAL}

(um novo enfoque para o estudo do procedimento em matéria processual)

Tese apresentada à Faculdade de Direito da Universidade de São Paulo como requisito parcial para obtenção do título de Doutor em Direito Processual, sob orientação do Prof. Dr. Carlos Alberto Carmona

FACULDADE DE DIREITO DA USP

SÃO PAULO

2007 
Banca Examinadora

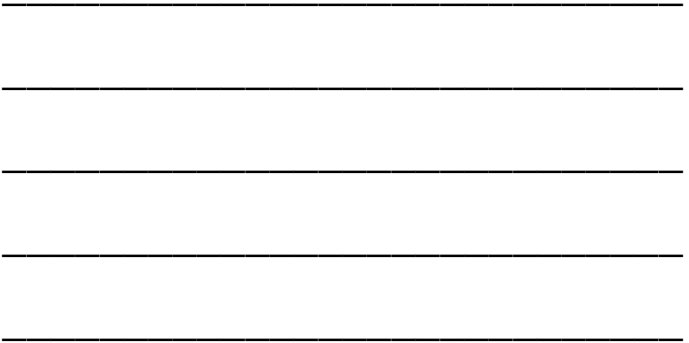




\section{AGRADECIMENTOS}

Mais difícil do que elaborar o trabalho é externar os agradecimentos de todos aqueles que, direta ou indiretamente, contribuíram para sua consecução.

Sem ordem de preferência, aí vão juristas que não podem deixar de ser nominalmente lembrados.

Aos meus professores das disciplinas que cursei na Faculdade de Direito da Universidade de São Paulo, tanto no Mestrado quanto no Doutorado, seja na área de concentração (Cândido Rangel Dinamarco, José Rogério Cruz e Tucci, José Roberto dos Santos Bedaque, Carlos Alberto Carmona, Flávio Luiz Yarshell, Carlos Alberto de Salles, Paulo Henrique dos Santos Lucon, Luiz Carlos de Azevedo e Antonio Carlos Marcato) ou fora dela (Paulo Borba Casella, José Eduardo Campos de Oliveira Faria, Eros Roberto Grau, Paula Andréa Forgioni e Luiz Gonzaga de Mello Beluzzo), pelos conhecimentos transmitidos.

Aos meus colegas do núcleo de estudos e debates do CEBEPEJ - Centro Brasileiro de Estudos e Pesquisas Judiciais - coordenado pelo querido Prof. Kazuo Watanabe, pela constate troca de idéias, muitas delas desenvolvidas no curso desta tese: Paulo Eduardo Alves da Silva, Léslie Shérida Ferraz, Valéria Ferioli Lagrasta, Rogério A. Correia Dias, Juliana Demarchi, Michel Romano, Susana Henrique da Costa, Daniel Issler, Marcos Antonio Garcia Lopes Lorencini e Marcos Paulo Veríssimo.

Aos componentes das bancas de defesa da minha dissertação de Mestrado (Carlos Alberto Carmona, Kazuo Watanabe e Estêvão Mallet) e da qualificação do Doutorado (Carlos Alberto Carmona, Kazuo Watanabe e José Rogério Cruz e Tucci), pelas valiosas sugestões de aprimoramento de ambos os trabalhos.

Aos professores Luiz Flávio Gomes e Ada Pellegrini Grinover, meus coordenadores no curso de pós-graduação telepresencial da Rede LFG, pelo apoio e confiança constantes.

Ao meu colega Márcio Henrique Mendes da Silva, da Faculdade Municipal de Direito de Franca, pela indispensável revisão final da tese.

E, principalmente, ao meu orientador Dr. Carlos Alberto Carmona, meu modelo de professor, pelo verdadeiro privilégio concedido de integrar o seleto grupo de seus admiradores e seguidores. 
"Muito se tem escrito pelos sábios sobre os inconvenientes públicos, e do Estado, que resultam os processos ordinários e suas delongas" (...) "Os senhores Reis deste Reino têm reconhecido a mesma necessidade da causa pública; e por muitos decretos têm mandado consultar o Desembargo do paço sobre as providências mais oportunas, a fim de se abreviarem as demandas sem prejuízo da Administração da Justiça, e se principiou a trabalhar neste importante negócio. Porém também estes reais projetos tão sábios, como providentes, não chegam a ultimar-se, e encher as paternais intenções dos Soberanos; ficando-se nesta falta observando a antiga Ordenação"

(Manoel de Almeida e Souza de Lobão. Tractado Prático Compendiário de todas as acções summarias, sua índole, e natureza em geral, e em especial, Das Summarias, Sumaríssimas, Preparatórias, Provisionaes, Incidentes, Preceitos Comminatorios, etc. Lisboa: Imprensa Nacional, 1847, do prefácio). 
Repito o gesto todos os dias

Olhos que não se cansam de olhar

Sua face; a mais bonita

A sensação de bem estar

Não quero dos céus outra vida

$A h$, minha rosa, és cativo o seu lugar 


\section{RESUMO}

É certo que os modelos procedimentais devem se adaptar às realidades do caso concreto. Todavia, pouco se tem contribuído no plano acadêmico para que a adequação do procedimento à sua substância seja efetivamente possível, ainda que contrariamente ao modelo disciplinado no Código de Processo Civil. Pretende-se com a presente tese despertar o interesse pelo estudo do procedimento, mais precisamente da necessidade dele estar sempre predisposto a atender às particularidades da demanda individualmente analisada. Partindo-se de uma visão descentralizadora da fonte normativa processual, com releitura da competência concorrente dos Estados e do Distrito Federal para legislar sobre procedimento, admite-se a flexibilização das regras procedimentais no plano normativo, com adequações do processo às realidades locais. Após, constatado que só a via legal não é suficiente, constrói-se toda uma teoria sobre a flexibilização procedimental, seus condicionamentos (finalidade, contraditório útil e fundamentação) e sua compatibilidade com a previsibilidade e segurança do sistema, bem como com o devido processo constitucional. Ao final, após breve incursão sobre o direito alienígena, indicam-se casos práticos de variação procedimental: a) flexibilização legal genérica; b) flexibilização legal alternativa; c) flexibilização judicial e d) flexibilização voluntária.

Palavras-chave: Procedimento - Competência concorrente - Adequação procedimental Direito material - Flexibilidade procedimental - Rigidez - Variação ritual. 


\begin{abstract}
It is clear that proceeding models must adapt to reality of the cases. However, little has been contributed by the academic plan so proper utilization of these proceedings can be effectively utilized rigorously, even if contrary to the civil process law. Herein, this dissertation elicits the interest for "proceeding" studies, focusing on the necessity for attending individual demands particularly analyzed. Starting with a decentralized standpoint from the regular process source, with re-lecture of the concurrent competence of States and the Union for legislating over the proceedings, flexibility of the proceeding's rules is admitted under the "normative plan", adapting the process according to local necessities. After realizing that the legal pathway is insufficient, a theory is built regarding the procedural flexibility, their conditions (goal, useful-contradictory, and fundament), and their compatibility with predictability and security of the system, likewise with the proper legal process. Finally, after a brief mention regarding the others systems, it is indicated practical cases of "ritual-variation": a) generical and legal authorization; b) alternative and legal authorization, c) judicial flexibility e d) voluntary flexibility.
\end{abstract}

Key words: Proceedings - Concurrent competence - Adaptation - Material rights Flexibility - Ritual variation. 


\section{SUMÁRIO}

1. INTRODUÇÃO

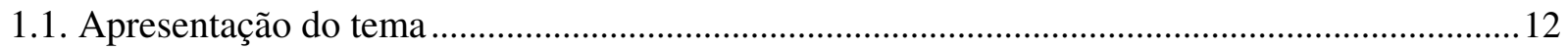

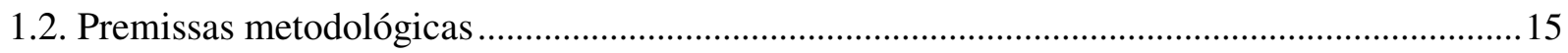

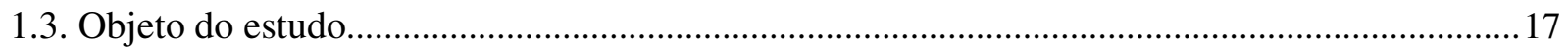

2. SISTEMA FEDERALISTA BRASILEIRO E CENTRALIZAÇÃO DOS PROBLEMAS DO PROCESSO NA ESFERA FEDERAL .............................................2

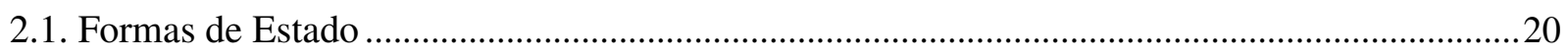

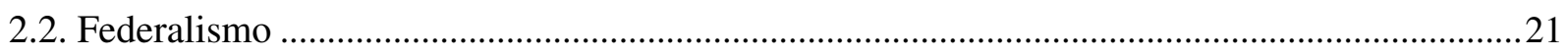

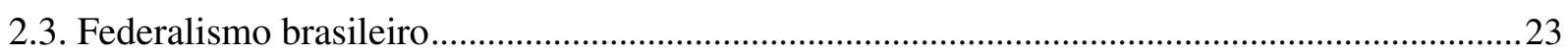

2.3.1. Repartição constitucional de competências legislativas na Constituição Federal de 1988

2.3.2. Competência legislativa concorrente e a dificuldade de se estabelecer o conceito

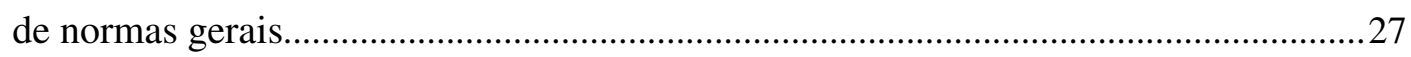

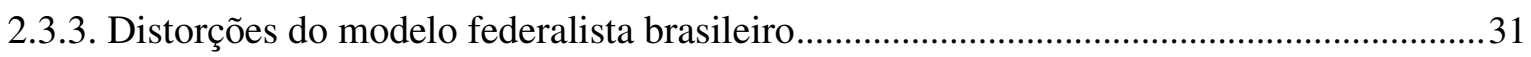

2.4. Competência para legislar sobre processo e procedimento no Brasil..........................................33

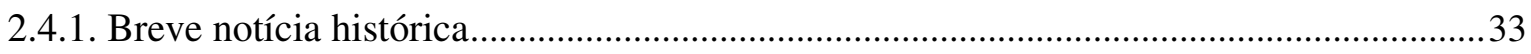

2.4.2. Competência para legislar sobre processo e procedimento na Constituição Federal

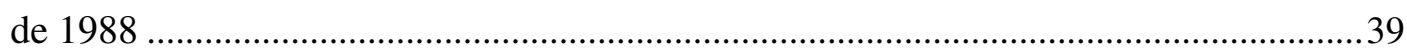

2.4.3. Normas processuais e normas procedimentais ................................................................... 41

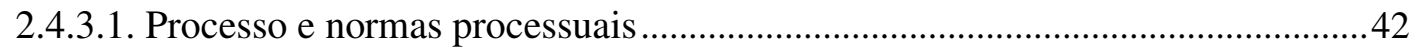

2.4.3.2. Procedimento e normas procedimentais ............................................................46

2.4.4. Normas gerais em matéria de procedimento processual e a inconstitucionalidade das normas desta natureza editadas pela União Federal após 1988.................................53

2.4.5. Normas não gerais em matéria procedimental e a relativa capacidade dos Estados e do Distrito Federal flexibilizarem o procedimento

2.4.6. Jurisprudência do Supremo Tribunal Federal e interpretação quanto à competência concorrente dos Estados e do Distrito Federal em matéria procedimental .

2.4.7. O fracasso da iniciativa legislativa em se estabelecer o alcance do art. 24 , XI, da Constituição Federal 
2.4.8. Competência concorrente dos Estados e do Distrito Federal para legislar sobre processo e procedimentos em sede de juizados especiais

3. FUNDAMENTOS DOGMÁTICOS DA FLEXIBILIZAÇÃO PROCEDIMENTAL....... 80

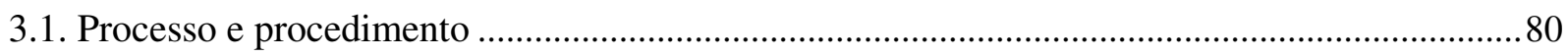

3.1.1. Distinção 80

3.1.2. Evolução terminológica e conceitual do sistema processual civil vigente em relação às legislações processuais antecedentes

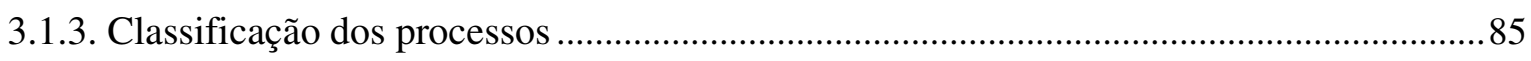

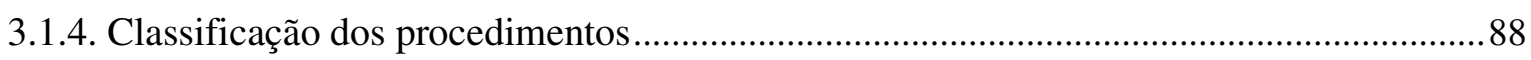

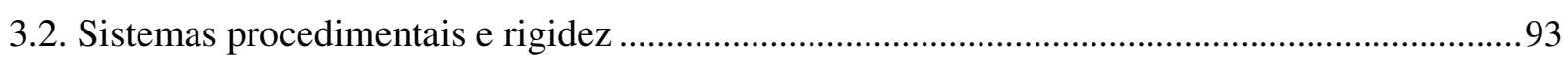

3.3. Procedimento rígido como regra de ordem pública .................................................................96

3.4. Procedimento rígido como fator de segurança e previsibilidade do sistema...............................97

3.5. Flexibilizando a rigidez do procedimento sem perder a previsibilidade e segurança do

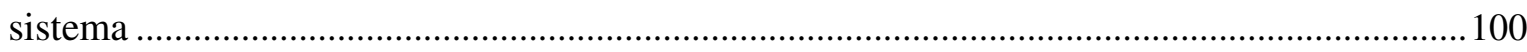

3.6. Requisitos indispensáveis à flexibilização procedimental......................................................... 103

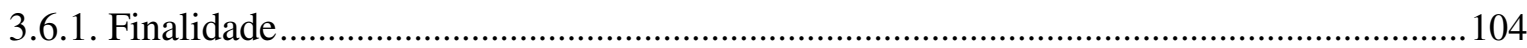

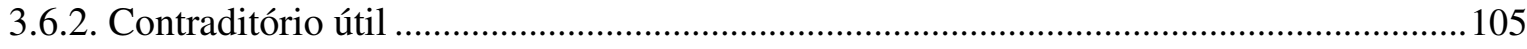

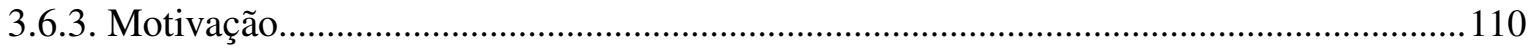

3.7. Procedimento como legitimador da atividade judicial .............................................................111

3.8. Compatibilização da função legitimante do procedimento com sua flexibilização..................114

3.9. Legitimação da decisão pelo contraditório útil e não pelo mero procedimento.........................114

3.10. Devido processo constitucional e flexibilização procedimental ............................................117

3.11. Flexibilização procedimental e instrumentalidade das normas ................................................120

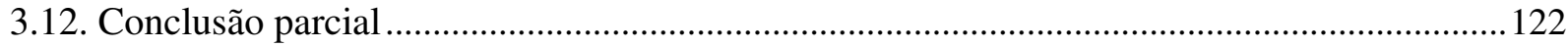

4. FLEXIBILIZAÇÃO DO PROCEDIMENTO EM OUTROS SISTEMAS ......................125

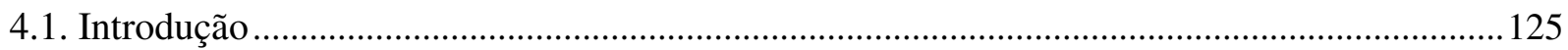

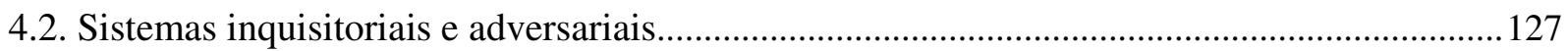

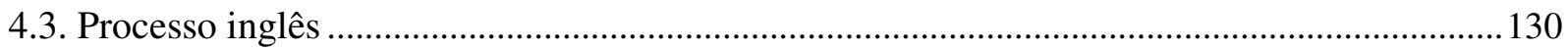

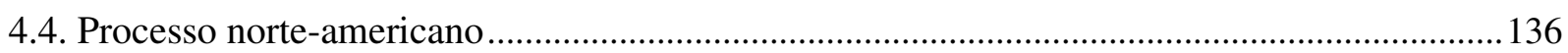

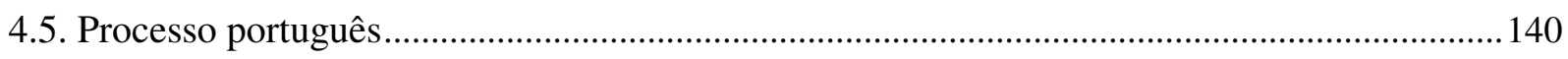

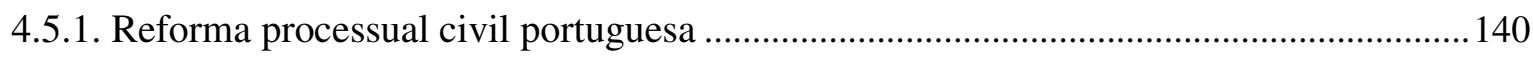

4.5.2. Princípio da adequação formal (art. 265-A do CPC Português)......................................... 144 
5.1. Introdução.

5.1.1. Princípios da adequação da adaptabilidade do procedimento 153

5.1.2. Princípio da adaptabilidade e sistemas de flexibilização do procedimento 157

5.2. Flexibilidade procedimental legal genérica. 160

5.2.1. Art. 153 do Estatuto da Criança e do Adolescente (Lei n. 8.069/90). 161

5.2.2. Art. 1.109 do CPC (jurisdição voluntária) 164

5.2.3. Art. 21 e $\S 1^{\circ}$ da Lei de Arbitragem (Lei n. 9.307/96) 168

5.2.4. Art. $6^{\circ}$ da Lei dos Juizados Especiais (Lei n. 9.099/95) 172

5.2.5. Atipicidade das medidas executivas nas obrigações de fazer, não fazer e dar coisa (art. 461, $\S 5^{\circ}$, e art. 461-A, $\S 3^{\circ}$, ambos do CPC, e art. 84, $\S 5^{\circ}$, do CDC)...................176

5.3. Flexibilidade procedimental legal alternativa 179

5.3.1. Conversão do procedimento sumário em ordinário (art. 277 , $\S 4^{\circ}$ e $5^{\circ}$ do CPC) 179

5.3.2. Facultatividade da audiência preliminar (art. $331, \S 3^{\circ}$, do CPC) 182

5.3.3. Ônus da prova (art. 333 do CPC) e sua inversão (art. $6^{\circ}$, VI, do CDC). 184

5.3.4. Interrupção do curso procedimental pela resolução antecipada do pedido. 188

5.3.4.1. Julgamento antecipadíssimo da lide (art. 285-A do CPC) 189

5.3.4.2. Julgamento antecipado da lide (art. 330 do CPC) 192

5.3.4.3. Súmula impeditiva de recursos (art. 518, $\S 1^{\circ}$, do CPC). 194

5.3.4.4. Julgamento monocrático dos recursos (art. 527, I, 557, § $1^{\circ}$ e $\S 1^{\circ}$-A, do $\mathrm{CPC})$ 196

5.3.5. Conversão legal de recursos (art. 527, II, e art. 544, § $3^{\circ}$, do CPC). 198

5.4. Flexibilidade procedimental judicial 201

5.4.1. Direitos difusos e coletivos e procedimento diferenciado 204

5.4.2. Inversão da ordem de produção de provas 207

5.4.3. Fungibilidade procedimental 209

5.4.3.1. Fungibilidade entre ritos e demandas 212

5.4.3.2. Fungibilidade entre defesas. 215

5.4.3.3. Fungibilidade entre procedimentos liquidatórios 217

5.4.3.4. Fungibilidade entre cautelares típicas e atípicas 219

5.4.4. Utilização de procedimento diverso do legal e abstratamente previsto 221

5.4.5. Variantes no âmbito do procedimento recursal .227

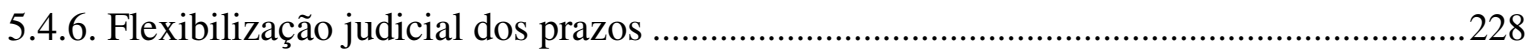

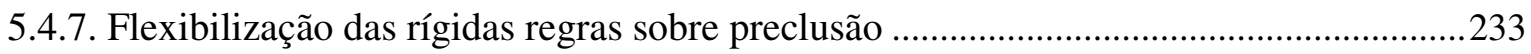

5.5. Flexibilidade procedimental voluntária 
5.5.1. Flexibilizando a cogência em favor da eleição do procedimento pela parte 236

5.5.2. Prorrogação convencional de prazos 241

5.5.3. Eleição do ato processual na série .243

6. CONCLUSÕES 244

REFERÊNCIAS BIBLIOGRÁFICAS 250 


\section{INTRODUÇÃO}

\subsection{Apresentação do tema}

Qualquer introdução de um trabalho acadêmico, mais do que toda a tese que se ofertará, já revela, ainda que não seja este o propósito de seu autor - iludido pela idéia de evitar a precocidade e a simplicidade do raciocínio - os motivos, os objetivos, a divisão e as principais conclusões do estudo. Na maioria das vezes, inclusive, de maneira bem mais sucinta e clara do que se verá nas páginas do próprio trabalho.

A rigidez do procedimento processual civil brasileiro sempre foi objeto das minhas mais altas reflexões, especialmente quando desenvolvia, nesta Casa, a dissertação de mestrado com o tema Técnicas de Aceleração do Processo - uma análise crítica à luz de dados estatísticos. ${ }^{1}$

Paradoxalmente, nosso sistema permite ao juiz brasileiro, com fundamento no art. 131, do Código de Processo Civil (princípio do livre convencimento motivado), que decida livremente, com base na lei, nas provas e na sua convicção pessoal, sobre a pretensão formulada. Mas não lhe permite, também com base naqueles mesmos elementos, no direito material, nas condições especiais ou na autorização das partes ${ }^{2}$, que opte pela prática de tal ou qual ato processual. Ou seja, permite-se ao juiz liberdade no principal, no julgamento da causa, mas não se lhe concede liberdade no minus, isto é, na escolha do melhor iter para a condução do processo.

Minha preocupação foi majorada quando, ao consultar nossa legislação e alguns precedentes jurisprudenciais, percebi que já há situações, pese em casos muito restritos,

\footnotetext{
${ }^{1} \mathrm{O}$ trabalho foi posteriormente publicado com o título Técnicas de aceleração do processo. Franca: Lemos e Cruz, 2003. As preocupações com o modelo procedimental brasileiro e os prejuízos à celeridade- especialmente em razão do papel diminuto dos Estados federados neste sentido - é logo revelada na página 66.

${ }^{2}$ A enumeração supra é exemplificativa. Há inúmeros outros fatores que devem nortear a eleição do procedimento que não só o valor da causa ou a tutela do direito material. (a) A complexidade das questões de fato ou de direito; (b) a complexidade da prova a ser produzida; (c) o número de litigantes; (d) o volume da prova oral; (e) a relevância da causa para pessoas não participantes do processo; entre outras, também devem influenciar na elaboração e eleição do procedimento, algo que não me parece ter estado na pauta dos legisladores e nem dos intérpretes pátrios. Prova disto, conforme veremos mais adiante, que parte da jurisprudência repulsa a simples idéia de se optar pelo procedimento ordinário quando ele se revele mais adequado à tutela do direito ofertado que o procedimento sumário, decretando a nulidade do julgado pelo vício de forma procedimental.
} 
que admitem a reclamada flexibilização do procedimento, permitindo que o magistrado ou as partes, dentro do processo, elejam o melhor ato processual a dar seguimento à série. $\mathrm{O}$ art. 153, do Estatuto da Criança e do Adolescente (Lei n. 8.069/90), por exemplo, permite, na inexistência de previsão legal sobre o procedimento na lei, que o magistrado crie o rito para os feitos afetos à Infância e Juventude. E o art. 21 da Lei de Arbitragem (Lei n. 9.307/96), admite expressamente que o processo arbitral obedecerá ao procedimento estabelecido pelas partes na convenção de arbitragem, que poderá se reportar às regras de um órgão arbitral institucional ou entidade especializada, facultada, ainda, a delegação da eleição das regras de rito ao próprio árbitro ou ao tribunal arbitral.

O extremo de minhas aflições com a rigidez legal que escraviza o procedimento processual civil brasileiro ${ }^{3}$, entretanto, ocorreu quando no exercício de minha atividade profissional, percebi que uma pronta e adequada tutela dos direitos, atenta aos valores constitucionais ${ }^{4}$, depende, muitas vezes, de uma liberdade procedimental que não é conferida pelo nosso sistema aos operadores do processo.

Com efeito, partindo-se da premissa que a adequada tutela jurisdicional não pode ser negada a pretexto da falta de um modelo legal de procedimento5, tem-se que a resposta em muitos casos depende em grande parte da flexibilização dos prazos, do retorno a fases processuais já superadas (com afastamento do rígido regime de preclusão a que estamos sujeitos), da combinação de diferentes ritos, da inserção de atos processuais não previstos no esquema procedimental padrão, da superação de óbices de natureza puramente formal em favor da tutela do direito material, e da adoção mais generosa da fungibilidade instrumental no sistema, providências estas que não são autorizadas genericamente pela nossa legislação.

Ora, o procedimento não precisa ser tão cartesiano como pinta a lei! A necessária racionalidade jurídica não se apresenta como assepsia lógica, tendo, pois, o direito brasileiro, plenas condições, dentro de sua perspectiva histórica e cultural, de

\footnotetext{
${ }^{3} \mathrm{E}$ vários motivos podem fazer com que o procedimento seja muito prejudicial ao exercício dos direitos: porque sujeitos a termos de exercício muito restritos, porque privados de adequada instrução probatória, ou simplesmente porque muito complexos ou muito longos (Cf. BIAVATI, Paolo. I procedimenti civili semplificati e accelerati: il quadro europeo e riflessi italiani. Rivista Trimestrale di Diritto e Procedura Civile, Milano, ano 56, n. 3, p. 754, sett. 2002).

${ }^{4}$ Conforme bem adverte Carlos Alberto Álvaro de Oliveira "a estrutura mesmo do processo civil não é moldada pela simples adaptação da técnica do instrumento processual a um objetivo determinado, mas especialmente por escolhas de natureza política, em busca de meios mais adequados e eficientes para a realização dos valores, especialmente os de conteúdo constitucional" (OLIVEIRA, Carlos Alberto Alvaro de. Poderes do juiz e visão cooperativa do processo. Revista da Ajuris, Porto Alegre, ano 30, n. 90, p. 55, jun. 2003).

${ }^{5}$ YARSHELL, Flávio Luiz. Tutela jurisdicional. São Paulo: Atlas, 1999. p. 180.
} 
apresentar soluções procedimentais mais adequadas do que os modelos rituais rigidamente previstos em lei. ${ }^{6}$

De fato, o exercício da jurisdição pelo Estado sempre foi uma manifestação de soberania, com aspectos de desejada solenidade, da qual o rito sempre foi importante figura. Hoje, todavia, o tema da tutela dos direitos substanciais surge como o conteúdo prevalente da função jurisdicional, de modo que a forma vem dia-a-dia perdendo destaque. As sociedades, em resumo, toleram uma quantidade limitada de procedimentos formais, e se não pode desprezá-los, "que pelo menos estas regras sejam reduzidas, céleres, flexíveis" ${ }^{\prime 7}$, pois as formas, de fato, são necessárias, mas o formalismo é uma deformação. ${ }^{8}$

Evidentemente, há válvulas de escape casuisticamente espelhadas pelo sistema e que acabam a permitir ao juiz, mediante certo elastério interpretativo, que altere o iter procedimental rigidamente estabelecido em lei. Mas os processualistas ainda não se preocuparam com uma investigação mais aprofundada sobre o tema, e, principalmente, sobre quais seriam os limites condicionantes à almejada flexibilização.

A presente tese objetiva suprir este espaço que há no direito processual civil brasileiro (eis a sua contribuição original para a ciência jurídica nacional), investigando amplamente - com base no direito comparado, na doutrina, na jurisprudência, e nos dispositivos legais que já temos - o procedimento processual em matéria cível sob a moderna ótica da efetividade e da tutela dos direitos, revisitando o instituto não através da reprodução de idéias de outros tempos ainda vigentes, mas especialmente repensando estas idéias à luz das exigências dos novos tempos, aferindo se ainda compatíveis com elas. ${ }^{9}$

\footnotetext{
${ }^{6}$ Cf. ZANETI JÚNIOR, Hermes. O problema da verdade no processo civil: modelos de prova e de procedimento probatório. Revista de Processo, São Paulo, n. 116, p. 369, jul./ago. 2004. O autor sugere a criação de um modelo probatório mais aderente à realidade brasileira, superando o antagonismo dos sistemas da commom law e continental. Mutatis mutandis, idêntico raciocínio pode ser feito no concernente ao modelo procedimental rígido por aqui vigente.

${ }^{7}$ Cf. BIAVATI, Paolo. I procedimenti civili semplificati e accelerati: il quadro europeo e riflessi italiani, cit., p. 774.

${ }^{8}$ LIEBMAN, Enrico Tullio. Manual de direito processual civil. 2. ed. Tradução e notas de Cândido Rangel Dinamarco. Rio de Janeiro: Forense, 1985. v. 1, p. 258. Dinamarco, aliás, aponta que a "instrumentalidade do direito processual ao substancial e do processo à ordem social constitui uma diretriz a ser permanentemente lembrada pelo processualista e pelo profissional, para que não seja subvertida a ordem das coisas, nem feitas injustiças em nome de um injustificável culto à forma" (DINAMARCO, Cândido Rangel. Os institutos fundamentais do direito processual. In: Fundamentos do processo civil moderno. 3. ed. São Paulo: Malheiros Ed., 2000. v. 1, p. 73).

${ }^{9}$ A nossa modernidade está na consciência de que o processo, como o direito em geral, é um instrumento de vida real, e como tal deve ser tratado e vivido, pensado como instrumento em favor do homem, e não contra ele (CAPELLETTI, Mauro. Problemas de reforma do processo civil nas sociedades contemporâneas. In: MARINONI, Luiz Guilherme (Coord.) O processo civil contemporâneo. Curitiba: Juruá, 1994. p. 29).
} 
O estudo do processo, em um Estado democrático e de direito como o nosso, não pode se fundar na aceitação de uma verdade incondicional construída através dos tempos, como a de que o procedimento processual é rígido e que não cabe às partes ou a Estado dispor da sua forma, predicado indispensável da segurança jurídica. A justificação racional desta assertiva só pode se fundar em argumentos igualmente racionais e pragmáticos $^{10}$, algo que não me parece ocorrer sem umas tantas ressalvas.

\subsection{Premissas metodológicas}

Desde já, para o adequado desenvolvimento do trabalho, algumas premissas devem ser estabelecidas, sob pena de extravasarmos os limites originários fixados para a exata compreensão da flexibilidade procedimental.

A primeira - e sem deixar de reconhecer a importância da deformalização dos atos processuais em favor da tutela dos direitos - no sentido de que o objeto da análise que se efetuará recairá com exclusividade sobre o procedimento como um todo, e não sobre um ou outro ato processual considerado individualmente ${ }^{11}$, sobre o que já há estudos de primeira grandeza. ${ }^{12}$ Não se enfrentarão questões atinentes à forma do ato processual de per si. O foco total do trabalho recai sobre a combinação dos atos processuais na cadeia lógica denominada procedimento. Referências a atos processuais individualmente considerados serão pontuais e apenas feitas à luz da importância do ato para todo o procedimento.

\footnotetext{
${ }^{10} \mathrm{Cf}$. Jürgen Habermas, para quem a validade do direito aponta não só para a expectativa de submissão à decisão, mas especialmente para expectativa de reconhecimento racionalmente motivado de uma pretensão de validade normativa, a qual só pode ser resgatada através da argumentação e dos discursos de cunho pragmático (HABERMAS, Jürgen. Direito e democracia: entre facticidade e validade. Rio de Janeiro: Tempo Brasileiro, 1997. p. 247 e 309).

${ }^{11}$ Os atos processuais não se apresentam isolados dentro do processo, "pois cada ato se encontra ligado e coordenado a um grupo mais ou menos numeroso de outros atos processuais que se sucedem no tempo e formam uma série contínua, como os elos de uma corrente; o grupo forma uma unidade que recebe o nome de procedimento e os atos são elementos constitutivos dessa unidade" (LIEBMAN, Enrico Tullio. Manual de direito processual civil, cit. p. 228).

${ }^{12}$ Cf. GRINOVER, Ada Pellegrini. Invalidade dos atos processuais e ação rescisória. Revista IOB de Direito Civil e Processual Civil, Porto Alegre, n. 39 p. 63-79, jan./fev. 2006; BEDAQUE, José Roberto dos Santos. Nulidade processual e instrumentalidade do processo. Revista de Processo, São Paulo, v. 15, n. 60, p. 3143, out./dez. 1990; WAMBIER, Teresa Arruda Alvim. Nulidades do processo e da sentença. 5. ed. São Paulo: Ed. Revista dos Tribunais, 2004; KOMATSU, Roque. Da invalidade no processo civil. São Paulo: Ed. Revista dos Tribunais, 1991.
} 
A segunda premissa - também sem desconhecer a importância da técnica de sumarização da cognição (sumarização material) para a efetividade do processo - no sentido de que não se revelará por aqui preocupação a não ser com a sumarização dos procedimentos (sumarização formal), isto é, com a redução dos prazos, recombinação ou supressão dos atos processuais, conversão de procedimentos, tudo a fim de que se possa, a final, com cognição plenária e estabilidade da decisão, se obter a melhor tutela jurisdicional. ${ }^{13}$ Daí porque não será feita referência neste estudo ao importante mecanismo da antecipação de tutela, previsto nos artigos 273 e. art. 461, $\S 3^{\circ}$, do CPC. Embora a sua concessão tenha certo impacto no curso do procedimento, esta decisão não alcança, como regra $^{14}$, imutabilidade, tampouco faz abreviar o curso do procedimento (que prossegue até o acertamento final $)^{15}$.

A terceira premissa é que não cogitamos, em hipótese nenhuma, que não haja o estabelecimento pelo sistema de regras formais a controlar o procedimento. O ideal, aliás, seria que o legislador fosse capaz de adequar os procedimentos em matéria processual às realidades do serviço judicial local e de cada causa em si, considerada pela sua relação com o direito material e com as partes envolvidas, ou permitisse expressamente que o juiz pudesse fazê-lo. Esta opção, pela segurança que proporciona ao sistema, nos seria mais cara, razão pela qual, inclusive, defenderemos com afinco a possibilidade plena dos Estados e do Distrito Federal legislarem efetivamente a respeito. Como o Estado, entretanto, não é capaz de prever e criar abstratamente procedimentos adequados para todas as situações da vida (até pelas dificuldades burocráticas do trâmite legislativo), então

\footnotetext{
${ }^{13}$ Valendo-se da lição de Victor Fairén Guillén, a sumariedade no processo pode assumir de caráter formal ou material. A sumarização se dá tanto quando se altera a moldura externa do processo - o procedimento, através da supressão de atos e de formalidades, da redução de prazos, etc. (caráter formal) - como também através da limitação da cognição do juiz sobre as questões processuais ou sobre a prova (caráter material). Seis, então, são os tipos de processos rigidamente considerados: a) ações de cognição plena e de procedimento ordinário; b) ações de cognição plena e de procedimento sumário; c) ações de cognição plena e de procedimento especial; d) ações de cognição sumária e de procedimento ordinário; e) ações de cognição sumária e de procedimento sumário (v.g.cautelares); e f) ações de cognição sumária e de procedimento especial (FAIRÉN GUILLÉN, Victor. El juidicio ordinário e los plenários rápidos. Barcelona: Bosch, 1953).

${ }^{14}$ Diz-se como regra, eis que há profunda controvérsia doutrinária sobre a "precariedade" da antecipação de tutela concedida com fundamento no art. 273, $\S 6^{\circ}$, do Código de Processo Civil. Pela definitividade de tal decisão, cf. MARINONI, Luiz Guilherme. Tutela antecipatória, julgamento antecipado e execução imediata da sentença. 4. ed. São Paulo: Ed. Revista dos Tribunais, 2000. p. 141-142.

${ }^{15}$ Tramita no Senado Federal o projeto de lei n. 186/2005, que objetiva estabilizar os efeitos da tutela antecipada concedida e não impugnada. Em síntese, requerida a antecipação de tutela em procedimento antecedente ou em curso, se a medida for deferida caberá ao demandado, se não concordar, propor a ação de conhecimento (em se tratando de antecipação em procedimento antecedente) ou requerer o prosseguimento da ação (quando a antecipação é concedida no curso do processo de conhecimento). Caso não o faça, a tutela se estabiliza, adquirindo autoridade de coisa julgada, algo que tem manifesto impacto no procedimento, que será abreviado.
} 
nossa opção será também pela flexibilização judicial das regras de procedimento, o que ocorrerá, de qualquer modo, apenas em situações excepcionais, assegurada a participação das partes e as demais garantias constitucionais do processo.

Finalmente, como última premissa - esta de ordem absolutamente formal estabeleça-se que, apesar das críticas feitas ao emprego da expressão rito para se referir ao procedimento, acabamos por utilizá-la no corpo de todo o trabalho como sinônimo de procedimento. Pese a carga de formalidade sacra que acompanha tal expressão -cujo emprego, desta forma, não seria conveniente em trabalho que sustenta, exatamente, a maleabilização do procedimento - a opção pelo uso se deveu a fatores de cunho histórico e pragmático, visto ainda ser comum na academia e nas lides forenses a utilização da citada expressão.

\subsection{Objeto do estudo}

Logo em seguida a este primeiro capítulo introdutório da tese, onde estão sendo estabelecidas as premissas do estudo, se investigará, no segundo capítulo, a relação do procedimento em matéria processual com o sistema federativo brasileiro. Após breve delimitação das balizas e das distorções do federalismo brasileiro, bem como da distinção entre normas processuais e normas procedimentais, ${ }^{16}$ se comprovará, através da análise dos precedentes do Supremo Tribunal Federal a respeito do tema, que apesar da autorização constitucional para que os Estados membros legislem sobre procedimento em matéria cível - adequando o processo às realidades locais em país continental como o nosso - ainda prevalece firme a idéia centralizadora que informava a Carta Constitucional de 1967/1969, concentrando-se o problemas relativos ao processo e ao procedimento na esfera federal (que não deixa espaço para que os Estados inovem em matéria procedimental, adequando os procedimentos processuais às suas realidades locais) ${ }^{17}$. Por

\footnotetext{
${ }^{16}$ Discussão que, após 1988, deixou a academia para ter relevante interesse prático, já que atualmente é da competência dos Estados e Distrito Federal legislar concorrentemente sobre procedimento em matéria processual (WAMBIER, Luiz Rodrigues. Sentença civil: liquidação e cumprimento. 3. ed. São Paulo: Ed. Revista dos Tribunais, 2006. p. 91).

${ }^{17}$ Basta ver, neste sentido, a Lei dos Juizados Especiais Cíveis (Lei n. 9.099/95) e Federais (Lei n. 10.259/2001), que, ao contrário do comando constitucional, disciplinaram por completo o processo e o procedimento destas Justiças Especializadas, não permitindo regulamentação alguma por parte dos Estados membros.
} 
força disto os procedimentos obedecem exclusivamente às normas traçadas pela União, independentemente da realidade judiciária local.

No capítulo seguinte (terceiro) - à luz da constatada centralização e uniformidade dos procedimentos em matéria cível no nosso país - se passará à investigação das razões de cunho social e político para a adoção de um modelo procedimental rígido. Após aferição dos procedimentos processuais previstos na legislação em vigor e das teorias sobre o tema - especialmente a teoria legitimadora de Niklas Luhmann, até hoje considerada referência máxima no que tange à análise global dos procedimentos $^{18}$ - se projetará reflexão a respeito da prevalência dos fundamentos que inspiraram a já citada rigidez, concluindo que ela não mais se coaduna, sem restrições, com os anseios atuais, que em detrimento da forma rígida e previamente fixada em lei prefere a participação das partes em contraditório útil (esta sim legitimadora da atividade judicial), e que a flexibilização não é incompatível com a previsibilidade, segurança jurídica e devido processo legal. Neste capítulo, também, se revelará preocupação com as balizas condicionadoras da flexibilidade judicial do procedimento, mais uma vez se alertando que a medida é de exceção e só pode ser utilizada em situações muito particulares.

No quarto capítulo, após breve comparação da rigidez procedimental nos sistemas adversariais e inquisitorias, serão apresentados os modelos de alguns países nos quais houve flexibilização do procedimento, demonstrando, assim, que longe de devaneio não compatível com a realidade, é possível sim, sem afetar a previsibilidade das regras do jogo, libertar nosso procedimento das amarras formais que o maculam, permitindo que as partes ou o juiz fujam do rigor formal conforme peculiaridades da causa. Especial destaque merecerá o ordenamento jurídico português, que sem precedente de direito comparado, estabeleceu um princípio geral da adequação formal do procedimento (art. 265-A do CPC).

No quinto capítulo se buscará, já com base exclusiva na realidade judiciária brasileira, a construção de uma teoria prática sobre a flexibilização procedimental, a partir da implementação do modelo gerencial do procedimento para casos anômalos em detrimento dos já superados modelos adversarial (adversarial system) e inquisitorial(inquistorial system). ${ }^{19}$ Revelará-se que o procedimento em nosso sistema há

\footnotetext{
${ }^{18}$ LUHMANN, Niklas. Legitimação pelo procedimento. Tradução de Maria da Conceição Corte Real. Brasília: Ed. da UnB, 1980.

${ }^{19}$ Conforme muito bem adverte Paulo Eduardo Alves da Silva, "o padrão do século XXI é que o processo seja gerenciado (material judge), em detrimento dos já tradicionais e falidos sistemas inquisitorial legalista e
} 
de se flexibilizar em quatro situações: a) mediante disposição legal genérica que conceda ao juiz poderes para moldar o procedimento ao caso concreto; b) mediante disposição legal que possibilite tramitações processuais alternativas pré-dipostas; c) por força de iniciativa judicial, ainda que não haja previsão legal; e d) voluntariamente, com as partes adequando o procedimento às suas pretensões; discorrendo-se, a seguir, sobre inúmeras situações de incidência prática do procedimento flexibilizado em cada uma destas situações.

Ao final, diante de todas as reflexões efetuadas no corpo do trabalho (Capítulo 6), serão ofertadas sínteses conclusivas, sempre com a lembrança de que ao plantar o novo, como não poderia deixar de ser, haverá uma série de dúvidas e inquietações. "Estas dúvidas, porém, nunca estiveram ausentes do mundo jurídico, ainda que se haja tentado expulsá-las com teorias formalizadas. As dúvidas e imperfeições fazem parte de qualquer teoria, mesmo porque nenhuma teoria pode ser dita finalizada". ${ }^{20}$

adversarial. O juiz, preocupado com o tempo, custo e outras particularidades da causa, é quem deve controlar integralmente a prática das tarefas processuais (e não assumi-las). A lei deve exclusivamente traçar os limites para atividade deste juiz gerente, sem engessá-lo a ponto de não poder gerenciar" (SILVA, Paulo Eduardo Alves. Condução planejada dos processos judiciais: a racionalidade do exercício jurisdicional entre o tempo e a forma do processo. 2006. Tese (Doutorado) - Faculdade de Direito, Universidade de São Paulo, São Paulo, 2006. p. 133).

${ }^{20}$ MARINONI, Luiz Guilherme. Novas linhas do processo civil. 4. ed. São Paulo: Malheiros Ed., 2000. p. 18. 


\section{SISTEMA FEDERALISTA BRASILEIRO E CENTRALIZAÇÃO DOS PROBLEMAS DO PROCESSO NA ESFERA FEDERAL}

\subsection{Formas de Estado}

As formas de Estado correspondem à maneira como dado país organiza o seu povo, seu território, sua estrutura de poder interna, especialmente no que tange à distribuição de competências. Só com a exata análise do modelo de Estado brasileiro que podemos compreender com clareza a centralização dos assuntos atinentes ao processo na esfera federal e suas conseqüências.

Há Estados dito Simples em detrimento dos ditos Compostos, isto se analisados sob a ótica da pluralidade das ordens jurídicas. Simples são os Estados em que há um único poder político e um único ordenamento jurídico (uma só Constituição). Compostos são Estados em que há uma pluralidade de poderes políticos (nacional, regional e/ou local), havendo, por conseguinte, pluralidade de ordenamentos jurídicos (várias Constituições).

Os Estados Simples, em função da descentralização, podem ser Unitários ou Regionais (também denominados constitucionalmente descentralizados). Nos primeiros há uma única ordem jurídica e as competências que eventualmente são repartidas ou delegadas só o são por graça do poder central, que pode ampliá-las ou restringí-las livremente (não havendo, portanto, garantia contra a vontade do poder central). Neste tipo de Estado os eventuais agrupamentos regionais ou locais não têm capacidade alguma de auto-organização, sendo toda sua estrutura moldada pela ordem jurídica central, que cria eventuais regulamentos das entidades parciais.

Já nos Estados Regionais ou constitucionalmente descentralizados ${ }^{21}$, a ordem jurídica é descentralizada, isto é, ocorre uma descentralização do poder ${ }^{22}$, que pode ser

\footnotetext{
${ }^{21}$ A Itália e a Espanha são bons exemplos de Estados Regionais, já que suas regiões, apesar da autonomia política, não possuem poder constituinte próprio, razão pela qual, além de sua organização ser aprovada por lei nacional, podem tais regiões ser suprimidas por reforma da Constituição Federal.

${ }^{22}$ Bem pondera Manoel Gonçalves Ferreira Filho que "não há Estado sem um certo grau de descentralização. Na realidade, o grau mínimo de descentralização é aquele em que somente a criação das normas individuais é conferida a órgãos subordinados e periféricos (descentralização administrativa)", enquanto a descentralização em grau maior ocorre quando aos órgãos periféricos é concedido poder para legislar a respeito de assuntos locais (descentralização legislativa). Da conjunção da descentralização administrativa e legislativa surge a descentralização política (FERREIRA FILHO, Manoel Gonçalves. Curso de direito constitucional. 32. ed. São Paulo: Saraiva, 2006. p. 50).
} 
administrativa ou política. Têm-se, assim, regiões que se aproximam dos EstadosMembros de uma Federação, pois possuem certa faculdade de auto-organização. Não obstante, as regiões não se confundem com os citados entes federados, pois não dispõem de Poder Constituinte decorrente, isto é, capacidade de, sem intervenção direta do poder central, se auto-organizarem de acordo com suas próprias Constituições (Constituições Estaduais). Por isto, o Estado Regional dispõe apenas de uma Constituição, enquanto suas regiões elaboram estatutos políticos administrativos ou leis locais, cuja validade é condicionada à aprovação pelo órgão central do poder.

No outro vértice da classificação temos os Estados Compostos (pluralidade de poderes políticos e de ordenamentos jurídicos). São de dois tipos: os Estados Confederados e os Estados Federados.

A Confederação nada mais é do que uma associação de Estados soberanos que se unem para manter a defesa e a paz externa. A Confederação tem personalidade jurídica internacional, mas isso não retira o poder soberano interno e externo dos Estados confederados em tudo que não foi abrangido pelo acordo constitutivo da Confederação. A Confederação é instituída por tratado, admitido o direto de secessão (possibilidade de retirada do país membro a qualquer tempo).

Sobre o outro modelo de Estado Composto - o Federalismo - discorre-se a seguir.

\subsection{Federalismo}

O Estado federal surgiu no final do século XVIII, mais precisamente nos Estados Unidos da América, como forma de manter uma aliança permanente ${ }^{23}$ de Estados, submetendo-os a uma única Constituição, e fazendo-os obedecer aos preceitos de um governo formado pela vontade de todas as unidades e com autoridade sobre todas elas. ${ }^{24}$ Sua formação se deu em alguns Estados por agregação - vários Estados preexistentes renunciando à sua soberania e se reunindo para formação de um único novo Estado (v.g.

\footnotetext{
${ }^{23}$ Cf. notícia de José Luiz de Anhaia Mello, no sentido de que já havia uma idéia de federação na antiguidade, só que não talhada em um ideário permanente e comum (MELLO, José Luiz de Anhaia. O Estado federal e suas novas perspectivas. São Paulo: Max Limonad, 1960. p. 19).

${ }^{24}$ DALLARI, Dalmo de Abreu. O Estado federal. São Paulo: Ática, 1986. p. 7.
} 
Estados Unidos e Alemanha) - e em outros por segregação ${ }^{25}$ - um único Estado soberano, por razões políticas e de eficiência administrativa, desmembra-se, descentralizando regionalmente sua administração e formando entes parciais (v.g. Brasil).

O Estado Federal é um Estado Composto com descentralização do poder. Logo, a Federação é técnica de descentralização de poder político que se organiza, em dada base territorial, através de competências que se repartem entre órgãos centrais e locais, havendo, portanto, vários centros de decisão política, além da pluralidade de ordenamentos jurídicos originários, motivo pelo qual os cidadãos e todos os entes federados deverão obediência a mais de uma Constituição (Federal e Regional) ${ }^{26}$.

O Poder Central soberano é exercido pela União, enquanto os poderes regionais autônomos cabem aos Estados federados. Há modelos federativos, como o do tipo brasileiro, que há ainda descentralização política no âmbito local (Distrito Federal e Municípios) $)^{27}$.

A participação dos Estados federados na formação da vontade nacional e a autonomia são os princípios basilares da estrutura federalista. A participação das entidades regionais no Poder Central se dá por meio de uma Câmara que os representa (o Senado Federal), cujos membros são eleitos pelos Estados federados e participam ativamente da elaboração das leis nacionais e da revisão da própria Constituição Federal. Já a autonomia (e não soberania, que é característica dos Estados confederados) advém da capacidade de auto-organização dos Estados-Membros (poder constituinte decorrente) dentro das regras da Constituição Federal. Para tanto, os entes regionais não necessitam deferência ou ratificação do Poder Central às constituições que elaboram.

\footnotetext{
${ }^{25}$ Cf. RAMOS, Dirceo Torrecillas. O federalismo assimétrico. 2. ed. Rio de Janeiro: Forense, 2000. p. 47-48. Não se pode deixar de já apontar - embora sobre isto discorreremos mais adiante - que nas federações por agregação, há uma resistência bem maior à universal tendência de centralização de poderes (inclusive os atinentes ao processo) na esfera central, algo que não se encontra nas federações por segregação como a brasileira.

${ }^{26}$ Aponta André Luiz Borges Netto que, apesar da multiplicidade de modelos federativos, ao menos quatro características são essenciais a todos eles: a) repartição de competências; b) autonomia política das unidades federadas; c) participação das unidades federadas na formação da vontade nacional; e d) atribuição de renda própria aos entes federados (BORGES NETTO, André Luiz. Competências legislativas dos Estados-Membros. São Paulo: Ed. Revista dos Tribunais, 1999. p. 44).

${ }^{27} \mathrm{Cf}$. indica Magno Guedes Chagas, o termo federalismo "não leva a uma única realidade, mas a vários modelos de Estado. O Estado Federal, conseqüentemente, é conceito de natureza vaga e polissêmica, sendo impossível traçar um modelo único, devendo-se, desse modo, perquirir o que há de essencial nos Estados ditos federais, isto é: o que os identifica como modelo de organização política" (CHAGAS, Magno Guedes. Federalismo no Brasil: poder constituinte decorrente na jurisprudência do Supremo Tribunal Federal. São Paulo: Sérgio Antonio Fabris, 2006. p. 58).
} 
A Constituição Federal - que é a base e o fundamento do Estado federado estabelece uma repartição de competências entre os entes federados (incluindo deveres, direitos e obrigações). Duas técnicas principais são empregadas nesta partilha: a de reserva de matérias de alçada exclusiva da União ou das entidades parciais (competência exclusiva), sobre as quais não é dado, sob pena de inconstitucionalidade, haver intervenção de outro ente federado (repartição horizontal de competências); e a técnica de repartição da mesma competência (competência concorrente), quando, então, os entes federados podem atuar sobre o mesmo assunto (repartição vertical de competências), havendo, na própria Constituição Federal, regras para evitar conflitos ocorridos pela atuação conjunta (v.g., art. 24 da Constituição Federal brasileira). ${ }^{28}$

Obviamente, quem tem o ônus deve ter o bônus. Por isto, é da essência do regime federativo - até para manter a autonomia das entidades parciais, permitindo que elas possam cumprir suas competências - que elas tenham renda própria e suficiente (repartição de rendas e capacidade tributária), cuja aplicação não sofre interferência do Poder Central, mas pode sofrer da Constituição Federal.

\subsection{Federalismo brasileiro ${ }^{29}$}

A Constituição imperial de 1824, apesar dos anseios federalistas que já rondavam o movimento de independência ${ }^{30}$, deu ao Brasil a forma de Estado Unitário Regional ou descentralizado. ${ }^{31} \mathrm{O}$ Brasil era dividido em 20 (vinte) províncias, cujo

\footnotetext{
${ }^{28}$ Cf. FERREIRA FILHO, Manoel Gonçalves. Curso de direito constitucional, cit., p. 52-53.

${ }^{29}$ Para compreensão do movimento histórico que culminou com a adoção do federalismo no Brasil, cf. ALENCAR, Luiz Carlos Fontes de. A federação brasileira e os procedimentos em matéria processual. Revista do Centro de Estudos Judiciários do Conselho da Justiça Federal, Brasília, ano 5, n. 13, p. 184186, jan./abr. 2001.

${ }^{30}$ Nos idos de 1831 a Câmara dos Deputados pretendeu fosse o império do Brasil uma monarquia federativa. O Senado, entretanto, bloqueou o curso da proposta (ALENCAR, Luiz Carlos Fontes de. Procedimentos em matéria processual. Revista do Centro de Estudos Judiciários do Conselho da Justiça Federal, Brasília, ano 2, n 4, p. 92, abr. 1998). Conforme nota de Florisberto Freire, "de 1824 a 1840 a idéia republicana chegou a assumir a forma de aspiração federalista. Chegou também a inspirar a elaboração do Direito Constitucional, quase sob os mesmos princípios da Constituição promulgada em 15.11.1891" (FREIRE, Florisberto. História constitucional da República dos Estados Unidos do Brasil. Brasília: Ed. da Unb, 1983. p. 279280). Cf., também, BASTOS, Aureliano Cândido Tavares. A província: estudo sobre a descentralização no Brasil. 3. ed. São Paulo: Nacional, 1975. p. 7.

${ }^{31} \mathrm{O}$ próprio art. $1^{\circ}$ da Carta Imperial de 1824 negava terminantemente a federação: "O Imperio do Brazil é a associação Politica de todos os Cidadãos Brazileiros. Elles formam uma Nação livre, e independente, que não admitte com qualquer outra laço algum de união, ou federação, que se opponha à sua Independência" (redação original).
} 
presidente era nomeado pelo Poder Central, e cujas atribuições, além de pífias, eram praticamente todas sujeitas à ratificação do Imperador. ${ }^{32}$

A primeira referência ao federalismo por nossas terras ocorreu com a proclamação da República (art. $2^{\circ}$ do Decreto n. 01, de 15.11.1889), que transformou as províncias em Estados, dando-lhes certa autonomia. Tal ideário foi consolidado pela Constituição Republicana de $1891^{33}$, a ratificar, também, a criação de um Estado federalista dual (União e Estados) ${ }^{34}$ e por segregação, algo que, conforme já vimos, tendia a uma concentração de poderes na União Federal. ${ }^{35}$

Os primeiros anos da República revelaram a absoluta disparidade entre os Estados federados brasileiros - alguns ricos, outros miseráveis - razão pela qual, com a Constituição de 1934, o modelo federalista brasileiro fez com que Poder-Central tivesse que participar mais incisivamente da realidade regional. $\mathrm{O}$ modelo adotado a partir de então era de federalismo orgânico ou cooperativo, com forte integração entre o governo central e os governos regionais. ${ }^{36}$ Pretendia-se, com isto, diminuir a diferença entre as regiões brasileiras, impondo à União o papel de colaborador constante no desenvolvimento regional.

O início do Estado Novo e a Constituição Getulista de 1937, o respiro democrático e a promulgação da Carta Constitucional de 1946, não alteraram a já referida tendência centralizadora, posto que à União, através de maciços investimentos nos Estados mais pobres, era dado consolidar a igualdade econômica e social do Estado Brasileiro. Manteve-se o regime federalista por cooperação, elevada a União ao suposto ator da igualdade entre os Estados federados.

Com o golpe militar de 1964 e a conseqüente promulgação da Constituição Federal de 1967 (e emenda de 1969), alterou-se o modelo federalista brasileiro no que

\footnotetext{
${ }^{32}$ BARROSO, Luis Roberto. Direito constitucional brasileiro: o problema da federação. Rio de Janeiro: Forense, 1982. p. 30.

${ }^{33}$ Logo no art. $1^{\circ}$ já se anunciava que a "Nação brasileira adota como forma de Governo, sob o regime representativo, a República Federativa, proclamada a 15 de novembro de 1889, e constitui-se, por união perpétua e indissolúvel das suas antigas Províncias, em Estados Unidos do Brasil”.

${ }^{34}$ No federalismo dual os Estados-Membros atuam de forma independente, não havendo interpenetração de uma esfera governamental em outra (CHAGAS, Magno Guedes. Federalismo no Brasil, cit., p. 60).

${ }^{35}$ Tendência que, paradoxalmente, não atingiu a competência para legislar sobre o processo (conforme veremos adiante), que nesta época permaneceu na alçada dos Estados federados.

${ }^{36}$ Cf. CASSEB, Paulo Adib. Federalismo: aspectos contemporâneos. São Paulo: Juarez de Oliveira, 1999. p. 10.
} 
tange à sua dualidade, pois se reconheceu a existência de outras entidades parciais além da União e dos Estados Federados: os Municípios.

De fato, os Estados Membros de um Estado federal podem ser Estados federais centralizados ou Estados federais descentralizados, algo que é determinado pela Constituição Federal. No primeiro caso, não há descentralização no âmbito do EstadoMembro (a extinta URSS é bom exemplo). No outro caso, a Constituição Federal pode determinar que as Constituições Estaduais adotem a descentralização, o que implica autonomia de entes locais ou intra-estaduais (os Municípios).

Não há, portanto, um só federalismo. Cada Estado assume as feições próprias do federalismo, como o Brasil, que inseriu no seu modelo, sem notícia de sistema análogo no estrangeiro, os Municípios. ${ }^{37}$

A Municipalização do Estado brasileiro, entretanto, não trouxe alterações na concentração de poderes nas mãos da União. Pelo contrário, até pelo regime militar que se instaurava, acentuou-se o papel da União em detrimento dos demais entes federados (Estados e Municípios), a ponto de alguns autores indicarem a inauguração de um novo modelo de federalismo (federalismo por integração), muito próximo da substituição do Estado Federal por um Estado Simples descentralizado. ${ }^{38}$

Com a Carta de 1988 foram mantidos os entes federados do regime anterior $\left(\operatorname{art} .1^{\circ}\right)$, elevando-se a forma federalista de Estado à cláusula pétrea (art. $60, \S 4^{\circ}$ ). Entretanto, procurou-se conferir maior autonomia aos entes federados parciais, especialmente aos Estados Membros, restabelecendo, ainda, o federalismo cooperativista das Constituições pré-militares.

Para isto, a Carta Magna reconhece e prevê competências e rendas a todos os entes federados (União, Estados e Municípios), repartindo, entre o Poder-Central e as entidades parciais, a responsabilidade pelo desenvolvimento local, regional e nacional. ${ }^{39}$

\footnotetext{
${ }^{37}$ Para análise desta pecular figura do direito brasileiro, cf. ALMEIDA, Fernando Dias Menezes de. Considerações sobre os Municípios no Brasil. In: TAVARES, André Ramos; FERREIRA, Olavo A. V. Alves; LENZA, Pedro (Orgs.). Constituição Federal 15 anos: mutação e evolução. São Paulo: Método, 2003. p. 313-319.

${ }^{38}$ Cf. FERREIRA FILHO, Manoel Gonçalves. Curso de direito constitucional, cit., p. 52-55 e 57.

${ }^{39}$ Interessante notar, também, que no regime federalista brasileiro reconhece-se, ainda, um quarto ente federado o Distrito Federal, verdadeiro tertium genus entre Município e Estado (a abarcar a competência e receitas de ambos, nos termos do art. 32, § $1^{\circ}$, da Constituição Federal), com capacidade de autoorganização, auto-governo e auto-administração (MORAES, Alexandre de. Direito constitucional. 15. ed. São Paulo: Atlas, 2004. p. 284).
} 
Apesar das boas intenções do constituinte, o modelo federalista inaugurado com a Constituição Federal de 1988 não alcançou seu propósito descentralizador ${ }^{40}$, sendo mantida, pois, em detrimento dos Estados-Membros e dos Municípios, forte concentração de poderes e rendas na esfera federal. É voz corrente na pauta de projetos para melhoria do Estado brasileiro a redefinição do pacto federativo.

\subsubsection{Repartição de competências legislativas na Constituição Federal de 1988}

A suposta autonomia das entidades federativas, entre outras coisas, pressupõe a existência de competências próprias, entre elas legislativas, administrativas e tributárias ${ }^{41}$, sem o que não há espaço para a formação de um ordenamento jurídico próprio destas entidades, elemento fundamental para a própria eficácia do sistema federativo. ${ }^{42}$

A simples repartição de competências, todavia, não é bastante para assegurar a autonomia dos entes federados. É mister que essas competências - ao menos no que toca ao âmbito legislativo - versem sobre matérias relevantes, de verdadeiro significado político, sob pena de se ter um conjunto de atribuições inexpressivas que não possibilitam o exercício da autonomia dos Estados-Membros. ${ }^{43}$

E é necessário, ainda, que União, Estados e Municípios, todos, respeitem e façam respeitar as competências estabelecidas na Carta Constitucional, algo que não me parece ocorrer muito bem na prática. De fato, conforme veremos a seguir, a União, principalmente, com o beneplácito do Poder Judiciário, e seguindo seu histórico centralizador, excede no mais das vezes os limites constitucionais de sua competência, avançando (especialmente no que toca à legislação concorrente) espaço reservado para a atuação dos Estados federados.

A Constituição Federal brasileira estabelece as competências legislativas próprias da União (art. 22), dos Estados (art. 25, $\S 1^{\circ}$ ) - a destes de maneira residual ou

\footnotetext{
${ }^{40} \mathrm{Cf}$. BORGES NETTO, André Luiz. Competências legislativas dos Estados-Membros, cit., p. 54.

${ }^{41}$ MORAES, Alexandre de. Direito constitucional, cit., p. 290.

${ }^{42}$ ROCHA, Carmem Lúcia Antunes. República e federação no Brasil: traços constitucionais da organização política brasileira. Belo Horizonte: Del Rey, 1997. p. 181.

${ }^{43}$ CHAGAS, Magno Guedes. Federalismo no Brasil, cit., p 76. Cf., também, BORGES NETTO, André Luiz. Competências legislativas dos Estados-Membros, cit., p. 85.
} 
remanescente - e dos Municípios (art. 30), algo que a doutrina denomina repartição horizontal de competências.

Sobrelevando a forte tendência centralizadora, o art. 22 da Constituição Federal abarca em vinte e nove incisos quase todas as questões de maior relevância nacional, amenizando a disposição através de um parágrafo único, a permitir (ilusoriamente) que lei complementar possa autorizar os Estados a legislar sobre estas questões.

A Carta Constitucional estabelece, ainda, competências legislativas concorrentes da União, Estados-federados e do Distrito Federal (art. 24), nestes casos, ressalvando que a atividade do Poder-Central é limitada ao estabelecimento de normas gerais. A este último modelo de repartição de competências dá-se o nome de repartição vertical. $^{44}$

\subsubsection{Competência legislativa concorrente e a dificuldade de se estabelecer o conceito de normas gerais}

O constituinte, ao abrir campo à competência concorrente, teve por escopo evidente dar maior elasticidade à participação legislativa dos Estados e do Distrito Federal, no intento de fortalecer a autonomia federativa, sem desfigurar a necessidade de um poder central harmonizador que se encontra na própria essência de uma federação moderna e dinâmica. $^{45}$

A utilização da técnica de repartição vertical de competências é muito adequada para países federativos como o Brasil, que com sua dimensão continental e imensas

\footnotetext{
${ }^{44}$ Assim se diz porque se trata de divisão de competência dentro de um mesmo campo material, diversamente do que ocorre com a divisão horizontal de competências, quando cada ente recebe atribuições exclusivas (MORAES, Alexandre de. Direito constitucional, cit., p. 300-301).

${ }^{45}$ Raul Machado Horta anota que "as Constituições federais passaram a explorar, com maior amplitude, a repartição vertical de competências, que realiza a distribuição de idêntica matéria legislativa entre a União Federal e os Estados-membros, estabelecendo verdadeiro condomínio legislativo, consoante regras constitucionais de convivência. A repartição vertical de competências conduziu à técnica da legislação federal fundamental, de normas gerais e diretrizes essenciais, que recai sobre determinada matéria legislativa de eleição do constituinte federal. A legislação federal é reveladora das linhas essenciais, enquanto a legislação local buscará preencher o claro que lhe ficou, afeiçoando a matéria revelada na legislação de normas gerais às peculiaridades e às exigências estaduais" (HORTA, Raul Machado. Estudos de direito constitucional. Belo Horizonte: Del Rey, 1995. p. 366).
} 
disparidades econômicas, geográficas e culturais entre os Estados, permitem que estes legislem sobre as realidades locais. ${ }^{46}$

Tanto é assim que os quatro parágrafos do art. 24 da Carta Constitucional dizem que, no âmbito da competência concorrente, a União limitar-se-á ao estabelecimento de normas gerais $\left(\S 1^{\circ}\right)$, prerrogativa esta que não exclui a competência complementar dos Estados e do Distrito Federal no estabelecimento também destas normas gerais $\left(\S 2^{\circ}\right)$. Não existindo lei federal sobre normas gerais, os Estados exercerão competência legislativa plena, dita competência supletiva $\left(\S 3^{\circ}\right)$, cujo produto terá sua eficácia ${ }^{47}$ suspensa em caso de superveniência de lei federal sobre normas gerais em sentido contrário $\left(\S 4^{\circ}\right)$. E mesmo que haja normas gerais sobre o assunto editadas pelo Poder Central, compete ao Estado e ao Distrito Federal a edição de normas específicas, detalhadas, minuciosas (competência suplementar), hábeis a particularizar e adaptar a matéria de sua competência à realidade regional. $^{48}$

À exceção do Município - que não tem competência concorrente - todos os demais entes federados são limitados pela norma. Da mesma maneira que a legislação estadual ou distrital que não se limitar à função complementar ou suplementar da lei federal é inconstitucional ${ }^{49}$, também é inconstitucional a lei federal que extrapola seus

${ }^{46}$ CHAGAS, Magno Guedes. Federalismo no Brasil, cit., p. 79. Ceneviva acentua que em nosso país o que vale para um Estado não vale para outro, eis que apesar da unidade legislativa, as realidades socioeconômicas são diferentes, o que aconselha diversidade de soluções (CENEVIVA, Walter. Falta que os Poderes se entendam: Legisladores e os exercentes do Poder Executivo não chegam a entender os problemas do Judiciário. Folha de S. Paulo, São Paulo, 10 mar. 2007. Disponível em: $<$ http://www1.folha.uol.com.br/fsp/cotidian/ff1003200706.htm>. Acesso em: 02 mar. 2007.

${ }^{47}$ Tecnicamente, como bem aponta Sérgio Bermudes, "eficácia, neste parágrafo, empregou-se como sinônimo de vigência. Revogada embora, a lei continua eficaz. Imagine-se a sentença, que fez atuar sua vontade concreta, ato judicial que subsistirá incólume à revogação, projetando, no futuro, a vontade da lei, que deixou de vigorar. No caso, admite-se a revogação, porque a lei local terá sido supletiva da lei federal e atuado como se lei federal fosse" (BERMUDES, Sérgio. Procedimentos em matéria processual. Revista de Direito da Defensoria Pública, Rio de Janeiro, ano 4, n. 5, p. 161, fev. 1991).

${ }^{48}$ Sobre a compatibilização das legislações federal, estadual e distrital, extremamente didática é a seguinte ementa do Supremo Tribunal Federal: "O art. 24 da CF compreende competência estadual concorrente nãocumulativa ou suplementar ( $\operatorname{art} .24, \S 2^{\circ}$ ) e competência estadual concorrente cumulativa (art. $24, \S 3^{\circ}$ ). Na primeira hipótese, existente a lei federal de normas gerais (art. $24, \S 1^{\circ}$ ), poderão os Estados e o DF, no uso da competência suplementar, preencher os vazios da lei federal de normas gerais, a fim de afeiçoá-la às peculiaridades locais (art. $24, \S 2^{\circ}$ ); na segunda hipótese, poderão os Estados e o DF, inexistente a lei federal de normas gerais, exercer a competência legislativa plena 'para atender a suas peculiaridades' (art. $24, \S 3^{\circ}$ ). Sobrevindo a lei federal de normas gerais, suspende esta a eficácia da lei estadual, no que lhe for contrário (art. 24, § $4^{\circ}$ ). A Lei 10.860, de 31/8/2001, do Estado de São Paulo foi além da competência estadual concorrente não-cumulativa e cumulativa, pelo que afrontou a Constituição Federal, art. 22, XXIV, e art. 24, IX, § $2^{\circ}$ e $\S 3^{\circ}$." (ADI n. 3.098, Rel. Min. Carlos Velloso, DJ 10/03/06).

${ }^{49}$ MIRANDA, Francisco Cavalcanti Pontes de. Comentários à Constituição de 1967 (com a emenda n. 1 de 1969). 2. ed. São Paulo: Ed. Revista dos Tribunais, 1970. v. 1, p. 170. 
limites e passa a disciplinar à exaustão matéria reservadas à legislação concorrente, esgotando o assunto ${ }^{50}$.

Isto porque sendo a Constituição Federal rígida - um dos alicerces, aliás, da Federação brasileira - as competências dos Estados membros são reservadas constitucionalmente, o que impede a União de adentrar nas competências dos demais entes por meio de legislação infraconstitucional ${ }^{51}$, sob pena de violação da própria Carta Magna e instauração de um regime que, na prática, se equivaleria ao de um Estado Simples.

Assim, em matéria de competência concorrente, é vedado ao ente central avançar sobre a competência suplementar dos Estados e do Distrito Federal, a quem constitucionalmente compete tecer minúcias e adequar a lei geral à realidade local. Em critério de valoração política, o constituinte entendeu que o Estado federado é mais apto a identificar seus problemas e a adotar providências legislativas destinadas a resolvê-los.

A grande dificuldade no tocante ao assunto é a de ser estabelecido, na falta de um critério legal objetivo, o que seriam as normais gerais, tarefa tormentosa e que tem dado azo a variadas interpretações. ${ }^{52}$

O Supremo Tribunal Federal foi capaz de identificar tal conceito para identificar o alcance do art. 22, XXVII da Constituição Federal (competência da União para legislar sobre normas gerais de licitação e contratação). Estabeleceu que "a formulação do conceito de 'normas gerais' é tanto mais complexa quando se tem presente o conceito de lei em sentido material: norma geral e abstrata. Ora, se a lei, em sentido material, é norma geral, como seria a lei de 'normas gerais' referida na Constituição? Penso que essas 'normas gerais' devem apresentar generalidade maior do que apresentam, de regra, as leis. Penso que 'norma geral', tal como posta na Constituição, tem o sentido de diretriz, de princípio geral. A norma geral federal, melhor será dizer nacional, seria a

\footnotetext{
${ }^{50}$ Neste sentido Alexandre de Moraes, para quem "a competência da União é direcionada somente às normas gerais, sendo de flagrante inconstitucionalidade aquilo que delas extrapolar" (MORAES, Alexandre de. Direito constitucional, cit., p. 301). E também Carlos Mário da Silva Velloso: "Na competência legislativa de normas gerais, diretrizes ou princípios, não poderá a União legislar sobre questões específicas, sobre particularidades. Se o fizer, cometerá inconstitucionalidade“ (VELLOSO, Carlos Mario da Silva. Temas de direito público. Belo Horizonte: Del Rey, 1994. p. 375).

${ }^{51}$ Cf. FERRARI, Regina Maria Nery. Efeitos da declaração de inconstitucionalidade. 4. ed. São Paulo: Ed. Revista dos Tribunais, 1999. p. 261. No mesmo sentido CHAGAS, Magno Guedes. Federalismo no Brasil, cit., p. 75.

${ }^{52}$ JUSTEN FILHO, Marçal. Comentários à lei de licitações e contratos administrativos. Rio de Janeiro: Aide, 1993. p. 13.
} 
moldura do quadro a ser pintado pelos Estados e Municípios no âmbito de suas competências". 53

Normas gerais referidas no art. $24, \S 1^{\circ}$, da Constituição Federal, são, ao nosso sentir, leis de caráter e abrangência nacional, de natureza mais genérica e abstrata do que as normas locais. ${ }^{54}$ São disposições que determinam parâmetros mínimos, com maior nível de generalidade e abstração que as leis editadas fora dos limites da competência concorrente. São disposições já predispostas a ser desenvolvidas e complementadas pela ação normativa subseqüente dos demais entes federados (Estados e Distrito Federal), "que se contenham no mínimo indispensável ao cumprimento dos preceitos fundamentais, abrindo espaço para que o legislador possa abordar aspectos diferentes, diversificados, sem desrespeito a seus comandos genéricos, básicos" ${ }^{25}$.

Não são normas gerais, por isto, as que se ocupem de detalhamentos, que minudenciem condições específicas, que esgotem por completo o assunto, de modo que nada deixam à criação própria do legislador a quem se destinam (o legislador estadual ou distrital), exaurindo, assim, o assunto de que tratam. ${ }^{56}$

Toda vez que a União, no exercício da competência concorrente, exceder os limites dos princípios e regras gerais, tem-se por inconstitucional e sem efeito as disposições por si emanadas, por manifesta violação do pacto federativo. ${ }^{57}$

\footnotetext{
${ }^{53}$ STF, ADI-MC n. 927-3/RS, Rel. Min. Carlos Velloso, j. 03.11.1993. Cf., também, STF, ADI-MC n. 933/GO, Rel. Min. Carlos Velloso, j. 04.11.1993; e STF, ADI n. 3098/SP, Rel. Min. Carlos Velloso, j. 24.11.2005.

${ }^{54}$ Sobre normas particulares, cf. JACQUES, Paulino. Da norma Jurídica (forma e matéria). 2. ed. Rio de Janeiro: Forense, 1963. p. 52 e ss. De acordo com o autor, são normas particulares as que vigoram dentro de certa porção de território (Municípios, Estados ou Distrito Federal), enquanto que as normas gerais têm vigência na extensão de todo território do Estado soberano (Brasil).

${ }^{55}$ Cf. BORGES, Alice Maria Gonzalez. Normas gerais nas licitações e contratos administrativos: contribuição para a elaboração de uma lei nacional. Revista de Direito Público, São Paulo, v. 24, n. 96, p. 81, out./dez. 1990.

${ }^{56}$ Cf. FERRAZ JÚNIOR, Tércio Sampaio. Normas gerais e competência concorrente: uma exegese do art. 24 da Constituição Federal. Revista da Faculdade de Direito da Universidade de São Paulo, São Paulo, v. 90, p. 245-251, 1995; VELLOSO, Carlos Mario da Silva. Lei Complementar Tributária. Revista de Direito Administrativo, São Paulo, n. 235, p. 117-138, jan./mar. 2004; REIS, Élcio Fonseca. Competência concorrente e normas gerais de direito tributário. Belo Horizonte: Mandamentos, 2000. p. 34-35.

${ }^{57}$ Cf. Marçal JUSTEN FILHO, Marçal. Comentários à lei de licitações e contratos administrativos, cit., p. 13.
} 


\subsubsection{Distorções do modelo federalista brasileiro}

Várias são as distorções e críticas que são feitas ao modelo federalista brasileiro.

Primeiro, a autonomia dos Estados Membros ou a descentralização de poder só ocorre, convenhamos, no âmbito administrativo-financeiro, e não no âmbito político.

Isto porque, se analisarmos a Constituição Federal, veremos que o rol de bens (art. 20), as receitas (artigos 153, 154 e 157) e as competências administrativas (art. 21) e legislativas (art. 22) da União são bem maiores e mais relevantes que a dos Estados e Municípios (art. 30), de modo que pouca importância tem a legislação estadual em assuntos de interesse maior. ${ }^{58}$

Mesmo na grande maioria dos casos em que se reconhece a competência concorrente para que os Estados Membros ou Distrito Federal disciplinem certos assuntos com a União (repartição vertical de competências), o Poder Central avança sobre o limite de edição de normas gerais, tratando minuciosamente de assuntos que fogem de sua alçada (art. 24 e §§). Consequiência é que a atuação política dos entes parciais, grosso modo, é quase nenhuma, já que sequer conseguem legislar a ponto de fazer valer suas normas particulares em seu território. ${ }^{59}$

Além disso, o poder de auto-organização dos Estados na Federação brasileira é extremamente limitado, a ponto de ser reduzido a quase nada ${ }^{60}$, o que faz igualar o nosso

\footnotetext{
${ }^{58}$ Correta, portanto, a análise de Dalmo de Abreu Dallari, para quem a igualdade que deveria haver entre União e Estados-Membros é comprometida: a) pela extensa enumeração das competências federais, entre as quais se encontram matérias de grande relevância nacional; b) pelo poder da União editar regras gerais em matéria de competência concorrente; e c) pela possibilidade de intervenção federal da União nos Estados (art. 34 da CF) (DALLARI, Dalmo de Abreu. O Estado federal, cit., p. 69-71).

${ }^{59}$ Janice Helena Ferreri Morbidelli, ao comentar que o federalismo norte-americano já padece do mesmo problema centralizador dos modelos federalistas por segregação, anota, em lição que também serve à realidade brasileira, que "deverá o federalismo americano preocupar-se com as formas de descentralização entre seus entes, concentrando a ação governamental central somente nas questões relevantes da vontade nacional, de conformidade com a Constituição e a Carta de Direitos (...). Por outro lado, para obter a descentralização desejada, deverá redefinir as atribuições dos Estados e do governo local, colocando as responsabilidades de cada um desses domínios, pois a maior defesa contra a centralização é propiciar governo estadual competente“ (MORBIDELLI, Janice Helena Ferreri. A federação. In: BASTOS, Celso Ribeiro. Por uma nova federação. São Paulo: Ed. Revista dos Tribunais, 1995. p. 22).

${ }^{60}$ Preciso, por isto, o comentário de Magno Guedes Chagas, fruto de profunda análise da jurisprudência do STF e das disposições da Carta Constitucional de 1988: "o âmbito de liberdade para a auto-organização dos Estados-membros no Brasil é pequeno, uma vez que a Constituição Federal estabelece praticamente toda a organização dos poderes estaduais, bem como a forma de investidura e prerrogativas de seus titulares, situação esta que leva a se questionar se o Estado-membro teria realmente um poder constituinte" (CHAGAS, Magno Guedes. Federalismo no Brasil, cit., p. 62 e 95-107).
} 
Estado Composto de modelo Federado ao Estado Simples de modelo Regional ou constitucionalmente centralizado. De fato, as Constituições Estaduais devem atenção aos denominados princípios sensíveis estabelecidos na Constituição Federal (art. 34, VII), bem como a todos os demais que regem a Administração Pública, determinem vedações ou fixem procedimentos de âmbito nacional (princípios constitucionais estabelecidos) ${ }^{61}$, algo que se tem globalmente reconhecido como princípio da simetria ou da similitude das Constituições Estaduais à Constituição Federal.

Segundo, tendo-se em vista a tendência centrípeta de concentração de poderes na União Federal desde a Constituição Federal de 1934, o Poder Legislativo Federal, com o beneplácito do Judiciário, interpreta a nova ordem federalista da Constituição Federal de 1988 - especialmente a repartição vertical de competências e o conceito de normas gerais do artigo 24, $\S 1^{\circ}$, da Constituição Federal - sob a ótica dos regimes centralizadores pretéritos, fazendo, assim, que mesmo diante do móvel descentralizador do constituinte, os Estados Membros permaneçam sob o jugo da vontade e das leis (e rendas) do Poder Central. Exemplificativamente, até se conhecem decisões em que o Judiciário declarou a inconstitucionalidade de norma estadual por entender que ela extrapolava os limites da legislação suplementar ${ }^{62}$. Mas não se tem notícia de julgados, talvez até por falta de provocação dos Estados e do Distrito Federal, em que nossa Suprema Corte tenha declarado inconstitucional lei federal por exceder os limites da legislação em matéria geral, algo que bem revela a realidade centralizadora. ${ }^{63}$

E terceiro, na maioria dos Estados federais, os senadores - que em tese deveriam representar os Estados na formação da vontade do poder central - estão presos a partidos políticos e não propriamente aos Estados que os elegem, razão pela qual não espelham a vontade regional na formação da vontade geral. ${ }^{64}$ Ouso dizer que o sistema bicameral brasileiro é uma farsa: temos duas casas que, na prática, tem a mesma natureza representativa.

\footnotetext{
${ }^{61}$ Cf. CHIMENTI, Ricardo da Cunha; CAPEZ, Fernando; ROSA, Márcio F. Elias; SANTOS, Marisa F. Curso de direito constitucional. 3. ed. São Paulo: Saraiva, 2006. p. 183.

${ }^{62}$ Tratava-se de norma estadual que dispensava estudo de impacto ambiental para fins empresariais, algo que nada tem a ver com questões de âmbito local, sendo, pois da alçada da União (STF, ADI 1.086/SC, Rel. Min. Ilmar Galvão). Em outra passagem, declarou-se a inconstitucionalidade de lei estadual, fundada na competência concorrente, a disciplinar rotulagem de produtos transgênicos, algo que também não tem relevância nem particularidade local (ADI 3.645/PR, Rel. Min. Ellen Gracie, j. 31.05.2006).

${ }^{63}$ Algo que não restou despercebido a Magno Guedes Chagas, Federalismo no Brasil, cit., p. 228.

${ }^{64}$ FERREIRA FILHO, Manoel Gonçalves. Curso de direito constitucional, cit., p. 52.
} 
Por isto, urge reconhecer o desaparecimento da velha ordem federativa, fincada no binômio Estado autônomo e Poder Central. A intervenção econômica e legislativa da União, já institucionalizada desde o nascimento da República, cassou praticamente a autonomia dos Estados, desfazendo a ilusão que publicistas de boa-fé e inocência vêm desde muito acalentando, ao batizar de federalismo cooperativo, um modelo que, dissimuladamente, não reconhece verdadeiramente a autonomia dos Estados, tampouco pode ser considerado federalista. ${ }^{65}$

E mesmo que se reconheça neste modelo atípico os traços de um Estado Federal, urge que se encerre o fim da simetria imposta constitucionalmente, permitindo que haja tratamento diferenciado entre os Estados Federados, de modo a solucionar as acentuadas diferenças sociais, econômicas e culturais existentes entre eles ${ }^{66}$, ou, mantida a simetria, ao menos concedendo receitas e reconhecendo competências mais relevantes no âmbito regional, permitindo, assim, que os Estados tenham verdadeira autonomia política.

Estas distorções no federalismo acabam refletindo no processo e no procedimento, visto que os Estados, pese a autorização constitucional (art. 24, XI, da CF), não conseguem adequar as normas processuais à realidade regional, flexibilizando-as de acordo com as necessidades que lhe são próprias. É sobre o que discorreremos a seguir.

\subsection{Competência para legislar sobre processo e procedimento no Brasil}

\subsubsection{Breve notícia histórica}

Sujeito o Brasil Colônia desde sua descoberta ao domínio português, por aqui tiveram vigência, ao menos em tese, as normas processuais lusitanas, a se iniciar com as constantes do Livro III das Ordenações Afonsinas (1.500 até 1.521). ${ }^{67}$

\footnotetext{
${ }^{65}$ Cf. BONAVIDES, Paulo. A Constituição aberta. 2. ed. São Paulo: Malheiros Ed., 1996. p. 398.

${ }^{66} \mathrm{~A}$ expressão federalismo assimétrico, ao menos no Brasil, deve-se ao gênio de Dircêo Torrecilas Ramos, que em obra clássica, apresenta verdadeiro projeto de rearranjo do Estado Federal brasileiro ( $O$ federalismo assimétrico, cit.). Cf., também, MORBIDELLI, Janice Helena Ferreri. Um novo pacto federativo para o Brasil. São Paulo: Celso Bastos, 1999. p. 34.

${ }^{67}$ As Ordenações Afonsinas são uma coletânea de leis promulgadas, como primeira compilação oficial do século XV, durante o reinado de Dom Afonso V. Iniciada sua elaboração no reinado de D. João I, a comissão composta por D. Duarte e Rui Fernandes acabou o trabalho em 1446, mas por ordem de infante
} 
Posteriormente, de 1521 até 1603 foram as normas constantes também do Livro III das Ordenações Manuelinas que regularam as nossas relações jurídicas processuais ${ }^{68}$.

\author{
Finalmente, as disposições do Livro III das Ordenações Filipinas vigoram no
}

Brasil de 1.603 até boa parte do período Imperial $^{69}$, de modo que por mais de 300

(trezentos) anos de nossa existência ficamos sob o jugo de leis do reino português.

D. Pedro foram introduzidas alterações. Suas fontes foram, sobretudo, leis existentes. Muitas disposições foram extraídas dos direitos romano e canônico. Pensa-se que o Livro das Leis e Posturas e as Ordenações de D. Duarte tenham sido trabalhos preparatórios desta codificação. As Ordenações encontram-se divididas em cinco livros, talvez à imitação dos Decretais de Gregório IX. Todos os livros são precedidos de preâmbulo, sendo que no primeiro (mais longo) se narra a história da compilação. Embora com cinco livros, as Ordenações estavam longe de constituir um sistema completo; no direito privado há institutos que são esquecidos e outros excepcionalmente lembrados. Estas Odernações não apresentam uma estrutura orgânica comparada a dos códigos modernos. No entanto, não ficaram em desvantagem comparadas com os outros códigos vigentes na época em outros países. As Ordenações Afonsinas ocupam uma posição destacada na história do direito português: representaram o final da evolução legislativa que vinha desde D. Afonso III, e forneceram as bases das colectâneas seguintes, que se limitaram a atualizá-las. Sendo substituídas no reinado de D. Manuel I, depressa caíram em esquecimento, sem terem chegado a ser impressas. Fonte: ENCICLOPÉIDA Wikipédia <http://pt.wikipedia.org/wiki/Ordena\%C3\%A7\%C3\%B5es_Afonsinas>. Acesso em: 08 dez. 2006.

${ }^{68}$ Com este nome se designa a nova codificação que D. Manuel I promulgou, em 1521, para substituir as Ordenações Afonsinas. Para explicar esta decisão do rei apontam-se dois motivos fundamentais: a descoberta da imprensa e a necessidade de correção e atualização das normas, assim como a modernização do estilo afonsino. Além disso, talvez o monarca tivesse querido acescentar às glórias do seu reinado uma obra legislativa. Em 1514 faz-se a primeira edição completa dos cinco livros das Ordenações Manuelinas. A versão definitiva foi publicada em 1521. Para evitar confusões, a Carta Régia de 1521 impôs que todos os possuidores de exemplares das ordenações de 1514 os destruissem no prazo de três meses, ao mesmo tempo que determinou aos Conselhos a aquisição de nova edição. Estas constituem já uma atualização das Ordenações Afonsinas, embora mantendo o plano adotado, compreendendo, portanto, cinco livros, subdivididos em títulos e parágrafos. Mas as alterações são importantes, como a supressão das normas revogadas. Quanto à forma, a principal diferença reside no facto de se apresentarem redigidas em estilo mais conciso e todo o decretório, só excepcionalmente aparecendo o extrato de algumas leis (nunca a transcrição literal). Vigeram até 1603, quando, então, foram substituídas pelas Ordenações Filipinas. Fonte: ENCICLOPÉIDA Wikipédia <http://pt.wikipedia.org/wiki/Ordena\%C3\%A7\%C3\%B5es_Afonsinas>. Acesso em: $08 \mathrm{dez} .2006$.

${ }^{69}$ Esta compilação jurídica resulou da reforma do código manuelino, como consequência do domínio castelhano, tendo sido mais tarde confirmada por D. João IV. Mais uma vez se fez sentir a necessidade de novas ordenações que representassem a expressão coordenada do direito vigente. A obra ficou pronta ainda no tempo de Filipe I, que a sancionou em 1595, mas só foi definitivamente mandada observar, após a sua impressão em 1603, quando já reinava Filipe II. O castelhano Filipe I, político hábil, quis mostrar aos portugueses o respeito que tinha pelas leis tradicionais do país, promovendo a reforma das ordenações dentro de um espírito tradicional. Estas Ordenações apresentam a mesma estrutura e arrumação de matérias que já se verificara nas Ordenações Manuelinas, conservando-se também o critério nestas estabelecido a respeito do preenchimento de lacunas. O livro III, que cuidava do processo, regulava o processo ordinário, o sumário, e ainda cuidava de alguns processo especiais. Também separava de maneira clara as fases postulatoria, instrutória, decisória e executória. Apesar disto, tem ausência de originalidade; pouca clareza e frequentes contradições, que resultam muitas vezes do excessivo apego ao texto manuelino: a falta de cuidado em suprimir alguns preceitos revogados. As Ordenações Filipinas, embora muito alteradas, constituíram a base do direito português até à promulgação dos sucessivos códigos do século XIX. Fonte: ENCICLOPÉIDA Wikipédia <http://pt.wikipedia.org/wiki/Ordena\%C3\%A7\%C3\%B5es_Afonsinas>. Acesso em: 08 dez. 2006. 
Com efeito, nascido Estado Unitário pela Constituição Imperial de 1824 (art. $1^{\circ}$ ), ao Poder Legislativo do Império (Assembléia Geral) competia, sob delegação e poder de veto do Imperador, legislar sobre processo (art. 15, VIII). ${ }^{70}$

Contudo, tal poder não foi exercido logo após a independência da dantes colônia brasileira (1822), razão pela qual as normas processuais das Ordenações Filipinas (livro III) ${ }^{71}$ tiveram vigência em todo território nacional (províncias) e para todas as causas até a edição do Regulamento n. 737, de 20 de novembro de 1850, que passou a disciplinar o processo das causas do comércio. As Ordenações continuaram a viger, mas só no concernente aos processos de natureza cível.

A fim de regular o procedimento cível (até então disciplinado pelas Ordenações Filipinas), o Governo Imperial encarregou o Conselheiro Antônio Joaquim Ribas para reunir todas as normas relativas ao processo civil, obra finalizada em 1876, quando a Consolidação das Leis do Processo Civil passou, então, a ter força de lei (resolução imperial). O diploma dividia-se em duas partes: a primeira, relativa à organização judiciária e a segunda, disciplinadora da forma do processo (que reproduzia o texto das Ordenações Filipinas). Lembre-se que o Regulamento n. 737 continuava válido para as causas do comércio.

Com a proclamação da República (1.889), uma das primeiras medidas tomadas pelo Governo Republicano com relação ao processo civil foi que se aplicassem também a ele - pela melhor qualidade da disciplina e pelo fim do uso das leis portuguesas - as disposições do Regulamento 737 de 1850. Isto se consolidou através do Decreto n. 763, de 19.09.1890, que, apesar de revogar por completo as Ordenações Filipinas, manteve em vigor as disposições do Código de Ribas que regulavam os processos especiais não compreendidos pelo referido Regulamento. ${ }^{72}$

Com a Constituição Federal de 1.891, embriagados pelo ideário federalista, os Estados-membros foram implicitamente autorizados a legislar sobre processo ${ }^{73}$,

\footnotetext{
${ }^{70}$ Art. 15. E' da attribuição da Assembléa Geral: VIII. Fazer Leis, interpretal-as, suspendel-as, e rovogal-as (redação original).

${ }^{71}$ Por um Decreto de 20.10.1823, da Assembléia Geral Constituinte, manteve-se em vigor no Brasil as leis então vigentes promulgadas em Portugal ou no Rio de Janeiro, especialmente as Ordenações Filipinas.

${ }^{72}$ Para ampla análise dos propósitos do Código de Ribas, cf. SANTOS, Moacyr Amaral dos. Ações cominatórias no direito brasileiro. São Paulo: Max Limonad, 1969. v. 1, p. 22-23.

${ }^{73}$ Vale a nota que na federação suíça, de dimensões e diferenças regionais bem inferiores que a brasileira, a Constituição Federal ainda mantém na esfera dos Cantões (Estados) a competência para legislar sobre
} 
continuando o Regulamento n. 737 a vigorar apenas naqueles Estados que não adotaram um Código de Processo Civil particular (Decreto n. 763, de 19.09.1890), como o Estado de Goiás. $^{74}$

Previa a Constituição de 1891 - intocada esta regra pela emenda constitucional de 1926 - que competia ao Congresso Nacional legislar privativamente sobre direito processual da Justiça Federal (art. 34, § 23) ${ }^{75}$, enquanto o art. 65, § $2^{\circ}$ - considerado por muitos o principal dispositivo da Federação que se inaugurava - facultava aos Estados em geral "todo e qualquer poder, ou direito, que lhes não for negado por cláusula expressa ou implicitamente contida nas cláusulas expressas da Constituição". ${ }^{76}$ Por força desta regra de competência residual puderam os Estados legislar sobre processo civil e penal.

A autonomia dos Estados em matéria processual foi recebida com aplausos por boa parcela da doutrina. O poder conferido a eles para legislar sobre processo representava "emulação determinante de importantes progressos jurídicos". 77

Progressos jurídicos estes, é conveniente destacar, que frutificaram, a partir de 1905 (Código Estadual do Pará), em alguns Códigos Estaduais do mais alto rigor técnico e científico (entre os quais costumeiramente se destaca os Códigos Estaduais de São Paulo

processo (MOREIRA, José Carlos Barbosa. A importação de modelos jurídicos. In: Temas de direito processual civil: $8^{a}$ série. São Paulo: Saraiva, 2004. p. 259). Também na federação mexicana a Constituição Federal (art. 121) autoriza os Estados a legislar sobre processo, de modo que cada um deles disciplina o tema conforme as particularidades locais (ALCALÁ-ZAMORA e CASTILLO, Niceto. Derecho procesal mexicano. México: Porruá, 1976. v. 1, p. 15-30).

${ }^{74}$ Conforme nos noticiou Antonio Luiz da Câmara Leal, Código de Processo Civil e Commercial do Estado de São Paulo comentado. São Paulo: Acadêmica, 1932. v. 4, p. 383.

${ }^{75} \mathrm{O}$ Decreto n. 3.084/1898 organizou a Justiça Federal e seu processo (Consolidação das leis referentes à Justiça Federal).

${ }^{76}$ A comissão que o Governo Provisório formou após a proclamação da República (1889-1891) para elaborar o projeto da Constituição Federal - conhecida como "Comissão dos Vinte e Um" - não pretendia a autonomia absoluta dos Estados em matéria processual. A redação da Carta Constitucional que por eles foi proposta era vazada nos seguintes termos: "Compete ao Congresso Nacional: Art. 13. Organizar, no prazo máximo de cinco anos, a codificação das leis civis, comerciais e criminais que devem regular as respectivas relações de direito em todo território nacional, bem como a codificação das leis do processo, sendo lícito aos Estados alterar as disposições de tais leis em ordem de adaptá-las convenientemente às suas condições particulares. Excedido esse prazo sem estar feito o trabalho de codificação, fica livre aos Estados organizar por si as codificações das leis" (MIRANDA, Francisco Cavalcanti Pontes de. Comentários ao Código de Processo Civil (1939). 2. ed. Rio de Janeiro: Revista Forense, 1958. t. 1, p. 40). Cf. também HORTA, Raul Machado. Unidade e dualidade da magistratura. Revista de Direito Público, São Paulo, v. 21, n. 87, p. 3542, jul./set. 1988.

${ }^{77}$ VALLADÃO, Haroldo. História do direito especialmente do direito brasileiro. Rio de Janeiro: Freitas de Bastos, 1973. p. 138. 
de 1930, da Bahia, do Distrito Federal e do Rio Grande do Sul) ${ }^{78}$, os quais influenciaram de modo bastante especial as legislações unificadas que os sucederam.

Obviamente, havia garantias mínimas que os Códigos Estaduais deveriam respeitar, condição esta altamente compatível com o regime federalista implantado, que, conforme já anotamos acima, concede ao Poder Constituinte competência para o estabelecimento de standarts mínimos de padronização nacional. $\mathrm{O}$ art. 72 de nossa primeira Carta Republicana ${ }^{79}$ estabelecia trinta e uma garantias constitucionais de observação compulsória pelos Estados Membros, muitas delas exclusivamente voltadas à formatação do direito processual civil ( $§ 15,16,18,23,28,29$ e 30).

Na Constituição Federal de 1934 (art. 5º XIX, “a”, e $\left.\S 3^{\circ}\right)^{80}$, o Poder Central da República resgatou para si, nos moldes do que já ocorria naturalmente no Estado Simples Imperial, a competência privativa para legislar sobre processo. Manteve, todavia, a competência suplementar e complementar do Estado membro para adequações locais, regra esta integralmente repetida na outorgada Constituição Getulista de 1937 (artigos 16, 18 e parágrafo único). ${ }^{81}$

\footnotetext{
${ }^{78}$ Para breve análise dos Códigos Estaduais, cf. WAMBIER, Teresa Arruda Alvim. Os agravos no CPC brasileiro. 4. ed. São Paulo: Ed. Revista dos Tribunais, 2005. p. 50-57.

${ }^{79}$ Art 72 - A Constituição assegura a brasileiros e a estrangeiros residentes no País a inviolabilidade dos direitos concernentes à liberdade, à segurança individual e à propriedade, nos termos seguintes: $\S 15$ Ninguém será sentenciado senão pela autoridade competente, em virtude de lei anterior e na forma por ela regulada; § 16 - Aos acusados se assegurará na lei a mais plena defesa, com todos os recursos e meios essenciais a ela, desde a nota de culpa, entregue em 24 horas ao preso e assinada pela autoridade competente com os nomes do acusador e das testemunhas; § 18 - É inviolável o sigilo da correspondência; $\S 19$ - Nenhuma pena passará da pessoa do delinqüente; $\S 23$ - À exceção das causas que, por sua natureza, pertencem a Juízos especiais, não haverá foro privilegiado; § 28 - Por motivo de crença ou de função religiosa, nenhum cidadão brasileiro poderá ser privado de seus direitos civis e políticos nem eximir-se do cumprimento de qualquer dever cívico; $§ 29$ - Os que alegarem motivo de crença religiosa com o fim de se isentarem de qualquer ônus que as leis da República imponham aos cidadãos, e os que aceitarem condecoração ou títulos nobiliárquicos estrangeiros perderão todos os direitos políticos; § 30 - Nenhum imposto de qualquer natureza poderá ser cobrado senão em virtude de uma lei que o autorize.

${ }^{80}$ Art. 34. Compete privativamente à União: XIX - legislar sobre: a) direito penal, comercial, civil, aéreo e processual, registros públicos e juntas comerciais. $\S 3^{\circ}$ - A competência federal para legislar sobre as matérias dos números XIV e XIX, letras $c$ e $i$, in fine, e sobre registros públicos, desapropriações, arbitragem comercial, juntas comerciais e respectivos processos; requisições civis e militares, radiocomunicação, emigração, imigração e caixas econômicas; riquezas do subsolo, mineração, metalurgia, águas, energia hidrelétrica, florestas, caça e pesca, e a sua exploração não exclui a legislação estadual supletiva ou complementar sobre as mesmas matérias. As leis estaduais, nestes casos, poderão, atendendo às peculiaridades locais, suprir as lacunas ou deficiências da legislação federal, sem dispensar as exigências desta.

${ }^{81}$ Art 16 - Compete privativamente à União o poder de legislar sobre as seguintes matérias: XVI - o direito civil, o direito comercial, o direito aéreo, o direito operário, o direito penal e o direito processual. Art 18 Independentemente de autorização, os Estados podem legislar, no caso de haver lei federal sobre a matéria, para suprir-lhes as deficiências ou atender às peculiaridades locais, desde que não dispensem ou diminuam as exigências da lei federal, ou, em não havendo lei federal e até que esta regule, sobre os seguintes assuntos: g) processo judicial ou extrajudicial. Parágrafo único - Tanto nos casos deste artigo, como no do artigo anterior, desde que o Poder Legislativo federal ou o Presidente da República haja expedido lei ou regulamento sobre a matéria, a lei estadual terse-á por derrogada nas partes em que for incompatível com a lei ou regulamento federal.
} 
Ao lado de vozes que louvaram a iniciativa unificadora, muitas outras se levantavam contra a inexistência de autonomia legislativa dos Estados Membros em matéria processual.

De um lado se alertava para a "funesta simetria nas leis de um país vastíssimo", ou que a centralização criava "um país oficial diferente do país real em sentimentos e opiniões diferentes". ${ }^{82}$

De outro lado, vinham aplausos, sob o fundamento de que "as conseqüências decorrentes desta fragmentação legislativa não foram das mais positivas" ${ }^{83}$, e que o pouco desenvolvimento da ciência processual brasileira se devia ao fato de que, em todo o país, pesquisadores, juízes e advogados não teriam se dedicado à feitura e aplicação da mesma lei.

Por isto, em determinados momentos da primeira República, dizia-se, em manifesto tom provocativo, que era mais fácil ao jurista "informar-se da legislação processual dos Estados estrangeiros do que da legislação processual de algumas partes do Brasil". ${ }^{84}$

Os Códigos Processuais dos Estados, todavia, não foram automaticamente revogados. O desaparecimento das legislações estaduais só se daria na medida em que o Poder Legislativo Central - exercendo a plenitude da competência processual reconhecida nas Cartas de 1934 e 1937 - restabelecesse a unidade do direito processual na Federação, algo que só aconteceu, parcialmente, com a Lei n 319, de 25 de novembro de 1936 (que uniformizava o sistema recursal em todo território nacional), e após, de maneira definitiva e completa, com legislação processual civil unificada de 1939 (Decreto-lei n. 1.608, de 18.09.1939).

\footnotetext{
${ }^{82}$ BASTOS, Aureliano Cândido Tavares. A província: estudo sobre a descentralização no Brasil, cit., p. 116.

${ }^{83}$ ALVIM NETTO, José Manoel de Arruda. Manual de direito processual civil. 8. ed. São Paulo: Ed. Revista dos Tribunais, 2003. p. 55.

${ }^{84}$ MIRANDA, Francisco Cavalcanti Pontes de. Comentários ao Código de Processo Civil (1939), cit, t. 1, p. 37. O autor ainda anotava que reservando a Constituição Federal de 1891 a competência privativa da União para legislar sobre direito civil (art. 34, n. 23), extremamente comuns eram os conflitos causados pela incerteza a respeito da fronteira entre direito material e direito processual, havendo, em muitos códigos estaduais, disposições de duvidosa constitucionalidade sobre direito civil, como questões sobre prova, prescrição, decadência, etc (p. 35 e 41), enquanto que a União, fingindo legislar sobre direito material (que era de sua competência privativa), contrabandeava normas de direito processual dentro delas (cf. também ALENCAR, Luiz Carlos Fontes de. A federação brasileira e os procedimentos em matéria processual, cit., p. 185). Em outra passagem da mesma obra, o mais conhecido jurista Alagoano dizia - com aguda crítica ao Ministro da Justiça Campos Sales - que a maior prova de que a "teimosia" pluralista não tinha sentido, se obtinha coma análise dos próprios Códigos Estaduais: imitavam-se reciprocamente, um a um, sem criatividade alguma, algo que demonstrava a desnecessidade de autonomia legislativa dos Estados membros na matéria (p. 38-39).
} 
Enquanto o Poder Legislativo da União não exerceu seu papel, a pluralidade de legislações em matéria processual manteve-se intacta, ressalvada a impossibilidade dos Estados alterarem suas próprias normatizações processuais a partir da vigência da Carta Constitucional de 1934 (16.07.1934), por absoluta falta de competência constitucional.

Na Carta democrática de 1946 manteve-se a competência da União para legislar privativamente sobre processo (art. $5^{\circ}, \mathrm{XV}$, “a”), bem como a competência complementar dos Estados $\left(\operatorname{art} .6^{\circ}\right){ }^{85}$

O golpe militar vinte e um anos após não trouxe alterações neste quadro, pois mesmo com a emenda constitucional n. 01, de 1969, a Constituição Federal de 1967 manteve a competência privativa da União para legislar sobre processo (art. 8, XVII, "b”), e a possibilidade dos Estados legislarem de modo complementar $\left(\operatorname{art} .8^{\circ}, \S 2^{\circ}\right){ }^{86}$

Foi na vigência desta Carta Constitucional que veio à tona no nosso atual Código de Processo Civil (Lei n. 5.869 de 11 de janeiro de 1973), diversas vezes emendado e remendado por dezenas de leis federais.

\subsubsection{Competência para legislar sobre processo e procedimento na Constituição Federal de 1988}

Apesar da manutenção da competência privativa da União para legislar sobre processo (art. 22, I, da Constituição Federal, que ainda acresceu ao caput do dispositivo a expressão exclusivamente não constante da Constituição Federal de 1967), o art. 24 da Constituição Federal - que trata da competência concorrente da União, dos Estados Federados e do Distrito Federal (excluídos os Municípios) - estabelece em seu inciso XI, que compete a todos eles legislar sobre procedimentos em matéria processual, algo que, sem representar retorno à autonomia estadual para legislar sobre processo - efetivamente foi novidade no âmbito da Carta Constitucional de 1988, já que a separação entre processo e procedimento sequer foi cogitada nas Cartas Constitucionais anteriores.

\footnotetext{
${ }^{85}$ Art $5^{\circ}$ - Compete à União: XV - legislar sobre: a) direito civil, comercial, penal, processual, eleitoral, aeronáutico e do trabalho. Art $6^{\circ}$ - A competência federal para legislar sobre as matérias do art. $5^{\circ}, n^{\circ} \mathrm{XV}$, letras $b, e, d, f, h, j, l, o$ e $r$, não exclui a legislação estadual supletiva ou complementar.

${ }^{86}$ Art. $8^{\circ}$. Compete à União: XVII - legislar sobre: b) direito civil, comercial, penal, processual, eleitoral, agrário, aéreo, marítimo e do trabalho; $\S 2^{\circ}$ - A competência da União não exclui a dos Estados para legislar supletivamente sobre as matérias das letras c, $d, e, n, q$ e $v$ do item XVII, respeitada a lei federal.
} 
A opção do constituinte de 1988 em permitir aos Estados membros e ao Distrito Federal que legislem sobre procedimento em matéria processual deve-se a fato de que, com as dimensões continentais de nosso país e as diferenças regionais gritantes, o regramento genérico emanado pela União havia de ser compatibilizado às realidades locais pela lei estadual ou distrital, tudo em prol da sua ideal aplicação. ${ }^{87}$

Conforme já advertimos em outro momento, em matéria de competência concorrente os parágrafos do art. 24 da Constituição Federal estabelecem que a União limitar-se-á ao estabelecimento de normas gerais $\left(\S 1^{\circ}\right)$, prerrogativa esta que não exclui a competência complementar dos Estados e do Distrito Federal no estabelecimento, também, destas normas gerais $\left(\S 2^{\circ}\right)$. Não existindo lei federal sobre normas gerais, os Estados exercerão competência legislativa plena (competência supletiva) $\left(\S 3^{\circ}\right)$, cujo produto terá sua vigência suspensa em caso de superveniência de lei federal sobre normas gerais em sentido contrário $\left(\S 4^{\circ}\right)$. E mesmo que haja normas gerais sobre o assunto editadas pelo Poder Central, compete ao Estado e ao Distrito Federal a edição de normas específicas, detalhadas, minuciosas, hábeis a particularizar e adaptar a matéria de sua competência à realidade regional (competência suplementar).

Quanto a edição de normas processuais, portanto, não há dificuldade alguma: só à União é lícito legislar.

Mas no que toca ao procedimento em matéria processual, como se trata de repartição vertical desta competência entre União, Estados e Distrito Federal, as seguintes são as conclusões: a) a União só pode editar normas gerais em matéria de procedimento, isto é, legislação fundamental, competindo aos Estados e Distrito Federal a edição de normas suplementares, exclusivamente com o propósito de atender às particularidades regionais; b) quedando-se omissa a União na edição destas normas gerais - e não há necessidade de que os outros entes políticos aguardem qualquer prazo para elaboração destas normas, ou interpelem a União para isto - a competência dos Estados federados e Distrito Federal no tocante ao procedimento é plena, isto é, podem editar leis gerais e particulares para valerem em seu território, sempre condicionadas às peculiaridades locais ${ }^{88}$; e c) todavia, na superveniência de lei federal geral sobre procedimentos em

\footnotetext{
${ }^{87}$ Cf. CHAGAS, Magno Guedes. Federalismo no Brasil, cit., p. 79.

${ }^{88}$ Edson Ribas Malachini indica, com correção, estar mal alocada a expressão "para atender a suas particularidades locais" no art. $24, \S 3^{\circ}$, da CF, pois que cuidando o dispositivo da hipótese em que a União é omissa na elaboração de normas gerais, a competência dos Estados e Distrito Federal é plena, tanto para
} 
matéria processual, as normas gerais editadas pelos Estados e Distrito Federal - mas não as específicas que atendem às particularidades locais - terão sua vigência suspensa no que contrariar as regras genéricas impostas pela União ${ }^{89}$, de modo que se pode dizer estarem elas sujeitas a condição resolutiva (até a vigência de lei federal superveniente).

A grande dificuldade, contudo, não se encontra propriamente na interpretação dos dispositivos constitucionais que tratam da competência para legislar sobre processo ou procedimento, que pelo visto não demandam maiores divagações.

O tormento do intérprete - e não encontramos quanto a isto trabalhos de fôlego mesmo após quase 20 anos da vigência da Constituição Federal de 1988 - é na definição, primeiro, de quais normas seriam processuais e quais seriam as normas procedimentais em matéria processual - conseqüentemente definindo a competência privativa da União sobre as primeiras e a concorrente em relação às outras - e depois, já estabelecidas quais são as normas processuais e quais são as procedimentais, saber quais destas últimas são genéricas (de competência da União) e quais são particulares (de competência dos Estados membros e do Distrito Federal). ${ }^{90}$

\subsubsection{Normas processuais e normas procedimentais}

A identificação de quais seriam normas processuais e quais seriam as normas procedimentais passa, necessariamente, pela análise e distinção dos conceitos de processo e procedimento. Obviamente, normas processuais seriam aquelas a regulamentar assuntos

\footnotetext{
as normas gerais não editadas quanto para as normas particulares, só estas atendentes das especificidades locais. Melhor alocada estaria a expressão no $\S 2^{\circ}$ do dispositivo, que cuida exatamente da competência suplementar dos Estados e Distrito Federal para atender às particularidades regionais (MALACHINI, Édson Ribas. A Constituição Federal e a legislação concorrente dos Estados e do Distrito Federal em matéria de procedimentos. Revista Forense, Rio de Janeiro, v. 89, n. 324, p. 52, out./dez. 1993).

${ }^{89}$ Esta última regra, que já estava no art. 18, parágrafo único, da CF de 1937, tem origem no direito alemão e representa o ideário não verdadeiro de que "direito federal corta direito local" (Cf. MIRANDA, Francisco Cavalcanti Pontes de. Comentários à Constituição de 1967 (com a emenda n. 1 de 1969), cit., p. 177).

${ }^{90}$ Compartilhando de certa forma nossa aflição, Luiz Rodrigues Wambier aduz que, apesar de não haver dúvida sobre a distinção teórica entre processo e procedimento, inúmeras são as dificuldades em "se saber se certa norma tem natureza processual ou procedimental, isto é, que temas de normatização processual são encartáveis exclusivamente na noção de normas não gerais de procedimento, com competência legislativa dos Estados membros. E, por outro lado, quais são de natureza processual, a respeito de que se manteve exclusiva competência da União Federal?" (Sentença civil: liquidação e cumprimento, cit., p. 91-92). Esta mesma dificuldade na diferenciação entre normas processuais e procedimentais também é apontada por CINTRA, Antonio Carlos; GRINOVER, Ada Pellegrini; DINAMARCO, Cândido Rangel. Teoria geral do processo. 21. ed. São Paulo: Malheiros Ed., 2005. p. 110.
} 
relacionados ao processo, enquanto as outras cuidariam dos procedimentos em matéria processual.

\subsubsection{Processo e normas processuais}

O termo processo não era usado no Direito Romano, tendo sido empregado pela primeira vez entre os Canonistas da Idade Média. A palavra deriva do verbo grego prosek ou proseko e significa "vir de trás e ir para adiante". Em latim vem de procedere: pro (adiante) e cedere (seguir, andar, caminhar). ${ }^{91}$

Exatamente por força de seu significado etimológico, o processo, por muito tempo, foi visto como simples sucessão de atos processuais. Não são poucos os conceitos que o colocam neste plano. ${ }^{92}$

Ocorre que processo, sendo notoriamente entidade complexa, pode ser encarado em acepção ampla ou formal e restrita ou substancial. Na primeira, abrange qualquer combinação de atos tendentes a uma finalidade conclusiva, conceito, portanto, equivalente ao de procedimento ${ }^{93}$. Na segunda acepção, mais técnica, processo é o instrumento pelo qual o Estado exerce a Jurisdição, o autor o direito de ação e o réu o direito de defesa, havendo entre seus sujeitos (partes e juiz), uma relação jurídica diversa da relação jurídica de direito material: a relação jurídica processual. ${ }^{94}$

\footnotetext{
${ }^{91}$ Os termos processos e direito processual são recentes na história da ciência jurídica. Na origem, o que hoje se designa por processo era o procedimento (procedura), o que contribui, convenha-se, para alimentar a confusão terminológica. Sobre a evolução destes conceitos, cf. SATTA, Salvatore. Dalla procedura al diritto processuale civile. Rivista Trimestrale di Diritto e Procedura Civile, Milano, ano 18, p. 28-36, mar. 1964.

${ }^{92}$ CINTRA, Antonio Carlos; GRINOVER, Ada Pellegrini; DINAMARCO, Cândido Rangel. Teoria geral do processo, p. 285. Cf., também, YARSHELL, Flávio Luiz. Tutela jurisdicional específica nas obrigações de declaração de vontade. São Paulo: Malheiros Ed., 1993. p. 136.

${ }^{93}$ Daí porque hoje não é incomum ouvir referências a processos fora do Poder Judiciário (processo administrativos, processo legislativo, etc).

${ }^{94}$ Autonomia primitivamente e notoriamente revelada por Oskar Von Bülow em 1868 (BÜLOW, Oskar von. La teoria de las excepciones procesales y los presupuestos procesales. Buenos Aires: Ejea, 1964. passim), mas posteriormente desenvolvida com algumas particularidades próprias por Chiovenda (CHIOVENDA, Giuseppe. Instituições de direito processual civil. Tradução de Paolo Capitanio. Campinas: Bookseller, 1998. v. 1, p. 77-88, v. I); Carnelutti (CARNELUTTI, Francesco. Instituições do processo civil. Tradução de Adrián Sotero de Witt Batista. Campinas: Servanda, 1999. v. 1, p. 339-341) e Liebman (LIEBMAN, Enrico Tullio. L'opera scientifica di James Goldshimidt e la teoria del rapporto processuale. In: Problemi del processo civile. Napoli: Morano, 1962. p. 132 e ss.).
} 
A partir desta teoria de processo como relação jurídica autônoma - que conta com ampla aceitação na doutrina nacional e internacional - inúmeras outras teorias sobre a natureza jurídica do processo foram surgindo ${ }^{95}$.

Parte da doutrina entende que processo representa a ciência processual, ou seja, o conjunto de regras e princípios que determinam as bases da organização judiciária e da competência dos juízes, estabelecendo a direção dos procedimentos judiciais ${ }^{96}$. Adotado este entendimento, normas processuais seriam todas aquelas que se prestam a informar a ciência processual, entre as quais também estão incluídas as normas procedimentais e as de organização judiciária ${ }^{97}$. Pela abrangência do conceito, imprestável ele para distinção pretendida.

Outros autores vêem a expressão processo com três significados distintos: um de sucessão de momentos em que se realiza um ato jurídico; outro como causa; e, finalmente, como sinônimo de autos ${ }^{98}$. Esta posição nos permite, embora sem a segurança desejada, traçar distinção entre as normas de natureza processual ou procedimental. As que disciplinam a sucessão de momentos em que se realiza o ato jurídico processual seriam normas procedimentais. As que cuidam do processo como causa - isto é, as regras

\footnotetext{
${ }^{95}$ Entre estas teorias, apenas a título exemplificativo, chamo a destaque, além da já citada teoria do processo como relação jurídica (Bülow), a teoria do processo como contrato, muito em voga no direito romano (Pothier); a de processo como quase-contrato (Guényvau); processo como instituição (Jayme Guasp e Couture); a de processo como entidade jurídica complexa (Foschini); a muito interessante teoria do processo como situação jurídica de Goldshimidt, apesar das severas críticas que ela sofreu de Liebman sob o fundamento de não ser propriamente publicística (L'opera scientifica di James Goldshimidt e la teoria del rapporto processuale, cit., p. 132 e ss.); e a também interessante teoria de Fazzalari, que vê o processo como procedimento em contraditório. Para uma rápida análise de todas estas teorias, cf. CINTRA, Antonio Carlos; GRINOVER, Ada Pellegrini; DINAMARCO, Cândido Rangel. Teoria geral do processo, cit., p. 286-290. O desenvolvimento destas teorias, todavia, não nos interessa neste momento. Dois são os motivos: primeiro, pois o que aqui devemos enfrentar é a conceituação de processo exclusivamente para identificação de quais são as normas que o regulam (normas processuais), sem o que não conseguiremos estabelecer com precisão sobre o que recai a competência legislativa da União e dos Estados membros no direito brasileiro; e segundo, porque à exceção das teorias mais primitivas e há muito superadas (processo como contrato ou quase-contrato), não conseguimos vislumbrar diferenças na adoção de quaisquer das outras teorias para determinar o alcance do que seriam as normas processuais.

${ }^{96}$ SILVA, De Plácido e. Vocabulário jurídico. 9. ed. Rio de Janeiro: Forense, 1986. v. 4, p. 456. Em sentido estrito, aduz que processo é o conjunto de ato que devem ser executados em ordem previamente estabelecida para que se investigue e se solucione as pretensões submetidas à tutela jurisdicional, acepção muito próxima da idéia de procedimento.

${ }^{97}$ É a classificação de normas processuais que, de maneira bastante objetiva, é defendida por Arruda Alvim, a falar em normas processuais strictu sensu, normas processuais civis estritamente procedimentais e normas processuais civis lato sensu, estas últimas referentes à organização judiciária (ALVIM NETTO, José Manoel de Arruda. Manual de direito processual civil, cit., v. 1, p. 135-147). Em sentido semelhante cf. CINTRA, Antonio Carlos; GRINOVER, Ada Pellegrini; DINAMARCO, Cândido Rangel. Teoria geral do processo, cit., p. 91.

${ }^{98}$ COUTORE, Eduardo J. Vocabulário jurídico. Buenos Aires: Depalma, 1976. p. 480.
} 
reguladoras do conflito e de sua solução - seriam normas processuais. Por muito vago este conceito fica totalmente descartado.

Enrico Tullio Liebman conceitua processo como uma série de atos jurídicos que se sucedem e ligados por uma finalidade comum, a sentença, que só é alcançada através do exercício de direitos, deveres e ônus entre os sujeitos do processo ${ }^{99}$. Definição que fez escola, e é acompanhada por Pontes de Miranda ${ }^{100}$, Alfredo de Araújo Lopes da Costa ${ }^{101}$, Moacyr Amaral do Santos ${ }^{102}$, e pela grande maioria da doutrina brasileira, que consegue visualizar com clareza no processo as suas duas facetas: substancial e formal; relação jurídica processual e procedimento.

Processo - cuja noção é eminentemente teleológica, finalística, voltada para o resultado almejado - é o conjunto de todos os atos necessários para a obtenção de uma providência jurisdicional num determinado caso concreto, podendo ele conter um ou mais procedimentos, ou, inclusive, apenas um procedimento incompleto.

Com efeito, se a parte não recorre da sentença de primeiro grau só há um procedimento; se ela recorre, há dois procedimentos (um em primeiro grau e outro em segundo grau); enquanto que se houver extinção prematura do feito, haverá menos de um procedimento. ${ }^{103}$

Mas além da faceta organizacional do processo e dos atos processuais (o procedimento) - mais simples ou mais complexa a depender do caso concreto - há também uma relação que une entre si os sujeitos processuais (partes, juiz, advogados, auxiliares da justiça), impondo-lhes deveres, direitos, ônus e sujeições, relação esta autônoma à de direito material e que, como tal, deve ter regras próprias (relação jurídica processual).

\footnotetext{
${ }^{99}$ LIEBMAN, Enrico Tullio. Manual de direito processual civil, cit., v. 1, p. 33.

${ }^{100}$ MIRANDA, Francisco Cavalcanti Pontes de. Tratado das ações. São Paulo: Ed. Revista dos Tribunais, 1970. t. 1, p. 287.

${ }^{101}$ COSTA, Alfredo de Araújo Lopes da. Manual elementar de direito processual. rev. e atual. por Sálvio de Figueiredo Teixeira. 3. ed. Rio de Janeiro: Forense, 1982. p. 43.

${ }^{102}$ SANTOS, Moacyr Amaral dos. Primeiras linhas do direito processual civil. Atualizada por Aricê Moacyr Amaral dos Santos. 23. ed. São Paulo: Saraiva, 2004. v. 1, p. 11-13.

${ }^{103} \mathrm{Cf}$. CARNELUTTI, Francesco. Instituições do processo civil, cit., v. 1, p. 472-473; LIEBMAN, Enrico Tullio. Manual de direito processual civil, cit., v. 1, p. 229; PASSOS, J.J. Calmon de. Comentários ao Código de Processo Civil. 4. ed. Rio de Janeiro: Forense, 1983. v. 3, p. 3; e DINAMARCO, Cândido Rangel. Os efeitos dos recursos. In: 2004. p. 106. . A nova era do processo civil. São Paulo: Malheiros Ed.,
} 
Às normas que disciplinam esta segunda faceta do processo (relação jurídica processual), que cuidam dos princípios e das disposições destinadas a possibilitar a administração da Justiça, emprestamos a natureza de normas puramente processuais ou normas processuais stricto sensu ${ }^{104}$. São elas as que regulam a atuação dos sujeitos processuais: partes (ônus, deveres, obrigações, faculdades, etc), juiz (competência, poderes, etc) e auxiliares (atribuições); a capacidade e modo de exercer o direito de ação (condições da ação, pressupostos processuais, intervenção de terceiros); a maneira de se postular ou se defender em juízo (petição inicial, respostas, provas, recursos e outros meios de impugnação, etc.); ou os efeitos da prestação da jurisdicional (eficácia da sentença e coisa julgada). ${ }^{105}$

São normas puramente processuais - e, portanto, de competência privativa da União - todas aquelas relacionados à gênese da relação jurídica processual, como jurisdição, ação, defesa e contraditório, ${ }^{106}$ entre as quais se inclui a definição da capacidade e legitimação das partes, a disciplina da prova, dos efeitos da sentença e da coisa julgada. $^{107}$

\footnotetext{
${ }^{104}$ Esta é a nomenclatura utilizada por Arruda Alvim para definir as normas "diretamente ligadas ao processo em si, regulando, por excelência, o processo contencioso, as atividades das partes, o reflexo destas atividades nas próprias partes e, eventualmente, sobre terceiros, o órgão jurisdicional e sua atividade, bem como a atividade dos auxiliares da Justiça" (ALVIM NETTO, José Manoel de Arruda. Manual de direito processual civil, cit., v. 1, p. 135).

${ }^{105} \mathrm{Em}$ sentido parcialmente semelhante cf. Sérgio Bermudes, a apontar que os Estados não podem legislar sobre "condições da ação, os pressupostos processuais, a intervenção de terceiros, as provas, os recursos, coisa julgada, elementos, como se sabe, atinentes às pessoas que reclamam a jurisdição, à prestação jurisdicional, à sua eficácia; instituições do processo e não do procedimento" (Procedimentos em matéria processual, cit., p. 164). Também Edson Ribas Malachini, para quem "as regras sobre competência; a exigência de citação e das intimações, atos de comunicação processual que se constituem em requisito fundamental do contraditório; as regras sobre os pressupostos processuais (inclusive sobre as nulidades) e as chamadas condições da ação; sobre os meios de prova, os requisitos da sentença, os recursos interponíveis, a coisa julgada, os pressupostos de admissibilidade da ação rescisória e da ação executiva e sobre certo princípio inerentes ao processo de execução certamente não são normas meramente procedimentais, mas - atendendo-se à dicotomia estabelecida na doutrina e no próprio Código de Processo Civil (especialmente o Título VII do Livro I e seus artigos 270 a 273), e que parece corresponder à natureza das coisas - normas processuais" (MALACHINI, Édson Ribas. A Constituição Federal e a legislação concorrente dos Estados e do Distrito Federal em matéria de procedimentos, cit., p. 53-54). E Ernane Fidélis dos Santos, a indicar que são normas de processo propriamente ditas as "relativas à jurisdição e competência, à ação e suas condições, à relação processual, sua formação, extinção e suspensão, às partes, aos atos processuais, do juiz e das partes, à matéria de prova e recursos" (SANTOS, Ernane Fidélis dos. Manual de direito processual civil. 10. ed. São Paulo: Saraiva, 2006. v. 3, p. 2).

${ }^{106} \mathrm{Cf}$. WAMBIER, Luiz Rodrigues. Sentença civil: liquidação e cumprimento, cit., p. 92.

${ }^{107}$ Arruda Alvim, embora apontando que estes assuntos não podem ser disciplinados por normas procedimentais não gerais - com o que não concordamos em absoluto, já que para nós temas como ação, defesa, contraditório, capacidade e legitimação das partes, disciplina da prova, efeitos da sentença e da coisa julgada, entre outros, são normas processuais (e não procedimentais) - corretamente aduz serem eles de competência exclusiva da União (ALVIM NETTO, José Manoel de Arruda. Manual de direito processual civil, cit., v. 1, p. 137-142).
} 
Mesmo as normas puramente processuais, entretanto, não dispensam regras procedimentais respectivas, condição essencial de funcionalidade daquelas. ${ }^{108}$ É um erro comum e muitas vezes cometido a separação absoluta que é feita entre processo e procedimento, conseqüentemente entre normas processuais e normas procedimentais, como se o ato processual pudesse sobreviver sem procedimento que lhe dê forma. ${ }^{109}$ Mesmo os institutos previstos nas normas puramente processuais demandam disciplina procedimental, algo que só pode ser feito por normas procedimentais.

Há, portanto, dois tipos de normas procedimentais: a) as puramente procedimentais (aquelas idealizadas a reger o procedimento processual estritamente considerado, isto é, a combinação dos atos processuais entre si e sua relação); e b) as normas acidentalmente procedimentais (idealizadas a disciplinar o procedimento para a realização dos institutos contemplados nas normas processuais).

Sobre estas normas que discorremos a seguir.

\subsubsection{Procedimento e normas procedimentais}

$\mathrm{Na}$ linguagem comum se usam, com freqüente promiscuidade, os termos processo e procedimento, designações que efetivamente não se confundem. ${ }^{110}$

Procedimento vem do latim procedere (andar para frente), e que não tem o mesmo sentido de processo, pois representa um meio exterior do que nos utilizamos, do começo ao fim, para realizar o objetivo intentado. O procedimento seria o invólucro; o processo a íntima substância. ${ }^{111}$

\footnotetext{
${ }^{108}$ ALVIM NETTO, José Manoel de Arruda. Manual de direito processual civil, cit., v. 1, p. 136.

${ }^{109}$ Cf. TORNAGHI, Hélio. Comentários ao Código de Processo Civil. 2. ed. São Paulo: Ed. Revista dos Tribunais, 1978. v. 2, p. 17-18.

${ }^{110}$ Cf. GAJARDONI, Fernando da Fonseca. Direito processual civil: processo cautelar. São Paulo: Ed. Revista dos Tribunais, 2006. v. 4, p. 15-16. Apesar disto, Calamandrei aponta a semelhança e dificuldade em se traçar uma distinção clara entre os dois institutos, já que o significado de processo é muito afim da expressão procedimento (CALAMANDREI, Piero. Instituciones de derecho procesal civil. Tradução de. Santiago Sentis Melendo. Buenos Aires: Depalma, 1943. v. 1, p. 241). Esta semelhança também é indicada por Jedor Pereira Baleeiro, ao se referir ao processo (conteúdo) e ao procedimento (continente) como irmãos siameses (BALEEIRO, Jedor Pereira. Processo e procedimento. Revista do Curso de Direito da Universidade Federal de Uberlândia, Uberlândia, v. 2, p. 220, dez. 1991).

${ }^{111} \mathrm{BÜLOW}$, Oskar von. La teoria de las excepciones procesales y los presupuestos procesales, cit., p. 46.
} 
Mas a definição que fez mesmo história no direito brasileiro foi a de João Mendes de Almeida Júnior, citado por quase todos aqueles que se dedicam ao estudo do procedimento. ${ }^{112}$ Para ele, o processo é uma direção no movimento, enquanto que o procedimento é o modo de se mover e a forma em que é movido o ato. O processo é o movimento em sua forma intrínseca; o procedimento é o mesmo movimento em sua forma extrínseca ${ }^{113}$, tal como se revela aos nossos sentidos. ${ }^{114}$

O procedimento é, por isto, o processo em sua dinâmica, o modo pelo qual os diversos atos se relacionam na série constitutiva do processo, representando o modo do processo atuar em juízo (seu movimento), ${ }^{115}$ pouco importando a marcha que tome para atingir seu objetivo final - que pode ser uma sentença declaratória, constitutiva, desconstitutiva ou condenatória (processo de conhecimento), a apuração do quantum debeatur (liquidação de sentença), a satisfação do direito (processo de execução) ou a obtenção de uma garantia (processo cautelar) ${ }^{116}$ - ou se a marcha alcançará o seu objetivo final (sentenças terminativas).

O processo é formado por um conjunto de atos processuais que se iniciam com a apresentação e aceitação da demanda, e terminam das diversas maneiras que a lei admite. O procedimento é o modo como se desenvolve o processo, seus trâmites, a maneira de sê$10^{117}$, que pode ser ordinário, sumário, sumaríssimo ou especial; breve ou dilatado; escrito ou oral; com uma ou várias instâncias; com período de prova ou sem ela; e assim

\footnotetext{
${ }^{112}$ Embora não se possa deixar de reconhecer que coube aos administrativistas, e não propriamente aos processualistas, o desenvolvimento inicial da disciplina e conceito do procedimento, cujo modelo não é exclusivo da Justiça, mas de qualquer setor do ordenamento jurídico, como a Administração Pública, o Poder Legislativo, etc. (cf. NALINI, José Renato. Processo e procedimento - distinção e a celeridade da prestação jurisdicional. Revista dos Tribunais, São Paulo, ano 85, v. 730, p. 680, ago. 1996). Isto ocorreu porque os processualistas, influenciados pela teoria da relação jurídica de Bulow, acabaram por rejeitar a idéia de procedimento, só retomada na metade final do século passado (DINAMARCO, Cândido Rangel. $A$ instrumentalidade do processo. 5. ed. São Paulo: Malheiros Ed., 1996. p. 126).

${ }^{113}$ Niceto Alcalá-Zamora e Castillo aponta que o procedimento mostra o movimento dos atos da ação em juízo na sua forma extrínseca, enquanto o processo é, essencialmente, de índole finalística ou teleológica (ALCALÁ-ZAMORA e CASTILLO, Niceto. Proceso, autocomposición y autodefensa. 2 . ed. México: Unam, 1970. p. 115-116).

${ }^{114}$ ALMEIDA JÚNIOR, João Mendes. Direito judiciário brasileiro. Atualizada por João Mendes Neto. 6. ed. Rio de Janeiro: Freitas Bastos, 1960. p. 243-244.

${ }^{115}$ PASSOS, J.J. Calmon de. Comentários ao Código de Processo Civil, cit., v. 3, p. 9.

${ }^{116}$ SANTOS, Ernane Fidélis dos. Manual de direito processual civil. 11. ed. São Paulo: Saraiva, 2006. v. 1, p. 27. Cf., também, Sérgio Bermudes, para quem o processo é uma unidade, formada pelos atos, por intermédio dos quais se exerce a função jurisdicional, enquanto o procedimento é a ordem ou sucessão consoante a qual se desenvolvem e se sucedem estes atos (Procedimento em matéria processual, cit., p. 162-163).

${ }^{117}$ Paulo Heerdt aduz que "se o processo é um conjunto de atos que visam a um efeito jurídico final, procedimento será o modo ou a forma como se desenvolvem estes atos, ou seja, o conjunto de normas que estabelecem a conduta a ser observada no desenvolvimento da atividade processual" (HEERDT, Paulo. Sumarização do processo e do procedimento. Revista da Ajuris, Porto Alegre, n. 48, p. 81, mar. 1991).
} 
sucessivamente. ${ }^{118}$ Por isto, já se afirmou, com razão, que o procedimento é a medida do processo, ou melhor, o método de trabalho ou a pauta do processo. ${ }^{119}$

Conforme já explicitamos, processo é mais que procedimento, já que este é apenas uma das facetas daquele. Procedimento seria o rito do processo, isto é, a sequiência dos atos que se realizam no exercício da jurisdição, assim como a relação que entre estes atos se estabelece na série, variáveis segundo as exigências do direito material, ou segundo outras necessidades ou conveniências que impressionaram o legislador. Já processo seria o conjunto dos atos entre si encadeados e tendentes a uma finalidade comum, a sentença; ou, em outros termos, seria o procedimento acrescido da relação jurídica que se estabelece entre o juiz e as partes, com eclosão de deveres, direito, pretensões, ônus e sujeições. ${ }^{120}$

Não existe processo sem procedimento. ${ }^{121}$ Sem o procedimento se torna impossível definir o que seja processo, uma vez que ele é a estrutura a relação jurídica processual $^{122}$. O procedimento estabelecido em lei, como um iter a ser seguido para obtenção da tutela, prevê os atos, suas formas, as posições subjetivas (ativas e passivas) e a

${ }^{118}$ PALLARES, Eduardo. Diccionário de derecho procesal civil. 11. ed. México: Porrua, 1978. p. 635.

${ }^{119}$ Cf. FENECH, Miguel. El proceso penal. 3. ed. Madrid: Agesa, 1978. p. 185; e DINAMARCO, Cândido Rangel. A instrumentalidade do processo, cit., p. 131.

${ }^{120}$ Cf. FABRÍCIO, Adroaldo Furtado. Comentários ao Código de Processo Civil. 7. ed. Rio de Janeiro: Forense, 1995. v. 8, p. 2; e MALACHINI, Édson Ribas. A Constituição Federal e a legislação concorrente dos Estados e do Distrito Federal em matéria de procedimentos, cit., p. 50. De acordo com Antonio Scarance Fernandes, o procedimento é visto como elemento essencial do processo, "seja quando se afirma que o processo é o procedimento realizado em contraditório, seja quando se entende que é entidade complexa formada por um conjunto de atos e situações, seja quando é definido como procedimento animado pela relação jurídica processual" (FERNANDES, Antonio Scarance. Teoria geral do processo e do procedimento penal. São Paulo: Ed. Revista dos Tribunais, 2005. p. 13).

${ }^{121}$ Mas há procedimento sem processo? José Frederico Marques responde positivamente a esta indagação, indicando os feitos de jurisdição voluntária como exemplo (MARQUES, José Frederico. Ensaio sobre a jurisdição voluntária. Campinas: Millenium, 2000. p. 207). Também neste sentido, trilha Fazzalari, ao indicar que quando o procedimento contempla atos normais de desenvolvimento do processo sem que haja contraditório ele é mero procedimento, que para ser processo não prescinde daquele elemento (FAZZALARI, Elio. La giurisdizione volontaria: profilo sistemático. Padova: Cedam, 1953. p. 71-73). Mas Hélio Tornaghi, bem acompanhado por Dinamarco (A instrumentalidade do processo, cit., p. 127) e Ernane Fidélis dos Santos (Manual de direito processual civil, cit., v. 3, p. 371), nega terminantemente tal possibilidade. Utilizando-se de metáfora que originariamente é de Carnelutti (Instituições do processo civil, cit., v. 1, p. 472) afirma que se o processo fosse uma escada, o procedimento seria os seus degraus (algumas escadas com eles mais curtos, outras com eles mais espaçados). Separado da escada o degrau, perde a escada por completo o seu caráter específico. Por isso o procedimento destacado do processo pode ser qualquer outra coisa, menos procedimento (Comentários ao Código de Processo Civil, cit., v. 2, p. 17-18).

${ }^{122}$ Neste sentido Rogério Lauria Tucci, correto ao aduzir que o processo sempre se formaliza em ao menos um procedimento, a que corresponde a sua esquematização formal, razão pela qual pode ser ele conceituado como "um conjunto de atos, realizados, sucessiva e coordenadamente, pelo agente do Poder Judiciário - juiz ou tribunal que o dirige - seus auxiliares, e demais pessoas dele integrantes e participantes, a propósito da definição de uma relação jurídica material tornada litigiosa (processo extrapenal, marcadamente o civil), ou do solucionamento de um conflito de interesses de alta relevância social (processo penal); e, outrossim, quando necessário, de sua realização prática (execução), bem como de sua assecuração (cautela)" (TUCCI, Rogério Lauria. Processo e procedimentos penais. Revista dos Tribunais, São Paulo, ano 87, n. 749, p. 487, mar. 1998). 
dimensão temporal do processo (os prazos). Assim, sem o procedimento, a relação jurídica processual seria algo amorfo, disforme, sem ossatura. ${ }^{123}$

O procedimento, todavia, embora não possa ser destacado do processo a ponto de ser estudado como uma ciência autônoma ${ }^{124}$, também não pode ser encarado como simples ordenação de atos, sem maiores condicionamentos. Faz-se necessário que o procedimento seja realizado em contraditório e cercado de todas as garantias necessárias para que as partes possam sustentar suas razões, produzir provas, e colaborar na formação do convencimento do juiz. ${ }^{125}$

A sedimentação dessas idéias, por isto, obrou para que hoje se encontre pacificado o entendimento de que "o procedimento não deve ser apenas um pobre esqueleto sem alma, tornando imprescindível ao conceito a regulação das atividades das partes e do órgão judicial, conexa ao contraditório paritário e ainda ao fator temporal, a fatalmente entremear esta atividade". ${ }^{126}$

Assim, só haverá devido processo legal se o procedimento for regularmente desenvolvido, com a concretização de todos os seus respectivos componentes e corolários, e num prazo razoável. ${ }^{127}$

Em síntese, tem-se que enquanto o processo é um instrumento de atuação da Jurisdição, para o exercício do direito de ação e de defesa, composto, como regra, de

\footnotetext{
${ }^{123}$ WATANABE, Kazuo. Da cognição no processo civil. 2. ed. Campinas: Bookseller, 2000. p. 122.

${ }^{124}$ Esta foi a proposta apresentada por José Ovalle Favela, ao aduzir, ainda que em nomenclatura há bom tempo considerada obsoleta para designar a disciplina do processo, que "as normas que regulam o processo jurisdicional e os órgãos encarregados de levá-lo a cabo (normas que constituem o direito processual em seu sentido objetivo) formam só uma parte do que se chama direito instrumental. Este inclui, ademais do direito processual, as regras que disciplinam os procedimentos legislativos e administrativos. Para distinguir estes últimos podemos agrupá-los sob a expressão 'direito procedimental', tal como propõe Fix-zamudio. As normas de Direito instrumental ou formal podem ser classificadas: 1) Direito processual; 2) Direito procedimental" (OVALLE FAVELA, José. Teoria general del proceso. México: Harla, 1991. p. 40).

${ }^{125}$ Cf. PICARDI, Nicola. La sucessione processuale. Milano: Giufré, 1964. p. 23 e 58-65; e FAZZALARI, Elio. Istituzioni di diritto processuale. 7. ed. Padova: Cedam, 1994. p. 78-85; Proceso (teoria generale). In: Novissimo Digesto Italiano. Torino: UTET, 1966. v. 13, p. 1.067, n. 6. Não acreditamos, entretanto, como fazem os citados autores, que possa ser destacada a noção de relação jurídica processual do conceito de processo (que para eles já integra o procedimento), até porque o contraditório apontado como integrante do conceito pelos mestres italianos (processo é procedimento em contraditório) é um dos condicionamentos constitucionais da relação jurídica processual. Exatamente como nós, cf. WATANABE, Kazuo. Da cognição no processo civil, cit., p. 122; e CINTRA, Antonio Carlos; GRINOVER, Ada Pellegrini; DINAMARCO, Cândido Rangel. Teoria geral do processo, cit., p. 290-293.

${ }^{126}$ OLIVEIRA, Carlos Alberto Alvaro de. Do formalismo no processo civil. São Paulo: Saraiva, 1997. p. 112. Para Dinamarco esta nova ótica sobre o procedimento fez, efetivamente, com que seu estudo fosse reabilitado pela doutrina moderna (A instrumentalidade do processo, cit., p. 126).

${ }^{127}$ TUCCI, Rogério Lauria. Direitos e garantias individuais no processo penal brasileiro. 1993. Tese (Titular de direito processual penal) - Faculdade de Direito da Universidade, São Paulo, São Paulo, 1993. p. 68-69.
} 
inúmeros atos processuais que o levam do pedido inicial ao final provimento, o procedimento é o modo, a maneira como estes diversos atos processuais se combinam em contraditório (sua ordem, forma, prazo e tempo), algo que é determinado pela lei ou por circunstâncias ligadas às pessoas ou à causa ${ }^{128}$. Metaforicamente, o processo seria um veículo (instrumento) de transporte de carga (Jurisdição, Ação e Defesa). O procedimento seria o tipo de veículo utilizado para o transporte desta carga, alguns mais rápidos, outros mais lentos, alguns que vão pelo ar, outros pelo mar, outros pelo chão, todos, entretanto, com o mesmo propósito: levar o veículo (processo) até o seu destino final (provimento jurisdicional). ${ }^{129}$

São normas procedimentais, por isto, todas aquelas que prevêem não o ato processual em si considerado, mas a forma como se combinam os atos processuais como um todo, lógica e cronologicamente ${ }^{130}$; as normas que regulam o modo de desenvolvimento da relação jurídica processual, a sua dinâmica e movimento (normas puramente procedimentais). ${ }^{131}$ Neste grupo estão as normas que ordenam a prática dos atos processuais nos feitos de rito comum (ordinário e sumário) e especiais; as que disciplinam a seqüência dos atos a serem praticados pelo juiz na audiência preliminar (art.

${ }^{128}$ Correto, por isto, Amaral dos Santos, ao apontar que "que o processo não se move do mesmo modo e com as mesmas formas em todos os casos; e ainda no curso do mesmo processo pode, nas suas diversas fases, mudar o modo de mover ou a forma em que é movido o ato“ (SANTOS, Moacyr Amaral dos. Primeiras linhas de direito processual civil, cit., v. 1, p. 11-13). E também Sérgio Shimura, para quem o procedimento, como aspecto externo do processo, varia conforme também varie o pedido formulado pelo autor, a defesa ofertada pelo réu, o tipo de prova utilizado, a espécie de decisão proferida, etc (SHIMURA, Sérgio Seiji. Arresto cautelar. São Paulo: Ed. Revista dos Tribunais, 1993. p. 17).

${ }^{129}$ Esta metáfora, um pouco menos elaborada, foi originariamente atribuída por Paulo Heerdt à Ovídio A. Baptista da Silva (HEERDT, Paulo. Sumarização do processo e do procedimento, cit., p. 81).

${ }^{130}$ Coube a Nicola Picardi o mérito de trazer à discussão em tema de procedimento, ao lado do seu aspecto organizacional, o seu aspecto temporal, sem o que, de fato, o procedimento fica reduzido a mero esquema formal, sem ritmo (PICARDI, Nicola. La sucessione processuale, cit., p. 77).

${ }^{131}$ Liebman anota que os atos processuais não se apresentam isolados, "pois cada ato se encontra ligado e coordenado a um grupo mais ou menos numeroso de outros atos processuais que se sucedem no tempo e formam uma série contínua, como os elos de uma corrente; o grupo forma uma unidade que recebe o nome de procedimento e os atos são elementos constitutivos dessa unidade". Aduz ainda, em lição que merece ser integralmente reproduzida, que a coordenação dos atos no procedimento manifesta-se no seu escopo, nos seus efeitos e na sua validade. Todos os atos têm o mesmo escopo (entendido em sentido formal), pois que se "destinam a provocar e preparar o ato final que complementará e encerrará o procedimento", sem prejuízo do escopo imediato e próprio de cada ato que o qualifica em sua individualidade. Afinal, o esquema do procedimento é manifestado em dois atos: um inicial (pedido) e outro final (sentença)“. Todos os atos intermediários não têm outro escopo senão o de "preparar essa resposta e o procedimento se encaminha com todo o seu peso na direção desse provimento final”. Daí porque é apenas o ato final que encerra o procedimento que tem, como regra, sua eficácia jurídica externa, isto é, não meramente processual (excepcionadas as situações de extinção do feito sem apreciação do mérito). Os efeitos dos outros atos operam apenas internamente ao próprio procedimento, só excepcionalmente tendo algum efeito substancial externo (como o despacho da inicial que interrompe a prescrição, a citação que gera prevenção, etc.). Finalmente, quanto a validade dos atos processuais, cada um deles tem seus próprio requisitos, mas todos devem ser interpretados em conjunto, pois a eficácia do conseqüente pode depender da validade do antecedente. (LIEBMAN, Enrico Tullio. Manual de direito processual civil, cit., v. 1, p. 228). 
331 do CPC); a ordem de produção de provas em audiência (art. 452 do CPC); a ordem dos processos nos tribunais (artigos 547 a 556 do CPC).

Mas além destas, também serão normas procedimentais as que dão forma aos institutos regulados nas normas processuais, que como tal não podem ficar sem alma, sem procedimento para sua realização prática (normas acidentalmente procedimentais). Assim, são normas desta natureza as que disciplinam a forma de se apresentar a petição inicial em juízo (artigos 282 e 283 do CPC), a contestação (artigos 300 e 301 do CPC), as exceções e a reconvenção (art. 299), o recurso de apelação (art. 514 do CPC) ou de agravo de instrumento (art. 524 e 525 do CPC); as regras que disciplinam os prazos; as que regulam a maneira de serem procedidas as citações e intimações ${ }^{132}$; entre tantas outras a cuidar não da combinação dos atos processuais como um todo, mas da forma de sua realização, do procedimento para a prática do ato processual em si considerado. ${ }^{133}$

O procedimento processual, portanto, deve ser analisado sob dupla ótica: a) modo e prazo de manifestação dos atos processuais das partes, dos magistrados ou da secretaria, algo disciplinado pelas normas acidentalmente procedimentais; e b) lugar que cada ato tem no conjunto do procedimento, ou seja, a ordenação formal dos atos, objeto das normas puramente procedimentais. ${ }^{134}$

\footnotetext{
${ }^{132}$ Pontes de Miranda, neste sentido, aponta que o procedimento compreende a regulação do ato processual em si considerado, desde a apresentação dos escritos, da oralidade, das citações, até a fixação dos prazos para a prática do ato processual (MIRANDA, Francisco Cavalcanti Pontes de. Comentários ao Código de Processo Civil. 2. ed. Rio de Janeiro: Forense, 1979. t. 3, p. 675).

${ }^{133}$ Por isto, Sérgio Bermudes aduz que os Estados só podem legislar sobre matérias a respeito do modo de desenvolvimento da relação jurídica processual, como as referentes "ao modo de postular, como a estrutura da petição inicial e da contestação, a oportunidade das manifestações posteriores, a suscitação de incidentes, tal, por exemplo, a ação declaratória incidental na sua forma e argüição de suspeição ou incompetência relativa; à distribuição; ao modo de citar-se, aos meios de se praticarem atos em outras comarcas; ao lugar dos atos processuais e ao respectivo tempo, inclusive prazos; à maneira de se efetivar o direito de recurso, nas modalidades previstas na norma do processo", e, ainda, "o modo de se colherem as provas, que a lei processual admite" e "a forma e estrutura dos pronunciamentos judiciais e respectiva comunicação aos interessados" (Procedimentos em matéria processual, cit., p. 164). Edson Ribas Malachini, em sentido mais semelhante ao nosso, indica que "os modos, as formas como as citações e as intimações se farão, como certas provas se produzirão; as regras sobre os ritos de certos recursos e, particularmente, sobre os procedimentos propriamente ditos, ou seja, sobre a seqüência dos atos a ser praticados em casos comuns (ordinária, sumária ou executivamente) ou em casos especiais - certamente são normas tipicamente procedimentais", como tal admitida a competência concorrente entre União (para normas gerais), Estados e Distrito Federal (para as normas particulares) (MALACHINI, Édson Ribas. A Constituição Federal e a legislação concorrente dos Estados e do Distrito Federal em matéria de procedimentos, cit., p. 53-54).

${ }^{134}$ MARTIN DE LA LEONA ESPINOSA, José Maria. La nulidad de actuaciones en proceso civil: análisis constitucional de la nulidad en la Ley orgánica del poder judicial. 2. ed. Madrid: Colex, 1996. p. 76.
} 
Este breve apanhado de normas puramente e acidentalmente procedimentais constantes do Código de Processo Civil ${ }^{135}$ nos coloca diante de uma outra indagação: poderia uma lei nacional ${ }^{136}$ editada pelo Estado Federal regrar tudo sobre procedimento em matéria processual vinculativamente para os Estados membros?

Rememore-se que o atual Código de Processo Civil (Lei n. 5.869 de 11 de janeiro de 1973) foi editado no regime constitucional pretérito (Constituição Federal de 1967), onde não havia, como já vimos, distinção constitucional entre competência para legislar sobre processo e sobre procedimento em matéria processual. Era lícito à União, portanto, editar todas as normas processuais ou procedimentais (já que as últimas estariam incluídas no sentido lato das primeiras), restando ao Estado e ao Distrito Federal, exclusivamente, a competência complementar (art. $8^{\circ}, \S 2^{\circ}$, da CF/1967).

O quadro constitucional agora é outro. O art. 24 e $\S \S$ da Constituição Federal de 1988 reconhecem a competência da União exclusivamente para a edição de normas gerais em matéria procedimental, sendo absolutamente inconstitucional as disposições suas que extravasem esta limitação e avancem sobre a competência privativa dos Estados e do Distrito Federal em editarem normas procedimentais não gerais. Estariam, portanto, implicitamente incompatibilizadas com a Constituição Federal as disposições do Código de Processo Civil e de outras leis nacionais anteriores à Constituição Federal de 1988 que cuidem puramente ou acidentalmente de matéria procedimental não geral? E as leis nacionais sobre procedimento não geral posteriores à Constituição Federal de 1988 (as inúmeras reformas do CPC, por exemplo): seriam elas viciadas pela incompetência legislativa? ${ }^{137}$

\footnotetext{
${ }^{135}$ No sentido de que os Códigos de Processo Civil e Penal atuais cuidam de normas processuais e também procedimentais, cf. ALENCAR, Luiz Carlos Fontes de. A federação brasileira e os procedimentos em matéria processual, cit., p. 186.

${ }^{136} \mathrm{É}$ de Geraldo Ataliba a precisa diferenciação entre leis nacionais e leis federais. As primeiras, a atingir todos os entes federados (União, Estados, Distrito Federal e Municípios), são emanadas pelo Congresso Nacional no papel de casa legislativa do Estado Federal (como o CPC). Ao lado delas, as leis federais, emanadas pelo Congresso Nacional no papel de casa legislativa da União, a regular exclusivamente as relações jurídicas dos órgãos federais (lei de criação de cargos no poder público federal, que discipline procedimento administrativo perante o INSS, etc.) (ATALIBA, Geraldo. Regime constitucional e leis nacionais e federais. Revista de Direito Público, São Paulo, n. 53-54, p. 62-69, jan./jun. 1980).

${ }^{137}$ Este é o entendimento de Fontes de Alencar, verbis: "nas reformas que se tem pretendido fazer no campo do processo civil, cabe a observação de que muito se tem tratado de procedimento, e não de processo. E porque procedimento em matéria processual não é tema da competência privativa da União, ela o faz de maneira inconstitucional" (...) "Devem os Estados atentar nessa sua competência legiferante a respeito de procedimentos em matéria processual, eliminando os percalços da vida forense. E não estou a cogitar de códigos procedimentais. Por enquanto, leis isoladas, regras tópicas, a atenderem a necessidade de cada região, de cada unidade da Federação, podem servir ao povo, que é alvo da atividade jurisdicional. Ou alguém aqui imagina, que na lonjura dos seringais amazonenses há um oficial de justiça carregando um mandado para fazer de viva voz a intimação?" (ALENCAR, Luiz Carlos Fontes de. A federação brasileira e os procedimentos em matéria processual, cit., p. 186).
} 
A resposta para esta indagação passa necessariamente pela delimitação, no campo do procedimento, do que seriam normas gerais, a respeito das quais a competência para edição é mesmo da União Federal.

\subsubsection{Normas gerais em matéria de procedimento processual e a inconstitucionalidade das normas desta natureza editadas pela União Federal após 1988}

Já estabelecida a distinção entre normas processuais e procedimentais, quanto a estas últimas resta, ainda, definição sobre quais delas seriam gerais (de competência da União), em detrimento das normas não gerais, específicas ou locais (de competência dos Estados e do Distrito Federal).

Inicialmente, já se saliente que eventuais normas não gerais editadas pela União antes da Constituição Federal de 1988 - quando então tinha ela competência plena para normas processuais e procedimentais gerais e não gerais (art. 8, XVII, "b", da Carta Constitucional de 1967) - subsistem enquanto os Estados e o Distrito Federal não venham a editar as suas respectivas normas não gerais, quando, então, revogarão as normas procedimentais não gerais editadas anteriormente pela União. ${ }^{138}$

Já quanto às normas procedimentais não gerais editadas pela União Federal após a Carta Constitucional vigente - e há algumas delas por força das inúmeras alterações do Código de Processo Civil desde 1994 - todas são inconstitucionais por vício de competência.

Trabalhemos uma pouco melhor esta questão das normas procedimentais gerais e a inconstitucionalidade das editadas pela União após 1988.

Quando discorremos sobre a repartição vertical de competência (item 2.3.2.), já havíamos estabelecido, genericamente, a dificuldade em se conceituar normas gerais para fins de aplicação do art. 24, $\S 1^{\circ}$, da Constituição Federal. Por lá, concluímos que as

\footnotetext{
${ }^{138}$ Cf. ALVIM NETTO, José Manoel de Arruda. Manual de direito processual civil, cit., v. 1, p. 136. Aponta, ainda, o professor aposentado da PUC-SP, que estas normas não gerais da União, conduzem "a um paradoxo, porquanto todas as possíveis regras ditas não gerais, atualmente, são gerais, pela circunstância de que se constituem num sistema com o atributo da uniformidade, e, pois, com aplicação uniforme em todo território nacional (dado que todas elas foram editadas pela União)".
} 
normas gerais são regras de caráter e abrangência nacional, de natureza mais genérica e abstrata do que as normas locais; são disposições a determinar parâmetros mínimos, com maior nível de generalidade e abstração, do que as leis editadas fora dos limites da competência concorrente; são disposições já predispostas a serem desenvolvidas e suplementadas pela ação normativa subseqüente dos Estados e Distrito Federal.

De modo inverso, não são gerais as disposições que se ocupem de detalhamentos, que minudenciem condições específicas, que esgotem por completo o assunto, de modo que nada deixam à criação própria do legislador a quem se destinam (o legislador estadual ou distrital), exaurindo, assim, o assunto de que tratam.

Frente a isto, normas gerais em matéria procedimental são as que determinam os parâmetros mínimos para o trâmite processual - visto como a combinação dos vários atos, fatos ou negócios processuais que conduzem o processo do seu início ao final (normas puramente procedimentais) - ou para a prática de determinado ato processual em si considerado (normas acidentalmente procedimentais).

Estes parâmetros mínimos - sujeitos (destinatário da norma de procedimento), objeto (qual ato processual ou combinação de atos é regulado pela norma) e forma essencial (mínimo aspecto organizacional) - são os que permitem o exercício do direito processual independentemente de qualquer outra complementação legislativa, algo que é essencial e evita que a omissão do Estado ou do Distrito Federal impeça o exercício dos direitos de cunho processual.

São normas gerais de procedimento, exemplificativamente, as que regulam a sequiência dos atos processuais no rito ordinário, sumário ou sumaríssimo; as normas que disciplinam os atos que devem ser praticados pelo juiz na audiência preliminar (art. 331 do CPC); e a maneira e a ordem como são argüidas as testemunhas em instrução (art. 452 do CPC) (normas puramente procedimentais). Mesmo sem complemento legal, é plenamente possível a utilização dos ritos padrões, a realização da audiência preliminar ou a colheita da prova oral - independentemente de particularidades locais - com base nestas normas ditas gerais.

Também são normas gerais as que regulam os requisitos mínimos para apresentação da petição inicial em juízo (art. 282 do CPC), ou a forma e o conteúdo mínimo da contestação (artigos 300 e 301 do CPC); que determinam as peças a 
obrigatoriamente instruir o agravo de instrumento (524 do CPC), ou o conteúdo do recurso de apelação (art. 514 do CPC); as regras que fixam abstratamente os prazos ou as que disciplinam a forma de sua contagem (normas acidentalmente procedimentais). Todas elas não exigem nada mais do que o essencial e logicamente necessário para a prática do ato processual.

Não são normas gerais em matéria de procedimento, entretanto, aquelas que ultrapassam os limites da generalidade, excedendo a disciplina dos sujeitos, objeto ou forma mínima do rito, ou disciplinando por inteiro a maneira de ser praticado o ato processual; que tecendo às minúcias, praticamente impeçam ou desprezem a atividade útil e suplementar do legislador estadual ou distrital (que é o destinatário da regra de competência).

Bom exemplo são as regras sobre tempo (art. 172 do CPC) e lugar (art. 176 do CPC) para a prática do ato processual, que, como tal, não tratam de sujeitos, objeto ou forma mínima. Só ao legislador local compete estabelecer onde serão praticados os atos processuais e em que horário. A União, ao fazê-lo, invade competência que é privativa das entidades parciais, únicas capazes, conforme as particularidades regionais, de estabelecer o melhor local para a prática dos atos processuais e o horário para fazê-lo. Os horários de trabalho das comunidades locais, os meios de transporte, o excesso de serviço ou o acúmulo de processos pendentes, tudo recomenda que o legislador local decida sobre extensão ou redução da jornada de trabalho, prática de atos processuais nos sábados, domingos e feriados, fora do fórum, etc ${ }^{139}$.

Estas normas editadas pela União que fixam tempo e lugar para a prática de ato processual, todavia, não podem ser consideradas inconstitucionais. Sendo editadas antes de 1988, quando a competência em matéria de procedimento em geral também era da Poder Central, são válidas até que os Estados e o Distrito Federal disciplinem o assunto de maneira diversa (o que farão com competência privativa para tanto). Após, automaticamente, perdem sua vigência diante da edição das normas locais.

\footnotetext{
${ }^{139}$ Parece-me ser este o entendimento de Arruda Alvim, para quem "se se entende que o procedimento é a forma assumida pelo processo, o encadeamento dos atos, fatos e negócios processuais, no que diz respeito à forma, ao tempo e ao lugar, são estas realidades, as que dizem respeito, tipicamente, a atos procedimentais, que podem assumir disciplinas em locais diferentes (i.e., podem ter aspectos peculiares), e, como tais, reguláveis pelos Estados (ALVIM NETTO, José Manoel de Arruda. Manual de direito processual civil, cit., v. 1, p. 140).
} 
Também não são normas gerais - e, portanto, fora da competência da União as que criam alternativas procedimentais muito específicas, como é o caso do art. 527, II, do Código de Processo Civil, acrescentado pela Lei n. 10.358/2002, e recentemente aperfeiçoado pela Lei n. $11.187 / 2005^{140}$. De fato, ao permitir que o relator do recurso de agravo de instrumento, entendendo não ser ele cabível (art. 523 do CPC), converta-o em agravo retido, determinando o encaminhamento do instrumento para apensamento em primeiro grau, o legislador federal se ocupou de detalhamento totalmente incompatível com a generalização que se exige das normas procedimentais editas pela União. Trata-se de disposição que, por ser posterior à Constituição Federal de 1988, é de manifesta inconstitucionalidade por vício de competência.

Por conta desta última afirmação já é chegada a hora de introduzirmos as primeiras reflexões sobre os efeitos deletérios da edição, pela União, de normas procedimentais não gerais, algo que inspirou o constituinte de 1988, por isto, a atribuir aos Estados e ao Distrito Federal a competência para estas normas não gerais.

A conversão do agravo de instrumento em agravo retido com a conseqüente irrecorribilidade de tal decisão (art. 527, parágrafo único, com redação pela Lei n. 11.187/2005) - e é tomado este exemplo único com a ressalva de que há outras normas não gerais e inconstitucionais como estas editadas após a Carta Constitucional de 1988 - foi concebida para resolver exclusivamente a realidade de no máximo dois ou três Estados da Federação, especialmente do Estado de São Paulo ${ }^{141}$.

\footnotetext{
${ }^{140}$ Para análise do novo regime do agravo, cf. o nosso A nova sistemática do recurso de agravo introduzida pela Lei n. 11.187/2005 e os prejuízos à justiça de $1^{\circ}$ grau. In: HOFFMAN, Paulo; RIBEIRO, Leonardo Ferres da Silva (Coord.). O novo regime do agravo de instrumento e do agravo retido. São Paulo: Quartier Latin, 2006. p. 159-168. Cf., também, JORGE, Flávio Cheim. A nova disciplina do cabimento do agravo: Lei 11.187, de 19/10/2005, Revista do Advogado, São Paulo, ano 26, n. 85, maio 2006.

${ }^{141}$ Fontes de Alencar traz como exemplos de normas procedimentais inconstitucionalmente editas pela União os artigos 511 (Lei n. 9.756/98) e 526 (Lei n. 9.139/95 e 10.352/2001), ambos do CPC (A federação brasileira e os procedimentos em matéria processual, cit., p. 186). De fato, determinar o momento de recolhimento e comprovação do preparo é questão específica afeta à legislação estadual ou distrital, que os fixará de acordo com a realidade local (horário de atendimento bancário do Estado, por exemplo). É o legislador local que deve, também, decidir sobre a necessidade e a forma da comunicação da interposição do agravo de instrumento em $1^{\circ}$ grau (art. 526 do CPC). Há Estados em que a informatização já possibilita ao juiz e ao agravado consultar on line as razões de agravo digitalizadas, algo que torna inútil o desnecessário trânsito de papéis previsto na lei federal.
} 
Com efeito, os dados estatísticos revelam que o Estado de São Paulo concentra mais de $45 \%$ dos feitos em trâmite no Brasil ${ }^{142}$. Como conseqüência disto, tem, também, um dos maiores índices de congestionamento de feitos em $2^{\circ}$ grau de todo o país ${ }^{143}$.

Isto porque, com o advento da Lei n. 9.137/1995 houve facilitação da recorribilidade das interlocutórias: os agravos de instrumento, que antes eram processados em primeiro grau, passaram a ter processamento e trâmite diretamente em $2^{\circ}$ grau, com manifesto abreviamento de tempo. Some-se a isto o aumento dos poderes liminares do juiz com as reformas do Código de Processo Civil (art. 273 e 461, $\S 3^{\circ}$, do CPC) ${ }^{144}$ e a inexistência de custas recursais no agravo até a Lei Estadual n. 11.347/2005. Temos, então, o quadro completo para uma explosão da recorribilidade das interlocutórias.

Pois, com isto, os Tribunais paulistas receberam verdadeira avalanche de agravos de instrumento. E para julgar estes inúmeros agravos contra decisões interlocutórias, foram sendo deixadas de lado as apelações (já eram muitíssimas) que, pela sua natureza, resolveriam o cerne o conflito propriamente dito.

A nova norma de procedimento recursal editada pela União tem nítido escopo de reduzir o número de agravos de instrumento (especialmente no Tribunal de Justiça do Estado de São Paulo), conseqüentemente tentando restabelecer a ordem de preferência de julgamentos, colocando as apelações em primeiro plano. Permitindo ao relator fazer o controle procedimental do agravo, possibilita-se a retenção obrigatória do agravo, algo que, diante da irrecorribilidade da decisão monocrática (art. 527, parágrafo único, do CPC), propicia diminuição de recursos em $2^{\circ}$ grau.

\footnotetext{
${ }^{142}$ Com $22 \%$ da população brasileira, São Paulo respondeu em 2003 por cerca de $49 \%$ do movimento judiciário nacional na Justiça Comum (incluindo a Federal). No entanto, enquanto a população paulista cresce $1,14 \%$ ao ano o número de processos aumenta 12,49\%. Para cada grupo de 10 habitantes há 03 processos (Fonte: Banco Nacional de Dados do Poder Judiciário - Supremo Tribunal Federal).

${ }^{143}$ São Paulo, no ano de 2003, alcançou a marca de 60,6\% de processos represados na Justiça do Estado de São Paulo. Dos mais de 362 mil casos novos na segunda instância, os desembargadores julgaram apenas 270 mil e os processos pendentes de julgamento chegaram a mais de 320 mil. Nos anos seguintes (2004 e 2005), após uma greve de mais de 90 dias, o número de processo represados em $2^{\circ}$ grau atingiu a alarmante marca de 500.000 feitos. Uma ação chegava a demorar até cinco anos para ser distribuída a um relator em São Paulo, enquanto em tribunais como o do Rio de Janeiro e o de Minas Gerais esse prazo variava de um a cinco dias. Mesmo após a emenda constitucional n. 45, que determinou a distribuição imediata de todos os feitos (art. 93, XV, da Constituição Federal), uma apelação pode ficar até seis anos para ser julgada em São Paulo, tendo a nova disposição constitucional, portanto, implicado simples mudança de prateleiras dos recursos, que, de qualquer forma, permanecem aguardando julgamento (Fonte: Banco Nacional de Dados do Poder Judiciário - Supremo Tribunal Federal).

${ }^{144}$ Sobre este tema cf. a excelente monografia de José Carlos Baptista Puoli, Os poderes do juiz e as reformas do processo civil. São Paulo: Juarez de Oliveira, 2002. p. 193 e ss.
} 
Ocorre que as Justiças Estaduais de Minas Gerais, Rio de Janeiro ou Goiás não precisam de tal regra, pois por lá o índice de congestionamento é inexistente, pois se julgam mais recursos do que os entrados no próprio ano (estando, por isto, sendo eliminadas as sobras dos anos anteriores). ${ }^{145}$ Qual a razão, então, para que se permita genericamente a conversão do agravo de instrumento em retido nestes Estados, quando eles são plenamente capazes de julgar os agravos de instrumento sem prejuízo das apelações? Não é benéfico ao processo como um todo que as interlocutórias sejam retificadas ou ratificadas antes da sentença, que por força do provimento do agravo pode se tornar prejudicada?

Já não é possível, pois, "que se tente preservar, no que toca aos procedimentos em matéria processual, aquela funesta simetria entre Estados e Distrito Federal, entes díspares sob vários aspectos. De outro ângulo, fruto verdadeiramente dessa desigualdade, diferenciados volumes de casos reclamando soluções surgem naquelas unidades da Federação, destacando-se a situação de São Paulo, que apenas na Justiça Estadual expõe cifra extravagante" de feitos. Por isso, "não é sequer imaginável que a lei, extraviando-se, procure impor ao Distrito Federal e aos Estados, errada e desnecessariamente, uniformidade de procedimentos em matéria processual". ${ }^{146}$

Esta foi a razão pela qual o constituinte permitiu aos Estados legislar sobre procedimento local, flexibilizando-o conforme a realidade judiciária local. ${ }^{147}$ A despeito da já mencionada centralização dos poderes, as entidades parciais foram agraciadas com pequena parcela de competência legislativa, que bem desenvolvidas "poderão solucionar

\footnotetext{
${ }^{145}$ Os Tribunais Estaduais de Minas Gerais, do Rio e de Goiás aparecem com índices de produtividade superiores a 100\% (contra os 60,6\% de São Paulo). O campeão de 2003 - o TJ mineiro - conseguiu julgar 21,9 mil recursos, enquanto deram entrada naquela corte 19,8 mil, atingindo a marca de $111 \%$ de apelações julgadas. Logo atrás, aparece o TJ do Rio, que apresentou um índice de aproveitamento de $110 \%$ (82,2 mil processos entrados e 91,2 mil julgados). Em seguida vem o TJ de Goiás, que atingiu a marca de 101,89\% de recursos julgados (Fonte: Banco Nacional de Dados do Poder Judiciário - Supremo Tribunal Federal). O Tribunal de Justiça do Rio de Janeiro informa que um recurso tem média de duração de 05 (cinco) meses, enquanto em São Paulo esta média supera os 04 (quatro) anos (Fontes: Tribunal de Justiça do Rio de Janeiro e Tribunal de Justiça de São Paulo).

${ }^{146}$ ALENCAR, Luiz Carlos Fontes de. Procedimentos em matéria processual, cit., p. 95.

${ }^{147}$ Esta foi a mensagem do texto constitucional captada por José Renato Nalini, quando aponta que o reconhecer da competência legislativa dos Estados em matéria procedimental "propiciará iniciativas estaduais de desincumbência da atribuição até agora não exercida", com reflexos na otimização do serviço público judicial decorrente da simplificação procedimental". E que a continuidade dos estudos delineadores da distinção entre processo e procedimento se mostra imprescindível, pois "com ela poderá o EstadoMembro implementar a vontade do constituinte e tornar a prestação jurisdicional mais célere, disciplinando o procedimento de acordo com as condições de desenvolvimento de cada unidade federada" (NALINI, José Renato. Processo e procedimento - distinção e a celeridade da prestação jurisdicional, cit., p. 673-674).
} 
problemas regionais, tudo a depender, como óbvio, da capacidade e criatividade do legislador local". 148

Por isto, quando a União edita norma procedimental específica como o art. 527, II, do CPC (Lei n. 11.187/2005), o faz em detrimento de parcela dos jurisdicionados, cuja condição local do Judiciário permite o julgamento imediato do agravo de instrumento, sem a possibilidade da facultativa retenção. ${ }^{149}$

\subsubsection{Normas não gerais em matéria procedimental e a relativa capacidade dos Estados e do Distrito Federal flexibilizarem o procedimento}

O engenho do legislador estadual ou distrital pode, diante de todo o exposto, contribuir decisivamente para a quebra da rigidez clássica do procedimento desenhado pelo Poder Central, flexibilizando-o em favor da pronta tutela dos direitos ${ }^{150}$.

O Estado ou o Distrito Federal, de acordo com sua conveniência, tem competência para, observadas as normas gerais mínimas editadas pela União, disciplinar, de maneira até diversa da constante da lei federal, o procedimento em matéria processual, desde que o faça para suplementá-la e para atender às particularidades regionais.

É possível, por isto, que haja lei estadual para disciplinar, exemplificativamente:

\footnotetext{
${ }^{148}$ BORGES NETTO, André Luiz. Competências legislativas dos Estados-Membros, cit., p. 60.

${ }^{149} \mathrm{E}$ vale a nota de que o avanço da União sobre matéria de competência legislativa dos Estados não é sentido, apenas, no âmbito da competência concorrente sobre procedimento em matéria processual. A União avança também sobre competência alheia quando desrespeita a regra que assegura o autogoverno da Magistratura (art. 96, I, “a”, da CF). Por exemplo, a recente Lei n. 11.340/2006 (Lei Maria da Penha) estabelece em seu art. 33, que enquanto não criadas ou instalados Juizados Especiais de Violência Doméstica e Familiar, a competência para as questões cíveis e criminais advindas da Lei será das Varas Criminais. Ao fazê-lo, o Legislativo federal disciplina questão de organização Judiciária, de competência exclusiva do Judiciário dos Estados Federados (art. 125, $\S 1^{\circ}$, da CF). No mesmo sentido cf. CUNHA, Rogério Sanches; PINTO, Ronaldo Batista. Violência doméstica. São Paulo: Ed. Revista dos Tribunais, 2007. p. 116-117.

${ }^{150}$ Bom exemplo de que o uso da criatividade pelos Estados pode catalisar a prestação jurisdicional está na Lei Estadual do Estado de Minas Gerais n. 13.454/2000, que apesar de declarada inconstitucional em alguns tópicos (não nos que se seguem), autorizou a utilização do juiz de paz para arrecadar bens de ausentes ou vagos (até que intervenha a autoridade competente), funcionar como perito em processos e exercer outras atividades judiciárias não defesas em lei, de comum acordo com o Juiz de Direito da comarca. Cf. neste sentido: STF, ADI 2938-MG, Rel. Min. Eros Grau, j. 09.06.2005.
} 
a) O local ou o horário para a prática dos atos processuais conforme as necessidades do povo local;

b) Serviços de protocolo e recepção de petições dirigidas ao primeiro e segundo graus, inclusive quanto a possibilidade de sua extensão em período noturno, fim de semanas, feriados, além da disciplina do recebimento de documentos por meio eletrônico;

c) Procedimentos especiais novos, não previstos por lei federal, mas capazes de tutelar de maneira mais adequada situações comum no Estado (como a previsão local de uma ação de imissão na posse com possibilidade de concessão de liminar, de uma nova cautelar típica com particularidades procedimentais próprias, ou de um novo procedimento para os executivos fiscais estaduais) $^{151}$;

d) A forma de cumprimento dos mandados pelos oficiais de justiça;

e) Novas modalidades de citação e intimação, desde que observadas as garantias constitucionais mínimas do contraditório e da ampla defesa, ${ }^{152}$

f) A comunicação dos atos processuais em seu território (cartas precatórias e de ordem, intimação por email, fax, etc.);

g) Ampliação de prazos, mesmo os rigidamente fixados no Código de Processo Civil ou leis processuais extravagantes, conforme as particularidades locais (por exemplo, em Estado cuja extensão territorial seja muito vasta, ou em que o transporte seja precário);

\footnotetext{
${ }^{151}$ Neste sentido Ernane Fidélis dos Santos indica a possibilidade dos Estados criarem procedimento de jurisdição voluntária que julgarem necessários para a tutela dos direitos (Manual de direito processual civil, cit., v. 3, p. 377).

${ }^{152}$ Este não é, entretanto, o pensamento de Ada Pellegrini Grinover, para quem "as regras sobre comunicação e intimação dos atos processuais são normas de processo, e não de procedimento" (....) " não se trata de mera regra de procedimento, considerado como simples relação entre os atos processuais, mas de regra de processo, entendido como relação entre os sujeitos processuais" (GRINOVER, Ada Pellegrini. Inconstitucionalidade de leis processuais estaduais. In: CALDEIRA, Adriano; FREIRE, Rodrigo da Cunha Lima (Coords.). Terceira etapa da reforma do Código de Processo Civil. Salvador: JusPodivm, 2007. p. 19-20).
} 
h) A definição do período em que os prazos processuais estarão suspensos por força de circunstâncias locais ${ }^{153}$, observadas as diretrizes gerais traçadas por norma geral editada pela União ${ }^{154}$;

i) A inserção, no bojo de procedimentos genéricos estabelecidos pelo legislador federal, de atos processuais não constantes do iter geral, ou discipliná-los, quanto à organização, de maneira distinta (inserindo, por exemplo, audiência de conciliação logo no início do processo, antes da citação do demandado);

j) A ordem dos processos nos tribunais, criando preferências de julgamento locais além dos já estabelecidos pela lei federal, ou inserindo audiências de conciliação compulsoriamente nos processos entrados em $2^{\mathrm{a}}$ instância;

k) Criação, conforme as possibilidades e necessidades locais, de uma nova modalidade de liquidação de sentença (por institutos oficiais de pesquisa, por exemplo);

1) A avaliação dos bens penhorados por oficial de justiça (art. 475-J, §§, e art. 680, ambos do CPC), ou a alienação particular (art. 685-C do CPC);

m) A colheita de depoimento por via telefônica. ${ }^{155}$

Note-se que os vários exemplos - que nem de longe esgotam a possibilidade de outras normas procedimentais específicas - contemplam tanto a disciplina do

\footnotetext{
${ }^{153}$ Lei estadual, por isto, pode definir a suspensão dos prazos processuais nas festas de fim de ano, a fim de possibilitar certo descanso aos advogados, observada a impossibilidade de determinar a suspensão das demais atividades do Judiciário, por força da vedação constitucional expressa quanto às férias forenses (Emenda Constitucional n. 45).

${ }^{154}$ No regime constitucional de 1967 , quando então não havia a competência dos entes parciais para legislarem sobre procedimento em matéria processual, o Supremo Tribunal Federal entendeu que não era lícito ao Estado federado disciplinar questão referente aos feitos que têm curso nas já extintas férias forenses (Recurso Extraordinário n. 87.728-PR, j. 05.03.1980, Rel. Min. Décio Miranda). Sobre este julgado, cf. SANTOS, Altamiro J. Processo e procedimento à luz das Constituições Federais de 1967 e 1988 - competência para legislar. Revista de Processo, São Paulo, ano 16, n. 64, p. 217-246, out./dez. 1991.

${ }^{155}$ Aliás, esta medida já é adotada na Inglaterra, cuja regra 3.1 da CPR autoriza o órgão judicial a colher depoimento por telefone ou qualquer outro método de comunicação, inclusive por sistemas de teleconferência ou análogos (R. 32.3).
} 
procedimento em si considerado (normas puramente procedimentais), quanto a forma para a prática do ato processual (normas acidentalmente procedimentais). ${ }^{156}$

Evidentemente, as normas procedimentais não gerais a serem estabelecidas pelo Estado ou Distrito Federal só podem ser veiculadas por lei estadual ou distrital. ${ }^{157}$ De fato, o art. 24 e parágrafos da Constituição Federal cuidam de competência legislativa (e não administrativa), como tal indelegável na inexistência de disposição específica a respeito. Assim, as situações retro enumeradas de modificação do iter ou de disciplina procedimental de ato processual específico não podem ser feitas nos regimentos internos dos tribunais, por portarias, provimentos ou resoluções.

Importante, anotar, também, que estas normas procedimentais não gerais estabelecidas pelas entidades parciais só tem validade nos limites territoriais de onde editadas, não sendo, portanto, de observação obrigatória por outros Estados ou pelo Distrito Federal. Por isto, matéria de comunicação interestadual entre os Judiciários será regida por normas procedimentais gerais editadas pela União. ${ }^{158}$

Mas tais leis, exatamente pela sua territorialidade, tem eficácia, inclusive, para as Justiças federal, eleitoral e trabalhista. Com efeito, as normas procedimentais fixadas pelos Estados e pelo Distrito Federal têm amplo alcance, inclusive sobre os feitos da competência das Justiças federais, que também deverão seguir, observada a territorialidade, estas normas não gerais de procedimento. É o que sobressai da Constituição de 1988, que diversamente da Carta Constitucional de 1891, não aponta ser competência da União legislar sobre processo e procedimento da Justiça Federal, deixando às entidades parciais a competência para legislação global em matéria procedimental

\footnotetext{
${ }^{156}$ Sálvio de Figueiredo Teixeira, ao comentar a inovação constitucional, anotava seu "alto alcance, atentando-se para as dimensões continentais de nosso País, com regiões bastante diversificadas, na apenas quanto a fatores geográficos, mas também de população, de vias de comunicação e até mesmo de cultura. Deficiências que hoje dificultam a boa prestação jurisdicional poderão ser afastadas ou minoradas com a criatividade do legislador estadual, podendo-se exemplificar com o aperfeiçoamento do sumaríssimo e com as adoções do monitório, de um novo modelo de agravo e até da figura do servidor qualificado, a liberar o juiz dos estafantes e burocráticos despachos de mera movimentação dos feitos, reservando-o para decisões, a teor do que já ocorre em outros países" (TEIXEIRA, Sálvio de Figueiredo. Revista de Crítica Universitária, São Paulo, v. 4, p. 164, 1987).

${ }^{157}$ O Supremo Tribunal Federal já entendeu que a disciplina para a prática do ato processual via fax constitui matéria sujeita ao princípio constitucional da reserva legal, consequentemente não podendo ser disciplinada por ato normativo secundário dos tribunais, como provimentos, portaria ou resoluções (AI-AgR 143.783AM, Rel. Min. Celso de Mello, j. 02.06.1992).

${ }^{158}$ ALVIM NETTO, José Manoel de Arruda. Manual de direito processual civil, cit., p. 141.
} 
local. ${ }^{159}$ Assim, criada uma preferência estadual de julgamento de determinada causa, ou estabelecida uma audiência prévia de conciliação em certo procedimento, todos os feitos que têm curso na Justiça federal, trabalhista ou eleitoral naquele Estado devem obediência à norma.

De mais a mais, parece-me oportuno observar que das decisões dos Tribunais de Justiça e dos Tribunais Regionais Federais relativas a normas procedimentais localistas não caberá recurso especial, aos menos com fundamento no art. 105, III, "a" e "c", da Constituição Federal. De fato, não estamos diante de regra que tenha sido editada pelo Poder Legislativo da União, e como tal, sendo sua essência uma particularidade local, não há o que se uniformizar.

\subsubsection{Jurisprudência do Supremo Tribunal Federal e a interpretação quanto à competência concorrente dos Estados e Distrito Federal em matéria procedimental}

Apesar da regra da descentralização normativa estabelecida pelo art. 24 e parágrafos da Constituição Federal, é possível se afirmar, sem exagero, especialmente em matéria de competência concorrente, que "será quase impossível os Estados legislarem originariamente sobre qualquer assunto" 160 , inclusive sobre procedimento em matéria processual.

Isto porque, como se já não bastasse a timidez do constituinte brasileiro no sentido de efetivamente outorgar aos entes federados parciais competências e rendas relevantes (cf. item 2.3.3.), o Supremo Tribunal Federal, embora consiga estabelecer na maioria das vezes (conforme veremos abaixo) com precisão os conceitos de normas processuais e procedimentais, não distingue as normas gerais das normas não gerais em matéria de procedimento, conseqüentemente, avalizando a postura centralizadora que é histórica em nosso sistema e obstando que o Estado e o Distrito Federal, através da criatividade de seus legisladores, possam inovar no procedimento, tornando-o mais maleável ou mais aderente à realidade local.

\footnotetext{
${ }^{159}$ Neste sentido, cf. ALENCAR, Luiz Carlos Fontes de. A federação brasileira e os procedimentos em matéria processual, cit., p. 186.

${ }^{160}$ BASTOS, Celso Ribeiro. Curso de direito constitucional. 11. ed. São Paulo: Saraiva, 1989. p. 171.
} 
O resultado desta postura jurisprudencial da mais alta corte constitucional é que não se encontram julgados que tenham pronunciado o excesso cometido pela União no tocante às normas procedimentais não gerais por si editadas, algo que, conforme já demonstramos, não é incomum.

Por outro lado os Estados e o Distrito Federal - que detém legitimidade seja pela sua Assembléia Legislativa, seja pelo Governador do Estado, para a propositura de Ação Declaratória de Inconstitucionalidade (103 da Constituição Federal) - quedam-se absolutamente inertes quando a União, excedendo os limites que lhe foram impostos pela Carta Magna para edição de normas gerais, esgota a disciplina procedimental em matéria processual, avançando sobre a competência que constitucionalmente é dos entes parciais.

Esta omissão dos Estados e do Distrito Federal acaba contribuindo decisivamente para que o modelo federalista traçado pela Constituição Federal de 1988, ao menos no que toca na repartição vertical de competências, não seja implantado em sua plenitude. Mesmo porque o Supremo Tribunal Federal admite não ter sido ainda definido o modelo de Federação a ser efetivamente observado nas práticas institucionais. Afinal os limites do poder constituinte estadual carecem de plena identificação; ainda se vacila em incluir os Municípios entre as entidades federativas; e - no que mais de perto concerne ao assunto ora tratado - ainda não foram fixados com exatidão os limites ao alcance do poder jurídico da União de impor (ou não impor), às demais pessoas estatais que integram a estrutura da Federação, o respeito a padrões heterônomos por ela própria instituídos como fatores de compulsória aplicação. ${ }^{161}$

Algumas decisões abaixo relatadas bem demonstrarão estas colocações.

Dentro do conceito de normas procedimentais, o Supremo Tribunal Federal entendeu que "o inquérito civil é procedimento pré-processual que se insere na esfera do direito processual civil como procedimento, à semelhança do que sucede com relação ao inquérito policial em face do direito processual penal". E concluiu, como deveria tê-lo feito mesmo, que quando o Estado legisla sobre inquérito civil o faz com base em competência procedimental que lhe é própria (art. 24, XI, da Constituição Federal), já que exclusivamente disciplina instituto previsto em norma processual (art. $8^{\circ}, \S 1^{\circ}$, da Lei $n$.

${ }^{161}$ STF, ADI 216-PB, relator Ministro Célio Borja, j. 23.05.1990. 
7.347/85), operacionalizando-o e dando-lhe, conforme a realidade dos Ministérios Públicos locais, fisionomia particular. ${ }^{162}$

Também aferindo a diferença entre processo e procedimento, entendeu que criativa lei estadual mineira poderia definir como atribuição dos juízes de paz a arrecadação provisória de bens de ausentes e bens vagos. Poderia, ainda, nomeá-los escrivão ad hoc ou permitir que sejam nomeados como peritos em processos, não invadindo a disposição local, portanto, em ofensa ao princípio federativo, competência da União para legislar sobre direito processual civil (art. 22, I, da CF). ${ }^{163}$ Assim mesmo haveria de sê-lo, pois se a norma processual fala em nomeação de depositário ou administrador (artigos 148 a 150 do CPC), de escrivão (artigos 160 a 170 do CPC) ou de perito (artigos 420 a 439 do CPC), sem, contudo, disciplinar o modo ou as condições para tanto, norma procedimental (acidental) que deverá fazê-lo conforme as circunstâncias locais.

De maneira precisa o Supremo, com a ressalva correta de que criação de recursos ou a disciplina das ações constitucionais é da reserva legal do legislador federal (art. 22, I, da Constituição Federal), estabeleceu que a reclamação não é nem recurso, nem ação constitucional. Situa-se ela no âmbito do direito constitucional de petição previsto no artigo $5^{\circ}$, inciso XXXIV da Constituição Federal. Em conseqüência, a sua adoção pelo Estado-Membro, pela via legislativa local, não implica invasão da competência privativa da União para legislar sobre direito processual. ${ }^{164}$

Assentou-se, também, que as disposições a respeito dos depósitos judiciais não se inserem no âmbito do direito processual, conseqüentemente, podendo ser disciplinadas pelos Estados membros conforme suas particularidades locais. ${ }^{165}$

Já no trato específico das normas processuais, estabeleceu, com exatidão, que norma estadual não pode atribuir competência ao Procurador-Geral de Justiça para

\footnotetext{
${ }^{162}$ STF, ADI 1.285-MC, Rel. Min. Moreira Alves, DJ 23/03/01.

${ }^{163}$ STF, ADI 2938-MG, Rel. Min. Eros Grau, j. 09.06.2005.

${ }^{164}$ STF. ADI 2.212, Rel. Min. Ellen Gracie, DJ 14/11/03.

${ }^{165}$ STF, ADI n. 1.933, Rel. Ministro Nelson Jobim, DJ de 31/05/2002; STF, ADI/MC n. 2.214, Rel. Min. Maurício Corrêa, DJ de 19/04/2002; STF, ADI 3.458, Rel. Min. Eros Grau, DJ 30/09/05.
} 
promover ação civil pública, já que se trata de questão a envolver legitimidade, matéria tipicamente processual e, por conseguinte, de competência privativa da União. ${ }^{166}$

No mesmo sentido, entendeu que norma estadual não pode ampliar a legitimidade para execução das condenações impostas pelo Tribunal de Contas (art. 71, § $3^{\circ}$, da Constituição Federal), permitindo que ele mesmo execute suas decisões, algo que além de violar o princípio da simetria (art. 75 da CF), é matéria estritamente processual por se ocupar de legitimidade. ${ }^{167}$

Também com razão o Supremo Tribunal Federal tem entendido, em reiteradas passagens, que matéria referente ao valor da causa, por não cuidar propriamente do procedimento para a prática do ato processual, mas sim de um requisito dele, não pode ser disciplinado por norma estadual, tampouco pode ser relegado por norma local ao controle extrajudicial de admissibilidade. ${ }^{168}$

Equivocadamente, entretanto, o Pretório Excelso estabeleceu que questão referente ao funcionamento de órgãos jurisdicionais e administrativos dos tribunais, especialmente no concernente à disciplina do procedimento a ser seguido para julgamento de autoridades possuidoras de foro por prerrogativa de função, está sujeito à reserva de lei federal (art. 22, I, da Constituição Federal), quando na verdade, por tratar de matéria procedimental e específica, estaria sujeita a reserva de lei estadual ou distrital. Com este equivocado entendimento, o Supremo, de qualquer modo, acertou ao não permitir que o Regimento Interno do Tribunal de Justiça do Distrito Federal e Territórios disciplinasse o procedimento destas ações originárias, já que - conforme vimos no item anterior - a autorização para os Estados e Distrito Federal é para legislarem sobre procedimento, e não para que órgãos administrativos o façam. ${ }^{169}$

Atualmente o Supremo Tribunal Federal - com sua nova composição - está na iminência de delimitar o alcance da competência legislativa dos Estados membros no tocante às normas não gerais ${ }^{170}$. Embora a questão envolva discussão sobre matéria de segurança no trânsito, na plenária realizada em 25.10.2006, a maioria dos Ministros,

\footnotetext{
${ }^{166}$ STF, ADI 1.916-MC, Rel. Min. Nelson Jobim, DJ 26/10/01; e STF, ADI-MC 1285/SP, Rel. Min. Moreira Alves, j. 25.10.1995.

${ }^{167}$ STF, Recurso Extraordinário n. 223.037/SE, Rel. Min. Maurício Corrêa, j. 02.05.2002.

${ }^{168}$ STF, ADI 2.052, Rel. Min. Eros Grau, DJ 18/11/05; ADI 2.655, Rel. Min. Ellen Gracie, DJ 26.03.2004.

${ }^{169}$ STF, ADI 2970, Rel. Min. Ellen Gracie, Informativo 423.

${ }^{170}$ Trata-se da ação declaratória de inconstitucionalidade n. 3.774, do Estado de Roraima, e cujo Relator é o Min. Joaquim Barbosa.
} 
especialmente a Min. Carmem Lúcia e o Min. Ricardo Lewandowski (coincidentemente os dois mais novos), externaram preocupação com a interpretação que se tem dado ao pacto federalista da Constituição Federal de 1988, e expressamente aduziram que o Supremo tem precípuo papel em incentivar a descentralização política no âmbito da competência concorrente. Por esta razão, vencidos os Ministros Joaquim Barbosa (relator), Eros Grau, Carlos Brito e Gilmar Mendes (este também a revelar preocupação com a interpretação centralizadora da corte constitucional, mas preferindo se posicionar em favor dela ao menos em juízo sumário), por maioria de votos a liminar pretendida pelo Procurador Geral da República foi indeferida, mantendo válida e eficaz a lei editada pelo Estado de Roraima com base em sua competência concorrente (art. 23, XII, da Constituição Federal).

O que efetivamente se espera do Supremo Tribunal Federal é que haja estabelecimento de balizas concretas, especialmente sobre poderes e limites, a respeito da autonomia dos entes parciais para legislação em matéria procedimental, dando segurança, assim, para que os Estados e o Distrito Federal, no âmbito da competência que lhes é constitucionalmente assegurada, possam inovar ou flexibilizar a rigidez procedimental clássica, adequando o processo civil (e penal) às suas realidades locais.

\subsubsection{O fracasso da iniciativa legislativa em se estabelecer o alcance do art. 24, XI, da Constituição Federal}

A fim de permitir que a regra do art. 24, XI, da Constituição Federal fosse efetivamente utilizada em favor do processo, a Câmara dos Deputados, por meio do projeto de lei n. 3.588/89, de autoria do Deputado Manoel Moreira, tentou disciplinar quais seriam as normas de procedimento processual de competência dos Estados e do Distrito Federal e que, portanto, estariam na sua mais completa alçada.

A rubrica do projeto já apontava que se pretendia "adaptar normas de direito processual ao disposto no art. 24, XI, da Constituição Federal”, estabelecendo “competência concorrente dos Estados e Distrito Federal para legislar sobre procedimentos em matéria processual, de acordo com a nova Constituição Federal, aplicando-se, na ausência de lei estadual, a legislação federal (art. $2^{\circ}$ )". 
Estabelecia logo o art. $1^{\circ}$ do citado projeto de lei que "os processos de competência dos Tribunais e Juízes dos Estados e do Distrito Federal obedecerão aos procedimentos previstos na respectiva lei de organização judiciária”, enquanto que o parágrafo único do dispositivo expressamente excepcionava da regra "os recursos dirigidos a outros tribunais", que se regeriam, exclusivamente, por lei federal.

$\mathrm{O}$ art. $3^{\circ}$ apontava que "a lei local poderá dispor quanto à forma, tempo, lugar e prazos dos atos processuais, observado o disposto nos parágrafos deste artigo”. Seguiam-se os parágrafos a determinar que: a) poderiam ser disciplinadas novas formas de citação e intimação além das previstas na lei federal, desde que assegurado o contraditório e a ampla defesa; b) os prazos para prática do ato processual poderiam ser fixados de maneira distinta pela lei local, mas deveriam constar expressamente, sob pena de prevalência do prazo fixado na lei federal, nas intimações e citações; e c) que os prazos para a prática de atos fora dos limites territoriais do Estado legiferante ou do Distrito Federal seguiriam o fixado na lei federal.

Finalmente estabelecia o projeto, em seu derradeiro dispositivo (art. $4^{\circ}$ ), que a lei local de organização judiciária poderia mandar aplicar às suas causas cíveis o procedimento dos então existentes juizados de pequenas causas (lei n. 7.244/84), "sem prejuízo de regular de outro modo o respectivo procedimento".

Era a consolidação cabal da possibilidade dos entes parciais criarem procedimentos locais em matéria processual.

$\mathrm{Na}$ justificação do projeto de lei o seu apresentante já anotava, como se tivesse previsto o futuro, que "a partir da vigência da nova Constituição, portanto, estão os Estados autorizados a instituir novos ritos procedimentais e novas formas para os atos processuais, mais consetâneos com sua respectiva realidade sócio-econômica, certamente propiciando mecanismos capazes de garantir uma justiça mais célere, mais eficiente e menos onerosa. Persiste, contudo, ainda vigente toda a legislação sobre matéria processual, incluídos os Códigos de Processo Civil e Processo Penal, baixados à luz da Constituição anterior pela União Federal, a única competente para legislar sobre aquele assunto. Diante desta nova situação, difícil se torna aos Estados exercer a nova competência enquanto não definidos os limites de sua atuação por lei federal que estabeleça quais, dentre as normas processuais ora vigentes, poderão ser derrogadas por lei local e quais haverão de 
prevalecer como normas gerais de que fala o $\S 1^{o}$ do art. 24 da nova Carta, circunscrevendo, assim, a discricionariedade legislativa agora garantida aos Estados para legislar sobre "procedimentos" (grifo nosso). ${ }^{171}$

De outra parte, "a manutenção pura e simples da situação atual representaria um obstáculo aos Estados que, reunindo melhores condições tecnológicas, econômicas e sociais, anseiem por oferecer ao Poder Judiciário melhores mecanismos legais, mais evoluídos e dinâmicos, no sentido de garantir ao povo prestação de justiça com qualidade equivalente, pelo menos, à já alcançada pelos países mais desenvolvidos". ${ }^{172}$

E continuava em outra passagem sugerindo que "seria, então, de se cogitar da elaboração de novos códigos instituindo apenas normas gerais de processo civil e penal. Esse trabalho, entretanto, demanda longos e apurados estudos, exigindo a participação ampla de toda a coletividade jurídica. Além dos mais, os Códigos atuais, principalmente o de Processo Civil, mais recente, são frutos dos trabalhos dos nossos mais renomados juristas, merecendo subsistir pelo menos enquanto não se apresentarem outras obras à altura que possam vir a substituí-los" (...) "Por outro lado, haverá ainda Estados que talvez prefiram manter a legislação processual em vigor, pelo menos enquanto não se sentirem capazes de aprimorá-la". ${ }^{173}$

O projeto recebeu o aval pleno da Comissão de Constituição de Justiça da Câmara dos Deputado, que em parecer relatado pelo Deputado federal José Thomaz Nono atestou sua constitucionalidade, juridicidade e técnica legislativa. ${ }^{174}$

Em 24.04.1993, contra o voto do PPR, o projeto foi aprovado e encaminhado ao Senado Federal, que após trâmite regular e parecer do Senador Ney Suassuna, aprovou o renumerado projeto de lei $\mathrm{n} .95 / 93$, sem emendas.

Foi, então, o projeto à sanção do Presidente da República que, todavia, o vetou, pelos seguintes motivos: "direito processual, segundo informa a doutrina, é o conjunto de princípios, normas jurídicas destinadas a possibilitar a administração da Justiça, enquanto o procedimento processual é o modo pelo qual aqueles princípios e normas devem ser aplicadas. Em suma, o Direito Processual constitui um todo do qual o procedimento

\footnotetext{
${ }^{171}$ Diário do Congresso Nacional, Seção I, dia 20.09.1989, p. 9.805.

${ }^{172}$ Diário do Congresso Nacional, Seção I, dia 20.09.1989, p. 9.805.

${ }^{173}$ Diário do Congresso Nacional, Seção I, dia 20.09.1989, p. 9.805.

${ }^{174}$ Diário do Congresso Nacional, seção I, dia 04.06.1992, p. 12.189.
} 
processual é uma das partes. Assim, tempo, lugar, prazos e comunicações dos atos processuais, inclusive recursos, constituem matéria de Direito Processual, e, em conseqüência, matéria a ser disciplinada privativamente pela União, nos termos do art. 22, I, da Constituição Federal, salvo se mediante lei complementar autorizar os Estados a legislar sobre questões específicas de Direito Processual (parágrafo único do art. 22 da Constituição). Ora, pelos seus artigos $1^{\circ}$ e $3^{\circ}$ o projeto de lei ordinária pretende deferir aos Estados e ao Distrito Federal competência para legislar, precisamente, sobre estas matérias, o que refoge aos mandamentos dos preceitos constitucionais transcritos" (...) "Ademais, trata-se de projeto de lei despiciendo, isso porque o art. 24, XI, da Constituição, é autoaplicável, independentemente de lei federal regulamentadora, eis que a competência dos Estados emana do próprio texto constitucional" (grifos nossos). ${ }^{175}$

Em 01.09.1999 o veto do Presidente da República Fernando Henrique Cardoso foi mantido por 327 (trezentos e vinte e sete) dos Deputados entre os 362 (trezentos e sessenta e dois) votantes.

O que sobreleva notar nas razões do veto é o primário ou intencional equívoco cometido pelo Presidente da República, seguido pelos congressistas, de creditar à disciplina do tempo, lugar, prazos e comunicações dos atos processuais, natureza de normas processuais, quando na verdade não o são.

Tempo, lugar, prazos e comunicação dos atos processuais são normas procedimentais, e como tal, observadas as normas gerais editadas pela União, de competência dos Estados e do Distrito Federal, nos termos do art. 24, XI, da Carta Constitucional.

Ao assim proceder, descortinou-se a já tanto propalada centralização dos problemas do processo no âmbito federal, e sepultou-se, ao arrepio da Carta Constitucional, qualquer possibilidade dos entes parciais disciplinarem o procedimento (e não o processo como constante das razões do veto) no âmbito local.

Mesmo com o reconhecimento de que o art. 24, XI, da Constituição Federal é auto-aplicável e, portanto, a independer de legislação infraconstitucional que lhe torne útil, a manutenção do veto presidencial acabou por reincorporar integralmente no âmbito

\footnotetext{
${ }^{175}$ Diário Oficial da União de 16.06.1995; mensagem 644, de 14.06.1995.
} 
federal, mesmo que de maneira indireta, temas procedimentais que não são mais de sua exclusiva alçada.

O fracasso desta iniciativa legislativa acabou por colaborar para que os Estados e o Distrito Federal, como se disciplinados pelo veto presidencial e pela timidez jurisprudencial em conter os avanços legislativos da União sobre matéria procedimental não geral, deixassem de exercer a competência legislativa que lhes foi incorporada no texto constitucional. $^{176}$

\subsubsection{Competência concorrente dos Estados e Distrito Federal para legislar sobre processo e procedimentos em sede de juizados especiais}

Uma exceção ao quadro dantes exposto é a encontrada no art. $24, \mathrm{X}$, da Constituição Federal. De acordo com o dispositivo, compete a União, aos Estados e ao Distrito Federal legislar concorrentemente sobre criação, funcionamento e processo dos juizados de pequenas causas, e não só sobre procedimento em matéria processual como consta do genérico inciso XI do dispositivo constitucional. ${ }^{177}$

Pois então os Estados e o Distrito Federal têm competência concorrente tanto para normas processuais quanto para as normas procedimentais já vistas, algo que lhes possibilita, efetivamente, criar regramento próprio e específico conforme as realidades locais.

\footnotetext{
${ }^{176}$ Embora não sejamos capazes de acompanhar com ânimo o veto presidencial a este projeto de lei, José Renato Nalini encontra avanço no aparente retrocesso, aduzindo que "se de um lado impediu o aperfeiçoamento da marcha das demandas institucionalizadas em processo jurisdicional, por outro reconheceu a desnecessidade de lei federal para que os Estados-Membros exerçam a competência do inc. XI do art. 24 da Constituição da República" (NALINI, José Renato. Processo e procedimento - distinção e a celeridade da prestação jurisdicional, cit., p. 687). Data venia, de nada adianta reconhecer a autoaplicabilidade do dispositivo in comento, se o seu conteúdo foi esvaziado de questões referentes ao tempo, lugar, prazos e comunicações dos atos processuais.

${ }^{177}$ Há quem afirme que o termo processo constante do art. 24, X, da Constituição Federal, não foi empregado tecnicamente, devendo, portanto, ser interpretado aqui como sinônimo de procedimento (ALVIM NETTO, José Manoel de Arruda. Manual de direito processual civil, cit., v. 1, p. 143; e ALENCAR, Luiz Carlos Fontes de. Constituição Federal de 1988. Juizados de pequenas causas. Juizados especiais cíveis e criminais. Processo e direito processual. Revista do Centro de Estudos Judiciários do Conselho da Justiça Federal, Brasília, ano 2, n. 5, ago. 1998). Não me parece correta tal interpretação, já que o legislador teve discernimento suficiente para utilizar adequadamente a expressão procedimento no art. 24 , XI, da CF, de modo que sabia o que fazia ao deferir aos Estados e ao DF, concorrentemente à União, competência para legislar sobre o processo (e não só procedimento) dos juizados.
} 
Obviamente, estando no campo da repartição vertical de competências, plenamente aplicáveis os parágrafos do art. 24 da Constituição Federal, isto é, a União só deverá editar, sob pena de inconstitucionalidade, normas gerais sobre criação, funcionamento e processo dos juizados de pequenas causas, competindo aos Estados e ao Distrito Federal todas as demais normas.

A questão que, todavia, é polêmica, e merece maior destaque, é a da exata compreensão do que seriam os juizados de pequenas causas mencionados no inciso.

Duas grandes correntes se formaram a respeito do tema.

A primeira aduz que juizados de pequenas causas não são juizados especiais cíveis, e como tal não se pode aplicar a disposição constitucional para permitir que o legislador estadual ou distrital cuide de processo dos JECs ou dos JEFs, disciplinados na sua inteireza, explicitamente, pelas leis federais n. 9.099/95 e 10.259/2001.

Os defensores desta posição ${ }^{178}$ - entre eles o próprio Supremo Tribunal Federal $^{179}$ - apontam que se na expressão "juizados de pequenas causas" estiver contido os “juizados especiais", há, então, grave pleonasmo cometido pelo legislador constituinte de 1988, já que logo mais no art. 98 da Constituição Federal, determinará que compete à União no Distrito Federal, nos Territórios e no âmbito federal $\left(\$ 1^{\circ}\right)$, e aos Estados, em seu âmbito, criar os juizados especiais, providos por juízes togados, ou togados e leigos, competentes para a conciliação, o julgamento e a execução de causas cíveis de menor complexidade e infrações penais de menor potencial ofensivo, mediante os procedimentos oral e sumaríssimo, permitidos, nas hipóteses previstas em lei, a transação e o julgamento de recursos por turmas de juízes de primeiro grau.

De acordo com os adeptos desta primeira corrente, a Constituição Federal de 1988 recepcionou os já extintos juizados de pequenas causas, que, então, tinham previsão na lei federal n. 7.244/1984, revogada posteriormente pela lei que coincidentemente criou os juizados especiais (art. 97 da Lei n. 9.099/95).

\footnotetext{
${ }^{178}$ Cf. ALENCAR, Luiz Carlos Fontes de. Constituição Federal de 1988, cit.; BASTOS, Celso Ribeiro; MARTINS, Ives Gandra da Silva. Comentários à Constituição do Brasil. São Paulo: Saraiva, 1993. v. 3, t. 3, p. 39; OLIVEIRA JÚNIOR, Waldemar Mariz. A Constituição da República e os procedimentos alternativos. Revista da Escola Paulista da Magistratura, São Paulo, v. 1, p. 67-81, 1993.

${ }^{179}$ STF, ADI n 1.127, Min.Paulo Brossard, j. 28/09/94.
} 
Sendo assim, a Carta Magna se refere a dois institutos distintos ${ }^{180}$, os juizados de pequenas causas para processamento de ações de conhecimento de até 20 saláriosmínimos - para os quais há competência concorrente dos Estados e Distrito Federal também para normas processuais (art. 24, X, da CF) ${ }^{181}$ - e também os juizados especiais, para processamento e execução de causas de até 40 salários-mínimos - que pela falta de previsão própria seguem a regra geral do sistema, isto é, compete a União ditar-lhes todas as regras processuais e as procedimentais gerais, restando aos Estados e ao Distrito Federal, exclusivamente, a competência para normas procedimentais não gerais (art. 24, $\mathrm{XI}$, da CF).

Já a segunda corrente e que advogamos ${ }^{182}$ parte da premissa que os juizados de pequenas causas equivalem no regime constitucional vigente aos juizados especiais referidos no art. 98, I, da Constituição Federal ${ }^{183}$, razão pela qual, no tocante aos feitos afetos ao JEC e ao JEF, a competência dos Estados e do Distrito Federal também abrange matéria processual, e não só procedimental como se encontra no art. 24, XI, da Constituição Federal.

De fato, a Lei 9.099/95, que cuida dos juizados especiais, considera “causas cíveis de menor complexidade" não só as que, pela sua natureza, são consideradas simples, como igualmente, as causas de reduzida expressão econômica. O art. $3^{\circ}$, I, da Lei dos

\footnotetext{
${ }^{180}$ É o que transparece, aliás, na Constituição do Estado de São Paulo, que no uso do poder constituinte decorrente previu, no art. 54, a existência no âmbito do Poder Judiciário paulista tanto dos juizados especiais (VIII), quanto dos juizados de pequenas causas (IX), como se fossem coisas distintas. Só que a própria Carta Constitucional paulista, mais adiante, acaba igualando os dois órgãos através de tratamento conjunto (artigos 83 e 87). A expressão baixa complexidade abarca, conforme a mens legis constitucional, a referência ao pequeno valor.

${ }^{181}$ Cf. OLIVEIRA JÚNIOR, Waldemar Mariz. A Constituição da República e os procedimentos alternativos, cit., p. 70; e BASTOS, Celso Ribeiro; MARTINS, Ives Gandra da Silva. Comentários à Constituição do Brasil. São Paulo: Saraiva, 1993. v. 3, t. 3, p. 40.

${ }^{182}$ Bem acompanhados, aliás, por MALACHINI, Édson Ribas. A Constituição Federal e a legislação concorrente dos Estados e do Distrito Federal em matéria de procedimentos, cit., p. 49-50; JESUS, Damásio Evangelista. A lei dos juizados especiais criminais anotada. São Paulo: Saraiva, 1995. p. 26; BATISTA, Weber Martins; FUX, Luiz. Juizados especiais cíveis e criminais e suspensão condicional do processo penal. Rio de Janeiro: Forense, 1996. v. 2; ABREU, Pedro Manoel. Juizados Especiais. Jurisprudência Catarinense, Florianópolis, ano 21, n. 72, p. 38, 1995; THEODORO JÚNIOR, Humberto. Curso de direito processual civil. .39. ed. Rio de Janeiro: Forense, 2006. v. 3, p. 453; e Cândido Rangel Dinamarco, um dos autores da lei de pequenas causas (Lei n. 7.244/84), para quem além de não haver distinção entre "juizados de pequenas causas" e "juizados especiais", a Lei n. 9.099/95 permite a esperança de um processo que favoreça de modo muito eficiente a percepção dos fatos e do próprio modo de ser do litígio (DINAMARCO, Cândido Rangel. Manual de pequenas causas. São Paulo: Ed. Revista dos Tribunais, 1986. passim, A instrumentalidade do processo, cit., p. 129).

${ }^{183}$ Este também é o entendimento de Edson Ribas Malachini, para quem a expressão pequenas causas é um tanto vaga e, interpretando-se teleologicamente os dispositivos constitucionais, pode ser incluída no bojo dos Juizados Especiais (MALACHINI, Édson Ribas. A Constituição Federal e a legislação concorrente dos Estados e do Distrito Federal em matéria de procedimentos, cit., p. 49-50.
} 
Juizados Especiais, fala, por isto, em competência para "causas cujo valor não exceda a 40 (quarenta) vezes o salário mínimo”. Não há dúvida, então, de que o texto constitucional, ao referir-se a causas cíveis de "menor complexidade" dá uma extensão maior ao conceito de "pequenas causas" firmado na Lei 7.244/84, que considerou, apenas e tão somente, o aspecto patrimonial das demandas. ${ }^{184}$

Ao referir-se a juizados de pequenas causas no inciso $\mathrm{X}$ do art. 24, induvidosamente, o legislador constituinte cometeu equívoco, mesmo porque se fosse sua intenção instituir duas modalidades de juizados, distintos, autônomos e independentes, os “juizados de pequenas causas certamente constariam no capítulo referente ao Poder Judiciário, como ocorre com os juizados especiais". ${ }^{185}$

Rememorando o período da constituinte, o Min. Rafael Mayer, então presidente do Supremo Tribunal Federal, anotou que havia dois itens autônomos em pauta no projeto de Carta Constitucional. "Um que se referia ao Juizado Especial, formado por juízes togados e Juizes leigos, para julgar determinadas causas, com menor complexidade, permitindo recursos para Turmas de Juízes. E havia um outro, que falava especificamente em Juizados de Pequenas Causas, em jurisdição única, para causas de pequena relevância e contravenções. Na revisão final, quando apenas se ajustaram os textos e se suprimiram excrescências, desapareceu esse título do Juizado de Pequenas Causas. E como este Juizado de Pequenas Causas tem sua colocação própria, na competência dos Estados, é de entender, daí, a amplitude, porque o constituinte considerou, certamente, que era desnecessário, porque se comportava dentro daquele dispositivo, um Juizado de uma maneira ampla, tanto os Juizados Especiais como os Juizados de Pequenas Causas, tal como era definido, aliás, sob proposta do Supremo Tribunal Federal". ${ }^{186}$

\footnotetext{
${ }^{184}$ Por isto que não me convence o argumento de que os dois juizados são distintos porque distintas as suas competências, ou seja, a do primeiro, estabelecida em face do "pequeno valor" das causas (até 20 salários mínimos, a que aludia a Lei $n^{\circ} 7.244 / 84$, que teria sido recepcionada pelo art. 24, X, da Constituição), e a do segundo, em razão da "menor complexidade" das questões cíveis (art. 98, I, da Carta Constitucional).

${ }^{185}$ Neste sentido, cf. o texto do Desembargador Rêmolo Letteriello, Mato Grosso do Sul: onde nasceram os juizados especiais. Tribunal de Justiça. Poder Judiciário. Mato Grosso do Sul. Disponível em: <http://www.tj.ms.gov.br/portal2005/juizados/doutrina/DTR_20050607181401.pdf>. Acesso em: 20 nov. 2006. Cf., também, do mesmo autor, Considerações sobre os juizados de pequenas causa. Revista dos Juizados Especiais de Pequenas Causas, TJ/RS, n. 2, p. 11-12, ago. 1991.

${ }^{186}$ Este entendimento foi apresentado no seminário O Poder Judiciário e a Nova Constituição, na conferência denominada Aspectos Gerais do Poder Judiciário, proferida no Tribunal de Justiça do Estado de São Paulo, e anteriormente reproduzida em parte no artigo: Supremo Tribunal Federal: corte constitucional do Brasil, Revista da Associação dos Advogados de São Paulo, São Paulo, n. 27, p. 50 e ss., jun. 1989.
} 
Ademais, não havia mesmo sentido para que o constituinte criasse poderosa regra de competência concorrente para juizado que, logo adiante, seria substituído por outro, de mesma natureza, a ser criado pelos Estados (art. 98 da Constituição Federal).

Usou, assim, o legislador, a expressão juizados de pequenas causas como sinônima dos juizados especiais, instituição que abarca as pequenas causas (art. $3^{\circ}$ da Lei $n$. 9.099/95). E assim o fez porque acreditou, embebido pelo propósito descentralizador, que para as causas de menor complexidade poderia cada Estado da federação e o Distrito Federal criarem regras processuais próprias, distintas conforme as realidades locais.

Por isto, havendo apenas um dos juizados (os especiais), de acordo com as regras instituídas nos parágrafos do art. 24 da Constituição Federal, a União tem competência para edição de normas gerais sobre a criação, o funcionamento e o processo deles, enquanto que aos Estados e Distrito Federal, que têm competência plena na omissão da União quanto as primeiras (competência complementar), compete a edição de normas processuais locais sobre os processos que por aí tem curso.

As Leis n. 9.099/95 e 10.259/2001, que respectivamente disciplinaram o funcionamento e o processo dos Juizados Especiais Estaduais e Federais (art. 98, I, da CF), entretanto, em muito excederam os limites da generalidade ${ }^{187}$, disciplinando por completo, em manifesta inconstitucionalidade, o processo e o procedimento dos juizados especiais. Deixou-se ao legislador local praticamente nada no tocante à adequação do processo e do procedimento das causas menos complexas à vontade e realidade locais. ${ }^{188}$

Pois se observarmos as citadas leis, veremos que elas regulam em minúcias tanto os aspectos relacionados à relação jurídica processual (competência, legitimidade,

\footnotetext{
${ }^{187}$ Mesma impressão revelada pelo Min. Ricardo Lewandowski na sessão plenária do Supremo Tribunal Federal realizada em 25.10.2006, para apreciação da medida liminar da ação declaratória de inconstitucionalidade n. 3.774, do Estado de Roraima, cuja Relatoria é do Min. Joaquim Barbosa.

${ }^{188}$ Prova disto é que as várias leis que disciplinaram os Juizados Especiais nos Estados e no Distrito Federal repetiram integralmente o texto da Lei n. 9.099/95, acrescentando, apenas, aspectos referentes à organização das unidades judiciárias dos Estados. Neste sentido, cf. a lei do Estado de Pernambuco de n. 11.279/1995; lei do Estado do Paraná de n. 11.468/96; lei do Estado do Rio de Janeiro de n. 2.556/1996; lei do Estado do Rio Grande do Sul de n. 9.466/95; lei n. 6.845/95 do Rio Grande do Norte; lei n. 2.330/1995 do Estado da Amazônia; lei complementar n. 24/1995 do Estado de Sergipe; entre muitas outras. Antes da edição da Lei n. 9.099/95, muitos Estados deram plena eficácia ao comando constante do art. 98 da Constituição Federal, disciplinando no âmbito local, com fundamento no art. 24, X, da Constituição Federal, o processo e o procedimento nos juizados. Nelas sim havia disciplina regional e inovadora, devendo, por isto, serem conferidas a lei do Estado do Mato Grosso do Sul de n. 1.071/1990, que inspirou decisivamente o teor da lei federal n. 9.099/95, com vários dispositivos idênticos; a lei do Estado de Santa Catarina de n. 8.151/90 e lei complementar 77/93; a lei do Estado da Paraíba de n. 5.466/1991; e a lei do Estado do Mato Grosso de n. 6.176/93; entre outras.
} 
cabimento, recursos, etc.) quanto ao procedimento sumaríssimo (combinação dos atos processuais). Restou aos Estados e ao Distrito Federal, apenas, disciplinar a distribuição dos juizados no bojo do seu território (que é matéria de organização judiciária e, como tal, de competência dos entes parciais mesmo), o horário de funcionamento das unidades, além de outras questões de somenos importância, o que, convenhamos, é muito pouco frente ao propósito descentralizador da Carta Constitucional.

A Constituição Federal ao estabelecer, exemplificativamente, que o procedimento dos juizados especiais seria oral e sumaríssimo (art. 98), já fixou os parâmetros mínimos para atuação do legislador estadual ou distrital, que, com base nisto, deveria modelar o procedimento de acordo com as conveniências locais. ${ }^{189}$ A lei federal $n$. 9.099/95 não tinha mais nada a fazer no tocante ao procedimento, daí porque a disciplina desta natureza nela constante é contrária às regras de compatibilização em matéria de repartição vertical de competências previstas na Constituição Federal(art. 24 e §§).

Este, entretanto, não é o entendimento do Supremo Tribunal Federal. Partindo da premissa de que os juizados especiais não se confundem com os juizados de pequenas causas e, portanto, crendo ser da União a competência para todas as normas processuais desta natureza, a Corte pronunciou, antes da vigência da Lei n. 9.099/95, que os Estados membros não podiam disciplinar o processo dos juizados, taxando de inconstitucional, portanto, as tentativas locais neste sentido, já que quanto ao processo sequer havia competência complementar dos Estados. ${ }^{190}$

Mesmo após a edição da Lei n. 9.099/95, todas as tentativas estaduais de suplementar, em matéria processual, os feitos que têm curso nos juizados, foram barradas

\footnotetext{
${ }^{189}$ No mesmo sentido, Edson Ribas Malachini aponta que "quanto ao procedimento não há normas gerais a serem estabelecidas em lei federal, porque os parâmetros - procedimento oral e sumaríssimo - já são suficientes para fixarem as diretrizes a seguir pelos legisladores estadual e distrital (MALACHINI, Édson Ribas. A Constituição Federal e a legislação concorrente dos Estados e do Distrito Federal em matéria de procedimentos, cit., p. 52).

${ }^{190}$ Foi o que ocorreu com as leis estaduais do Mato Grosso do Sul (n. 1.071/90) e da Paraíba (n. 5.466/91), que disciplinaram, antes da vigência da Lei n. 9.099/95, com base no comando constante do art. 24, X, da Constituição Federal, o processo e o procedimento dos juizados especiais cíveis e criminais. No julgamento do HCs ns. 71.713 e 72.930, ficou consignado que inexistindo competência concorrente dos Estados para o processo dos juizados, impossível que eles, valendo-se de competência complementar (art. $24, \S 1^{\circ}$, do CF), operacionalizassem o art. 98 da Constituição Federal antes da edição de lei federal sobre o processo. E em outras passagens o Supremo aduziu que "dada a distinção conceitual entre os juizados especiais e os juizados de pequenas causas (cf. STF, ADI n 1.127, cautelar, 28/09/94, Brossard) aos primeiros não se aplica o art. 24, X, da Constituição, que outorga competência concorrente ao Estado-Membro para legislar sobre o processo perante os últimos. Consequiente inconstitucionalidade da lei estadual que, na ausência de lei federal a respeito, outorga competência penal a juizados especiais e lhe demarca o âmbito material." (HC 75.308, Rel. Min. Sydney Sanches, DJ 01/06/01).
} 
pelo Supremo, sempre sob o fundamento de que não compete aos Estados legislar sobre o processo dos juizados (art. 24, X, da Constituição Federal), mas exclusivamente sobre normas procedimentais não gerais (art. 24, XI, da Constituição Federal).

Neste sentido, nossa Corte constitucional pronunciou descaber confusão entre a competência concorrente da União, Estados e Distrito Federal para legislar sobre procedimentos em matéria processual (artigo 24, inciso XI), com a privativa para legislar sobre direito processual, prevista no artigo 22, inciso I, ambos da Constituição Federal. Os Estados, por isto, não têm competência para a criação de recurso em sede de juizados (embargos de divergência contra decisão de turma recursal), típica matéria processual fora de sua alçada. ${ }^{191}$

No mesmo sentido estabeleceu, por se tratar de matéria tipicamente processual (e, portanto, da reserva da lei federal), que lei estadual que dispõe sobre juizados especiais não pode introduzir novas hipóteses de aplicação do procedimento previsto no artigo 28 do Código de Processo Penal, com determinação de encaminhamento dos autos ao Procurador Geral de Justiça nos casos em que a autoridade judiciária discordar da postura processual adotada pelo representante do Ministério Público. ${ }^{192}$

O que sobreleva notar desta postura centralizadora do Supremo Tribunal Federal é que, com ela, nem para causas de menor complexidade, admite-se que os Estado e o Distrito Federal possam flexibilizar as regras processuais e procedimentais em favor de suas realidades locais, algo que me parece não ter sido o desejo da Carta Constitucional.

\subsection{Conclusão parcial}

Os países que adotaram o federalismo têm, geralmente, realidades regionais heterogêneas, extensão continental e sociedade complexa, razões que exigem melhorias dos serviços públicos, inclusive do serviço público judiciário, algo que só ocorre com a descentralização. ${ }^{193}$

\footnotetext{
${ }^{191}$ STF, AI 253.518-AgR, Rel. Min. Marco Aurélio, DJ 30/10/98; STF, RE 273.899/SC, Rel. Min. Sepúlveda Pertence; AI-AgR 210.068/SC, Rel. Min. Marco Aurélio, j. 28.08.1998.

${ }^{192}$ STF, ADI 2.257-MC, Rel. Min. Nelson Jobim, DJ 06/04/01.

${ }^{193}$ BONAVIDES, Paulo. A Constituição aberta, cit., p. 46.
} 
Não se pode aceitar, como acena equivocadamente, data venia, parte da doutrina, que a interpretação descentralizadora em favor dos Estados e do Distrito Federal para legislação em matéria processual e procedimental acarrete violação do princípio da isonomia (art. $5^{\circ}$, caput, da Constituição Federal), visto que jurisdicionados, em diversos locais da federação, teriam "direitos diferentes". 194

O simples abraçar, pelo Estado brasileiro, do regime federalista, já implica reconhecimento de inúmeras diferenças regionais, hábeis, portanto, a ensejar tratamento não igualitário aos jurisdicionados postados em locais diferentes dentro da imensidão do território brasileiro.

Ao contrário do afirmado, este tratamento diferenciado vem em favor da isonomia, e não contra ela. Possibilita que nos mais diversos rincões do país jurisdicionados recebam tratamento igualitário conforme suas igualdades, e não tratamento igualitário tendo realidades completamente desiguais.

Caso doutrina, jurisprudência (especialmente o Supremo Tribunal Federal) e os próprios entes federados se postassem de conformidade com este ideário - que não precisa de alteração legislativa para ser implantado, pois já decorre da interpretação correta do texto constitucional - certamente muito dos problemas do processo (e do procedimento) poderiam ser solucionados pela via legislativa no âmbito local, evitando este sem número de reformas do Código de Processo Civil ${ }^{195}$ que, apesar de bem intencionadas, buscam expressamente solucionar problema de um ou outro Estado da federação, onde as causas da ineficiência do sistema judicial são históricas e sociais. ${ }^{196}$

Destarte, muito embora tenha procurado redefinir a fisionomia do Estado brasileiro, atribuindo maior grau de autonomia aos entes da Federação no tocante ao direito

\footnotetext{
${ }^{194}$ ALVIM NETTO, José Manoel de Arruda. Manual de direito processual civil, cit., v. 1, p. 150.

${ }^{195}$ Luiz Rodrigues Wambier, em artigo não publicado, anota que entre os desafios do processualista após as últimas reformas do Código de Processo Civil está o de "discutir os dados obtidos pelas áreas envolvidas em todas as unidades da Federação, e não apenas em unidades em que o sistema é visível e historicamente problemático" (WAMBIER, Luiz Rodrigues. A reforma daqui por diante. Artigo não publicado). Pareceme que o professor paranaense está exatamente a indicar que as reformas processuais não podem visualizar só problemas locais, ainda que do Estado economicamente mais importante do país. Exatamente para evitar estas reformas que valem para todos, mas que visam apenas parcela dos jurisdicionais, é que propomos a revitalização das normas procedimentais estaduais ou distritais.

${ }^{196}$ Como bem aponta José Renato Nalini, "na verdade não têm sido as normas de processo as responsáveis pelo aparente aquilosamento da Justiça, mas a inflexibilidade e o anacronismo das normas de procedimento" (NALINI, José Renato. Processo e procedimento - distinção e a celeridade da prestação jurisdicional, cit., p. 679).
} 
processual como um todo - mais incisivamente no âmbito dos juizados especiais, e um pouco mais modestamente no âmbito da justiça comum - a Constituição de 1988 não conseguiu alterar o curso histórico de nosso federalismo. Ao arrepio da Lei Maior, a tradição centralista talhou a disciplina do processo civil brasileiro, que continua com seus modelos básicos, genéricos e extremamente rígidos, sem possibilidade de conformação de sua estrutura à realidade da causa ou da região onde tem curso a demanda.

Enquanto não se alcança esta evolução interpretativa e efetivamente os Estados avencem na construção de modelos procedimentais próprios - o que é recomendável e tornam desnecessárias intervenções judiciais para adequar o procedimento à realidade da causa - é com base nas normas postas na legislação federal, e na criatividade dos juízes e das partes, que devemos encontrar, então, a via para flexibilização do procedimento. E isto só será possível se compreendermos, em seu cerne, as razões que justificam o modelo rígido adotado em nosso país, sem o que não conseguiremos demonstrar que a flexibilização não é incompatível com a previsibilidade, a segurança jurídica e o devido processo legal. 


\section{FUNDAMENTOS DOGMÁTICOS DA FLEXIBILIZAÇÃO PROCEDIMENTAL}

\subsection{Processo e procedimento}

\subsubsection{Distinção}

No capítulo anterior já tivemos a oportunidade de estabelecer a diferença entre processo e procedimento (item 2.4.3.).

Por lá, consignamos que processo - cuja noção é eminentemente teleológica, finalística, voltada para o resultado almejado - é entidade complexa composta pelo conjunto de todos os atos necessários para a obtenção de uma providência jurisdicional num determinado caso concreto, podendo ele conter um ou mais procedimentos (procedimento recursal), ou, inclusive, apenas um procedimento incompleto (indeferimento da petição inicial). O processo é o veículo pelo qual o Estado-Juiz, ou quem lhe faça às vezes, exerce a jurisdição (dever-poder de dizer o direito de forma definitiva), o autor o direito de ação e o réu o direito de defesa (contraditório). Não interessa para o estudo do processo se o autor tenha ou não ação ${ }^{197}$, ou se, tendo ação, tenha acolhido ou não o seu pedido (pretensão). O processo é indiferente, apenas neste sentido, ao seu conteúdo, pois que a sua natureza instrumental simplesmente conduz o direito de ação reclamado até uma resposta do órgão jurisdicional, que pode ser positiva, caso em que se aprecia o mérito do pedido (procedência ou improcedência), ou negativa, casos em que o feito é extinto sem julgamento do mérito (art. 267 do CPC).

\footnotetext{
${ }^{197}$ Ação é o direito público subjetivo de obter do Estado/Juiz, ou de quem lhe faça às vezes (arbitragem - Lei 9.307/1996), resposta a uma pretensão regularmente formulada. De acordo com a teoria autonomista e abstrativista da ação, somente tem ação e, portanto, direito de obter resposta à pretensão formulada, aquele que preencher o binômio pressupostos processuais e condições da ação. Presentes estes requisitos o juiz reconhece, através da sentença (art. 269 do CPC), o direito de ação do postulante, ofertando-lhe uma resposta à sua pretensão, que pode ser positiva (procedência do pedido) ou negativa (improcedência do pedido). Já se ausentes referidos pressupostos, o juiz, também através de uma sentença, não reconhece o direito de ação do postulante, deixando de dar resposta ao pedido formulado (mérito), nem o acolhendo, nem o negando (art. 267 CPC).
} 
Já o procedimento é a faceta dinâmica do processo, é o modo pelo qual os diversos atos processuais se relacionam na série constitutiva do processo, representando o modo do processo atuar em juízo (seu movimento), pouco importando a marcha que tome para atingir seu objetivo final, que pode ser uma sentença de mérito ou terminativa, a apuração do quantum debeatur (liquidação de sentença), a satisfação do direito (processo de execução) ou a obtenção de uma garantia (processo cautelar). No procedimento é que são fixadas as regras (prazos, modo etc.) para que as partes, o juiz e os auxiliares da justiça pratiquem os atos processuais tendentes a conduzir cada tipo de processo do começo ao fim.

Assim, no âmbito do processo de conhecimento brasileiro, se o procedimento (ou rito) for o sumário, a contestação escrita ou oral deve ser ofertada em audiência (art. 278 do $\mathrm{CPC}$ ), enquanto que se o procedimento for o ordinário, a contestação, necessariamente escrita, deve ser apresentada no prazo de 15 (quinze) dias a contar da juntada aos autos do mandado de citação (artigos 297 c.c. 241, II, ambos do CPC); no procedimento ordinário são requisitos da sentença o relatório, a fundamentação e a parte dispositiva (art. 458 do CPC), enquanto que no procedimento sumaríssimo dispensa-se o relatório (art. 38, da Lei 9.099/1995). Note-se nestes exemplos que o processo é o mesmo (processo de conhecimento), mas que o modo e o tempo para a prática dos atos processuais (o procedimento) são distintos.

Tivemos a oportunidade de destacar, também no capítulo anterior, que entre as teorias sobre a natureza jurídica do processo em sentido lato, a que conta com o maior prestígio é a que o tem como relação jurídica. Assim, processo seria entidade complexa composta de: a) relação jurídica processual; que é o elo a ligar os sujeitos do processo (partes e Estado-Juiz) em uma série de situações jurídicas, atribuindo-lhes deveres, obrigações, sujeições e ônus; e b) procedimento; que é a maneira como os atos processuais são ligados entre si, o iter a ser seguido até a obtenção do provimento final.

\subsubsection{Evolução terminológica e conceitual do sistema processual civil vigente em relação às legislações processuais antecedentes}

Na Carta Constitucional de 1891 previa-se a competência da União e também dos Estados federados para legislarem sobre processo, cada um devendo discipliná-lo para sua própria Justiça. O Decreto Federal n. 3.084/1898 (Consolidação das leis referentes à 
Justiça Federal) organizou o processo no âmbito da União. Os Estados, enquanto não promulgaram seus Códigos processuais, continuaram a se valer do regulamento 737/50 para as causas comerciais, e da Consolidação de Ribas de 1876 para as causas cíveis.

Pelo artigo 675 da Consolidação de Ribas, havia 17 (dezessete) ações ditas sumárias, com procedimento distinto do ordinário. De acordo com próprio Conselheiro, tais causas ${ }^{198}$ assim tinham sido imaginadas em razão da parvidade de seu objeto, do favor de que gozam, ou da urgência da decisão. ${ }^{199}$

As causas comerciais desenvolviam-se ordinariamente de acordo com os números 23 a 235 do Regulamento 737, de 25.11.1850. As ações sumárias eram previstas nos números 236 a 245 e as ações especiais nos números 246 a 320.

Tanto na Consolidação de Ribas quanto no regulamento 737/50 a promiscuidade entre as expressões "acção", processo e procedimento era constante. Utilizavam-se as tais palavras como se fossem sinônimas.

Com o advento dos Códigos Estaduais, cada unidade da federação passou a prever seus processos e procedimentos, embora ainda sem nenhum rigor técnico na diferenciação entre estes institutos. ${ }^{200}$

Analisando apenas aqueles Códigos Estaduais apontados ora ou outra como os mais importantes, tinha-se na legislação da Bahia processo ordinário (artigos 67 a 318), sumário (artigos 319 a 330), sumaríssimo (artigos 331 a 339) e especial (artigos 340 a 1.053); em São Paulo, processo comum, composto pelas ações ordinárias, sumária e sumaríssima (artigos 474 a 490), e processos especiais (491 a 938), em ampla heterogeneidade; no Rio Grande do Sul - o mais meticuloso dos Códigos Estaduais - 05

\footnotetext{
${ }^{198}$ Eram as seguintes as ações especiais: 1) causas de mais de $100 \$$ até $500 \$ 000$ sobre bens de raiz; 2) as da liberdade; 3) as de assignação de dez dias; 4) as possessórias, intentadas dentro de ano e dia; 5) as de despejo de casas; 6) as de depósito convencional; 7) as de alimentos; 8) as de soldadas; 9) as de juramento d'alma; 10) as de reformas de autos; 11) as de preceito cominatório ou embargos à primeira; 12) as de inventário e partilhas; 13) as de demarcação; 14) as arbitrais; 15) as preparatórias; 16) as incidentes; e 17) os processos administrativos.

${ }^{199}$ RIBAS, Antonio Joaquim. Consolidação das leis do processo civil. 3. ed. Rio de Janeiro: Jacintho Ribeiro dos Santos, 1915. p. 459 e ss.

${ }^{200}$ Conforme aponta José de Moura Rocha, não existia qualquer norte para a classificação das ações e dos processos (procedimentos, melhor). A classificação dos processos era feita de acordo com o procedimento, fruto da confusão que se fazia no princípio entre os dois institutos (ROCHA, José Moura. Sobre os procedimentos especiais. Revista de Processo, São Paulo, ano 14, n. 53, p. 24, jan./mar. 1989).
} 
(cinco) tipos de processos: a) ordinário; b) sumário geral; c) sumário especial (artigos 512 a 824); d) sumaríssimo geral; e e) sumaríssimo especial (artigos 826 a 872).

Com o restabelecimento da unidade legiferante em matéria processual na Constituição Federal de 1934, os Códigos Estaduais continuaram a regular os processo no âmbito estadual até a vigência da legislação unificada de 1939, que para todos os efeitos revogou as legislações locais.

O revogado Código de Processo Civil de 1939 (Decreto-lei n. 1.608) indicava a existência de 03 (três) processos: a) o ordinário, cabível toda vez que não houvesse processo especial previsto no Código (livro III); b) os especiais, no total de 38 (trinta e oito), muitos deles de jurisdição voluntária (livro IV); e c) os acessórios, em um total de 23 (vinte e três) (livro V). Regulava em uma última parte (livro VIII), ainda, a execução.

Também aqui não se vislumbrava distinção clara entre processo e procedimento $^{201}$, tanto que no bojo dos procedimentos especiais era encontrada a nominada ação executiva (art. 298 e ss), medida cujo cunho de satisfatividade se aproxima muito da atual execução por título extrajudicial (Lei n. 11.382/2006). E no livro dos processos acessórios havia verdadeira miscelânea entre processos de natureza cautelar e algumas modalidades de processo de conhecimento, como os embargos de terceiro (art. 707 e ss.). ${ }^{202}$

Foi com o Código de Processo Civil de 1973 (Lei n. 5.869) que se estabeleceu como mais rigor distinção entre processo e procedimento ${ }^{203}$, com explicitação das espécies de processo segundo a pretensão, algo que já era pacífico na doutrina. O vigente Código de

\footnotetext{
${ }^{201}$ O que não passou despercebido por Luiz Machado Guimarães, preciso ao indicar que referida divisão não era propriamente de processos, mas sim de procedimentos (GUIMARÃES, Luiz Machado. Comentários ao Código de Processo Civil. Rio de Janeiro: Revista Forense, 1942. v. 4, p. 8).

${ }^{202}$ Não se retire, entretanto, o mérito da legislação unificada de 1939. Afirma-se que foi a primeira legislação processual moderna a vigorar no Brasil, já que as Ordenações, a Consolidação de Ribas e o Regulamento 737/50 carregavam um modelo processual medieval. Referido diploma era de tamanha qualidade técnica que as regras de forma e sobre os poderes do juiz foram dele praticamente copiadas pelo CPC ainda vigente.

${ }^{203}$ Distinção até hoje, data venia, não visualizada com clareza pelo legislador português, que ainda utiliza com promiscuidade as expressões processo e procedimento. O CPC luso, no livro III, Título I, que cuida do processo, mais precisamente no capítulo IV, fala-se em procedimentos cautelares, dividindo-o em procedimento cautelar comum (seção I) e procedimentos cautelares especificados (seção II). Já no capítulo VI do mesmo Título I, cuidam-se das formas de processo, dividindo-se eles entre processo de declaração (seção II) e processo de execução (seção III). Mais adiante, ao tratar especificadamente do processo de declaração no Livro III, Título I, nomina-se o procedimento base de processo ordinário (subtítulo I), reservando-se os subtítulos seguintes para o processo sumário (II) e sumaríssimo (III). Por fim, fala no Título IV do mesmo livro em processos especiais. Também em constante confusão, o Codigo de Procedimiento Civil chileno utiliza-se da expressão procedimiento para qualificar tanto os processos de conhecimento e execução, como também para identificar os procedimentos ordinários e especiais, pese na doutrina ser encontrada exata diferenciação entre proceso e procedimiento (cf. CAROCCA PÉREZ, Alex. Manual de derecho procesal. Santiago: LexisNexis, 2003. p. 19).
} 
Processo Civil prevê a existência dos três ${ }^{204}$ tradicionais processos classificados conforme o objeto da tutela jurisdicional - conhecimento (livro I), execução (livro II) e cautelar (livro III) - seguidos de seus respectivos procedimentos (comuns e especiais).

No livro IV, reservou espaço para os procedimentos especiais ${ }^{205}$, que embora possam ser considerados processos de conhecimento, têm, por particularidades ligadas ao direito material ou à qualidade das partes litigantes, combinação diversa dos seus atos processuais, isto é, procedimento distinto do comum, bem como parcela (não preponderante) de atividade executiva e cautelar. ${ }^{206}$ É este último livro dividido em duas partes, uma para cuidar dos processos contenciosos e outra para os voluntários.

Pontes de Miranda, comentando a utilização das expressões processo e procedimento no Código de Processo Civil de 1973, aplaudiu o legislador, embora ressalvando que os dispositivos contidos no capítulo do procedimento ordinário (art. 282 e

\footnotetext{
${ }^{204}$ Conforme aponta Araken de Assis, essa tripartição apresentou, nas análises iniciais, o mérito de realçar e conferir autonomia à função cautelar, e de modo sem paradigma no direito comparado (ASSIS, Araken de. Fungibilidade das medidas inominadas cautelares e satisfativas. Revista de Processo, São Paulo, Ano 25, n. 100, p. 36, out./dez. 2000), o que mereceu aplausos de Ovídio Baptista da Silva (Comentários ao Código de Processo Civil. Porto Alegre: Lejur, 1985. p. 3) e de Galeno Lacerda (Comentários ao Código de Processo Civil. Rio de Janeiro: Forense, 1980. p. 2-6). Mas como bem anotado por José Carlos Barbosa Moreira (O processo cautelar. In: ___. Estudos sobre o novo Código de Processo Civil. Rio de Janeiro: Líber Júris, 1974. p. 230) e BEDAQUE, José Roberto dos Santos. Tutela cautelar e tutela antecipada: tutelas sumárias e de urgência - tentativa de sistematização. 3. ed. São Paulo: Malheiros Ed., 2003. n. 28, p. 186-194), talvez não seja muito correto classificar o processo cautelar como um terceiro gênero, pois que ele não tem uma finalidade em si próprio (enquanto o conhecimento e a execução têm). Fosse talvez recomendável uma classificação entre processos que têm fins próprios ou definitivos (conhecimento e execução) e os que não têm ou não são definitivos (cautelar), como o faz Francesco Carnelutti (Instituições do processo civil, cit., v. 1, p. 111-112 e 134).

${ }^{205}$ Carnelutti criticava a utilização da expressão procedimentos especiais, como é corrente no CPC pátrio, para o processo civil italiano. Dizia que os procedimentos especiais contemplam verdadeiros processos especiais, que não se amoldam nem no processo de conhecimento, tampouco no de execução, daí porque "essa arquitetura não satisfazia às exigências científicas" (Instituições do processo civil, cit., v. 1, p. 473474). Já para Pontes de Miranda a opção pela nomenclatura procedimentos especiais foi correta, pois são eles "formas de procedimento para obtenção de tutela jurídica quando, por algum dado de direito material, ou documento em que se funda a demanda, ou da pessoa autora, ao legislador pareceu ser inadequada a forma ordinária. Não há razão unitária nem sequer elemento comum para a especialidade”, já que a eleição resulta "da sugestão plural de muitas razões, histórica e logicamente diferentes, e nem sempre justiçáveis perante a crítica científica" (MIRANDA, Francisco Cavalcanti Pontes de. Comentários ao Código de Processo Civil. Rio de Janeiro: Forense, 1977. v. 13, p. 4), no que é acompanhado por Adroaldo Furtado Fabrício (Comentários ao Código de Processo Civil, cit., v. 8, t. 3, p. 2).

${ }^{206}$ A opção pela colocação dos procedimentos especiais em um livro autônomo do CPC de 1973 (Livro IV) é bastante discutível do ponto de vista científico. Embora se aplauda a facilidade de organização do diploma processual por conta desta opção, é fato que os procedimentos especiais deveriam ser tratados no Livro I do CPC, ao lado dos demais procedimentos (comuns) do processo de conhecimento. Em sentido semelhante, também criticando a colocação dos procedimentos especiais no livro IV do CPC vigente, cf. PASSOS, J.J. Calmon de. Comentários ao Código de Processo Civil, cit., v. 3, p. 4; DINAMARCO, Cândido Rangel. Procedimentos especiais de jurisdição voluntária. In: Fundamentos do processo civil moderno, cit., v. 1, p. 378; e, principalmente, FABRÍCIO, Adroaldo Furtado. Comentários ao Código de Processo Civil, cit., v. 8 , p. 10-11.
} 
ss.) não tenham contemplado apenas suas estrutura, mais também disciplinando os pressupostos essenciais ao exercício da ação e a própria res in iudicium deducta. ${ }^{207}$

Também Dinamarco deixou assente que foi só mesmo no Código de Processo Civil atual que as expressões processo e procedimento foram empregadas de maneira correta, esta última para designar a disciplina dos atos do processo, intrinsecamente ou em sua seqüência ou correlação, como procedimento comum, procedimento ordinário, procedimento sumário (art. 272), procedimentos especiais (livro IV), tipos de procedimento (art. 50, parágrafo único), o que representou verdadeira evolução já que, como visto, o $\mathrm{CPC} / 39$ falava impropriamente em processo ordinário, processos especiais, etc ${ }^{208}$.

Mesmo assim, apesar da evidente evolução técnica e terminológica, o Código de Processo Civil de 1973 manteve a confusão entre processo e procedimento em algumas pouquíssimas passagens, como, por exemplo, quando manda se instaurar procedimento (e não processo) administrativo contra o funcionário ou o juiz relapso (artigos 194 e 198 do CPC) ${ }^{209}$, ou quando se refere ao processo voluntário como procedimento (art. 1.104 do CPC). ${ }^{210}$

\subsubsection{Classificação dos processos}

Tanto o processo quanto o procedimento admitem classificações, evidentemente a variar de autor para autor.

Conforme se dirijam à regulamentação de um conflito de interesses em ato ou em potência, distinguem-se em processos contenciosos ou voluntários. ${ }^{211}$ Na primeira espécie estariam os processos em que o objetivo é a solução do conflito (lide), do qual decorre incompatibilidade de fruição plena entre os adversários. No segundo estariam as demandas em

\footnotetext{
${ }^{207}$ MIRANDA, Francisco Cavalcanti Pontes de. Comentários ao Código de Processo Civil, cit., t. 3, p. 674. É acompanhado na ressalva por Calmon de Passos (Comentários ao Código de Processo Civil, cit., v. 3, p. 11).

${ }^{208}$ DINAMARCO, Cândido Rangel. Vocabulário de direito processual civil. In: Fundamentos do processo civil moderno, cit., v. 1, p. 205.

${ }^{209}$ TORNAGHI, Hélio. Comentários ao Código de Processo Civil, cit., v. 2, p. 91. Também merece destaque o equívoco cometido na redação primitiva do CPC/73, quando apontava, no art. 274, que o procedimento comum era composto pelo processo (e não procedimento) ordinário e sumaríssimo, incorreção esta oportunamente sanada pela Lei n. 8.952/94.

${ }^{210}$ Dinamarco justifica esta opção sob o fundamento de que, à época, evitava-se a utilização da nomenclatura processo para designar outros feitos não afetos à Jurisdição, algo que com o passar dos anos foi sendo superado para se admitir referência a processo administrativo, processo legislativo, etc (Vocabulário de direito processual civil, cit., p. 205-206).

${ }^{211}$ CARNELUTTI, Francesco. Instituições do processo civil, cit., v. 1, p. 73.
} 
que o objetivo imediato não é propriamente a solução de um conflito, mas sim evitar que ele ocorra ou se perpetue ${ }^{212}$, ou como se diz mais modernamente, demandas cujo objetivo é a intervenção do Judiciário a fim de emprestar validade a negócios jurídicos privados.

Outra classificação coloca lado a lado os processos individuais e coletivos. Os primeiros, a tutelarem situações individualizadas; os outros, aptos à tutela dos interesses difusos, coletivos ou individuais homogêneos (art. 82 do Código de Defesa do Consumidor). ${ }^{213}$

O critério, todavia, que tem maior utilidade prática e que, como tal, deve preponderar - até porque revelado na distribuição dos livros do CPC/73 e reconhecido internacionalmente ${ }^{214}$ - é o que classifica os processos tendo-se em vista a natureza da prestação jurisdicional desejada ${ }^{215}$ : processo de conhecimento (Livro I), de execução (Livro II) e cautelar (Livro III). ${ }^{216}$

${ }^{212} \mathrm{Cf}$. COSTA, Alfredo de Araújo Lopes da. A administração pública e a ordem jurídica privada. São Paulo: Ed. Bernardo Álvares, 1961. p. 1; e MARQUES, José Frederico. Ensaio sobre a jurisdição voluntária, cit., p. 113 e ss.

${ }^{213}$ No direito chileno fala-se em procedimientos singulares para os primeiros e procedimientos universales para os outros (CAROCCA PÉREZ, Alex. Manual de derecho procesal, cit., p. 21).

${ }^{214}$ ALCALÁ-ZAMORA e CASTILLO, Niceto. Princípios técnicos y políticos de uma reforma procesal. Honduras: [s.n.], 1950. p. 10; CARNELUTTI, Francesco. Diritto e processo. Napoli: Morano Editore, 1958. p. 353; LIEBMAN, Enrico Tullio. Manual de direito processual civil, cit., v. 1, p. 162-163; JAUERNIG, Othmar. Direito processual civil (Zivilprozessrecht). Tradução de F. Silveira Ramos. 25. ed. Coimbra: Almedina, 2002. p. 40-41. Mesmo em Portugal, onde o processo cautelar é considerado mero procedimento (sem nenhuma autonomia), ele acaba recebendo, de certa forma, tratamento como se fosse gênero autônomo no Livro III, Título I, Capítulo IV, do CPC Português (GERALDES, António Santos Abrantes. Temas da reforma do processo civil - processo cautelar comum. Coimbra: Almedina, 2000. v. 3, p. 34-36). Da mesma forma no Chile, o processo cautelar (las medidas precautorias) recebe disciplina conjunta e não autônoma com o processo de conhecimento (declarativos), nos termos do art. 290 e ss. do Código de Procedimiento Civil. Por lá, autonomia só há quanto ao processo de conhecimento e de execução (cf. CAROCCA PÉREZ, Alex. Manual de derecho procesal, cit., p. 19).

${ }^{215}$ Esta classificação é empregada pela doutrina sob as mais distintas nomenclaturas, embora, de se convir, todas representando a mesma realidade. Para Emilio Betti estes tipos de processo correspondem à divisão das funções da jurisdição (BETTI, Emílio. Diritto processuale civile italiano. 2 ed. Roma: Foro Italiano, 1936. n. 1, p. 2); para Cintra-Grinover-Dinamarco ela corresponde às espécies de provimentos jurídicos que se pretende (Teoria geral do processo, cit., p. 273), no que são acompanhados por Calmon de Passos (Comentários ao Código de Processo Civil, cit., v. 3, p. 4); já para Rogério Lauria e Tucci, a presente classificação se dá em razão da modalidade da tutela jurisdicional pleiteada pelo autor (Processo e procedimentos especiais, cit., p. 492).

${ }^{216} \mathrm{Na}$ modelagem que nosso sistema deu para a ação monitória (art. 1.102a e ss do CPC), não nos parece lícito classificá-la - como o faz Dinamarco (DINAMARCO, Cândido Rangel. A reforma do Código de Processo Civil. 5. ed. São Paulo: Malheiros Ed., 2001. p. 229) - como um quarto tipo de processo (misto de conhecimento com execução), mas sim como um processo de conhecimento com procedimento especial, já que prepondera a atividade declarativa em detrimento das demais (Cf. TALAMINI, Eduardo. Tutela monitória. 2. ed. São Paulo: Ed. Revista dos Tribunais, 1998. p. 190; MIRANDA, Francisco Cavalcanti Pontes de. Tratado das ações, cit., t. 1, p. 117-122). Em alguns países, como na Itália, a monitória ou o processo de injunção recebe tratamento como se fosse uma modalidade autônoma de processo, e não um mero procedimento, o que não me parece adequado pela razão já exposta. Neste sentido cf. Francesco Carnelutti, para quem a monitória é um tertium genus entre conhecimento e execução (Instituições do processo civil, cit., v. 1, p. 132). 
Processo de conhecimento é o instrumento pelo qual se reclama do Estado/Juiz um acertamento, uma declaração de direitos, o fim de um estado de dúvida ou incerteza jurídica. No processo de conhecimento é que se dissipam as dúvidas sobre o direito material em litígio, proferindo o juiz uma sentença de mérito a afirmar quem tem razão (quem tem o direito), se é o autor ou o requerido.

Processo de execução, por sua vez, é o veículo que o sistema coloca à disposição do Estado/Juiz para, através de atos de coerção ou sub-rogação sobre a pessoa ou o patrimônio alheio, satisfazer o comando constante da sentença condenatória (proferida em prévio processo de conhecimento) ou de documento que tenha semelhante eficácia: os títulos executivos extrajudiciais (art. 585 do CPC, com a redação dada pela Lei n. $11.382 / 2006) .^{217}$

Já o processo cautelar é instrumento de natureza subsidiária e auxiliar dos outros dois processos, que objetiva proteger o estado das pessoas, coisas e provas que se pretende no futuro ou concomitante processo de conhecimento ou de execução. Em outros termos, o processo cautelar tem escopo acautelatório: garante a eficácia e utilidade de outro processo. Daí porque se observa nele uma dupla instrumentalidade (instrumento para a proteção de outro instrumento, qual seja, o processo de conhecimento ou de execução). ${ }^{218}$

Essa classificação dos processos põe à mostra seu artificialismo, e só se sustenta por razões didáticas e funcionais. Evidentemente, há cognição nos processos de execução e cautelar; execução nos processos de conhecimento (v.g. art. 412 do CPC e art. 65 da Lei n. 8.245/91) e cautelar (v.g. art. 819, caput, que alude à execução do arresto); e medidas acautelatórias nos processos de conhecimento (art. 266) e execução (art. 615, III). Ninguém se atreveria afirmar "que nos processos de execução e cautelar o juiz não

\footnotetext{
${ }^{217}$ A Lei 11.232/2005, na esteira do que já havia acontecido para as obrigações de fazer, não fazer (Lei 8.952/94) e entregar (Lei 10.444/2002), deu fim à autonomia formal do processo de execução das sentenças que reconheçam obrigação de pagar quantia, já que a satisfação do direito declarado se dará nos próprios autos do processo de conhecimento, sem instauração de nova relação jurídica processual como ocorria anteriormente (artigos 475-I e 475-J do CPC). Processo de execução formalmente autônomo só restará para a vindicação de direitos retratados em títulos extrajudiciais, em títulos paraestatais como a sentenças arbitral e estrangeira líquidas, ou para as execuções especiais (Fazenda Pública e alimentos).

${ }^{218}$ Exemplificativamente, no arresto de bens (art. 813 e ss. do CPC) o credor buscará, antes do momento próprio de expropriação do processo de execução, evitar que o devedor dissipe os bens garantidores do pagamento do débito; na cautelar de produção antecipada de provas (art. 846 do CPC), buscará o requerente, antes da fase instrutória do processo de conhecimento, colher provas que estão na iminência de se perder. Cf. o nosso Direito processual civil IV - processo cautelar, cit., p.16-17, 78-84 e 105-111.
} 
conhece do próprio processo e do thema decidendum proposto pelas partes, cuja função precípua decorre da preponderância, na aspiração do autor, de uma dessas tarefas". ${ }^{219}$

Revela-se, ademais, que no direito processual civil, como se houvesse um retorno às suas origens sincréticas, a tendência atual é a unificação das atividades cognitivas, executivas e cautelares em um único processado, como já ocorreu com a execução de sentença (Lei n. 11.232/2005), e certamente, em breve, se consolidará quanto à atividade cautelar ${ }^{220}$, o que coloca em risco toda esta tipologia tradicional que foi apresentada. $^{221}$

\subsubsection{Classificação dos procedimentos}

Os procedimentos, por sua vez, podem ser classificados de duas maneiras distintas.

Quanto à forma dos atos processuais praticados em seu bojo, os procedimentos podem ser orais e escritos, embora nos dias de hoje não haja como conceber procedimentos nem estritamente escritos, nem estritamente orais. ${ }^{222} \mathrm{O}$ procedimento eletrônico ou virtual da lei n. 11.419/2006 - e não se trata de processo eletrônico como consta do capítulo III da lei, já que estamos no campo da forma para prática do ato processual, como tal, matéria eminentemente procedimental - é espécie de procedimento escrito, mudando só a base de registro dos atos processuais (de papel para registros informáticos).

\footnotetext{
${ }^{219}$ ASSIS, Araken de. Fungibilidade das medidas inominadas cautelares e satisfativas, cit., p. 37.

${ }^{220} \mathrm{O}$ art. $273, \S 7^{\circ}$, acrescido pela Lei n. 10.444/2002, em abono ao sincretismo anunciado, já expressamente admite que o magistrado, presentes os requisitos legais, conceda medidas cautelares incidentais ao processo de conhecimento - isto é, sem instauração de um processo cautelar autônomo - quando requeridas equivocadamente a título de antecipação de tutela. Para análise das tendências futuras do processo cautelar brasileiro, especialmente no tocante ao fim de sua autonomia, cf. CARNEIRO, Athos Gusmão. Tutelas e urgência. Medidas antecipatórias e cautelares. Esboço de reformulação legislativa. Revista de Processo, São Paulo, ano 31, n. 140, p. 72-85, out. 2006.

${ }^{221}$ A este respeito cf. a acertada crítica de Flávio Luiz Yarshell quanto à classificação dos processos como se fossem departamentos estanques, algo que efetivamente não são (Tutela jurisdicional, cit., p. 175-176).

${ }^{222}$ Mesmo no procedimento sumaríssimo dos Juizados Especiais Cíveis e Federais não se pode dizer que o procedimento é oral, pese o que consta do art. $2^{\circ}$ da Lei n. 9.099/95. Também neste procedimento boa parte dos atos processuais é praticada de forma escrita (pedido inicial, redução do essencial dos depoimentos a temo, sentença, recurso inominado, etc), admitindo-se, todavia, o armazenamento de todas estas informações em suporte informático.
} 
Já quanto ao modo como os atos se movem ${ }^{223}$, os procedimentos devem ser classificados conforme a natureza da prestação jurisdicional pretendida em seus respectivos processos.

De acordo com o Código de Processo Civil de 1973, no processo de conhecimento os procedimentos podem ser comuns (art. 271 do CPC) ou especiais (livro IV). ${ }^{224}$

Há 02 (dois) tipos de procedimentos comuns: a) o procedimento ordinário, que é o padrão e será sempre utilizado na inexistência de regra procedimental específica ${ }^{225}$; e b) o procedimento sumário, que tem hipóteses de cabimento bem delimitadas na lei (artigos 275 a 280 do $\mathrm{CPC}$ ). Pende acirrada controvérsia doutrinária ${ }^{226}$ se o procedimento sumaríssimo dos Juizados Especiais seria um procedimento de uma Justiça Especializada, ou simplesmente um procedimento especial.

Há, todavia, pelo menos 25 (vinte e cinco) procedimentos especiais no processo de conhecimento: 15 (quinze) procedimentos de jurisdição contenciosa ${ }^{227}, 10$ (dez) procedimentos de jurisdição voluntária, além de outros 16 (dezesseis) procedimentos conservados do Código de Processo Civil de 1939 (art. 1.218 do CPC), alguns deles já revogados. Sem contar, ainda, vários outros procedimentos especiais previstos em legislação extravagante. ${ }^{228}$

\footnotetext{
${ }^{223}$ Cf. TUCCI, Rogério Lauria. Processo e procedimentos penais, cit., p. 493-494, mar. 1998.

${ }^{224} \mathrm{E}$ vamos, para fim de levar adiante este estudo, passar à margem do direito processual do trabalho, que considerado por nós ciência autônoma em relação ao direito processual civil, tem no bojo do seu processo de conhecimento procedimentos próprios: a) procedimento ordinário do art. 843 e ss. da CLT; b) procedimento sumário da Lei n. 5.584/70, que não altera em nada o rito ordinário da CLT, exclusivamente vedando o recurso das causas de sua alçada (02 salários-mínimos), salvo se versarem sobre matéria constitucional $\left(\operatorname{art} .2^{\circ}, \S 4^{\circ}\right.$ ); e c) procedimentos sumaríssimo da Lei n. 9.957/2000, que encurta o procedimento de tal forma que deve ele ser solucionado em 15 dias, com recurso a ser julgado no prazo máximo de 10 dias (admitindo confirmação da decisão pelos seus próprios e jurídicos fundamentos).

${ }^{225}$ Daí a equivocada a menção legislativa constante do art. 271 do CPC, mandando aplicar a todas as causas o procedimento comum. Sendo o procedimento ordinário o leito padrão dos feitos que não contem com regramento especial (inclusive o sumário), era só a ele que o legislador deveria ter feito referência.

${ }^{226}$ Isto porque quando da edição do CPC/1973, o atual procedimento sumário era o sumaríssimo, de modo que só havia procedimento comum ordinário e sumaríssimo. Com a edição da Lei n. 9.099/95, e posteriormente com o advento da Lei n. 8.952/94 (que tornou o procedimento sumaríssimo em sumário), restou deslocado do regime comum o procedimento sumaríssimo dos Juizados Especiais, de modo que, ao nosso ver, não se pode acondicioná-lo na locução do 272 do CPC, especialmente porque é procedimento de uma Justiça Especializada. O mais atípico, entretanto, é que enquanto considerado um procedimento especial em relação aos comuns do CPC, o sumaríssimo das Leis n. 9.099/95 e 10.429/2001 é comum em sede de Juizados, já que é o único que regula o iter dos procedimentos nesta especializada.

${ }^{227}$ Cf. por todos MARCATO, Antonio Carlos. Procedimentos especiais. 12. ed. São Paulo: Atlas, 2006.

${ }^{228}$ Entre eles destacam-se exemplificativamente a ação civil pública (Lei n. 7.347/85), a ação popular (Lei n. 4.717/65), a ação de alimentos (5.478/68), a busca e apreensão dos bens alienados fiduciariamente (DL
} 
Mesmo com o fim da autonomia formal da liquidação de sentença por força da Lei n. 11.232/2005 (art. 475-A e ss. do CPC), de se convir que também no bojo deste incidente cognitivo temos ao menos dois procedimentos distintos: a liquidação por arbitramento (art. 475-C do CPC) e por artigos (art. 475-E do CPC).

No processo de execução os procedimentos variam conforme o conteúdo do título jurídico. Há os procedimentos executivos comuns, em número de 03 (três): a) para entrega de coisa certa ou incerta (artigos 621 a 631 do CPC); b) de obrigação de fazer ou não fazer (artigos 632 a 645 do CPC); e c) por quantia certa contra devedor solvente (art. 646 e ss. do CPC); além dos procedimentos executivos lato, decorrentes das sentenças condenatórias proferidas no processo civil estatal, que seguem o regime dos artigos 461, 461-A e 475-J e ss, nos temos do art. 475-I (com redação pela Lei n. 11.232/2005), todos do CPC.

Mas há, também, os procedimentos executivos especiais. No Código de Processo Civil vigente temos três deles: a) execução contra a Fazenda Pública (art. 730 do CPC); b) execução de alimentos (art. 732 e ss. do CPC); e c) execução por quantia contra devedor insolvente (artigos 748 a 786-A do CPC). E em legislação extravagante, embora haja pouquíssimos procedimentos especiais executivos, chamo em destaque a execução hipotecária de crédito vinculado ao Sistema Financeiro da Habitação (SFH), prevista na Lei n. 5.741/71.

No âmbito do processo cautelar, também temos os procedimentos comuns e os especiais. Tanto para as cautelares inominadas concedidas com base no poder geral de cautelar do juiz (art. 798 do CPC), quanto para as cautelares nominadas, previstas no art. 888 do CPC (outras medidas provisionais), aplica-se o procedimento geral do capítulo I do Livro III do CPC (disposições gerais), em especial os artigos 801 a 804. Este é o procedimento comum das cautelares. ${ }^{229}$

911/69), o despejo, a renovatória, a revisional e a consignação em pagamento da lei de locações (Lei n. 8.245/91), a falência (Lei n. 11.101/2005), a ação de improbidade administrativa (Lei n. 8.429/92), a ação de desapropriação (DL 3.365/41), a ação de separação judicial, a ação de divórcio e o mandado de segurança (Lei n. 1.533/51). Para análise destes procedimentos especiais, cf. GAJARDONI, Fernando da Fonseca; SILVA, Márcio Henrique Mendes da (Coords.). Manual dos procedimentos especiais de legislação extravagante. São Paulo: Método, 2006.

${ }^{229}$ GAJARDONI, Fernando da Fonseca. Direito processual civil: processo cautelar, cit., v. 4, p. 48. 
Já para as cautelares típicas ou nominadas previstas nos artigos 813 a 887 do $\mathrm{CPC}$, o procedimento é especial, havendo regência própria para cada uma delas, aplicandose apenas subsidiariamente a parte geral (art. 812 do CPC). ${ }^{230}$

Além destas cautelares com procedimentos especiais previstas no Código de Processo Civil, há, ainda, a medida cautelar fiscal, cuja disciplina se encontra na Lei n. $8.397 / 1992$.

Este é o rol de variedades procedimentais que o Código de Processo Civil vigente, conforme a tutela pretendida, oferece aos seus consumidores. À exceção destes modelos previamente e rigidamente estabelecidos pela lei, é voz corrente que não é dado às partes ou ao juiz criar ou mesclar procedimentos, tampouco escolhê-los livremente.

O resultado desta restrição à opção ritual, por um lado, é a preponderância de intrincadas questões formais em torno de nugas, "próprias de um processo assaz burocrático e formalista, o que pode ser observado na atuação diuturna dos juízos e tribunais, que ao invés de se concentrarem no litígio, isto é, na questão substancial, vivem a enfrentar e a decidir, sem uniformidade (o que gera recurso e mais recursos), quizilas procedimentais criadas pela interpretação e cumprimento das normas disciplinares de cada qual dessas muitas dezenas de procedimentos". ${ }^{231}$

Por outro lado, não é incomum que para algumas demandas inexista um rito capaz de tutelar adequadamente a pretensão veiculada. Pese a enorme variedade de procedimentos, não se podia pretender que o legislador imaginasse, antecipadamente, todas as pretensões que justificariam a criação de um procedimento diferenciado ${ }^{232}$, especialmente se relevarmos a inexistência de simultaneidade entre a evolução da sociedade e do ordenamento jurídico.

Daí porque já se adianta nossa sugestão, de lege ferenda, para que seja criado, nos termos do que já ocorre no sistema processual civil português especificamente para a adequação ritual (item 4.5.2), ou como ocorre em nosso sistema no tocante ao poder geral

\footnotetext{
${ }^{230}$ GAJARDONI, Fernando da Fonseca. Direito processual civil: processo cautelar, cit., v. 4, p. 48.

${ }^{231}$ Cf. ARAGÃO, E. D. Moniz de. Procedimento: formalismo e burocracia. Revista Forense, Rio de Janeiro, v. 358 , p. 54-55, nov./dez. 2001. O autor ainda noticia, com base na análise dos repertórios de jurisprudência, ser enorme o número de julgados que se atém a questões meramente formais, em detrimento absoluto das questões substanciais.

${ }^{232} \mathrm{Cf}$. BEDAQUE, José Roberto dos Santos. Efetividade do processo e técnica processual: tentativa de compatibilização. 2005. Tese (Titular de Direito Processual Civil) - Faculdade de Direito, Universidade de São Paulo, São Paulo, 2005. p. 60.
} 
de cautela do juiz (art. 798 do CPC), de um poder supletivo, ou melhor, integrativo da eficácia global dos procedimentos processuais, admitindo que o juiz, na inexistência de procedimento adequado, possa criá-lo ou adaptá-lo como base nos modelos rituais já existentes.

Ademais, como apontado, o leque de especialidades procedimentais contemplado no sistema processual civil vigente - diversamente de um cardápio de restaurante em que se escolhe livremente a refeição desejada - não permite liberdade na escolha do rito processual, de modo que para a doutrina dominante: a) inexistindo previsão de procedimento especial ou sumário, então, só resta a via ordinária para a postulação (art. 271 do (PC), ainda que ela seja incapaz de tutelar adequadamente o direito material subjacente; e b) havendo previsão de procedimento especial específico, a parte deve adotálo, só em alguns casos podendo renunciar ao rito diferenciado em favor do procedimento padrão (ordinário). ${ }^{233}$

A questão que ora se impõe é a seguinte: estes tantos procedimentos são úteis? Não seria mais fácil, eficaz, produtivo, admitir que é dado às partes eleger o procedimento, ou ao juiz efetuar a adequação formal dele às peculiaridades da causa, caso a caso? Ao mesmo tempo em que se encerram as citadas nusgas sobre questões procedimentais, também não se torna efetivamente útil este sem número de ritos diferenciados, permitindo, ainda, a adequada tutela do direito material $?^{234}$

\footnotetext{
${ }^{233}$ Rui Portanova ressalta que "se o autor quiser recusar as especialidades e as variedades, desde que não faça combinações tumultuárias, o Código de Processo Civil oferece a porta grande do procedimento comum para abrigar todas as causas". Afinal, "considerando que a via ordinária sempre oferece a maior possibilidade de defesa ao réu", é possível a liberdade de escolha pela ordinarização" (PORTANOVA, Rui. Princípios do processo civil. Porto Alegre: Livr. do Advogado, 1995. p. 182-183), salvo, conforme já sustentamos em outra ocasião, nas "situações excepcionais decorrentes da incompatibilidade lógica entre a pretensão formulada e o procedimento comum (v.g. o inventário e a divisão/demarcação)", casos em que o rito especial será obrigatório (GAJARDONI, Fernando da Fonseca. Breve introdução aos procedimentos especiais de jurisdição contenciosa. In: ___ _ SILVA, Márcio Henrique Mendes da (Coords.). Manual dos procedimentos especiais de legislação extravagante, cit., p. 21).

${ }^{234} \mathrm{~A}$ impressão sobre a desnecessidade de tantos procedimentos especiais é revelada por Athos Gusmão Carneiro. Após apontar que "inexistem direitos subjetivos de primeira classe, dignos de um procedimento solene, e direito subjetivos de segunda classe, que possam ser tratados sem as garantias inerentes ao procedimento padrão", anota que deveria o legislador (e eu me pergunto porque não o juiz?) "buscar um ponto de equilíbrio entre os interesses da celeridade e os da eficiência instrumental, só cogitando de procedimento diverso do procedimento padrão quando a natureza do direito material exija o acréscimo de atos processuais, ou sua supressão ou inversões da ordem procedimental" (CARNEIRO, Athos Gusmão. Considerações sobre o processo e os Juizados de Pequenas Causas. Revista de Processo, São Paulo, ano 13, n. 51, p. 23, jul./set. 1988). Dinamarco também se espanta com o elevado número de procedimentos especiais (ações típicas) previstos em nosso sistema, revelando, ainda, que na Europa esse número é bem mais reduzido (DINAMARCO, Cândido Rangel. Das ações típicas. In: civil moderno, cit., v. 1, p. 342). Fundamentos do processo
} 
Deve haver uma razão para manutenção deste ideário de enclausuramento procedimental a cubículos rígidos, que passa, necessariamente, pelo enfrentamento das questões sobre a dogmática do procedimento, sua natureza função no bojo do processo civil.

Sobre isto e sobre a possibilidade de compatibilizarmos, mediante certas condições, valores geralmente apontados como informadores do procedimento (previsibilidade, segurança, legitimidade, devido processo legal) com a almejada flexibilização procedimental, discorreremos mais adiante.

\subsection{Sistemas procedimentais e rigidez}

Já vimos que o processo não existe sem o procedimento (item 2.4.3.2.).

E vimos, também, que todo procedimento impõe a observância de uma forma, que pode ser analisada em dois sentidos: a) modo de manifestação dos atos processuais das partes, dos magistrados ou da secretaria (algo disciplinado por normas acidentalmente procedimentais); e b) lugar que cada ato tem no conjunto do procedimento, ou seja, a ordenação formal dos atos (objeto de disciplina pelas normas puramente procedimentais). ${ }^{235}$

No tocante ao modo de manifestação do ato processual pelos atores do processo, todos os sistemas dos quais se têm notícias adotaram ou adotam um sistema rígido, ainda que com poucas regras de forma. Do ápice da rigidez formalista da primeira fase do processo romano ${ }^{236}$, passando pela fase menos regrada do direito romanobarbárico $^{237}$, ou tornando a um regime de acentuado cunho rígido e formal como era o do

\footnotetext{
${ }^{235}$ Cf. MARTIN DE LA LEONA ESPINOSA, José Maria. La nulidad de actuaciones en proceso civil, cit., p. 76.

${ }^{236}$ No processo romano, mais precisamente no período das legis actiones (754 ac até 149 ac), o modo de manifestação dos atos processuais pelas partes era regrado com absoluta formalidade, com necessidade de obediência rigorosa a palavras e gestos próprios que, descumpridos ou mal executados, davam ensejo à anulação do processo. Conhecida é a passagem de Gaio, em que narra a perda de uma ação por quem, "agindo por causa de videiras ceifadas mecionara videira, pois a Lei das XII Tábuas, na qual se fundava a ação por videiras cortadas, falava de árvores cortadas em geral" (Institutas, 4.11). Daí porque "todas estas ações da lei tornaram-se pouco a pouco odiosas. Pois, dada a extrema sutileza dos antigos fundadores do direito, chegou-se à situação de quem cometesse o menor erro perdesse a causas" (Institutas, 4.30). Cf. CRUZ E TUCCI, José Rogério; AZEVEDO, Luiz Carlos. Lições de história do processo civil romano. São Paulo: Ed. Revista dos Tribunais, 2001. p. 75, 198 e 203.

${ }^{237} \mathrm{O}$ sistema romano-barbárico (século VI) era absolutamente rudimentar, com preocupação mínima com as regras de forma. O processo nada mais era do que uma luta, com regras mínimas de controle pelo chefe do grupo. Não havia poder judiciário. "A liquidação era feita entre indivíduos. Pedia-se ao mais poderoso ou àquele que exercia a soberania não que fizesse justiça, mas que constatasse, em função dos seus poderes políticos, mágicos, religiosos, a regularidade do procedimento" (FOUCAULT, Michel. A verdade e as formas jurídicas. 3. ed. Rio de Janeiro: Ed. Nau, 2003. p. 65).
} 
direito canônico ${ }^{238}$, a maneira para a prática do ato processual sempre foi disciplinada, ainda que com menos intensidade em alguns sistemas.

Já quanto à ordenação formal dos atos o modelo procedimental de um sistema varia conforme maior ou menor flexibilidade na aplicação destas regras ao caso concreto; se há liberdade ou não das partes e do juiz para modificarem essas regras, se afastando da ordem legal previamente prevista; se o regime preclusivo é tênue ou rigoroso, admitindo ou não o retorno a fase processuais já superadas no tempo. ${ }^{239}$

Com base nisto, dois sistemas processuais são conhecidos e indicados pela doutrina:

a) sistema da legalidade das formas procedimentais

b) sistema da liberdade de formas procedimentais 240

No primeiro sistema, o lugar em que cada ato processual tem cabimento se encontra rigidamente pré-estabelecido em lei, podendo o desrespeito à prescrição legal implicar invalidade do próprio ato processual, do seu conjunto (do procedimento todo), ou do resultado do processo (da sentença).

\footnotetext{
${ }^{238} \mathrm{O}$ grande "salto qualitativo dado na direção do formalismo e da burocracia esteve no direito canônico: não apenas o julgamento de formalizou e o processo passou a adquirir fases precisas, como também a justificativa para as diversas reformas passou a carecer de razões e explicações que seriam dadas pelos juristas" (LOPES, José Reinaldo de Lima. Uma introdução à história social e política do processo. In: WOLKMER, Antonio Carlos (Coord.). Fundamentos da história do direito. 2. ed. Belo Horizonte: Del Rey, 2001. p. 404). Oportunamente, o formalismo do processo canônico, que foi incorporado pelos tribunais régios no século XII, foi combatido pela própria Igreja no século XIV, no primeiro movimento registrado de flexibilização formal da história. Duas bulas do Papa Clemente V (Saepe contingit e Dispendiosam), no século XIV, propunham a substituição do processo canônico tradicional (o solenis ordo judiciorum) por um processo menos formal, mais flexível (Cf. AZEVEDO, Luiz Carlos; CRUZ E TUCCI, José Rogério. Lições de processo civil canônico: história e direito vigente. São Paulo: Ed. Revista dos Tribunais, 2001. p. 59-60).

${ }^{239}$ Giuseppe Chiovenda, em interessante passagem, aponta que difícil é o problema de legislação processual em definir "se as normas devem ser determinadas pela lei ou se devem deixar determinar pelo juiz em cada caso, segundo as exigências do momento. Na maior parte das leis prevalece o primeiro sistema como o que mais garantias oferece aos litigantes. Certamente, a extensão dos poderes do juiz no tocante à forma é um meio poderoso de simplificação processual (...), mas não é possível senão em proporção da confiança que, em um determinado momento, inspira aos cidadãos confiança no seu sistema judicial" (CHIOVENDA, Giuseppe. Princípios de derecho procesal civil. 3 ed. Madrid: Inst Ed. Reus, 2000. p. 115).

${ }^{240}$ BRITO, Pedro Madeira de. O novo princípio da adequação formal. In: SOUZA, Miguel Teixeira (Coord.) Aspectos do novo processo civil. Lisboa: Lex, 1997. p. 33. Calamandrei, ao investigar as interações entre jurisdição de equidade e de direito, anota, em referência válida ao conflito entre os sistemas da legalidade e da liberdade das formas, que no primeiro "as forças políticas das quais nasce o direito vêm a desembocar e atura sobre os órgãos encarregados de formular as leis, qualquer que seja o nome que os mesmo recebam e qualquer que seja a forma em que estejam constituídos“, opção que "o juiz deve aceitar sem discuti-lo, sem poder começar de novo, por sua conta, o trabalho de valorização política”, algo que lhe é completamente outorgado no regime da liberdade das formas“ (CALAMANDREI, Piero. Direito processual civil. Tradução de Luiz Abezia e Sandra Drina Fernandez Barbery. Campinhas: BookSeller, 1999. v. 1, p. 98-99).
} 
Este sistema tem por grande mérito a previsibilidade e a segurança que ofertam ao jurisdicionado, ciente da maneira como se desenvolverá o processo do início ao fim. Mas é burocrático e em muitas ocasiões implica a prática de atos processuais desnecessários ou inadequados à efetiva tutela dos direitos.

Já no segundo sistema não há uma ordem legal pré-estabelecida para a prática dos atos processuais, competindo aos sujeitos do processo (ora às partes, ora ao juiz) determinar a cada momento qual o ato processual a ser praticado.

O sistema de liberdade de forma do procedimento permite um encaminhamento mais célere ao feito, já que possível a eliminação dos atos desnecessários do iter, bem como sua adequação à efetiva tutela do direito material. Gera, todavia, suposta insegurança, visto que as partes podem ser surpreendidas por decisões surpresas e exigências formais desarrazoadas. Além disso, aduz-se que o juiz pode, conscientemente ou não, ceder a influências prejudiciais ao interesse de uma das partes, manipulando o procedimento em desfavor da igualdade. ${ }^{241}$

Não há sistemas totalmente puros, embora seja manifesta a preferência pelo primeiro deles e a preponderância das regras legais sobre o procedimento ${ }^{242}$. Prova disto é que alguns autores chegam a ponto de considerar a adequação do procedimento a forma prescrita em lei como pressuposto processual de validade da relação jurídica processual ${ }^{243}$, algo que, todavia, não encontra eco algum na doutrina padrão sobre o tema.

Então, partindo-se da afirmação de que não há sistemas puros, mas apenas tendentes à rigidez (como o nosso), é necessário saber se a manutenção deste ideário ainda é compatível com o modelo processual moderno, e quais seriam os prejuízos (se é que existentes) de se permitir uma maior maleabilização das regras do procedimento, com a possibilidade das partes, até certo ponto, elegerem dentre os vários modelos legais aquele que mais lhes aprouver, ou de se permitir que o juiz - seja para a adequação da causa ao direito material ou a qualidade dos litigantes, seja simplesmente porque a lei assim facultou - possa ordenar variações rituais.

\footnotetext{
${ }^{241}$ Fritz Baur aduz, ainda, que sendo livre o juiz para escolher o iter procedimental, poderia ele, diante de situações idênticas, encaminhar o feito de forma distinta, o que sem dúvida depõe a igualdade da partes. (BAUR, Fritz. Potere giudiziale e formalismo del diritto processuale. Rivista Trimestrale di Diritto $e$ Procedura Civile, Milano, n. 2, p. 1689-1691, 1965).

${ }^{242}$ CHIOVENDA, Giuseppe. Princípios de derecho procesal civil, cit., p. 115.

${ }^{243}$ Iñaki Esparza Leibar, El pressupuesto procesal del procedimiento adecuado, Granada, 1996, apud BRITO, Pedro Madeira de. O novo princípio da adequação formal, cit., p. 33.
} 


\subsection{Procedimento rígido como regra de ordem pública}

Diz a doutrina corrente que as normas de direito processual, como regra, são de ordem pública e cogentes, especialmente se tratantes de forma ou de prazos, sendo a dispositividade a mais absoluta exceção. ${ }^{244}$

E assim é porque o procedimento, no direito processual eminentemente publicístico como o atual, atende, sobretudo, a interesses público. Não foi instituído, como regra, para favorecer ou para beneficiar as partes, tampouco para contemplar a comodidade de alguma delas. $\mathrm{O}$ interesse envolvido na criação de procedimentos, especialmente de cunho, sumário ou especial, parece, sobretudo, atender a um reclamo estatal em extrair da função jurisdicional, do trabalho jurisdicional mesmo, um rendimento maior. Portanto o procedimento ou o rito não é objeto possível de convenção das partes, de transigência ou de renúncia delas ${ }^{245}$, mesmo que ambas e também o juiz estejam completamente concordes quanto a isto. $^{246}$

Decorre daí, como aponta Humberto Theodoro Júnior, não haver como a parte ou juiz, conforme sua conveniência pessoal, dispor de um rito, de um procedimento, que não foi criado para eles, mas sim para a atuação de uma função soberana do Estado. ${ }^{247}$

Afinal, "a atuação da justiça deve seguir um procedimento rígido; um método formal definido em lei que o processo deve trilhar até o juiz encontrar a solução da lei para aquele caso. Esse procedimento não pode ser alterado nem pelas partes nem pelo Estado-juiz". ${ }^{248}$

\footnotetext{
${ }^{244}$ MIRANDA, Francisco Cavalcanti Pontes de. Comentários ao Código de Processo Civil (1939), t. 1, p. 5051. Acrescenta ainda, na mesma passagem, que "as normas dispositivas de direito processual quase sempre atendem à renunciabilidade aos benefícios (e.g., maior segurança, que a lei criou), ou a que está a disciplinar atos possíveis das partes que, pelas circunstâncias, estejam em melhores situações para escolher o caminho tomado. Diante de três interpretações da mesma forma, uma que a tem por imperativa, e outra, dispositiva, e a terceira interpretativa, ou de duas delas, é princípio de interpretação das leis processuais que se prefira a que lhe atribui cogência".

${ }^{245}$ Trecho do voto de Adroaldo Furtado Fabrício, VI Encontro Nacional dos Tribunais de Alçada, Belo Horizonte, 1981. Sobre as conclusões do encontro, cf. TEIXEIRA, Sálvio de Figueiredo. Procedimento sumaríssimo: necessidade de sua reformulação. Revista da Faculdade de Direito, Curitiba, n. 21, ano 21, p. 91-99, 1983-1984.

${ }^{246} \mathrm{Cf}$. Calmon de Passos, para quem as normas quanto ao procedimento são cogentes e, portanto, de observância obrigatória pelas partes e julgadores (PASSOS, J.J. Calmon de. Comentários ao Código de Processo Civil, cit., v. 3, p. 31).

${ }^{247}$ Trecho do voto de Humberto Theodoro Júnior, VI Encontro Nacional dos Tribunais de Alçada, Belo Horizonte, 1981, que ainda conclui ser inaceitável "qualquer tese que defenda a livre disponibilidade ou a fungibilidade de procedimentos e ritos". Sobre as conclusões do encontro, cf. TEIXEIRA, Sálvio de Figueiredo. Procedimento sumaríssimo: necessidade de sua reformulação, cit., p. 91-99.

${ }^{248}$ SILVA, Paulo Eduardo Alves. Condução planejada dos processos judiciais: a racionalidade do exercício jurisdicional entre o tempo e a forma do processo, cit., p. 4.
} 
Por isto Cândido Rangel Dinamarco, com a sua costumeira lucidez, bem coloca ainda ser indigesta a idéia de adaptação do procedimento pelo magistrado ao caso concreto. $^{249}$

A jurisprudência tradicional aponta, nesta esteira, que a escolha do procedimento não é faculdade da parte ou do juiz, mas sim questão de ordem pública, cuja violação gera a nulidade do processo (RT 492/102, 479/185 e 491/207). Assim se posicionou o Tribunal de Justiça do Estado do Paraná, ao asseverar se revestir de nulidade o processo, tratando-se de ação versante sobre domínio de coisa móvel, em que seja impresso o rito ordinário em vez do sumário, adequado por força do art. 275, II, do CPC ${ }^{250}$. Também o extinto $2^{\circ}$ Tribunal de Alçada Civil do Estado de São Paulo era no sentido de que é de ordem pública o preceito do art. 275 do CPC, não podendo ficar ao alvedrio da parte ou do juiz a escolha do procedimento processual. ${ }^{251}$

Portanto, para a doutrina tradicional, havendo procedimento diferenciado para dada demanda (sumário ou especial), não é dado à parte ou ao julgador eleger rito diverso. Como também não é lícito ao titular de direito não contemplado por um procedimento específico, ou ao Estado-Juiz, se valer de outro procedimento que não o ordinário. E muito menos, pelas razões anteriores, podem os sujeitos processuais mesclar ou alterar os procedimentos rigidamente fixados em lei.

\subsection{Procedimento rígido como fator de segurança e previsibilidade do sistema}

Desde Montesquieu já se ouve referência de que "as formalidades da justiça são necessárias à liberdade”, pois, sem elas, não há como se controlar a atividade judicial, evitar o arbítrio e tampouco se permitir um processo com julgamento justo. ${ }^{252}$

Por isto, o legislador, no intuito de dar ordem, clareza, precisão e segurança de resultados às atividades processuais, bem como de salvaguardar os direitos das muitas

\footnotetext{
${ }^{249}$ DINAMARCO, Cândido Rangel. Instituições de direito processual civil. 4. ed. São Paulo: Malheiros Ed., 2002. v. 1, p. 493.

${ }^{250}$ Apelação Cível n. 305/89, Rel. Des. Wilson Reback, j. 30.08.1989.

${ }^{251}$ Apelação n. 185.629-2, Rel. Juiz Teixeira Mendes, in JTACiv-SP n. 103/309.

${ }^{252}$ MONTESQUIEU. O espírito das leis. São Paulo: Abril Cultural, 1973, 1. 29. Rudolf Von Ihering, também em conhecida passagem, ensinava que "a forma é inimiga jurada do arbítrio e irmã gêmea da liberdade" (IHERING, Rudolf von. O espírito do direito romano. Tradução da Rafael Benaion. Rio de Janeiro: Calvino F., 1934. v. 1, p. 164).
} 
pessoas interessadas nelas, "alçou algumas exigência técnicas a regras legais e subordinou a eficácia dos atos processuais à observância dos requisitos de forma". ${ }^{253}$

Tais requisitos constituem-se em uma formalidade mínima que preside todo o processo, pois indispensável para que o Estado possa cumprir integralmente a prestação jurisdicional, e ao mesmo tempo obter confiança do povo nas decisões do Poder Judiciário. $^{254}$

O sistema recorre, portanto, a um método racional denominado procedimento, do qual os resultados - em razão exatamente deste procedimento - são controláveis externamente, isto é pelos destinatários da decisão, pelo juiz da impugnação e, em geral, por todos os interessados. ${ }^{255}$

No Brasil, de todos aqueles que se dedicaram ao estudo da forma procedimental nenhum deles o fez com mais dedicação do que Carlos Alberto Alvaro de Oliveira. De acordo com o estudioso gaúcho, entre as funções do formalismo estaria a de se emprestar previsibilidade ao procedimento e de disciplinar o poder do juiz, atuando como garantia de liberdade contra o arbítrio dos órgãos que exercem o poder do Estado. ${ }^{256}$

Ainda de acordo com ele, as regras procedimentais, para cumprirem seu papel eminentemente garantista, devem ser rígidas, pois "a realização do procedimento deixada ao simples querer do juiz, de acordo com as necessidades do caso concreto, acarretaria a possibilidade de desequilíbrio entre o poder judicial e o direito das partes" ${ }^{257}$,

${ }^{253}$ LIEBMAN, Enrico Tullio. Manual de direito processual civil, cit., v. 1, p. 225.

${ }^{254}$ PORTANOVA, Rui. Princípios do processo civil, cit., p. 180.

${ }^{255}$ CARRATA, Antonio. Funzione dimostrativa della prova: verità del fatto nel processo e sistema probatório. Rivista de Diritto Processuale, Padova, ano 56, n. 1, p. 84, genn./mar. 2001.

${ }^{256} \mathrm{E}$ no conceito de formalismo, estaria compreendida "não só a forma, ou as formalidades, mas especialmente a delimitação dos poderes, faculdades e deveres dos sujeitos processuais, coordenação de sua atividade, ordenação do procedimento e organização do processo, com vistas a que sejam atingidas as suas finalidades primordiais" (OLIVEIRA, Carlos Alberto Alvaro de. Do formalismo no processo civil, cit., p. 6-7).

${ }^{257}$ OLIVEIRA, Carlos Alberto Alvaro de. Do formalismo no processo civil, cit. p. 7-8. Pela rigidez das regras procedimentais, continua o autor a advertir, "em primeiro lugar, que o aumento dos poderes do juiz não deve significar, necessariamente, completa indeterminação destes poderes. De modo nenhum a pretendida restauração da autoridade do poder estatal no processo deverá implica renúncia a se normatizar o seu desenvolvimento. Tal solução transferiria ao órgão judicial o poder de criar ao seu bel prazer, caso por caso, a regra processual mais apropriada para o desenvolvimento do procedimento, conduzindo a total indeterminação e imprevisibilidade. Incrementar-se-ia, assim, de forma totalmente desnecessária, o arbítrio do poder estatal dentro do processo. Não obstante a função social do processo, o excesso de poderes do órgão judicial poderia desembocar num processo substancialmente privado de formas, conduzido segundo a livre discricionariedade do juiz, com provável prejuízo à igualdade substancial das partes e violação do princípio da certeza jurídica, sem falar do eventual menosprezo ao nexo entre o direito material e o processual" (OLIVEIRA, Carlos Alberto Alvaro de. Poderes do juiz e visão cooperativa do processo, cit., 
além de risco à celeridade. ${ }^{258}$

No mesmo sentido trilha Calmon de Passos, para quem "permitir que a atividade processual se desenvolva segundo melhor pareça às partes - os mais autorizados juízes do próprio interesse, ou nos moldes fixados pelo magistrado, o melhor árbitro das necessidades no caso particular - porque técnico e imparcial, seria olvidar-se que numa ou outra hipótese a incerteza e a insegurança representariam o alto preço de vantagens muito discutíveis. A legalidade da forma, por conseguinte, se impôs como solução universal, estando na lei, e somente nela, toda a ordenação da atividade a ser desenvolvida para que o Estado realize os seus fins de justiça". ${ }^{259}$

Por isto, os atos processuais que compõem o rito processual, de acordo com a maior parte da doutrina, devem estar previstos expressamente e em lei, pois a previsibilidade e a anterioridade do procedimento é que conferem à decisão judicial os penhores de legalidade e legitimidade, sendo dele requisitos inafastáveis. ${ }^{260}$

O Superior Tribunal de Justiça, ressaltando a importância da rigidez procedimental, já pontuou que tem ela por objetivo gerar segurança e previsibilidade. Apontou, ainda, que "a liberdade absoluta impossibilitaria a seqüência natural do processo. Sem regras estabelecidas para o tempo, o lugar e o modo de sua prática, o procedimento jamais chegaria ao fim. A garantia da correta outorga da tutela jurisdicional está, precisamente, no conhecimento prévio do caminho a ser percorrido por aquele que busca a solução para uma situação conflituosa”. ${ }^{261}$

p. 59). O próprio autor em outra passagem aduz que instaurado "o processo, o seu modo, ritmo e impulso escapam à disponibilidade das partes, elementos que devem ser disciplinados por normas legais cogentes”, mas acaba relativizando seu rigoroso discurso ao admitir que "no entanto, possa o juiz em certas hipóteses levar em conta as exigências concretas do caso" (Poderes do juiz e visão cooperativa do processo, cit., p. 71).

${ }^{258}$ Para Hélio Tornaghi, "a observância rigorosa das formas e prazos legais é a melhor receita para conciliar rapidez e segurança” (Comentários ao Código de Processo Civil. 2. ed. São Paulo: Ed. Revista dos Tribunais, 1974. v. 1, p. 382).

${ }^{259}$ PASSOS, J.J. Calmon de. Comentários ao Código de Processo Civil, cit., v. 3, p. 6. No mesmo sentido Karl Engisch, quando aponta que "a fim de evitar o arbítrio judicial e garantir e assegurar a liberdade civil, as leis deveriam determinar-se de tal maneira a vincularem univocamente o juiz. Uma indeterminação da lei que permitisse ao juiz converter-se em criador do direito, em legislador, seria contraditória à luz da teoria da divisão dos poderes (ENGISH, Karl. La idea de concreción em el derecho y em las ciencias jurídicas actuales. 2. ed. Pamplona: [s.n.], 1968. p. 179).

${ }^{260}$ Cf. DINAMARCO, Cândido Rangel. A instrumentalidade do processo, cit., p. 127; YARSHELL, Flávio Luiz. Tutela jurisdicional, cit. p. 170; e DIDIER JÚNIOR, Fredie. Sobre dois importantes, e esquecidos, princípios do processo: adequação e adaptabilidade do procedimento. Revista Gênesis de Direito Processual Civil, Curitiba, n. 21, p. 530-541, jul./set. 2001.

${ }^{261}$ RMS 8005/SC, Rel. Min. Gilson Dipp, 5a Turma, j. 06.04.2000. 
Esta é a razão pela qual o sistema processual civil brasileiro foi desenhado originariamente para que não houvesse disponibilidade das partes quanto aos seus procedimentos (como vimos no item precedente), como também para que não fosse possível a eleição dos atos processuais a serem praticados ao longo do iter, moldado com rigidez a fim de sustentar a adoção de um rígido sistema de prazos e preclusões. ${ }^{262}$

\subsection{Flexibilizando a rigidez do procedimento sem perder a previsibilidade e segurança do sistema}

O desenvolvimento dos atos processuais não é livre e espontâneo, senão regrado e organizado em preceitos predeterminados. São as normas de procedimento as que submetem a disciplina do processo, sinalizando os preceitos a utilizar, estabelecendo a ordem das atuações, medindo em unidades de tempo sua direção. Todas estas regras são técnicas, quer dizer, vêm concebidas em função de sua utilidade para o processo.

Exatamente por isto "a experiência aconselha mudá-las quando sua utilização torna estéril e dissipa os fins do processo". Sendo as regras de procedimento preestabelecidas como garantia, estas normas não podem "substantivar-se, quer dizer, converter-se em fim próprio por si mesmo. Isso conduz ao formalismo, defeito que deve ser firmemente rechaçado por converter em fim o que não é mais do que um meio". ${ }^{263}$

Ocorre que pela índole do nosso sistema procedimental rígido, as normas do procedimento só podem ser adaptadas à adequada tutela do direito material por força de disposição legal, cujo processo legislativo demanda espera incompatível com a ânsia pela tutela adequada. $^{264}$

\footnotetext{
${ }^{262}$ Conforme bem aponta Paulo Eduardo Alves da Silva, tirante a hipótese de realização facultativa da audiência preliminar prevista no art. 331 do Código de Processo Civil (§ $3^{\circ}$ ), ainda não se pode afirmar que "a flexibilidade formal e o ativismo judicial tenham deixado de se subordinar à lei e à rigidez procedimental", pois "o procedimento judicial estabelecido no Código de Processo Civil tece em detalhes como devem agir as partes e o juiz no processo", já que "os agentes do processo judicial têm seus passos minimamente planejados em nível genérico e abstrato pela lei”, que disciplina o procedimento de maneira minuciosa e extensa. (Condução planejada dos processos judiciais: a racionalidade do exercício jurisdicional entre o tempo e a forma do processo, cit., p. 38).

${ }^{263}$ RAMOZ MENDES, Francisco. Derecho procesal civil. 3. ed. Barcelona: Bosch, 1986. p. 340.

${ }^{264}$ Por esta razão que insistimos, na segunda parte deste trabalho (Capítulo 2), pela descentralização normativa dos problemas do processo para outras esferas políticas, o que propiciaria, com mais vigor, a reclamada adequação do procedimento pela via legal.
} 
Daí porque, inexistindo adequação procedimental no plano normativo, não me parece haver dúvida de que as variações rituais possam ser autorizadas judicialmente.

De fato, a relação entre justiça e forma criou a ilusão de que a legalidade e a rigidez do procedimento são sinônimas de previsibilidade e de segurança jurídica, sem o que haveria margem para o arbítrio. ${ }^{265}$

Todavia, partindo do pressuposto de que a segurança jurídica reside na previsibilidade das ações futuras e de suas conseqüência, é possível ser evitado o arbítrio independentemente das regras procedimentais estarem estabelecidas em norma cogente e pretérita.

Para que as regras procedimentais tenham seu poder ordenador e organizador, coibindo o arbítrio judicial, para que promovam a igualdade das partes e emprestem maior eficiência ao processo, tudo com vistas a incentivar a justiça do provimento judicial ${ }^{266}$, basta que sejam de conhecimento dos litigantes antes de sua implementação no curso do processo, sendo de pouca importância a fonte de onde provenham.

Ou seja, sendo as variações rituais implementadas apenas após a participação das partes sobre elas em pleno contraditório, não se vê como a segurança jurídica seja abalada, já que o desenvolvimento do processo está sendo regrado e predeterminado judicialmente, o que o faz previsível.

O estabelecimento de regras procedimentais por lei genérica, impede as adequações rituais conforme o direito material a ser objeto de tutela, o que ocasiona (como no nosso sistema) a proliferação de dezenas de procedimentos especiais, também incapazes de se adaptarem às circunstâncias do litígio em si. Pois em uma sociedade moderna, os conflitos pululam em uma velocidade não acompanhada simultaneamente por alterações legislativas e implementação de ritos especiais. ${ }^{267}$

\footnotetext{
${ }^{265}$ Eis porque Ovídio Baptista da Silva sinaliza que embora no plano político o Estado tenha ultrapassado o modelo liberal que serviu de inspiração para a rigidez dos modelos procedimentais, no plano da justiça ainda se crê que o minucioso rigor formal maximiza a segurança processual e a certeza nos julgamentos (SILVA, Ovídio A. Baptista. Processo e ideologia: o paradigma racionalista. Rio de Janeiro: Forense, 2004. p. 143).

${ }^{266}$ OLIVEIRA, Carlos Alberto Alvaro de. Do formalismo no processo civil, cit., p. 183.

${ }^{267}$ Esta, aliás, é a premissa que informa todas as recentes reformas processuais que incrementam os poderes do juiz na condução do processo, especialmente as que utilizam conceitos jurídicos indeterminados e que, como tal, deixam ao bom alvitre do julgador encontrar a melhor adaptação das normas ao caso concreto. Neste sentido cf. PUOLI, José Carlos Baptista. Os poderes do juiz e as reformas do processo civil, cit., p. 71-74.
} 
Daí porque a absoluta rigidez formal é regra estéril e que dissipa os fins do processo, que é o de oferecer em cada caso, processado individualmente e conforme suas particularidades, a tutela mais justa. A preocupação do processo há de se ater aos resultados, e não com formas pré-estabelecidas e engessadas com o passar dos séculos.

Não se nega que certo rigor formal "é a espinha dorsal do processo", e que "seria impensável o processo sem determinada ordem de atos e paralela distribuição de poderes entre os sujeitos" 268 . O que não parece certo é vincular a fonte de emissão destas regras exclusivamente à norma cogente, ou estabelecer que só assim há previsibilidade, conseqüentemente segurança aos contendores, como se o juiz fosse um ser inanimado incapaz de ordenar adequadamente o rito processual. ${ }^{269}$

O juiz, investido por critério estabelecidos na Constituição Federal, é também agente político do Estado, portador de seu poder, inexistindo, portanto, "razão para enclausurá-lo em cubículos formais dos procedimentos, sem liberdade de movimentos e com pouquíssima liberdade criativa". 270

É preciso, pois, conforme bem aponta José Roberto dos Santos Bedaque, "reconhecer no julgador a capacidade para, com sensibilidade e bom senso, adequar o mecanismo às especificidades da situação, que não é sempre a mesma". 271

Ademais, as variações procedimentais implementadas por determinação judicial poderão ser controladas pela finalidade e pelo já citado contraditório obrigatório, bem como pela possibilidade de reexame da decisão em sede recursal, até porque as alterações do iter padrão ordinário, sumário ou especial - que como tal devem continuar a reger os

\footnotetext{
${ }^{268}$ OLIVEIRA, Carlos Alberto Alvaro de. Do formalismo no processo civil, cit., p. 108-109.

${ }^{269}$ Cf. BEDAQUE, José Roberto dos Santos. Poderes instrutórios do juiz. 3. ed. São Paulo: Ed. Revista dos Tribunais, 2001. p.13-14; CRUZ E TUCCI, José Rogério. Tempo e processo. São Paulo: Ed. Revista dos Tribunais, 1998. p. 35. Flávio Luiz Yarshell, embora resistindo à transferência ao juiz da regulação do procedimento (ao seu ver perigosa quebra de unidade na sua disciplina), admite certa dose de variação ritual em detrimento do modelo legal. E assim o faz por força dos poderes diretivos e de impulso essenciais para que o juiz, como agente do Estado, aplique adequadamente o direito objetivo. Ressalva, todavia, que qualquer modificação há de ser excepcional e deve preservar o contraditório, o caráter racional do procedimento e atender aos escopos da jurisdição (YARSHELL, Flávio Luiz. Tutela jurisdicional, cit., p. 170-171).

${ }^{270}$ DINAMARCO, Cândido Rangel. A instrumentalidade do processo, cit., p. 129.

${ }^{271}$ BEDAQUE, José Roberto dos Santos. Efetividade do processo e técnica processual: tentativa de compatibilização, cit., p. 41, 67, 104-108, Em sentido semelhante, no tocante ao árbitro, cf. CARMONA, Carlos Alberto. Arbitragem e processo: um comentário à Lei n. 9.307/96. 2. ed. São Paulo: Atlas, 2004. p. 250.
} 
processos em que não haja necessidade de variação ritual - deverão ser precedidas de convincente motivação pelo órgão condutor do procedimento. ${ }^{272}$

Oportunamente (item 5.4), à luz da realidade brasileira, nos ocuparemos das inúmeras situações em que a flexibilização judicial do procedimento, a bem da tutela dos direitos, já é admitida por útil e consentânea com os princípios que regem o direito processual civil, pese ainda a absolutamente majoritária afirmação doutrinária em sentido contrário.

\subsection{Requisitos indispensáveis à flexibilização procedimental}

Obviamente, algum critério, ainda que mínimo, deve haver para que possa ser implementada a variação ritual, sob pena de tornarmos nosso sistema imprevisível e inseguro, com as partes e o juiz não sabendo para onde o processo vai e nem quando ele vai acabar. ${ }^{273}$

Este critério consiste na necessidade de existência de um motivo para que se implemente, no caso concreto, uma variação ritual (finalidade), na participação das partes

\footnotetext{
${ }^{272}$ Algo que não acarretará sobrecarga dos Tribunais de $2^{\circ}$ grau, por força do novo regime de agravo com retenção obrigatória (art. 522 do CPC, com redação pela lei n. 11.187/2005), já que a aferição da variação procedimental eleita será feita, excepcionados os casos de grave prejuízo, só quando do julgamento de eventual apelação (art. 523 do CPC), e à luz do princípio informador do regime das nulidades processuais: a existência de efetivo prejuízo ao sucumbente (artigos 244 e 250 do CPC). Destaque-se, entretanto, que a falta de interposição de agravo da decisão que implemente a variação ritual implica preclusão quanto a alegação de prejuízo, nos termos do art. 245 do Código de Processo Civil.

${ }^{273}$ No direito português, onde a adequação formal é expressamente permitida (art. 265-A do CPC luso), apontam-se como requisitos condicionantes da flexibilização: a) prévia oitiva dos interessados; b) alteração procedimental pautada e fundamentada em critérios objetivos fundados no direito material: não se pode admitir que o juízo afira a necessidade de adequação conforme os sujeitos, já que não se espera que através deste instrumento ele assegure igualdade substancial das partes; c) a alteração não pode servir para determinar o afastamento da preclusão já verificada: tal regra, além de subverter a lógica do sistema e beneficiar às escâncaras a parte desidiosa, oportunizaria retardamento do curso processual; d) estabelecimento de uma seqüência procedimental em princípio rígida, que oferte um mínimo de certeza aos litigantes: a necessidade de segurança e o próprio acesso à justiça impõem que se garanta um conhecimento efetivo e prévio de todo o procedimento que se seguirá; e e) respeito aos demais princípios fundamentais do processo: como o do contraditório, da ampla defesa (não pode haver restrição aos articulados previstos em lei), do dispositivo, da economia processual (a fixação não pode contemplar atos inúteis, sendo ilegal a assim prevista) e da fundamentação (sem o que a parte não poderá controlar a pertinência da flexibilização) (BRITO, Pedro Madeira de. O novo princípio da adequação formal, cit., p. 64-65). De acordo com Carlos Ferreira "o estabelecimento do princípio da indisponibilidade das formas processuais, sem limitações, merece-nos alguma dúvida. Compreende-se que certos princípios base do processo patrocinado pelo Estado como a igualdade das partes e a imparcialidade e dignidade do tribunal não possam ser, em nenhum caso, afastados pelas partes. Esta idéia vale também para os poderes de adaptação do juiz" (FERREIRA, Carlos. Os poderes dos juízes e das partes. Revista da Ordem dos Advogados, Lisboa, n. 3, p. 215, 1990).
} 
da decisão flexibilizadora (contraditório), e na indispensabilidade de que sejam expostas as razões pela quais a variação será útil para o processo (motivação).

\subsubsection{Finalidade}

A primeira condição para a variação ritual é a finalidade. Como regra, os procedimentos seguirão o esquema formal desenhado pelo legislador, o que lhes garante indiscutível segurança e previsibilidade. Só em caráter excepcional é que se permitirá a flexibilidade.

Três situações mais específicas autorizarão a variação.

A primeira delas - a mais comum - ligada ao direito material: toda vez que o instrumento predisposto pelo sistema não for apto à tutela eficaz do direito reclamado, possível a variação ritual. É o que ocorre com ampliação de prazos rigidamente fixados em lei para garantir a defesa, com a ampliação da fungibilidade de meios em favor da tutela dos direitos, entre outras situações práticas que oportunamente serão tratadas.

A segunda relacionada com a higidez e utilidade dos procedimentos, isto é, com a possibilidade de dispensa de alguns empecilhos formais irrelevantes para a composição do iter, que de todo modo atingirá seu escopo sem prejuízo das partes.

Com efeito, o juiz, no caso concreto, deverá verificar a idoneidade da exigência formal, desprezando-a caso não haja lógica para a imposição legal havida por mero culto à forma. ${ }^{274}$ Exemplificativamente, é o que se dá com a inversão da ordem de produção de provas (art. 452 do CPC). A precedência do exame pericial à colheita da prova oral, além de gerar a realização de dispendiosa perícia para aferição do dano em momento anterior à comprovação do próprio dever de indenizar, não se justifica do ponto de vista finalístico, já que não há razão lógica para esta precedência. Ouvir o perito na mesma audiência em que se ouvirão as partes e as testemunhas, é tecnocracia incompatível com a possibilidade de ser designado posteriormente novo ato para esta finalidade.

\footnotetext{
${ }^{274} \mathrm{Cf}$. BEDAQUE, José Roberto dos Santos. Efetividade do processo e técnica processual: tentativa de compatibilização, cit., p. 423-425.
} 
Finalmente, a terceira situação que autoriza a variação ritual tem relação com a condição da parte. Nada impede que o juiz, a bem da proteção do hipossuficiente e equilíbrio dos contendores, altere o procedimento para a composição de uma igualdade processual e material consoante os valores constitucionais. ${ }^{275}$ É o que ocorre com a superação de regras rígidas de preclusão em favor do necessitado cuja defesa técnica e gratuita não seja adequada. Ou que o juiz, a vista do requerimento conjunto e consensual dos litigantes, permita a variação do procedimento.

\subsubsection{Contraditório útil}

A segunda limitação à flexibilidade procedimento é o respeito ao princípio do contraditório.

O contraditório é princípio que pode ser decomposto. Na sua faceta formal, dizse que só é operacionalizado se as partes tiveram oportunidade de participação. Na sua faceta material, tem-se o contraditório apenas se a participação foi capaz de influir na decisão proferida. ${ }^{276}$

Uma perspectiva do contraditório não convive sem a outra. Ninguém influi em uma decisão sem participar do processo de elaboração dela. Tampouco vale a participação meramente por participar, sem efetiva e real possibilidade de atuar sobre o convencimento do órgão jurisdicional, sem que o contraditório seja útil.

Mas para que a parte possa participar-influindo, é mister que tenha conhecimento e que seja comunicada, pela lei ou pelo juiz, sobre o curso do processo, mais precisamente sobre os atos processuais que se praticarão. ${ }^{277} \mathrm{O}$ juiz participa em contraditório no processo pelo diálogo com as partes, sendo seu dever convidá-las ao debate quando pretenda inovar no processo, quando pretenda tomar alguma providência

\footnotetext{
${ }^{275}$ Cf. GRECO, Leonardo. O princípio do contraditório. Revista Dialética de Direito Processual, São Paulo, n. 24, p. 74-78, mar. 2005.

${ }^{276}$ Cf. TARZIA, Giuseppe. La paritá delle armi tra le ter parti e poteri del giudice nel processo civile. Studi Parmensi, v. 18, p. 357-359, 1977; TROCKER, Nicolò. Processo civile e Constituzione. Milano: Giuffrè, 1974. p. 370; MARINONI, Luiz Guilherme. Novas linhas do processo civil, cit., p. 258-259; GRECO, Leonardo. O princípio do contraditório, p. 74-78.

${ }^{277}$ TROCKER, Nicolò. Processo civile e Constituzione, cit., p. 468.
} 
fora do padrão legal, ou quando vá adotar oficiosamente solução até então não vislumbrada pelos litigantes ou expressada na lei. ${ }^{278}$

Dentro destas coordenadas, o princípio do contraditório não se esgota na ciência bilateral dos atos do processo e na possibilidade de influir nas decisões judiciais, mas faz também depender da participação das partes a própria formação dos procedimentos e dos provimentos judiciais. ${ }^{279}$

Tem-se, então, um trinômio: conhecimento-participação-influência, sem o que o princípio do contraditório não se opera em sua completude.

As legislações mais modernas, todas, têm se inclinado no sentido de maximizar o alcance do princípio do contraditório, tornando-o verdadeiro imperativo de democracia no âmbito do procedimento.

De acordo com o atual $\S 139-1$ da ZPO Alemã ${ }^{280}$ é vedado ao Tribunal, em princípio, colocar-se, para fundamentar sua decisão, em ponto de vista estranho ao das partes, por elas considerado irrelevante ou por ambos valorado de maneira diferente da que parece ao órgão judicial, a menos que este lhes faça a respectiva indicação e lhes dê ensejo de manifestar-se previamente.

\footnotetext{
${ }^{278}$ DINAMARCO, Cândido Rangel. O princípio do contraditório e sua dupla destinação. In: Fundamentos do processo civil moderno, cit., v. 1, p. 135. Cf. também GRINOVER, Ada Pellegrini. O conteúdo da garantia do contraditório. In: . Novas tendências do direito processual. Rio de Janeiro: Forense, 1990. p. 17-25, 31-32 e 34-37.

${ }^{279}$ OLIVEIRA, Carlos Alberto Alvaro de. A garantia do contraditório. Revista Forense, Rio de Janeiro, ano 95 , v. 346, p. 16, abr./jun. 1999. De acordo com o autor, para que seja atendido o contraditório, "insta a que cada uma das partes conheça as razões argumentações expendidas pela outra, assim como os motivos e fundamentos que conduziram o órgão judicial a tomar determinada decisão, possibilitando-se sua manifestação a respeito em tempo adequado (seja mediante requerimentos, recursos, contraditadas, etc.) Também se revela imprescindível abrir-se a cada uma das partes a possibilidade de participar do juízo de fato, tanto na indicação da prova quanto na sua formação, fator este último importante mesmo naquela determinada de ofício pelo órgão judicial. $\mathrm{O}$ mesmo se diga no concernente à formação do juízo de direito, nada obstante decorra dos poderes de ofício do órgão judicial ou por imposição da regra iura novit curia, pois a parte não pode ser surpreendida por um novo enfoque jurídico de caráter essencial tomado como fundamento da decisão, sem ouvida os contraditores".

${ }^{280} \mathrm{Cf}$. MOREIRA, José Carlos Barbosa. Breve notícia sobre a reforma do processo civil alemão. In:

Temas de direito processual: $8^{\mathrm{a}}$ série, cit., p. 201-202. Diz ainda o mesmo $\S 139$ da ZPO, mais precisamente ao tratar da audiência, que "o presidente deve fazer com que as partes se expressem inteiramente sobre os fatos decisivos (erhellich tatsachen) e formulem pedidos úteis e particularmente completem as alegações insuficientes dos fatos invocados e indiquem meios de prova. Neste desiderato, ele deve, se necessário, trazer às partes a situação litigiosa em seus aspectos factuais e jurídicos e fazer perguntas. O presidente deve chamar a atenção para os meios que devem ser levantados de ofícios pelo tribunal. Ele deve permitir a todos os agentes processuais, sobre suas pretensões, que formulem perguntas" (tradução livre).
} 
Lúcio Grassi ensina, com olhos nesta disposição e em todo o moderno sistema processual civil alemão, que ele, além de impor ao juiz o dever de solicitar das partes o esclarecimento sobre questão de fato ou de direito que repute importante para o deslinde da causa, recomenda ao julgador que discuta com elas as possíveis soluções para o litígio, quer no plano da apreciação da prova, quer na própria interpretação do direito, devendo ainda, de maneira absolutamente excepcional, recomendar a alteração de algum dos elementos da ação (causa de pedir ou do pedido) de modo a evitar a propositura de uma nova demanda a se basear na mesma relação jurídica ${ }^{281}$, bem como advertir o autor sobre a sua desídia probatória. ${ }^{282}$

O novo Código de Processo Civil Japonês de 1996, manifestamente influenciado pela doutrina alemã, expressa em seu art. 149 o dever do tribunal esclarecer as partes sobre o caso a si submetido, inclusive fazendo sugestões. ${ }^{283}$

Também o Código de Processo Civil italiano, em seu art. 183, tem disposição vedando que as partes sejam surpreendidas por decisões inesperadas, ainda que seja possível ao juiz conhecer de determinada matéria oficiosamente. ${ }^{284}$

O moderno Código de Processo Civil Português, em art. $3^{\circ}$, n. 3 (necessidade de pedido e contradição), expressamente aponta que "o juiz deve observar e fazer cumprir, ao longo de todo o processo, o princípio do contraditório, não lhe sendo lícito, salvo caso de manifesta necessidade, decidir questões de direito ou de facto, mesmo que de conhecimento oficioso, sem que as partes tenham tido a possibilidade de sobre elas se pronunciarem". Em outros termos, o dispositivo impõe expressamente que as partes devem ser previamente consultadas pelo órgão judicial antes de ser adotada alguma medida atípica, até então não vislumbrada por elas ou prevista expressamente na lei. ${ }^{285}$

\footnotetext{
${ }^{281}$ Para uma ampla análise sobre a possibilidade, não contemplada em amplitude no nosso sistema (artigos 264 do CPC), de alteração do pedido e da causa de pedir após o ajuizamento da ação, especialmente no direito alemão e português, cf. OLIVEIRA, Carlos Alberto Alvaro de. Poderes do juiz e visão cooperativa do processo, cit., p. 59.

${ }^{282}$ GRASSI, Lúcio. Cognição processual civil: atividade dialética e cooperação intersubjetiva na busca da verdade real. Revista Dialética de Direito Processual. São Paulo, n. 6, p. 48, set. 2003.

${ }^{283}$ TANIGUCHI, Yasuhei. O código de processo civil japonês de 1996: um processo para o próximo século? Revista de Processo, São Paulo, v. 25, n. 99, p. 67, jul./set. 2000.

${ }^{284}$ Art. 183: Il giudice richiede alle parti, sulla base dei fatti allegati, i chiarimenti necessari e indica le questioni rilevabili d'ufficio delle quali ritiene opportuna la trattazione.

${ }^{285}$ Eis o que diz a exposição de motivos do Decreto Lei n. 329-A/95, diploma alterador do Código de Processo Civil Português, por força da autorização legislativa concedida pela Lei n. 33/1995: "nenhuma pretensão pode ser apreciada sem que ao legítimo contraditor, regularmente chamado a juízo, seja facultada oportunidade de deduzir oposição. Prescreve-se como dimensão do princípio do contraditório, que ele
} 
Mais adiante o diploma lusitano adota expressamente o denominado princípio da cooperação (art. 266), bem como o dever de boa fé processual (art. 266-A) e de recíproca correção (art. 266-B), que como corolários do contraditório já anunciado, passam a ser regras fundamentais e estruturantes de todo o processo civil. ${ }^{286}$

De acordo com a exposição de motivos do diploma que consolidou a reforma processual portuguesa (Decreto-Lei n. 329-A, de 1995), “consagra-se o princípio da cooperação, como princípio angular e exponencial do processo civil, de forma a propiciar que juízes e mandatários cooperem entre si, de modo a alcançar-se, de um uma feição expedita e eficaz, a justiça do caso concreto $^{287}$; e procurando plasmar, mais uma vez, como adiante melhor se irá especificando, tal princípio nos regimes concretamente estatuídos (v.g. audiência preliminar, marcação de diligências, averiguação de existência de bens penhoráveis). Tem-se, contudo, plena consciência de que nesta sede se impõe a renovação de algumas mentalidades, o afastamento de alguns preconceitos, de algumas inusitadas e esotéricas manifestações de um já desajustado individualismo, para dar lugar a um espírito humilde e construtivo, sem desvirtuar, no entanto, o papel que cada agente judiciário tem no processo, idôneo a produzir o resultado que a todos interessa - cooperar com a boa-fé numa sã administração da justiça. $\mathrm{Na}$ verdade, sem a formação desta nova cultura judiciária facilmente se poderá pôr em causa um dos aspectos mais significativos desta revisão, que se traduz numa visão cooperante, e não uma visão autoritária”.

Miguel Teixeira de Sousa ${ }^{288}$, ao comentar o novo dispositivo, aponta que do princípio da cooperação extraem-se quatro principais deveres do órgão judicial, todos diretamente relacionados à potencialização do princípio do contraditório: a) dever de esclarecimento, consistente na atividade do tribunal se esclarecer junto as partes sobre suas dúvidas em relação às alegações, pedidos ou posições do juízo (vide artigos 266-A e 266, números 2 e 3); b) dever de prevenção, que impõe ao julgador o dever de alertar o

envolve a proibição da prolação de decisões surpresas, não sendo lícito aos tribunais decidir questões de facto ou de direito, mesmo que de conhecimento oficioso, sem que previamente haja sido facultada às partes a possibilidade de sobre elas se pronunciarem - e aplicando-se tal regra, não apenas na $1^{\text {a }}$ instância, mas também na regulamentação de diferentes aspectos atinentes à tramitação e julgamento dos recursos".

${ }^{286} \mathrm{Cf}$. REGO, Carlos Francisco de Oliveira Lopes do. Comentários ao Código de Processo Civil. 2. ed. Coimbra: Almedina, 2004. v. 1, p. 264-271; e NETO, Abílio. Código de processo civil anotado. 18. ed. Lisboa: Ediforum, 2004. p. 355-358.

${ }^{287}$ A exposição de motivos ainda exemplifica que "como clara decorrência do princípio da cooperação, estabelece-se a regra da marcação das diligências, máxime das audiências preliminar e final, mediante prévio acordo de agendas, especificando-se a forma que pareceu mais adequada, eficaz e desburocatizada de concretização de tal princípio, nos casos em que o andamento do processo não haja ainda propiciado o contacto directo entre os vários intervenientes na diligência".

${ }^{288}$ SOUZA, Miguel Teixeira de. Estudos sobre o novo processo civil. 2. ed. Lisboa: Lex, 1997. p. 65. 
contendores sobre eventuais deficiências ou insuficiências de suas alegações ou pedidos, prevenindo que o uso inadequado do processo possa frustrar os objetivos pretendidos (vide artigos 508, n.1, 508-A, n. 1, 690, n. 4, e 701, n. 1); c) dever de consultar as partes, a determinar que o Tribunal alerte os litigantes sobre matérias que conhecerá oficiosamente, ou interpretação não cogitada pelos eles (art. $3^{\circ}$, n. 3), única maneira para que possam influir na decisão do juiz, não sendo pegos de surpresa por ela (uberraschungsentscheidungen) e d) dever de auxiliar as partes, que consiste na necessidade de colaboração com os litigantes na remoção de óbices sérios na obtenção de informações ou documentos importantes para a solução da demanda (art. 266, n. 4).

Não há mais, então, no processo civil moderno, espaço para a investigação solitária do órgão judicial em verdadeiro monólogo, pois “o diálogo recomendado pelo método dialético, amplia o quadro de análise, constrange à comparação, atenua o perigo de opiniões pré-concebidas e favorece a formação de um juízo mais aberto e ponderado"289, tudo a contribuir para a mais adequada tutela do direito material.

Logo, se não se pode tomar as partes de surpresa sob pena de ofensa ao princípio do contraditório, eventual alteração procedimental não prevista no iter estabelecido legalmente depende da plena participação delas, até para que as etapas do procedimento sejam previsíveis. $^{290}$

E isto só será possível se o julgador, antes da alteração da rígida regra legal, propiciar às partes efetiva oportunidade para se manifestarem sobre a conveniência da inovação, pois, ainda que não estejam de acordo com a flexibilização do procedimento $^{291}$, a participação efetiva dos litigantes na formação desta decisão é o bastante para se

\footnotetext{
${ }^{289}$ Cf. Carlos Alberto Alvaro de Oliveira, que ainda bem aponta a necessidade de ser afastada a concepção primitiva de que o contraditório só recai sobre as provas (A garantia do contraditório, cit., p. 13).

${ }^{290}$ Cf. SILVA, Paulo Eduardo Alves. Condução planejada dos processos judiciais: a racionalidade do exercício jurisdicional entre o tempo e a forma do processo, cit. p. 133. Cf. também, MARINONI, Luiz Guilherme. Novas linhas do processo civil, cit., p. 254.

${ }^{291}$ Neste sentido, aduz Artur Stamfords que provocada a participação das partes, legitima-se a decisão não tanto pela justificativa, como prevê o direito processual, mas sim pela formação de um clima social que institucionaliza o reconhecimento da opção por força da participação na sua adoção (STAMFORDS, Artur. As audiências judiciais como processo de legitimação e justiça social: à luz da teoria da justiça de Rawls e da legitimação pelo procedimento de Luhman. Revista da Escola Superior da Magistratura do Estado de Pernambuco, Olinda, v. 3, n. 7, p. 55, jan./jun. 1998. Também Niklas Luhmann, ao anotar que a discussão é mecanismo legitimador pois, "a função legitimadora do procedimento não está em se produzir consenso entre as partes, mas em tornar inevitáveis e prováveis decepções em decepções difusas: apesar de descontentes, as partes aceitam a decisão" (LUHMANN, Niklas. Legitimação pelo procedimento, cit., p. 4 e 64-68).
} 
precaverem processualmente, inclusive valendo-se de recursos para reparar eventuais iniqüidades.

Evidentemente, a necessidade de contraditório para as inovações procedimentais é exigência que só se coaduna com o espírito dialético do processo se a participação da parte para a formação do novo rito for útil, isto é, capaz de lhe assegurar alguma vantagem. Se a variação ritual lhe for ser benéfica, sua participação pode ser excepcionalmente e licitamente tolhida, pois acabaria consistindo em um simples participar por participar, o que, além de retardar a prestação jurisdicional, vai de encontro, como já vimos, à faceta material do contraditório, mais precisamente na capacidade de influir na decisão. ${ }^{292}$ Daí porque, já se advirta, haverá, ora ou outra, excepcionalmente, possibilidade de flexibilização procedimental mesmo antes da oitiva das partes. ${ }^{293}$

Portanto, no âmbito da flexibilização dos procedimentos, toda vez que for adequada a inversão da ordem, inserção ou exclusão de atos processuais abstratamente previstos, a ampliação dos prazos rigidamente fixados, ou outra medida que escape do padrão legal, indispensável a realização de contraditório preventivo ${ }^{294}$, desde que útil aos fins colimados pela variação ritual.

\subsubsection{Motivação}

Derradeiramente, o último requisito para a implementação das variações rituais é a necessidade de fundamentação da decisão que altera o iter legal, condição esta que não diverge, por força de disposição constitucional (art. 93, IX, da CF), da sistemática adotada para toda e qualquer decisão judicial.

\footnotetext{
${ }^{292}$ Limitação que já se dá legitimamente e em caráter de exceção, sem maiores problemas práticos, com a concessão de medidas liminares cautelares (art. 798 do CPC) e antecipatórias (art. 273 do CPC) inaudita altera pars, e também com o julgamento liminar das ações repetitivas (art. 285-A do CPC, com redação pela Lei n. 11.277/2006).

${ }^{293}$ É o que ocorrerá, conforme veremos no item 5.4.4., quando o magistrado, para possibilitar conciliação antes da apresentação da resposta pelo réu, manda citá-lo para comparecimento à audiência de conciliação, da qual iniciará o lapso, caso infrutífero o acordo, para oferecimento de contestação. Observe-se que a variação ritual ordenada será feita sem oitiva das partes, já que para o autor a providência não lhe causa prejuízo algum, e para o réu menos ainda, já que verá ampliado seu prazo para responder à demanda. Temse, aqui, típico exemplo de contraditório inútil, como tal possível de ser dispensado.

${ }^{294}$ De acordo com Antonio Carrata, a expressão contraditório preventivo deve ser entendida como "o princípio geral que obriga o juiz a sobrepor a preventiva discussão entre as partes o exercício de seus poderes de ofício" (Funzione dimostrativa della prova: verità del fatto nel processo e sistema probatório, cit., p. 100-101). Fredie Didier, com precisão, indica que agir de ofício é poder agir sem provocação, não agir sem provocar as partes, de modo que elas, como regra, sempre devem ser ouvidas previamente (DIDIER JÚNIOR, Fredie. Direito processual civil. 4. ed. Salvador: JusPodiVm, 2004. v. 1, p. 26 e ss.).
} 
Trata-se de imposição de ordem política e afeta muito mais ao controle dos desvios e excessos cometidos pelos órgãos jurisdicionais inferiores na condução do processo do que propriamente à previsibilidade ou a segurança do sistema. ${ }^{295}$ É na análise da fundamentação que se afere em concreto a imparcialidade do juiz, a correção e justiça dos próprios procedimentos e decisões nele proferidas.

Sendo a decisão sobre a variação ritual considerada interlocutória - e não ato meramente ordinatório como boa parte dos praticados pela secretaria por força de disposições procedimentais legais (art. 162, § $4^{\circ}$, do CPC) - indispensável que haja justificação das razões da flexibilização procedimental, até para permitir que as partes, como já afirmado, possam controlar, através de recursos, os fins justificadores (item 3.7.1) e a proporcionalidade da decisão.

\subsection{Procedimento como legitimador da atividade judicial}

Investigações de cunho sócio-político levaram boa parte da doutrina a afirmar que o procedimento é o fator de legitimação da atividade estatal (executiva, legislativa e judicial).

De modo especial no tocante à atividade judicial, aduzem que como os juízes não decidem sobre negócios jurídicos seus, mas de terceiros, valendo-se do poder estatal que lhe foi conferido pela lei, e não da autonomia da vontade, é exigível que o material preparatório do julgamento final seja recolhido e elaborado segundo regras conhecidas por todos. ${ }^{296}$ Daí porque a decisão proferida no processo só seria legítima se proferida após regular procedimento.

\footnotetext{
${ }^{295} \mathrm{Na}$ Teoria Geral do Direito vê-se a fundamentação como fator de legitimação do sistema jurídico, da própria atuação do magistrado como agente do poder político, ou como método de domesticação do poder (cf. CAYMNI, Pedro Leonardo Summers. O papel da fundamentação das decisões judiciais na legitimação do sistema jurídico. Revista Dialética de Direito Processual, São Paulo, n. 17, p. 115-133, ago. 2004). A advogada Maria Cristina da Silva Carmingnani, após louvar a possibilidade de flexibilização judicial do direito através da adpatação das decisões aos casos concretos, ressalva que sempre o comando adaptador deve ser fundamentado e nunca completamente divorciado dos princípios que regem o sistema, o que afasta o risco de arbitrariedades (CARMINGNANI, Maria Cristina da Silva. O direito judicial como forma de resolução dos anseios por justiça. Revista do IASP, São Paulo, ano 8, n. 16, p. 262-263, jul./dez. 2005).

${ }^{296}$ CINTRA, Antonio Carlos; GRINOVER, Ada Pellegrini; DINAMARCO, Cândido Rangel. Teoria geral do processo, p. 286-290.
} 
Tais investigações, ao menos em tese, teriam mais cabimento, ainda, em países como o nosso, onde os magistrados não são eleitos pelo povo, mas sim selecionados através de concursos públicos de provas e títulos (art. 93, I, da CF) ou de nomeações políticas (como ocorre com os ministros dos Tribunais Superiores). Não tendo os julgadores recebidos do próprio titular do poder - o povo (art. $1^{\circ}$, parágrafo único, da $\mathrm{CF}$ ) a sua capacidade decisória (a Jurisdição), somente um procedimento formal, onde as partes pudessem participar, evitaria o arbítrio e produziria, ao final, um resultado, se não desejável, ao menos suportável pelos litigantes.

A problemática da legitimidade se situa no interregno da moral, do direito, da religião e da política. Desde os mais remotos tempos tem se procurado por critérios de justificação e validade para as relações de poder e de conformação das condutas sociais ${ }^{297}$, regras estas cuja origem é assentada na necessidade de aceitação e pacificação dos ânimos relativamente à implantação de uma determinada ordem política-jurídica. ${ }^{298}$

Na era moderna foi Max Weber (1864-1918) quem deu início à análise sociológica da questão da legitimação. Relacionando a legitimidade com a fórmula da obediência, construiu uma teoria em que a autoridade se assentava na tradição, no carisma ou em critérios racionais-legais. ${ }^{299}$ Aplicada sua teoria à realidade brasileira, veríamos que a autoridade dos poderes estatais se fundaria na racionalidade-legalidade, especialmente na Constituição Federal, diploma legitimante das instituições públicas nacionais.

Todavia, tornando à questão do procedimento como legitimador da atividade estatal, nenhum outro autor se destacou mais do que Niklas Luhmann (1927-1998), que com sua teoria sistêmico-funcional do direito, via a legitimidade como uma disposição generalizada para aceitar decisões de conteúdo ainda não definido, dentro de certos limites

\footnotetext{
${ }^{297}$ De fato, as primeiras construções legitimadoras do poder são fruto da crença na magia e nas forças naturais, como ocorria nas civilizações antigas, em que o faraó era a corporificação do astro-rei. Em Roma, a autoridade espiritual e o poder temporal caminhavam juntos e decorriam das tradições e dos costumes antigos. Já na idade média, construções como as do poder divino dos reis deram sustentáculo por séculos às decisões da monarquia absolutista. E mesmo na concepção contratualista de Hobbes, que abandona como premissa o direito divino, se vê a legitimação do poder como decorrência do pacto entre os homens em favor de um soberano, com vistas à superação da barbárie do direito natural, o que, conforme posteriormente afirmaria Rousseau, condicionaria a legitimidade decisória dos soberanos.

${ }^{298}$ DINIZ, Antônio Carlos de Almeida. Legitimação procedimental e modernidade - a problemática da legitimidade jurídica política em sociedades complexas. Revista de Informação Legislativa, Brasília, ano 38, n. 150, p. 99, abr./jun. 2001.

${ }^{299}$ WEBER, Max. Economia e sociedade. Brasília: Ed. da Unb, 1998. p. 139.
} 
de tolerância, o que só ocorria através do curso de um procedimento decisório com participação das partes. $^{300}$

De acordo com Luhmann, o procedimento legitimaria as decisões estatais na medida em que reduziria ou neutralizaria as expectativas de ilusões e decepções das partes, que teriam no seu curso um filtro constante.

Embora sua obra abarque outras esferas decisórias de poder (político, administrativo, legislativo), no âmbito judicial Luhmann coloca que o desenvolver do procedimento faz com que o conflito seja posto de lado enquanto todos os atores processuais buscam uma decisão. Com o correr do procedimento, a discrepância entre os contendores, que no início do processo era maior, vai se arrefecendo, até que a decisão final, se não aceitável, torne ao menos as decepções difusas. ${ }^{301}$

$\mathrm{Na}$ sua concepção, o conteúdo da decisão é de pouca valia, já que "em sociedade complexas que concluíram o processo de positivação do direito, a legitimidade é o efeito não da referência a valores, mas da aplicação de certos procedimentos instituídos para produzir decisões" onde os próprios sujeitos participam dos limites das regras estabelecidas, e onde a legitimidade decorre do próprio sistema. ${ }^{302}$

Muito embora os processos se iniciem e se encerrem com decisões normativas e de conteúdo variável, a legitimidade do processo residiria na fórmula procedimental, isto é, na série de atos processuais concatenados, cujas regras formais bastariam como premissas legitimadoras da decisão, e não no conteúdo da decisão em si considerado. ${ }^{303}$

Para Luhman, os procedimentos não teriam outra função ${ }^{304}$, a não ser a de desviar e amortizar as frustrações, estagnando as expectativas através de protocolos, atos,

\footnotetext{
${ }^{300}$ Tércio Sampaio Ferraz, na introdução da tradução brasileira de Niklas Luhmann, Legitimação pelo procedimento, cit., p. 3-4.

${ }^{301}$ LUHMANN, Niklas. Legitimação pelo procedimento, cit. p. 51-113.

${ }^{302}$ Esta referência à teoria de Luhmann é de Norberto Bobbio, Estado, governo, sociedade. São Paulo: Paz e Terra, 1999. p. 93.

${ }^{303}$ DINIZ, Antônio Carlos de Almeida. Legitimação procedimental e modernidade, cit., p. 105.

${ }^{304}$ Para facilitar a compreensão da inutilidade do conteúdo da decisão na ótica de Luhmann, vale o recurso às indagações de Artur Stamford: "É, portanto, insuficiente para solver os litígios, recorrer-se apenas aos textos legislativos, às jurisprudências e às doutrinas. Será o direito um arsenal de preceitos dos quais os magistrados buscam argumentos legitimadores de suas decisões, convencendo-se assim as partes litigantes a acatarem a decisão final? Tem o direito alguma relação com a justiça ou é uma técnica de domínio social? Responder a estas perguntas reporta-nos à dificuldade em atribuir um conteúdo ao que se possa ter por justiça, quando se buscam critérios objetivos de justiça, e ao que se entende por legitimação. Como julgar os casos concretos convictos de estar aplicando a justiça, o direito mais justo e assim fazer as partes litigantes acatarem a decisão? (STAMFORDS, Artur. As audiências judiciais como processo de legitimação e justiça social: à luz da teoria da justiça de Rawls e da legitimação pelo procedimento de Luhman, cit., p. 47).
} 
promessas, discussões, retóricas e decisões praticada ao longo do iter, de modo que os protestos dos litigantes são fracionadamente absorvidos e, ao final, as decepções são controladas.

\subsection{Compatibilização da função legitimante do procedimento com sua flexibilização}

Mesmo seguindo à risca o ideário legitimante defendido por Luhmann - o que não admitimos, conforme veremos logo abaixo - a flexibilização do procedimento processual não tornaria a decisão nele proferida menos legítima, tampouco afetaria a sua função de desviar e amortizar as frustrações ao longo do iter. Em nenhuma passagem da elaboração da teoria sistêmica-funcional se condicionou o poder legitimante do procedimento à sua rigidez.

Por isto, mesmo com um procedimento maleável conforme as circunstâncias do caso concreto, a decisão final do processo estaria legitimada, já que curso procedimental teria neutralizado as expectativas de ilusões e decepções das partes com o produto final da prestação jurisdicional.

Aliás, admitida a participação das partes na construção do próprio rito, o potencial legitimante do procedimento seria catalisado, pois a conformação das partes se daria não só quanto ao resultado do processo, mas também quanto ao caminho nele adotado para se alcançar o resultado final. De certo o afastamento das iniqüidades da rigidez procedimental contribuiriam para melhor aceitação do produto concebido após regular procedimento.

\subsection{Legitimação da decisão pelo contraditório útil e não pelo mero procedimento}

Pese seu grande conteúdo científico, a teoria de Luhmann peca na análise da legitimação das decisões judiciais, já que não dá a atenção merecida ao principal fator de condicionamento político da atividade jurisdicional: o contraditório útil.

Com efeito, como bem coloca Dinamarco, o que legitima os atos de poder não é a mera e formal observância dos procedimentos - ou a irreparável fundamentação do seu 
produto final (a sentença), eu acrescento - mas a participação que mediante o correto cumprimento das normas procedimentais tenha sido possível aos destinatários, razão pela qual é melhor falar em legitimação pelo contraditório, e não pelo simples procedimento vazio. $^{305}$

Ao se preocupar com a participação das partes no curso do procedimento, a teoria sistêmica deixou de enfocar a participação efetiva dos destinatários da decisão como fato principal, sobrepondo o mero procedimento sobre o contraditório, o que efetivamente não pode ocorrer.

A capacidade do procedimento em amortizar as frustrações e as derrotas é diretamente proporcional ao nível de participação das partes na formação do resultado, e porque não do próprio procedimento. Conforme já afirmamos, ao se permitir aos litigantes influenciar também sobre o fluxo procedimental, o poder de conformação com a decisão é maximizado, ainda que sua fundamentação seja falha.

O procedimento só por si é fórmula vazia. É o contraditório útil que lhe preenche o conteúdo e lhe dá poder para legitimar a decisão.

Por isto, a flexibilização procedimental, com alteração do rito padrão estabelecido por lei ou com a construção de um novo modelo ritual, não afeta o poder legitimante da decisão, desde que no processo tenha sido assegurada aos litigantes efetiva participação em contraditório. ${ }^{306}$

A exigência de contraditório, todavia, só se coaduna com o espírito dialético do processo se a participação da parte para a formação da decisão for útil, isto é, capaz de lhe assegurar alguma vantagem. Se a decisão lhe for ser benéfica, conforme já advertimos anteriormente, sua participação pode ser excepcionalmente e licitamente tolhida, pois acabaria consistindo em um simples participar por participar, o que, além de retardar a prestação jurisdicional, vai de encontro à faceta material do contraditório (capacidade de influir na decisão).

\footnotetext{
${ }^{305}$ DINAMARCO, Cândido Rangel. O princípio do contraditório e sua dupla destinação, p. 125. No mesmo sentido Carlos Alberto Alvaro de Oliveira, para quem o exercício da Jurisdição é plenamente legitimado "mediante melhor e mais acabada comunicação do órgão judicial com os atores do processo" (OLIVEIRA, Carlos Alberto Alvaro de. Por um novo paradigma processual. Revista Forense, Rio de Janeiro, ano 96, v. 350, p. 404, abr./jun. 2000).

${ }^{306} \mathrm{Cf}$. Dinamarco, para quem "se algum procedimento excluísse a participação dos sujeitos envolvidos no litígio, ele próprio seria ilegítimo e chocar-se-ia com a ordem constitucional” ( $A$ instrumentalidade do processo, cit., p. 131).
} 
Daí porque não se vê inconstitucionalidade alguma no novo art. 285-A do Código de Processo Civil brasileiro - com redação pela Lei n. 11.277/2006 - que permite ao juiz "quando a matéria controvertida for unicamente de direito e no juízo já houver sido proferida sentença de total improcedência em outros casos idênticos", dispensar a citação do réu e repetir a prolação da sentença anterior através de mera reprodução de seus fundamentos. ${ }^{307}$

Note-se que a participação do réu neste procedimento abreviado, que outrora denominamos julgamento antecipadíssimo da $\operatorname{lide}^{308}$, ao menos na primeira fase é inexistente, pois ele não sofre lesão alguma pelo fato de não ter podido convencer o juiz quando ele próprio já está convencido pela prévia apreciação de casos similares - de que a razão está consigo.

Por isto, plenamente legítima a decisão proferida neste procedimento. Sendo o réu - pretensamente lesionado pela falta de citação - o vencedor da ação, não se vê utilidade alguma no contraditório, já que a decisão lhe é benéfica e o contraditório não é capaz de lhe trazer vantagem alguma.

Em resumo, o procedimento ou a fundamentação da decisão, por si só, são desimportantes. Ao menos no campo sócio-político, seja a decisão, seja o procedimento flexibilizado, só são legítimos se acompanhados da efetiva participação das partes no processo de sua elaboração. ${ }^{309}$

\footnotetext{
${ }^{307}$ A Ordem dos Advogados do Brasil, dias após a publicação da Lei n. 11.277, de 08.02.2006, ajuizou perante o Supremo Tribunal Federal uma ADIN contra o art. 285-A, do CPC (ADIN n. 3.695/DF, Rel. Min. Cézar Peluso), onde são apontadas 05 (cinco) inconstitucionalidades no dispositivo. A referida ADIN aguarda julgamento, mas além da intervenção do Instituto Brasileiro de Direito Processual em favor da constitucionalidade da norma (em trabalho da lavra de Cássio Scapinella Bueno), já há parecer do Procurador Geral da República pela improcedência do pedido, de modo que o prognóstico que se faz de seu resultado é o de improcedência, com o conseqüente reconhecimento da constitucionalidade da Lei n. 11.277/2006.

${ }^{308} \mathrm{Cf}$. GAJARDONI, Fernando da Fonseca. O princípio constitucional da tutela jurisdicional sem dilações indevidas e o julgamento antecipadíssimo da lide. Revista de Processo, São Paulo, ano 131, n. 141, p. 150179, nov. 2006.

${ }^{309}$ No campo prático, entretanto, participação em contraditório, mesmo que de forma intensa, não representa maior poder de conformação com a decisão. Legitimidade e aceitação, ao menos no Brasil, são realidades que andam em direções opostas, já que o ímpeto recursal de nossos operadores jurídicos reclama inúmeras decisões para a mesma causa. Poder de conformação mesmo só se tem por aqui com a coisa julgada, ainda que o procedimento tenha se dado em pleno contraditório e a sentença seja de exata fundamentação. Mesmo assim, hoje já se sustenta a possibilidade de relativizar a coisa julgada, criando, por isto, a situação prática de se deslegitimar a decisão até então soberana. A este respeito cf. DINAMARCO, Cândido Rangel. Relativizar a coisa julgada material. In: A nova era do processo civil, cit., p. 220-266; MEDINA, José Miguel Garcia; WAMBIER, Teresa Arruda Alvim. O dogma da coisa julgada: hipóteses de relativização. São Paulo: Ed. Revista dos Tribunais, 2003. p. 170-203; e GRINOVER, Ada Pellegrini. Princípio da proporcionalidade: coisa julgada e justa indenização. No prelo. Artigo cedido pela autora para o curso de pós-gradução do Instituto Brasileiro de Direito Processual Civil, Rede de Ensino Luiz Flávio Gomes e UNISUL.
} 


\subsection{Devido processo constitucional e flexibilização procedimental}

Não há incompatibilidade entre a flexibilização procedimental com o princípio do devido processo legal (art. 5 , LIV, da Constituição Federal), que, como aponta prestigiosa doutrina, é base sobre a qual todos os demais princípios constitucionais se sustentam (contraditório e ampla defesa, juiz natural, publicidade, licitude da prova, dever de motivação das decisões judiciais, etc.). ${ }^{310}$

Por devido processo constitucional ${ }^{311}$ (expressão bem melhor que devido processo legal, fruto de uma tradução ipsis literis de due processo of law) entende-se o conjunto de garantias constitucionais que, de um lado, asseguram às partes o exercício de suas faculdades e poderes processuais, e do outro garantem o escorreito exercício do poder. É princípio que se aplica a qualquer procedimento que tenha por objeto o trinômio vidaliberdade-patrimônio, de modo que há devido processo legal judicial, legislativo, administrativo e, porque não, no âmbito privado. ${ }^{312}$

Modernamente, a cláusula do devido processo compreende o direito constitucional a um procedimento adequado, isto é, conduzido sob o pálio do contraditório, aderente à realidade social e consetâneo com a relação de direito material controvertida. ${ }^{313}$

Exatamente por isto a adequação do procedimento abstratamente e rigidamente previsto em lei às peculiaridades ligadas ao direito material, caso a caso, acaba por favorecer o princípio do devido processo legal ao invés de esmorecê-lo.

\footnotetext{
${ }^{310}$ NERY JÚNIOR, Nelson. Princípios do processo civil na Constituição Federal. 2. ed. São Paulo: Ed. Revista dos Tribunais, 1995. p. 27.

${ }^{311}$ De todos aqueles que se dedicam ao estudo do processo civil à luz da Constituição Federal, merece destaque especial Cássio Scarpinella Bueno, que em recente trabalho propõe o estudo desta disciplina com a consciência "de que a interpretação do direito é valorativa e que o processo, como método de atuação do Estado, não tem como deixar de ser, em igual medida, valorativo, até como forma de realizar adequadamente aqueles valores: no e pelo processo" (BUENO, Cássio Scarpinella. Curso sistematizado de direito processual civil. São Paulo: Saraiva, 2007. v. 1, p. 71).

${ }^{312}$ Cf. SARMENTO, Daniel. A vinculação dos particulares aos direitos fundamentais no direito comparado e no Brasil. In: BARROSO, Luis Roberto (Orgs.). A nova interpretação constitucional: ponderação, direitos fundamentais e relações privadas. 2 ed. Rio de Janeiro: Renovar, 2006. p. 193-284. O Supremo Tribunal Federal já asseverou que na hipótese de exclusão de associado decorrente de conduta contrária aos estatutos - típica relação privada - "impõe-se a observação do devido processo legal, viabilizando o exercício da ampla defesa" (RE n ${ }^{\circ}$ 158215-4/RS, 2a turma, Relator Ministro Marco Aurélio, DJ de 07/06/1997). E o Tribunal de Justiça do Rio de Janeiro, da mesma forma, já entendeu que "de acordo com a Constituição Federal e Estatuto Social, a expulsão do quadro social depende da instalação do devido processo legal, no qual está seguro amplo direito de defesa. Se tal não foi observado, anula-se a penalidade" (Apelação $n^{\circ}$ 2000.001.12810, Relator Desembargador Bernardino M. Leituga, $16^{\text {a }}$ Câmara Cível, j. em 07/11/2000).

${ }^{313}$ CINTRA, Antonio Carlos; GRINOVER, Ada Pellegrini; DINAMARCO, Cândido Rangel. Teoria geral do processo, cit., p. 84.
} 
De fato, o devido processo constitucional é princípio de duplo sentido: material (substantive due process) e formal (procedural due process).

Por devido processo constitucional material entende-se a necessidade de elaboração e aplicação regular e correta da lei, bem com de sua razoabilidade, senso de justiça e enquadramento nas preceituações constitucionais. ${ }^{314}$ Por força disto o julgador, observando que o procedimento construído abstratamente pelo legislador é inadequado à tutela efetiva do direito material ou da parte, deve se valer da razoabilidade, e voltando-se para justiça do caso em concreto, há de providenciar a variação ritual para adequação do procedimento às especificidades da causa. Afinal, a razoabilidade (ou proporcionalidade) decorrência clara, necessária e lógica do devido processo legal material - é método de interpretação do direito (e não princípio como dizem alguns) que torna "possível a justiça do caso concreto, flexibilizando-se a rigidez das disposições normativas abstratas". ${ }^{315}$ E se as disposições normativas que impedem a justiça do caso em concreto são procedimentais, nada impede que se adaptem em favor da garantia constitucional de um processo justo.

Já o devido processo constitucional em sentido formal nada mais é do que a possibilidade efetiva de a parte ter acesso à justiça, deduzindo pretensão e defendendo-se do modo mais amplo possível, conforme as regras previamente estabelecidas. ${ }^{316}$ Não há, todavia, necessidade de que estas regras abstratamente consideradas sejam fixadas pela via legislativa, tampouco que sejam modeladas genericamente, sem possibilidade de adequação judicial, demanda a demanda. Assim, desde que a flexibilização do procedimento não tolha dos litigantes o acesso à justiça, o direito de ação e de defesa na amplitude prevista na Constituição Federal e nas normas processuais, é plenamente possível a ocorrência de variações rituais, boa parte delas, aliás, tendentes exatamente a potencializar a eficácia das garantias constitucionais citadas (ampliação de prazos abstratamente considerados por circunstâncias ligadas à dificuldade da defesa, afastamento da rigidez no concernente à preclusão a bem da verdade real, etc); desde que mantida a previsibilidade das variações rituais, algo que é assegurado com o contraditório útil, plenamente possível a flexibilização com respeito a esta faceta do devido processo constitucional.

\footnotetext{
${ }^{314}$ CRUZ E TUCCI, José Rogério; TUCCI, Rogério Lauria. Constituição de 1988 e processo: regramentos e garantias constitucionais do processo. São Paulo: Saraiva, 1989. p. 15; e CRUZ E TUCCI, José Rogério; TUCCI, Rogério Lauria. Devido processo legal e tutela jurisdicional. São Paulo: Ed. Revista dos Tribunais, 1993. p. 13.

${ }^{315}$ DIDIER JÚNIOR, Fredie. Direito processual civil, cit., p. 14.

${ }^{316}$ NERY JÚNIOR, Nelson. Princípios do processo civil na Constituição Federal, cit., p. 27.
} 
Aponta-se que sendo o procedimento o penhor da legalidade no exercício do poder, é garantia da parte que ele siga o modelo preestabelecido em lei, sendo os desvios e omissões procedimentais encarados como violação do devido processo legal. Ressalva-se, entretanto, que o due process of law não se resume a mera garantia de legalidade, importando mesmo é a estrutura de oportunidades e de respeito a faculdades e poderes processuais que a Constituição e a lei impõem ao juiz que comanda o processo, de modo que "a liberdade das formas, deixada ao juiz entre parâmetros razoavelmente definidos e mediante certas garantias fundamentais aos litigantes é que, hoje, caracteriza os procedimentos mais adiantados". 317

Ademais, a regulamentação particularizada das modalidades de instauração e desenvolvimento do processo não se atém necessariamente à garantia devido processo legal. Esta garantia não pode ser dita violada por haver um processo com reduzida rigidez formal que consente ao juiz adaptar as modalidades de procedimento às diversas exigências do direito que caso a caso se apresentem. ${ }^{318}$

Engana-se, portanto, quem vincula o respeito ao devido processo legal à obediência de um trâmite processual estabelecido em regras rígidas fixadas em lei. Além disto não constar de nenhum dispositivo constitucional, o art. $5^{\circ}$, LIV, da Constituição Federal não determina que o processo siga à risca as normas procedimentais estabelecidas em lei, mas sim que seja oportunizado às partes o direito a um processo justo, isto é, onde lhes sejam assegurados o respeito às garantias constitucionais (contraditório, isonomia, juiz natural, etc.) e às oportunidades previstas na norma processual, algo que pode ser perfeitamente alcançado ainda que com um procedimento que se adapte judicialmente à realidade. ${ }^{319}$

\footnotetext{
${ }^{317}$ DINAMARCO, Cândido Rangel. A instrumentalidade do processo, cit., p. 127-128. Prossegue o ilustre professor das Arcadas apontando que "não é enrijecendo as exigências formais, num fetichismo à forma, que se asseguram direitos; ao contrário, o formalismo obcecado e irracional é fator de empobrecimento do processo e cegueira para os seus fins. No processo civil brasileiro temos a promessa da liberdade das formas em normas programáticas dos dois sucessivos Códigos de Processo Civil nacionais, mas só a promessa: ambos foram tão minuciosos quanto à forma dos atos processuais que com segurança se pode afirmar ser o princípio da legalidade formal o que realmente prepondera".

${ }^{318}$ TROCKER, Nicolò. Il nuovo art. 111 della Constituzione e il giusto processo in matéria civile: profili generali. Rivista Trimestrale di Diritto e Procedura Civile, Milano, n. 2, p. 392, giug. 2001.

${ }^{319}$ Vale a referência à boa nota de Paulo Eduardo Alves da Silva, "as garantias constitucionais do processo compõem o quadro mínimo para qualquer processo judicial, o limite para a flexibilização da forma dos atos processuais e dos tipos procedimentais. Se o procedimento é flexibilizado ou a ordem dos atos invertida, mas as garantias constitucionais do processo são observadas, nenhum prejuízo houve para as partes e para a justiça da decisão. Além do mais, ater-se às garantias constitucionais do processo na composição do devido processo possibilita sustentar a adaptação do procedimento às necessidades do caso concreto, minimizando o tempo e os custos da resolução judicial do conflito - exigência permanente na atualidade" (Condução planejada dos processos judiciais: a racionalidade do exercício jurisdicional entre o tempo e a forma do processo, cit , p. 133). Cf., também, BEDAQUE, José Roberto dos Santos. Efetividade do processo e técnica processual: tentativa de compatibilização, cit., p. 59-63.
} 


\subsection{Flexibilização procedimental e instrumentalidade das formas}

$\mathrm{O}$ art. 154 do Código de Processo Civil é expresso no sentido de que os atos e termos processuais (documentação do ato) não dependem de forma, salvo quanto a própria lei o exigir. Interpreta-se de maneira ampla tal disposição a fim de contemplar, também sob a sua égide, o conjunto dos atos processuais, isto é, o procedimento processual. Esta sempre foi a voz corrente no estudo do tema, de modo que havendo previsão legal de forma individual (só para dado ato) ou global (para ordem dos atos no procedimento), não é dado às partes ou ao juiz contrariar a disposição cogente.

A análise da forma do ato processual em si considerado é mais simples, pois basta a aferição da adequação do ato praticado ao modelo legal. Sendo o ato praticado na exata forma e acordo com o modelo legal é válido. Estando, porém, em dissonância deste mesmo modelo o ato é inválido.

Já no tocante à análise da forma no bojo do procedimento, há de ser feita importante distinção. Se houver relação de dependência entre os atos do procedimento pode haver a contaminação de um ato perfeito por outro anterior praticado de maneira viciosa, algo a comprometer a regularidade de todos os demais atos posteriores do procedimento e dele mesmo. Não havendo, por outro lado, esta relação - como nos casos em que cada ato do procedimento se esgota em si mesmo e em sua finalidade específica, sem relação de dependência com os demais atos - a violação da regra formal não tem conseqüências para o conjunto. ${ }^{320}$

A conseqüência da violação da forma, todavia, sofre temperamento pela própria disposição legal já citada (art. 154 do CPC), bem como pelos artigos 244 e 250, parágrafo único, do Código de Processo Civil (estes últimos mais relacionado com a análise do procedimento como um todo). Ainda que haja violação formal, o ato se considerará válido desde que atinja sua finalidade, mesmo que o sistema sancione o descumprimento da regra de forma com a pena de nulidade.

Estas regras enunciam o denominado princípio da instrumentalidade das formas, e embora esteja fundamentalmente referido aos atos processuais considerados

\footnotetext{
${ }^{320}$ FREITAS, José Lebre de. Introdução ao processo civil: conceito e princípios gerais. 2. ed. Coimbra: Coimbra Ed., 2007. p. 141. Cf., também, TORNAGHI, Hélio. Comentários ao Código de Processo Civil, cit., v. 2, p. 239; e WAMBIER, Teresa Arruda Alvim. Nulidades do processo e da sentença, cit., p. 143.
} 
individualmente, também é plenamente aplicável à seqüência que determinada causa deve seguir, ou seja, o respectivo procedimento. ${ }^{321}$

Assim, vê-se que a forma exigida pelo legislador constitui mero meio, sendo o mais importante os fins de cada ato e o escopo final do processo.. Afinal, se o vício não impediu nem comprometeu o exercício dos poderes e deveres, ônus e faculdades dos sujeitos processuais, o procedimento é completamente válido, ainda que em ofensa à regra de forma. Em tema de nulidades processuais esta é a regra central a presidir toda a atividade do julgador. ${ }^{322}$

O que me parece importante salientar da leitura que é feita destas regras especialmente no tocante ao procedimento - é que o nosso próprio sistema parece ter dado à ordenação dos atos processuais bem menos valor do que na prática se tem emprestado a ela.

E sendo assim, ainda que haja no sistema uma forma predisposta à tutela do direito, possível se verificar se para o conjunto não é admissível uma outra escolha, mais adequada aos objetivos do próprio processo, já que o importante ao final é que a forma se modele à tutela, e não o contrário. ${ }^{323}$

Eis aqui o fundamento da flexibilização das regras de forma, ainda que previstas genericamente e rigidamente pelo sistema.

De fato, os procedimentos abstratamente previstos pelo legislador são um modelo formal cujo principal escopo é debelar a crise de direito material. Se a variação

\footnotetext{
${ }^{321}$ BRITO, Pedro Madeira de. O novo princípio da adequação formal, cit., p. 35 .

${ }^{322}$ KOMATSU, Roque. Da invalidade no processo civil, cit., p. 133. BEDAQUE, José Roberto dos Santos. Efetividade do processo e técnica processual: tentativa de compatibilização, cit., p. 419. A partir do fundamento da forma como meio, o autor constrói, com a sua particular sensibilidade para a interação do processo com o direito material, toda uma teoria para o trato dos vícios processuais. De acordo com ele, em fases já adiantadas do procedimento, encontrados problemas relacionados à técnica, não há de se obstar o prosseguimento do processo, como seria feito caso o vício tivesse sido detectado inicialmente. Já despendido tempo, energia e dinheiro de todos os sujeitos do processo, a preocupação maior do juiz deve ser com a eliminação do defeito a fim de que o instrumento possa ser reaproveitado, competindo-lhe extrair do processo o maior rendimento possível, aproveitando tudo o que foi feito e desconsiderando nulidades processuais em prol da economia e por força da natureza instrumental do processo. Então, a análise dos vícios processuais de forma e de técnica sempre será feita em um juízo prospectivo (para o futuro), imaginando que em virtude deles o processo não alcançará seu fim. Mas já superadas as fases e os momentos adequados para análise destes vícios, encontrando-os, deve o magistrado fazer não mais um juízo para o futuro, mas sim um juízo retrospectivo (olhando para trás): se eles não foram capazes de macular os escopos do processo e se for possível outorgar tutela jurisdicional definitiva, devem ser estes vícios dados por superados (BEDAQUE, José Roberto dos Santos. Efetividade do processo e técnica processual: tentativa de compatibilização, cit., p. 99-104).

${ }^{323}$ BEDAQUE, José Roberto dos Santos. Efetividade do processo e técnica processual: tentativa de compatibilização, cit., p. 56.
} 
ritual se impõe para solução mais rápida e adequada do litígio, então não há espaço, apesar do vício de forma, para se falar em nulidade, já que o escopo do procedimento foi plenamente atingido.

Obviamente - e conforme já reiteradas vezes apontamos - a variação deve respeitadas as garantias constitucionais e processuais dos litigantes, exatamente para que não se possa, diante do prejuízo comprovado, ter-se por viciada a variação procedimental. ${ }^{324}$ Daí porque na mescla ou na criação de procedimentos novos deve o magistrado sempre atentar para o feixe de garantias contemplado na cláusula do devido processo legal.

\subsection{Conclusão parcial}

Quanto mais um sistema for capaz de ter predispostos em lei procedimentos adequados à tutela de todos os direitos melhor será. Isto gera indiscutível previsibilidade e segurança. Esta foi a razão pela qual sustentamos, no Capítulo precedente, a imperiosa necessidade de utilização das regras de descentralização normativa, constantes da Constituição Federal, no tocante ao procedimento.

Contudo, sendo fato notório que as circunstâncias cotidianas sempre acabam por criar situações novas ainda não imaginadas pelo legislador, este ideário é praticamente inatingível, de modo que é no plano da doutrina que se deve buscar fundamento para a flexibilização, ainda que sem amparo expresso no direito posto.

Este fundamento se encontra na premissa de que as regras procedimentais não têm um valor em si mesmo e devem ser examinadas à luz dos objetivos para as quais concebidas, bem como do interesse efetivo das partes.

Por isto, inexistindo procedimento ideal para a tutela de dada situação, seja no plano prático, seja simplesmente no plano normativo, compete ao juiz, com a participação efetiva das partes em contraditório útil, adequar o procedimento às peculiaridades da causa, criando ou mesclando ritos.

\footnotetext{
${ }^{324}$ Importante destacar que Ada Pellegrini Grinover, na análise do que denomina princípio do prejuízo, aponta que a atipicidade constitucional acarreta a nulidade absoluta do ato processual, com presunção jure et de jure de prejuízo, de modo que nesta situação haveria dispensa da prova do dano pela violação da regra de forma (Invalidade dos atos processuais e ação rescisória, cit., p. 65).
} 
Assim o fará, em caráter excepcional e fundamentadamente, só quando constatar: a) a inexistência de previsão legal adequada; b) a inutilidade da regra formal avaliada no seu aspecto finalístico; ou c) a situação das partes litigantes, a justificar variação ritual, a bem da igualdade material ou do consenso.

Nestas condições, a flexibilização das regras procedimentais não se incompatibiliza com o princípio do devido processo legal. Pelo contrário, vai ao encontro dele, possibilitando que o procedimento seja moldado particularizadamente, sem prejuízo da previsibilidade e da segurança do sistema. ${ }^{325}$

Os mais cautelosos certamente objetarão - como já objetaram nas primeiras comunicações que fizemos a respeito deste tema - que a teoria tem pouca repercussão prática, e que o Judiciário brasileiro não está habilitado para gerenciar o procedimento.

Para a primeira das críticas, responde-se que além das hipóteses legalmente autorizadas de flexibilização das regras procedimentais (itens 5.2. e 5.3), há inúmeras outras situações não legalizadas que revelam a utilidade prática da flexibilização, muitas delas, inclusive, já presentes no foro e amparadas pela jurisprudência, conforme veremos no item 5.4..$^{326}$

Para a segunda das objeções, anoto que não se pode pretender obstar a evolução de um sistema pela alegação genérica de incapacidade de seus operadores, ainda mais quando desprovida de comprovação científica. Fosse mesmo assim, também não teríamos razões para aperfeiçoar o processo no plano normativo, já que os atores jurídicos, de qualquer modo, seriam incapazes de operá-lo adequadamente.

Para bem demonstrar que a flexibilização ritual não é devaneio, pelo contrário, é recomendável no âmbito do processo civil moderno, importante, antes mesmo da aferição

\footnotetext{
${ }^{325}$ Como anota Dinamarco, "o que precisa ficar muito claro, como fator de segurança para as partes e como perene advertência ao juiz, é a substancial exigência de preservação das fundamentais garantias constitucionais do processo, expressas no contraditório, igualdade, inafastabilidade de controle jurisdicional e na cláusula do due processo of law. Cada ato do procedimento há de ser conforme a lei, não em razão de estar descrito na lei nem na medida do rigor das exigência legais, mas na medida da necessidade de se cumprir certas funções do processo e porque existem funções a cumprir" (A instrumentalidade do processo, cit., p. 129-130).

${ }^{326}$ Em pesquisa de campo realizada com juízes estaduais paulistas, Paulo Eduardo Alves da Silva constatou que processos conduzidos por magistrados que controlam o fluxo do processo são solucionados de maneira mais rápida. $\mathrm{O}$ pior resultado encontrado foi exatamente dos processos em que não havia atuação dos juízes na condução do procedimento, isto é, magistrados que não interferem no rito, deixando que ele simplesmente siga o modelo legal (Condução planejada dos processos judiciais: a racionalidade do exercício jurisdicional entre o tempo e a forma do processo, cit., p. 176-180).
} 
da aplicação da teoria na sistemática nacional, uma breve incursão sobre o tema no direito alienígena, onde se constatará a confiança depositada pelos sistemas na eleição dos ritos pelas partes, bem como no gerenciamento do procedimento pelo juiz.

É o que fazemos a seguir. 


\section{FLEXIBILIZAÇÃO DO PROCEDIMENTO EM OUTROS SISTEMAS}

\subsection{Introdução}

Os estudos de direito comparado são fundamentais para o desenvolvimento de qualquer ciência, pois só assim um ordenamento jurídico pode se beneficiar dos avanços conquistados e implementados fora de suas fronteiras, bem como se precaver de fracassos legislativos ocorridos em outros países. ${ }^{327}$

Mesmo assim, a inserção de modelos processuais alienígenas em dado sistema, ainda que exitosas onde implementadas, não vem com garantia de sucesso, visto que as realidades judiciárias e culturais locais acabam por condicionar a eficácia dos modelos simplesmente transplantados de fora ${ }^{328}$, mesma razão que também acaba por não garantir que um modelo ineficaz testado em outro país não possa dar certo no Brasil, operando por aqui os efeitos que por lá se esperavam.

Por isso, já se advertiu na doutrina nacional que a supervalorização de modelos estrangeiros é um dos mitos do futuro da justiça, e que no caso específico de nosso país, o máximo cuidado deve ser posto na recepção de produtos vindos dos Estados Unidos e da Inglaterra, especialmente porque são sistemas muito mais afeiçoados à formação

\footnotetext{
${ }^{327}$ Osvaldo Agripino Castro Júnior aponta que a justificativa de uso do direito comparado decorre dele ser uma ferramenta útil à reforma da legislação e do sistema judicial, bem como à integração de sistemas econômicos, uma vez que somente a análise de uma variedade de culturas e sistemas judiciais, jurídicos e econômicos, demonstra o que é fundamental e conceitualmente necessário para um sistema. Trata-se de "um método que proporciona não somente soluções alternativas para serem usadas em reformas do sistema judicial, mas também um melhor entendimento do sistema doméstico" (CASTRO JUNIOR, Osvaldo Agripino de. A relevância do direito comparado e direito e desenvolvimento para a reforma do sistema judicial brasileiro. Revista de Informação Legislativa, Brasília, ano 41, n. 163, p. 52, jul./set. 2004). Aponta-se, também, que o direito comparado é imprescindível para a criação ou alteração de um determinado instituto (LOSANO, Mario G. Os grandes sistemas jurídicos. Lisboa: Editorial Presença, 1978. p. 27).

${ }^{328}$ Como ocorreu em território nacional, por exemplo, com a inserção em nosso sistema da ação monitória (art. 1.102a do CPC, pela Lei n. 9.079/95). Para que o procedimento monitório tivesse utilidade, era necessário que o número de mandados monitórios embargados fosse mínimo. Ocorre que em pesquisa de campo que levamos adiante perante a Justiça Estadual Paulista no ano de 2002, revelou-se que apenas $18,8 \%$ dos mandados monitórios não são embargados, dado a indicar que mais de $80 \%$ das ações monitórias acabam seguindo a via cognitiva, e não a executiva como se esperava como base na experiência de alguns países europeus. Para análise ampla da citada pesquisa de campo, especialmente para obtenção dos dados obtidos no tocante à ação monitória, cf. o nosso: Breve análise estatística de alguns pontos da primeira fase das reformas processuais civis no âmbito da justiça estadual paulista. Revista da Escola Paulista da Magistratura, São Paulo, v. 5, n. 1, p. 47-63, jan./jun. 2004.
} 
jurisprudencial do direito (common law) do que o nosso, de linhagem européia continental e com o predomínio de fontes normativas escritas (civil law). ${ }^{329}$

A distinção dantes tão expressiva entre os sistemas da common law e da civil law, todavia, acabou, com o passar dos anos, sendo atenuada pela influência recíproca das boas iniciativas adotadas em cada qual dos sistemas. Ora países adeptos do padrão continental implementaram medidas típicas do processo da common law, adotando, entre outras providências, os precedentes judiciais como fonte primária do direito ${ }^{330}$, ora os sistemas anglo-saxônicos se curvaram ao direito escrito ${ }^{331}$, de modo que não mais se conservam, de maneira geral, modelos puros, resistentes à saudável influência recíproca dos outros sistemas. ${ }^{332}$

Daí porque, apesar da cautela supra na importação dos institutos alienígenas para o direito brasileiro, será bom visualizar como alguns ordenamentos estrangeiros

\footnotetext{
${ }^{329}$ MOREIRA, José Carlos Barbosa. O futuro da justiça: alguns mitos. In: Temas de direito processual: $8^{\mathrm{a}}$ série, cit., p. 9-10. Há, todavia, quem sustente o contrário, ou seja, que é da comparação e importação de institutos vindos de sistemas aparentemente antagônicos (como o da civil e da common law) que surgem os melhores resultados para aperfeiçoamento de ambos os sistemas (Castro Júnior, cit., p. 61).

${ }^{330}$ Sem grande esforço, traga-se à colação a recente adoção, no sistema processual civil brasileiro, da súmula vinculante (art. 103-A da Constituição Federal e Lei n. 11.417/2006) e da súmula impeditiva de recursos (art. 518, § $1^{\circ}$, do CPC, com redação pela Lei n. 11.276/2006), típicas medidas dos sistemas que utilizam os precedentes judiciais como fonte primária do direito. Para análise de outras influências do sistema da common law no direito brasileiro, especialmente do direito norte-americano, cf. MOREIRA, José Carlos Barbosa. O processo civil brasileiro entre dois mundos. In: cit., p. 41-52.

${ }^{331}$ Desde 26.04.1999 a Inglaterra, em abandono ao modelo padrão dos precedentes judiciais, tem um código de processo civil (civil procedure rules) a respeito do qual falaremos mais adiante (cf. ANDREWS, Neil $\mathrm{H}$. A new civil procedural code for England: party-control 'going, going, gone'. Civil Justice Quarterly, v. 19, p. 19-38, 2000). Também o império japonês adotou, desde 1998, um código de processo civil escrito (cf. TANIGUCHI, Yasuhei. O código de processo civil japonês de 1996: um processo para o próximo século?, cit., p.50-73).

${ }^{332}$ Bem aponta Barbosa Moreira por isto que estes modelos não costumam se reproduzir na realidade como substâncias quimicamente puras e que a inclusão de dado ordenamento em uma das categorias se inspira no critério da predominância das características, e não da exclusividade (MOREIRA, José Carlos Barbosa. Duelo e processo. In: Temas de direito processual: $8^{\mathrm{a}}$ série, cit., p. 214). Rachel Sztajn e Érica Gorga indicam que, "na prática, existe uma crescente convergência entre as tradições de direito consuetudinário e as de direito romano-germânico, a qual possibilita uma adaptação funcional dos institutos originários de uma tradição em outra. Essa tendência é guiada por uma necessidade de adaptação do aparato normativo perante a complexidade dos fenômenos sociais e busca proporcionar aumento de eficiência, através do 'empréstimo' dos mecanismos promotores de eficiência de outro sistema (com os custos dele decorrentes). Assim, por exemplo, a tradição de direito consuetudinário vem crescentemente passando por um processo de codificação e de criação de leis, ingressando numa age os statutes, enquanto os precedentes judiciais têm ganhado força vinculante nos ordenamentos de tradição de direito romanogermânico, tal como ocorreu com a aprovação da reforma o Judiciário brasileiro em 2004. Este trabalho argumenta que essas tendências podem ser explicadas como processos de adequação que tanto a tradição de direito consuetudinário como a de direito romano-germânico vêm realizando com o objetivo de promover a eficiência de cada sistema jurídico" (GORGA, Érica; SZTAJN, Rachel. Tradições do direito. In: ZYLBERSZTAJN, Décio; SZTAJN, Rachel (Coords.). Direito e economia: análise econômica do direito e das organizações. Rio de Janeiro: Elsevier, 2005. p. 149).
} 
enfrentam a questão da rigidez procedimental - pouco importando se filiados ao sistema de precedentes ou do direito escrito - trazendo adiantadamente à nota que os regimes estudados permitem às partes e ao magistrado, na falta ou na falha do procedimento, a adequação do rito às circunstâncias da causa, ora em maior, ora em menor intensidade.

\subsection{Sistemas inquisitoriais e adversariais}

Denomina-se adversarial system o modelo que se caracteriza pela predominância das partes na determinação da marcha do processo e na produção das provas. No inquisitorial system, ao revés, as mencionadas atividades recaem de preferência sobre o juiz ${ }^{333}$, embora possam também ser inteiramente disciplinadas em lei.

Em regra os sistemas filiados ao tronco anglo-saxão são predominantemente adversariais, enquanto que os inquisitoriais existem preponderantemente nos sistemas filiados à família romano-germânica.

No modelo clássico, simétrico e persuasivo da common law, dito adversarial ${ }^{334}$, o procedimento está caracterizado pelo desenvolvimento de diálogo entre as partes e pela passividade do juiz diante da investigação da verdade e da disciplina do procedimento. Este modelo, dito isonômico, põe as partes em pé de igualdade, cabendo ao juiz papel de expectador dos debates e fiscalizador das regras do jogo (inclusive quanto a relativas ao procedimento), sendo-lhe, na origem, vedado intervir na inexistência de discordância de um dos litigantes quanto ao comportamento da outro ${ }^{335}$, pois que o direito processual nestes sistemas é disponível como regra.

Por outro lado, no modelo moderno ou assimétrico, dito inquisitorial, tão caro aos sistemas do tronco romano-germânico, o procedimento é caracterizado por forte

\footnotetext{
${ }^{333}$ Cf. GRINOVER, Ada Pellegrini. Iniciativa instrutória do juiz no processo penal acusatório. Revista Brasileira de Ciências Criminais, São Paulo, v. 7, n. 27, p. 71-79, jul./set. 1999.

${ }^{334}$ Michele Taruffo traz a nota de que a doutrina americana e inglesa consideram este modelo o mais eficaz sistema inventado para a condução do processo e descoberta da verdade (TARUFFO, Michele. Modelli di prova e di procedimento probatório. Rivista di Diritto Processuale, Padova, ano 45, n. 2, p. 29, apr./giug. 1990).

${ }^{335}$ Barbosa Moreira narra pitoresco caso de magistrado convidado a demitir-se por ter, oficiosamente, interferido no âmbito probatório, inquirindo oficiosamente testemunha, o que, inclusive, ocasionou a anulação do julgado (MOREIRA, José Carlos Barbosa. Notas sobre alguns aspectos do processo (civil e penal) nos países anglo-saxônicos. In: 2001. p. 160. . Temas de direito processual: $7^{\mathrm{a}}$ série. São Paulo: Saraiva,
} 
ativismo judicial, ou seja, por um juiz que participa ativamente do procedimento e da investigação da verdade. É considerado assimétrico justamente por conta desta participação do juiz que verticalizando a relação jurídica processual, acaba por desigualar a relação de isonomia entre as partes. Há neste modelo verdadeira apropriação do processo pelo Estado-juiz, em maior ou menor intensidade a variar de país para país, já que todo o procedimento é minuciosamente regrado pela lei ou pelo juiz, sem possibilidade de convenção ou intervenção das partes a respeito. ${ }^{336}$

Exatamente por força da ampliação dos poderes do juiz na condução do processo, tem se exigido dos sistemas inquisitoriais uma maior rigidez legal no exercício destes poderes, especialmente no tocante à condução do procedimento, sob a falha premissa de que só assim é possível o controle do arbítrio judicial. Premissa falha - repitase - pois como já investigamos no capítulo precedente, a participação das partes em contraditório e a possibilidade de recurso para as instâncias superiores garantem suficientemente o processo contra decisões procedimentais arbitrárias ou ofensivas das garantias constitucionais do processo.

Enquanto isto, nos sistemas adversariais ou isonômicos, esta realidade se altera substancialmente, pois o centro do poder não está na figura do juiz, e a lei não representa a fonte primária do direito. $\mathrm{O}$ procedimento não é tido como garantia contra o arbítrio, mas sim como técnica para coordenar o andamento da causa e os debates em torno do conflito, de modo que acaba se adequando a ele conforme as partes conduzem o procedimento, e não o contrário.

Eis a razão pela qual os sistemas processuais de tradição adversarial, pese a originária passividade do juiz, acabaram por desenvolver mecanismos de variação procedimental. Visualizando o procedimento não como garantia, mas sim como meio de descoberta da verdade, admitiu-se que as partes - ou o próprio juiz com o passar do tempo (case manegement) - pudessem adequar o instrumento ao seu fim, bem como pudessem sancionar eficazmente aquele que se valesse do procedimento para obter vantagem imoral ou ilícita (contempt power). A atipicidade dos procedimentos, pois, traz em contrapartida a responsabilização das partes pelo seu mau uso.

\footnotetext{
${ }^{336}$ ZANETI JÚNIOR, Hermes. O problema da verdade no processo civil: modelos de prova e de procedimento probatório, cit., p. 353-354 e 357-358. Cf. também GARCIA, Maria. Sistemas constitucionais comparados: o sistema inglês (common law) e Constitucional e Ciência Política, São Paulo, ano 3, n. 9, p. 53-72, out./dez. 1994.
} 
Já nos processos filiados ao regime inquisitorial, apesar de mais condizentes com o ativismo judicial e possibilidade do juiz controlar o procedimento, as inúmeras limitações legais aos poderes do juiz acabaram por tolher seu ativismo, conseqüentemente reduzindo-o, em menor ou maior escala a depender do país, ao burocrático papel de condutor do rito abstratamente fixado, sem possibilidade intervir no seu percurso. Paradoxalmente, pese haver reconhecimento dos poderes do juiz na investigação oficiosa dos fatos, ou na prolação de decisões com base em seu livre convencimento (até mesmo sem atender aos precedentes das instâncias superiores), não se lhe permite regular com liberdade o instrumento (o que parece ser um minus em relação ao plus que é a decisão).

É importante novamente destacar que a influência recíproca dos sistemas acabou, com o passar dos anos, fazendo com que os ordenamentos adversariais e inquisitoriais se aproveitassem das experiências um do outro. Já se reconhece certo ativismo ao juiz dos ordenamentos filiados ao sistema adversarial ${ }^{337}$, enquanto que se introduzem nos ordenamentos inquisitoriais, ainda que no plano normativo, maior poder das partes no controle dos procedimentos. Em contrapartida, os poderes do juiz e das partes passam a ser limitados por normas escritas no primeiro sistema, enquanto que ganham força os precedentes judiciais e os poderes sancionatórios do juiz no segundo.

Por isto, embora guardadas as devidas diferenças entre os dois sistemas, a experiência dos sistemas da adversariais da common law pode e deve ser aproveitada nos ordenamentos inquisitoriais da civil law como o nosso, de modo a romper com a idéia de tipicidade dos remédios que, por vezes, conduz a situações de perplexidade, em que se reconhece a existência do direito no plano material, mas não se divisa o meio para que ele seja tutelado (declarado ou atuado). Como bem aponta Flávio Yarshell, "é essa atipicidade

\footnotetext{
${ }^{337}$ No sentido de que mesmo nos modelos da common law cada vez mais se abandona o modelo adversarial em prol de ritos mais simplificados e disciplinados em lei, como os do sistema inquisitorial, cf. TARUFFO, Michele. La ricerca della veritá nel adversary system anglo-americano. Rivista di Diritto Processuale, Padova, ano 32, n. 4, p. 596-634, out./dez. 1977. E anotando que a própria Justiça dos países da common law, tradicionalmente caracterizada pela inércia do juiz, passou na década de 90 a incentivar a intervenção condutora do magistrado a fim de coibir os abusos do adversarial system, bem como para assegurar a regular marcha do processo, cf. GUINCHARD, Serge et al. Droit processuel: droit commun et droit compare du procès. 2. ed. Paris: Dalloz, 2003. p. 694; MARKS, K. H. The interventionist Court and procedure. Monash University Law Review, Melbourne-Austrália, n. 18, p. 1-15, 1992; ROGERS, Andrew. The managerial or interventionist judge. Journal of Judicial Administration, Austrália, n. 3, p. 96-110, 1993; DOYLE, John. The judicial role in a new millennium. Journal of Judicial Administration, Austrália, LawBook, v. 10, n. 3, p. 133-148, 2001.
} 
do sistema da common-law que pode e deve servir de inspiração para impedir que exista posição jurídica de vantagem sem um remédio apto a torná-la efetiva". 338

Enfim, não me parece equivocado afirmar que há uma tendência universal de aproximação entre os sistemas adversariais e inquisitoriais, a ponto de podermos prever que em um futuro não muito distante as diferenças substanciais entre estes dois sistemas só restarão como reminiscência histórica. ${ }^{339}$ Basta ver, neste sentido, o que já acontece na União Européia, que faz integrar juridicamente e sem alarde, até como decorrência lógica dos propósitos do bloco, países afetos aos dois regimes.

Certamente em substituição a estes dois sistemas surgirá um terceiro, fruto da convergência dos regimes anteriores. Um sistema muito mais aberto e apto às adequações casuísticas, em cujo modelo o julgador não será visto como simples condutor de um procedimento rigidamente estabelecido pela lei ou pelas partes, mas sim como gerenciador do processo.

Esta nossa conclusão sobre a eclosão de um novo sistema gerencial no estudo do processo civil se revelará pela análise de alguns ordenamentos jurídicos (Inglaterra, Estados Unidos e Portugal), que independentemente de se filiarem ao sistema adversarial ou inquisitorial, acabam permitindo que o procedimento seja flexibilizado em favor da adequada tutela dos direitos, pouco se importando se isto representa ou não quebrantamento do modelo processual historicamente desenhado.

\subsection{Processo inglês}

Como já vimos, nos ordenamentos filiados ao sistema adversarial, entre eles o Inglês, o papel das partes na condução do processo é maximizado em detrimento do órgão judicial, sobretudo no que concerne ao acervo probatório e condução do procedimento, exatamente o oposto do que ocorre nos ordenamentos do padrão inquisitorial.

\footnotetext{
${ }^{338}$ YARSHELL, Flávio Luiz. Tutela jurisdicional, cit., p.179-180.

${ }^{339}$ Esta nossa impressão nos parecer ser compartilhada por J. A. Jolowicz, Adversarial and inquisitorial models of civil procedure. Internacional and Comparative Law, Oxford, v. 52, n. 2, p. 281-295, 2003. Oxford Journals. Disponível em: <http://iclq.oxfordjournals.org/content/vol52/issue2/index.dtl>. Acesso em: 24 jan. 2007.
} 
Esta liberdade, todavia, acabou por fazer com que o sistema inglês fosse impregnado por uma lentidão patológica, atribuída em boa parte à exagerada subordinação do processo à vontade dos litigantes. Para tentar solucionar este grave problema, desde 26 de abril de 1999 a Inglaterra tem um código de processo civil (Civil Procedure Rules). ${ }^{340}$

Logo na regra n. 1.4.2 da civil procedure rules (CPR), já são apresentados doze itens para implementação do active case manegement no processo civil inglês, conferindose ao magistrado britânico, pois, papel ativo na condução do processo. ${ }^{341}$

Desde já se adiante que em linhas gerais o case management inglês é semelhante ao norte-americano. Ambos operam pela outorga de poderes de direção ao juiz para o alcance de um processo justo, rápido e econômico, bem como incentivam o uso dos meios alternativos de solução das controvérsias. A partir da reforma operada no sistema processual civil inglês, a diferença entre ambos os modelos é a fonte normativa: o case management norte-americano, conforme veremos adiante, está fundado em disposições não legais editadas por um centro de acompanhamento do funcionamento das cortes federais (o Federal Judicial Center), enquanto que o case management inglês tem incidência por força de disposição legal cogente (as Civil Procedure Rules).

\footnotetext{
${ }^{340} \mathrm{O}$ surgimento da CPR vem sendo apregoado como a maior transformação legislativa no âmbito processual civil inglês desde 1870, para alguns colocando até mesmo em xeque a filiação deste sistema ao modelo adversarial (J. A. Jolowicz, Adversarial and inquisitorial models of civil procedure, cit, p. 281-282). Conforme nota Barbosa Moreira, o passo decisivo para a eclosão deste diploma foi dado em 1994, "quando o então Lord Chacellor incumbiu eminente magistrado, Lord Woolf, de empreender pesquisa relativa à situação da Justiça civil inglesa e de oferecer sugestões para melhorar seu desempenho, ao qual se irrogavam defeitos do gênero lamentando mundo afora, em tantos outros sistemas judiciais. $\mathrm{O}$ trabalho levado a cabo por Lord Woolf achou expressão em dois relatórios sobre o acesso à Justiça, o Interim Report de 1995 e o Final Report do ano subseqüente, cujas conclusões suscitaram, como era de se esperar, reações contrastantes, variáveis entre um apoio entusiástico e uma veemente rejeição" (MOREIRA, José Carlos Barbosa. Uma novidade: o Código de Processo Civil inglês. Revista Gênesis de Direito Processual Civil, São Paulo, ano 4, n. 13, p. 554, jul./set. 1999).

${ }^{341}$ Rule1.4.2. Active case management includes: a) encouraging the parties to co-operate with each other in the conduct of the proceedings; b) identifying the issues at an early stage; deciding promptly which issues need full investigation and trial and accordingly disposing summarily of the others; c) deciding the order in which issues are to be resolved; d) encouraging the parties to use an alternative dispute resolution procedure if the court considers that appropriate and facilitating the use of such procedure; e) encouraging the parties to use an alternative dispute resolution procedure if the court considers that appropriate and facilitating the use of such procedure; f) helping the parties to settle the whole or part of the case; fixing timetables or otherwise controlling the progress of the case; g) considering whether the likely benefits of taking a particular step justify the cost of taking it; $h$ ) considering whether the likely benefits of taking a particular step justify the cost of taking it; i) dealing with as many aspects of the case as it can on the same occasion; j) dealing with the case without the parties needing to attend at court; k) making use of technology; 1) and giving directions to ensure that the trial of a case proceeds quickly and efficiently.
} 
Apesar da aproximação, o citado diploma inglês ainda resta distanciado dos padrões dos códigos do sistema romano-germânico. Enquanto os diplomas civilistas costumam se dividir em livros, estes divididos em títulos, capítulos e seções, as CPR são formatadas na atualidade em 76 partes, tratadas como se fossem independentes. O máximo de correspondência que há entre as citadas partes são remissões feitas logo abaixo de seu texto a outras partes do diploma.

Para entoar o escopo geral das CPR de permitir às cortes tratar os casos individualmente e de forma justa (R.1.1.1) ${ }^{342}$, são estabelecidas diretrizes gerenciais para todos os julgadores: a) identificar as questões envolvidas nos casos, b) resolver as questões simples rapidamente, e estabelecer parâmetros para a resolução das demais questões; c) estabelecer cronogramas das providências que serão adotadas no procedimento, inclusive determinando a ordem em que os atos serão praticados e os seus prazos; e d) controlar o volume de provas, limitando-as ao necessário ${ }^{343}$.

A disposição inicial do diploma enuncia, ainda, que as CPR objetivam a simplificação e drástica redução do número de formas de instaurar o processo. Daí porque a regra 26.1.2 estabelece apenas três procedimentos (tracks, procedures, ou courses of action) para a solução das demandas, disciplinados preponderantemente com base no valor da causa: a) o das pequenas causas (small claims track); b) das causas de porte médio (fast track); c) e das causas maiores (multi track). Na regra 26.6 se encontram as disposições regulamentares da adoção de cada um destes procedimentos.

A eleição destes procedimentos, todavia, não ficou exclusivamente na esfera legislativa, ou estritamente atrelada ao valor da causa. ${ }^{344}$ Salvo nas situações expressamente vedadas pelas CPR, as partes e o juiz podem optar por quaisquer destes procedimentos, respeitados alguns mínimos limites legais que indicam os dados tidos como relevantes para a opção procedimental (matters relevant to allocation to a track), nos

\footnotetext{
${ }^{342}$ Rule 1.1: These Rules are a new procedural code with the overriding objective of enabling the court to deal with cases justly.

${ }^{343}$ GERLIS, Stephen; LOUGHLIN, Paula. Civil procedure. 2. ed. London: Cavendish, 2004. p. 101.

${ }^{344}$ Mesmo que involuntariamente, parece que o sistema inglês adotou por inteiro a lição de Moniz Aragão, no sentido de que "há importantes fatores a ponderar no momento de eleger o procedimento a seguir. Devem ser levados em conta não apenas a relação substancial objeto do litígio, mas, também, elemento e dados capazes de imprimir maior velocidade à marcha do procedimento, ao mesmo que lhe atribuam mais aptidão para adequada investigação dos fatos, de modo a ser alcançado um julgamento não só célere como justo (incluída sua repercussão extra partes). Em suma, é necessário permitir que o juiz e as partes influir na escolha do procedimento que se mostre mais adequado, a bem de conferir o máximo possível de eficiência ao processo (ARAGÃO, E. D. Moniz de. Procedimento: formalismo e burocracia, cit. p. 58).
} 
termos da regra de n. 26.8. ${ }^{345}$ Entre eles, destacam-se a complexidade dos fatos, do direito ou das evidências, o número de litigantes ou sua qualidade especial, os reflexos da decisão para pessoas que não serão partes, a quantidade de prova oral a ser produzida; etc.

Além disso, na constatação destes dados tidos por relevantes no curso do processo, nada impede que o procedimento seja modificado (re-allocation track), com a adoção de iter padrão diverso do inicial (R. 26.10) ${ }^{346}$ independentemente, repita-se, do valor da causa.

Mas há mais. Ao lado da liberdade na escolha do procedimento em abstrato, dentro de cada um dos ritos previamente estabelecidos permite-se a variação ritual em favor da adequada tutela dos direitos.

De acordo com a rule $27.8 .1^{347}$, no small claims track o juízo é livre para estabelecer o procedimento que lhe pareça mais justo (to be fair) para a audiência preliminar (prelimnary hearing), cuja realização, aliás, pode ser até dispensada em algumas circunstâncias (R. 27.6).

Ao enunciar os poderes do órgão judicial no case manegement, a CPR permite ao julgador, salvo disposição expressa em sentido contrário, prorrogar ou abreviar prazos legais, futuros ou já superados, por exemplo, aceitando, mediante justificação adequada e a luz de ponderação sobre os prejuízos hipotéticos com a não submissão da decisão ao $2^{\circ}$ grau, a apresentação de recurso fora de prazo (R. 3.1.2). ${ }^{348}$

\footnotetext{
${ }^{345}$ Rule 26.8: When deciding the track for a claim, the matters to which the court shall have regard include: a) the financial value, if any of the claim; b) the nature of the remedy sought; c) the likely complexity of the facts, law or evidence; d) the number of parties or likely parties; e) the value of any or other Part 20 claim and the complexity fo any matter relating to it; f) the amount of oral evidence wich may be required; g) the importance of the claim to persons who are not parties to the proceedings; h) the views expressed by the parties and; i) the circumstances of the parties.

${ }^{346}$ Rule 26.10:. The court may subsequently re-allocate a claim to a different track.

${ }^{347}$ Rule 27.8.1: The court may adopt any method of proceeding at a hearing that it considers to be fair.

${ }^{348}$ Rule 3.1: The list of powers in this rule is in addition to any powers given to the court by any other rule or practice direction or by any other enactment or any powers it may otherwise have. 3.1.2. Except where these Rules provide otherwise, the court may: a) extend or shorten the time for compliance with any rule, practice direction or court order (even if an application for extension is made after the time for compliance has expired); b) extend or shorten the time for compliance with any rule, practice direction or court order (even if an application for extension is made after the time for compliance has expired); c) require a party or a party's legal representative to attend the court; d) hold a hearing and receive evidence by telephone or by using any other method of direct oral communication; e) direct that part of any proceedings (such as a counterclaim) be dealt with as separate proceedings; f) stay the whole or part of any proceedings or judgment either generally or until a specified date or event; g) consolidate proceedings; h) try two or more claims on the same occasion; i) direct a separate trial for any issue; $j$ ) decide the order in which issues are to be tried; $\mathrm{k}$ ) exclude an issue from consideration; 1) dismiss or give judgment on a claim after a decision on a preliminary issue; 11) order any party to file and serve an estimate of costs; m) take any other step or make any other order for the purpose of managing the case and furthering the overriding objective.
} 
Feição análoga tem a norma a cuja luz o órgão judicial pode autorizar que a reconvenção, em vez de ser oferecida com a defesa, venha a sê-lo em qualquer outro tempo (R. 20.4.2, "b") $)^{349}$

É lícito ainda ao julgador, em disposição totalmente inspirada na ordem n. 14 da Suprema Corte Americana ${ }^{350}$, abreviar por completo qualquer procedimento, rejeitando ou acolhendo o pedido do autor, sempre que não haja perspectiva de sucesso da pretensão formulada com base nos precedentes anteriores, ou quando sendo provável o êxito da demanda, o requerido não tenha reais chances de sucesso na defesa que ofertará (Rule 24.2.). ${ }^{351}$

A Rule 3.1.2. prevê, ainda, em regra de encerramento, que o órgão judicial pode tomar qualquer outra medida ou emitir qualquer outra ordem com o propósito de gerenciar o processo e fazê-lo atingir seus propósitos (“m”), de modo que, em total oposição à passividade dos juízes dos ordenamentos adversariais, inimaginável é o alcance das atividades do juiz no sistema inglês. ${ }^{352}$

Quanto à vontade das partes, excepcionada disposição legal expressa em sentido contrário, elas podem acordar livremente sobre quaisquer prazos legais ou judiciais para a prática dos atos processuais (R. 2.11) ${ }^{353}$.

Vê-se, assim, que diversamente do nosso sistema, na Inglaterra a disciplina legal do processo reconheceu ao juiz e às partes poder suficiente para influenciar no

\footnotetext{
${ }^{349}$ Rule 20.4.2: A defendant may make a counterclaim against a claimant: a) without the court's permission if he files it with defence; or b) at any other time with the courts permission.

${ }^{350}$ POLLOCK, Frederick. The genius of the common law. New York: Columbia University Press, 1912. p. 83.

${ }^{351}$ Rule 24.2: The court may give summary judgment against a claimant or defendant on the whole of a claim or on a particular issue if a) it considers that: i) that claimant has no real prospect of succeeding on the claim or issue; or ii) that defendant has no real prospect of successfully defending the claim or issue; and; b) there is no other compelling reason why the case or issue should be disposed of at a trial.

${ }^{352}$ Eis aqui uma característica peculiar da justiça civil inglesa. Inexistindo provimento adequado para a tutela dos direitos, há uma ampla variedade de medidas que o juiz pode emanar independentemente de previsão legal, algo que se aproxima de um padrão de discricionariedade judicial ainda negado por grande parte dos estudiosos do processo. Embora, de fato, seja temerário deixar ao juiz a liberdade de escolher se concede ou não determinado provimento, e em caso positivo, em quais condições, o sistema inglês confia na judicial discretion de seus magistrados, consistente na adequação da medida ao sistema e ao senso médio de justiça (equidade). A discricionariedade judicial é tão valorizada no citado sistema, que as cortes de apelação, ao apreciarem recursos das decisões dos juízes emitidas com base em tal poder, só em situações absolutamente excepcionais substituem os provimentos concedidos. Cf. JACOB, Jack I. H. La giustizia civile in Inghilterra. Tradução italiana de Elisabetta Silvestrino.Bologna: Mulino, 1995. p. 171-172.

${ }^{353}$ Rule 2.11: Unless these Rules or a practice direction provide otherwise or the court orders otherwise, the time specified by a rule or by the court for a person to do any act may be varied by the written agreement of the parties
} 
procedimento. Adotou-se a flexibilização tanto na eleição dos ritos quanto na sua composição.

Nada impede, por isto, que haja eleição procedimental, ou que os três procedimentos padrões sejam mesclados ou alterados em alguma de suas etapas, tudo com vista a melhor adequar o instrumento à tutela do direito. ${ }^{354}$

Evidentemente, também por lá há preocupações com os excessos que possam ser cometidos pelos julgadores na disciplina do procedimento, o que, sem dúvida, compromete o exercício das garantias processuais dos litigantes. Ainda mais quando todos estes poderes são exercitáveis de ofício (R 3.3.1) $)^{355}$ e independentemente da oitiva prévia das partes (R. 3.3.4) ${ }^{356}$.

A diferença é que na Inglaterra, sem alarde ou resistência, sabe-se que as arbitrariedades, inclusive sobre o procedimento, são controláveis pelo $2^{\circ}$ grau, que reformam decisões judiciais sob o fundamento de que a condução desproporcional do caso ofende o princípio central do art. 1.1. da CPR: o direito a um processo justo. ${ }^{357}$ Há, todavia, informes de que os advogados ingleses, apesar de criticar o excesso de poder dos juízes na condução do procedimento no novo regime, pouco recorrem das decisões proferidas como base no mau uso dele $\mathrm{s}^{358}$, talvez até porque a forma é absolutamente desimportante no direito inglês, cujo regime de sanatória dos vícios é amplíssimo (R. 3.10 $0^{359}, 40.12 .1^{360} \mathrm{e}$ $\left.40.12 \cdot 2^{361}\right)$.

\footnotetext{
${ }^{354}$ É a síntese de Barbosa Moreira: "dentro de certos limites e levando em consideração os elementos indicados no texto, o órgão judicial goza de alguma latitude no determinar o procedimento aplicável a cada causa (veja-se, por exemplo, a rule 26.7(2), atinente a causas sem valor financeiro) e pode até substituir por outro procedimento adotado de início (rule 26.10)" (MOREIRA, José Carlos Barbosa. Uma novidade: o Código de Processo Civil inglês, cit., p. 555).

${ }^{355}$ Rule 3.3.1:Except where a rule or some other enactment provides otherwise, the court may exercise its powers on an application or of its own initiative.

${ }^{356}$ Rule.3.3.5: The court may make an order of its own initiative, without hearing the parties or giving them an opportunity to make representations.

${ }^{357}$ A jurisprudência inglesa narra caso em que o juiz, ao estabelecer prazo para apresentação de testemunhas, o fez sob pena de julgar a demanda em favor da parte contrária em caso de inércia. A corte superior, em sede recursal, anulou a sanção por entendê-la desproporcional à providência reclamada (GERLIS, Stephen; LOUGHLIN, Paula. Civil procedure, cit., p. 101).

${ }^{358}$ SILVA, Paulo Eduardo Alves. Condução planejada dos processos judiciais: a racionalidade do exercício jurisdicional entre o tempo e a forma do processo, cit., p. 76.

${ }^{359}$ Rule 3.10: Where ther has been an error of procedure, such as a failure to comply with a a rule or practice direction: a) the error does not invalidate any step taken in the proceedings unless the court so orders; and b) the court may make na orde to remedy the error.

${ }^{360}$ Rule 40.12.1: The court may at any time correct an accidental slip or omission in a judgment or order.

${ }^{361}$ Rule 40.12.2: A party may apply for a correction without notice.
} 
A reforma processual civil inglesa, de acordo com fontes do governo britânico, foi considerada exitosa logo após três anos de adoção da CPR. Acompanhamento estatístico da reforma mostrou que o tempo médio de julgamento de um caso nas cortes locais caiu de 639 (seiscentos e trinta e nove) dias em setembro de 1997 (antes das CPR) para 498 (quatrocentos e noventa e oito) dias em 2000-2001. Revelou, ainda, que o tempo entre a reclamação e a audiência inicial nos juizados de pequenas causas, apesar de aumentar logo após a introdução das CPR, começou a cair a partir de 2002. E que a substituição do regime não escrito pela CPR no tocante ao processo, foi seguida, ainda, logo após o primeiro ano de vigência da reforma, de um aumento significativo de casos submetidos aos meios alternativos de solução das controvérsias (ADR) ${ }^{362}$, o que está contribuindo para a formação de uma cultura jurídica menos adversarial na Inglaterra e para a diminuição do número de demandas ajuizadas. ${ }^{363}$

Por outro lado, parece não haver dúvida que o custo da justiça civil inglesa aumentou após as CPR, o que está a merecendo estudos do governo inglês no sentido de minorá-los sem prejuízo da melhora do sistema. ${ }^{364}$

\subsection{Processo norte-americano}

Ao investigar o sistema norte-americano, a primeira nota que necessariamente deve ser feita é a que os Estados têm a mais absoluta autonomia no tocante à disciplina do direito processual civil de seus Tribunais, o que, conforme já anotamos anteriormente, é fruto da formação por agregação do Estado Federado naquele país. Podem, assim, as Cortes estaduais disciplinar regionalmente o seu processo (conforme suas particularidades

\footnotetext{
${ }^{362}$ Vale o destaque de que a CPR carreiam à parte vencedora as custas do processo caso reste comprovado que não se tentou a composição alternativa quando era ela viável, o que sem sombra de dúvida incentiva a prática das ADRs.

${ }^{363}$ Para análise estatística da evolução do sistema judicial inglês por força da reforma implementada em 1999 , vale a pena conferir três relatórios do governo britânico, ambos facilmente obtidos no site do Department of Constitucional Affairs (www.dca.gov.uk). Os dois primeiros deles denominados Emergin findigs e Further Findings: a continuing evaluation of the Civil Justice Reforms (2002), cuidam especificadamente da questão do tempo e do custo dos processos judiciais civis após a CPR. O outro é o anual repporting 2005/2006, que monitora o uso dos ADR na Inglaterra, especialmente pelo próprio governo.

${ }^{364}$ Neste sentido, remeto o leitor ao estudo levado a cabo por dois professores da Nottinghan Law School, que investigaram em 2003-2004, mediante entrevistas com juízes, servidores da justiça e advogados, o êxito das reformas operadas: PEYSNER, John; SENEVIRATNE, Mary. The management of civil cases: the courts and the post Woolf landscape. Londres: DCA, 2005. (Research Series n. 9). DCA: Department for Constitutional Affairs: Justice, rights and democracy. Disponível em: <http://www.dca.gov.uk/research/2005/9_2005_full.pdf>. Acesso em: 23 jan. 2007.
} 
locais), ou simplesmente seguir o modelo traçado para a Justiça Federal, de modo que para uma análise global do sistema seria necessária a investigação do regime adotado em cada um dos Estados, o que extravasa por completo os limites deste estudo.

Por aqui, analisaremos apenas e no que nos interessa de perto o procedimento nas Cortes federais norte-americanas (Federal District Courts), que adotam como fonte normatizante as Federal Rules of Civil Procedure (FRCP), editada pela Suprema Corte dos EUA por força do título 2.072 do United States Code. ${ }^{365}$

Com base na observação do que se passava nas ciências médicas - onde os tratamentos variavam de acordo com a doença e as condições pessoais dos pacientes -as cortes federais americanas desenvolveram, em meados de 1970, um programa para condução dos processos judiciais individualizadamente, projeto por lá denominado judicial case management. ${ }^{366}$

Tal projeto ganhou importância logo nos anos seguintes, já que o governo federal apercebeu-se que a ineficiência do seu sistema judicial influenciava negativamente na competitividade dos negócios norte-americanos no mercado internacional, razão pela qual foram implementadas inúmeras modificações no Judiciário norte-americano (Civil Justice Reform Act de 1990) a fim de aumentar sua produtividade e reduzir o tempo de duração das demandas ${ }^{367}$.

Basicamente, o case management das cortes federais norte-americanas - todo elaborado à luz das FRCP - trabalha em duas frentes:

a) busca da solução do conflito por via dos meios alternativos de resolução das controvérsias (ADR);

\footnotetext{
${ }^{365} \mathrm{Na}$ verdade, no tocante à prova, o sistema federal americano segue um diploma paralelo, as Federal Rules of Evidences.

${ }^{366}$ DUNWORTH, Terence; KAKALI. James S. Preliminary observations on implementation of the pilot program of the civil Justice Reform Act of 1990. Stanford Law Review, v. 46, n. 6, p. 1303-1337, jul. 1994. JSTOR. Disponível em: <http://links.jstor.org/sici?sici=00389765(199407)46\%3A6\%3C1303\%3APOOIOT\%3E2.0.CO\%3B2-I,com>. Acesso em: 23 jan. 2007.

${ }^{367}$ Cf. SIPES, Larry L. Reducing delay in State Courts - a march against folly. Rutgers Law Review, New York, n. 37, p. 299-317, 1985.
} 
b) flexibilização judicial do procedimento, permitindo ao juiz que, junto às partes, previamente estipule as etapas do desenvolvimento do feito, gerenciando-o. ${ }^{368}$

Apesar de haver, como regra, uma única forma de processo de acordo com a $\mathrm{FRCP}^{369}$, não há um modelo único de case management, mas sim vários modelos estabelecidos conforme a natureza da demanda e as condições materiais e individuais das cortes federais em $\mathrm{si}^{370}$.

Todos este modelos, entretanto, têm características comuns que podem ser genericamente apontadas: a) envolvimento do magistrado com o caso logo no início do feito; b) participação mais ativa do julgador na investigação da verdade; c) elaboração de planos e cronograma dos atos procedimentais específicos para cada caso; d) treinamento adicional dos juízes em técnicas de gerenciamento de casos; e) planejamento de prazos e procedimentos diferenciados para demandas simples, individuais e casos complexos, com pluralidade de partes e diversidade de questões ${ }^{371}$.

\footnotetext{
${ }^{368}$ CLARK, Mary; MCKENA, Judith A.; HOOPER, Laural L. Case management procedures in the Federal Courts of Appeals. Washington: FJC, 2000. p. xi. Citada obra - que foi discutida exaustivamente no ano de 2004, em reunião do núcleo de estudos e debates do Centro Brasileiro de Estudos e Pesquisas Judiciais (CEBPEJ), com a presença dos Professores Kazuo Watanabe e Carlos Alberto de Salles - representa a consolidação das citadas experiências das diversas cortes federais de apelação. Disponível em: $<$ http://www.fjc.gov/public/pdf.nsf/lookup/caseman1.pdf/\$file/caseman1.pdf>. Acesso em: 23 jan. 2007.

${ }^{369}$ Rule 2: there shall one form of action to be known as "civil action".

${ }^{370}$ Cf. HIRSCH, Allan; SCHWARZER, Willian W. The elements of case management: a pocket guide for judges. 2. ed. Washington: FJC, 2006. p. 1. Federal Judicial Center. Disponível em: <http://www.fjc.gov/library/fjc_catalog.nsf>. Acesso em: 23 jan. 2007.

${ }^{371}$ TAYLOR, Stephen E. Case management: a fundamental concept for the 90's and beyond. Federal Washington, Litigation Guide, 1993. p. 426. Parte destes princípios orientadores é revelada pela disciplina da pretrial conference (scheduling conference ou status conference) no regime americano, que entre outras finalidades objetiva, nos termos da Rule 16 (que também empresta nome a esta audiência), expedir disposições sobre o trâmite do processo; estabelecer o mais breve possível o contínuo controle sobre a causa, que não se atrasará por falta de gerenciamento; desencorajar atividades probatórias inúteis e dispor sobre o objeto da prova; facilitar o estabelecimento dos limites da controvérsia; estabelecer as datas das demais conferências; etc. Esta audiência - certamente também serviu de inspiração para a disciplina da nossa audiência do art. 331 do CPC - é experiência relativamente recente no direito norte-americano (surgiu em 1929), e serviu significativamente para garantir uma melhor apresentação dos casos, um menor número de surpresas no julgamento, decisões mais equânimes e acordos mais justos. A sua estrutura é a seguinte: 1. abertura pelo requerente; 2 . abertura pelo requerido; 3. apresentação pelo requerente de suas provas diretas; 4. apresentação, pelo requerido de suas provas diretas; 5. apresentação de contradita pelo autor; 6. apresentação do contradita pelo requerido; 7. abertura do argumento final pelo requerente; 8. argumento final pelo requerido; 9. fechamento do argumento final pelo requerente; 10. instruções para eventual júri (FRIEDENTHAL, Jack H.; KANE, Marty Kay; MILLER, Arthur C. Civil procedure. 3. ed. St. Paul: West Group, 1999. p. 442-445).
} 
Some-se a estas diretrizes a absoluta e já citada preferência pela solução não adjudicada do conflito, e então se tem o modelo padrão de case management norteamericano.

A experiências e as estatísticas do gerenciamento implementado nas diversas cortes federais são centralizadas em um órgão do governo norte-americano, o Federal Judicial Center, que desde 1967 sistematiza e fiscaliza as práticas judiciais, ministrando treinamento aos juízes e fomentando o intercâmbio de informações entre as várias cortes federais $^{372}$.

O bom funcionamento do case management pressupõe a existência de uma considerável estrutura material para as cortes. Além dos juízes, há inúmeros auxiliares especializados (advogados, mediadores, conciliadores, etc.) que auxiliam efetivamente os magistrados em tarefas propriamente jurisdicionais (triagem dos casos, busca pela autocomposição, elaboração de minutas de decisões, etc. $)^{373}$.

Para os fins deste estudo, o que sobreleva notar é que o case management norteamericano parte do princípio que é dado ao magistrado e não mais exclusivamente às partes ou à lei, estabelecer qual a melhor rota a ser seguida para a solução da demanda. Seja utilizando-se dos procedimentos gerenciais reconhecidos pelo Federal Judicial Center, seja estabelecendo por si mesmo qual o melhor encaminhamento da causa (elaborando-se um plano próprio de condução do caso logo no início do processado), o fato é que não há vinculação do julgador aos rígidos modelos estabelecidos pelas leis processuais. $^{374}$

\footnotetext{
${ }^{372}$ Fartíssima é a literatura sobre as experiências das cortes federais americanas, especialmente sobre os métodos e técnicas de implementação do case management, boa parte publicada pelo próprio Federal Judicial Center. Destaco os seguintes livros, todos obteníveis para download no site FEDERAL JUDICIAL CENTER. Disponível em: <http://www.fjc.gov/library/fjc_catalog.nsf>: HIRSCH, Allan; SCHWARZER, Willian W. The elements of case management: a pocket guide for judges, cit; KRAFKA, Carlo; LOMBARD, Patrícia. 2003-2004 District Court Case-Weighiting study: final report to the subcommittee on judicial statistics of the committee on judicial resources of the judicial conference of the United States. Washington: FJC, 2005; SUPERVISOR'S Roles in Case Management (Available from the Education Division); CLARKE, Bruce M.; REAGAN, Robert Tiothy. Redistricting litigation: an overview of legal, statistical and case management issues. Washington: FJC, 2002; NIEMIC, Robert J. et al. Guide to judicial management of cases in ADR. Washington: FJC, 2001.

${ }^{373}$ Cf. CLARK, Mary; MCKENA, Judith A.; HOOPER, Laural L. Case management procedures in the Federal Courts of Appeals, cit., p. 1-7.

${ }^{374}$ Inclusive, vale o destaque que desde 01.01.2007, uma emenda as FRCP autorizou a prática de atos processuais de modo virtual, inclusive a realização conferências.
} 
A forma do procedimento é tão desimportante para o modelo de processo norte americano (R. 61). ${ }^{375}$ - o que demonstra não ser ela representação alguma de justiça da decisão - que eventuais vícios são incapazes de comprometer, como regra, o resultado dos julgamentos, sendo raríssimas as hipóteses de anulação das decisões prolatadas por vício de forma. ${ }^{376}$

\subsection{Processo português}

\subsubsection{Reforma processual civil portuguesa}

Uma das incontestáveis realidades do mundo moderno é a globalização da economia, com a formação cada vez mais corriqueira de blocos econômicos formados por diversos países que, imbuídos de objetivos comuns (no mais das vezes crescimento econômico e social), acabam se unindo e formando grupos mais ou menos coesos, mais competitivos no mercado internacional. Mercosul, Nafta e União Européia são alguns dos exemplos desta verdade.

A plena integração econômica, todavia, só é possível se acompanhada da conseqüente adequação da legislação interna dos países membros, inclusive processual, com as diretrizes traçadas pelo conjunto. De nada adiantaria se admitir o livre trânsito de papéis entre os países do bloco se a diversidade entre as suas legislações internas impedisse, aqui ou acolá, a exigibilidade do crédito neles representado; se o processo civil de determinado país associado tutelasse adequadamente o direito e em tempo razoável,

\footnotetext{
${ }^{375}$ Rule 61: No error in either the admission or the exclusion of evidence and no error or defect in any ruling or order or in anything done or omitted by the court or by any of the parties is ground for granting a new trial or for setting aside a verdict or for vacating, modifying, or otherwise disturbing a judgment or order, unless refusal to take such action appears to the court inconsistent with substantial justice. The court at every stage of the proceeding must disregard any error or defect in the proceeding which does not affect the substantial rights of the parties.

${ }^{376}$ Para ampla análise dos precedentes que informam tal afirmação, cf. FIELD, Richard H.; KAPLAN, Benjamin; CLERMONT, Kevin. Materials for a basic course in civil procedure. New York: The Foundation Press, 1990. p. 727-774.
} 
enquanto que logo no país ao lado o sistema fosse falho e incapaz de dar pronta solução aos conflitos entre os negociantes do bloco econômico. ${ }^{377}$

Indispensável, pois, que a pretendida integração econômica viesse acompanhada de efetiva integração jurídica, com cada país membro do grupo, se não renunciando a parcela de sua autonomia legislativa, seguindo as diretrizes gerais traçadas consensualmente para todo o bloco.

Exatamente com este propósito integrador prevê expressamente o artigo 65 do Tratado de instituição da União Européia - autêntica norma padrão de justiça civil comunitária e da qual emana a competência legislativa processual dos órgãos legislativos do bloco econômico ${ }^{378}$ - que "as medidas no domínio da cooperação judiciária em matéria civil que tenham uma incidência transfronteiriça a adotar, nos termos do artigo 67, e na medida do necessário ao bom funcionamento do mercado interno, terão por objetivo, nomeadamente: a) melhorar e simplificar: o sistema de citação e de notificação transfronteiriça dos atos judiciais e extrajudiciais; a cooperação em matéria de obtenção dos meios de prova; e o reconhecimento e a execução das decisões em matéria civil e comercial, incluindo as decisões extrajudiciais; b) promover a compatibilidade das normas aplicáveis nos Estados-Membros em matéria de conflitos de leis e de jurisdição; c) eliminar os obstáculos à boa tramitação das ações cíveis, promovendo, se necessário, a compatibilidade das normas de processo civil aplicáveis nos Estados-Membros" (destaque nosso). ${ }^{379}$

${ }^{377}$ Cf. PEREZ RAGONE, Álvaro J. Actividad probatória transfronteriza dentro da la Unión Europea: perspectivas en la cooperación judicial comunitária. Revista de Processo, São Paulo, ano 31, n. 139, p. 7880, set. 2006.

${ }^{378}$ Cf. ADAM, R. La cooperazione in materia di giustizia e affari interni tra comunitarizzazione e método intergovernativo. Il Diritto dell'Unione Europea, UE, fasc. 2-3, p. 481-509, 1998; BASEDOW, Jürgen. The communitarization of the conflict of laws under the treaty of Amsterdam. Common Market law Review, Holanda, n. 37, p. 687-708, 2000; FAZZALARI, Elio. Per un processo comune europeo. Rivista Trimestrale di Diritto e Procedura Civile, Milano, p. 665-692, 1994; BIAVATI, Paolo. Processo comunitario e formazione di un processo comune europeo. Rivista Trimestrale di Diritto e Procedura Civile, Milano, ano 49, n. 3, p. 769-788, lugl./sett. 1994; TARZIA, Giuseppe. L'ordine europeo del processo civile. Rivista di Diritto Processuale, Padova, ano 56, n. 4, p. 902-937, ott./dic. 2001.

${ }^{379}$ Por conta desta norma vários regulamentos têm sido elaborados pelo Conselho Europeu, todos com o fito de padronização dos procedimentos no âmbito da União Européia, entre eles os relativos a: a) processo de insolvência (Regulamento n. 1.346/2000); b) notificações e citações para atos judiciais e extrajudiciais no âmbito civil e comercial (Regulamento n. 1.348/2000); c) competência judiciária e reconhecimento e execução de sentenças estrangeiras cíveis e comerciais (Regulamento n. 44/2001); d) cooperação entre Estados-membros no domínio da obtenção de provas (Regulamento n. 1.206/2001); e e) competência, reconhecimento e execução de decisões em matéria matrimonial e em matéria de responsabilidade parental (Regulamento n. 2.201/2003); f) título executivo europeu de créditos não contestados (Regulamento n. 805/2004). Para análise de todos eles cf. RIBEIRO, Antonio da Costa Neves. Processo civil da União Européia 1. Coimbra: Coimbra Ed., 2002. passim. 
Dentro destas diretivas da União Européia, o Estado Português, no ano de 1993, deu início a um processo interno de reformulação legislativa de suas normas processuais, movimento que tinha por objetivo "concretizar, no processo civil, o direito fundamental de acesso à justiça e aos tribunais, consagrando que tal direito envolve a obtenção em prazo razoável de uma decisão de mérito e afirmando como princípios estruturantes do processo civil o princípio do contraditório, designadamente na medida em que em momento prévio à decisão, tenha sempre lugar a audição das partes sobre as questões de direito ou de facto suscitadas, e o princípio da igualdade das partes" (art. $2^{\text {o }}$ da Lei n. 33/1995) ${ }^{380}$.

Atento a tal objetivo, o XXII Governo Constitucional Português formulou a revisão do Código de Processo Civil através do Decreto-Lei n. 329-A, de dezembro de 1995, com retificações posteriores autorizadas pela Lei n. 28, de 02.08.1996, e implementadas pelo Decreto-Lei n. 180, de 25.09.1996.

A opção de política legislativa expressamente anunciada pelo governo revisor, a par da certeza e segurança do direito e da afirmação da liberdade e da autonomia da vontade das partes, foi no sentido de confrontar o sistema de direito processual civil com exigências de eficácia prática, bem como tornar a justiça mais pronta e, nessa medida, mais justa. Em outros termos, o revisor português optou expressamente pela eficácia das normas processuais em detrimento de um sistema tecnicamente perfeito e rigidamente filiado ao padrão inquisitorial.

Entre os vários parâmetros estabelecidos para atendimento das linhas mestras da reforma - todos submetidos a debates públicos com participação efetiva da Ordem dos Advogados e da comissão nomeada pelo Centro de Estudos Judiciários português - de se destacar que a exposição de motivos do Decreto-Lei n. 329-A/95 estabeleceu, além do recurso quanto mais possível à adoção de cláusulas gerais, "a garantia da prevalência do fundo sobre a forma, através da previsão de um poder mais interventor do juiz, compensado pela previsão do princípio da cooperação, por uma participação mais activa das partes no processo de formação da decisão".

\footnotetext{
${ }^{380}$ Destaque-se que pela sistemática constitucional portuguesa (artigos 164, “e”, 168, “q" e 169, n. 3) as alterações do Código de Processo Civil podem ser efetuadas diretamente pelo Poder Executivo (via decreto), desde que previamente autorizadas de forma genérica pela Assembléia da República Portuguesa, o que veio com a citada Lei n. 33/1995.
} 
Tantas foram as novidades implementadas na legislação processual civil portuguesa - muitas, inclusive, inserindo em tal sistema continental típicas medidas dos ordenamentos filiados à common law - que o estudo delas mereceria, por si só, uma outra tese.

Por exemplo: a) de acordo com a exposição de motivos da do DL 329-A/95 "a face mais responsável, adulta e civilizada da advocacia impõe a consagração de uma modalidade de citação que é inerente a um estatuto democratizante e cristalino da própria lide processual”, razão pela qual os artigos. 245/246 prevêem nova modalidade de citação aproximada da dos países adeptos do padrão adversarial, a citação por mandatário, em que se autoriza o advogado do autor a promover, por si ou por terceiro, o chamamento do demandado a juízo; b) sempre na preocupação de realização efetiva e adequada do direito material e no entendimento do que será mais útil à paz social e ao prestígio e dignidade da administração da justiça corrigir que perpetuar um erro juridicamente insustentável, o art. 669 , n. 2, permite, embora em termos necessariamente circunscritos e com garantias do contraditório, o suprimento do erro de julgamento mediante a reparação da decisão de mérito pelo próprio juiz decisor nos casos em que por lapso manifesto de determinação da norma aplicável ou na qualificação jurídica, a sentença tenha sido proferida com violação da lei expressa, ou naqueles casos em que dos autos constem elementos, designadamente de índole documental, que, só por si inequivocamente, impliquem decisão em sentido diverso e não tenham sido considerados igualmente por lapso manifesto; c) institui-se a inovadora figura do recurso per saltum da $1^{\mathrm{a}}$ instância para o Supremo Tribunal de Justiça, em substituição da normal apelação para a Relação, quando segundo as regras gerais, a causa for susceptível de recurso até aquele Tribunal e as partes apenas tiverem suscitado questões de direito, que se configurem como objeto idôneo do recurso de revista (art. 725); d) introduz-se a figura do litisconsórcio eventual ou subsidiário (art. 31-B c.c. art. 469 do CPC), admitindo a formulação de pedidos subsidiários contra réus diversos dos originariamente demandados, prevenindo-se numerosas hipóteses de ilegitimidade passiva, e permitindo-se ao autor formulação de um pedido principal contra quem considera ser o provável devedor e de um pedido subsidiário contra o hipotético titular passivo da demanda; e e) o art. 924 e ss. estabelece um processo de execução sumário, traduzido na desnecessidade de citação inicial do executado, com imediata realização da penhora e concentração, em momento ulterior a esta, da reação à admissibilidade, quer da própria execução, quer da penhora efetuada. 
Duas inovações, entretanto, em vista do objeto deste estudo, merecem especial destaque. O princípio da cooperação, do qual já discorremos no item 3.7.2. deste trabalho. E o princípio da adequação formal, sobre o qual dissertamos a seguir, e que introduziu clara ruptura com o sistema processual até então vigente ${ }^{381}$, que não permitia uma tramitação processual maleável capaz de se adequar a uma realidade em constante mutação, descolada das velhas e ultrapassadas querelas doutrinárias.

\subsubsection{Princípio da adequação formal (art. 265-A do CPC Português)}

$\mathrm{O}$ art. 265-A do CPC português, que encerra o denominado princípio da adequação formal, tinha originariamente a seguinte redação dada pelo Decreto-Lei 329A/95: "quando a tramitação processual prevista na lei não se adequar às especificidades da causa, deve o juiz oficiosamente e com o acordo das partes, adaptar o processado" (destaque nosso).

A redação do dispositivo, contudo, foi alterada antes mesmo de sua entrada em vigor pelo Decreto-Lei 180-96, que lhe emprestou a seguinte nova redação, atualmente vigente: "quando a tramitação processual prevista na lei não se adequar às especificidades da causa, deve o juiz oficiosamente, ouvidas as partes, determinar a prática de actos que melhor se ajustem ao fim do processo, bem como as necessárias adaptações" (destaque nosso).

Da comparação das diferentes redações resulta que o princípio da adequação formal, na versão inicial do DL 329-A/95, havia procedido a uma drástica limitação da aplicação do dispositivo, ao condicioná-lo à existência de um acordo entre as partes. Tal limitação arriscava-se a esvaziá-lo de utilidade prática, por ser manifesta a dificuldade de, em situações controvertidas, obter referido acordo dos contendores. Além disso, a disposição dava a entender que aos litigantes era lícito criar uma forma processual

\footnotetext{
${ }^{381}$ É da exposição dos motivos do Decreto-Lei n. 329-A/95 que se extrai a seguinte passagem: "ter-se-á de perspectivar o processo civil como um modelo de simplicidade e de concisão, apto a funcionar como um instrumento, como meio de ser alcançada a verdade material pela aplicação do direito substantivo, e não como estereótipo autista que a si próprio se contempla e impede que seja perseguida a justiça, afinal, o que os cidadãos apenas pretendem quando vão a juízo" Daí porque "o direito de acesso aos Tribunais envolverá identicamente a eliminação de todos os obstáculos injustificados à obtenção de uma decisão de mérito, que opere justa e definitiva composição do litígio, privilegiando-se assim claramente a decisão de fundo sobre a mera decisão de forma".
} 
alternativa à instituída por lei, algo que não foi a intenção primitiva do legislador lusitano. ${ }^{382}$

A alteração legislativa também compatibilizou o dispositivo com o que já constava do art. 31, n. 3, do CPC português, que expressamente autoriza o juiz a permitir a cumulação de pedidos com procedimentos diversos, desde que haja interesse relevante ou quando a apreciação conjunta das pretensões seja indispensável para a justa composição do litígio. Nestes casos, note-se que a autorização da cumulação não depende da concordância das partes, e que ao juiz compete oficiosamente adaptar o procedimento às particularidades das pretensões em concurso. ${ }^{383}$

As razões que levaram o legislador português à adoção do princípio da adequação formal, além de obviar a adequação da legislação infraconstitucional às diretrizes da Carta Constitucional Lusa (art. 20.5) ${ }^{384}$, são bem expressadas na exposição de motivos do Decreto-Lei n. 329-A/95: "obviar-se a que regras rígidas de natureza estritamente procedimental possam impedir a efectivação em juízo dos direitos e a plena discussão acerca da matéria relevante para propiciar a justa composição do litígio". 385

Com efeito, o novo princípio da adequação formal vem romper com o apertado regime da legalidade das formas processuais ${ }^{386}$. Através dele, visa-se remover um obstáculo ao acesso à justiça em obediência à natureza instrumental da forma do processo; se a tramitação prevista na lei não se adequar ao fim do processo. Conferem-se, então, os

\footnotetext{
${ }^{382}$ Cf. REGO, Carlos Francisco de Oliveira Lopes do. Comentários ao Código de Processo Civil, p. 262. De acordo com Abílio Neto, o condicionamento da aplicação do dispositivo à prévia audição das partes (e não mais ao acordo delas) tem inegável vantagem "em termos de economia processual, com vista a uma desejável e rápida decisão de mérito", até porque os poderes conferidos ao juiz são discricionários, ficando "sempre aberta a possibilidade de recurso à parte que se opôs à projectada e decretada adequação formal (Código de processo civil anotado, cit., p. 354).

${ }^{383}$ Solução, repare-se, distinta da adotada pelo CPC brasileiro, que em seu art. $292, \S 2^{\circ}$, autoriza a cumulação de pedidos para os quais haja previsão de procedimentos diversos, mas desde que a parte renuncie ao rito especial em favor do procedimento ordinário, opção que traz manifesto prejuízo àquele que tinha abstratamente previsto um rito especial em seu favor (como no caso da cumulação de ação de rescisão de contrato com possessória).

${ }^{384}$ Art. 20.5. Para a defesa dos direitos, liberdades e garantias pessoais, a lei assegura aos cidadãos procedimentos judiciais caracterizados pela celeridade e prioridade, de modo a obter tutela efectiva e em tempo útil contra ameaças ou violações desses direitos.

${ }^{385}$ Anota Abílio Neto que a consagração do princípio da adequação traduz a concretização da regra enunciada no art. 2, n. 2, do CPC - "a todo direito, excepto quando a lei determine o contrário, corresponde a acção adequada a fazê-lo reconhecer em juízo, a prevenir ou reparar a violação dele e a realizá-lo coercitivamente, bem como os procedimentos necessárias para acautelar o efeito útil da acção" - bem como da regra enunciada no art. 10, n. 3, do Código Civil português, a determinar que o juiz, na falta de caso análogo, integre as lacunas da lei "segundo a norma que o próprio intérprete criaria, se houvesse de legislar dentro do espírito do sistema" (Código de processo civil anotado, cit., p. 354).

${ }^{386}$ REGO, Carlos Francisco de Oliveira Lopes do. Comentários ao Código de Processo Civil, cit., p. 261.
} 
correspondentes poderes ao juiz para adaptar a seqüência processual às especificidades da causa apresentada em juízo, reordenando os atos processuais a serem praticados no iter, inclusive com a determinação da prática de ato não previsto ou a dispensa de ato inútil previsto, ou ainda com a alteração da ordem dos atos abstratamente disciplinados em lei. ${ }^{387}$

A possibilidade agora consagrada de o juiz adaptar a tramitação do processo, com derrogação das disposições legais sobre sua sequiência, contudo, "tem tanto de aliciante para a realização da justiça no processo civil, como de ameaçador para as garantias daqueles que exercem o seu direito à jurisdição", especialmente porque “contrariamente a outros princípios que norteiam a reforma do processo civil e em relação aos quais se ponderou um novo equilíbrio, no princípio da adequação formal encontramos uma disciplina nova e desconhecida". ${ }^{388}$

Acrescente-se a isto, ainda, o fato de que não há antecedentes históricos, tampouco paralelos em direito comparado, a facilitar a interpretação do novel princípio na extensão em que foi contemplado pelo CPC Português.

Por isto, a doutrina portuguesa vem se esforçando para traçar limites à aplicação do dispositivo, bem como obviar as hipóteses práticas de sua utilização.

Estão excluídas do âmbito de abrangência do princípio da adequação formal questões sobre ${ }^{389}$ :

a) A forma para a prática do ato processual em si considerado, que não pode ser dispensada pelo juiz, ainda que a repute injusta, se a própria lei expressamente já a alocou como essencial;

b) A qualificação do ato processual, como nos casos em que se nomina equivocadamente um ato praticado, embora seu conteúdo seja apto para o fim pretendido. Nestes casos não haverá alteração da ordem formal dos atos do procedimento, pois que o ato praticado sob a errada rotulação atingirá, de qualquer forma, a finalidade predisposta, motivo pelo qual não se lança mão

\footnotetext{
${ }^{387}$ Cf. BRITO, Pedro Madeira de. O novo princípio da adequação formal, cit., p. 36 e 51; e BATISTA, J. Pereira. Reforma do processo civil: princípios fundamentais. Lisboa: Lex, 1997. p. 66.

${ }^{388}$ BRITO, Pedro Madeira de. O novo princípio da adequação formal, cit., p. 31 e 49.

${ }^{389}$ BRITO, Pedro Madeira de. O novo princípio da adequação formal, cit., p. 38-40 e 67-68
} 
da adequação formal, mas sim do princípio da fungibilidade das formas, que tem previsão expressa no CPC luso (artigos 474, n. 3, 687, n. 4, 688 n. 5);

c) Pressupostos processuais, que não podem ser dispensados a pretexto de incompatíveis com a adequação formal. Assim, impossível deliberação que admita o processamento de ações com vários pedidos cumulados, entre os quais se encontra um que não é da competência do juízo;

d) Procedimentos alternativos. A opção por um dos procedimentos fixados abstratamente em lei: também não constitui verdadeiro caso de adequação formal. A seqüência alternativa também se encontra prevista na lei, de modo que não há adequação, mas mera aplicação de iter predisposto pelo legislador (como nos casos de dispensa da audiência preliminar) ${ }^{390}$.

e) Procedimentos especiais. Se já existe um procedimento especial estabelecido, pois o juízo de adequação entre o procedimento e o direito material já foi feito pelo legislador, não compete ao juiz suplantá-lo fazendo nova adequação.

Por outro lado, tem-se indicado como hipóteses de aplicação prática da adequação formal as seguintes situações, sempre, se ressalvando que: a) a adequação só se justifica se houver circunstâncias específicas, relacionadas ao direito material, a aconselhar a variação da forma do procedimento processual, de modo que, como bem aponta doutrina e jurisprudência ${ }^{391}$, a adequação formal é medida da mais absoluta exceção; e b) impossível a enumeração de todas as hipóteses de adequação formal, já que a realidade judiciária e a eclosão de casos práticos no cotidiano forense sempre estão a formular novas hipóteses de utilização do princípio em análise (sendo, pois, correta a opção legislativa em não se descrever as hipóteses de adequação) $)^{392}$ :

a) Cumulação de objetos processuais.

\footnotetext{
${ }^{390}$ Em sentido contrário ao exposto, Carlos Francisco de Oliveira Lopes do Rego vê na opção por tramitações processuais alternativas previstas em lei representação prática do princípio da adequação formal (Comentários ao Código de Processo Civil, 2, cit., p. 263).

${ }^{391}$ NETO, Abílio. Código de processo civil anotado, cit., p. 354. Como já decidiu o Supremo Tribunal de Justiça Português, o "o artigo 265-A do CPC95 deve ser aplicado casuisticamente e com cuidado, sob pena de indisciplina e insegurança" (Agravo 97A726, Rel. Cardona Ferreira, j. 18.11.1997).

${ }^{392}$ BRITO, Pedro Madeira de. O novo princípio da adequação formal, cit., p. 41-48.
} 
Nos casos de coligação (artigos 30 e 31$)^{393}$, cumulação de pedidos (artigos 468 a 470$)^{394}$ ou reconvenção (art. 274) (395 $^{395}$ e apensação de ações (art. $275),{ }^{396}$ o sistema processual civil português admitia a cumulação, desde que houvesse compatibilidade procedimental. Com o novo princípio o juiz pode criar um procedimento que compatibilize todos os objetos pretendidos, ainda que tenha que se afastar do regramento do procedimento comum ou especial estabelecido para cada um dos objetos cumulados, nos termos dos artigos 31, n. 2 e 3, 274, n. 3, 392, n. 3 e 470, todos do CPC Português. ${ }^{397}$

b) Inadequação do procedimento previsto em lei para demanda com objeto simples. Tem se admitido, mesmo nas hipóteses em que a demanda tenha um único pedido, a utilização de um procedimento diverso do estabelecido pela lei para uma mais adequada e justa composição do litígio;

c) Adequação de uma fase do processo. Também possível a aplicação do dispositivo aos casos em que seja necessário praticar em dado momento

\footnotetext{
${ }^{393}$ Trata-se de figura não conhecida no nosso sistema e distinta do litisconsórcio. Enquanto no litisconsórcio há identidade de relações jurídicas entre as partes, na coligação são várias as relações jurídicas e vários os interessados na demanda. Assim, possível no direito português a cumulação por coligação de um pedido de divórcio com o de despejo, ajuizado concomitantemente contra o cônjuge adúltero e o inquilino, pela reiterada prática de atos sexuais no imóvel locado. O primeiro pedido (divórcio) pela ruptura dos deveres conjugais. O segundo pedido (despejo), pela aplicação do prédio em práticas ilícitas, imorais ou desonestas. Apesar de distintos os procedimentos previstos abstratamente para cada pedido coligado, neste caso a adequação formal atua para possibilitar a cumulação.

${ }^{394}$ Como nos casos em que se pretende a tutela da personalidade - a que corresponde a um processo especial (art. 1474 do CPC Português) - com o pedido de indenização correspondente à violação deste direito, que segue o rito comum. Admite-se a cumulação destes pedidos através da utilização da adequação formal e criação de um procedimento apto a tutelar ambas as pretensões.

${ }^{395}$ De acordo com a doutrina lusa, é na reconvenção que se tem a maior utilidade prática para a aplicação do princípio da adequação formal. Por exemplo, utilizando-se o autor de procedimento especial para depósito de rendas (art. 1024 do CPC português), até então não era dado ao demandado/senhorio valer-se da reconvenção para a retomada do prédio, já que inexistindo previsão de rito especial para tal pleito seguia ele o procedimento comum. Com o princípio da adequação, lícito ao juiz, na tutela do direto material, admitir a reconvenção, adequando o procedimento a uma tramitação suscetível de tutelar o direito do réu/reconvinte.

${ }^{396}$ É o fenômeno semelhante à nossa conexão (art. 103 do CPC) ou continência (104 do CPC), que implica reunião de processos que poderiam ter corrido conjuntamente por estarem presentes os requisitos da coligação ou da reconvenção. A admissão do apensamento destas ações e processamento conjunto deve ocorrer especialmente nas hipóteses de conexão por subordinação, onde há um nexo de prejudicialidade entre os pedidos cumulados, o que pode gerar a edição de decisões absolutamente incompatíveis. Para os casos de conexão por coordenação - quando as decisões proferidas de maneira diversa podem conviver sem contradição - a possibilidade de cumulação de pedidos com procedimentos diversos me parece que fica ao exclusivo critério da oportunidade e conveniência das partes e do juiz (embora o art. 265-A utilize o verbo "dever").

${ }^{397}$ De acordo com a exposição de motivos do Decreto-Lei n. 329-A/95, a cumulação de causas com base na adequação elimina "um dos principais inconvenientes ligados à criação e previsão dos processos especiais, com campo de aplicação rigidamente estabelecidos - tornando eventualmente inviável a cumulação de pretensões, substancialmente conexas, cuja apreciação conjunta e global será, em muitos casos, condição sine qua non para o perfeito entendimento dos termos do litígio e sua dirimição de forma justa e adequada".
} 
atos processuais que só seriam praticados oportunamente (como a oitiva de uma testemunha na audiência preliminar quando repute necessária para apreciação de uma exceção que deva conhecer logo aí).

Dentro desta mesma idéia base de evitar que regras de índole estritamente procedimental possam obstar ou criar dificuldades insuperáveis à plena realização dos fins do processo - flexibilizando-se ou eliminando rígidos espartilhos, de natureza formal e adjetiva, suscetíveis de dificultarem, em termos excessivos e desproporcionados, a efetivação em juízo dos direitos, a jurisprudência tem construído, ao lado da doutrina, toda uma casuística sobre o tema:

a) Já se admitiu a intervenção de terceiro no processo de expropriação à luz da adequação formal, alterando-se o procedimento executivo para permitir a participação efetiva do interessado ${ }^{398}$;

b) Não se reconheceu violação ao princípio da adequação pelo simples fato de o juiz de $1^{\text {a }}$ instância não ter oficiosamente inquirido algumas testemunhas $^{399}$;

c) Admitiu-se, com base no art. 265-A do CPC, que a omissão da parte ao aperfeiçoar o requerimento inicial e vir indicar a forma de processo executivo, nos termos dos ns. 1 e 2 dos artigos 811-B e do $n^{\circ} 1$ do artigo 466 do CPC, não deve conduzir ao indeferimento liminar do pedido, mas deve tal irregularidade ser suprida oficiosamente pelo próprio juiz ${ }^{400}$;

d) Não se permitiu que o juiz, com base no art. 265-A, altere ou amplie o pedido formulado pela parte, já que a disposição é de manifesto caráter procedimental, e não material. ${ }^{401}$

\footnotetext{
${ }^{398}$ Ac. RL de 04.10.2001: Coletânea de Jurisprudência do STJ, n. IV, p.114.

${ }^{399}$ Supremo Tribunal de Justiça, Recurso de Revista n. 03B3417, Rel. Noronha do Nascimento, j. 01.07.2004. Destaca-se do acórdão a seguinte passagem sobre a adequação formal "o que aqui se contempla é a concertação da forma do processo com o fim visado e que mais não é do que a pretensão cuja resolução é pedida. $\mathrm{O}$ juiz deve, pois, adaptar a forma desconforme à pretensão formulada, quando e sempre que se verifique uma discordância prática que obste ou obstaculize à apreciação da pretensão. Mas isto nada tem que ver com a realização ou não de uma inquirição disputada e sobre a qual as partes nem sequer estão de acordo. A efectivação ou não de uma inquirição (ainda para mais nos termos em que tudo se passou) não cai na previsão do art. $^{\circ} 265-$ A". $^{\circ}$

${ }^{400}$ Tribunal da Relação de Lisboa, Agravo n. 0053082, Rel. Malheiros de Ferraz, j. 12.11.1998.

${ }^{401}$ Tribunal da Relação do Porto, Apelação n. 0050999, Rel. Pinto Ferreira, j. 06.11.2000.
} 
Como o princípio da adequação formal consta da parte geral do Código de Processo Civil português, é ele perfeitamente aplicável aos processos cautelares ${ }^{402}$ e de execução $^{403}$, não se tratando, portanto, de regra exclusiva do processo declarativo (de conhecimento). Também a jurisprudência tem admitido a sua aplicação no âmbito do procedimento recursal $^{404}$. Tem se estendido, ainda, a aplicação do princípio para outras áreas do direito, como os processos constitucional, trabalhista, tributário, administrativo e penal, pois que o processo civil é ramo subsidiário a todos eles. ${ }^{405}$

Quanto ao momento em que se deliberará sobre a adequação formal não há disposição legal a respeito, de modo que a oportunidade da decisão se aferirá caso a caso. Tratando-se, entretanto, da cumulação de objetos (art. 31 do CPC português), tendo-se em vista que o juiz não precisa de autorização das partes nem de prévia oitiva do requerido, logo na sua primeira manifestação no processado haverá deliberação fundamentada a respeito. Já para determinar alteração do iter procedimental abstratamente previsto, o juiz deverá previamente ouvir as partes (art. 266 do CPC), após o que fixará a sequiência dos atos processuais que irão se seguir ${ }^{406}$. A fixação do procedimento adequado logo na petição inicial, sem oitiva do demandado, implica nulidade dos atos processuais praticados por ofensa aos princípios da cooperação e do contraditório.

A decisão que ordena a adequação do procedimento às particularidades da causa tem conteúdo variado. O julgador pode optar: a) por uma forma de processo já existente, caso em que mandará aplicar determinado procedimento especial previsto no sistema a um caso que teria curso abstratamente pelo procedimento comum ${ }^{407}$, ou determinar que o processo onde tenha admitido a cumulação de pedidos siga o rito do processo de um dos pedidos cumulados; ou b) pela fixação de uma tramitação sucedânea, hipótese em que fixará uma nova ordenação de atos não prevista em lei e que pode

\footnotetext{
${ }^{402}$ Como nos casos em que o credor e vizinho pretende, ao mesmo tempo, arrestar bens para garantia do crédito e embargar obra nova. Dois pleitos cautelares que encontram previsão de ritos distintos no CPC português, e a cujo respeito deve ser permitida a cumulação por com base na adequação formal.

${ }^{403}$ Vislumbra-se, com base na adequação, a possibilidade de cumulação da execução de quantia pelo rito comum com a execução de crédito alimentar, que tem rito especial (art. 1118 do CPC português).

${ }^{404}$ Tribunal da Relação do Porto, Agravo n. 0325744, Rel. Marques de Castilho, j. 02.12.2003.

${ }^{405}$ BRITO, Pedro Madeira de. O novo princípio da adequação formal, cit., p. 61-63.

${ }^{406}$ FREITAS, José Lebre de. Introdução ao processo civil: conceito e princípios gerais, cit., p. 179.

${ }^{407}$ É o que ocorre no caso de divisão de patrimônio de pessoas em regime de união estável, para o qual o sistema português não prevê procedimento próprio. Nestes casos tolera-se a utilização do procedimento especial de inventário, da mesma forma que se admite para os casos de extinção da sociedade conjugal (art. 1404 do CPC português).
} 
consistir na mera conjugação de diferentes seqüências de formas do processo ${ }^{408}$, ou na imposição da prática ou omissão de atos abstratamente previstos.

Neste último caso em que o procedimento será literalmente criado pelo magistrado, duas observações são de sumo relevo. Primeiro, sempre se aplicará a regra do art. 463, n. 1, do CPC - utilizando-se o regramento do das disposições gerais e comuns, e subsidiariamente o rito ordinário - para os atos processuais cujo iter não foi modificado pelo juiz, tudo como se o novo procedimento fosse expressamente previsto em $1 \mathrm{ei}^{409}$. E segundo, ao providenciar a adequação, deve o juiz estabelecer, de uma única vez, todo o plano da tramitação sucedânea que estabelece para a causa, única maneira para que fiquem asseguradas as garantias das partes, que devem conhecer, sem quaisquer reservas ou limitações, todas o esquema previsto pelo julgador. ${ }^{410}$

Estabelecido o plano de tramitação da causa, deve ele, como regra, ser observado até decisão final do processo, sob pena de, tanto quanto a não observância de qualquer outro procedimento previamente estabelecido pela lei, ocorrer nulidade em caso de prejuízo a um dos contendores (artigos. 199 e 201, n. 1, do CPC português). ${ }^{411}$ O procedimento estabelecido pela adequação formal, assim, é tão vinculativo quanto aqueles decorrentes de imposição legal.

De modo excepcional, entretanto, autorizam-se outras variações no curso da causa já formalmente adequada, casos que deverão ser precedidas de prévia oitiva dos litigantes e estabelecimento claro das novas regras do procedimento.

Da decisão do juiz que determina a adequação ou a readequação formal do processo cabe recurso de agravo. As partes, por isto, ficam garantidas contra eventuais decisões em desconformidade com o modelo constitucional do processo ou que lhes tolham garantias processuais.

O princípio da adequação também terá grande utilidade prática com a mudança de procedimentos por futuras leis. De fato, sempre que o sistema processual passa por reformas, inúmeros procedimentos são alterados com feitos iniciados sob o regime

\footnotetext{
${ }^{408}$ É o que ocorrerá no já citado exemplo de coligação entre um pedido de divórcio e despejo, para o qual deverá o magistrado, na impossibilidade lógica de aplicar à tutela das pretensões qualquer dos ritos abstratamente previstos, criar um procedimento novo para possibilitar apreciação dos pedidos cumulados.

${ }^{409}$ BRITO, Pedro Madeira de. O novo princípio da adequação formal, cit., p. 54-55.

${ }^{410}$ REGO, Carlos Francisco de Oliveira Lopes do. Comentários ao Código de Processo Civil, p. 263.

${ }^{411}$ SOUZA, Miguel Teixeira de. Estudos sobre o novo processo civil, cit., p. 35.
} 
pretérito, muitas vezes sendo praticamente incompatíveis os procedimentos revogado e novo. A adequação, nestes casos, serviria de fonte normativa para permitir ao juiz, avaliando o caso em concreto, a estipulação do melhor proceder, seja através da aplicação integral de um dos dois procedimentos, seja através da combinação lógica de atos processuais de cada um dos regimes (o revogado e o vigente). ${ }^{412}$

\footnotetext{
${ }^{412}$ Aliás, tal pretensão foi expressamente revelada pelo legislador português, ao prever no art. 28 do DecretoLei n. 180/96, que as partes podem concordar em submeter os processos em andamento ao novo regime procedimental imposto pela reforma legislativa que por lá se operou. Para tanto, deverá o juiz adequar o processo, obstando que a imediata aplicação da lei nova possa implicar desarmonia às várias fases do processo.
} 


\section{FLEXIBILIDADE PROCEDIMENTAL NO PROCESSO CIVIL BRASILEIRO}

\subsection{Introdução}

\subsubsection{Princípios da adequação da adaptabilidade do procedimento}

Já vimos que as formas processuais correspondem a uma necessidade de ordem, certeza e eficiência. Sua observância representa uma garantia de andamento regular e legal do processo e de respeito aos direitos das partes, sendo, pois, o formalismo indispensável ao processo.

Só que, como bem adverte autorizada doutrina, "é necessário evitar, tanto quanto o possível, que as formas sejam um embaraço e um obstáculo à plena consecução do escopo do processo; é necessário impedir que a cega observância da forma sufoque a substância do direito". 413

Por isto, o legislador, ao regular as formas (que em grande parte são o resultado de uma experiência que se acumulou durante séculos ${ }^{414}$ ), "deve preocupar-se em adaptá-las às necessidades e costumes do seu tempo, eliminando o excessivo e o inútil". 415

A adaptação do processo ao seu objeto e sujeitos, assim, dá-se, em princípio, no plano legislativo, mediante elaboração de procedimentos e previsão de formas adequadas às necessidades locais e temporais. Esta é a regra.

Mas é recomendável que ocorra também, conforme já indiciamos outrora, no próprio âmbito do processo, com a concessão de poderes ao juiz para, dentro de

\footnotetext{
${ }^{413}$ LIEBMAN, Enrico Tullio. Manual de direito processual civil, cit., v. 1, p. 225. A cientista política Maria Teresa Sadek destaca, entre os fenômenos que compõem da nominada crise da justiça: a) crise estrutural do sistema de justiça; b) crise institucional; e c) crise relativa aos procedimentos (SADEK, Maria Teresa. Poder Judiciário: perspectivas de reforma. Opinião Pública, São Paulo, v. 10, n. 1, p. 1, maio 2004). Aponta ainda, nos termos de pesquisa que conduziu junto aos magistrados brasileiros, que logo após a falta de recursos materiais, indicada pela grande maioria como sendo o principal fator a obstaculizar o bom funcionamento do Judiciário, vem o excesso de formalidades nos procedimentos judiciais (ARANTES, Rogério Bastos; SADEK, Maria Teresa. A crise do Judiciário e a visão dos juízes. Revista da USP, São Paulo, n. 21, p. 42, mar./maio 1994).

${ }^{414}$ Para análise da evolução histórica da forma através dos tempos, cf., por todos, FOUCAULT, Michel. A verdade e as formas jurídicas, cit., especialmente p. 53-78.

${ }^{415}$ LIEBMAN, Enrico Tullio. Manual de direito processual civil, cit., v. 1, p. 226.
} 
determinados limites - todos já devidamente estudados no Capítulo 3 - realizar a adequação de forma concreta. ${ }^{416}$

Com efeito, a moderna ênfase que se dá ao aspecto eficacial do processo (no seu aspecto material e temporal), sugestiona que se deve conferir ao procedimento o ritmo necessário à efetiva atuação jurisdicional ${ }^{417}$. Se não se obtém isto por força de modelos legais aptos à tutela adequada e tempestiva do direito material, há de se conferir ao juiz "condições de acelerar procedimentos, ou de freá-los, de acordo com a necessidade concreta e sempre atendida a garantia dos superiores princípios do processo". ${ }^{418}$

Fala-se em princípio da adequação para designar a imposição sistemática dirigida ao legislador federal e estadual para que construa modelos procedimentais aptos para a tutela especial de certas partes ou do direito material ${ }^{419}$; e princípio da adaptabilidade (ou da elasticidade processual ${ }^{420}$ ) para designar a atividade do juiz de flexibilizar o procedimento inadequado ou de reduzida utilidade para melhor atendimento das peculiaridades da causa. ${ }^{421}$

\footnotetext{
${ }^{416}$ Cf. BEDAQUE, José Roberto dos Santos. Efetividade do processo e técnica processual: tentativa de compatibilização, cit., p. 61. O Desembargador paulista aponta, ainda, que "deve a legalidade da forma ser abrandada por algumas idéias próprias do princípio da liberdade, no sentido de possibilitar ao juiz adequar a forma às necessidades e especificidades da situação concreta" (Efetividade do processo e técnica processual: tentativa de compatibilização, cit., p. 424).

${ }^{417}$ BEDAQUE, José Roberto dos Santos. Direito e processo. 2. ed. São Paulo: Malheiros Ed, 2001. p. 54-58.

${ }^{418}$ NALINI, José Renato. Processo e procedimento - distinção e a celeridade da prestação jurisdicional, cit., p. 686. Afinal, os princípios constitucionais do processo incidem sobre a sua estrutura técnica, de modo que não só o legislador infraconstitucional deve traçar um processo que corresponda a estes princípios, mas também os processualistas devem extrair do sistema as tutelas que permitam a realização concreta do direito à adequada, efetiva e tempestiva tutela jurisdicional (MARINONI, Luiz Guilherme. Novas linhas do processo civil, cit., p. 48).

${ }^{419}$ Fredie Didier Júnior, ao se referir ao princípio da adequação, aduz que "a construção do procedimento deve ser feita tendo-se em vista a natureza e as idiossincrasias do objeto do processo a que servirá; o legislador deve atentar para esta circunstância, pois um procedimento inadequado ao direito material pode importar verdadeira negação da tutela jurisdicional" (Sobre dois importantes, e esquecidos, princípios do processo: adequação e adaptabilidade do procedimento, cit., p. 530-541). Cf., também, BUENO, Cássio Scarpinella. Curso sistematizado de direito processual civil, cit., p. 484-485.

${ }^{420}$ Calamandrei, à luz da revogada legislação processual italiana, apontava que, sem esmorecer o princípio da legalidade das formas, a lei de seu país "temperava a excessiva rigidez, adotando no lugar de um tipo de procedimento único e invariável para todas as causas, um procedimento adaptável às circunstâncias, que pode ser, em caso de necessidade, abreviado ou modificado, podendo assumir múltiplas figuras, em correspondência com as exigências concretas da causa". Ressalve-se, entretanto, que o autor apenas admitia o emprego da elasticidade com a eleição de caminhos previamente e genericamente estipulados pela lei, e não que as partes ou o juiz elegessem livremente o melhor ato processual da série (CALAMANDREI, Piero. Direito processual civil, cit., v. 1, p. 299-300).

${ }^{421}$ Com efeito, Carlos Alberto Alvaro de Oliveira, embora recuse a submissão do procedimento ao arbítrio judicial, reconhece a necessidade de mais aguda atividade do juiz no bojo do processo, confiando-lhe sua efetiva direção (Poderes do juiz e visão cooperativa do processo, cit., p. 58), razão pela qual, sendo o juiz agente político do Estado, "portador de poder deste e expressão da democracia indireta praticada nos estados ocidentais contemporâneos", não há "razão para enclausurá-lo em cubículos formais do procedimento, sem liberdade de movimentos e com pouquíssima liberdade criativa" (Do contraditório, cit.,
} 
A flexibilização do procedimento, assim, é condição inexorável da aplicação do princípio da adaptabilidade.

Ambos os princípios se operam do ponto de vista subjetivo (partes) ${ }^{422}$ ou objetivo (direito material). ${ }^{423}$

Subjetivamente, a qualidade das partes justifica a alteração do procedimento, eis que exatamente por isto não se estará quebrantando a garantia constitucional da isonomia (art. $5^{\circ}$, caput, da CF), mas sim a potencializando. Assim, o procedimento é legislativamente alterado para que a Fazenda Pública e o Ministério Público contem com prazos mais extensos para a prática dos atos processuais (art. 188 do $\mathrm{CPC}$ ); para que nos processos em que haja interesse de incapazes intervenha o Ministério Público (art. 82, I, do CPC); para que os incapazes ou a Fazenda Pública não possam litigar pelo procedimento sumaríssimo dos Juizados Especiais Cíveis, cujas garantias processuais são menos acentuadas (art. $8^{\circ}$, e $\S 1^{\circ}$, da Lei n. 9.099/95); etc. Mas nada impede que o juiz promova a variação ritual à luz das características da parte litigante, seja quando o legislador lhe dá expressamente tal atribuição (ampliação dos prazos por força de circunstâncias excepcionais da parte, nos termos do art. 181 do CPC; inversão do ônus da prova nos termos do art. $6^{\circ}$, VIII, do CDC), seja quando ele não foi capaz de antever regramento flexibilizador, pese sua imperiosidade para o restabelecimento do equilíbrio de forças entre os litigantes (utilização de procedimento diverso nos casos em que o réu, estando em local distante, tiver incapacidade ou grande dificuldade de se deslocar até a Comarca para a audiência inicial do rito sumário, sumaríssimo ou especial ${ }^{424}$ ).

p. 13). Dinamarco, também ressalvando ainda não ser digerível a idéia de submissão total das regras de procedimento aos desígnios do julgador, aceita, no entanto, certa dose de liberdade do juiz, inclusive para amoldar o procedimento às especificidades do direito material (DINAMARCO, Cândido Rangel. $A$ instrumentalidade do processo, cit., p. 136). Cf., também, COMOGLIO, L. Paolo. Direzione del processo e responsabilitá del giudice. In: Studi in Onore di Enrico Tulio Liebman. Milano: Giuffrè, 1979. v. 1, passim.

${ }^{422}$ Destaque-se que neste aspecto diferenciamos nossa concepção de flexibilidade procedimental da adotada pela doutrina portuguesa, que só a admite com base em critérios objetivos fundados no direito material, não admitindo que o juízo afira a necessidade de adequação conforme os sujeitos, assegurando igualdade substancial das partes (cf. BRITO, Pedro Madeira de. O novo princípio da adequação formal, cit., p. 64-65).

${ }^{423}$ Em sentido semelhante cf. LACERDA, Galeno Velhinho de. O código como sistema legal de adequação do processo. Revista do Instituto dos Advogados do Rio Grande do Sul, Porto Alegre, p. 161-170, 1976. O ilustre autor gaúcho, todavia, anota mais um aspecto na sua classificação, o teleológico, que, a nosso ver, por ter matiz objetiva e relacionada ao direito material, não necessita de autonomia classificatória.

${ }^{424}$ Algo que corriqueiramente ocorre em ações de alimentos, cujo procedimento especial do art. $5^{\circ}$ a $7^{\circ}$ da Lei n. 5.478/1968, aliado à regra especial de competência do art. 100, II, do CPC, impõe o comparecimento do demandado hipossuficiente, muitas vezes domiciliado em outro Estado da federação, perante o juízo do domicílio do alimentando, sob pena de revelia. Não me parece haver impedimento para que o juiz, à luz da reclamada hipossuficiência, deixe de decretar a revelia e aceite, sem maiores prejuízos ao autor, o processamento da demanda pela via ordinária. 
Também em vista do direito material (objetivamente) é possível a variação ritual. A lei o faz, exemplificativamente, quando ordena os procedimentos ordinário, sumário, sumaríssimo e especial, à luz, entre outros critérios da pretensão econômica (valor da causa); quando elege, embora sem o rigor que seria necessário ${ }^{425}$, direito que entende ser digno de uma proteção mais eficiente ou célere (possessórias, alimentos, busca e apreensão em alienação fiduciária); ou quando, pela forma como se apresenta o direito material, concede tutela de maneira bem mais rápida ao jurisdicionado (mandado de segurança e monitória). ${ }^{426}$ Mas é possível que esta variação seja efetuada, da mesma maneira, pelo juiz, que verificando a inaptidão do procedimento para a tutela adequada ou potencializada do direito material, ordena a flexibilização, ainda que ausente previsão legal específica (invertendo a ordem de produção de provas, garantindo contraditório nos embargos de declaração com efeitos infringentes, elegendo a medida de apoio mais adequada para o cumprimento das obrigações de fazer e dar, etc.).

Os princípios da adequação e da adaptabilidade, apesar de não gozarem de previsão legal específical ${ }^{427}$, parecem estar implícitos no sistema processual civil brasileiro, a ponto de festejados autores, pese a omissão de tantos outros, os indicarem como integrantes do que se convencionou chamar Teoria Geral do Processo ${ }^{428}$. São

${ }^{425}$ GAJARDONI, Fernando da Fonseca. Breve introdução aos procedimentos especiais de jurisdição contenciosa, cit., p. 20. No mesmo sentido Fredie Didier Júnior, para quem "as razões que levam à criação de procedimentos mais diferenciados, com técnicas ainda mais avançadas de tutela, não são assim tão claras e objetivas. Algumas espécies de direito material não têm a relevância e as peculiaridades próprias que imponham uma tutela mais rápida. No entanto, nitidamente por fatores ideológicos, a tutela especial é criada", como ocorre no caso da busca e apreensão da alienação fiduciária e na execução extrajudicial do crédito hipotecário (Sobre dois importantes, e esquecidos, princípios do processo: adequação e adaptabilidade do procedimento, cit., p. 530-541).

${ }^{426}$ Cf. DIDIER JÚNIOR, Fredie. Direito processual civil, cit., v. 1, p. 36-39.

${ }^{427}$ Algo que é proposto expressamente por Carlos Alberto Alvaro de Oliveira (Efetividade do processo de conhecimento. Revista de Processo, São Paulo, n. 96, p. 66, out./dez. 1999).

${ }^{428}$ LACERDA, Galeno Velhinho de. O código como sistema legal de adequação do processo, cit., p. 161; DIDIER JÚNIOR, Fredie. Direito processual civil, cit., v. 1, p. 36. Em sentido expressamente contrário, indicando que tais princípios são exclusivos do direito do trabalho, cf. CATHARINO, José Martins. Princípios do direito processual do trabalho. In: FRANÇA, Rubens Limongi (Org.). Enciclopédia Saraiva do Direito. São Paulo: Saraiva, 1977. v. 61, p. 27 e ss.; e SOUZA, Wilson Alves de. Princípios do direito processual do trabalho: o princípio da adequação e suas variantes. $L T r$ : revista legislação do trabalho, São Paulo, v. 50, n. 2, p. 171-172, fev. 1986. De acordo com este último autor, se o direito material do trabalho tem peculiaridades, a sua aplicação só poderia ser concretizada a contento mediante um direito processual adequado àquele. Assim, se prevalece no direito do trabalho o princípio da proteção ao trabalhador, e a norma processual comum é igualitária, compete ao direito processual do trabalho prescrever normas processuais respeitantes da desigualdade do direito material. Por isto, necessários instrumentos processuais adequados para combater a acintosa desigualdade real, política, e econômica e sociológica de empregadores e empregados, razão pela qual, com o princípio da adequação, busca-se restabelecer no procedimento a situação de igualdade (Princípios do direito processual do trabalho, cit., p. 171). Doutrina e jurisprudência têm indicado como decorrência prática desta maleabilização das regras procedimentais, que não existe no direito do trabalho inépcia da inicial; que nada impede a juntada, pelo reclamante, de documentos a qualquer tempo; e que pode haver o deferimento de pedidos não expressamente formulados pelo empregado, utilizando-se da teoria do pedido implícito ou necessariamente decorrente. 
princípios, portanto, de aplicação também nos outros tipos de processos (penal, tributário, trabalhista, etc.), inclusive fora do âmbito judicial (processo administrativo, processo legislativo, processo arbitral).

Por isto, se o legislador não foi capaz de modelar adequadamente os procedimentos para a exata tutela do direito material, ou se ele não atentou para especial condição da parte litigante (princípio da adequação), nada impede que o juiz, percebendo a necessidade de variação ritual, a faça no caso concreto (princípio da adaptabilidade).

\subsubsection{Princípio da adaptabilidade e sistemas de flexibilização do procedimento}

A aplicação do princípio da adaptabilidade, naturalmente, tem natureza subsidiária. Só incide nos casos em que o legislador não criou especificamente um procedimento individualizado e adequado para a tutela do direito ou da parte (como se pressupõe ter ocorrido com os procedimentos especiais). Se o procedimento é ideal e atende com perfeição às características do caso não há espaço para a adaptação.

A riqueza da práxis forense, todavia, bem tem demonstrado que o legislador é incapaz de modelar, com perfeição, procedimentos específicos para todas as situações cotidianas. Sempre há de surgir um caso novo que, por força do direito debatido ou da qualidade de um dos litigantes, justifique uma calibração do procedimento às circunstâncias da causa, e, portanto, a aplicação do princípio da adaptabilidade.

A partir desta constatação pragmática, o operador jurídico deve buscar, a bem da funcionalidade do sistema, a construção de uma teoria plausível para justificar a adaptação, algo que só é possível, como já vimos, através da flexibilização das regras do procedimento.

Três são os sistemas de flexibilização procedimental.

O primeiro deles é o da flexibilização por força da lei. De fato, disposição legal pode autorizar o juiz a proceder a adaptação do procedimento à causa. Esta autorização pode ser incondicionada (como o fez o legislador português no já estudado art. 265-A do CPC luso, sob o nome de princípio da adequação formal), hipótese em que a norma deixa a critério do julgador a variação procedimental adaptadora, sem indicá-la expressamente; ou 
pode o legislador prever tramitações alternativas para a causa ${ }^{429}$, casos em que o juiz, conforme as opções previamente postas na legislação, elege a que pareça ser mais adequada para a tutela do caso em concreto $^{430}$, não podendo, todavia, escolher outra fora do rol legal.

Um segundo sistema é o da flexibilização procedimental judicial. Ainda que não haja previsão legal alguma a respeito, competiria ao juiz, com base nas variantes do caso em concreto (objetivas e subjetivas), modelar o procedimento para a obtenção de adequada tutela, elegendo quais os atos processuais que se praticarão na série, bem como sua forma e o modo. ${ }^{431}$ Trata-se de modelo muito próximo ao da liberdade das formas, diferenciando-se dele, todavia, pelo caráter subsidiário de incidência. Neste regime, a flexibilização judicial só se daria em caráter excepcional e mediante uma série de condicionamentos, restando, pois, preservado o regime da legalidade das formas como regra. No regime da liberdade das formas a regra é que o juiz, em todos os procedimentos, delibere sobre o iter.

O terceiro sistema seria o da flexibilização voluntária das regras de procedimento (como ocorre na primeira parte do art. 21 da Lei de Arbitragem). Competiria às partes eleger alguns procedimentos ou alguns atos processuais da série, ainda que também em caráter excepcional e com condicionamentos.

Por vinculado ao sistema da legalidade das formas, nosso país se filiou, preponderantemente, ao primeiro regime de flexibilização procedimental, com ampla incidência do modelo legal de tramitações procedimentais alternativas em detrimento do modelo legal genérico de flexibilização. A regra de flexibilização do procedimento no Brasil é, portanto, a do estabelecimento legislativo de variantes rituais previamente

\footnotetext{
${ }^{429}$ Vale relembrar que pesa controvérsia, na doutrina portuguesa, se estas situações de variantes procedimentais já predispostas pelo legislador são consideradas hipóteses de adequação formal. Pela negativa, cf. BRITO, Pedro Madeira de. O novo princípio da adequação formal, cit., p. 38-40 e 67-68. Pela afirmativa, REGO, Carlos Francisco de Oliveira Lopes do. Comentários ao Código de Processo Civil, cit., p. 263.

${ }^{430} \mathrm{Em}$ vista do revogado CPC italiano, Calamandrei apontava que o seu sistema, fugindo do arbítrio judicial na eleição do procedimento, construía o procedimento não como uma peça só, mas sim como um "mecanismo composto de peças desmontáveis e combináveis entre si de distintas maneiras, que corresponde à sensibilidade das partes e à prudência do juiz ao montar caso a caso do modo mais conforme aos fins da justiça" (CALAMANDREI, Piero. Direito processual civil, cit., v. 1, p. 300).

${ }^{431}$ Calamandrei, ao investigar o poder criador do juiz, anota que em alguns casos o sistema processual substitui a fórmula de criação legislativa do direito pela de formulação judicial, casos em que, mesmo não havendo os caracteres de generalidade e abstração próprios da lei, o comando judicial, ainda que limitado e em caso singular, tem eficácia inovativa típica do ato legislativo (CALAMANDREI, Piero. Direito processual civil, cit., v. 1, p. 165).
} 
imaginadas pelo legislador, como nos artigos 330; 331, § 3º 527, II; 557 e 557-A; todos do CPC. Só em algumas poucas e específicas hipóteses (lamentavelmente) que o nosso legislador admitiu a flexibilização de maneira genérica, delegando ao juiz a adaptabilidade, como fez na última parte do art. 21 da Lei de Arbitragem (Lei n. 9.307/96), ou no art. 153 do Estatuto da Criança e do Adolescente (Lei n. 8.069/90).

Nas demais hipóteses em que, apesar da omissão legislativa, as variantes rituais forem indispensáveis para a construção de um procedimento aderente à qualidade especial das partes ou ao direito material, não me parece afastada a possibilidade de ser permitida a adaptação com base na instrumentalidade das formas. Não sendo, todavia, o regime padrão brasileiro, o seu emprego só se dará em caráter absolutamente excepcional (inexistência de procedimento legal útil ou adequado) e observados os condicionamentos já estudados outrora (finalidade, contraditório útil e motivação) (cf. item 3.6).

Finalmente, pese a aparente indisponibilidade dos procedimentos, é possível, à luz de um novo enfoque do direito processual e análise de algumas situações já contempladas em lei, permitir aos litigantes certa dose de liberdade na escolha do procedimento ou de alguns atos processuais.

Abaixo procuraremos investigar a incidência prática dos regimes de flexibilização apresentados, assim sumarizados:

- Flexibilidade procedimental legal genérica

- Flexibilidade procedimental legal alternativa

- Flexibilidade procedimental judicial

- Flexibilidade procedimental voluntária

Os três primeiros regimes são dirigidos preponderantemente à figura do juiz (dominus processus), responsável por dirigir e conduzir o procedimento do começo ao fim (art. 125 do CPC). A atuação das partes se dá em colaboração a bem da eleição da melhor opção procedimental.

No último regime a equação se inverte. A flexibilidade parte dos litigantes, competindo ao juiz papel secundário de controle da legalidade e, especialmente, da razoabilidade, da opção eleita. 


\subsection{Flexibilidade procedimental legal genérica}

O estudo da flexibilidade procedimental por força da lei pressupõe que o legislador, não se julgando totalmente capacitado em promover a prévia antevisão das nuances práticas e conseqüente adaptação dos procedimentos ao caso em concreto, ou a deixou ao exclusivo critério do órgão judicial, ou indicou algumas variantes procedimentais a serem judicialmente eleitas conforme as particularidades do feito.

No primeiro caso tem-se a flexibilização legal genérica, em que será mesmo o juiz, com a colaboração das partes, que elegerá a melhor combinação de atos processuais. No outro caso tem-se a flexibilização legal por tramitações procedimentais alternativas (item 5.3.)

Anote-se que nas situações em que é conferido ao juiz o poder de eleger o melhor procedimento para o caso, sua decisão deve ser pautada pela consciência e equidade, o que não significa que o juiz seja aqui livre para decidir segundo seu capricho individual. A autorização é para que, em conjunto com as partes, procure, caso a caso, a solução que corresponda melhor às concepções morais e econômicas vigentes ao seu tempo, adaptando o procedimento, assim, às circunstâncias subjetivas ou objetivas da causa. ${ }^{432}$

Trata-se, assim, de um critério de encaminhamento de casos singulares, que se apresenta como essencial e sob a forma de uma cláusula geral. A atividade do juiz é muito mais complexa - e por isto mesmo de se exercer com muito mais cautela - do que a de conduzir o procedimento cujos atos processuais já tenham sido eleitos pelo legislador, que os estabelecera prévia e rigidamente. ${ }^{433}$

\footnotetext{
${ }^{432}$ Cf. CALAMANDREI, Piero. Direito processual civil, cit., v. 1, p. 98-99. O autor nomina esta atividade criadora do juiz como "diagnose política das forças sociais, que no sistema da formulação legal, está realizado exclusivamente pelos órgãos legislativos".

${ }^{433} \mathrm{~A}$ luz desta complexidade para a utilização da equidade, inclusive no aspecto processual, coube a Aristóteles, em lição não superada até hoje, definir que o "eqüitativo é justo, porém, não o é legalmente justo, e sim uma correção da justiça legal. A razão disto é que toda a lei é universal, mas a respeito de certas coisas não é possível fazer uma afirmação universal que seja correta. Portanto, quando a lei se expressa universalmente e surge um caso que não é abrangido pela declaração universal, é justo, uma vez que o legislador falhou, e errou por excesso de simplicidade, corrigir a omissão, em outras palavras, dizer o que o próprio legislador teria dito se estivesse presente, e que teria incluído na lei se tivesse conhecimento do caso" (ARISTÓTOLES. Ética a Nicômano. São Paulo: Abril Cultural, 1979. v. 2, p. 136. (Os pensadores)). No mesmo sentido cf. FRANÇA, Rubens Limongi. Formas e aplicação do direito positivo. São Paulo: Ed. Revista dos Tribunais, 1969. p. 73-74; e CARMINGNANI, Maria Cristina da Silva. O direito judicial como forma de resolução dos anseios por justiça, cit., p. 253.
} 
Daí porque neste modelo, tanto quanto na flexibilização judicial do procedimento, incidem todos os condicionamentos estudados no item 3.7 supra (finalidade, contraditório útil e motivação).

\subsubsection{Art. 153 do Estatuto da Criança e do Adolescente (Lei n. 8.069/90)}

$\mathrm{O}$ art. 153 do Estatuto da Criança e do Adolescente (Lei n. 8.069/90) é bom exemplo de disposição legal que contempla a flexibilidade de maneira genérica, deixando ao bom critério do juiz, sem restrições expressas, a eleição do melhor procedimento. Consta do dispositivo que "se a medida judicial a ser adotada não corresponder ao procedimento previsto nesta ou em outra Lei, a autoridade judicial poderá investigar os fatos e ordenar, de ofício as providências necessárias, ouvido o Ministério Público". 434

No dizer de prestigiosa doutrina, o texto legal dispõe, a um tempo, sobre procedimento e poderes do juiz. Na parte que nos interessa, anota que não existindo procedimento específico contemplado na lei, a regra não será mais a da aplicação subsidiária do procedimento ordinário previsto no CPC, mas sim de adoção do procedimento que parecer mais adequado para a tutela jurídica da situação. ${ }^{435}$

Em virtude desta diretriz, o ECA conferiu ao juiz ampla liberdade no que toca ao procedimento, libertando-o de amarras formais corriqueiras nos procedimentos regulados pelo Código de Processo Civil. ${ }^{436}$

Contudo, é óbvio que a liberdade conferida não é um "cheque em branco". Como em toda hipótese de flexibilização do procedimento, deverão ser observados os condicionamentos mínimos para variação do procedimento (finalidade, contraditório útil e motivação), não sendo possível, ainda, que com a variação ritual se ofendam as garantias

\footnotetext{
${ }^{434}$ Esta disposição não é nova e só foi repetida do revogado Código de Menores, que em seu art. 87 dispunha: "se a medida judicial a ser adotada não corresponde a procedimento previsto nesta ou em outra lei, a autoridade judiciária poderá investigar livremente os fatos e ordenar, de ofício, as providências".

${ }^{435}$ WATANABE, Kazuo. In: CURY, Munir (Coord.). Estatuto da Criança e do Adolescente comentado 6. ed. São Paulo: Malheiros Ed., 2003. p. 496.

${ }^{436}$ LIBERATI, Wilson Donizeti. Comentários ao Estatuto da Criança e do Adolescente. 9. ed. São Paulo: Malheiros Ed., 2006. p. 155.
} 
constitucionais do processo. ${ }^{437}$ A atuação obrigatória do Ministério Público nestes atípicos procedimentos (art. 82, I, do CPC) está aí exatamente para garantia contra iniqüidades. ${ }^{438}$

Alguns comentadores do ECA apontam que a disposição nada mais faz do repetir o disposto no art. 1.109 do CPC, eis que a autorização para o juiz proceder de forma liberta no procedimento é fruto da natureza não contenciosa da jurisdição exercida pelo juiz da infância e da juventude. ${ }^{439}$

Não nos parece assim. Primeiro, porque a norma não faz referência ao caráter voluntário da jurisdição para permitir a aplicação do dispositivo (que, aliás, está no capítulo dos procedimentos do ECA, entre os quais há inúmeros de manifesta contenciosidade). E segundo, principalmente, porque em várias atuações do juiz da infância, muitas a respeito das quais não há sequer previsão legal, há indiscutível resistência do infante, genitores ou do violador das normas de proteção do ECA, manifestado, daí, o caráter contencioso da demanda.

A utilidade e a enorme abrangência do dispositivo vêm sendo postas em relevo pela jurisprudência e doutrina.

$\mathrm{Na}$ inexistência de disposição legal específica, competirá ao juiz fixar o procedimento para constatação das circunstâncias de abandono de infante, especialmente para verificar, junto aos órgãos competentes, a existência de registro de desaparecimento da criança, tudo com vistas à identificação dos pais. Neste procedimento, onde poderão ser ouvidas testemunhas e expedidos ofícios, caso não seja identificada a origem da criança, poderá o magistrado determinar a inscrição de seu registro com dados fictícios (dados de caridade), nos termos do art. 102 do ECA. Esgotadas todas as diligências e mesmo assim não sendo localizados os genitores, a criança será colocada em família substituta e no cadastro de crianças aptas a adoção (art. 50 do ECA). ${ }^{440}$

Outra atuação do juiz da infância e da juventude para a qual não há procedimento previsto em lei é a de suprimento de autorização para viagem ao exterior

\footnotetext{
${ }^{437}$ HERKENHOFF FILHO, Helio Estellita. Suprimento judicial de autorização para viagem ao exterior. Jus Navegandi. Disponível em: <http://jus2.uol.com.br/doutrina/texto.asp?id+4743>. Acesso em: 22 ago. 2006.

${ }^{438}$ ELIAS, Roberto João. Comentários ao Estatuto da Criança e do Adolescente. 2. ed. São Paulo: Saraiva, 2004. p. 178.

${ }^{439}$ ELIAS, Roberto João. Comentários ao Estatuto da Criança e do Adolescente, cit., p. 157.

${ }^{440}$ CARNEIRO, Rosa. Da desnecessidade de citação por edital nos pedidos de adoção de crianças e adolescentes cujos pais são desconhecidos. Ministério Público. Rio Grande do Sul. Disponível em: <www.mp.rs.gov.br/infancia/doutrina/id178.htm?impressao+1\&>. Acesso em: 23 ago. 2006.
} 
(artigos 84 e 85 do ECA). Recusando-se imotivadamente um dos genitores a permitir que o filho viaje ao exterior, a saída do país só será permitida após prévia autorização judicial, caso em que o magistrado, dentro de seu livre arbítrio e da urgência que acode o caso (viagem urgente), regulará o procedimento para constatação da indevida recusa (inclusive quanto aos prazos). ${ }^{441}$

Reconheceu-se, também, dever judicial de investigar narrativa de maus tratos apresentada por coordenadoria municipal de bem estar social, na forma do art. 153 do ECA, sendo vedado ao juiz negar sua atuação a pretexto de que o Conselho Tutelar tem atribuições para aplicação de medidas adequadas. ${ }^{442}$

Em outro julgado, assentou-se até mesmo, com base no art. 153 do ECA, a desnecessidade de citação da genitora dos menores notoriamente abandonados para o procedimento de colocação deles em entidade de abrigo ${ }^{443}$, ou a concessão de tutela liminar, antes mesmo da necessária emenda da inicial, tudo para a proteção integral do infante. $^{444}$

$\mathrm{Na}$ inexistência de previsão procedimental, adotou-se a liberdade de procedimento do ECA para desacolher pedido de genitor (sem advogado), no qual impugnava a negativa de matrícula de seu filho junto a Escola Estadual, por força de decisão do Conselho da Escola (indisciplina e rebeldia do infante). ${ }^{445}$

E em mais de uma passagem, se reconheceu a possibilidade de se adotar a flexibilização do procedimento em ações de busca e apreensão, ajuizada pelo Ministério

\footnotetext{
${ }^{441}$ Em nossa experiência profissional já atuamos em caso de suprimento contencioso de autorização para viajar ao exterior, onde o genitor, não concordando com a mudança de domicílio da ex-esposa e guardiã do filho para a África do Sul, se opôs à saída do infante do país. Ajuizada a ação pela guardiã para obter o suprimento, adotou-se procedimento célere, com citação pessoal do genitor para resposta em 05 (cinco) dias, realizando-se concomitantemente estudo social no ato citatório, e posterior instrução (prova oral). Ao final deferiu-se o pedido inicial, e como não foi concedido efeito suspensivo à apelação interposta, a autora viajou acompanhada do filho para o exterior.

${ }^{442}$ TJ/SP, Apelação n. 077.777.0/3-00, Rel. Des. Sérgio Gomes, Sumaré, Câmara Especial, j. 14.05.2001. No mesmo sentido cf. TJ/RS, Agravo de instrumento n. 70004707741, Rel. Des. Marilene Bonzanini Bernardi, $2^{\text {a }}$ Câmara Especial, Santa Cruz do Sul, j. 23.06.2003, v.u.

${ }^{443}$ TJ/SP, Apelação n. 25.546.0/4-00, Rel. Des. Lair Loureiro, Marília, Câmara Especial, j. 29.06.1995.

${ }^{444}$ TJ/MG, Apelação n. 1.000.00.316279-9/000(1), Rel. Des. Corrêa de Marins, 4 ${ }^{\mathrm{a}}$ Câmara Cível, j. 10.04.2003, Belo Horizonte, v.u.

${ }^{445}$ TJ/SP, Apelação n. 23.683-0/6, Rel. Des. Lair Loureiro, Guarulhos, Câmara Especial, j. 01.06.1995.
} 
Público com fundamento no ECA, para o fim de retirar dos genitores crianças exploradas para a prática de mendicância. ${ }^{446}$

\subsubsection{Art. 1.109 do CPC (jurisdição voluntária)}

Sem adentrarmos em intrincadas discussões a respeito do tema, o fato é que são conhecidas as dificuldades que a própria doutrina tem para explicar o que seja jurisdição voluntária. $^{447}$ Aponta-se que não se trata de atividade jurisdicional ${ }^{448}$, pois não se estaria compondo litígios, declarando, satisfazendo ou acautelando direitos. ${ }^{449}$ Muito menos voluntária, pois se exerce, em princípio, mediante provocação das partes (art. 1.104, CPC). Chega-se, até, a afirmar que inexiste processo nesta sede, mas mero procedimento (cf. item 2.4.3.2.). Trata-se de "função estatal de administração de direitos subjetivos (de ordem privada principalmente), que o Estado exerce, preventivamente, através de órgãos judiciários, com o objetivo de constituir negócios e relações jurídicas dos particulares, ou de modificar e extinguir relações e negócios já existentes". 450

De qualquer forma, o fato é que a lei, para certos tipos de atos, exige a intervenção da Administração Pública para a constituição de negócios jurídicos privados, seja de ordem patrimonial, seja de ordem pessoal. Tal intervenção pode se operar através de órgãos judiciais (interdição, autorização para casamento de incapaz em virtude de gravidez), extrajudiciais, mas dependentes do Judiciário (Cartório de Registro Civil nos casamentos, separação e divórcios; Cartório de Notas na doação) ou órgãos administrativos independentes do Judiciário (registro de patentes no Departamento Nacional de

\footnotetext{
${ }^{446}$ TJ/MG, Apelação n. 1.000.00.254328-8/000(1), Rel. Des. Kildare Cavalho, $3^{\text {a }}$ Câmara Cível, Belo Horizoente, j. 08.05.2003, v.u.; Apelação n. 1.000.00.253875-9/000(1), Rel. Des. Kildare Carvalho, $3^{\mathrm{a}}$ Câmara Cível, Belo Horizonte, j. 08.08.2002, v.u.

${ }^{447}$ Cf. COSTA, Alfredo de Araújo Lopes da. A administração pública e a ordem jurídica privada, cit., p. 1; e MARQUES, José Frederico. Ensaio sobre a jurisdição voluntária, cit., p. 113 e ss. Para análise da distinção entre jurisdição contenciosa e voluntária, cf. por todo SANTOS, Moacyr Amaral dos. Primeiras linhas de direito processual civil, cit., v. 1, p. 80-82.

${ }^{448}$ Em sentido contrário: DINAMARCO, Cândido Rangel. Procedimentos especiais de jurisdição voluntária, cit., v. 1, p. 384; FAZZALARI, Elio. La giurisdizione volontaria: profilo sistemático, cit., cap. II-IV, passim; SILVA, Ovídio A. Baptista. Curso de processo civil. 5. ed. São Paulo: Ed. Revista dos Tribunais, 2000. v. 1, p. 44-50.

${ }^{449}$ Afinal, a atuação do Judiciário nos feitos de jurisdição voluntária: a) não objetiva a aplicação do direito, mas sim a constituição de situações jurídicas novas; b) não substitui a vontade das partes, eis que o juiz atua como mero interventor para emprestar validade ao negócio jurídico privado; e c) não objetiva, como regra, solucionar um conflito, eis que inexistente (CINTRA, Antonio Carlos; GRINOVER, Ada Pellegrini; DINAMARCO, Cândido Rangel. Teoria geral do processo, cit., p. 163).

${ }^{450}$ MARQUES, José Frederico. Instituições de direito processual civil. Campinas: Millenium, 2000. v. 1, p. 304.
} 
Propriedade Industrial, arquivamento de documentos na Junta Comercial, fiscalização do Ministério Público sobre as fundações) ${ }^{451}$. É a lei, em última instância, qualificando o interesse privado a ser tutelado, que define o órgão estatal a intervir: judicial, extrajudicial ou administrativo ${ }^{452}$.

Exatamente por se tratar de atividade jurisdicional atípica, o legislador permitiu que o magistrado, na busca da melhor intervenção no negócio jurídico alheio, pudesse se afastar dos critérios de legalidade estrita de fundo e de forma (art. 127 do $\mathrm{CPC})^{453}$. O art. 1.109 do CPC, que trata da jurisdição voluntária, aponta que "o juiz decidirá o pedido no prazo de 10 (dez); não é, porém, obrigado a observar critério de legalidade estrita, podendo adotar em cada caso a solução que reputar mais conveniente e oportuna”.

\footnotetext{
${ }^{451}$ MARQUES, José Frederico. Instituições de direito processual civil, cit., p. 301-302.

${ }^{452}$ Exatamente por isso - por não afastar o controle judicial dos atos em geral, já que não se trata de atividade jurisdicional, mas sim administrativa - é que nada impede vir a lei, em nova apreciação sobre o interesse privado a ser tutelado, a dispensar a intervenção ou alterar o órgão interventor, fazendo com que ele deixe de ser exercido pelo Judiciário, e passe a ser por uma serventia oficializada (extrajudicial), ou por um órgão independente (Ministério Público), e vice-versa, como recentemente ocorreu através da Lei n. 11.441/2007, que facultou o curso das separações, divórcios e inventários consensuais perante o Cartório de Notas. A conclusão não é nossa, mas sim de José Roberto dos Santos Bedaque, para quem "poderia a atividade do juiz, nesses casos, ser exercida por órgãos administrativos, o que, aliás, ocorre em outros casos (realização de casamento, transmissão de domínio sobre bens imóveis, constituição de sociedades). Quisesse o legislador infraconstitucional transferir a homologação de uma separação consensual para qualquer ente público (MP, p. ex.), tal regra não violaria o princípio da inafastabilidade da jurisdição (CF, art. $\left.5^{\circ}, \mathrm{XXXV}\right)$, pois não se trata de atividade tipicamente jurisdicional" (BEDAQUE, José Roberto dos Santos. Direito $e$ processo, cit., p. 65). No mesmo sentido, DINAMARCO, Cândido Rangel. Procedimentos especiais de jurisdição voluntária, cit., p. 392; e CALAMANDREI, Piero. Direito processual civil, cit., v. 1, p. 157.

${ }^{453}$ Existe interessante discussão doutrinária se a autorização legal permite que o juiz deixe de aplicar a lei posta. Se há dúvida no que toca à aplicação das regras de fundo, não parece haver dúvida alguma no que toca às regras de procedimento: aqui o juiz pode se afastar do modelo legal em favor de uma mais adequada solução da demanda. Daí porque equivocado, a nosso ver, o julgado, no sentido de que "a autorização para que o juiz decida sem observar o critério da legalidade estrita nos processos de jurisdição voluntária não configura autorização para que decida contra a lei” (TJ/MS, MS n. 245/85, Rel. Des. Leão Neto do Carmo, j. 19.08.1985), sem que seja feita a ressalva de que o entendimento é exclusivo para as regra de direito material. No âmbito procedimental, se a autorização é para a não aplicação da legalidade estrita, perfeitamente possível que o magistrado se afaste da disposição legal cogente que, ao seu entender, é procedimentalmente iníqua para o caso concreto. Daí porque também não concordamos integralmente com Marcato, que não faz ressalva quanto a vinculação do juiz ao direito constituído nos casos de jurisdição voluntária (MARCATO, Antonio Carlos. Procedimentos especiais, cit., p. 327). Se é permitido ao juiz, conforme assevera o próprio autor, exercer sua tarefa de acordo com "critérios de conveniência e oportunidade", isto implica, ao menos no âmbito processual, na dispensa de atos processuais e inserção de outros na série, o que vai de encontro à lei posta. Aliás, neste sentido, decidiu com razão o extinto Tribunal de Alçada mineiro que a liberdade de se afastar do critério de legalidade estrita refere-se à "atividade processual” do juiz, não podendo alcançar "o direito material” (RJTAMG 51/126).
} 
No que nos interessa, trata-se de regra legal flexibilizadora do procedimento de cunho genérico, apontada por parcela da doutrina como permissiva do exercício da jurisdição de equidade (em contraposição à jurisdição de direito). ${ }^{454}$

O recurso à equidade neste tipo de jurisdição, pode deixar clara a inadequação da norma jurídica abstrata devido a, por exemplo, um processo de mudanças sociais ou práticas. A equidade, assim, exige uma reflexão permanente sobre o Direito e sua aplicação (donde dizer-se ser a equidade a consciência do direito, ou o direito aplicado ao caso concreto). Duas são, portanto, as funções para a equidade: "proporcionar um critério para a interpretação jurídica, concedendo ao intérprete maior autonomia, e constituir-se, como consciência do Direito, em impulso para as respectivas mudanças, buscando o Direito, o novo Direito, como solução justa para os casos concretos”. ${ }^{455}$

Daí porque, observadas as limitações mínimas já estudadas (finalidade, contraditório útil e motivação), pode o juiz, à luz da equidade, eleger qual o melhor procedimento para a sua atuação em sede de jurisdição voluntária, alterando, excluindo ou acrescentando ato processual à série padrão. ${ }^{456}$ Só fará incidir o procedimento ordinário geral (art. 271 do CPC) se não houver nenhuma variante objetiva ou subjetiva que justifique a inovação procedimental, ou procedimento especial previsto nos artigos $1.113 \mathrm{e}$ ss. do CPC. ${ }^{457}$

Exemplificativamente, em sede de interdição (art. 1.177 e ss. do CPC), possível a dispensa do ato processual perícia, referida no art. 1.183 do CPC, quando no interrogatório do interditando já ficar constatada a sua mais absoluta incapacidade para a

\footnotetext{
${ }^{454}$ CINTRA, Antonio Carlos; GRINOVER, Ada Pellegrini; DINAMARCO, Cândido Rangel. Teoria geral do processo, cit., p. 156; cf. Dinamarco, Procedimentos especiais de jurisdição voluntária, cit., p. 397-398. A equidade é uma cláusula geral que se faz presente, em maior ou menor grau de intensidade, em todos os sistemas jurídicos que se tem notícia desde Roma. Excepcional por natureza, só é aplicável às hipóteses legais previamente estabelecidas. Conforme Guido Alpa, várias são as formas de equidade, entre elas a interpretativa, a corretiva, a quantificadora, a integrativa e, a processual, como se sustenta ocorrer na hipótese ora em estudo (ALPA, Guido. Trattato di diritto civile: storia, fonti, interpretazione. Milano: Giuffrè, 2000. p. 961 e ss.).

${ }^{455}$ Cf. AMARAL NETO, Francisco dos Santos. A equidade no Código Civil brasileiro. Revista do Centro de Estudos Judiciários, Brasília, n. 25, p. 18, abr.jun. 2004.

${ }^{456}$ Esta, aliás, é a astuta observação de Ernane Fidélis dos Santos, no sentido de que o juiz não tem a faculdade de alterar o direito material, mas pode alterar as normas procedimentais, aceitando, por exemplo, testemunho oral pelo escrito, ou perícia por informação técnica (Manual de direito processual civil, cit., v. 3, p. 375-376).

${ }^{457}$ No sentido de que o procedimento ordinário, com as alterações dos artigos 1.103 a 1.111 do CPC, é o rito padrão dos procedimentos de jurisdição voluntária, cf. DINAMARCO, Cândido Rangel. Procedimentos especiais de jurisdição voluntária, cit., p. 394.
} 
vida civil, ou a sua substituição por atestado de incapacidade subscrito pelo médico particular do enfermo.

Possível, também, a dispensa do ato de interrogatório do interditando, referido no art. 1.181 do CPC, quando o oficial de justiça, ao proceder a citação, já constatar o estado vegetativo do interessado. ${ }^{458}$

No pedido de alienação judicial de bem, nada impede que o magistrado afrouxe o rigor formal da norma, autorizando a alienação particular de imóvel de incapaz sujeito a tutela ou curatela (art. 1750 do CC), ou que, tendo dúvida sobre a idoneidade e seriedade do representante de menor não sujeito a tutela ou curatela, determine, a despeito da inexigência legal, a alienação de seus imóveis por hasta pública. ${ }^{459}$

Ainda em relação à alienação judicial de bens, admite-se com base na norma flexibilizadora a realização de uma única praça ${ }^{460}$. E antes mesmo da Lei n. 11.382/2006 (art. 685-C do CPC), já admitíamos a alienação particular do bem comum (via corretor de imóveis), com fundamento na flexibilidade do procedimento expropriatório haurida do art. 1.109 do $\mathrm{CPC}^{461}$

Já se entendeu, por exemplo, que não é nula sentença proferida em feito de jurisdição voluntária, ainda que não se observem os rigores do art. 458 do CPC para sua prolação, eis que o art. 1.109 do CPC flexibiliza as regras de forma nesta seara. ${ }^{462}$

Ademais, há inúmeros procedimentos de jurisdição voluntária em que não há citação (v.g. separação judicial consensual) e sequer resposta (interdição), o que denota o caráter altamente adaptável dos procedimentos em feitos desta natureza, com possibilidade de dispensa de atos processuais expressamente previstos para a série (artigos 1.105 e 1.106 do CPC).

\footnotetext{
${ }^{458} \mathrm{TJ} / \mathrm{SP}$, Agravo de Instrumento n. 329.487-4/5, São José dos Campos, $7^{\text {a }}$ Câmara de Direito Privado, Relator: Oswaldo Breviglieri, j. 31.03.04. Cf., também, RT 786/270 e JTJ 170/166.

${ }^{459}$ Manual de direito processual civil, cit., v. 3, p. 376.

${ }^{460} \mathrm{TJ} / \mathrm{SP}$. Agravo de Instrumento n. 198.531-4 - Catanduva - 5a Câmara de Direito Privado - Relator: Rodrigues de Carvalho - j. 17.05.2001.

${ }^{461}$ RT 767/238 e JTJ 158/209. Em sentido contrário cf. JTJ 220/180.

${ }^{462}$ TJ-SP, Apelação Cível n. 92.385-4 - Monte Azul Paulista - 6 Câmara de Direito Privado - Relator: Ernani de Paiva - j. 23.03.2000.
} 


\subsubsection{Art. 21 e $§ 1^{\circ}$ da Lei de Arbitragem (Lei n. 9.307/96)}

A arbitragem é um mecanismo de solução das controvérsias pela qual um ou vários terceiros recebem, através de uma convenção de natureza privada firmada pelas partes, poderes para, sem a intervenção do Estado, solucionar, definitivamente, os litígios relativos a direitos patrimoniais.

Embora tradicionalmente prevista nas legislações civis e comerciais brasileiras, somente com o advento da Lei n. 9.307, de 23.9.1996, que a arbitragem passou de "velharia bolorenta e imprestável ${ }^{463}$ " a avançado mecanismo extrajudicial de solução das controvérsias.

De fato, diferentemente do tratamento até então reservado ao instituto (artigos 1.072 a 1.102 do $\mathrm{CPC})^{464}$, a Lei n. $9.307 / 96$ inovou na ordem jurídica interna, reconhecendo a eficácia da cláusula compromissória - admitindo, inclusive, sua execução específica para fins de instituição compulsória do Juízo Arbitral (art. $7^{\circ}$ ) - e dispensando de homologação estatal os laudos arbitrais, os quais têm eficácia de título executivo, independentemente de qualquer chancela do Judiciário (art. 31 da Lei n. 9.307/96).

No que tange ao procedimento, tanto quanto no direito francês e italiano ${ }^{465}$, o art. 21 da nossa lei prevê que "a arbitragem obedecerá ao procedimento estabelecido pelas partes na convenção de arbitragem, que poderá reportar-se às regras de um órgão arbitral institucional ou entidade especializada, facultando-se, ainda, às partes delegar ao próprio árbitro, ou ao tribunal arbitral, regular o procedimento".

Os $\S \S 1^{\circ}$ e $2^{\circ}$ do dispositivo (art. 21 da Lei n. 9.307/96) completam a disciplina do assunto ao indicarem que "não havendo estipulação acerca do procedimento, caberá ao árbitro ou ao tribunal arbitral discipliná-lo", sempre respeitados "os princípios do contraditório, da igualdade das pares, da imparcialidade do árbitro e de seu livre convencimento".

\footnotetext{
${ }^{463}$ CARMONA, Carlos Alberto. Arbitragem e processo: um comentário à Lei n. 9.307/96, cit., p. 16.

${ }^{464}$ Cf. CARMONA, Carlos Alberto. Arbitragem internacional. Revista Forense, Rio de Janeiro, n. 329, p. 2539, mar. 1995.

${ }^{465} \mathrm{E}$ para análise de direito comparado em relação ao tema, remetemos o leitor ao breve, porém excelente, estudo de J.M. Othon Sidou, A arbitragem no direito comparado e a lei n. 9.307/96. Revista da Academia Brasileira de Letras Jurídicas, Rio de Janeiro, ano 10, n. 10, p. 99-122, 2. sem. 1996.
} 
Vê-se, então, que em sede de procedimento arbitral, três são as possibilidades rituais. Não havendo estipulação das regras de forma pelas partes $\left(1^{\mathrm{a}}\right.$ opção) ${ }^{466}$, que também não indicaram as regras do órgão arbitral institucional, de uma entidade especializada, ou, acrescente-se, de um procedimento outro qualquer, previsto, por exemplo, no Código de Processo Civil ( $2^{\mathrm{a}}$ opção $)^{467}$, competirá ao árbitro, juiz de fato e de direito da causa (art. 18 da Lei n. 9.307/96), eleger o melhor procedimento para a solução do conflito ( $3^{\mathrm{a}}$ opção), sempre respeitadas as garantias constitucionais do processo. ${ }^{468}$

Note-se, assim, que houve inversão da sistemática até então adotado pelo CPC (artigos 1.091 a 1093 do CPC), eis que o legislador não traçou um procedimento suplementar para a hipótese de as partes nada terem disciplinado quanto ao procedimento arbitral, casos em que restará ao árbitro tal tarefa.

Pese a fonte dos poderes do árbitro (a convenção de arbitragem) ser distinta da fonte dos poderes do juiz estatal (a lei), o fato é que em ambas as hipóteses a função de ambos é idêntica: solucionar o conflito da melhor forma possível. E, para tanto, a lei confere ao árbitro ampla liberdade procedimental nas hipóteses em que as partes não dispuseram a respeito.

Observe-se o paradoxo: o árbitro, que aprecia exclusivamente questões relacionadas a direito disponíveis de cunho privado (art. $1^{\circ}$ da Lei n. 9.307/96), pode receber das partes expressa ou tacitamente poderes para eleger o procedimento, adequando-o à exata tutela da situação subjetiva e objetiva do caso. Mas o juiz, a quem é conferido, em tese, o dever de decidir também sobre direitos indisponíveis

\footnotetext{
${ }^{466} \mathrm{~A}$ estipulação de regras procedimentais pelas partes permite-lhes definir prazos específicos para cada uma (inclusive diferenciados), inclusive para o árbitro, meios de prova, regras sobre distribuição do ônus da prova, forma de condução da audiência (inclusive com possibilidade de perguntas diretas às testemunhas), ordem de produção de provas, existência de recursos no âmbito do próprio procedimento arbitral, etc. A respeito cf. CARNEIRO, Paulo Cezar Pinheiro. Aspectos processuais da nova lei de arbitragem. In: CASELLA, Paulo Borba (Coord.). Arbitragem: lei brasileira e praxe internacional. 2. ed. São Paulo: LTr, 1999. p. 291-315; e MAGALHÃES, José Carlos de. Arbitragem e processo judicial. Revista do Advogado da AASP, São Paulo, ano 26, n. 87, p. 63-64, set. 2006.

${ }^{467}$ Cf. SANTOS, Francisco Cláudio Almeida. As provas no procedimento arbitral. Revista de Processo, São Paulo, ano 22, n. 88, p. 83, out./dez. 1997. E aqui vale destacar que as regras aplicáveis do órgão arbitral institucionalizado, da entidade especializada, ou do próprio CPC, são aquelas que eram válidas no momento da celebração da cláusula ou do compromisso, visto que passam elas a integrar, tais quais vigentes, a própria convenção, sendo desprezadas, portanto, eventuais alterações normativas estabelecidas após esta data.

${ }^{468}$ Certamente, entre estas três opções rituais, a hipótese menos comum é a de eleição de procedimento especial pelas próprias partes, principalmente em sede de cláusula compromissória, eis que as partes não desejam e imaginam o conflito futuro e incerto. E a mais comum, segura e utilizada é a de indicação do procedimento de órgão institucional para a solução do conflito, ainda que o árbitro eleito não seja vinculado ao órgão (CARMONA, Carlos Alberto. Arbitragem e processo: um comentário à Lei n. 9.307/96, p. 249-250).
} 
(hipoteticamente de maior grau de importância), não recebe do legislador brasileiro, ao menos de forma genérica e de maneira expressa, autorização para a adequação formal do procedimento, nem que seja só para estas causas!

Isto porque, como regra, o procedimento judicial é rígido. Até em função da necessidade de controle do arbítrio do desconhecido julgador; o juiz nem as partes têm muita flexibilidade na sua condução. Os prazos são definidos em lei ou, em alguns casos, pelo juiz, mas nunca pelas partes, compelidas a observar as disposições genéricas da lei processual. A perda de um prazo tem conseqüências legais que, como regra, não podem ser afastadas pelo juiz (preclusão e revelia).

Já o processo arbitral é flexível, permitindo às partes definir os prazos que lhes convêm, a forma e a ordem da produção da prova. O perdimento de um prazo pode ser relevado e não acarreta, necessariamente, a presunção de veracidade dos fatos. Não pululam questões processuais e recursos de questões processuais, eis que a maleabilidade permite o caminhar do procedimento conforme a vontade dos litigantes ou do órgão julgador, e não se tem, como regra, um $2^{\circ}$ grau re-ratificador das deliberações arbitrais.

Pois é nesta possibilidade de manipulação do procedimento conforme a vontade das partes ou circunstâncias do caso que se aponta residir uma das grandes vantagens da arbitragem. $^{469}$ Não me parece vedado, inclusive, que mesmo após a eleição do procedimento, ou até mesmo no início do curso do processo arbitral, possam as partes, consensualmente, aditar a convenção de arbitragem para alterar o procedimento inicialmente escolhido.

Eleito o árbitro como o responsável pelo estabelecimento do procedimento (expressa ou tacitamente), compete a ele estabelecer previamente, fundamentadamente e com a participação das partes, os prazos e a ordem dos atos processuais que serão praticados na série. Não é porque estamos diante de jurisdição ${ }^{470}$ não estatal que as

\footnotetext{
${ }^{469}$ A conclusão é de José Carlos de Magalhães, que ainda aduz ser um risco ao sucesso da arbitragem a sua processualização como nas demandas judiciais (Arbitragem e processo judicial, p. 64-65).

${ }^{470}$ Jurisdição mesmo! Antes do advento da Lei n. 9.307/96, Nelson Nery Júnior e Rosa Maria de Andrade Nery já indicavam ser adeptos da teoria jurisdicionalista da arbitragem. (NERY JÚNIOR, Nelson; NERY, Rosa Maria de Andrade. Código de processo civil comentado e legislação extravagante. 1. ed. São Paulo: Ed. Revista dos Tribunais, 1994. 94, nota ao art. 1.078). No mesmo sentido, mas já com vistas à Lei n. 9.307/96, sustentamos em outro estudo o caráter jurisdicional da arbitragem (GAJARDONI, Fernando da Fonseca. Aspectos fundamentais de processo arbitral e pontos de contato com a Jurisdição estatal. Revista de Processo, São Paulo, n. 106, p. 190-192, abr./jun. 2002), bem acompanhados por João Bosco Lee (A especificidade da arbitragem comercial internacional. In: CASELLA, Paulo Borba (Coord.). Arbitragem:
} 
limitações à flexibilidade do procedimento - todas devidamente estudadas no item 3.7 podem ser desprezadas. ${ }^{471} \mathrm{O}$ procedimento eleito deve ter como objetivo resolver a disputa rápida, eficiente e economicamente. ${ }^{472}$

Todavia, mesmo que não deixado ao critério do árbitro a eleição do procedimento, não se lhe pode negar - como não se nega ao juiz também, dentro do ponto de vista defendido neste estudo - um certo grau de poder flexibilizador, um certo poder normativo no âmbito do procedimento. Afinal, haverá sempre espaço para adaptação ao caso efetivo as regras rituais aplicáveis, "até porque não se imagina um procedimento pré-concebido que seja tão completo que possa prever todas as situações e vicissitudes" de um caso in concreto. ${ }^{473}$

Seja o procedimento arbitral eleito pelas partes (inclusive com remissão a regras institucionais), seja o procedimento fixado pelo árbitro - inclusive com o poder flexibilizador que nos referimos há pouco - todos devem se subsumir ao modelo constitucional do processo civil brasileiro. É o limite que se impõem ao princípio da autonomia da vontade que rege o processo arbitral, eis que o procedimento (e o processo mesmo) não pode atentar contra os corolários do devido processo legal, entre eles o contraditório, a ampla defesa, a igualdade, da imparcialidade do árbitro e de seu livre convencimento, sob pena de nulidade da sentença arbitral (art. 32, VIII, c.c. art. 33, § $2^{\circ}$, I, da Lei n. 9.307/96). ${ }^{474}$

lei brasileira e praxe internacional, cit., p. 196); Adolfo Rivas (El arbitraje según el derecho argentino. Revista de Processo, São Paulo, v. 12, n. 45, p. 72, jan./mar. 1987); e Carlos Alberto Carmona. (Arbitragem e jurisdição. Revista de Processo, São Paulo, v. 15, n. 58, p. 33, abr./jun. 1990). Há autores, entretanto, como Giuseppe Chiovenda (Princípios de derecho procesal civil, cit., p. 109) e José Carlos Magalhães (Arbitragem internacional privada. In: ; BAPTISTA, Luiz Olavo (Coords.). Arbitragem comercial. Rio de Janeiro: Freitas Bastos, 1986. p. 17-30. p. 17-30) que vêem na arbitragem espécie de contrato (teoria contratualista), bem como outros que lhe dão natureza autônoma (BARRAL, Welber. Arbitragem e jurisdição. In: CASELLA, Paulo Borba (Coord.). Arbitragem: lei brasileira e praxe internacional, cit., p. 163-175).

${ }^{471}$ Como bem anota Luiz Olavo Baptista, o árbitro deverá ter suficiente sagacidade para escolher regras que sejam realmente necessárias para se adaptar à situação, e assim não se deixar levar pela tentativa de chicana ou de transformar o procedimento numa Disneyworld de processualistas"(BAPTISTA, Luiz Olavo. Arbitragem: aspectos práticos. Revista Brasileira de Arbitragem, n. 0, São Paulo, p. 218, jul./out. 2003).

${ }^{472}$ Este, aliás, é o enunciado n. VI, item X, do Código de Ética da American Bar Association (ABA) e American Arbitration Association (AAA) para os árbitros em disputas comerciais. Para análise de todos os enunciados, cf. LEMES, Selma Maria Ferreira. Árbitro: o padrão de conduta ideal. In: CASELLA, Paulo Borba (Coord.). Arbitragem: lei brasileira e praxe internacional, cit., p. 233-268.

${ }^{473}$ CARMONA, Carlos Alberto. Arbitragem e processo: um comentário à Lei n. 9.307/96, cit., p. 250. Eis porque não é incomum em procedimentos arbitrais a inversão da ordem tradicional de produção de provas, o poder concedido às partes de quesitar diretamente às testemunhas, a designação de audiência final comum para apresentação de alegações finais de forma oral.

${ }^{474}$ Para ampla abordagem sobre os princípios aplicáveis ao processo arbitral, especialmente da independência e da imparcialidade, cf. LEMES, Selma Maria Ferreira. Árbitro: princípios da independência e da imparcialidade. São Paulo: LTr, 2001, especialmente p. 52-72. Cf., também, SILVA NETO, Orlando Celso. Princípios do processo e arbitragem. In: CASELLA, Paulo Borba (Coord.). Arbitragem: lei brasileira e praxe internacional, cit., p. 352-366. 
A flexibilização do procedimento arbitral não pode ser confundida, por outro lado, com libertinagem ou promiscuidade procedimental. Uma vez fixado o procedimento pelas partes ou pelo árbitro, eventual violação injustificada do iter, acompanhado da prova do indispensável prejuízo, gera inconteste nulidade da sentença arbitral. ${ }^{475}$ Entendimento diverso tornaria inviável o curso da arbitragem, com ofensa expressa aos postulados de segurança e previsibilidade que informam o estudo do procedimento em matéria processual.

\subsubsection{Art. $6^{\circ}$ da Lei dos Juizados Especiais (Lei n. 9.099/95)}

O art. $6^{\circ}$ da Lei n. 9.099/95 aponta, na esteira do que já vinha expresso no art. $5^{\circ}$ da Lei dos Juizados de Pequenas Causas (Lei n. 7.244/1984), órgão sucedido pelos Juizados Especiais Cíveis, que "o juiz adotará em cada caso a decisão que reputar mais justa e equânime, atendendo aos fins sociais da lei e às exigências do bem comum".

$\mathrm{Na}$ doutrina encontram-se duas posições diametralmente opostas a respeito da natureza desta disposição.

A primeira, aparentemente majoritária, aponta que aí não se autoriza diversamente do que ocorre com os já analisados artigos 1.109, do CPC (jurisdição voluntária), e 21, da Lei de Arbitragem (Lei n. 9.307/96) - o que se convencionou chamar julgamento por equidade (art. 127 do CPC). Aduzem os defensores desta posição, que o texto não usa a expressão equidade, mas sim equânime, o que só serve para reforçar o dever do juiz de, em sede de Juizados, dar uma interpretação mais alargada às normas de forma de fundo, conclamando-o, neste plano, à escolha de teses que mais se coadunem com a indispensável justiça do caso concreto. ${ }^{476}$ Ao raiar desta interpretação haveria uma maior limitação (e não vedação) do magistrado na calibração da lei às peculiaridades do caso concreto.

\footnotetext{
${ }^{475}$ SANTOS, Francisco Cláudio Almeida. As provas no procedimento arbitral, cit., p. 84.

${ }^{476}$ DINAMARCO, Cândido Rangel. Manual dos juizados especiais cíveis. 2. ed. São Paulo: Malheiros Ed., 2001. p. 40; SILVA, Jorge Alberto Quadros de Carvalho. Lei dos juizados especiais cíveis anotada. 2. ed. São Paulo: Saraiva, 2001. p. 35-36; THEODORO JÚNIOR, Humberto. Curso de direito processual civil, cit., v. 3, p. 462; BATISTA, Weber Martins; FUX, Luiz. Juizados especiais cíveis e criminais e suspensão condicional do processo penal, cit., p. 232; e Joel Dias Figueira, a apontar que "o que legislador procurou fazer por meio do artigo objeto destes comentários foi ressaltar, e com absoluta razão, a necessidade de fazer ver, de uma vez por todas, que se faz imprescindível ultrapassar a barreira da mera subsunção para se atingir, finalmente, uma interpretação e aplicação da norma jurídica ao caso concreto, dentro de padrões sociológicos, axiológicos e teleológicos de interpretação (FIGUEIRA JÚNIOR, Joel Dias. Juizados especiais estaduais cíveis e criminais - comentários à Lei n. 9.099/95. 4. ed. São Paulo: Ed. Revista dos Tribunais, 2005. p. 150).
} 
Uma outra corrente ${ }^{477}$, da qual somos partidários, vê no dispositivo verdadeira autorização para julgamento por equidade, autorizada, portanto, de maneira genérica, a flexibilização das normas processuais e materiais em favor de um julgamento mais aderente à realidade da causa.

Com efeito, a expressão equânime é adjetivo daquele que age com equidade, não me parecendo, assim, que a obediência às regras de legalidade estrita seja imposta do ponto de vista redacional. Ademais, na medida em que o art. 25 da Lei n. 9.099/95 fala em possibilidade de julgamento por equidade pelo juiz leigo eleito pelas partes como árbitro, fazendo expressa referência ao artigo $6^{\circ}$ da mesma lei, não me parece que o dispositivo tenha querido dizer outra coisa se não que é dado a qualquer julgador em sede de JEC (juízes togados, leigos ou árbitros), diante de circunstância específicas do caso concreto, se afastar das regras legais cogentes. ${ }^{478}$

A primeira, interpretação, data venia, ignora por completo o espírito informador dos Juizados. Reduzi-lo a apenas mais um procedimento especial, excluindo a possibilidade da jurisdição de eqüidade, é frustrar os próprios objetivos deste sistema. ${ }^{479}$ De fato, pela sua própria natureza de justiça coexistencial, pacificadora e de ampliação de acesso à Justiça ${ }^{480}$, faz-se necessário, para o adequado exercício da função dos juízes, conciliadores e árbitros, o abrandamento da jurisdição de direito em favor do uso

\footnotetext{
${ }^{477}$ NERY JÚNIOR, Nelson; NERY, Rosa Maria de Andrade. Código de processo civil comentado e legislação extravagante. 7. ed. São Paulo: Ed. Revista dos Tribunais, 2003. p. 1.526; COELHO, Fábio Ulhoa. Curso de direito civil. São Paulo: Saraiva. 2003. v. 1, p. 123, e WAMBIER, Luiz Rodrigues. Apontamentos sobre os Juizados Especiais Cíveis. Juizados Especiais Cíveis e Criminais. Caxias do Sul: Ed. Plenum, v. 1, [s.n.]. CDROM. Marisa dos Santos Ferreira e Ricardo da Cunha Chimenti apontam que é dado ao juiz apreciar os conflitos em sede de JECs ou JEFs sem se sujeitar de forma absoluta à vontade contida na regra legal, sem subordinar-se cegamente ao direito escrito, obviamente mediante decisão fundamentada a justificar a aplicação da medida de exceção (CHIMENTI, Ricardo da Cunha; SANTOS, Marisa Ferreira. Juizados especiais cíveis e criminais - federais e estaduais. 2. ed. São Paulo: Saraiva, 2004. p. 188). Ou, como aduz, Carreira Alvim, "os juizados são, ou pelo menos deveriam ser, o repositório natural da justiça de equidade, pois é a justiça de cada caso, como soa o artigo em comento, ou justiça feita caso a caso, e não em bloco" (ALVIM, J. Eduardo de Carreira. Juizados especiais cíveis estaduais. Curitiba: Juruá, 2003. p. 42).

${ }^{478}$ Poderia, ainda, ser acrescentado um outro argumento de natureza histórica. A redação projetada do art. $5^{\circ}$ da Lei dos juizados de pequenas causas - que é ipsis literis a do estudado art. $6^{\circ}$ da Lei n. 9.099/95 - era no sentido de que "o juiz decidirá com base na lei, atendendo aos seus fins sociais e às exigências do bem comum e adotando em cada caso a decisão que reputar mais equânime". Se houve supressão da expressão com base na lei, foi justamente para ser dado maior enfoque à questão do julgamento por eqüidade, o que vem ao encontro de nossa tese.

${ }^{479}$ PALERMO, Hertha Helena Rollemberg Padilha. Decisão por eqüidade nos Juizados Especiais Cíveis. 1998. Dissertação (Mestrado) - Faculdade de Direito, Universidade de São Paulo, São Paulo, 1998. p.133.

${ }^{480}$ Para exata compreensão da importância dos Juizados Especiais para o sistema judicial como um todo, bem como de seus desafios e problemas, remetemos o leitor ao nosso Técnicas de aceleração do processo, cit., p. 86-89, bem como ao recente diagnóstico levado a cabo em 2006 pelo Ministério da Justiça em parceria com o CEBEPEJ - Centro Brasileiro de Estudos e Pesquisas Judiciais. Disponível em: $<$ www.mj.gov.br/reforma>.
} 
fundamentado da equidade, temperado, por óbvio, pelos fins sociais da lei (como aponta o art. $6^{\circ}$ ). Só assim é possível dar amplo cumprimento aos princípios informadores constantes do art. $2^{\circ}$ da Lei n. 9.099/95: oralidade, simplicidade, informalidade, economia processual, celeridade e a busca da autocomposição.

Seja como for, adeptos de ambas as posições convergem em admitir, mesmo com base só nos citados princípios informadores do JEC (art. $2^{\circ}$ da Lei n. 9.099/95) e sem admissão do juízo de eqüidade, que os operadores deste sistema estão libertos do tradicional zelo pelas formas dos atos processuais, isto a fim de cumprir com fidelidade a mens dessa nova ordem processual. ${ }^{481} \mathrm{O}$ juiz, ao menos quanto às regras de forma (a discussão quanto às regras de fundo persiste sem solução aparente), é "livre para dar ao feito o procedimento que se revelar mais adequado à rápida e justa composição da lide", sem se afastar, por óbvio, das garantias constitucionais do processo. ${ }^{482}$

Por isto, há amparo legal e doutrinário para que o julgador, ao menos no sistema dos Juizados que cuida, em tese, de causas de menor valor ${ }^{483}$, inove no âmbito procedimental $^{484}$, criando ou mesclando procedimentos diversos, fundamentadamente, para o fim de alcançar uma mais justa e equânime decisão, ainda que com afastamento dos padrões legislativos abstratos. ${ }^{485}$

Plenamente possível, assim, que o juiz, verificando estarem os ânimos das partes exaltados, suspenda o curso do feito por período suficiente para que seja possível um diálogo mais esclarecedor. Esta prática, em conflitos relacionados a direito de

\footnotetext{
${ }^{481}$ DINAMARCO, Cândido Rangel. Manual de pequenas causas, cit., p. 52.

${ }^{482}$ THEODORO JÚNIOR, Humberto. Curso de direito processual civil, cit., v. 3, p. 457.

${ }^{483}$ Informação que não é verdadeira, pois a jurisprudência dominante vem entendendo, à luz do art. $3^{\circ}$, II, da Lei n. 9.099/95, que quaisquer das causas do art. 275, II, do CPC, independentemente de seu valor, podem ter curso perante os Juizados Especiais Cíveis (enunciado n. 58 do FONAJE).

${ }^{484}$ Lamentando a timidez dos juízes em geral na utilização do juízo de eqüidade referido no art. $6^{\circ}$ da Lei n. 9.099/95, mas já vislumbrando mudanças, cf. o bom estudo de CARLIN, Marcelo. O julgamento por equidade nos juizados especiais cíveis: uma abordagem à luz da convergência entre os sistemas jurídicos da civil law e da common law e do movimento contemporâneo de acesso à justiça. 2004. Dissertação (Mestrado) - Faculdade de Direito do Vale do Itajaí - SC (UNIVALI), 2004. p. 140-142.

${ }^{485}$ Comentando o art. 113 do já revogado Código italiano, que também falava em causas de escassa importância econômica, e o art. 114, que cuidava de causas disponíveis cuja regulação integral poderia ter sido efetuada contratualmente, Calamandrei apontava que "o poder de eqüidade refere-se às relações que encontram já na codificação sua plena e perfeita regulação jurídica; de maneira que quando o juiz é chamado a decidir sobre uma destas relações, não tem necessidade de criar para a mesma a norma jurídica, que existe já na lei. Aqui a eqüidade é considera não só como - Poder do juiz de temperar o direito vigente - poder de criar o direito, mas como poder de adaptar o direito já existente às especiais exigências do caso singular, no espírito da codificação vigente" (CALAMANDREI, Piero. Direito processual civil, cit., v. 1, p. 166-167).
} 
vizinhança, tem sido bastante frutífera, em muitos casos possibilitando, inclusive, a autocomposição oportuna.

Também não se vê óbice à dispensa da audiência conciliatória prevista no art. 21, da Lei n. 9.099/95, quando o juiz aferir que o deslocamento da parte para duas audiências (de conciliação e instrução) puder lhe acarretar grave prejuízo, ou ampliar consideravelmente os custos do processo. ${ }^{486}$

Admissível, também, com base no já citado juízo de eqüidade, que se permita ao condomínio ou ao espólio ajuizar ação perante os Juizados, apesar da inexistência de autorização legal a respeito, ampliando, assim, o rol de legitimados do art. $8^{\circ}$ da Lei n. 9.099/95. Este é o sentido dos verbetes n. 09, 72 e 111 do FONAJE (Fórum Nacional dos Juizados Especiais Cíveis), que dão correta interpretação ao ideário de ampliação do acesso à justiça.

Por falar em FONAJE, inúmeros enunciados deste órgão - que consolida a experiência dos Juizados Especiais de todo o país - indicam interpretações flexibilizadoras do procedimento sumaríssimo, algumas complementares ao regime legal, outras fazendo prevalecer, ainda que em contraste manifesto com a Lei n. 9.099/95, razões de cunho pragmático de casos concretos sobre disposições normativas genéricas.

Por exemplo, além dos já citados enunciados n. 09, 72 e 111 (legitimação ativa do condomínio e do espólio), tem-se o enunciado n. 13, que indica serem os prazos processuais nos Juizados Especiais Cíveis, inclusive na execução, contados da data da intimação ou ciência do ato respectivo, e não da juntada da intimação, observando-se as regras de contagem do Código de Processo Civil ou do Código Civil, conforme o caso; o enunciado n. 25 aduz que a multa cominatória não fica limitada ao valor de quarenta (40) salários mínimos, embora deva ser razoavelmente fixada pelo juiz, obedecendo-se o valor da obrigação principal, mais perdas e danos, atendidas as condições econômicas do devedor; o enunciado n. 31 admite pedido contraposto no caso de ser a parte ré pessoa jurídica (pese não poder ajuizar ação neste sistema); o enunciado n. 33 facilita as

\footnotetext{
${ }^{486}$ Chegam-me alarmantes notícias de que muitos jurisdicionados, agindo de forma criminosa, utilizam-se da regra de foro do art. $4^{\circ}$, III, da Lei n. 9.099/95, para obter vantagem ilegal em detrimento de grandes empresas sediadas em locais distantes. Ajuízam ações de reparação de danos por fatos inexistentes em seu domicílio e, contando com a ausência do demandado na audiência de conciliação - até porque o custo do deslocamento é muitas vezes superior ao próprio pedido - acabem obtendo êxito na demanda por força da revelia (art. 20 da Lei n. 9.099/95).
} 
comunicações processuais, dispondo que é dispensável a expedição de carta precatória nos Juizados Especiais Cíveis, cumprindo-se os atos nas demais comarcas, mediante via postal, por ofício do Juiz, fax, telefone ou qualquer outro meio idôneo de comunicação; o enunciado n. 35 aponta serem dispensáveis os debates orais finda a audiência de instrução; o enunciado n. 43, dispensando o arresto, permite a penhora imediata de bens na execução do título judicial quando não localizado o executado; o enunciado n. 71 , contrariando completamente o art. 52 da Lei n. 9.099/95, diz ser cabível a designação de audiência de conciliação em execução de título judicial; e o enunciado n. 89, entre outros, permite, em afronta à sistemática procedimental padrão, que a incompetência territorial seja reconhecida de ofício no sistema de juizados especiais cíveis.

De tudo se vê que a regra do art. $6^{\circ}$ da Lei n. 9.099/95, invocada ou não em concurso com os princípios do art. $2^{\circ}$ do mesmo diploma, concedem ao juiz poder de inovar ritualmente. Eis, então, mais uma regra legal flexibilizadora de cunho genérico.

Por fim, vale a nota de que na arbitragem ajustada perante os juizados especiais - sendo eleito um ou mais dos juízes leigos como árbitros - o julgamento de equidade é sempre admissível, independentemente de autorização das partes (art. 25 da Lei n. 9.099/95 c.c. art. 11, II, da Lei n. 9.307/96).

\subsubsection{Atipicidade das medidas executivas nas obrigações de fazer, não fazer e dar coisa (art. 461, $\S 5^{\circ}$ e art. 461-A, $\S 3^{\circ}$, ambos do CPC, e art. 84, $\S 5^{\circ}$, do CDC)}

O último exemplo de disposição legal que propicia ao juiz, de maneira genérica, poderes expressos para a adequação da forma ao caso concreto está no art. $461, \S 5^{\circ}$, do CPC, sucessor natural e temporal do art. $84, \S 5^{\circ}$, do Código de Defesa do Consumidor (Lei n. 8.069/90).

Prevê a disposição, aplicável ao regime de cumprimento das sentenças que reconheçam obrigação de fazer, não fazer e dar coisa (art. 475-I do CPC), bem como à satisfação das decisões antecipatórias de tutela de mesma natureza (art. 461, § $3^{\circ}$, do CPC), que "para a efetivação da tutela específica ou a obtenção do resultado prático equivalente, poderá (leia-se: deverá) o juiz, de ofício ou a requerimento, determinar as medidas necessárias, tais como a imposição de multa por tempo de atraso, busca e apreensão, 
remoção de pessoas e coisas, desfazimento de obras e impedimento de atividade nociva, se necessário com requisição de força policial".

De acordo com uníssona doutrina, a expressão tais como revela o caráter meramente exemplificativo dos atos processuais executivos citados no dispositivo, permitindo ao juiz, livremente, eleger, além das medidas de apoio enumeradas, qualquer outra que seja adequada, suficiente e proporcional para obtenção da tutela específica ${ }^{487}$ ou de resultado que lhe equivalha ${ }^{488}$. Eis aqui a natureza genérica da regra geral de flexibilização do procedimento executivo.

Possível, assim, que sejam deferidas medidas executivas não previstas pelo legislador, como o bloqueio de bens ou valores, seqüiestro, restrições a direitos, proibição de freqüência a determinados lugares ou celebração de certos tipos de contrato, nomeação de interventor judicial em negócio jurídico alheio ${ }^{489}$, fechamento de estabelecimento industrial ou comercial, interrupção de anúncio televisivo ou determinação pra que se faça um, retirada de mercadoria de circulação, etc., tudo com vistas à satisfação da obrigação.

Há, portanto, nesta seara, atipicidade das medidas executivas. O juiz pode ordenar, de ofício ou a requerimento da parte, conjunta ou separadamente, qualquer ato executivo direto (ou de sub-rogação) ou indireto (ou de coerção) necessário para satisfação da obrigação. Abandonou-se o vetusto modelo de tipicidade das medidas executivas ${ }^{490}$ - onde estão elas todas previamente explicitadas pelo legislador - para permitir ao julgador a integração da norma jurídica com a eleição da medida mais adequada à satisfação do caso concreto.

\footnotetext{
${ }^{487}$ Por tutela específica, que se entenda aquela relacionada ao objeto do direito a ser satisfeito, de sorte que os meios executivos atuam diretamente sobre o objeto do direito exeqüendo ou sobre a coisa devida, de modo a proporcionar uma restauração idêntica da situação jurídica violada, através de uma direta restituição" (YARSHELL, Flávio Luiz. Tutela jurisdicional específica nas obrigações de declaração de vontade, cit., p. 33). Cf., também, DINAMARCO, Cândido Rangel. Efetividade do processo e os poderes do juiz. In: . Fundamentos do processo civil moderno, cit., v. 1, p. 595.

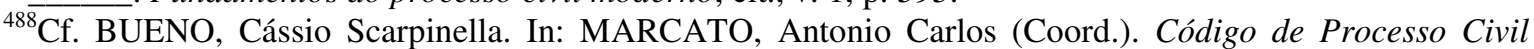
interpretado. São Paulo: Atlas, 2004. p. 1413; THEODORO JÚNIOR, Humberto. Curso de direito processual civil, cit., v. 3, p. 34; ABELHA, Marcelo. Manual de execução civil. Rio de Janeiro: Forense, 2006. p. 219220; DESTEFFENNI, Marcos. Curso de direito processual civil. São Paulo: Saraiva: 2006. v. 1, p. 493; GRINOVER, Ada Pellegrini. Tutela jurisdicional nas obrigações de fazer e não fazer. In: TEIXEIRA, Sálvio de Figueiredo (Org.). Reforma do Código de Processo Civil. São Paulo: Saraiva, 1996. p. 257.

${ }^{489}$ Este interventor é figura assemelhada a do receiver, master, administrators e committees do direito norte americano, que é um terceiro nomeado compulsoriamente pelo magistrado para administrar a pessoa jurídica renitente, cumprindo, assim, a obrigação determinada na sentença (geralmente cessar uma atividade ilícita, como poluir um rio). No Brasil, o art. 63 da Lei Antitruste (Lei n. 8.884/94) faz menção a tal figura, que a nosso ver pode ser utilizada genericamente com base no art. 461, § 5', do CPC (Cf. WATANABE, Kazuo. Tutela antecipatória e tutela específicas das obrigações de fazer e não fazer. In: TEIXEIRA, Sálvio de Figueiredo (Org.). Reforma do Código de Processo Civil, cit., p. 45).

${ }^{490}$ Trata-se do regime ainda vigente, mesmo após as Leis n. 11.232/2005 e 11.382/2006, para a execução de obrigação por quantia.
} 
Obviamente, para a eleição do melhor ato de apoio da série, o juiz há de atentar para as limitações inerentes ao regime geral de flexibilização (como o contraditório útil), além das vedações legais específicas do processo de execução. ${ }^{491}$ Deve, por exemplo, rememorar que ainda vige no nosso sistema executivo, pese cada vez de forma mais abrandado, o princípio da menor onerosidade (art. 620 do CPC), a impor ao juiz, sempre que houver duas medidas executivas possíveis e igualmente vantajosas ao credor, a eleição da que for menos gravosa ao devedor. Deve, também, atentar para o princípio da proporcionalidade, corolário do devido processo legal substancial, e para a vedação constitucional da prisão civil por dívida (art. $5^{\circ}$, LXVII da CF). ${ }^{492}$

De qualquer modo vale destacar que a presente regra flexibilizadora, mesmo diante das limitações supra, tem enorme alcance na efetiva satisfação das obrigações de fazer, não fazer e dar coisa certa, especialmente se empregada junto com as multas diárias referidas nos $\S \S 2$ e $4^{\circ}$ do art. 461 do CPC, e se os juízes usarem de criatividade no seu uso $^{493}$, inclusive estendendo o alcance da norma para abranger, também, as obrigações de igual natureza constantes dos títulos executivos extrajudiciais. ${ }^{494}$

\footnotetext{
${ }^{491}$ Para ampla análise dos limites judiciais para a eleição da melhor medida de apoio da série, cf MEDINA, José Miguel Garcia. Execução civil. 2. ed. São Paulo: Ed. Revista dos Tribunais, 2004. p. 410-418. Cf., também, DINAMARCO, Cândido Rangel. A reforma da reforma. 4. ed. São Paulo: Malheiros Ed, 2003.

${ }^{492}$ Mesmo fora dos casos legais em que se admite a prisão civil por dívida (alimentos e depositário infiel), estamos entre aqueles que crêem na possibilidade do emprego desta medida coercitiva em casos extremos, onde já tenham sido esgotadas todas as outras medidas coercitivas e de sub-rogação para a tutela específica da obrigação ou obtenção do resultado prático equivalente. Primeiro, pois cremos que a plena tutela dos direitos é decorrência do princípio da inafastabilidade da tutela jurisdicional (art. $5^{\circ}, \mathrm{XXXV}$, da CF), de modo que, havendo antinomia entre duas disposições constitucionais, há de se empregar o princípio da proporcionalidade para a solução do conflito aparente, no caso, em favor do credor que não teve satisfeita a obrigação por omissão ardilosa e ofensiva à boa-fé por parte do obrigado. E segundo, pois o art. $5^{\circ}$, LXVII, da $\mathrm{CF}$, proíbe a prisão civil por dívida, e não a prisão civil por descumprimento de determinação judicial. Há, portanto, possibilidade de prisão do obrigado por desobediência civil (diversa da de natureza penal pela prática do crime de desobediência), que como medida coercitiva cede quando a obrigação for cumprida. Neste exato sentido cf. MARINONI, Luiz Guilherme. Técnica processual e tutela dos direitos. São Paulo: Ed. Revista dos Tribunais, 2004. p. 292-295; e SHIMURA, Sérgio Seiji. Execução provisória. In: et al. Nova reforma processual civil comentada. São Paulo: Método, 2002. p. 413-414; WATANABE, Kazuo. Tutela antecipatória e tutela específicas das obrigações de fazer e não fazer, cit., p. 46-47; e GUERRA, Marcelo Lima. Direitos fundamentais e a proteção do credor na execução civil. São Paulo: Ed. Revista dos Tribunais, 2003. p. 136. Em sentido contrário cf. MEDINA, José Miguel Garcia. Execução civil, cit., p. 463; e WAMBIER, Teresa Arruda Alvim. Impossibilidade de decretação da pena de prisão como medida de apoio, com base no art. 461, para ensejar o cumprimento da obrigação in natura. Revista de Processo, São Paulo, n. 112, p. 196-221, out./dez. 2003.

${ }^{493}$ Esta é a esperança de Dinamarco, ao rogar aos juízes, conscientes dos grandes poderes de que são investidos por esta disposição, "empreguem-nos efetivamente e, sem imprudência, mas também sem timidez, valham-se deles para o cumprimento de sua missão de oferecer tutela jurisdicional efetiva a quem tiver o direito a um fazer alheio ou a uma abstenção" (DINAMARCO, Cândido Rangel. A execução na reforma do Código de Processo Civil. In:
} Fundamentos do processo civil moderno, cit., v. 2, p. 1.162).

${ }^{494}$ No sentido da aplicação do art. $461, \S 5^{\circ}$, do CPC, também para os títulos executivos extrajudiciais, cf. ABELHA, Marcelo. Manual de execução civil, cit., p. 230. 


\subsection{Flexibilidade procedimental legal alternativa}

O segundo regime legal de flexibilidade procedimental é o que permite tramitações alternativas.

Trata-se de modelo, conforme já visto, que o sistema coloca à disposição do juiz várias opções procedimentais, competindo a ele eleger, também com a participação das partes, a que melhor se adapte ao caso concreto, só que agora com uma restrição bem maior no seu campo de atividade, eis que o legislador já lhes pré-fixou as variantes possíveis.

Em outros termos, aqui o juiz não detém, ao menos no âmbito legal, de ampla margem de atuação como nos casos anteriores, em que a flexibilização do procedimento se dava genericamente. Neste modelo as variantes rituais já são estabelecidas abstratamente pelo legislador, competindo ao magistrado, ouvidas as partes, optar por aquilo que melhor convém à tutela subjetiva e objetiva do processo.

Em princípio, é vedado às partes ou ao juiz se afastar do modelo legal, excepcionada a necessidade de variação com base na incapacidade das diversas opções tutelarem adequadamente e utilmente o caso concreto (item 5.4.).

O presente modelo, apesar da omissão da doutrina a respeito, é a regra do nosso sistema. Daí porque será tratado abaixo apenas em suas principais ocorrências. ${ }^{495}$

\subsubsection{Conversão do procedimento sumário em ordinário (art. $277, \S 4^{\circ}$ e $5^{\circ}$ do CPC)}

É dever do juiz, logo no despacho inicial, fazer o controle do cabimento do procedimento eleito pela parte, respeitada a opção ritual quando for ela possível (vide item 3.4. supra). Esta é a locução do art. 295, V, do CPC, que considera inepta a petição inicial

\footnotetext{
${ }^{495} \mathrm{O}$ que significa que há outras regras de flexibilidade legal alternativa como, por exemplo: a) a que permite ao Tribunal, no julgamento dos recursos contra decisões extintivas do feito sem apreciação do mérito, o imediato julgamento do mérito da demanda, isto quando a causa versar sobre questão unicamente de direito e estiver em condições de imediato julgamento (art. 515, $\S 3^{\circ}$, do CPC); b) a que permite ao Tribunal, ao constatar, no julgamento do recurso, a existência de nulidade sanável, ordenar a realização ou a renovação do ato processual viciado, prosseguindo, ato contínuo, na apreciação da causa (art. 515, § $4^{\circ}$, com redação pela Lei n. 11.276/2006); c) a que autoriza o juiz a definir o prazo da apresentação do rol de testemunhas em cartório (art. 407 do CPC) ou o prazo para contestação da rescisória (art. 491 do CPC); d) a que possibilita a recepção da impugnação com ou efeito suspensivo da execução, o que determinará, inclusive, se o processamento do incidente se dará em apartado ou nos mesmos autos (art. 475-M, $\S 2^{\circ}$, do CPC); etc.
} 
quando o tipo de procedimento escolhido pelo autor não corresponder à natureza da causa ou ao valor da ação (caso em que só não será indeferida se puder adaptar-se ao tipo de procedimento legal).

Pode ocorrer, entretanto, que no curso do procedimento surja controvérsia que, dirimida, acabe por indicar o não cabimento do rito eleito.

É o que ocorre no procedimento sumário.

De fato, dispõe os $\S \S 4^{\circ}$ e $5^{\circ}$ do art. 277 do CPC (com redação pela Lei n. 9.245/95), ambos a tratar do procedimento sumário, que o juiz, na audiência, decidirá a impugnação ao valor da causa ou a controvérsia sobre a natureza da demanda, determinando, se for o caso, a conversão do procedimento sumário em ordinário, idêntica solução que adotará quando houver necessidade de prova técnica de maior complexidade, incompatível com a brevidade do rito sumário.

A dicção legal, então, determina a conversão do procedimento sumário em ordinário - sem nenhuma outra opção ritual aparente - em três circunstâncias.

A primeira, quando por força do acolhimento da impugnação apresentada em audiência de conciliação, o valor da causa exceder o valor de 60 salários-mínimos previsto no art. 275, I, do CPC, caso em que não mais será cabível o procedimento sumário pela superação do teto legal. Tudo bem que pode (e deve) o magistrado, logo no despacho inicial, fazer o controle oficioso do valor da causa quando existente parâmetro legal (art. 259 do CPC). ${ }^{496}$ Mas não o tendo feito, nada impede que o faça após provocação do réu. ${ }^{497}$

Também deve haver conversão do rito quando, diante da impugnação aventada pelo réu, ficar constatado que a natureza da demanda não for compatível com as hipóteses

\footnotetext{
${ }^{496}$ RT 656/102, 596/119, RJTJSP 128/260, 93/316.

${ }^{497}$ Controverte-se na doutrina sobre a ocorrência de deslocamento, no âmbito do procedimento sumário, da questão sobre o cabimento do rito para momento oportuno e prévio à contestação. Com efeito, acolhida a alegação de que o valor da causa supera o teto, a conseqüência é a conversão do rito, com abertura de novo prazo (o do ordinário) para que o pólo passivo apresente a contestação (que, então, não mais será ofertada em audiência). A questão não esclarecida pela doutrina, todavia, se refere à forma de argüição do excesso do valor da causa, havendo posição que insiste na autonomia do incidente (art. 261 do CPC), e outra, com fundamento no art. 278 do CPC, que aponta ser o valor da causa, ao menos no procedimento sumário, questão a se veicular em contestação. Em nosso entender, pouco importa a forma de argüição, eis que o relevante é que o réu impugne o valor da causa, sob pena de preclusão, a fím de obter a conversão do rito. Se o réu pretende evitar a antecipação dos argumentos de defesa, que então faça a impugnação por petição em separado ou oralmente, logo no início da audiência do art. 277 do CPC. A respeito do assunto, cf. ASSIS, Araken de. Procedimento sumário. São Paulo: Malheiros Ed., 1996. p. 88, e CARNEIRO, Athos Gusmão. Do rito sumário na reforma do CPC. São Paulo: Saraiva, 1996. p. 46.
} 
do art. 275, II, do CPC. Exemplificativamente, autoriza-se a utilização do procedimento sumário para os casos de arrendamento rural (art. 275, II, “a”, do CPC), mas não para as hipóteses de locação, cujas ações se processam pelos ritos especiais da Lei n. 8.245/91. Também aqui o magistrado deveria ter feito o controle do cabimento do rito logo no despacho inicial.

A última hipótese de conversão se dá quando houver necessidade de prova pericial complexa para solução da controvérsia, entendida esta, a nosso ver, como a de realização lenta e dispendiosa, incompatível, portanto, com a brevidade e economicidade que se espera deste rito. ${ }^{498}$ Não há, todavia, parâmetros seguros para definição do que seria uma prova pericial complexa em detrimento de uma menos complexa, pois toda prova desta natureza tem certo grau de complexidade: se não tivesse, não seria necessário que o juiz se apoiasse nos conhecimentos técnicos de terceiro para solucionar a demanda. ${ }^{499}$

Bastante interessante é o posicionamento a sustentar, ainda que a luz de uma interpretação bem ampliativa do art. $277, \S 5^{\circ}$, do CPC, ser possível a conversão do rito quando a única prova necessária para solução da controvérsia for a pericial. De fato, não havendo necessidade de produção de prova oral em audiência - e sendo praticamente incipientes as situações em que as partes postulam a oitiva do perito (435 do CPC) - não há porque se manter o rito sumário formatado em duas audiências, quando o rito ordinário permite o julgamento bem mais célere da demanda sem nenhuma (ou uma) audiência, com apresentação de laudo, manifestação das partes e prolação de sentença (sem audiência). ${ }^{500}$

Seja como for, o fato é que há opção ritual diante das circunstâncias objetivas narradas (valor da causa, natureza da demanda e complexidade da prova) para que se possa ordenar uma variação ritual, com conversão do procedimento sumário em ordinário.

\footnotetext{
${ }^{498}$ Cândido Dinamarco faz acurada crítica quanto a esta possibilidade de conversão do rito, eis que, ao entender do professor das Arcadas, não há utilidade na inovação porque, no momento em que surgisse a percepção da complexidade, nada obstaria a que se produzisse a prova assim mesmo, sem conversão alguma” (DINAMARCO, Cândido Rangel. A reforma do Código de Processo Civil, cit., p. 252).

${ }^{499}$ Já se entendeu que em matéria de acidente de trânsito, "havendo necessidade de prova pericial complexa, envolvendo o veículo acidentado e o local dos fatos, em pista de teste da empregadora, justifica-se a conversão do rito procedimental" (2 $2^{\circ}$ TACiv/SP, Agravo de Instrumento n. 748.638-00/3, $11^{\text {a }}$ Câm., Rel. Juiz Egídio Giacóia, j. 09.09.2002). Também já se entendeu que em sede de indenização por acidente de trabalho que vitimou menor, a ação contra o empregador, ainda que o valor da causa seja inferior ao teto do sumário, deve ter trâmite pelo rito ordinário, eis que é a via onde o infante poderá ser mais adequadamente tutelado ( $2^{\circ}$ TACiv/SP, Agravo de Instrumento n. 664.963-00/6, 6 ${ }^{\text {a }}$ Câm., Rel. Juiz Souza Moreira,. j 21.3.2001).

${ }^{500}$ ASSIS, Araken de. Procedimento sumário, cit., p. 89.
} 


\subsubsection{Facultatividade da audiência preliminar (art. 331, $§ 3^{\circ}$, do CPC)}

Com tríplice finalidade - conciliatória, saneadora e delimitatória da fase instrutória (fixação de pontos controvertidos e deliberação quanto à produção de provas) - a Lei n. 8.952/94 introduziu em nosso sistema a denominada audiência preliminar (art. 331 do CPC).

Em seu modelo original, referido ato processual era de realização obrigatória, mesmo nas causas em que o direito em litígio fosse indisponível. Entendia-se que apesar de não se prestar para os fins conciliatórios, nestes casos sobejaria a importância desta audiência para que as partes pudessem ter contato com o julgador, bem como para que ele pudesse, no próprio ato, sanear o processo e delimitar a sua fase instrutória. ${ }^{501}$

A formatação ao ato emprestada pela Lei n. 8.952/94 foi objeto de algumas críticas. Dizia-se que a inserção desta audiência no sistema apenas tornava obrigatória uma possibilidade que, na praxe cotidiana, já ocorria. Não eram poucos os juízes que se valiam da regra do artigo 342 do Código de Processo Civil para convocar as partes em juízo e tentar uma conciliação. ${ }^{502}$ Apontava-se, ainda, que seria o juiz, diante das circunstâncias específicas do caso, a pessoa mais recomendada para decidir se realizaria ou não o ato, especialmente diante da sobrecarga nas pautas de audiência. Afinal, a realização desse ato em todos os feitos de procedimento ordinário, mesmo naqueles em que improvável ou impossível a obtenção da autocomposição, só serviria para aumentar o volume de trabalho forense e o tempo entre a distribuição da ação e a prolação da sentença, mormente se levado em conta que o prazo máximo de trinta dias mencionado no caput do artigo 331, como quase todos os prazos impróprios, não é, em regra, obedecido.

A nosso ver, o próprio sistema tornou-se contraditório, ao prever a obrigatoriedade da realização da audiência preliminar. Se o principal objetivo da inserção

\footnotetext{
${ }^{501}$ Louvando o advento desta nova audiência no sistema processual civil brasileiro, cf. DINAMARCO, Cândido Rangel. A reforma do código de processo civil, cit., p. 115-140; BERMUDES, Sérgio. A reforma do Código de Processo Civil. 2. ed., São Paulo: Saraiva, 1996. p. 44 e ss.; NERY JÚNIOR, Nelson. Audiência preliminar e saneamento do processo. In: TEIXEIRA, Sálvio de Figueiredo (Org.). Reforma do Código de Processo Civil, cit., p. 335-346; TUCCI, Rogério Lauria. A nova fase saneadora do processo civil brasileiro. In: TEIXEIRA, Sálvio de Figueiredo (Org.). Reforma do Código de Processo Civil, cit., p. 347-369.

${ }^{502}$ Para Augusto Tavares Rosa Marcacini a faculdade de convocação das partes para uma audiência conciliatória era "muito mais saudável para o sistema do que a aparente obrigatoriedade definida no artigo 331” (MARCACINI, Augusto Tavares Rosa. Estudo sobre a efetividade do processo civil. 1999. Tese (Doutorado) - Faculdade de Direito, Universidade de São Paulo, São Paulo, 1999. p. 201). E Vicente Greco Filho lhe fazia coro, aduzindo que a obrigatoriedade da audiência do artigo 331 do Código de Processo Civil em todas as hipóteses, contradizia os próprios objetivos da reforma, levando à burocratização da Justiça (GRECO FILHO, Vicente. Litigância de má-fé. In: TEIXEIRA, Sálvio de Figueiredo (Org.). Reforma do Código de Processo Civil, cit., p. 578).
} 
foi a autocomposição da lide, como se admitir que algumas demandas, na maioria versando sobre direitos disponíveis, podiam ser julgadas antecipadamente (art. 330, CPC), sem a prévia prática conciliatória? ${ }^{503}$

Diante destas ponderações, o legislador achou por bem voltar atrás, e com a edição da Lei n. 10.444/2002, acrescentou um $\S 3^{\circ}$ ao art. 331 do CPC, a prever que "se o direito em litígio não admitir transação, ou se as circunstâncias da causa evidenciarem ser improvável sua obtenção, o juiz poderá, desde logo, sanear o processo e ordenar a produção da prova, nos termos do $\S 2^{\circ}$ ".

Eliminou-se, com isso, o caráter obrigatório da audiência preliminar, ficando a critério do juiz a designação da audiência, que se realizará somente nas hipóteses em que o direito em litígio for disponível e, o sendo, quando for vislumbrada a possibilidade de sucesso na autocomposição.

A realização da audiência preliminar é, assim, interessante variante ritual, dependente das circunstâncias do caso. Se bem realizada pode ser importante mecanismo de autocomposição da lide. Caso não seja, certamente afasta a realização de uma audiência inútil, cujo conteúdo decisório (saneamento e delimitação do objeto da instrução) é praticável de maneira bem mais fácil e célere pela via escrita. ${ }^{504}$

\footnotetext{
${ }^{503}$ Cf. nosso Técnicas de aceleração do processo, cit., p. 148-151. Neste estudo concluímos, à luz de dado estatístico colhido em pesquisa de campo junto a juízes estaduais paulistas, que a obrigatoriedade desta audiência não era justificável do ponto de vista operacional, pois apenas 28,9\% das audiências preliminares realizadas frutificavam em acordo.

${ }^{504}$ Vale destacar, por isto, nossa preocupação com o projeto de lei da Câmara dos Deputados de n. 94/2002, que pretende novamente inserir no sistema a obrigatoriedade da audiência preliminar, desconsiderando todas as desvantagens apontadas. $\mathrm{O}$ art. 26 do projeto altera o art. 331 do CPC, que, então, passaria a ter a seguinte redação: "Art. 331. Se não se verificar qualquer das hipóteses previstas nas seções precedentes, o juiz designará audiência preliminar, a realizar-se no prazo máximo de trinta dias, para a qual serão as partes intimadas a comparecer, podendo fazer-se representar por procurador ou preposto, com poderes para transigir. §1o Na audiência preliminar, o juiz ouvirá as partes sobre os motivos e fundamentos da demanda e tentará a conciliação, mesmo tendo sido já realizada a mediação prévia ou incidental. §2o A lei local poderá instituir juiz conciliador ou recrutar conciliadores para auxiliarem o juiz da causa na tentativa de solução amigável dos conflitos. §3o Segundo as peculiaridades do caso, outras formas adequadas de solução do conflito poderão ser sugeridas pelo juiz, inclusive a arbitragem, na forma da lei, a mediação e a avaliação neutra de terceiro. §4o A avaliação neutra de terceiro, a ser obtida no prazo a ser fixado pelo juiz, é sigilosa, inclusive para este, e não vinculante para as partes, sendo sua finalidade exclusiva a de orientálas na tentativa de composição amigável do conflito. §5o Obtido o acordo, será reduzido a termo e homologado pelo juiz. §6o Se, por qualquer motivo, a conciliação não produzir resultados e não for adotado outro meio de solução do conflito, o juiz, na mesma audiência, fixará os pontos controvertidos, decidirá as questões processuais pendentes e determinará as provas a serem produzidas, designando audiência de instrução e julgamento, se necessário". A última notícia que se tem do projeto é que ele já foi aprovado pelas duas Casas legislativas, tendo tornado à Câmara dos Deputados por força das emendas sofridas no Senado Federal.
} 


\subsection{3. Ônus da prova (art. 333 do CPC) e sua inversão (art. $6^{\circ}$, VI, do CDC)}

As regras constantes do art. 333 do CPC, sem dúvida alguma, são umas das mais (ou as mais) importantes disposições normativas do Direito Processual Civil brasileiro. A conhecida redação do dispositivo diz que o ônus da prova incumbe ao autor quanto ao fato constitutivo do seu direito (i), e ao réu quanto à existência de fato impeditivo, modificativo ou extintivo do direito do autor (ii).

Ônus, diversamente de obrigação ou dever ${ }^{505}$, são aquelas atividades que a parte realiza no processo em seu próprio benefício, não podendo ser compelida a praticá-las, ainda que a omissão acarrete-lhe indiscutível prejuízo. Assim, descumprido o ônus da por aquele que o tinha, a consequiência é o decaimento do benefício previsto pelo sistema, em outras palavras, a incidência dos efeitos prejudiciais da omissão (no caso, a improcedência do pedido).

O fenômeno da repartição legal do ônus da prova pode ser encarado pelos seus aspectos subjetivo e objetivo ${ }^{506}$.

Subjetivamente, o ônus é uma disposição dirigida exclusivamente às partes e terceiros interventores. O sistema já avisa aos participantes do processo de quem é o dever de provar determinado fato, bem como as conseqüências negativas da inexistência da prova no momento do julgamento. Este aspecto do ônus da prova vem sendo abrandado pela doutrina mais moderna, eis que o princípio da aquisição processual e os poderes instrutórios do juiz (art. 130 do CPC) acabam por beneficiar aquele que não produziu a prova. Afinal, mesmo que não tenha produzido a prova, se ela estiver no processo isto basta para que a parte se desincumba do ônus que era seu.

Já do ponto de vista objetivo, as regras sobre o ônus da prova não seriam dirigidas às partes, mas sim ao juiz, servindo de parâmetro para orientá-lo no momento do julgamento e para evitar que o processo acabe "empatado". De acordo com elas, sendo vedado ao magistrado deixar de proferir decisão diante da inexistência de prova das

\footnotetext{
${ }^{505}$ A diferenciação entre ônus, dever e obrigação é bem feita por Arruda Alvim: "a obrigação pede uma conduta cujo adimplemento ou cumprimento traz benefícios à parte (...) havendo omissão do obrigado este será ou poderá ser coercitivamente obrigado pelo sujeito ativo". Já com o ônus "o indivíduo que não o cumprir sofrerá, pura e simplesmente, via de regra, as conseqüências negativas do descumprimento que recairão sobre ele próprio". E arremata que o dever é a sujeição com característica da perpetuidade, não se esgotando, pois, com o cumprimento (Manual de direito processual, cit., v. 2, p. 493).

${ }^{506}$ Cf. MOREIRA, José Carlos Barbosa. Julgamento e ônus da prova. In: ___. Temas de direito processual: $2^{\mathrm{a}}$ série. São Paulo: Saraiva, 1980. p. 73-74; BUZAID, Alfredo. Do ônus da prova. Estudos de direito. São Paulo: Saraiva, 1972. v. 1, p. 66; SILVA, Ovídio A. Baptista. Curso de processo civil, cit., v. 1, p. 344-345.
} 
alegações (art. 126 do CPC), e estando o juiz diante deste quadro de non liquet mesmo após já ter se valido, sem êxito, da atividade probatória oficial (art. 130 do CPC), só lhe restaria julgar o processo em desfavor daquele que não provou o fato que lhe competia.

Exatamente pela maior atenção que a doutrina dá ao aspecto objetivo do ônus da prova, ${ }^{507}$ aponta-se, de maneira uniforme, que são tais regras de juízo ou de julgamento. ${ }^{508}$ Só são aplicadas no momento de composição da lide, isto é, na hora em que o juiz sentencia o processo, competindo ao julgador, apenas neste momento, carrear a derrota àquele que se desincumbiu do ônus probatório, pois inexistentes as provas de suas alegações.

No tocante propriamente às regras padrão sobre ônus da prova (art. 333 do CPC) não há reflexos procedimentais dignos de nota. São regras genericamente válidas, aplicadas, indistintamente, a todos os processos de conhecimento e cautelar, seja qual for o procedimento (comum ou especial).

A questão, todavia, ganha contornos completamente distintos diante de disposição legal do Código de Defesa do Consumidor a autorizar a inversão judicial destas regras. ${ }^{509}$ Indica o art. $6^{\circ}$, VIII, da Lei n. 8.078/90, que entre os direitos básicos do consumidor está o de ter a sua defesa facilitada no processo civil, "inclusive com a inversão do ônus da prova, a seu favor", quando, "a critério do juiz, for verossímil a alegação ou quando for ele hipossuficiente, segundo as regras ordinárias de experiência".

\footnotetext{
${ }^{507}$ Neste sentido, destacando a preponderância da faceta objetiva do ônus da prova em detrimento da subjetiva, Hernando Devi Echandía pontua que o sistema não determina quem deve fazer a prova, mas sim quem assume o risco de não produzi-la (DEVI ECHANDÍA, Hernando. Teoria general de la prueba judicial. 6 ed. Buenos Aires: Zavalia, 1988. t. 1, n. 126). Cf., também, PACÍFICO, Luiz Eduardo Boaventura. O ônus da prova no direito processual civil brasileiro. São Paulo: Ed. Revista dos Tribunais, 2001. p. 131-142, especialmente p. 135; e MICHELI, Gian Antonio. L'onere della prova. 2. ed. Padova: Cedam, 1966. p. 110.

${ }^{508} \mathrm{Na}$ doutrina: BEDAQUE, José Roberto dos Santos. Poderes instrutórios do juiz, cit., p. 117-118; PACÍFICO, Luiz Eduardo Boaventura. O ônus da prova no direito processual civil brasileiro, cit., p.135139. Jurisprudencialmente já se entendeu que "a regra do ônus da prova só tem pertinência como regra de juízo (regra de decidir), que é, aos casos em que, encerrada a instrução, fique ao julgador dúvida intransponível acerca da existência de fato constitutivo ou liberatório" (TJ/SP, RT 706/67).

${ }^{509}$ Vale o destaque que além da inversão judicial, as regras sobre o ônus da prova também podem ser invertidas convencionalmente, nos limites do art. 333, parágrafo único, do CPC, ou por disposição legal, como ocorre, por exemplo, com a adoção, pelo sistema, das presunções judicias (hominis) ou simples (art. 335 do CPC) e das presunções legais relativas (art. 334, IV, do CPC). Nestes casos, embora não haja reflexos no procedimento, pois as partes (aspecto subjetivo) e o julgador (aspecto objetivo) estão previamente cientes destas regras, não se segue o regime padrão do art. 333, caput, do CPC. Cf. GONÇALVES, Marcus Vinicius Rios. Novo curso de direito processual civil. 3. ed. São Paulo: Saraiva, 2006. v. 1, p. 433-435; e ALVES, Francisco Glauber Pessoa. O princípio jurídico da igualdade e o processo civil brasileiro. Rio de Janeiro: Forense, 2003. p. 150.
} 
Note-se que apesar da disposição indicar, aparentemente, duas hipóteses de inversão judicial do ônus da prova nas relações de consumo ${ }^{510}$ - verossimilhança e hipossuficiência - na verdade há apenas uma situação em que ela efetivamente ocorre (hipossuficiência). De fato, no caso da verossimilhança, não há propriamente uma inversão, pois o magistrado, com apoio nas máximas de experiência e das regras da vida, considera produzida a prova que incumbe a uma das partes, autorizando, a partir daí, as conseqüências legais. Note-se que não se impõe à parte contrária a produção da prova que, pelo regime geral (art. 333 do CPC), competiria ao consumidor, mas sim presume-a existente com base na verossimilhança da alegação do consumidor. ${ }^{511}$

A situação mesmo que autoriza a inversão judicial é a do consumidor considerado hipossuficiente. Hoje, parece não haver mais dúvida de que a hipossuficiência referida no dispositivo não é a econômica, mas sim a técnica, isto é, a relacionada à possibilidade de produzir a prova. ${ }^{512}$ Será deferida a inversão quando a produção da prova necessária for impossível ou muito difícil ao consumidor, por depender de conhecimentos técnicos ou informações que, como regra, estão em poder do fornecedor. ${ }^{513}$

Há controvérsia na doutrina e na jurisprudência a respeito da necessidade do juiz, ao inverter judicialmente as regras do ônus da prova, comunicar expressamente e previamente aos litigantes a realização da operação.

Os defensores de que não há tal necessidade ${ }^{514}$, fundam sua posição no aspecto objetivo das regras do ônus da prova, isto é, no fato de que são elas regras julgamento. O

\footnotetext{
${ }^{510} \mathrm{E}$ tem se entendido, com razão, ser aplicável esta regra que autoriza a inversão do ônus da prova, também, em sede de ações coletivas, isto por força do micro-sistema processual coletivo formado pela conjugação do CDC (art. 90) com a Lei de Ação Civil Pública (art. 21 da Lei n. 7.347/85), que propicia cotejo conjunto e aplicação recíproca dos dois diplomas. A este respeito, por todos cf. LEONEL, Ricardo de Barros. Manual do processo coletivo. São Paulo: Ed. Revista dos Tribunais, 2002. p. 149-150.

${ }^{511}$ WATANABE, Kazuo et al. Código Brasileiro de Defesa do Consumidor (comentado pelos autores do anteprojeto). 5. ed. Rio de Janeiro: Forense, 1997. p. 617.

${ }^{512}$ Cf. CRUZ E TUCCI, José Rogério; TUCCI, Rogério Lauria. Devido processo legal e tutela jurisdicional, cit., p. 116; THEODORO JÚNIOR, Humberto. Direitos do consumidor. Rio de Janeiro: Forense, 2001. p. 140. Cf., também, TJ/RJ, Décima Quinta Câmara Cível, Agravo de Instrumento 2006.002.03231, Rel. Desembargador Celso Ferreira Filho, julgado em 03/07/2006; e JTAERGS 102/213.

${ }^{513}$ Fazendo a ressalva que o ônus só pode ser carreado ao fornecedor se ele tiver condições técnicas e informações suficientes para produzir a prova, cf. GRECO FILHO, Vicente. Direito processual civil brasileiro. 16. ed. São Paulo: Saraiva, 2003. v. 2, p. 193.

${ }^{514}$ Eis um precedente a revelar esta posição: "É a prolação da sentença o momento adequado para a inversão do ônus da prova, a favor do consumidor, porquanto encerrada a fase instrutória, dispõe o magistrado de elementos suficientes para analisar a conveniência dessa inversão, sem que isso represente ofensa ao princípio da ampla defesa do fornecedor, já que este tem ciência de que, de acordo com o art. $6^{\circ}$, VIII, do CDC, a regra pode ser invertida se o juiz considerar verossímil a alegação (TA/MG, AI n. 286.614-6, Rel. Juiz Brandão Teixeira, j. 28.10.99). Doutrinariamente adotam tal entendimento PACÍFICO, Luiz Eduardo
} 
juiz só aferirá se há a hipossuficiência do consumidor no momento de prolatar a sentença e após constatar o non liquet, carreando ao fornecedor o ônus por ter se desincumbido da prova. Anotam, por força desta interpretação, que compete ao fornecedor produzir todas as provas que estejam ao seu alcance (o que vem a bem da verdade real), eis que o juiz, no momento da sentença, pode entender ser pertinente a inversão pela incapacidade técnica do consumidor em produzir a prova (hipossuficiência), carreando ao fornecedor o ônus de não as ter produzido.

Outra posição entende que as regras sobre o ônus da prova, embora sejam, de fato, regras de julgamento, convertem-se em regras de procedimento quando invertidas judicialmente, competindo ao juiz, assim, avisar previamente as partes (preferencialmente na audiência preliminar do art. 331 do CPC) que encontra hipossuficiência do consumidor e que, como tal, aplicará de modo invertido o ônus da prova no caso de invencível non liquet. $^{515}$

O cotejo das duas posições com a experiência prática acaba por nos convencer de que a segunda corrente é muito mais coerente com as premissas desta investigação. Se um dos valores tutelados pelas regras de forma é a previsibilidade das ações dos atores processuais, somente quando há o prévio estabelecimento do procedimento processual é que as partes são capazes de antever e de programar todo o curso do processo. Tanto é assim que sustentamos, durante todo este estudo, ser fundamental, nas hipóteses em que

Boaventura. O ônus da prova no direito processual civil brasileiro, cit., 160; WATANABE, Kazuo et al. Código Brasileiro de Defesa do Consumidor (comentado pelos autores do anteprojeto), cit., p. 619-620; MATOS, Cecília. O ônus da prova no Código de Defesa do Consumidor. Revista de Direito do Consumidor, São Paulo, v. 11, p. 161-169, jul./set. 1994; e NERY JÚNIOR, Nelson; NERY, Rosa Maria de Andrade. Código de processo civil comentado e legislação extravagante, cit., p. 723.

${ }^{515}$ Eis agora um precedente a adotar esta posição: "Quando, a critério do juiz, configurar-se a hipótese de inversão do ônus da prova, nos termos do art. $6^{\circ}$, VIII, do CDC, sob pena de nulidade, é mister a prévia determinação à parte, em desfavor de quem se inverte o ônus, para que prove o fato controvertido. A inversão sem esta cautela implicará em surpresa e cerceamento de defesa (TA-RS, Ap. Cível n. 110.664, Rel. Juiz Márcio Oliveira Puggina, RT 14/114). Doutrinariamente adotam tal entendimento Francisco Glauber Pessoa Alves, O princípio jurídico da igualdade e o processo civil brasileiro, cit., p. 159; OLIVEIRA, James Eduardo. Código de Defesa do Consumidor: anotado e comentado. São Paulo: Atlas, 2004. p. 72; CAMBI, Eduardo. A prova civil: admissibilidade e relevância. São Paulo: Ed. Revista dos Tribunais, 2006. p. 418; SILVA, Bruno Freire e. A inversão judicial do ônus da prova. Revista de Processo, São Paulo, ano 32, n. 146, p. 341-342, abr. 2007; SICA, Heitor Vitor Mendonça. Questões velhas e novas sobre inversão do ônus da prova. Revista de Processo, São Paulo, ano 32, n. 146, p. 63-64, abr. 2007 (com a reserva de que a discussão não tem relevância prática); e Silvio Luis Ferreira da Rocha, que ainda adverte: "a inversão do ônus da prova não deve afrontar o devido processo legal e a segurança jurídica. $\mathrm{O}$ fornecedor não pode ser surpreendido ao final do processo e diante da não prova do nexo de causalidade entre o defeito do produto e o dano, que deveria ter sido feita pelo autor, ter a ação julgada procedente em seu favor porque o juiz resolveu, diante da hipossuficiência ou da verossimilhança da alegação do consumidor, inverter o ônus da prova. A inversão deverá ser determinada por ocasião da audiência do art. $331, \S 2^{\circ}$, do CPC (ROCHA, Silvio Luis Ferreira da. Responsabilidade civil do fornecedor pelo fato do produto no direito brasileiro. 2. ed. São Paulo: Ed. Revista dos Tribunais, 2000. p. 94). 
autorizada a flexibilização do procedimento legal, a participação das partes A partir do momento em que se admite que a inversão só se dê quando do julgamento, não se pode esperar do fornecedor que, em um exercício de premonição, anteveja como um profeta o non liquet e, se acautelando, produza a prova que nem se sabe ser necessária. Pese a maior atenção ao aspecto objetivo das regras do ônus da prova, a própria doutrina não afasta, por completo, a importância do seu aspecto subjetivo ${ }^{516}$, isto é, a indicação prévia para as partes de quais serão as conseqüências de sua desídia probatória.

A inversão judicial, assim, a bem de serem evitadas as tão criticadas "decisões surpresas", é regra de procedimento. E mesmo que se prefira a adoção da posição tradicional (regra de julgamento), a bem do princípio do contraditório, que ao menos se lhe abra uma exceção para permitir que as partes sejam previamente e expressamente alertadas da possibilidade de inversão. O fundamento é pouco importante frente ao alcance dos objetivos colimados: tornar o encaminhamento procedimental previsível.

Eis que, então, adotado este posicionamento, estamos diante de mais uma regra de procedimento que autoriza tramitações alternativas: ou se seguem as regras padrão sobre o ônus da prova ou, na hipótese legal, invertem-se judicialmente estas regras, com todos os reflexos procedimentais que isto acarreta.

\subsubsection{Interrupção do curso procedimental pela resolução antecipada do pedido}

$\mathrm{O}$ processo de conhecimento, em qualquer de seus procedimentos (comuns ou especiais), como regra, tem quatro fases distintas: postulatória, saneadora, instrutória e decisória.

Se no curso do procedimento houver recurso das partes quanto a qualquer das decisões tomadas no iter (incidentais ou final), inaugura-se, então, um novo procedimento, paralelo (agravo de instrumento) ou conseqüente (apelação, embargos de declaração e infringentes, recursos extraordinário e especial). O procedimento recursal também tem, como regra, suas fases: postulação, contra-postulação e decisão colegiada.

\footnotetext{
${ }^{516}$ PACÍFICO, Luiz Eduardo Boaventura. O ônus da prova no direito processual civil brasileiro, cit., p. 139142.
} 
Tanto os procedimentos em $1^{\circ}$ grau de jurisdição quanto o recursal foram abstratamente modelados para percorrerem todas as citadas fases. Afinal, estas fases foram logicamente formatadas para o correto exercício da jurisdição e efetiva participação das partes em contraditório.

Todavia, em circunstâncias excepcionais, e sem prejuízo da apreciação do pedido formulado ${ }^{517}$ e do respeito às garantias constitucionais do processo, o legislador possibilita o julgador que abrevie o curso do procedimento, suprimindo uma ou mais das fases retro-mencionadas.

Surge, então, a variante ritual alternativa da interrupção do curso procedimental pela resolução antecipada do pedido, que encontra no nosso sistema diversos dispositivos a revelá-la.

\subsubsection{Julgamento antecipadíssimo da lide (art. 285-A do CPC)}

O legislador, atento à dimensão objetiva do art. 5, LVXXVIII, da CF (princípio da tutela jurisdicional sem dilações indevidas), acrescido pela emenda constitucional $\mathrm{n}$. 45/2004 (Reforma do Judiciário), criou pela Lei n. 11.277/2006 ${ }^{518}$ - que inseriu no bojo do CPC o art. 285-A - poderoso instrumento de contenção da demanda e de célere solução das controvérsias ${ }^{519}$, permitindo ao juiz "quando a matéria controvertida for unicamente de direito e no juízo já houver sido proferida sentença de total improcedência em outros casos idênticos", a dispensa da citação, com a prolação da sentença, "reproduzindo-se o teor da anteriormente prolatada" (art. 285-A, caput, do CPC).

\footnotetext{
${ }^{517}$ Esta é a razão pela qual não se fará análise da extinção do processo, sem julgamento do mérito, pelo indeferimento da inicial, que como tal não aprecia o pedido formulado pela parte, deixando sem solução a crise de direito material.

${ }^{518}$ A Ordem dos Advogados do Brasil, dias após a publicação da Lei n. 11.277, de 08.02.2006 (29.03.2006), ajuizou perante o Supremo Tribunal Federal uma ação declaratória de inconstitucionalidade do art. 285-A, do CPC (ADIN n. 3.695/DF, Rel. Min. Cezar Peluso). A referida ADIN aguarda julgamento, mas além da intervenção do Instituto Brasileiro de Direito Processual, na qualidade de amicus curiae, em favor da constitucionalidade da norma, já há parecer do Procurador Geral da República pela improcedência do pedido, de modo que o prognóstico que se faz de seu resultado é o do reconhecimento da constitucionalidade do art. 285-A do CPC.

${ }^{519}$ Estima-se, principalmente na Justiça Federal, que mais de $50 \%$ dos feitos de matéria tributária, previdenciária e habitacional - onde preponderam discussões nitidamente de direito cuja solução independe da produção de provas - estejam em condições de assim serem julgadas, com nítido ganho temporal tanto no próprio feito quanto nos demais que não admitem aplicação da norma (que terão sua apreciação acelerada pela desobstrução das vias judiciais).
} 
De acordo, ainda, com o $\S \S 1^{\circ}$ e $2^{\circ}$ do citado dispositivo, se o autor apelar do julgamento liminar da ação repetida, é facultado ao juiz decidir no prazo de 05 (cinco) dias por não manter a sentença, determinando o prosseguimento da demanda. Caso contrário deverá ordenar a citação do réu para responder ao recurso, posteriormente o encaminhando para a instância superior.

Descortina-se nítido o propósito da nova norma de permitir ao magistrado que, mesmo antes da citação da parte ex adversa - e, portanto, com dispensa de parcela da fase postulatória (resposta), e dispensa integral das fases instrutória e saneadora - julgue improcedente (e não procedente) a demanda quando a tese jurídica (causa de pedir) já lhe seja conhecida, tendo sido afastada em outros feitos, antecipando, assim, o julgamento da causa. $^{520}$

A grande novidade do dispositivo não está propriamente no seu conteúdo, mas sim na sua generalização. Antes da Lei n. 11.277/2006, já havia no sistema dois dispositivos que permitiam (e ainda permitem) ao juiz o liminar julgamento de improcedência da ação, pese em situações bastante específicas.

A primeira delas está no art. 269, IV, do CPC, que combinado com o art. 295, IV, do mesmo diploma, permite ao juiz o indeferimento da inicial pelo advento da prescrição ou da decadência, ou seja, com afastamento da pretensão do autor (julgamento de mérito).

É certo que tal dispositivo - ao menos no tocante à prescrição - era de quase nenhum utilidade prática, pois, como sempre foi tradição no direito brasileiro, era vedado o reconhecimento de ofício da prescrição para questões patrimoniais (o que acabava contemplando praticamente todas as suas hipóteses). ${ }^{521}$ Mas com o advento do CC/2002, que admitia o reconhecimento da prescrição - mesmo a tutelante de direitos patrimoniais em favor de absolutamente incapaz (art. 194), e mais recentemente com a alteração do art.

\footnotetext{
${ }^{520} \mathrm{O}$ art. 285-A do CPC foi objeto do meu O principio constitucional da tutela jurisdicional sem dilações indevidas e o julgamento antecipadíssimo da lide, cit., p. 150-179. Na ocasião sustentei, inclusive, que é possível a aplicação do art. 285-A do CPC, tendo por caso paradigma súmula dos Tribunais Superiores, pois, se é admitida a improcedência de plano com base no simples entendimento do juízo, com muito mais razão há de se admitir o julgamento liminar quando a pretensão contrarie dispositivo de súmula dos Tribunais Superiores, que é motivo hoje para o não recebimento do recurso (art. 518, §§, do CPC, com redação pela Lei n. 11.276/2006) e para o seu julgamento monocrático pelas instâncias superiores (art. 557, $\S 1^{\circ}$-A, do CPC).

${ }^{521}$ Por todos, cf. AMORIM FILHO, Agnelo. Critério científico para distinguir a prescrição da decadência e para identificar as ações imprescritíveis. Revista dos Tribunais, São Paulo, ano 86, n. 744, p. 725-750, out. 1997.
} 
219, $\S 5^{\circ}$, do Código de Processo Civil pela Lei n. 11.280/2006, que revogando a norma de direito material citada admitiu o reconhecimento de qualquer natureza de prescrição de ofício (patrimonial ou não), de se reconhecer o fortalecimento da hipótese de julgamento liminar da improcedência da ação.

A decadência, por sua vez - excetuada a convencional - sempre pode ser reconhecida de ofício pelo juiz (art. 210 e 211 do CC), algo que não era atípico, especialmente nas ações fundadas no Código de Defesa do Consumidor (art. 26 da Lei n. $8.078 / 90)$.

A outra hipótese de julgamento liminar de improcedência da ação é fruto da Medida Provisória n. 2.225-45/2001 (ainda em vigor por força da Emenda Constitucional n. 32), que acrescentou ao art. 17 da Lei n. 8.429/92 (Lei de Improbidade Administrativa) inúmeros parágrafos.

De acordo com o rito imprimido pela citada MP, aplica-se às ações de improbidade administrativa uma fase de defesa prévia muito cara aos crimes praticados por funcionários públicos (art. 513 a 518 do Código de Processo Penal). Por isso, ajuizada a ação e ofertada ao acusado a possibilidade de oferecer uma defesa preliminar $\left(\S 7^{\circ}\right)$, o juiz pode, além do indeferimento da inicial pela inadequação da via eleita ou vícios formais (art. 283 c.c. art. 295 do CPC), julgar a ação improcedente de plano (mérito), desde que convencido da inexistência do ato de improbidade pelos elementos trazidos aos autos (inclusive os de fato!). Caso o juiz, entretanto, entenda presentes elementos suficientes para o processamento da ação, receberá a petição inicial e determinará a citação do demandado $\left(\S 9^{\circ}\right)$ - em decisão agravável $\left(\S 9^{\circ}\right)$ - quando então se completará a formação da relação jurídica processual.

Note-se que em ambos os casos citados (prescrição/decadência e improbidade administrativa) o sistema já admitia o julgamento liminar da improcedência da ação, razão pela qual, se há algo novo no art. 285-A do CPC, repita-se, é a generalização de sua aplicação para todas as ações cíveis (incluindo aqui as trabalhistas). ${ }^{522}$

\footnotetext{
${ }^{522}$ Revelando visão pessimista sobre o instituto se colocam Luis Rodrigues Wambier, Teresa Arruda Alvim Wambier e José Miguel Garcia Medina, apontando o dispositivo como "visão eloqüente e lamentável da tentativa de resolver os problemas do país (inclusive do processo) pela via de negativa de fruição das garantias constitucionais", já que o pretendido desafogamento do primeiro grau implicará sobrecarga nos tribunais, que terão de "cumprir, de certo modo, o papel do juízo de primeiro grau, na hipótese do réu oferecer suas contra-razões", algo que podia ser evitado com o simples julgamento antecipado da lide
} 


\subsubsection{Julgamento antecipado da lide (art. 330 do CPC)}

Uma outra variante ritual alternativa, contemplada no art. 330, do CPC, é a que permite ao juiz, finda a fase postulatória, dispensar integralmente a fase saneadora e a fase instrutória, proferindo julgamento do processo no estado em que se encontra.

Aponta o citado dispositivo que "o juiz conhecerá diretamente do pedido, proferindo sentença: i) quando a questão de mérito for unicamente de direito, ou sendo de direito e de fato, não houver necessidade de produção de prova em audiência; ou ii) quando ocorrer a revelia (art. 319)".

Tanto quanto as demais variantes estudadas neste tópico, o julgamento antecipado é medida de exceção e só pode ser empregado, sob pena de cerceamento do direito à prova, de maneira fundamentada e nas restritas hipóteses contempladas no dispositivo, que bem se resumem a uma: desnecessidade de produção de provas para o julgamento do conflito. ${ }^{523}$

Com efeito, o direito à prova, bem como a prática de todos os atos a ela inerentes, é garantia constitucional decorrente do próprio exercício do direito de ação e do contraditório. A dilação probatória, por isto, faz parte do modelo procedimental pátrio, que foi moldado para permitir à parte a comprovação de todos os fatos por si alegados no processo (fase instrutória). Somente quando a prova de fato for realmente dispensável por

(MEDINA, José Miguel Garcia; WAMBIER, Luis Rodrigues; WAMBIER, Teresa Arruda Alvim. Breves comentários à nova sistemática processual civil 2. São Paulo: Ed. Revista dos Tribunais, 2006. p. 63-64). Não me convence a crítica. Primeiro, porque a aplicação racional das garantias, em especial compatibilizadas com outras de idêntico status (como a da duração razoável do processo), não nega vigência à Constituição Federal. E segundo, porque partem os autores, a meu ver, da equivocada premissa de que as cortes de $2^{\circ}$ grau desempenharão papel de reforma das decisões proferidas com base no art. 285A do CPC, quando eles mesmos, em determinada passagem da citada obra, com acerto apontam que a sentença a ser repetida deve estar em consonância com a jurisprudência dominante, até para compatibilizar o art. 285-A com a súmula impeditiva de recursos (art. 518, §§, do CPC) e com o julgamento monocrático dos recursos improcedentes (art. 557, § $1^{\circ}$-A, do CPC). Já em visão otimista sobre a norma, Luiz Guilherme Marinoni bem aponta que "o novo instituto constitui importante arma para a racionalização do serviço jurisdicional. É racional que o processo que objetiva decisão acerca da matéria de direito, sobre a qual o juiz já firmou posição, seja desde logo encerrado, evitando gasto de energia para a obtenção da decisão a respeito de 'caso idêntico' ao já solucionado. O processo repetitivo constituiria formalismo desnecessário, pois tramitaria somente para autorizar o juiz a expedir decisão cujo conteúdo foi definido no primeiro processo" (MARINONI, Luiz Guilherme. Ações repetitivas e julgamento liminar. Site pessoal Prof. Luiz Guilherme Marinoni. Disponível em: <http://www.professormarinoni.com.br/admin/users/35.pdf>. Acesso em: 07 maio 2007).

${ }^{523}$ Cf. DINAMARCO, Cândido Rangel. Julgamento antecipado do mérito. In: processo civil moderno, cit., v. 2, p. 1.032-1.033. Fundamentos do 
inexistir controvérsia a respeito (questão exclusivamente de direito e contumácia ${ }^{524}$ ), ou quando tais fatos forem impertinentes ou irrelevantes para a decisão do mérito (fato incontroverso, notório ou já comprovado por documento), é que se admite o julgamento antecipado, com dispensa de audiências. ${ }^{525}$ Do contrário, a sentença proferida é nula por violação de garantia constitucional. ${ }^{526}$

Todavia, a utilidade do art. 330 do CPC é enorme, e tem nítidos efeitos sobre a qualidade temporal do processo quando empregada adequadamente, seja pela desobstrução das vias judiciais, seja pelo próprio oferecimento de tutela jurisdicional mais rapidamente. Boa parte dos casos em trâmite no Judiciário brasileiro são mesmo solucionáveis apenas com análise de documentos já apresentados pelas partes nos articulados iniciais, quando não independentemente de qualquer comprovação fática. ${ }^{527}$

Por isto, permitir-se que um feito se arraste pela fase instrutória quando as provas a serem produzidas forem dispensáveis, sem emprego oportuno da variante ritual alternativa ora em análise, é deficiência técnica tão grave quanto a de ser julgado antecipadamente o feito quando o caso exigia dilação probatória. ${ }^{528}$

\footnotetext{
${ }^{524} \mathrm{~A}$ expressão contumácia foi empregada aqui voluntariamente, com o sentido de total omissão do réu quanto o curso do processo. Se o réu só for revel e não contumaz - como ocorre com aquele que oferta resposta intempestiva, constituindo advogado para representá-lo no processo - não se pode proceder ao julgamento antecipado sem ressalvas, eis que passa a ser ônus do réu a produção de provas a fim de afastar a presunção relativa de veracidade dos fatos advinda da revelia (art. 319 do CPC). Daí porque, no art. 330, II, do CPC, a lei se refere exclusivamente à hipótese do réu revel que também é contumaz.

${ }^{525}$ Conforme notícia de Dinamarco, este foi o espírito e o propósito que informou a inserção, no bojo do CPC de 1973, do capítulo destinado ao julgamento do processo no estado: suprimir a desnecessária realização de audiências (DINAMARCO, Cândido Rangel. Julgamento antecipado da lide após a perícia. In:

Fundamentos do processo civil moderno, cit., v. 1, p. 460).

${ }^{526} \mathrm{~A}$ jurisprudência dos tribunais pátrios, especialmente do Superior Tribunal de Justiça, é iterativa a este respeito. Cf. Resp. n. 898.123/SP, Rel. Min. Jorge Scartezzini, $4^{a}$ Turma, j. 13.02.007, vu; Resp. n. 651.315/MT, Rel. Min. Castro Filho, $1^{a}$ Turma, j. 09.08.2005, vu; e Resp. n. 649.191/SC, Rel. Min. Carlos Alberto Menezes Direito, $3^{\mathrm{a}}$ Turma, j. 19.08.2004, vu.

${ }^{527}$ Estas idéias já foram desenvolvidas em nosso Técnicas de aceleração do processo, cit.,p. 146.

${ }^{528}$ Precisa neste sentido é a nota de José Carlos Barbosa Moreira: "Deficiências técnicas na aplicação da norma são fontes de numerosas desgraças. Para começar, dão ensejo à inútil sobrevivência de boa quantidade de processos que, de certo, não contribuiriam com contribuem para obstruir os canais judiciais, se os juízes deles incumbidos manejassem com maior destreza instrumentos que lhe oferecem os dispositivos do Código de Processo Civil concernentes ao indeferimento da petição inicial e extinção do feito (arts. 295 e 329, respectivamente)" (MOREIRA, José Carlos Barbosa. Efetividade do processo e técnica processual. In: . Temas de direito processual: $6^{a}$ série. São Paulo: Saraiva, 1997. p. 23).
} 


\subsubsection{Súmula impeditiva de recursos (art. $518, \S 1^{\circ}$, do CPC)}

No nosso sistema jurídico, desde o advento da República, as proposições constantes da jurisprudência, inclusive as súmulas, como regra, tinham caráter persuasivo e não vinculante, ou seja, não tinham obrigatoriedade equivalente à da lei. A sua finalidade era a de conferir estabilidade à jurisprudência, facilitando o julgamento das questões semelhantes. $^{529}$

Com a emenda constitucional n. 45 e regulamentação advinda da Lei n. $11.417 / 2006$, re-introduziu-se ${ }^{530}$ no nosso sistema a chamada súmula vinculante, preceito interpretativo emanado pelo Supremo Tribunal Federal, cuja observância é obrigatória tanto pelos órgãos da Administração Pública quanto pelas instâncias inferiores do Judiciário (art. 103-A da Constituição Federal).

Dois tipos de súmulas conviverão no nosso sistema. As súmulas vinculantes, editadas pelo Supremo Tribunal Federal com base no fórum qualificado de $2 / 3$ de seus membros, de caráter cogente (art. $2^{\circ}$ da Lei n. 11.417/2006); e as súmulas persuasivas, emitidas genericamente por todos os Tribunais (especialmente os Superiores), aprovadas conforme disciplinado em seus regimentos internos, e cuja aplicação não é obrigatória. ${ }^{531}$

Às súmulas persuasivas, apesar do seu caráter facultativo, não se pode negar importância. Conforme já investigamos outrora (item 4.1.), diante da cada vez mais crescente influência da common law e do sistema de precedentes no direito brasileiro, a sedimentação das decisões adotadas topicamente pelas instâncias superiores sobre determinado assunto, até por disciplina judiciária, são costumeiramente seguidas pelos juízes de instâncias inferiores. ${ }^{532}$

\footnotetext{
${ }^{529}$ Para amplo levantamento sobre o tema, cf. CRUZ E TUCCI, José Rogério. Precedente judicial como fonte do direito. São Paulo: Ed. Revista dos Tribunais, 2004, especialmente p. 247-312.

${ }^{530} \mathrm{O}$ verbo re-introduzir foi adequadamente empregado, vez que no período Colonial e Imperial, quando ainda estávamos sob o jugo das Ordenações, os assentos da Casa de Suplicação tinham força vinculante. Vale a nota, inclusive, que com a transformação, em 1808, do Tribunal de Relação do Rio de Janeiro em Casa da Suplicação para o Brasil, reconheceu-se a esta corte a prerrogativa de emitir assentos interpretativos no âmbito de sua jurisdição (CRUZ E TUCCI, José Rogério. Precedente judicial como fonte do direito, cit., p. 147).

${ }^{531}$ TAVARES, André Ramos. Nova lei de súmula vinculante. São Paulo: Método, 2007. p. 23-26 e 35.

${ }^{532}$ Isto porque, conforme bem aponta Marinoni, afirmar que o juiz tem o direito de julgar de forma diferente aos tribunais superiores constitui gritante equívoco. Se é o Superior Tribunal de Justiça quem dá a última palavra em relação à interpretação da lei federal, qual é a racionalidade de se dar ao juiz o poder de proferir uma decisão que lhe seja contrária? (...)“Portanto, decidir de forma contrária à súmula apenas obriga à interposição de recurso, consumindo mais tempo e despesas, seja da administração da justiça, seja do próprio cidadão. Sendo assim, a afirmação da prerrogativa de o juiz decidir de "forma diferente" do
} 
Exatamente por isto, a Lei n. 11.276/2006, em interessante mecanismo de contenção e variação do procedimento recursal, alterou a redação do art. 518 do CPC para constar que o juiz "não receberá o recurso de apelação quando a sentença estiver em conformidade com súmula do Superior Tribunal de Justiça ou do Supremo Tribunal Federal” ( $\left(1^{\circ}\right)$, suprimindo, assim, as fases recursais da contra-postulação e da decisão colegiada. Antes, atividade semelhante, com dispensa da fase de decisão colegiada, só podia ser feita monocraticamente pelo relator, nos termos do art. 557 do CPC. ${ }^{533}$

Repare-se que apesar da locução cogente do dispositivo ("não receberá"), o recebimento ou não do recurso ficará mesmo a critério do juízo a quo, sem que haja maiores problemas em relação a isto. Primeiro, porque definir se a decisão está ou não em conformidade com a súmula é tarefa, convenhamos, subjetiva. Sendo a súmula o resumo da interpretação sobre a validade, alcance e eficácia da norma jurídica, sempre sobejarão questões de fato impugnáveis a justificar a recepção do recurso (e o afastamento da aplicabilidade da súmula inteiramente ao caso). E segundo, porque se de um lado cabe agravo de instrumento contra a decisão que não recebe o recurso com base no art. 518, § $1^{\circ}$, do CPC, por outro, da decisão que indevidamente o recebe, não cabe recurso algum, sendo manifesta a falta de interesse recursal do recorrido, que não sofre prejuízo pelo processamento regular do recurso. No máximo o recorrido pode, com fundamento no art. 557 do CPC, vindicar, em contra-razões, o não conhecimento do reclame. ${ }^{534}$

entendimento fixado pelos tribunais superiores, longe de ser algo que tenha a ver com a consciência do magistrado, constitui um ato de falta de compromisso com o Poder Judiciário, que deve estar preocupado, dentro do seu sistema de produção de decisões, com a efetividade e a tempestividade da distribuição da justiça. E não só um ato de falta de compromisso com o Judiciário, mas também um ato que atenta contra a cidadania, pois desconsidera o direito constitucional à razoável duração do processo"(...)"Nessa perspectiva, as decisões que afrontam súmulas dos tribunais superiores soam como um lamentável exercício de rebeldia, que só se transforma em realidade no caso em que a decisão estadual ou regional se torna coisa julgada diante da falta de preparo dos advogados em empregar os devidos recursos para corrigir a interpretação extravagante" (MARINONI, Luiz Guilherme. Ações repetitivas e julgamento liminar, cit. Sobre a importância dos precedentes jurisprudenciais para a segurança e estabilidade jurídica, cf., também, MANCUSO, Rodolfo de Camargo. Divergência jurisprudencial e súmula vinculante. São Paulo: Ed. Revista dos Tribunais, 1998. p. 288, CUNHA, Sérgio Sérvulo da. O efeito vinculante e os poderes do juiz. São Paulo: Saraiva, 1999. p.288; e WAMBIER, Teresa Arruda Alvim. Nulidades do processo e da sentença, cit., p. 329.

${ }^{533}$ MEDINA, José Miguel Garcia; WAMBIER, Luis Rodrigues; WAMBIER, Teresa Arruda Alvim. Breves comentários à nova sistemática processual civil 2, cit., p. 226.

${ }^{534}$ Este parece ser o entendimento, aliás, de Cândido Rangel Dinamarco, a sustentar ser irrecorrível a decisão que determina o processamento do recurso, já que o órgão ad quem, de qualquer forma, fará, independentemente de provocação do prejudicado, novo juízo de admissibilidade do recurso (DINAMARCO, Cândido Rangel. Agravo inadmissível. In: Fundamentos do processo civil moderno, cit., p. 1.156-1.157). 
Por isto, estamos convictos de que o art. $518, \S 1^{\circ}$, do CPC, se insere de modo global no regime de flexibilização alternativa do procedimento, eis que é possível ao magistrado, com base na lei, determinar ou não o processamento do recurso, suprimindo ou não fases do procedimento recursal.

\subsubsection{Julgamento monocrático dos recursos (art. 527, I, 557, § $1^{\circ}$ e $\$ 1^{\circ}$-A, do CPC)}

Outra variante ritual alternativa cada vez mais empregada na prática forense, isto por força da invencível da carga de recursos submetidos à apreciação dos Tribunais ${ }^{535}$, e que vem a reforçar, também, a tendência já apontada de valorização dos precedentes, é a que permite ao relator decidir monocraticamente o recurso.

Aponta o art. 557, caput, do CPC (a quem o art. 527, I, do CPC, tutelante do agravo de instrumento, faz referência expressa), que "o relator negará seguimento a recurso manifestamente inadimissível, improcedente, prejudicado ou em confronto com súmula ou com jurisprudência dominante do respectivo tribunal, do Supremo Tribunal Federal, ou de Tribunal Superior". Paralelamente, o $\S 1^{\circ}$-A do dispositivo permite também, desde que a decisão esteja em confronto com súmula ou com jurisprudência dominante do Supremo Tribunal Federal ou de Tribunal Superior, que o relator dê provimento ao recurso, reformando a decisão impugnada.

Antes da Lei n. 9.756/1998, que deu a redação supra ao art. 557 do CPC, era da tradição jurídica brasileira que ao relator só era dado processar o feito e prepará-lo para o julgamento, não, porém, julgá-lo, algo que, de ordinário, era tarefa privativa do colegiado, juiz natural dos recursos. ${ }^{536}$ As exceções ficavam com o agravo de instrumento - que na redação primitiva do dispositivo já podia ser rejeitado pelo relator quando manifestamente improcedente - e com os recursos extraordinário e especial, nos termos do art. 38 da Lei n. 8.038/1990 (rejeição com base em súmula).

\footnotetext{
${ }^{535}$ Para análise completa dos dados que confirmam tal assertiva, cf. o nosso Técnicas de aceleração do processo, cit., p. 147-148.

${ }^{536}$ MOREIRA, José Carlos Barbosa. Algumas inovações da Lei n. 9.756 em matéria de recursos cíveis. In: Temas de direito processual: $7^{\mathrm{a}}$ série, cit., p. 73 .
} 
$\mathrm{Na}$ sistemática atual, entretanto, reconhece-se genericamente o poder do relator de decidir, monocraticamente, o destino de qualquer recurso ${ }^{537}$, o que vem cada vez mais diminuindo o número de julgamentos colegiados e aproximando, ao menos parcialmente, o papel desempenhado pelos Desembargadores e Ministros com o desenvolvido pelo juiz de $1^{\mathrm{o}}$ grau.

Aqui também, tanto quanto já mencionado na análise do art. 518, $\S 1^{\circ}$, do $\mathrm{CPC}$, a impressão de cogência do art. 557, caput, do CPC (“o relator negará seguimento”) cede espaço à subjetividade do ato, já que caberá ao relator - e só a ele - decidir se o recurso é manifestamente inadmissível, improcedente, prejudicado, ou em confronto com súmula ou jurisprudência dominante (aliás, nem se sabe ao certo o que e qual será a jurisprudência dominante). Caso seja determinado o processamento do recurso em seus moldes tradicionais, não pode o recorrido atacar esta decisão irrecorrível ${ }^{538}$, tampouco o revisor ou o órgão colegiado pretender que o relator, ainda que presentes os requisitos do art. 557 do CPC, julgue monocraticamente o recurso, o que confirma o caráter opcional da disposição.

A impressão salientada de que o art. 557 contempla uma variante procedimental ganha ainda mais relevo quando, à luz do $\$ 1^{\circ}$-A do dispositivo, se encontra a expressão "poderá dar provimento ao recurso", inequívoca demonstração da facultatividade do dispositivo. Com a razão de ser do caput do dispositivo e do $\S 1^{\circ}$-A é idêntica (permitir ao relator julgar monocraticamente), não há espaço para se creditar cogência a um dos dispositivos em detrimento do outro. ${ }^{539}$

Apesar do manifesto propósito aceleratório da norma, da decisão do relator que julgar monocraticamente o recurso cabe agravo para o colegiado (art. 557, $\S 1^{\circ}$, e 545, ambos do CPC), o que chega até a tornar prejudicial o uso da faculdade procedimental aqui

\footnotetext{
${ }^{537}$ MEDINA, José Miguel Garcia. Juízo de admissibilidade e juízo de mérito dos recursos na nova sistemática recursal e sua compreensão jurisprudencial de acordo com as leis n. 9.756/98 e 9.800/99. In: ALVIM, Eduardo Pellegrini de Arruda; NERY JÚNIOR, Nelson; WAMBIER, Teresa de Arruda Alvim (Coords.). Aspectos polêmicos e atuais dos recursos. São Paulo: Ed. Revista dos Tribunais, 2000. p. 369; e NERY JÚNIOR, Nelson; NERY, Rosa Maria de Andrade. Código de processo civil comentado e legislação extravagante, cit., p. 950.

${ }^{538}$ DINAMARCO, Cândido Rangel. Agravo inadmissível, cit., v. 2, p. 1.156-1.157.

${ }^{539}$ Este entendimento também é revelado por Dinamarco, para quem o legislador "quis deixar ao prudente arbítrio do próprio relator a opção entre julgar por si próprio, monocraticamente, ou encaminhar o caso ao colegiado. Naturalmente, esta opção sempre dependerá do grau de convicção do relator, a quem competirá, com honestidade profissional, abster-se de julgar quando sentir que a matéria não é tão segura que legitime esses verdadeiros atalhos procedimentais instituídos pela lei” (DINAMARCO, Cândido Rangel. O relator, a jurisprudência e os recursos. In: 1.106). . Fundamentos do processo civil moderno, cit., v. 2, p. 1.105-
} 
deferida. Conforme já advertiu autorizado doutrina, a possibilidade de julgamento monocrático é inócua, eis que implicará duplo julgamento da mesma matéria pelo relator e pelo colegiado ao qual este se vincula. ${ }^{540}$ É manifesto que quem já recorreu não se conformará com a decisão singular do relator, só porque se trata de um juízo hierarquicamente superior. O benefício temporal com o improvimento ou provimento singular do recurso, além de prejudicado, é revertido, com a análise do agravo interno pelo colegiado. Melhor que se fixasse a irrecorribilidade dessa decisão no âmbito do mesmo tribunal, pese a discussão acentuada que se instauraria a respeito da constitucionalidade da subtração da decisão do órgão colegiado. ${ }^{541}$

Seja como for, é certo que com o julgamento monocrático do recurso pelo relator, especialmente no que toca à análise do mérito da pretensão recursal (provimento e improvimento) dispensa-se a fase de julgamento colegiado pelo Tribunal, o que implica reflexos procedimentais evidentes, a passar pela apreciação antecipada do pleito recursal, e supressão do direito da parte em sustentar oralmente suas razões perante o colegiado (art. 554 do CPC). ${ }^{542}$

\subsubsection{Conversão legal de recursos $\left(527\right.$, II, e art. 544, $\S 3^{\circ}$, do CPC)}

Outra variante ritual alternativa a merecer destaque é a que permite ao relator do recurso sua conversão em outra modalidade recursal, conversão esta que pode vir acompanhada ou não de um julgamento monocrático, nos moldes do explicitado pelo art. 557 do CPC (item. 5.3.3.4 supra).

\footnotetext{
${ }^{540}$ ARMELIN, Donaldo. Apontamentos sobre as alterações ao Código de Processo Civil e à Lei n. 8.038/90, impostas pela Lei n. 9.756/98. In: WAMBIER, Teresa Arruda Alvim (Coord.). Aspectos polêmicos e atuais dos recursos cíveis de acordo com a Lei n. 9.756/98. São Paulo: Ed. Revista dos Tribunais, 1999. p. 209.

${ }^{541}$ José Carlos Baptista Puoli bem defende a constitucionalidade da opção legal de supressão do órgão colegiado no julgamento de alguns recursos. Além do argumento de cunho pragmático no sentido de que há, no âmbito dos Tribunais, "síndrome da unanimidade", a representar que é mesmo o relator que acaba por definir a sorte do recurso mesmo nos julgamentos colegiados, o autor destaca do ponto de vista dogmático que, à exceção de poucas hipóteses constitucionais em que se impôs a colegialidade (art. 97 da $\mathrm{CF}$ ), a Carta Constitucional deixou a critério do legislador infraconstitucional a eleição do julgador em $2^{\circ}$ grau (Os poderes do juiz e as reformas do processo civil, cit., p. 202-203). No mesmo sentido José Miguel Garcia Medina (Juízo de admissibilidade e juízo de mérito dos recursos na nova sistemática recursal e sua compreensão jurisprudencial de acordo com as leis n. 9.756/98 e 9.800/99, cit., p. 374).

${ }^{542} \mathrm{Em}$ sentido contrário à nota supra, MOREIRA, José Carlos Barbosa. Lei n. 9.756: uma inconstitucionalidade flagrante e uma decisão infeliz. In: Temas de direito processual: $7^{\mathrm{a}}$ série, cit., p. 83-86). Apesar da insurgência do ilustre professor carioca, o Supremo Tribunal Federal já teve a oportunidade de se pronunciar no sentido da constitucionalidade da Lei n. 9.756/98 (Agravo Regimental no Recurso Extraordinário. n. 227.030, Rel. Min. Carlos Veloso, j. 11.5.1999).
} 
Duas são as hipóteses legais em que é autorizada esta conversão.

Indica o art. 527, II, do CPC, com redação dada pela Lei n. 11.187/2005, que recebido o agravo de instrumento pelo relator, ele, em decisão irrecorrível (art. 527, parágrafo único, do $\mathrm{CPC})^{543}$, “converterá o agravo de instrumento em agravo retido, salvo quando se tratar de decisão suscetível de causar à parte lesão grave e de difícil reparação, bem como nos casos de inadmissão da apelação e nos relativos aos efeitos em que a apelação é recebida, mandando remeter os autos ao juiz da causa”.

Note-se que o dispositivo - também aqui interpretado de modo a admitir que a conversão se opere apenas facultativamente, à luz da convicção do relator - implica

${ }^{543} \mathrm{O}$ art. 527, parágrafo único, do CPC, embora tenha pretendido isto, não disse claramente que a decisão que ordena a conversão é irrecorrível. De acordo com a norma, a reforma do ato é possível quando do julgamento do agravo pelo órgão colegiado, bem como nos casos em que o próprio relator o reconsiderar. $\mathrm{O}$ detalhe é que ambas operações, na prática, não são logicamente possíveis. A primeira (reforma pelo colegiado), pois tendo havido a conversão, não haverá julgamento colegiado do agravo de per si, eis que somente serão apreciados, na forma retida, se houver recurso de apelação e indispensável reiteração futura (art. 523, § $1^{\circ}$, do CPC). E na segunda hipótese, ordenada a conversão os autos tornam de imediato ao primeiro grau para apensamento aos principais, de modo que não há nem onde ser materializado o pedido de reconsideração. Conforme já adverti em outra oportunidade, onde sustentei o enorme prejuízo que a Lei n. 11.187/2005 trouxe à justiça de $1^{\circ}$ grau, a tentativa de obstar o recurso da conversão - exatamente o que diferencia o regime atual de conversão do pretérito (Lei n. 10.352/2001) - esbarra na utilização do mandado de segurança como sucedâneo recursal (art. $5^{\circ}$, II, da Lei n. 1.533/51), já que os antigos agravos internos simplesmente serão substituídos pelos writs (GAJARDONI, Fernando da Fonseca. A nova sistemática do recurso de agravo introduzida pela Lei n. 11.187/2005 e os prejuízos à justiça de $1^{\circ}$ grau, cit., p. 159-166). No sentido do exposto, isto é, do cabimento do mandado de segurança como sucedâneo recursal para atacar a decisão que converteu o instrumento em retido, acompanhemos a recentíssima decisão do STJ: "Processo civil. Recurso em mandado de segurança. Possibilidade de impetração do writ dirigido diretamente ao Plenário do Tribunal a quo, visando a impugnar decisão irrecorrível proferida pelo Relator que, nos termos do art. 522, inc. II, do CPC (com a redação dada pela Lei $\mathrm{n}^{\circ} 11.187 / 2005$ ), determinou a conversão do agravo de instrumento interposto pela parte, em agravo retido. - As sucessivas reformas do Código de Processo Civil estabeleceram um processo cíclico para o agravo de instrumento: Inicialmente, ele representava um recurso pouco efetivo, de modo que sua interposição vinha sempre acompanhada da impetração de mandado de segurança que lhe atribuísse efeito suspensivo. Visando a modificar essa distorção, a Lei no 9.139/95 ampliou o espectro desse recurso, tornando-o ágil e efetivo, o que praticamente eliminou o manejos dos writs para a tutela de direitos supostamente violados por decisão interlocutória. - O aumento da utilização de agravos de instrumento, porém, trouxe como contrapartida o congestionamento dos Tribunais. Com isso, tornou-se necessário iniciar um movimento contrário àquele inaugurado pela Lei $\mathrm{n}^{\circ}$ 9.139/95: o agravo de instrumento passou a ser restringido, inicialmente pela Lei $\mathrm{n}^{\circ}$ 10.3522001 e, após, de maneira mais incisiva, pela Lei $n^{\circ} 11.187 / 2005$. - A excessiva restrição à utilização do agravo de instrumento e a vedação, à parte, de uma decisão colegiada a respeito de sua irresignação, trouxe-nos de volta a um regime equivalente àquele que vigorava antes da Reforma promovida pela Lei ${ }^{\circ}$ 9.139/95: a baixa efetividade do agravo de instrumento implicará, novamente, o aumento da utilização do mandado de segurança contra ato judicial. - A situação atual é particularmente mais grave porquanto, agora, o mandado de segurança não mais é impetrado contra a decisão do juízo de primeiro grau (hipótese em que seria distribuído a um relator das turmas ou câmaras dos tribunais). Ele é impetrado, em vez disso, contra a decisão do próprio relator, que determina a conversão do recurso. Com isso, a tendência a atravancamento tende a aumentar, já que tais writs devem ser julgados pelos órgãos plenos dos Tribunais de origem. - Não obstante, por ser garantia constitucional, não é possível restingir o cabimento de mandado de segurança para essas hipóteses. Sendo irrecorrível, por disposição expressa de lei, a decisão que determina a conversão de agravo de instrumento em agravo retido, ela somente é impugnável pela via do remédio heróico. Recurso especial conhecido e provido“ (Resp. n. 22.846-MT, $3^{\text {a }}$ Turma, Rel. Min. Fátima Nancy Andrighi, j. 01.03.2007, vu). 
supressão de todo o procedimento autônomo de processamento do agravo de instrumento, eis que prejudicadas as fases de contra-postulação e de decisão colegiada e imediata do recurso.

O móvel da disposição, originariamente introduzida pela Lei n. 10.352/2001, e posteriormente alterada pela Lei n. 11.187/2005, é manifesto: permitir que a $2^{\mathrm{a}}$ instância, assoberbada pela multiplicação de agravos por força do regime de autonomia procedimental inserido no sistema pela Lei n. 9.139/1995, passe a apreciar agravos exclusivamente de questões urgentes ou impossíveis de chegarem ao conhecimento do Tribunal por outra via, liberando-se, assim, espaço para julgamento das apelações. A regra geral do sistema agora é que os agravos sejam todos retidos (art. 522 do CPC), apenas excepcionalmente admitidos os agravos de instrumento. Este é o mote da variante ritual ora analisada.

Uma segunda hipótese legal de variante ritual alternativa, esta sim podendo implicar julgamento imediato do recurso convertido, com supressão de inúmeros atos do procedimento recursal, está no art. $544, \S \S 3^{\circ}$ e $4^{\circ}$, do CPC, disposição a simplesmente repetir a autorização que já era deferida pelo art. $28, \S \S 3^{\circ}$ e $4^{\circ}$ da Lei n. 8.038/90.

Diz a primeira parte do dispositivo, aplicável em princípio apenas ao agravo de decisão denegatória do processamento dos recursos excepcionais (extraordinário e especial) $)^{544}$, que "poderá o relator, se o acórdão recorrido estiver em confronto com a súmula ou jurisprudência dominante do Superior Tribunal de Justiça, conhecer do agravo para dar provimento ao próprio recurso especial"; disposição que, observe-se, contempla dupla operação: i) primeiro o agravo da decisão denegatório é recebido como recurso especial; e ii) ato contínuo é provido para reforma do próprio acórdão recorrido.

Obviamente, esta operação não impede a aplicação do já estudado art. 557, caput, do CPC, que permite a rejeição monocrática do agravo quando manifestamente inadmissível, improcedente, prejudicado, ou em confronto com súmula ou jurisprudência dominante. $^{545}$ Não impede, também, a extensão da norma para também possibilitar a

\footnotetext{
${ }^{544}$ Em princípio, já que, conforme veremos oportunamente, sustentamos a utilização analógica da norma para os agravos de instrumento interpostos das decisões que não recebam recurso de apelação, especialmente das que se fundarem no art. 518, $\S 1^{\circ}$, do CPC (súmula impeditiva de recursos). Trata-se de regra de flexibilização judicial do procedimento (item 5.4.5. infra).

${ }^{545}$ Em sentido contrário, Dinamarco aponta que a omissão do art. 544, § $3^{\circ}$, foi voluntária, eis que, no caso, não se quis admitir que o relator do recurso especial pudesse improvê-lo, mas tão só provê-lo. O improvimento seria reservado exclusivamente ao julgamento colegiado $(\mathrm{O}$ relator, a jurisprudência e os recursos, cit., v. 2, p. 1.106-1.107).
} 
conversão de agravo em recurso extraordinário e conseqüente provimento monocrático. ${ }^{546}$ Tampouco impossibilita a parte de se valer do agravo interno para remeter a apreciação da questão para o colegiado (art. 545 do CPC).

Uma segunda parte do dispositivo autoriza apenas a conversão do agravo de decisão denegatória em recurso especial e extraordinário. Diz a disposição que "poderá ainda (o relator), se o instrumento contiver os elementos necessários ao julgamento do mérito, determinar sua conversão, observando-se, daí em diante, o procedimento previsto ao recurso especial" ou do recurso extraordinário, nos termos do $\S 4^{\circ}$ do mesmo artigo. Neste caso, diante da possibilidade de plena compreensão da controvérsia ante a fartura de documentos que acompanharam o instrumento, o agravo simplesmente é convertido em recurso excepcional, a partir daí processado conforme artigos 541 a 543 do CPC (julgamento colegiado do recurso).

Ambas as variantes rituais são bastante oportunas e, se bem empregadas, agilizam consideravelmente o procedimento recursal, eis que além de diminuírem o número de recursos a serem objeto de apreciação (conversão do agravo de instrumento em retido), em outros casos acabam por acelerar o julgamento do próprio recurso principal (conversão do agravo de decisão denegatória em recurso excepcional).

\subsection{Flexibilidade procedimental judicial}

O estudo do direito processual civil deve ser levado a cabo sempre com viva atenção às suas ligações com o direito material, sem o que se corre o risco de reduzi-lo em um pouco interessante computar de formalidades e prazos. ${ }^{547}$

Por isto o legislador, como já visto (princípio da adequação), é obrigado a abandonar a ordinariedade ${ }^{548}$ e construir procedimentos diferenciados a atender diferentes

\footnotetext{
${ }^{546}$ NERY JÚNIOR, Nelson; NERY, Rosa Maria de Andrade. Código de processo civil comentado e legislação extravagante, cit., p. 940. Contra: DINAMARCO, Cândido Rangel. O relator, a jurisprudência e os recursos, cit., v. 2, p. 1.107.

${ }^{547}$ LIEBMAN, Enrico Tullio. Manual de direito processual civil, cit., v. 1, p. 35.

${ }^{548}$ Os sistemas processuais da era Moderna, em sua origem, eram radicados em um pressuposto metodológico: a generalização do método procedimental e cognitivo ordinário, independentemente do direito material objeto da lide (CLAUS, Ben-Hur Silveira. A ordinarização do procedimento: uma herança do racionalismo sob interrogação. Revista da Ajuris, Porto Alegre, ano 27, n. 83, t. 1, p. 22, set. 2001). Ao juiz não era dado julgar com base em juízo sumário, a ponto de ser lhe vedada, em alguns Estados, a possibilidade de interpretar a lei (MONTESQUIEU. O espírito das leis, cit., p. 158). Foi através da obra de
} 
situações do direito material $^{549}$. Se ele não o faz ${ }^{550}$, nada impede que o juiz o faça, adequando o procedimento aos valores concebidos na Constituição Federal (princípio da adaptabilidade). ${ }^{551}$

Mortara e a fundação da escola sistemática por Chiovenda, que a antiga doutrina do século XIX vai ficando para trás, trazendo consigo a chamada publicização do processo civil. "O processo deixa de ser algo que diz respeito somente às partes, passando a ser visto como um local onde o Estado exprime sua autoridade, $\mathrm{e}$ que objetiva não apenas a tutela dos interesses privados, mas também a realização do interesse público na administração da justiça" (TARUFFO, Michele. La giustizia civile in Itália dal'700 a oggi. Bologna: Il Mulino, 1980. p. 188). A ação, que antes era vista como um apêndice do direito material, passa a ser pensada como um direito autônomo e público. Consequentemente, erigido ao status de ciência, o processo ergueu seus conceitos, afastando-se o mais que podia da noção do direito material que, no passado, lhe era ínsita. Levou-se, entretanto, às últimas consequiências a abstração, de modo que o processo se olvidou do direito material, supondo que o procedimento não deveria ser desenhado de acordo com as necessidades do direito substancial. "Em outras palavras, a doutrina supôs que um procedimento indiferente ao direito material, ou um único procedimento, seria suficiente para garantia tutela adequada às mais diversas situações conflitivas concretas" (MARINONI, Luiz Guilherme. Novas linhas do processo civil, cit., p. 41). $\mathrm{Ou}$, como anotou Bem Hur Silveira Claus, "parece que a ciência processual civil moderna, como que fascinada pelo encanto de sua lógica intrínseca - a beleza da arquitetura conceitual do processo parece ter capturado os processualistas para o interior de sua estrutura estética - quedou-se seduzida de tal forma pela idéia de autonomia do direito de ação que acabou por desenvolver tal conceito a um plano talvez demasiadamente liberto de qualquer vínculo com o direito material, o que teria redundado em perda da efetividade processual. O superdimensionamento do conceito de autonomia do direito de ação teria, assim, conduzido a um método procedimental alheio ao seu objetivo último: a realização do direito material" (CLAUS, Ben-Hur Silveira. A ordinarização do procedimento: uma herança do racionalismo sob interrogação, cit., p. 22). O próprio CPC/1973, ao menos antes das tantas reformas que the foram introduzidas, apresentava-se vinculado a esta concepção racionalista dos séculos XVIII e XIX, sobretudo à doutrina de Thomas Hobbes, segundo a qual a questão da justiça é um problema do legislador, não do Juiz, cuja missão, como oráculo da lei, é a de simplesmente aplicá-la, sem qualquer consideração ou avaliação sobre critérios empregados pelo sistema legal constituído (SILVA, Ovídio A. Baptista. Antecipação de tutela - duas perspectivas de análise. Revista da Ajuris, Porto Alegre, n. 70, p. 92, jul. 1997).

${ }^{549}$ José Alberto dos Reis bem anota que "onde quer que se descubra um direito substancial com caracteres específicos que não se coadunem com os trâmites do processo comum há de organizar-se um processo especial adequado a tais caracteres" (REIS, José Alberto dos. Processos Especiais. Coimbra: Coimbra Ed., 1982. v. 1, p. 2). Vale, por isto, a nota de que o emprego da expressão tutela diferenciada no texto está a significar tutela de cognição ordinária, mas moldadas às específicas situações do direito material ou da parte litigante, e não tutela de cognição sumária.

${ }^{550} \mathrm{E}$ se o legislador constrói procedimentos diferenciados, mas sem razão lógica, como ocorre nos atípicos procedimentos desenhados pelo Decreto Lei n. 911/69, ou Decreto n. 70/66, não me parece haver óbice para que o juiz, à luz da desigualdade perpetrada no caso em concreto, fulmine a indevida eleição procedimental, restabelecendo a ordinariedade. Cf., neste exato sentido, MARINONI, Luiz Guilherme. Novas linhas do processo civil, cit., p. 264-265. Cf., também, DINAMARCO, Cândido Rangel. A instrumentalidade do processo, cit., p. 136.

${ }^{551}$ Marinoni aponta que autor, para receber exatamente aquilo que tem direito, precisa de uma série de medidas estabelecidas pelo legislador - em especial o procedimento - que lhe propicie tutela jurídica adequada. Aduz que "alguns falam em efetividade da tutela jurisdicional, mas não aceitam a existência de um direito à ação adequada. Porém, se o procedimento adequado, apenas para tomarmos um exemplo, é garantido pelo princípio da inafastabilidade, o direito de ação compreende o direito ao procedimento adequado, e, então, podemos falar em ação adequada. A doutrina, quando trata do interesse de agir, lembra, por exemplo, que o mandado de segurança não é a medida adequada para a cobrança de créditos pecuniários. Como se vê, a doutrina sempre tratou da ação falando sobre o procedimento. Se falta interesse de agir quando o procedimento é inadequado, o direito de ação exige não só que o procedimento seja útil, mas que ele também seja efetivo. Não há sentido para continuarmos pensando o direito de ação como simples direito ao uma sentença, quando sabemos que o direito de ação assegura a tutela jurisdicional adequada; a menos que se entenda que o direito de ação é garantido quando o procedimento é inefetivo". E conclui: "o direito de ação tem como corolário o direito ao procedimento adequado à tutela do direito afirmado, pouco importando se aquele que vai propor a ação tem, efetivamente, direito material" (Novas 
Mas há mais. Não é só sobre a perspectiva do direito material que os procedimentos devem ser modelados, eis que as condições particulares das partes, em Estado que preza pela igualdade substancial (art. 5', caput, da Constituição Federal), também devem influir nas opções desta natureza.

Assim, não eleito procedimento adequado pela lei em vista do direito material ou da situação especial da parte litigante, compete ao juiz, com a constante colaboração das partes e observadas as condicionantes já estudadas, fazê-10 ${ }^{552}$.

No presente item, serão investigadas algumas situações práticas em que se têm exigido do juiz brasileiro, mesmo inexistindo previsão legal a respeito, enorme dose de criatividade. A bem da adequada tutela do direito material, e por que não, da mais útil, eficaz e célere prestação jurisdicional, inúmeras variantes procedimentais têm surgido no foro, com deslocamento do foco da legalidade das formas em favor da flexibilização judicial do procedimento. ${ }^{553}$

linhas, cit, p. 213-215). No mesmo sentido Kazuo Watanabe, preciso ao indicar que se não fosse a intransigência doutrinária, o art. 75 do já revogado Código Civil (a todo direito corresponde a uma ação que o assegura) poderia ter sido interpretado como a explicitação, a nível infraconstitucional, do princípio da efetividade e da adequação da tutela jurídica processual. Com efeito, fosse o dispositivo lido como "a toda afirmação de direito corresponde uma ação que o assegure", não haveria mais a carga imanentista que comprometia o texto, consequentemente, podendo o dispositivo ser mantido com aplausos no novo Código Civil (Código Brasileiro de Defesa do Consumidor (comentado pelos autores do anteprojeto), cit., p. 523-524).

${ }^{552}$ Isto porque "ante o avanço da ciência e tecnologia dos mais variados campos, impõe-se idêntico avanço da ciência do processo, no sentido de acompanhar, com a mesma velocidade e segurança, os avanços eletrônicos e a sucessão dos acontecimentos que desfilam velozmente diante do atônito cidadão do mundo atual". Por isto "cabe aos processualistas encontrar esses meios adequados, elaborando instrumentos modernos e atualizados à pronta e eficaz manifestação do Estado, intervindo nos conflitos de interesse de seus cidadãos e compondo os litígios para a consecução da paz social" (HEERDT, Paulo. Sumarização do processo e do procedimento, cit, p. 108). Afinal, como aduz Eduardo Couture, "o progresso do direito deve manter natural paralelismo como progresso da ciência" (COUTORE, Eduardo J. Fundamentos del derecho procesal civil. 3. ed. Buenos Aires: Depalma, 1958. p. 262) Daí porque Mariângela Gama de Magalhães Gomes aponta que "o procedimento desejado é aquele que, sem afrontar determinadas garantias do acusado, permite ao juiz ter o mais amplo conhecimento acerca do fato controvertido. Assim, faz-se necessário que haja uma técnica de adequação do processo à natureza do direito ou à peculiaridade da pretensão a ser tutelada" (GOMES, Mariângela Gama de Magalhães. Devido processo legal e direito ao procedimento adequado. Revista Brasileira de Ciências Criminais, São Paulo, ano 13, n. 55, p. 299, jul./ago, 2005). Cf., também, MARINONI, Luiz Guilherme. Técnica processual e tutela dos direitos, cit., p. 222-226.

${ }^{553}$ Rememore-se, como o faz Paulo Eduardo Alves da Silva, que "o ordenamento brasileiro é de tradição formalista legalista. A lei define, passo a passo, o trâmite do processo judicial e, em tese, nem o juiz nem as partes podem modificar a sequiência definida em lei (indisponibilidade do procedimento)". (...) "Ainda assim, relatos de juízes, advogados, promotores de justiça e outros profissionais que operam diariamente perante diversas instâncias da justiça brasileira, sustentam que a experiência do magistrado consegue cunhar práticas que agilizam o andamento dos processos e permitem minimizar os efeitos da morosidade. Há juízos em que os processo caminham melhor e outros em que a morosidade é mais sentida. O que difere? Se o procedimento é o mesmo e é indisponível, por que a condução de um juiz gera melhores resultados que a do outro?" Daí porque o autor propõe a substituição da dinâmica procedimental legal pela dinâmica procedimental judicialmente planejada, de modo a permitir que o procedimento seja planejado no caso concreto, de modo a corresponder á exigência do tempo (Condução planejada dos processos judiciais: a racionalidade do exercício jurisdicional entre o tempo e a forma do processo, cit, p. 4). 


\subsubsection{Direitos difusos e coletivos e procedimento diferenciado}

A superação da perspectiva imanentista e puramente autonomista do processo, pelo advento da noção de sua instrumentalidade, incorporou no âmbito do processo civil moderno uma maior preocupação dos operadores do direito com os resultados obtidos a partir do emprego da técnica processual.

Frente a isto, a produção normativa passou a ter foco não mais na valorização da perfeição técnica, mas sim nos benefícios que a legislação traria para os titulares do direito material.

É nesta perspectiva que surgiram os diplomas preocupados com a ampliação de acesso à justiça e, principalmente, com a tutela dos direitos transindividuais e das minorias. ${ }^{554}$ A evolução da sociedade e das relações de massa fez surgir estes novos direitos, até então desprovidos de instrumentos aptos a tutelá-los, de modo que coube ao legislador criar, à luz da instrumentalidade, mecanismos processuais adequados à proteção integral destas situações da vida.

O processo coletivo, assim, passa a ser visto como o instrumento destinado a tornar acessível a justiça para aquelas situações em que ocorram ameaças ou lesões a interesses e direito que, pelos métodos tradicionais do processo individual, não seriam tuteláveis. ${ }^{555}$

Todavia, a disciplina legal dos interesses metaindividuais e de sua proteção, pese o esforço legislativo, acabou sendo realizada de forma desordenada, com evoluções e involuções ${ }^{556}$. A pluralidade de diplomas a respeito do tema - muitos deles ainda elaborados à luz do processo individual - faz com que o processo civil coletivo, ainda hoje, padeça de uma série de empecilhos interpretativos. ${ }^{557}$ Legitimação, competência, coisa

\footnotetext{
${ }^{554}$ E aqui vale ser citadas as sempre lembradas Lei de Ação Civil Pública (Lei n. 7.347/85), Código de Defesa do Consumidor (Lei n. 8.078/90), Estatuto da Criança e do Adolescente (Lei n. 8.069/90), Estatuto da Cidade (Lei n. 10.259/2001), Estatuto do Idoso (Lei n. 10.741/2003), entre outras.

${ }^{555}$ LEONEL, Ricardo de Barros. Manual do processo coletivo, cit., p. 21-22.

${ }^{556}$ Entre as maiores delas, a reforma advinda da Medida Provisória n. 2.180-35, que limitou o cabimento da ação civil pública para veicular pretensão concernente a tributos e contribuições sociais (art. $1^{\circ}$, parágrafo único, da Lei n. 7.347/85), e a Lei n. 9.494/97, que entre outras coisas mutilou o cabimento de medidas de urgência e de ações coletivas para a proteção dos interesses individuais homogêneos contra o Estado ( $\operatorname{art.} 1^{\circ}$ e $\operatorname{art.} 2^{\circ}$-A).

${ }^{557}$ Empecilhos estes, destaque-se, que pretendem ser solucionados pelo advento de uma legislação específica para o trato do processo coletivo, o Código Brasileiro de Processo Coletivo (CBPC), que revogará boa parte da legislação esparsa a respeito do tema. Conhecem-se vários anteprojetos a respeito, todos de excelente qualidade técnica e de incontestável juridicidade. Entre eles, destaque merece o coordenado por Ada Pellegrini Grinover, elaborado junto ao programa de mestrado e doutorado da Faculdade de Direito da Universidade de São Paulo, e posteriormente encampado pelo Instituto Brasileiro de Direito Processual. A última notícia que temos deste anteprojeto é que foi ele encaminhado ao Ministério da Justiça e, atualmente, está posto a consulta pública.
} 
julgada são, definitivamente, pontos nervosos sobre os quais ainda muito papel e saliva serão gastos pelos tribunais e pelos estudiosos do tema. ${ }^{558}$

Os reflexos deste quadro no âmbito do procedimento são evidentes. Na medida em que o sistema ainda não disponibiliza instrumentos inteiramente adequados para a tutela destes direitos metaindividuais, só resta ao magistrado, nas situações da vida em que isto for necessário, adaptar o instrumento às particularidades do direito coletivo que, se repita, são completamente distintas das do processo individual. ${ }^{559}$

Com efeito, no âmbito do processo coletivo, há uma forte presença de interesse público primário, a justificar uma atuação bem mais incisiva do magistrado na busca da verdade e na proteção dos direitos metaindividuais. ${ }^{560}$

Por conta disto, pese a inexistência de previsão legal, de rigor que judicialmente se flexibilize o procedimento, seja ele qual for o empregado ${ }^{561}$, para permitir que no curso do feito coletivo seja alterado o pedido ou a causa de pedir, mesmo sem concordância da parte adversa ou após o saneamento do processo (art. 264, parágrafo único, do CPC). Nestes casos, o procedimento literalmente seria revertido, tornando a fases anteriores, tudo sem prejuízo do amplo contraditório deferido à parte contrária. ${ }^{562}$

\footnotetext{
${ }^{558}$ Cf. FREIRE JÚNIOR, Américo Bedê. Pontos nervosos da tutela coletiva: legitimação, competência e coisa julgada. In: MAZZEI, Rodrigo; NOLASCO, Rita Dias. Processo civil coletivo. São Paulo: Quartier Latin, 2005. p. 66-81.

${ }^{559}$ ALPA, Guido. Interessi difusi. Revista de Processo, São Paulo, ano 21, n. 81, p. 159, jan./mar. 1996.

${ }^{560}$ DIDIER JÚNIOR, Fredie; ZANETI JÚNIOR, Hermes. Curso de direito processual civil: processo coletivo. Salvador: JusPodvum, 2007. v. 4, p. 118.

${ }^{561}$ Como regra nas ações coletivas, à exceção do mandado de segurança e de injunção coletivos (que tem procedimento regido pela Lei n. 1.533/51), emprega-se o procedimento comum do Código de Processo Civil (art. 272) (MAZZILI, Hugo Nigro. A defesa dos interesses difusos em juízo. 11. ed. São Paulo: Saraiva, 1999. p. 122123). Fredie Didier Jr. e Hermes Zaneti Jr., a meu ver sem razão, apontam que o procedimento comum da tutela coletiva é o previsto pela conjugação dos regimes da Lei de Ação Civil Pública com o Código de Defesa do Consumidor (Curso de direito processual civil: processo coletivo, cit. p. 58-59). Ocorre que não há disciplina integral do procedimento nestes diplomas, de modo que restaria o procedimento comum do CPC, com algumas alterações. Por fim, crendo só ser cabível o procedimento ordinário diante da complexidade da matéria - o que também não nos parece totalmente adequado, eis que há ações coletivas de baixa complexidade no âmbito da prova - está Ricardo Barros Leonel (Manual do processo coletivo, cit., p. 225-227).

${ }^{562}$ O que é novidade por aqui não o é em outros ordenamentos jurídicos. Os artigos 235 , $\S 3^{\circ}$ e 263 , ambos da Ordenança Processual alemã (na redação de novela de 1933), permite genericamente, inclusive para ações individuais, a modificação dos elementos da demanda, independente de anuência do adversário, se entendido pelo julgador estar presente a oportunidade da medida (OLIVEIRA, Carlos Alberto Alvaro de. Poderes do juiz e visão cooperativa do processo, cit., p. 82). No mesmo sentido é o Código de Processo Civil português, que em seu art. 272, autoriza a modificação do pedido e da causa de pedir, por acordo, em $1^{\mathrm{a}}$ ou $2^{\mathrm{a}}$ instância (salvo se perturbar a instrução, discussão e julgamento do feito), e no art. 273 estabelece a possibilidade de dedução superveniente de sanção pecuniária compulsória, perspectivada como mera ampliação conseqüente ao pedido primitivo, e esclarece que é admitida a modificação simultânea do pedido e da causa de pedir, desde que tal não importe alteração da própria relação material controvertida, tudo independentemente de acordo das partes.
} 
Poderia se objetar que o interesse público é no sentido de que a Justiça se realize com presteza e funcionalidade, algo que fica de certa forma comprometido com a admissão da alteração da causa de pedir ou do pedido, com retorno à fases anteriores. Contudo, ao menos em tema de direito coletivos, há de prevalecer o interesse público maior de se tutelar de forma rápida e eficaz a situação jurídica de um sem número de interessados em detrimento da regra formal estabilizadora. ${ }^{563}$

Valendo-se do mesmo fundamento de repercussão e alcance do direito tutelado em sede coletiva, é conveniente que o juiz, a fim de ampliar a representação e estimular a participação da sociedade no destino da ação coletiva, manipule o procedimento, à míngua de previsão legal, a fim de incentivar a formação de assistência litisconsorcial ativa entre os co-legitimados em certas ações coletivas $^{564}$, e até mesmo convide entidades a participarem do feito como amicus curiae (art. 89 da Lei n. 8.884/1994). ${ }^{565}$

Também me parece saudável que o procedimento seja maleabilizado para oportunizar que outro legitimado assuma a titularidade do feito quando, no julgamento da ação coletiva, se chegar à conclusão que a parte autora é ilegítima. ${ }^{566}$

Por fim, e entre outras soluções que apenas exemplificativamente podem ser cogitadas, institutos como o da preclusão e poderes instrutórios do juiz devem ser

\footnotetext{
${ }^{563}$ Esta operação, que hoje só pode ser autorizada pela via da flexibilização judicial do procedimento, pretende se tornar norma cogente no anteprojeto de CBPC: “Art. $4^{\circ}$ - Pedido e causa de pedir - Nas ações coletivas, a causa de pedir e o pedido serão interpretados extensivamente, em conformidade com o bem jurídico a ser protegido. Parágrafo único. A requerimento da parte interessada, até a prolação da sentença, o juiz permitirá a alteração do pedido ou da causa de pedir, desde que seja realizada de boa-fé, não represente prejuízo injustificado para a parte contrária e o contraditório seja preservado, mediante possibilidade de nova manifestação de quem figure no pólo passivo da demanda, no prazo de 5 (cinco) dias”.

${ }^{564}$ O Código de Defesa do Consumidor já alvitra tal solução em seu art. 94, mas a objetivar simplesmente o ingresso dos lesados no feito. Aqui se pretende mais: que em toda ação coletiva, para a proteção de qualquer interesse metaindividual (difuso, coletivo ou individual homogêneo), sejam os co-legitimados expressamente convidados a atuarem no feito.

${ }^{565}$ BUENO, Cássio Scarpinella. Amicus curiae no processo civil brasileiro. São Paulo: Saraiva, 2006. p. 633640; e DIDIER JÚNIOR; Fredie; ZANETI JÚNIOR, Hermes. Curso de direito processual civil: processo coletivo, cit., p. 117.

${ }^{566}$ Exemplificativamente, quando a ação fosse ajuizada por associação, a despeito de sua ilegitimidade face à ausência de constituição anua (art. $5^{\circ}$, V, da Lei n. 7.347/85, com redação pela Lei n. 11.448/2007), outro legitimado poderia ser convidado a continuar no feito; ou quando o Ministério Público ajuizasse uma ação civil pública para a proteção de direito individual homogêneo sem repercussão social (súmula 07 do CSMP/SP), caso em que uma entidade tutelar dos direitos ali protegidos poderia ser convidada a encampar o pólo ativo da ação.
} 
revisitados, tudo com vistas a que os tutelados pela demanda não sejam prejudicados pela omissão do autor da ação. ${ }^{567}$

\subsubsection{Inversão da ordem de produção de provas}

Em tema de momento da produção da prova, o Código de Processo Civil tem disciplina rigorosa.

Os artigos 283 e 396 apontam que os documentos devem ser juntados com a petição inicial e a resposta, excepcionados os documentos novos, quando destinados a fazer prova de fatos ocorridos depois dos articulados ou para contrapor aos que foram juntados aos autos, casos em que serão juntados a qualquer tempo (art. 396, parágrafo único).

A prova pericial é produzida antes da audiência de instrução, eis que as partes podem querer ouvir o perito a respeito do seu trabalho técnico (art. 435 do CPC).

A inspeção judicial pode ser ordenada em qualquer fase do processo, mas só, por óbvio, até a prolação da sentença (art. 404 do CPC).

E toda a prova oral (depoimento pessoal e testemunhas) será produzida em audiência (art. 336 do CPC) e na seguinte ordem: I - o perito e os assistentes técnicos responderão aos quesitos de esclarecimentos, requeridos no prazo e na forma do art. 435; II - o juiz tomará os depoimentos pessoais, primeiro do autor e depois do réu; III - finalmente, serão inquiridas as testemunhas arroladas pelo autor e pelo réu (art. 453 do CPC).

A cogência das disposições que fixam a ordem de produção de provas, todavia, não pode ser levada tão a sério. Questões de conveniência e oportunidade na produção da prova, bem como outras relacionadas ao custo e a dificuldade em realizar algumas delas (especialmente a dispendiosa prova pericial), justificam que as rígidas disposições da legislação sejam fundamentadamente flexibilizadas para a mais adequada, célere e menos custosa resolução do conflito.

\footnotetext{
${ }^{567}$ E não convence o argumento que a disciplina da coisa julgada nas ações coletivas (art. 103 do CDC) já é o bastante para evitar prejuízos por conta da letargia do autor. Primeiro, porque em se tratando de direitos difusos e coletivos, a coisa julgada, embora não prejudique as ações individuais, atinge todos os demais legitimados coletivos, seja na procedência ou na improcedência. E segundo, porque a perda de uma oportunidade para solucionar coletivamente o conflito já é razão suficiente para se sustentar a maleabilização das regras sobre preclusão e iniciativa probatória do juiz.
} 
Por exemplo, nas ações de indenização, toda vez que houver fundada dúvida sobre a caracterização da culpa do demandado pelo evento, não há sentido para a produção prévia da custosa prova pericial comprobatória do dano, se nem se sabe ainda se o primeiro elemento da responsabilização civil (culpa) se caracterizou (art. 186 do CC). Pois realizada a perícia prévia comprobatória do dano e de sua extensão, e só posteriormente colhida a prova oral, corre-se o risco de, não comprovada a culpa, ter-se por irrelevante a prova produzida. ${ }^{568}$

Ademais, a oitiva do perito em audiência (art. 435 do CPC) é providência de rara incidência prática, que não justifica a limitação legal à produção primeira da prova oral, principalmente porque pode ser designada uma nova audiência para tanto (qual prejuízo há nisso?), ou até mesmo serem encaminhadas dúvidas das partes ao perito para resposta escrita.

Também no que toca à produção da prova testemunhal, a prévia ciência do objetivo da prova oral - algo que corriqueiramente é feito pelos advogados ao juiz em audiência - pode justificar, a bem da economia processual e do suficiente dimensionamento do evento, a oitiva de testemunhas do demandado antecedentemente às testemunhas do autor. Não se vê razão lógica alguma para que se limite a extensão dos poderes do juiz para tal definição, principalmente porque não há prejuízo aparente na inversão.

No âmbito do depoimento pessoal, possível que os esclarecimentos das partes (e a obtenção da confissão) só sejam necessários após a colheita da prova testemunhal, quando então surgir dúvida a respeito dos fatos alegados. ${ }^{569}$

\footnotetext{
${ }^{568}$ Em 31.05.2001, a $8^{\text {a }}$ Câmara do extinto $1^{\circ}$ Tribunal de Alçada Civil do Estado de São Paulo, no Agravo de Instrumento n. 696.159-00/4, cujo relator era o Desembargador Kiotisi Chicuta, aceitou a fundamentada postergação da produção da perícia para após a realização da prova oral. No caso, a decisão agravada por nós proferida se assentava na "fundada dúvida quanto a culpa da requerida no evento, mormente sabido que se trata de requisito indispensável para a responsabilidade civil em caso como os tais. Ademais, a prova pericial, além de custosa, poderia se tornar desnecessária em caso de afastamento da responsabilidade da requerida". Constou do voto do relator que "evidentemente a postura adotada não é aquela clássica e na qual se permite dilação probatória a mais ampla possível, mas, ainda assim, não se vislumbra prejuízo ao direito do agravante. Em Comarcas desprovidas de recursos para efetivação de exames e periciais, mesmo porque, em geral, carentes de profissionais que se disponham a servir de colaboradores, os processos restam paralisados por meses e no aguardo de laudos efetivados por profissionais de outras cidades com maiores recursos material e humano, localizadas na própria região. A objetividade deve ser a tônica, respaldada pela experiência vivida pelos Juizes de carreira, sem se mencionar a economia processual na efetivação de prova que se pode mostrar, diante de outros subsídios, totalmente desnecessária. Não existe, outrossim, inversão tumultuária das provas. A perícia, desde que assim determinada, constituirá em prova do juízo e não apenas das partes, e nada impede que, caso assim seja necessário, que preste o experto os necessários esclarecimentos em audiência”.

${ }^{569} \mathrm{O}$ Tribunal de Justiça do Estado de São Paulo já referendou a possibilidade de inversão em acórdão assim ementado: "Prova - Depoimento pessoal - Colheita após oitiva de testemunhas - Possibilidade - Preclusão - Inocorrência - Recurso provido. Embora seja recomendável a observância da ordem de produção das provas orais em audiência estabelecida no artigo 452 do Código de Processo Civil, não se trata de norma peremptória, de modo que se admite a alteração na aludida ordem, desde que não cause prejuízos a quaisquer das partes, evitando-se ainda a ocorrência de cerceamento na produção de prova que poderá trazer elementos para a formação da convicção do juiz". (Agravo de Instrumento n. 896.414-0/0 - São Paulo - 27 $7^{\mathrm{a}}$ Câmara de Direito Privado - Relator: Jesus Lofrano - j. 14.06.05 - v.u.).
} 
E mesmo documentos que não sejam novos, desde que não tenham sido dolosamente ocultados têm sua juntada admitida em qualquer fase do processo (não só nos articulados iniciais), tudo a bem da descoberta da verdade. ${ }^{570}$

Vê-se, assim, que no âmbito da ordem de produção de provas, as regras legais hão de se flexibilizar judicialmente a fim de adequar o instrumento às particularidades da fase instrutória.

\subsubsection{Fungibilidade procedimental}

A fungibilidade merece um novo enfoque por parte da doutrina. ${ }^{571}$ Atualmente, sua aplicação está restrita, pese a inexistência de previsão legal ${ }^{572}$, no âmbito dos recursos; e de forma explícita no tocante às medidas de urgência (art. $273, \S 7^{\circ}$, e 805 , do CPC) e ações possessórias (art. 920 do CPC).

Todavia, a fungibilidade não deve ficar limitada às hipóteses previstas em lei ou na jurisprudência, devendo, por isto, ser considerada princípio geral do processo ${ }^{573}$, apta a

\footnotetext{
${ }^{570} \mathrm{O}$ Superior Tribunal de Justiça, há quase $10(\mathrm{dez})$ anos, vem apontando que documentos complementares, mesmo que não sejam novos, podem ser juntados a qualquer tempo (Resp. n. 61.829/SP, Rel. Min. Nilson Naves, $3^{\text {a }}$ Turma, j. 01.04.1997, v.u.). Também o Tribunal de Justiça do Estado de São Paulo tem idêntica posição, exemplificativamente em acórdão assim ementado: "Prova - Pretendida juntada de documentos fora dos prazos normais - Admissibilidade - Exegese do artigo 397, do Código de Processo Civil - Recurso provido. Documentos podem ser juntados a qualquer tempo. Somente aqueles tidos como pressupostos da causa é que devem acompanhar a inicial e a defesa. Os demais podem ser oferecidos em outras fases e até mesmo na via recursal. O que veda a lei é o intuito de ocultação ou o propósito de surpreender o Juiz" (Agravo de Instrumento n. 221.558-4 - Assis - $7^{\text {a }}$ Câmara de Direito Privado - Relator: Oswaldo Breviglieri - 10.04.02 - v.u.).

${ }^{571}$ Enfoque este, convém destacar, que já vem sendo dado por novos estudos sobre o tema, especialmente os de Guilherme de Freira Barros Teixeira ( $O$ princípio da fungibilidade no processo civil. 2005. Tese (Doutorado) - Faculdade de Direito, Universidade de São Paulo, São Paulo, 2005), Sidnei Amendoeira Júnior (A fungibilidade de meios: conversão do ato praticado no processo civil brasileiro e possibilidade de escolha dentre meios processuais postos à disposição das partes. Tese (Doutorado) - Faculdade de Direito, Universidade de São Paulo, São Paulo, 2006), Eduardo de Avelar Lamy (Princípio da fungibilidade no processo civil. São Paulo: Dialética, 2007) e Rita de Cássia Correia Vasconcelos (Princípio da fungibilidade: hipóteses de incidência no processo civil contemporâneo. São Paulo: Ed. Revista dos Tribunais, 2007).

${ }^{572}$ Teresa Arruda Alvim Wambier, em interessante estudo sobre o tema, justifica a aplicação da fungibilidade na seara recursal vigente, mesmo sem previsão legal expressa, porque diversamente do revogado regime do CPC de 1939 (art. 810) - que gerava uma série de dúvidas quanto a qual seria o recurso adequado - a sistemática recursal implantada pelo CPC de 1973 tornou mais simples o ato de escolha do recurso adequado. Ciente disso o próprio legislador não incluiu expressamente no Código o princípio da fungibilidade. Contudo, a realidade prática se mostrou "mais rica e mais complexa do que a imaginação do legislador", razão pela qual, diante do surgimento de hipóteses de dúvida sobre qual recurso interpor mesmo no regime do CPC de 1973, a doutrina acabou mantendo tal princípio, embora sem previsão legal, entre aqueles que informam a prática recursal (WAMBIER, Teresa Arruda Alvim. O óbvio que não se vê: a nova forma do princípio da fungibilidade. Migalhas. Disponível em: <www.migalhas.com.br>. Acesso em: 22 maio 2006).

${ }^{573}$ BEDAQUE, José Roberto dos Santos. Efetividade do processo e técnica processual: tentativa de compatibilização, cit., p. 115.
} 
ser empregada em qualquer situação. ${ }^{574}$ Raciocínios mais flexíveis trazem, como regra, melhores soluções ao sistema, principalmente porque as situações de dúvida são incontáveis e tendem a se multiplicar "na exata proporção da quantidade e da velocidade das alterações que se vão introduzindo no texto da lei". ${ }^{575}$

Por fungibilidade entende-se a operação de se receber um ato processual praticado por outro, isto na suposição de que, além de mais adequado aos fins pretendidos, a adaptação represente ganho de efetividade ou de economia processual.

Os fundamentos de inspiração para a fungibilidade estão na instrumentalidade das formas e na proteção à boa-fé do jurisdicionado, que supõe praticar o ato mais adequado ou útil, pese não o seja em realidade. ${ }^{576}$

A nosso sentir, o único requisito para aplicação da fungibilidade é a ocorrência de boa-fé. A dúvida objetiva - requisito que vem sendo apontado pela doutrina como indispensável para a aplicação do princípio $^{577}$ - é, certamente, a maior das representações de boa-fé que pode existir. Mas certamente não a única. Mesmo em casos que não haja a dúvida objetiva é possível que se proceda, com base na fungibilidade, a adequação do instrumental equivocadamente empregado para o ideal ou mais útil tutela do direito ${ }^{578}$. $\mathrm{O}$ processo, nunca é demais lembrar, é instrumento de veiculação do direito material, não podendo ser, portanto, obstáculo à realização dele. ${ }^{579}$

\footnotetext{
${ }^{574}$ Neste sentido Teresa Arruda Alvim Wambier propõe uma aplicação mais ampliativa da fungibilidade, sob o fundamento de que a dúvida é uma constante do sistema processual, inclusive quanto ao cabimento de ações: "Como se faz o depósito com o objetivo de suspender a exigibilidade do crédito tributário? No bojo do mandado de segurança? Por meio de ação cautelar? Ou se trata de depósito que pode ser feito sem que haja ação em curso? Como se consegue o destrancamento dos recursos excepcionais, nos casos em que, pela letra da lei, deveria ficar retidos, mas esta retenção implicaria ofensa a princípios constitucionais? Deve-se entrar com uma ação cautelar: ou basta um mero pedido? Aliás, junto a que órgão, tribunal a quo ou ad quem?" (WAMBIER, Teresa Arruda Alvim. O óbvio que não se vê: a nova forma do princípio da fungibilidade, cit.).

${ }^{575}$ WAMBIER, Teresa Arruda Alvim. O princípio da fungibilidade sob a ótica da função instrumental do processo. Revista dos Tribunais, São Paulo, n. 821, p. 40, mar. 2004.

${ }^{576}$ Cf. a respeito LAMY, Eduardo de Avelar. Princípio da fungibilidade no processo civil, cit., p. 101-117 e 136-144.

${ }^{577}$ NERY JÚNIOR, Nelson. Princípios fundamentais - teoria geral dos recursos. 5. ed. São Paulo: Ed. Revista dos Tribunais, 2000. p. 119-134.

${ }^{578}$ Como ocorre, veremos, com o processamento do mandado de segurança como ação de rito comum, nas hipóteses em que o autor carece de prova pré-constituída; ou com o recebimento de embargos à execução como ação declaratória negativa. Em ambas as situações não há dúvida alguma quanto a medida correta, mas a boa-fé da parte no ajuizamento da medida, ainda que incorreta, justifica a aplicação da fungibilidade.

${ }^{579}$ BUENO, Cássio Scarpinella; MAGRI, Berenice Soubhie Nogueira. Tutela cautelar no sistema recursal do Código de Processo Civil modificado. Revista de Processo, São Paulo, v. 12, n. 83, p. 43, jul./set. 1996.
} 
A adaptação judicial com base na fungibilidade pode ser operada de duas maneiras distintas: a) pelo recebimento e processamento do ato processual inadequado como sendo o adequado; e b) pelo recebimento do ato processual menos útil como sendo o mais útil.

Na primeira situação a operação, que pode se dar oficiosamente, objetiva evitar que a parte seja prejudicada pelo erro escusável, principalmente nas hipóteses em que a doutrina e a jurisprudência ainda não chegaram a um denominador comum quanto ao ato processual adequado, ou a respeito da forma para se atingir determinado fim pretendido. ${ }^{580}$ O ideal é que seja aceito meio equivocadamente empregado como sendo o correto, mas se isto não for procedimentalmente possível que, então, se opere a conversão de um ato em outro, com os reflexos daí decorrentes.

Na segunda situação - que depende de concordância do interessado, eis que a opção pela via de menor utilidade pode revelar certa dose de estratégia processual - o papel do juiz é o de atuar com base no princípio da cooperação, alertando a parte de que ato processual diverso alcançaria melhores resultados do que o praticado. Nestes casos, havendo a concordância do autor do ato, a conversão do menos útil no mais útil é a única solução.

Inúmeras são as hipóteses de incidência prática da fungibilidade no âmbito do procedimento, muitas delas já moldadas à luz da jurisprudência mais moderna, antenada e influenciada diretamente pela doutrina instrumentalista. Abaixo bons exemplos, entre muitos outros que existem, de como a fungibilidade é importante princípio no âmbito da flexibilização judicial do procedimento.

\footnotetext{
${ }^{580}$ Como ocorre com a questão da medida cabível para destrancar os recursos excepcionais retidos (art. 542, § $3^{\circ}$, do CPC). O STF ainda não firmou posição definitiva sobre isto, "oscilando entre considerar adequada ora a reclamação, ora medida cautelar, ou até agravo de instrumento, para que a parte prejudicada com a retenção do recurso extraordinário, na forma do art. 542, § $3^{\circ}$, do CPC lhe obtenha processamento imediato". Por esta razão, o próprio Tribunal, considerando a incerteza da jurisprudência, tem aceitado o processamento das três citadas medidas para a finalidade desejada, dando-as por fungíveis (MC/RJ n. 3.598. Rel. Cezar Peluso, DJ 10.02.2006). Diga-se o mesmo a respeito da dúvida que há quanto ao meio adequado para dar efeito suspensivo ao recurso de apelação que não o tenha, com base no art. 558, parágrafo único, do CPC. Mandado de segurança, agravo, simples pedido autônomo dirigido ao relator, ou medida cautelar (instrumento de nossa preferência), todas as medidas devem ser tidas por fungíveis, eis que não há definição legal ou jurisprudencial a respeito (RT 755/133). Há, também, que se admitir o cabimento de agravo ou apelação contra a antecipação de tutela concedida na própria sentença, visto inexistir consenso doutrinário e jurisprudencial a respeito do recurso cabível.
} 


\subsubsection{Fungibilidade entre ritos e demandas}

Conforme vimos, o procedimento nada mais é do que a combinação lógica e temporal dos atos processuais no âmbito do processo. A razão de ser de todos os procedimentos está na segurança e previsibilidade do sistema. Já os motivos que inspiram sua diferenciação são os mais diversos possíveis, alguns louváveis, outros nem tanto (cf. item 3.1.2.).

Por isto, tendo em vista que os procedimentos derivam da mesma razão de ser, eleito dado procedimento pela parte, nada impede que o juiz, oficiosamente nos casos de equívoco, e mediante prévia manifestação do interessado nos casos em que o rito eleito for de menor utilidade, proceda a adaptação, aproveitando o instrumental ofertado a bem da tutela dos direitos.

Além disso, mesmo que o procedimento já tenha tido curso pela via equivocado, compete ao magistrado, se respeitados os princípios constitucionais do processo, se esforçar para aproveitar o instrumental, solucionando o conflito apesar da forma não ter sido a tecnicamente perfeita.

Assim, já se entendeu possível a conversão de mandado de segurança - que é processo de conhecimento de rito especial - em processo de conhecimento de rito comum, quando constatado, no começo ou no final do feito, a inexistência de prova préconstituída. $^{581}$

Já se admitiu, também, a recepção e julgamento do writ, no qual havia se operado a decadência da impetração (art. 18 da Lei n. 1.533/51), como ação declaratória. ${ }^{582}$

\footnotetext{
${ }^{581}$ Exatamente este é o pensamento da juíza carioca Cristina Gutiérrez, que indaga: “o ajuizamento do mandado de segurança, quando a verificação do alegado direito líquido e certo demanda dilação probatória, tem conduzido os julgadores a extinguirem o processo, sem julgamento do mérito, apoiando-se no disposto no art. 267, VI, do Código de Processo Civil e art. $8^{\circ}$ da Lei n. 1533/51, ressalvando ao impetrante o acesso às vias ordinárias. Será que tal entendimento ortodoxo, usualmente adotado por nós julgadores, está em consonância com os princípios constitucionais, entre eles o denominado direito à ordem jurídica justa de que falam os modernos processualistas?”. E conclui: “A conversão judicial do mandado de segurança em ação de rito ordinário nenhum prejuízo trará à defesa. Ao revés, na linha do acesso à denominada ordem jurídica justa, garantir-se-ão à parte a celeridade e a efetividade do processo, evitando-se ao final, a sua extinção sem julgamento do mérito, bem como novo ajuizamento, com recolhimento de custas e taxa judiciária" (GUTIÉRREZ, Cristina. Dever judicial de adequação do procedimento à pretensão deduzida em juízo. Revista da EMERJ, Rio de Janeiro, v. 4, n. 13, p. 107 e 111, 2001).

${ }^{582}$ TJ/SP, Apelação Cível n. 205.864-5, Rel. Roberto Bedaque, j. 20.10.2004, v.u. Tratava-se de caso em que, apesar do manifesto direito do postulante à sexta-parte, revelou-se a ocorrência da decadência da impetração, o que inviabilizaria, ao menos em tese, a tutela do direito material no caso. Contudo, revelando que não havia diferença entre a tutela mandamental ou declaratória, pois que eventuais especificidades do
} 
E não temos dúvida em admitir que constatada a ilegitimidade passiva da autoridade coatora ao final do writ, nada impede que os atos processuais já praticados sejam aproveitados, especialmente as informações do pólo passivo, ordenando-se a integração à lide da autoridade coatora correta, inclusive, se necessário, com encaminhamento dos autos ao juízo competente por força da modificação do pólo passivo.

No mesmo sentido, não parece inviável o processamento de processo monitório como processo de conhecimento de rito comum (sumário ou ordinário), toda vez que não houver prova escrita da obrigação, ou que ela não enseje segurança suficiente no juízo para, em cognição sumária, deferir a expedição de mandado de pagamento ou de entrega (art. 1.102a e ss. do CPC). ${ }^{583}$ Referida decisão pode ser tomada oficiosamente em sede inicial ou, até mesmo, quando do julgamento da causa, aproveitando-se os atos processuais praticados, com simples conversão de eventuais embargos ao mandado monitório em contestação, e prosseguimento da ação daí por diante (conforme veremos no item a seguir).

Plenamente possível o recebimento de ação de reintegração de posse de imóvel rural arrendado (Estatuto da Terra), ou mesmo de imóvel urbano locado (Lei n. 8.245/91), quando a ação adequada para a tutela da posse do arrendante/locatário é a ação de despejo.

A doutrina admite, ainda, a fungibilidade entre ação rescisória e a nominada querela nulitattis insanabilis (ação declaratória de inexistência), eis que existe completa divergência no âmbito jurisprudencial sobre quais seriam as hipóteses de nulidade e de inexistência. ${ }^{584}$

No âmbito dos procedimentos executivos, é legal a conversão de execução de obrigação de fazer, não fazer ou entrega em execução por quantia, toda vez que a obrigação restar inadimplida pelo devedor. A conversão será deferida à opção do credor e, principalmente, quando a execução específica, mesmo com a multa, não surtir efeito, casos em que sempre será precedida de outro procedimento de liquidação de sentença para

procedimento mandamental não alterariam o resultado que de qualquer forma se chegaria pela via comum, deferiu à parte o direito, aduzindo que o reconhecimento da carência da ação na oportunidade não seria condizente com a natureza instrumental do processo. Atualmente o caso pende de apreciação de recurso no Superior Tribunal de Justiça (Resp. n. 850.516/SP, Rel. Min. Nilson Naves, 6 a Turma).

${ }^{583}$ Este foi o entendimento abraçado pelo Tribunal de Justiça do Estado do Paraná: "Processo Civil. Ação Monitória. Sentença extintiva que reconhece carência da ação, e remete as partes à via ordinária. Ajuizamento anterior de embargos ao mandado. Conversão do rito especial em ordinário. Aproveitamento da ação. Referência legislativa: Código de Processo Civil, artigos 250 e 1.102c, § 2 “ (TJ/PR, Apelação Cível n. 58.751-9, Rel. Dês. Ulysses Lopes, $1^{a}$ Câmara, Acórdão 13894, j. 25.08.1997).

${ }^{584}$ Por todos, cf. WAMBIER, Teresa Arruda Alvim. Nulidades do processo e da sentença, cit., 6. ed. 2007, p. 492-498. 
apuração do quantum (art. 627, parágrafo único, e art. 633, parágrafo único, ambos do CPC).

Da mesma forma, tem se admitido - embora aqui a fungibilidade seja mais tecnicamente de processos (e não de procedimentos) - a recepção de processo de conhecimento como execução, sempre que isto se afigure mais útil ao credor e ele detenha título executivo (art. $475-\mathrm{N}$ e 585 do CPC). ${ }^{585}$ Nestes casos, como se trata de recepção à luz da utilidade, é indispensável a concordância do autor com a operação, eis que pode o credor pretender, com o ajuizamento de processo de conhecimento (de rito comum ou monitória), converter o título executivo extrajudicial em judicial, cujas medidas predispostas no sistemas para cumprimento são bem mais eficazes. ${ }^{586}$

Também tem se aceitado ${ }^{587}$ a operação inversa toda vez que, na inexistência de título executivo, se operar a recepção de uma execução como ação de conhecimento, seja de rito comum (ordinário ou sumário), seja pelo rito especial da ação monitória, a depender, por óbvio, do valor da causa (art. 275, I, do CPC), ou da existência de prova escrita (art. 1.102a e ss.). ${ }^{588}$

\footnotetext{
${ }^{585}$ Neste exato sentido, há pelo menos 20 (vinte) anos, já havia decidido o extinto $1^{\circ}$ TACiv/SP: "Procedimento ordinário. Cobrança de valor de seguro. Rito inidôneo. Hipótese de título de crédito. Adaptação do processo à via executiva para realização da penhora. Admissibilidade. Transformação da contestação em embargos. Anulação, apenas, dos atos inaproveitáveis. Aplicação do art. 250 do CPC, em atenção à economia processual - O art. 250 do CPC apenas prevê, nos casos de erro de forma do processo, a sanção anulação dos atos que não possam ser aproveitados. Assim, adotando-se o rito ordinário para a ação de cobrança de valor de seguro, tratando-se este de título de crédito, admite-se a adaptação à via executiva, realizando-se a penhora e servindo a contestação como embargos, que se processarão nos mesmo autos, atendendo-se à legislação processual, sem causar maiores transtornos" ( $1^{\circ}$ Tribunal de Alçada Civil de São Paulo, Agravo de Instrumento n. 373.320-0, Rel. Juiz Régis de Oliveira, $7^{\mathrm{a}}$ Câmara, j. 5.5.87).

${ }^{586} \mathrm{De}$ fato, pode o credor pretender se valer das medidas de apoio previstas no art. $461, \S 5^{\circ}$, para cumprimento da obrigação de fazer, não fazer e entrega, algo que não lhe é deferido caso ajuíze ação de execução de título extrajudicial (artigos 621 a 645 do CPC); ou, diante da Lei n. 11.232/2005, o exeqüente, a bem da satisfação da obrigação de pagar, pode preferir o regime executivo do art. 475-J e ss. do CPC, que além de impor multa pelo não cumprimento da obrigação, reduz demasiadamente o âmbito de abrangência da defesa (impugnação) apresentada pelo devedor (art. 475-L do CPC) em comparação com a defesa (embargos) apresentável na execução de título extrajudicial (art. 745 do CPC). A este respeito, cf. THEODORO JÚNIOR, Humberto. Opção do credor entre a ação executiva e a ação ordinária de cobrança. Revista Dialética de Direito Processual, São Paulo, n. 4, p. 80-92, jul. 2003.

${ }^{587}$ Com a oposição de Calmon de Passos, para quem "inexiste possibilidade de conversão de um processo (impróprio) em outro (próprio), só se admitindo a de um procedimento (impróprio) em outro (próprio, na mesma espécie de processo (cognição, execução ou cautelar). Assim, pode-se adaptar o procedimento ordinário ao sumaríssimo (atual sumário), e vice-versa, como se pode converter uma execução por quanti certa em outro tipo de procedimento executivo, mas não será viável, em nenhuma hipótese, converter-se um proceso de cognição em processo de execução ou vice e versa, porquanto, na espécie, o próprio pedido é que estaria sendo modificado, o que não é admissível na sistemática do Código" (PASSOS, J.J. Calmon de. Comentários ao Código de Processo Civil, cit., v. 3, p. 265).

${ }^{588}$ A questão da conversibilidade da ação de execução em monitória ecoou no âmbito do Superior Tribunal de Justiça a partir da edição da súmula n. 223 do STJ (o contrato de abertura de crédito em conta-corrente não é título executivo). Inúmeras execuções tinham trâmite, até então, com fundamento no entendimento dantes
} 


\subsubsection{Fungibilidade entre defesas}

Antes das Leis n. 11.232/2005 e 11.382/2006, a defesa do devedor no âmbito da execução por quantia se fazia através de um processo cognitivo autônomo nominado embargos do devedor, cujo processamento dependia, como regra, de prévia segurança do juízo através da penhora (antiga redação do art. 737, I, do CPC).

Excepcionalmente, o devedor podia se defender através de objeção de executividade no bojo da própria execução, instrumento talhado jurisprudencialmente para permitir que o executado não fosse obrigado, em evidente prejuízo, a garantir com bens uma execução totalmente nula para só então se defender.

Não se admitia, contudo, a ampliação dos estreitos limites da objeção para permitir produção de provas por parte do devedor, ou para que pudesse aventar matéria que não fosse de ordem pública no âmbito da objeção. A única exceção ficava por conta da prova pré-constituída do pagamento.

Coube à doutrina ${ }^{589}$, então, construir interessante tese sobre o cabimento de ação declaratória negativa nos casos em que o devedor tivesse perdido o prazo para opor embargos à execução, ou que, não tendo bens a oferecer em garantia, necessitasse ofertar defesa que culminaria na extinção da execução em curso.

consolidado da eficácia executiva do contrato de abertura de crédito em conta-corrente. Com a mudança de posicionamento, procurou-se salvar estas execuções, convertendo-as em monitória. Orientação inicial apontava que "não tendo ainda havido a constrição de bens e rejeitados in limine os embargos à execução, possível é a conversão da execução em ação monitória, à falta de qualquer prejuízo. Aplicação dos princípios da instrumentalidade das formas, economia e celeridade processuais (REsp 603896/DF; Rel. Ministro Barros Monteiro, $4^{\mathrm{a}}$ Turma, j. 07.02.2006). Contudo, acabou por prevalecer no âmbito da $2^{\mathrm{a}}$ seção, o entendimento que a conversão só seria operável se ainda não houvesse ocorrido a citação para a ação executiva (EREsp 575.855, Rel. Ministro Ari Pargendler; j. 27.09.2006). Com isto, inúmeras execuções - inclusive as garantidas - foram extintas, dando ensejo à repropositura de um sem número de ações monitórias

${ }^{589}$ SHIMURA, Sérgio Seiji. Título executivo. São Paulo: Saraiva, 1997. p. 354; TELLES, Gil Trotta. Propositura de ação declaratória negativa depois de ajuizada execução de título extrajudicial. Revista dos Tribunais, São Paulo, ano 81, n. 677, p. 28-33, mar. 1992; CRUZ E TUCCI, José Rogério. Tutela processual do direito do executado. Revista da Ajuris, Porto Alegre, n. 61, p. 99-120, 1994 (especialmente p. 107), 1994. Também na jurisprudência encontram-se julgados neste sentido, especialmente no âmbito do STJ (Resp. n. 135.355/SP, Rel. Min. Eduardo Ribeiro, $3^{\mathrm{a}}$ Turma, j. 04.04.2000, v.u.). 
Nestes casos, nada impedia, então, que diante de embargos incabíveis pela intempestividade ou pela falta de penhora, o juiz os convertesse em ação declaratória negativa, processados, todavia, sem efeito suspensivo da execução. ${ }^{590}$

Com o atual regime implantando pelas já citadas leis que reformaram o processo de execução a operação perdeu sentido ${ }^{591}$ no âmbito da execução dos títulos extrajudiciais, eis que, atualmente, os embargos independem de prévia segurança do juízo (art. 736, de acordo com a Lei n. 11.382/2006).

Esta hipótese de fungibilidade continua válida, outrossim, para a execução de título judicial, já que a impugnação (art. 475-L e 475-M do CPC) continua a depender da penhora.

Portanto, nada impede o recebimento da intempestiva ou incabível impugnação do art. 475-M do CPC como ação declaratória negativa, fazendo-se as emendas e adequações procedimentais necessárias. Embora a declaratória seja uma ação autônoma, de convirmos que acaba funcionando, tanto quanto os embargos, como meio de defesa do devedor.

Por fim, no âmbito da fungibilidade entre defesas, outras conversões seriam lícitas e recomendáveis, com todos os reflexos procedimentais daí decorrentes. Por exemplo, o recebimento de eventual contestação equivocadamente ofertada no âmbito do processo monitório como embargos a mandado monitório (art. 1.102-C do CPC); o recebimento de embargos à execução indevidamente interpostos pelo cônjuge, para proteção de sua meação ou até mesmo para aventar impenhorabilidade do bem comum (art. $1^{\text {o }}$ da Lei n. 8009/90), como embargos de terceiros (art. 1.046 do CPC); ou a recepção de impugnação sem garantia do juízo como objeção de executividade, toda vez que a matéria alegada fosse de ordem pública.

\footnotetext{
${ }^{590}$ A hipótese nos é trazida por Bedaque, ao citar acórdão proferida pela $12^{\text {a }}$ Câmara do extinto $1^{\mathrm{o}} \mathrm{TACiv} / \mathrm{SP}$, em 12.12.2000, na Apelação Cível n. 814.931-5 (BEDAQUE, José Roberto dos Santos. Efetividade do processo e técnica processual: tentativa de compatibilização, cit., p. 116).

${ }^{591}$ Ressalve-se que a perda de sentido empregada no texto se refere à desnecessidade de dar bens em garantia para apresentação de defesa, razão pela qual não há mais espaço para a objeção de executividade. Todavia, se houve perda do prazo para apresentação dos embargos, a objeção de executividade continua bastante útil para que o devedor avente as questões de ordem pública inbidoras do feito executivo.
} 


\subsubsection{Fungibilidade entre procedimentos liquidatórios}

Também no âmbito dos procedimentos liquidatórios é lícito o emprego da fungibilidade.

Como sabido, a liquidação de sentença é o instrumento processual hábil a emprestar liquidez a títulos executivos desprovidos desta essencial característica, sem o que não se pode dar início à fase executiva do processo.

A disciplina do incidente de liquidação de sentença é encontrada nos artigos 475-A a 475-H, com a redação da Lei n. 11.232/2005, onde são previstos os procedimentos liquidatórios de arbitramento ou por artigos.

A opção por cada destes procedimentos se dá conforme o grau de indeterminação do valor da condenação, que não foi, em ambos os casos, fixado na fase de conhecimento. Se os elementos para a fixação do valor já estiverem nos autos, mas para sua análise for necessário o emprego de conhecimentos técnicos fora da alçada judicial, valer-se-á da liquidação por arbitramento, nomeando-se perito para tanto. Caso, entretanto, os elementos para a quantificação não estiverem no processado, sendo indispensável sua demonstração para apuração do valor, a liquidação será feita por artigos, competindo ao interessado fazer prova dos fatos novos. ${ }^{592}$

Assim, o juiz e as partes, à luz destas premissas, é que fixarão a forma pela qual se procederá a liquidação. Daí porque o art. 475-I, do CPC, indica que a liquidação por arbitramento será realizada quando for determinado pela sentença ou convencionado pelas partes, e ainda quando o exigir a natureza do objeto da liquidação.

Pode ocorrer, entretanto, de a sentença condenatória genérica estabelecer a liquidação por arbitramento como procedimento para apuração do quantum, mas, no curso da liquidação, restar constatado que, para isto, é indispensável produzir-se prova de fato novo (i.e, fato que não podia ser revelado na fase de conhecimento ou que foi voluntariamente desprezado pelo órgão julgador).

\footnotetext{
${ }^{592}$ GAJARDONI, Fernando da Fonseca. Reflexões sobre a nova liquidação de sentença. In: SANTOS, Ernane Fidélis dos; WAMBIER, Luiz Rodrigues; NERY JÚNIOR, Nelson; WAMBIER,Teresa Arruda Alvim Wambier (Coords.). Execução civil: estudos em homenagem a Humberto Theodoro Júnior. São Paulo: Ed. Revista dos Tribunais, 2007. p. 543-544.
} 
Nestes casos, diante do princípio da fungibilidade, é indispensável - pese o que consta da sentença - a conversão do rito da liquidação por arbitramento para liquidação por artigos, sob pena da apuração do quantum ficar comprometida, com inegável reflexo na própria tutela do direito material. ${ }^{593}$

Apesar da dicção do art. 475-G - que veda a discussão da lide ou a modificação da sentença que a julgou em sede de liquidação - há de ser feito esforço para compatibilizar a proibição com o desiderato maior de adequar o procedimento aos seus fins. Primeiro, porque o mote da disposição, evidentemente, é obstar a reabertura da discussão quanto ao an debeatur, algo que nem de longe toca na opção procedimental eleita pela sentença. E segundo, pois parece pouco relevante o rito que se escolha para a liquidação de sentença, já que tanto num quanto noutro dos procedimentos, o que se pretende é a obtenção do quantum debeatur, com constituição plena do título executivo judicial. 594

O raciocínio inverso também nos parece lícito sustentar. Determinada a liquidação por artigos e constatada a desnecessidade de prova de fato novo, sendo plenamente possível a apuração do quantum com base na análise técnica dos elementos já constantes dos autos, nada impede que se converta o procedimento em liquidação por arbitramento.

A aplicação da fungibilidade entre os procedimentos de liquidação é realizada do ponto de vista da necessidade (e não da utilidade). Por isto, a operação pode se dar oficiosamente. Mas é recomendável, na esteira do que estamos sustentando no âmbito de

\footnotetext{
${ }^{593}$ O Superior Tribunal de Justiça já se pronunciou a respeito do tema, aduzindo que "não ofende a coisa julgada, todavia, a alteração da forma de liquidação, em hipóteses excepcionais, como a ora em examinada, devendo ser utilizado para a liquidação de sentença o procedimento que melhor se adequar à espécie. Exigindo a sentença condenatória a suplementação por meio de procedimento outro que não aquele nela previamente determinado, o caminho será o de seu reajustamento ao caso concreto, sob pena de se inviabilizar a liquidação ou de se processá-la de forma inadequada ou injusta para as partes. Permite-se, assim, excepcionalmente, como no caso, a sua modificação na fase de liquidação" (REsp. 348.129/MA, Rel. Min. César Asfor Rocha. j. 21.02.2002, DJ 27.05.2002, p. 177).

${ }^{594}$ No mesmo sentido cf. MEDINA, José Miguel Garcia; WAMBIER, Luis Rodrigues; WAMBIER, Teresa Arruda Alvim. Breves comentários à nova sistemática processual civil 2, cit., p. 118; e WAMBIER, Luiz Rodrigues. Sentença civil: liquidação e cumprimento, cit., p. 139-141, onde o autor faz interessante e válido paralelo entre os fins da fungibilidade no bojo das possessórias e a fungibilidade no âmbito dos procedimentos de liquidação. Também parece aceitar esta tese Humberto Theodoro Júnior, que apesar de aduzir "não tem as partes e o juiz disponibilidade acerca dos procedimentos previstos para a liquidação de sentença", ressalva que "não se pode deixar de observar que, em alguns casos, o procedimento estipulado pela lei acaba sendo infrutífero, visto que não logra alcançar a efetiva determinação do quantum", razão pela qual "haverá de ser tomada providência para que por outro meio procedimental se possa superar o indesejável impasse" (THEODORO JÚNIOR, Humberto. Curso de direito processual civil, cit., v. 2, p. 109).
} 
todo este estudo, que se oportunize às partes manifestação a respeito da operação, inclusive com a possibilidade de prática de atos processuais que seriam incompatíveis com o regime inadvertidamente imposto na sentença.

\subsubsection{Fungibilidade entre cautelares típicas e atípicas}

Em nosso sentir, provimentos cautelares e antecipatórios conservam diferenças dignas de distinção prática e teórica, principalmente nas situações dos artigos 273, II (abuso do direito de defesa) e $\S 6^{\circ}$ (incontrovérsia de parcela dos pedidos cumulados) do $\mathrm{CPC}$, as quais, para serem concedidas, independem do traço característico das cautelares em geral: o periculum in mora. ${ }^{595}$

De qualquer forma a lei, por razões de cunho eminentemente prático, acabou por abarcar estas situações desiguais sob a fungibilidade legal do art. $273, \S 7^{\circ}$, do CPC, permitindo que o juiz possa conceder incidentalmente, presentes os requisitos das cautelares, medidas desta natureza requeridas sob a rubrica de medidas antecipatórias, e vice e versa. ${ }^{596}$

Mesmo antes da lei n. 10.444/2002 (que inseriu o $§ 7^{\circ}$ no art. 273 do CPC), ao menos no âmbito das próprias cautelares, a doutrina já indicava a existência de fungibilidade entre estas medidas ${ }^{597}$, sendo lícito ao juiz, com fundamento no art. 805 do

\footnotetext{
${ }^{595}$ GAJARDONI, Fernando da Fonseca. Direito processual civil: processo cautelar, cit., v. 4, p. 32-36.

${ }^{596}$ Esta questão da fungibilidade de duplo sentido vetorial não é pacífica. Mas tem prevalecido em doutrina e jurisprudência esta interpretação. Neste sentido: DINAMARCO, Cândido Rangel. A reforma da reforma, cit., p. 92-94; BEDAQUE, José Roberto dos Santos. Tutela cautelar e tutela antecipada: tutelas sumárias e de urgência - tentativa de sistematização, cit., p. 381-382; WAMBIER, Luiz Rodrigues; WAMBIER, Teresa Arruda Alvim. Breves comentários à $2^{a}$ fase da reforma do Código de Processo Civil. 2. ed. São Paulo: Ed. Revista dos Tribunais, 2002. p. 61-63; ASSIS, Araken de. Fungibilidade das medidas inominadas cautelares e satisfativas, cit., p. 52; e BUENO, Cássio Scarpinella. Tutela antecipada. 2. ed. São Paulo; Saraiva, 2007. p. 140-147. Este último e brilhante autor faz precisa pontuação sobre a indiferença da utilização da técnica cautelar ou antecipatória para solucionar problemas práticos. E o faz à luz da nova redação do art. 489 do CPC (Lei n. 11.280/2006), que admite a suspensão da executoriedade da sentença na pendência de ação rescisória, desde que presentes os requisitos da cautela ou da antecipação. Nós mesmos, em outra oportunidade, já abraçamos o entendimento de que a disposição deve ser lida desta maneira, em "interpretação mais benéfica à tutela dos direitos, com desapego às condicionantes de ordem formal, admitindo a concessão de medidas antecipatórias a despeito do pedido de medida cautelar, desde que preenchidos os rigorosos requisitos do art. 273 do CPC. Nestes casos, a única ressalva é que também seja convertido o processo cautelar ajuizado em processo de conhecimento, já que os pleitos antecipatórios não se processam de forma autônoma" (Direito processual civil: processo cautelar, cit., v. 4, p. 38).

${ }^{597}$ CALAMANDREI, Piero. Introdução ao estudo sistemático dos procedimentos cautelares. Tradução de Carla Roberta Andreasi Bassi. Campinas: Servada, 2000. p. 121-122 (o autor fala em variabilidade das cautelares); THEODORO JÚNIOR, Humberto. Processo cautelar. 19. ed. São Paulo: Leud, 2000. p.145146; CARVALHO FILHO, Milton Paulo de. Processo cautelar. São Paulo: Atlas, 2005. p. 23-24.
} 
CPC e também no seu poder geral de cautela (art. 798 do CPC), o recebimento ou a substituição de uma medida cautelar requerida por outra igualmente útil, ainda que oficiosamente. $^{598}$

Estaríamos diante, portanto, de legítima violação do princípio da adstrição do juiz ao pedido (art. 128 e 460 do CPC), justificável pela natureza protetiva ínsita dos provimentos cautelares. Rememore-se que o processo cautelar protege a um outro processo, e não diretamente ao direito da parte, de modo que a fungibilidade permite ao Estado a própria proteção do seu instrumento de aplicação da Jurisdição. Afinal, sendo o processo cautelar um dos meios de garantia da eficácia do processo, sem ele toda a função jurisdicional estaria ameaçada.

O grande problema no âmbito da fungibilidade das medidas cautelares está no fato de que parte da doutrina e da jurisprudência segue firme na não admissão da concessão de cautelares atípicas quando ausentes os requisitos de cautelares típicas. Aduzem que se o próprio legislador já estabeleceu os requisitos legais para a concessão da cautela, não poderia o juiz suplantar ou dispensar tais requisitos, recebendo medida típica com atípica (fungibilidade), e concedendo a medida com base em seu poder cautelar geral (art. 798 do CPC). ${ }^{599}$

Não nos parece mais que seja assim.

A tutela de segurança não pode ser enclausurada pelo legislador infraconstitucional, eis que ela decorre do princípio constitucional da inafastabilidade do controle jurisdicional (art. $5^{\circ}, \mathrm{XXXV}$, da $\mathrm{CF}$ ).

Ademais, é evidente que o legislador não tem condições de estipular, para todos os casos da vida, quais os requisitos que devem ser preenchidos para que a parte obtenha a

\footnotetext{
${ }^{598}$ Ao aferir, por exemplo, que o requerido bloqueio cautelar da transferência de determinado veículo no CIRETRAN não impede sua alienação - já que os bens móveis se transferem pela tradição e o certificado de transferência do veículo está em poder do demandado - perfeitamente possível ao juiz, apesar da inexistência de pedido da parte, determinar a apreensão do certificado de transferência do automóvel, ou até mesmo do próprio bem.

${ }^{599}$ Eis o que diz Milton Paulo de Carvalho Filho: "o juiz não está autorizado, a pretexto de seu poder geral de cautela, a substituir medidas cautelares típicas ou nominadas por inominadas quando ausentes os requisitos legais exigidos para as primeiras" (...) "a fungibilidade, portanto, não pode ser empregada para burlar as exigências do legislador quanto às cautelares nominadas" (CARVALHO FILHO, Milton Paulo de. Processo cautelar, cit., p. 21 e 25). E nós mesmo já anotamos que "não pode o juiz, a pretexto de proteger o direito da parte, conceder medida cautelar que contrarie a lei, ou que se afaste dos rigorosos requisitos imaginados pelo legislador para concessão de certas cautelas típicas ou nominadas" (Direito processual civil: processo cautelar, cit., v. 4, p. 31).
} 
cautela. Sempre haverá uma particularidade, uma situação nova, um evento novo a justificar, pese o não preenchimento dos requisitos pré-estabelecidos pelo legislador, a concessão da medida. ${ }^{600}$.

Assim, ainda que ausentes os requisitos legais da tutela cautelar típica, mas presentes os requisitos genéricos da cautelar atípica previstos no art. 798 do CPC (fumus boni iuris e periculum in mora), de rigor que seja aplicada a fungibilidade procedimental, recebendo-se a medida típica por atípica, e concedendo-se a cautela com base no poder geral do juiz. ${ }^{601}$

É o que ocorre, por exemplo, com a ordem cautelar de bloqueio de bens ou de valores, emitida pelo juiz com base em seu pode geral, nas hipóteses em que a ação de conhecimento para constituição do título ainda esteja em fase inicial. Nestes casos, apesar de ausentes os requisitos legais do arresto cautelar requerido - eis que inexistente prova literal da dívida líquida e certa ou equivalente (art. 814 do CPC) - lícita é a conversão do procedimento para o das cautelares atípicas (art. 802 e ss. do CPC), com concessão da medida desde que a situação de risco e a aparência do direito justifiquem a preservação patrimonial.

\subsubsection{Utilização de procedimento diverso do legal e abstratamente previsto}

O juiz, diante de particularidades próprias da causa, é o melhor árbitro do procedimento a ser seguido, devendo fixá-lo a fim de adaptá-lo ao direito material e à situação específica das partes litigantes. Desde que garanta aos contendores o devido

\footnotetext{
${ }^{600}$ Conforme bem pontua Teresa Arruda Alvim Wambier, "razões de ordem formal não devem obstar que a parte obtenha a seu favor provimento cujo sentido e função sejam o de gerar condições à plena eficácia da providência jurisdicional pleiteada ou a final, ou em outro processo, seja de conhecimento, seja de execução" (O princípio da fungibilidade sob a ótica da função instrumental do processo, cit., p. 44).

${ }^{601}$ Este é o entendimento de Araken de Assis, que ainda faz a interessante ressalva de que admissão genérica de tutelas de urgência (art. 798 e 273) pode tornar letra morta a disciplina das medidas típicas, pois sempre é preferível optar por formular um pedido genérico em vez de se arriscar a não preencher os requisitos exigidos para as medidas nominadas, como arresto ou seqüestro (ASSIS, Araken de. Fungibilidade das medidas inominadas cautelares e satisfativas, cit., p. 49-51. Também pensa assim Humberto Theodoro Júnior, a anotar que o entendimento restritivo quanto à admissão das cautelares inominadas para concessão de medidas tidas por típicas "não deve mais prevalecer, dada a amplitude com que o direito passou a assegurar a chamada tutela de segurança ou de precaução". E arremata aduzindo que nada impede ao juiz, dentro do poder cautelar geral, de deferir medida atípica, mesmo em se tratando de situação a que normalmente corresponderia uma medida típica: "o que importa é determinar qual a medida que o caso, de per si, está a exigir" (Processo cautelar, cit., p. 102). Por fim, ainda, no mesmo sentido, cf. MARINS, Victor A. A. Bomfim. Tutela cautelar: teoria geral e poder geral de cautela, Curitiba: Juruá, 1996. p. 231; e SILVA, Ovídio A. Baptista. Do processo cautelar. Rio de Janeiro: Forense, 1996. p. 60.
} 
processo constitucional e previsibilidade de suas ações, pode excepcionalmente manipular o procedimento. Estas são, grosso modo, as premissas da flexibilidade judicial do procedimento sustentadas neste estudo.

Em vista disto, a experiência cotidiana do foro tem recomendado que alguns modelos genericamente previstos pelo legislador, em circunstâncias bastante específicas, sejam substituídos, parcial ou integralmente, por outros modelos procedimentais muito mais aptos à tutela do caso em concreto.

A adoção do procedimento sumário cognitivo, por exemplo, em muitas situações é pior que a adoção do procedimento ordinário. Salvo nas hipóteses em que há possibilidade de conciliação, marca-se uma audiência apenas para que o advogado do requerido entregue a contestação, ato contínuo abrindo-se vista dos autos ao autor para manifestação. Além disso, um sem número de audiências são re-designadas pelo descompasso entre a data da audiência e a obediência ao prazo de 10 (dez) dias para citação prévia do requerido (art. 278 do CPC). ${ }^{602}$

Ora, se por si só o rito sumário já não é utilizado lá com grande utilidade, quanto mais o será nas hipóteses em que a própria autocomposição é inviável, como ocorre nas ações ajuizadas contra o Poder Público.

Daí porque para a tutela mais célere do direito material, em vista da capacidade e disponibilidade da parte para transacionar, a prática vem admitindo a adoção do rito ordinário nestes casos, mesmo em contradição expressa à disposição legal.

Isto já vem acontecendo, com alguma resistência jurisprudencial ${ }^{603}$, em matéria de acidente de trabalho, em que a lei determina o processamento da demanda pelo rito sumário (art. 129, II, da Lei n. 8.213/91). Todavia, praticamente todos os magistrados que

\footnotetext{
${ }^{602}$ PORTANOVA, Rui. Princípios do processo civil, cit., p. 180.

${ }^{603}$ ACIDENTE DO TRABALHO - PROCEDIMENTO SUMÁRIO - AUDIÊNCIA DE CONCILIAÇÃO SUPRESSÃO - INADMISSIBILIDADE - EXEGESE DO ARTIGO 277 DO CÓDIGO DE PROCESSO CIVIL E ARTIGOS 129, II E 132 DA LEI 8.213/91. Torna-se imperiosa, na ação acidentária que se processa pelo rito sumário, a realização da audiência prévia de conciliação, posto que nela poderá o INSS utilizar-se da faculdade de transigir, nos termos do artigo 132, da Lei n ${ }^{\circ}$ 8.213/91 ( $2^{\circ} \mathrm{TACiv} / \mathrm{SP}$, Agravo de Instrumento n. 568.724 - $8^{\mathrm{a}}$ Câm., Rel. Juiz Orlando Pistoresi, j. 25.3.99). No mesmo sentido são os seguintes julgados do extinto $2^{\circ}$ Tribunal de Alçada Civil de São Paulo: Agravo de Instrumento n. 586.84100/3, (JTA/LEX 179/305); Agravo de Instrumento n. 574.000-00/8; 12a Câm; Rel. Juiz Arantes Theodoro, j. 24.6.99; Agravo de Instrumento n. 585.296-00/5, $12^{\mathrm{a}}$ Câm., Rel. Juiz Gama Pellegrini,j. 26.8.99; Agravo de Instrumento n. 585.291-00/7; $3^{\text {a }}$ Câm., Rel. Juiz Ferraz Felisardo, j. 14.9.99; Agravo de Instrumento n. 711.844-00/8; $7^{\text {a }}$ Câm., Rel. Juiz Willian Campos, j. 30.10.2001.
} 
atuam em primeiro grau acabam processando a acidentária típica pelo rito ordinário, visto serem incipientes (se não inexistentes) casos em que o INSS, na qualidade de demandado, transige (art. 132 da Lei n. 8.213/91) na audiência inicial (art. 277 do CPC). Assim não há razão plausível para a realização da audiência de conciliação, eis que além de atrasar o trâmite processual, acaba prejudicando a própria parte autora (especialmente se relevarmos que eventual transação pode se operar na audiência de instrução $\left.{ }^{604}\right){ }^{605}$

Também nas lides trabalhistas, ajuizada a ação pelo procedimento sumaríssimo (art. 852-A ${ }^{606}$ e 895 da CLT, com redação pela Lei n. 9.957/2000), extremamente comum apesar da falta de previsão legal - a conversão do procedimento em ordinário nos casos em que o pólo passivo desaparece após o ajuizamento da ação. ${ }^{607}$ Note-se que não se trata aqui de hipótese de conversão do rito a pedido da parte, mas sim inovação artificiosa do juízo em vistas à tutela do direito material, que ficará sem socorro, ou só será socorrido tardiamente em outra ação pelo rito ordinário, caso esta demanda seja arquivada (extinta) por impossibilidade de citação pessoal do reclamado (como parece querer o art. 852-B, $\S$ $1^{\text {o }}$, da CLT). Por isto, opera-se a conversão judicial do procedimento, com designação de nova data para audiência e determinação da expedição e publicação de edital de notificação do reclamado. Não adotar a conversão do rito no caso é divorciar-se dos princípios da celeridade e da economia processual que informam todo o processo do trabalho, e mais recentemente todo o processo judicial ou administrativo (art. $5^{\circ}$, LXXVIII, da CF).

Em sentido diametralmente o oposto - mas também com fito único e evidente de tentar solucionar o conflito da melhor forma possível, sem a realização de atos processuais inúteis ou desnecessários - a praxe tem recomendado, principalmente quando

\footnotetext{
${ }^{604}$ Como, aliás, já entendeu o próprio $2^{\circ} \mathrm{TACiv} / \mathrm{SP}$ : “dadas as próprias características da ação acidentária, nada impede que a tentativa de conciliação se faça a final, por ocasião da audiência de instrução e julgamento". (Agravo de Instrumento n 573.668-00/0, 9a Câm., Rel. Juiz Claret de Almeida, j. 28.7.99).

${ }^{605}$ Muito mais coerente, por isto, o seguinte precedente: ACIDENTE DO TRABALHO - PROCEDIMENTO SUMÁRIO - AUDIÊNCIA DE CONCILIAÇÃO - SUPRESSÃO - OFENSA AO PRINCÍPIO DO CONTRADITÓRIO E DO DIREITO DE DEFESA - INOCORRÊNCIA - ADMISSIBILIDADE. Conquanto subordinada ao rito sumário, a supressão da audiência de conciliação nas ações acidentárias não ofende o princípio do contraditório e nem prejudica o direito de defesa do INSS que sabidamente não celebra acordos. (Agravo de Instrumento n. 564.642, $7^{\text {a }}$ Câm., Rel. Juiz S. Oscar Feltrin, j. 16.3.99).

${ }^{606}$ Eis a redação do citado dispositivo: "os dissídios individuais cujo valor não exceda a quarenta vezes o valor do maior salário-mínimo vigente na data do ajuizamento da reclamação ficam submetidos ao procedimento sumaríssimo".

${ }^{607}$ No sentido do exposto: TRT 15 Região. Recurso Ordinário (procedimento sumaríssimo) n. 023205/2000. Recorrente: Aparecida Ferreira de Souza. Recorrido: Funbepe - Fundação beneficente de Pedreira. Origem: Amparo/SP. Rel. Juiz Mauro César Martins de Souza. Cf. também FONTES, André. Procedimento sumaríssimo trabalhista - a conversibilidade do rito em benefício da celeridade processual. Repertório de Jurisprudência IOB, São Paulo, n. 1, cad. 2, p. 17-19, 2002).
} 
seja possível a conciliação logo no início do processado, a utilização do procedimento especial da separação judicial contenciosa.

De fato, conforme reza o Decreto-Lei n. 968/49, no âmbito dos procedimentos judiciais desta natureza é mister que o magistrado designe, logo após o recebimento da petição inicial, audiência para tentativa de reconciliação e conciliação das partes. Não obtida a reconciliação ou a conversão da separação litigiosa em consensual, o prazo para resposta do réu (15 dias) se principia na própria audiência. ${ }^{608}$

Exatamente por evitar a beligerância prematura advinda da preparação da contestação antes da tentativa de reconciliação/conciliação, é que o rito especial da separação tem emprego muito mais adequado para as demandas cuja narrativa inicial revele alta probabilidade de autocomposição. A parte, ciente de que só após a audiência infrutífera se iniciará o prazo para contestação, comparece ao ato com o espírito muito mais aberto à solução negociada do conflito.

Em vista disto o Tribunal de Justiça do Estado de São Paulo, considerando os bons resultados do Setor de Conciliação em Segundo Grau de Jurisdição do Tribunal de Justiça (Provimento CSM nº 843/2004), e as diretrizes do Projeto de Gerenciamento de Casos desenvolvido pelo Centro Brasileiro de Estudos e Pesquisas Judiciais - CEBEPEJ, e implementado, com êxito, nas Comarcas de Patrocínio Paulista e Serra Negra (CSM processo G 37.979/2004 - DEMA), fez editar os provimentos de números 893/2004 e 953/2005, a disciplinar, no âmbito da Justiça Estadual paulista, a criação, instalação e funcionamento dos Setores de Mediação e Conciliação. ${ }^{609}$

De acordo com o art. $5^{\circ}, 1^{\circ}$, do provimento n. 953/2005 (antigo art. $4^{\circ}, \S 3^{\circ}$, do Provimento n. 993/2004), recomenda-se designação de audiência de conciliação em todos os feitos em que haja possibilidade de acordo, seja no âmbito do direito de família ou sede de direitos disponíveis, "preferencialmente, após o recebimento da petição inicial,

\footnotetext{
${ }^{608}$ GOMES JÚNIOR, Cyrilo Luciano. Separação judicial e divórcio (de acordo com a Lei n. 11.112/2005). In: GAJARDONI, Fernando da Fonseca; SILVA, Márcio Henrique Mendes da (Coords.). Manual dos procedimentos especiais de legislação extravagante, cit., p. 340.

${ }^{609}$ Paralelamente ao aplauso que merece a iniciativa do Estado de São Paulo em disciplinar os setores de mediação no seu âmbito, aqui cabem também críticas a respeito da forma como isto foi feito. Os provimentos CSM n. 893/2004 e 953/2005 trazem novas regras de procedimento, tanto que indicam a utilização do rito das separações para todos os processos encaminhados ao setor de mediação. Embora seja mesmo da competência dos Estados a edição destas regras procedimentais específicas, como já vimos (item 2.4.), de se convir que o Tribunal de Justiça usurpou competência da Assembléia Legislativa Estadual, a quem cabe criar estas novas regras procedimentais pela via legal.
} 
determinando a citação do réu e sua intimação, por mandado ou carta, para comparecimento à audiência no Setor de Conciliação, constando do mandado ou carta que o prazo para apresentação da resposta começará a fluir a partir da data da audiência se, por algum motivo, não for obtida a conciliação".

Os resultados do emprego desta variante procedimental a bem da autocomposição já são sentidos, a ponto de hoje, no Estado de São Paulo, existirem mais de 70 unidades com setores de conciliação instalados, todas funcionando na fase processual com o procedimento da separação contenciosa. ${ }^{610}$

Também no âmbito executivo a flexibilização judicial do procedimento tem surtido desejáveis efeitos, principalmente quando o devedor é o Estado e a ação é de cunho previdenciário.

Como é posto pelo art. 730 do CPC, na execução contra a Fazenda Pública a devedora será citada pessoalmente (art. 222, “c”, do CPC) para opor embargos em 30 (trinta) dias (Lei n. 9.494/97, com a redação que lhe foi dada pela Medida Provisória n. 2180-35), citação que se fará acompanhar do cálculo ofertado pelo credor, nos termos do art. 614, II, do CPC. ${ }^{611}$

Acontece que em inúmeros casos o credor encontra verdadeira dificuldade na elaboração desta conta. Às vezes pela falta de ciência de todos os elementos necessários para apuração do quantum (de regra, conhecidos pelo devedor). Outras porque as próprias regras de cálculo - variáveis conforme o ente federado - são complexas e distintas das utilizadas corriqueiramente na apuração de débitos contra particulares.

\footnotetext{
${ }^{610} \mathrm{Na}$ comarca de Patrocínio Paulista, por exemplo, nos 15 meses iniciais de funcionamento do setor de mediação e conciliação (jun. 2004 a set. 2005), 73\% das audiências realizadas em matéria familiar frutificaram em autocomposição, enquanto que no âmbito das demais causas este percentual atingiu 50\% (Fonte: Tribunal de Justiça do Estado de São Paulo).

${ }^{611}$ Eis, neste sentido, o entendimento do Superior Tribunal de Justiça: PROCESSUAL CIVIL E PREVIDENCIÁRIO. EXECUÇÃO. CITAÇÃO DO DEVEDOR POR CARTA PRECATÓRIA. FALTA DE JUNTADA DO DEMONSTRATIVO DE CÁLCULO. NULIDADE. ARTIGOS 225, II, 604, 614, II E 730, DO CPC. I - Dependendo o valor da condenação apenas de cálculo aritmético, o pedido de execução deve estar instruído com a memória discriminada e atualizada do cálculo, que deve ser juntada, por cópia, ao mandado de citação do devedor para opor embargos. II - A falta de juntada importa em prejuízo do devedor, por privar-lhe de elemento essencial à formulação da defesa através de embargos, resultando nula a citação. III - Caso, ademais, em que a citação foi feita por carta precatória que subentende domicílio do devedor fora da jurisdição do Juízo de Execução, sem acesso fácil aos autos. IV - Recurso conhecido e provido (REsp 396164 / RS, Ministro Gilson Dipp, 5 Turma, j. 20.06.2002).
} 
Para tentar solucionar esta dificuldade, principalmente nos casos em que a parte é hipossuficiente ou esteja sendo assistida pela defensoria pública ou órgão que lhe faça às vezes, parece recomendável que a regra procedimental seja invertida, determinando-se que a devedora - que tem setores específicos para elaboração e conferência destas contas apresente o cálculo do valor devido.

Assim, o procedimento inicial da execução contra a Fazenda Pública nestes casos, não será mais iniciado com a apresentação de cálculo pelo credor. Sendo exeqüível a sentença, intima-se a Fazenda Pública, por seu procurador (e não mais pessoalmente, o que representa enorme ganho de tempo) para elaboração de cálculos, em prazo variável conforme as particularidades da causa e do serviço fazendário.

Apresentados os cálculos, da conta será dada vista ao credor, por seu advogado, que, então, poderá: a) confirmar a sua correção, caso em que será homologada e, a partir daí, expedido o competente precatório judicial (art. 100 da CF); ou b) rejeitar o cálculo, apresentando conta supletiva que, então, servirá para a citação da Fazenda Pública, seguindo-se o rito padrão do art. 730 do CPC.

A inversão supra sugerida, além de fazer com que o procedimento seja manipulado em favor do credor hipossuficiente, resolve dois problemas práticos. Primeiro, torna desnecessário o emprego do art. $475-\mathrm{B}, \S 2^{\circ}$, do $\mathrm{CPC}$, que cria um procedimento preparatório para elaboração da conta quando o cálculo depender de dados existentes em poder do devedor. Afinal, se o Estado apresentar as contas, ainda que equivocadas, nelas constarão os elementos utilizados para o cálculo e que só eram de conhecimento seu. E segundo, principalmente, reduz-se drasticamente a oposição de embargos à execução, já que tendo o pólo passivo ofertado os cálculos, se houver concordância do credor, falece ao devedor interesse de agir na oposição.

Além disso, em vista do cálculo ofertado pelo devedor, pode o credor, ainda que ele esteja parcialmente incorreto, preferir abrir mão de parcela do valor efetivamente devido a bem da expedição mais célere do precatório. ${ }^{612}$

\footnotetext{
${ }^{612}$ Ressalte-se, todavia, que esta inversão procedimental não encontra eco na jurisprudência do STJ: RECURSO ESPECIAL. PREVIDENCIÁRIO. PROCESSUAL CIVIL. EMBARGOS À EXECUÇÃO. MEMÓRIA DO CÁLCULO PELO DEVEDOR. EXIGÊNCIA INEXISTENTE. Não há determinação legal no sentido de que o devedor esteja obrigado a apresentar memória do cálculo que julgue correta. É o credor quem deve trazer aos autos a memória de cálculo discriminada. Recurso conhecido e provido. (REsp

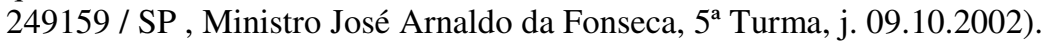




\subsubsection{Variantes no âmbito do procedimento recursal}

Ao lado das inúmeras variantes legais do procedimento recursal $\left(518, \S 1^{\circ} ; 527\right.$, I e II; 544, $\S 3^{\circ} ; 557$ e $\S 1^{\circ}$-A, do CPC) - todas devidamente estudadas no tópico atinente à flexibilidade legal alternativa (item 5.3 supra) - nesta seara a prática judicial também vem moldando (ou deveria moldar) variantes rituais bastante interessantes, pese a omissão legislativa.

Assim, em sede de embargos de declaração - cujo objetivo principal é o de sanar obscuridade, omissão ou contradição do julgado (art. 535 do CPC) - doutrina ${ }^{613}$ e jurisprudência ${ }^{614}$ vêm firmando entendimento segundo o qual é imperiosa a prévia oitiva do embargado, apesar da omissão legislativa a respeito, quando este recurso anômalo tenha natureza modificativa ou infringente. Afinal, sendo o contraditório elemento estruturante e sob o qual se finca todo nosso sistema processual, o procedimento, inclusive o recursal, deve ser judicialmente moldado a preservá-lo, permitindo ao embargado produzir argumentos que possam impedir a alteração do julgado pretendida atipicamente em sede de declaratórios.

Também no âmbito do procedimento recursal, de se admitir, diante do novel regime da súmula impeditiva de recursos (Lei n. 11.276/2005), que o agravo de instrumento da decisão que não recebe a apelação contra a sentença que estiver de acordo com os enunciados do Supremo Tribunal Federal ou do Superior Tribunal de Justiça, seja recebido e processado como apelação, valendo-se analogicamente do art. $544, \S 3^{\circ}$, do CPC.

A operação será efetuada toda vez que o relator observar, em agravo instruído com todas as peças necessárias para a completa compreensão da controvérsia de fato e de direito, a má aplicação do art. 518, § $1^{\circ}$, do CPC, e, especialmente, quando aferir que a sentença não se coaduna com a orientação pretoriana superior (pese o não recebimento do recurso).

\footnotetext{
${ }^{613}$ Neste sentido cf. YARSHELL, Flávio Luiz. Tutela jurisdicional, cit., p. 171; FARIAS, Talden. O princípio do contraditório em face dos embargos declaratórios com efeito modificativo ou infringente. Revista Dialética de Direito Processual, São Paulo, n. 18, p. 108-112, set. 2004; FERNANDES, Luis Eduardo Simardi. Embargos de declaração: efeitos infringentes, prequestionamento e outros aspectos polêmicos, São Paulo: Ed. Revista dos Tribunais, 2003. p. 100-101 (com ressalvas); e DINAMARCO, Cândido Rangel. Os embargos de declaração como recurso. In: A nova era do processo civil, cit., p. 185-188.

${ }^{614}$ STJ EResp n.172.082/DF, Rel. Min. Hamilton Carvalhido, 3a Seção, DJ 04.08.2003; STJ, Resp 491-311MG, Min. José Delgado, $1^{\text {a }}$ Turma, j. 06.05.2003; STJ, Resp. 615.532/RF, Rel. Min. José Arnaldo da Fonseca, $5^{\text {a }}$ Turma, j. 06.04.2004.
} 
As vantagens da conversão procedimental são evidentes. Além de evitar o tramitar de autos entre instâncias, manifesta é a aceleração do julgamento do mérito do reclamo, principalmente se combinada a regra com a possibilidade de provimento monocrático do recurso convertido (art. 557, § $1^{\circ}$-A c.c. art. $544, \S 3^{\circ}$, do CPC).

A medida sugerida não prejudica, ademais, o contraditório, eis que fica ele garantido através da oportunidade concedida ao agravado de oferecer contra-minuta às razões de agravo, ato que será recebido como contra-razões de apelação para todos os fins.

\subsubsection{Flexibilização judicial dos prazos}

O procedimento se desenrola e se desenvolve no tempo, de modo que um dos meios para disciplinar a sua caminhada é exatamente a fixação de prazos, que nada mais são que os períodos de tempo estabelecidos para a realização válida de um ato processual na série. ${ }^{615}$

Nosso sistema processual civil é bastante claro a respeito. O art. 177 do CPC expressamente dispõe que os atos processuais das partes realizar-se-ão nos prazos prescritos em lei, sob pena de preclusão (art. 183 do CPC). ${ }^{616}$

Aliás, é graças à combinação das regras sobre prazo com as regras de preclusão temporal que o processo caminha adiante e de forma ordenada. Não praticado o ato no prazo fixado passa-se, independentemente de qualquer declaração, ao ato processual seguinte fixado para a série, somente em circunstância excepcionais sendo admitida nova abertura do prazo para que a parte pratique o ato processual superado no tempo (art. 183, $\S \S$ do CPC). ${ }^{617}$

\footnotetext{
${ }^{615}$ LIEBMAN, Enrico Tullio. Manual de direito processual civil, cit., v. 1, p. 233.

${ }^{616} \mathrm{E}$ no mesmo sentido vai, também, boa parte das legislações continentais. Por exemplo, diz o art. 136 da LEC espanhola (Ley 1/2000) diz que "transcurrido el plazo o pasado el término señalado para la realización de un acto procesal de parte se producirá la preclusión y se perderá la oportunidad de realizar el acto de que se trate. E o art. 152 do Codice di Procedura Civile italiano, em redação menos clara, anota que: " $\mathrm{i}$ termini per il compimento degli atti del processo sono stabiliti dalla legge; possono essere stabiliti dal giudice anche a pena di decadenza, soltanto se la legge lo permette espressamente. I termini stabiliti dalla legge sono ordinatori, tranne che la legge stessa li dichiari espressamente perentori".

${ }^{617}$ LIEBMAN, Enrico Tullio. Manual de direito processual civil, cit., v. 1, p. 236.
} 
Várias são as classificações dos prazos processuais. ${ }^{618}$ A que mais de perto nos interessa, diz que são prazos dilatórios aqueles que as partes, de comum acordo, podem reduzir ou prorrogar (art. 181 do CPC), e são peremptórios os prazos que não é lícito, nem às partes, nem ao juiz, alterar, salvo em comarcas onde for difícil o transporte - casos em que poderão ser prorrogados em até 60 dias - ou nos casos de calamidade pública, quando, então, poderá ser excedido o limite anterior (art. 182 do CPC).

Raros são os exemplos de prazos dilatórios na nossa legislação processual. ${ }^{619} \mathrm{~A}$ preponderância do sistema da legalidade das formas no CPC/73 fez com que a maioria esmagadora dos prazos de nosso sistema fosse considerada como peremptórios pela doutrina e jurisprudência, ou seja, sem possibilidade de flexibilização judicial.

Estamos, todavia, na contramão da modernidade.

O Código de Processo Civil Português, por exemplo, além de por fim aos prazos processuais privilegiados do Estado nos litígios de direito privado pela reforma de 1995, faculta a qualquer das partes (inclusive ao Estado) a possibilidade de requerer e obter a prorrogação do prazo para contestar ou apresentar articulados subseqüentes à contestação (art. 486), em termos paralelos e por período idêntico ao que se prevê ao Ministério Público (item 4). Assim, quando o Tribunal considerar que ocorre motivo ponderoso ${ }^{620}$ que impeça ou dificulte anormalmente ao réu ou ao seu mandatário judicial a organização da defesa, poderá, a requerimento deste e sem prévia audição da parte contrária, em decisão irrecorrível (item 6), prorrogar o prazo da contestação, até o limite máximo de 30 (trinta) dias (item 5) ${ }^{621}$. Permite, ainda, independentemente de prorrogação ou de justo

\footnotetext{
${ }^{618}$ Assim, consideram-se judiciais os prazos fixados pelo juiz e legais os estabelecidos em lei (art. 177 do $\mathrm{CPC}$ ); comum o prazo para que mais de uma parte pratique o ato processual, e simples aquele prazo destinado para a prática do ato por apenas uma das partes; prazo impróprio o destinado a prática de atos pelo juiz e serventuários da justiça (artigos 189 e 190 do CPC) - cujo descumprimento acarreta apenas sanções administrativas e disciplinares (artigos 193, 194 e 198 do CPC) - e prazo próprio o destinado à prática de atos pelas partes e intervenientes, cujo descumprimento, em regra, gera preclusão (art. 183 do CPC).

${ }^{619}$ Os exemplos mais citados são os do art. 265, II, do CPC (suspensão do processo cognitivo, a pedido das partes, por até 06 meses), art. 454 do CPC (dilação do prazo por mais 10 minutos para debates em audiência de instrução e julgamento), e do art. 791, II e III do CPC (suspensão da execução a pedido da parte ou pela inexistência de bens penhoráveis).

${ }^{620} \mathrm{Já}$ se decidiu que motivo ponderoso, para efeito de prorrogação de prazo para contestar, é a ocorrência de evento, não imputável à parte nem aos seus representantes ou mandatários, que obste à organização atempada da defesa. Entendeu-se, ainda, que o pedido de prorrogação deve ser justificado e provado (NETO, Abílio. Código de processo civil anotado, p. 661).

${ }^{621}$ A doutrina portuguesa aponta que esta disposição do CPC reformado nada mais fez do que restabelecer a igualdade das partes, eis que no regime pretérito o recurso à dilação judicial do prazo era privativo do Ministério Público. Aduz, ainda, que o próprio Tribunal Constitucional português já havia declarado a inconstitucionalidade desta antiga distinção de regime (que na época permitia prorrogação do prazo por 03
} 
impedimento, que qualquer ato seja praticado dentro de 03 (três) dias após seu termo final, casos em que sua validade fica dependente do imediato pagamento de determinado multa, variável conforme o tempo de atraso (art. 145, itens 5, 6 e 7, com redação pelo Decreto-Lei n. 234/2003). ${ }^{622}$

Ao enunciar os poderes do órgão judicial no case manegement, a CPR Inglesa permite ao julgador, salvo disposição expressa em sentido contrário, prorrogar ou abreviar prazos legais, futuros ou já superados (R. 3.1.2). ${ }^{623}$

A legislação processual civil italiana (art. 154 do CPC), embora não com o mesmo alcance das anteriores, permite a oficiosa dilação dos prazos ordinatórios pelo juiz ao menos uma vez, desde que antes do vencimento do termo originário. ${ }^{624}$

E desde julho de 1977 o processo civil alemão, alterado pela chamada emenda de simplificação, permite ao tribunal bastante flexibilidade na orientação da causa, cabendo ao juiz a fixação de limites temporais para a realização de atos processuais e das audiências. $^{625}$

meses), sob o fundamento de que "é injustificado, irrazoável, intolerável e arbitrário" que a faculdade só fosse deferida ao MP, como se parte não tivesse, também, dificuldade, em alguns casos, para elaborar a defesa no prazo de 20 dias (hoje são 30 dias) fixado pela legislação portuguesa pretérita (acórdão n. 266/97, in DR, II, 20.05.97, p. 5815). Finalmente, aponta-se que "o regime estabelecido no n. 5 assenta numa cláusula geral, que outorga ao juiz poderes amplamente discricionários e de natureza prudencial na apreciação da justificabilidade objectiva da prorrogação pretendida pela parte", revelando, ainda, a existência de um poder discricionário judicial, como tal irrecorrível (REGO, Carlos Francisco de Oliveira Lopes do. Comentários ao Código de Processo Civil, cit., p. 409-410).

${ }^{622} \mathrm{~A}$ redação dos dispositivos é a seguinte: "5. Independentemente de justo impedimento, pode o acto ser praticado dentro dos três primeiros dias úteis subsequientes ao termo do prazo, ficando a sua validade dependente do pagamento imediato de uma multa de montante igual a 1/8 da taxa de justiça que seria devida ao final do processo, ou parte do processo, se o acto for praticado no primeiro dia, de um $1 / 4$ da taxa de justiça, se o acto for praticado no segundo dia, ou de $1 / 2$ da taxa de justiça, se o acto for praticado no terceiro dia, não podendo, em qualquer dos casos, a multa exceder a 5 UC. 6. Praticado o acto em qualquer dos três dias úteis seguinte sem ter sido paga a multa devida, logo que a falta seja verificada a secretaria, independentemente de despacho, notificará o interessado para pagar a multa no montante igual ao dobro da mais elevada prevista no número anterior, sob pena de se considerar perdido o direito de praticar o acto, não, podendo, porém, a multa exceder a 10 UC. 7. O juiz pode determinar a redução ou a dispensa da multa nos casos de manifesta carência econômica ou quando o respectivo montante se revele manifestamente desproporcionado".

${ }^{623}$ Rule 3.1.2: Except where these Rules provide otherwise, the court may: a) extend or shorten the time for compliance with any rule, practice direction or court order (even if an application for extension is made after the time for compliance has expired); b) extend or shorten the time for compliance with any rule, practice direction or court order (even if an application for extension is made after the time for compliance has expired).

${ }^{624}$ Art. 153. Il giudice, prima della scadenza, puo' abbreviare, o prorogare anche d'ufficio, il termine che non sia stabilito a pena di decadenza. La proroga non puo' avere una durata superiore al termine originario. Non puo' essere consentita proroga ulteriore, se non per motivi particolarmente gravi e con provvedimento motivato.

${ }^{625}$ GRASSI, Lúcio. Cognição processual civil: atividade dialética e cooperação intersubjetiva na busca da verdade real, cit., p. 48. 
Nosso sistema tem lá algumas hipóteses em que ao órgão julgador é conferida a possibilidade de adequação do prazo às circunstâncias da causa. $\mathrm{O}$ art. $7^{\circ}$ da Lei $\mathrm{n}$. 4.717/65, que cuida especificamente da ação popular, permite a prorrogação do prazo de contestação de 20 (vinte) dias por mais 20 (vinte) dias, atendendo à dificuldade que o réu possa vir a ter na elaboração de sua defesa. O art. 491 do CPC, tratante da ação rescisória, concede ao relator o poder de fixar, conforme as circunstâncias do caso, o prazo mínimo de 15 (quinze) dias e máximo de 30 (trinta) dias para que o demandado possa ofertar resposta. O art. 407 do CPC, com redação dada pela Lei n. 10.358/2001 - com nítido móvel de permitir a adequação do prazo para arrolar testemunhas com a capacidade material de a unidade judicial intimá-las tempestivamente - permite ao juiz fixar tal prazo em número de dias anteriores à audiência de instrução. E o art. 454 do CPC, ao cuidar da audiência de instrução e julgamento, deixa a critério do juiz a prorrogação do prazo dos debates realizados em 20 (vinte) minutos por mais 10 (dez) minutos (caput), bem como o estabelecimento do termo final para apresentação dos memoriais escritos substitutivo dos debates nas causas onde haja questões mais complexas $\left(\S 3^{\circ}\right)$.

Estas disposições flexibilizadoras do prazo são, entretanto, extremamente tímidas. As circunstâncias da causa recomendam, ainda que inexistente autorização legal, que os prazos sejam adaptados judicialmente conforme a complexidade da matéria de fato e de direito debatido (direito material), ou, ainda, conforme as particularidades pessoais da parte litigante.

A flexibilização judicial do prazo, além disso, potencializa o alcance dos princípios do contraditório e da ampla defesa. Ao se permitir que o magistrado manipule o prazo, o litigante pode obter tempo suficiente para levantamento das prova e preparação da defesa ideal. ${ }^{626}$

Imagine-se uma ação civil pública, em que se acuse determinada empresa de prática lesiva ao meio ambiente. A complexidade da defesa a ser apresentada - a depender da colheita de elementos técnicos, levantamento de documentos antigos ou localizados até,

\footnotetext{
${ }^{626}$ A idéia não é nova, e já foi sustentada de maneira eficiente por Leonardo Greco: "Ainda hoje entre nós o réu é chamado a se defender no prazo legal, sob pena de presumir verdadeiros os fatos contra ele alegados. A lei ignora se esse prazo é ou não suficiente para que o réu possa articular uma boa defesa. Também lhe é indiferente se no momento da citação o réu estava em condições favoráveis ou desfavoráveis para encetar buscas de provas, a escolha de advogado e tudo o mais que se faz necessário para poder influir eficazmente na decisão. O processo justo, que trata as partes com dignidade, confere ao juiz o poder de, sem prejuízo da sua celeridade, dosar os prazos de acordo com as necessidades defensivas da parte, que variam em função das circunstâncias do direito material". (O princípio do contraditório, cit., p. 75-76).
} 
quem sabe, em outro país - torna pífio o prazo de 15 (quinze) dias fixado abstratamente pelo legislador, comprometendo o modelo constitucional de processo desenhado pelo constituinte de 1988. Ou uma ação ajuizada em litisconsórcio por vários funcionários públicos. Não seria mais razoável do que a possibilidade de limitação do litisconsórcio multitudinário pelo sistema processual civil brasileiro (art. 46, parágrafo único, CPC), permitir-se ao juiz ampliar o prazo de reposta a fim de garantir ao pólo passivo adequada defesa? Certamente esta solução, além de permitir tratamento uniforme a todos os litisconsortes, acabaria com o grave inconveniente de se decidir se a limitação implica indeferimento parcial da inicial ou desmembramento de feitos, seja para a mesma ou para outra unidade judicial.

Assim, não há com se manter o ideário de peremptoriedade dos prazos processuais. Além das hipóteses de dilação já previstas no art. 182 do CPC, em toda e qualquer situação que o tempo fixado pelo legislador não for suficiente para a adequada prática do ato processual, deve o juiz ampliá-lo fundamentadamente, de modo a garantir que o instrumento se adapte ao seu objetivo. ${ }^{627}$

Aliás, a adoção do regime de flexibilização dos prazos, inclusive, torna inúteis regras que diferenciam os prazos conforme a natureza da partes (Fazenda Pública e Ministério Público). Sendo possível ao juiz adequar o tempo às particularidades da causa, não há sentido para previsão legal das prerrogativas de prazo dos artigos 188 e 191, ambos do CPC.

É lógico que não havendo particularidades na causa a justificar a dilatação dos prazos, devem ser seguidos os legalmente fixados no sistema (que devem servir, aliás, de limite mínimo para a atividade flexibilizadora do juiz), até por conta de um predicado básico de segurança e previsibilidade. $\mathrm{O}$ que não se concebe é que o prazo legal seja inalterável, como se todas as causas fossem iguais e os prazos rigidamente fixados, da mesma forma, suficientes para a adequada prática do ato processual.

Também é evidente que a dilatação do prazo deve se fundar nos critérios da razão e da proporcionalidade, inclusive sendo possível, à luz da imperiosa necessidade, a ampliação destes prazos após sua fixação, tudo sujeito ao controle da parte contrária e da instância superior, em caso de recurso.

\footnotetext{
${ }^{627}$ Embora no âmbito criminal, já há precedentes no sentido de que a complexidade do caso pode aumentar os prazos processuais (TJ/SC, HC 2007.016524-2, Rel. Des. Souza Varella, 1 a Câmara Criminal).
} 


\subsubsection{Flexibilização das rígidas regras sobre preclusão}

Como já dito, o andamento ordenado e coerente do processo é obtido não só através dos prazos, mas também das regras de preclusão. A falta do exercício do direito no momento oportuno (preclusão temporal), ou a prática do próprio ato processual aguardado (preclusão consumativa) ou de algum outro incompatível com aquele que se esperava ver praticado (preclusão lógica), acarreta a perda da faculdade processual, que, excetuadas as hipóteses raras do art. 183, $\S$, do CPC (justa causa), não mais pode ser exercitada.

Ocorre que especialmente em tema de preclusão temporal - que é mesmo a preclusão por excelência - a interpretação rígida do nosso sistema tem levado a situações comprometedoras da lógica e da razão, como se o processo fosse um jogo de cartas em que a não apresentação de uma delas no momento exato comprometesse toda a sorte do jogo.

Hoje, à luz da elasticidade e adaptabilidade do procedimento às circunstâncias da causa, é possível se construir um modelo de preclusão temporal mais flexível, ainda que compatível com a necessidade de assegurar ao processo um andamento expedito e isento de contradições e recuos, garantindo certeza das situações processuais (que é o objetivo maior do instituto). ${ }^{628}$ Em contraposição à idéia de garantia assegurada pela forma, tem-se que o procedimento demasiado ritualizado e com efeitos preclusivos tão rigorosos não permite o alcance da justiça material que se procura através do processo, contradizendo a própria função do Estado de realizá-la. ${ }^{629}$

A preclusão temporal pode ser encarada do ponto de vista extrínseco (ou acidental) ou intrínseco (ou natural). A preclusão extrínseca cuida do período de tempo dentro do qual o ato processual pode ser praticado. Já a preclusão intrínseca é a que deriva da análise da incompatibilidade do ato que se pretende praticar com o estágio atual em que o processo se encontra. A primeiro, portanto, diz respeito estritamente ao prazo. A segunda, estritamente à fase do processo. ${ }^{630}$

Pois o foco da preclusão temporal não deve estar mais na sua faceta extrínseca, isto é, no prazo para a prática do ato, mas sim no seu aspecto intrínseco, mais precisamente na fase em que o processo se encontra.

\footnotetext{
${ }^{628}$ LIEBMAN, Enrico Tullio. Manual de direito processual civil, cit., v. 1, p. 236.

${ }^{629}$ BRITO, Pedro Madeira de. O novo princípio da adequação formal, cit., p. 34.

${ }^{630}$ POLI, Roberto. Sulla sanabilitá della inosservanza di forme prescrite a pena de preclusione e decadenza. Rivista de diritto processuale, Padova, Cedam, n. 2, p. 450, abr./jun. 1996.
} 
Com efeito, ainda que não haja a estrita obediência do prazo legal ou judicial, deve se admitir a prática do ato processual sempre que o procedimento não tenha avançado adiante, isto é, mudado de fase. ${ }^{631}$

O princípio da instrumentalidade, que inspira e informa a inteira disciplina do exercício do direito de ação, reza que as formas (dos atos) do processo não são previstas e prescritas pela lei para a realização de um fim próprio e autônomo, mas sim são previstas como instrumento idôneo para o alcance de certo resultado, o qual representa o único verdadeiro objetivo que a norma disciplinadora da forma do ato interessa conseguir. ${ }^{632}$

À luz desta instrumentalidade, os prazos tendem, por isto, a satisfazer três exigências: a) a exigência de que no momento da efetiva decisão da causa as partes já tenham exposto ao juiz as suas razões de fato e de direito; b) a exigência de que seja respeitado o desenvolvimento do processo através das suas sucessivas fases processuais (postulatória, instrutória, decisória); e c) a exigência de que seja observado o contraditório, o direito de defesa, a imparcialidade do juiz, que certamente seria violada se findo o prazo a outra parte, surpreendendo o adversário, praticasse novo ato. ${ }^{633}$

Logo, se apesar da ofensa do prazo legal ou judicial, as exigências anteriores forem atendidas, não há motivo para se obstar a prática do ato processual ainda que intempestivo. Se a razão prevalente dos termos processuais é a de garantir certeza e ritmo (mais exatamente concentração) ao procedimento, e se ainda é possível a prática do ato processual sem violação das fases do desenvolvimento do processo ou do contraditório, dispensa-se a forma temporal dada pelo legislador a bem da adequada tutela das partes e do direito material, afastando-se a aparente preclusão extrínseca havida. ${ }^{634}$

\footnotetext{
${ }^{631}$ Neste sentido Dinamarco aponta que não é "só o decurso do tempo que conta, todavia: para extinguir-se a faculdade ou poder processual, é preciso que tenha sido praticado um ato subseqüente, de modo que (máxime no sistema brasileiro de procedimento rígido), a prática do ato omitido significaria um retrocesso incompatível com o sistema" (Nota n. 148 ao Manual de direito processual Civil de Liebman, cit., p. 236).

${ }^{632}$ Por isto: a) as normas que cuidam de forma devem ser interpretadas privilegiando o aspecto funcional delas, em contrapartida ao aspecto meramente sancionatório; b) o respeito das prescrições formais é necessário somente no que indispensável para o alcance do escopo do ato jurídico processual; e c) a eventual inobservância da prescrição formal resta irrelevante se o ato visado alcançou igualmente o escopo para o qual destinado (MANDRIOLI, Crisanto. Corso di diritto processuale civile. Torino: Giappichelli, 1993. v. 1, p. 366 e ss.).

${ }^{633}$ POLI, Roberto. Sulla sanabilitá della inosservanza di forme prescrite a pena de preclusione e decadenza, cit., p. 459.

${ }^{634}$ POLI, Roberto. Sulla sanabilitá della inosservanza di forme prescrite a pena de preclusione e decadenza, cit., p. 478. Ainda que não seja possível a prática do ato processual por conta da mudança da fase do processo - o que implicaria manifesto prejuízo ao seu andamento - Roberto Poli aduz que, se por alguma razão, o procedimento teve um curso anormal, isto é, não atendeu às prescrições legais, eventual retomada da demanda pelo seu rito normal permite a prática do ato, mesmo que tenha o interessado se omitido na primeira oportunidade (Sulla sanabilitá della inosservanza di forme prescrite a pena de preclusione e decadenza, cit., p. 470).
} 
Assim: a) pese fixado o prazo de 10 (dez) dias para que testemunhas sejam arroladas (art. 407 do CPC), nada impede que elas sejam ouvidas em audiência se a parte as traz espontaneamente ao ato, oportunizando, por óbvio, ao ex adverso, o pedido de redesignação para investigação dos vínculos de impedimento e de suspeição; b) não indicadas ou trazidas testemunhas para ouvida em audiência, possível requerimento para realização de repetição do ato em outra oportunidade, desde que a instrução ainda não tenha sido encerrada; c) concedido o prazo de 10 (dez) dias para oitiva do autor a respeito da contestação ofertada (artigos 326 CPC), nada impede que a manifestação seja recebida a destempo, enquanto o magistrado não tenha passado à fase posterior (julgamento do processo ou designação de audiência); d) não ofertados os documentos na inicial ou na contestação (art. 396 do CPC), perfeitamente possível que sejam apresentados até o julgamento da causa em $1^{\circ}$ ou $2^{\circ}$ grau de jurisdição; e) não apresentado assistente ou quesitos para perícia (art. $420, \S 1^{\circ}$, do CPC), nada impede que isto seja feito até a sua realização, ou até mesmo quando da apresentação de quesitos suplementares pela parte contrária; e assim por diante. ${ }^{635}$

Sem dúvida a preclusão temporal é essencial para o desenvolvimento do procedimento. O que não se pode admitir é que o procedimento seja escravizado pelo tempo, a ponto de não permitir, quando não haja prejuízo ao seu desenvolvimento lógico e global, a prática de ato processual fora do prazo abstratamente fixado.

\subsection{Flexibilidade procedimental voluntária}

Não me parece que o extremismo de parte da doutrina pátria na manifestação pela cogência das regras procedimentais seja compatível com o ideário instrumentalista e com os escopos do processo, tampouco com o princípio da liberdade que é base de nosso sistema constitucional.

\footnotetext{
${ }^{635} \mathrm{~A}$ interpretação proposta - que para alguns há de por em risco a celeridade e a logicidade do procedimento - pode até ser adjetivada de tímida se comparada com a adotada em outros países. No sistema japonês, por exemplo, não há um prazo final para a apresentação de alegações: as partes podem apresentá-las sempre, ainda que o processo já esteja em sua fase instrutória ou decisória. Ao contrário do que parece, isto não gera tantos problemas (TANIGUCHI, Yasuhei. O código de processo civil japonês de 1996: um processo para o próximo século?, cit., p. 50-73). Na Civil Procedures Rules inglesa, a Rule n. 3.1.2 é ainda mais incidente, permitindo a prática de atos processuais cujo prazo já estava vencido, por exemplo, aceitando, mediante justificação adequada e a luz de ponderação sobre os prejuízos hipotéticos com a não submissão da decisão ao $2^{\circ}$ grau, a apresentação de recurso fora de prazo. Já no sistema português (art. 712 do CPC), expressamente se concede ao Tribunal o poder de ordenar produção de provas a bem da melhor tutela do caso em concreto.
} 
Se por um lado, como regra, as normas processuais no todo (incluídas as procedimentais) são de ordem pública e, como tal, de observância obrigatória por todos os atores processuais - com o que não discordamos em princípio - por outro, inúmeras situações ligadas ao direito material, à realidade das partes, ou simplesmente à inexistência de prejuízo, devem permitir a eleição do procedimento, inclusive pelas próprias partes. ${ }^{636}$

No presente item, abordaremos algumas situações reais em que a parte eleger o procedimento ou o ato processual da série que seja mais adequado à tutela do seu direito. ${ }^{637}$

Como já apontamos anteriormente, o magistrado pode até advertir o litigante, com base no princípio da cooperação, a respeito das conseqüências deletérias da opção eleita. Mas sendo a variante facultativa, compete-lhe aceitar a opção e tocar o procedimento conforme a opção estratégica da parte. Afinal, o ativismo do juiz exibe-se perfeitamente conciliável com o ativismo das partes conscientes e cooperadoras. ${ }^{638}$

\subsubsection{Flexibilizando a cogência em favor da eleição do procedimento pela parte}

A impossibilidade de a parte eleger o procedimento conforme sua preferência nem sempre foi vigente no nosso sistema.

\footnotetext{
${ }^{636}$ Como já ocorre com as regras a respeito da distribuição do ônus da prova (art. 333, parágrafo único, do CPC), suspensão do processo (art. 265, II, do CPC), prorrogação tácita (art. 114 do CPC) e voluntária de competência, (art. 111 do CPC); eleição do litisconsórcio faculativo (art. 46 do CPC); eleição do foro (art. 111 do CPC), e celebração de compromisso arbitral (art. 267, VII), que apesar de serem normas processuais, não são cogentes.

${ }^{637}$ Afinal, "a natureza de direito público da norma processual não importa dizer que ela será necessariamente cogente. Embora inexista processo convencional, mesmo assim em certas situações admite-se que a aplicação da norma processual fique na dependência da vontade das partes - o que acontece em vista dos interesses particulares dos litigantes, que no processo se manifestam. Têm-se, no caso, as normas processuais dispositivas" (CINTRA, Antonio Carlos; GRINOVER, Ada Pellegrini; DINAMARCO, Cândido Rangel. Teoria geral do processo, cit., p. 92).

${ }^{638}$ Bem anota Moniz de Aragão que, embora a lei consagre diversos procedimentos à disposição dos interessados, ela predetermina a sua escolha, não deixando ao alvedrio das partes e dos juízes optar pelo que pareça mais adequado aos peculiares interesses em jogo. Pese a tipicidade dos procedimentos, sugestiona o professor paranaense que "é necessário conceber os ritos processuais não somente em função do problema material a equacionar e resolver, mas também - e principalmente - em função de como alcançar esse objetivo com maior celeridade e eficiência, isto é, com o maior grau de presteza e certeza que for possível. Para tanto, é necessário privilegiar o processo, aumentar sua participação como ingrediente na fórmula de composição dos procedimentos, obviamente sem deixar de considerar com a indispensável ponderação a relação substancial; é necessário, portanto, racionalizar os ritos processuais; é necessário, outrossim, que a lei consinta ao juiz e às partes mais liberdade do que até hoje lhes conferiu" (ARAGÃO, E. D. Moniz de. Procedimento: formalismo e burocracia, cit., p. 56-57).
} 
$\mathrm{O}$ art. 245 do Regulamento 737 permitira o acordo das partes para adoção do rito sumaríssimo, ainda que esse não fosse legalmente previsto para a espécie. Disposições similares eram contidas no Código de Minas Gerais (art. 390) e do Estado do Rio de Janeiro (art. 1.347). À época sustentava-se, inclusive, com apoio no princípio da liberdade de contratar, a possibilidade da convenção a respeito, mesmo sem texto legal permisisivo. ${ }^{639}$

Foi com o Código de Processo Civil de 1939, e posteriormente de 1973, que se acabou de vez com as regras que facultavam a eleição do procedimento pela parte. Conforme já vimos anteriormente (item 3.3. supra), o procedimento, no direito processual eminentemente publicístico como o atual, atende, sobretudo, a interesses público, não tendo sido instituído, como regra, para favorecer ou para beneficiar as partes, tampouco para contemplar a comodidade de alguma delas. Assim, a definição do procedimento é estatal, sendo vedado às partes elegê-lo.

Mais modernamente, todavia, se tem encontrado na doutrina, e também na jurisprudência nacional, impressão diversa.

Tem se sustentando que a parte pode, salvo em situações excepcionais decorrentes da incompatibilidade lógica entre a pretensão formulada e o procedimento comum (como ocorre no procedimento especial do inventário ou na divisão e demarcação de terras), optar pelo rito ordinário em detrimento do especial ${ }^{640}$

Não resta mais dúvida, também, que a utilização do rito sumaríssimo perante os juizados especiais é facultativa para o autor ${ }^{641}$, ou que é livre pelo demandante a eleição do

\footnotetext{
${ }^{639}$ PASSOS, J.J. Calmon de. Comentários ao Código de Processo Civil, cit., v. 3, p. 31.

${ }^{640}$ GAJARDONI, Fernando da Fonseca. Breve introdução aos procedimentos especiais de jurisdição contenciosa, cit., cit., p. 21; PAULA, Jônatas Luiz Moreira de. Comentários ao Código de Processo Civil. Barueri: Manole, 2003. v. 2, p. 181. Na verdade, pode se cogitar que as formas procedimentais são, em princípio, todas típicas. Não se pode deixar de ressalvar, entretanto, que apesar da tipicidade das formas, há procedimentos processuais fungíveis, isto é, aqueles que podem ser substituídos regularmente pelo rito ordinário (nos termos do art. 292, § $2^{\circ}$, do CPC), e há também os procedimentos processuais infungíveis, mais precisamente aqueles não se pode substituir (como o inventário).

${ }^{641}$ Este é enunciado n. 01 do Fórum Nacional de Coordenadores de Juizados Especiais do Brasil (XX FONAJE - São Paulo - nov. 2006): o exercício do direito de ação nos Juizados Especial Cível é facultativo para o autor. E também a posição do Superior Tribunal de Justiça a respeito do tema (REsp n. 146.189/RJ, Ministro Relator Barros Monteiro, DJ de 29.06.1998).
} 
procedimento comum ou do procedimento especial monitório para a cobrança de dívidas fundadas em documento escrito sem eficácia de título executivo (art. 1.102a do CPC). ${ }^{642}$

E embora ainda haja vozes em sentido contrário $^{643}$, mais modernamente também se tem entendido que a opção daqueles que fazem jus ao rito sumário pelo ordinário não compromete a higidez procedimental, razão pela qual lícito o ajuizamento da demanda pelo procedimento mais completo (não o contrário).

Com efeito, "o procedimento ordinário é mais completo e o mais apto à perfeita realização do processo de conhecimento, pela amplitude com que permite às partes e ao juiz pesquisar a verdade real e encontrar a justa composição da lide. Está estruturado segundo fases lógicas, que tornam efetivos os princípios fundamentais do procedimento, como o da iniciativa da parte, o do contraditório e do livre convencimento do julgador". ${ }^{644}$

Daí porque sempre a utilização do rito ordinário é opção da parte que faça jus ao procedimento sumário ou especial ${ }^{645}$, salvo raríssimas exceções já apontadas, ligadas ao direito material em litígio, para as quais haja procedimento especial próprio, que não utilizado compromete a própria tutela do direito.

Alguns julgados das 3as e 4as Turmas do Superior Tribunal de Justiça têm endossado a tese mais moderna, no sentido de que a "liberdade que tem o autor de preferir

\footnotetext{
${ }^{642} \mathrm{O}$ Superior Tribunal de Justiça, diante da natureza cognitiva da monitória e em vista de sua finalidade de agilizar a prestação jurisdicional, concluiu que é cabível o procedimento monitório sempre que o credor possuir documento que comprove o débito, mas que não tenha força de título executivo, ainda que lhe seja possível o ajuizamento da ação pelo rito ordinário ou sumário, cujo cabimento não foi afastado pelo advento do novel procedimento (REsp. n 208.870/SP, Relator Ministro Sálvio de Figueiredo Teixeira, DJ de 28/6/99).

${ }^{643}$ PASSOS, J.J. Calmon de. Comentários ao Código de Processo Civil, cit., v. 3, p. 263-264; YARSHELL, Flávio Luiz. Tutela jurisdicional, cit. p. 182. Para ampla análise da controvérsia sobre a obrigatoriedade do rito sumário: CARNEIRO, Athos Gusmão. Do rito sumário na reforma do CPC, cit., p. 15-16; e ASSIS, Araken de. Procedimento sumário, cit., p. 37-39.

${ }^{644}$ THEODORO JÚNIOR, Humberto. Curso de direito processual civil, cit., v. 2, p. 366. No mesmo sentido o Tribunal de Justiça do Estado de São Paulo tem entendimento consolidado de que não se fala "em nulidade processual ou inadequação de rito, quando embora previsto o rito sumário para o procedimento, o autor opta por requerer a adoção do rito ordinário, mais amplo por natureza, cujo prejuízo de demora de tramite somente a ele poderia interessar, posto que não acarreta limitação ou o cerceamento de defesa, máxime inexistindo qualquer prejuízo ao demandado" (Agravo de Instrumento n. 896.543-0/6 - Americana - 25 Câmara de Direito Privado - Relator: Amorim Cantuária - 28.06.05 - v.u.).

${ }^{645}$ Rui Portanova, após ressaltar que o princípio da preferibilidade pelo rito ordinário possibilita, na maioria das vezes, sua utilização em substituição aos demais ritos, aponta que o interesse público que é protegido pela forma, e não o direito material como lançamos no texto, é o fator determinante das situações em que isto não seja possível. Não encontramos diferença, até por crer que o interesse público protegido pela forma é a adequada tutela do direito material. De qualquer forma, bem vai o autor gaúcho quando anota ser "o caso concreto que dirá quando o interesse público inviabilizará a troca procedimental, razão pela qual não sendo ele atingido, plenamente possível a opção" (Princípios do processo civil, cit., p. 179 e 181).
} 
o procedimento ordinário ao sumário, ou ao especial, não implica em (sic) infração à norma, pois o primeiro é o leito comum e amplo por onde podem correr quaisquer causas". 646

Até porque seria ilógico, convenhamos, admitir que a parte possa preferir o rito sumaríssimo da Lei n. 9.099/95 ao ordinário (como já anotado), e não possa fazê-lo em relação ao procedimento sumário, que é ritualmente mais amplo que o procedimento especial dos Juizados Especiais.

O importante a observar, portanto, é que há sim no nosso sistema certo espaço para a opção ritual, ao menos entre os procedimentos comuns e a maior parte dos especiais (como o sumaríssimo e a monitória). E que, conseqüentemente, eles não foram construídos tão só em favor do interesse público, mas também no interesse das próprias partes litigantes, já que, grosso modo, todos os procedimentos (comuns ou especiais) têm o mesmo fim: ordenar os atos processuais a fim de levar a pretensão verberada no pedido inicial até a resposta final do órgão julgador.

Ora, se até mesmo a relação jurídica processual estatal pode ser objeto de renúncia pelas partes através da celebração de convenção de arbitragem (Lei n. 9.307/96), não se vê como o procedimento processual não possa ser objeto de opção pelo autor, desde que, obviamente, isto não implique prejuízo efetivo para o réu (como ocorre na questão da troca do ordinário pelo sumário). ${ }^{647}$

Lícito, portanto, que a parte autora eleja o procedimento que lhe pareça mais adequado, ainda que haja no sistema indicação de um outro iter a ser seguido, devendo o órgão julgador, desde que a forma seja apta a tutelar o direito e não haja prejuízo efetivo à parte adversa, respeitar esta escolha. ${ }^{648}$

\footnotetext{
${ }^{646}$ REsp n. 198.280/RJ, Rel. Ministro Barros Monteiro, DJ 30.10.2000; REsp n. 262.669/CE, Rel. Ministro Sálvio de Figueiredo Teixeira, DJ 16.10.2000; REsp n. 118.365/RS, Rel. Ministro Ruy Rosado de Aguiar, DJ 08.09.1997; REsp. n. 62.318/SP, Rel. Min. Waldemar Zveiter, DJ 06.11.95; e REsp n. 63.152/RJ, Rel. Min. Nilson Naves, j. 11.09.1995. Também devem ser destacados antigos precedentes do STJ, no sentido de que não há nulidade pela conversão ou adoção do procedimento ordinário em causa que deveria ter curso pelo rito sumário: Resp. n. 13.573-SP, 11.200-SP, 5.604-MG, 5.100, 3166 e 19789-RS.

${ }^{647}$ STJ, REsp. n. 737.260/MG, Relatora Ministra Fátima Nancy Andrighi, j. 21.07.2005.

${ }^{648}$ Embora não se trate especificamente de eleição de procedimentos - mas sim eleição de processo - vale o lembrete de que mais recentemente se tem admitido, como já vimos, o manejo da ação de conhecimento no lugar da ação de execução fundada em título executivo extrajudicial, isto a fim de conferir ao credor a possibilidade de que, sobre o título de crédito negocial, obtenha a autoridade da res iudicata. Cf THEODORO JÚNIOR, Humberto. Opção do credor entre a ação executiva e a ação ordinária de cobrança, cit., p. 89-92; PASSOS, J.J. Calmon de. Comentários ao Código de Processo Civil, cit., v. 3, p. 265.
} 
Por força disto, o art. 295, IV, do Código de Processo Civil, que determina a adaptação do rito pelo órgão julgador, é norma que só deve ser utilizada excepcionalmente e exclusivamente nas hipóteses em que não seja possível, por questões ligadas à situação da parte ou ao direito material, o processamento da demanda pelo rito eleito. ${ }^{649}$

Podemos, então, sintetizar as opções procedimentais da parte enunciando as seguintes regras:

1. O procedimento ordinário sempre é cabível, salvo se circunstâncias ligadas ao direito material ou à qualidade da parte impuserem o rito especial;

2. O procedimento sumário nunca é obrigatório;

3. O procedimento sumaríssimo dos Juizados Especiais nunca é obrigatório;

4. O procedimento especial, excetuados os casos em que o rito seja indispensável para a própria tutela da parte ou do direito, sempre pode ser renunciado em favor do rito comum (ordinário ou sumário);

5. O procedimento especial, ainda que não seja abstratamente previsto para determinado caso, pode ser utilizado se a sua formatação for mais adequada para a tutela do direito material. ${ }^{650}$

Mesmo fora destas opções, mesmo nos casos de opções procedimentais pacificamente indevidas - como a utilização do rito sumário no lugar do ordinário para causas não previstas no art. 275, do Código de Processo Civil, o processamento de uma demanda não prevista na Lei n. 9.099/95 ou 10.259/2001 pelo seu rito sumaríssimo ${ }^{651}$, ou o não processamento da demanda por um daqueles ritos especiais obrigatórios - não haverá

\footnotetext{
${ }^{649}$ Aliás, o citado art. 295, V, do Código de Processo Civil dá a entender que os procedimentos previstos no sistema são mesmo elegíveis pelo autor. Não fosse assim, o dispositivo não falaria em indeferimento da petição inicial quando o tipo de procedimento escolhido não correspondesse à natureza da causa. Usaria outro verbo e permitiria, expressamente, que o juiz oficiosamente efetuasse a adequação, sem necessidade de ordenação de emenda.

${ }^{650}$ Como já vem ocorrendo, aliás, para os casos de reconhecimento e dissolução de sociedade de fato em que se usa o procedimento da separação judicial (Lei n. 6.515/77).

${ }^{651}$ Pese a referência legislativa expressa de que o processo será extinto sem julgamento do mérito quando inadmissível o procedimento sumaríssimo (art. 51, II, da Lei n. 9.099/95), estamos entre aqueles que acredita na possibilidade dos autos serem remetidos à Justiça comum, desde que a parte esteja assistida por advogado ou se disponha a constituí-lo de imediato.
} 
automática nulidade do processado. Nestas situações, conforme sempre foi voz corrente na doutrina e jurisprudência nacionais, há de se indagar sobre a existência de prejuízo, conforme regime próprio do tema, sem o que não se decretará nulidade (artigos 244 e 250 do Código de Processo Civil). ${ }^{652}$

Concluindo, apesar de se afirmar que as normas procedimentais são cogentes, nosso sistema, vagarosamente, foi construindo tantas hipóteses de opção ritual que a regra se relativizou, tornando-se quase uma exceção. Por isto, já se pode analisar o procedimento sob uma outra ótica, e afirmar que ele é adaptável também conforme a vontade da parte, mantendo no campo das exceções apenas àquelas poucas hipóteses em que determinado rito é indispensável para a tutela do direito material ou da parte, ou nas situações em que a utilização do rito mais abreviado cause prejuízo efetivo ao direito do prejudicado pela adoção do procedimento menor. ${ }^{653}$

\subsubsection{Prorrogação convencional de prazos}

Como já estudamos no item 5.4.6. supra, são prazos dilatórios aqueles que as partes, de comum acordo, podem reduzir ou prorrogar (art. 181 do CPC), e são peremptórios os que não é lícito, nem às partes, nem ao juiz, alterar. (art. 182 do CPC).

Raros são, entretanto, os prazos convencionais no sistema, e mais raros ainda os casos de prazos desta natureza em que não há ingerência do juiz sobre a convenção. $\mathrm{O}$ art. 265, II, do CPC, que autoriza a suspensão convencional do processo cognitivo, sem controle judicial, por até 06 meses, e o art. 791, II, do CPC, que autoriza a mesma providência no âmbito da execução (sem limite temporal), sãs os únicos exemplos lembrados.

Mas nem sempre foi assim. No regime revogado do CPC/1939, apesar de já haver a diferenciação entre prazos dilatórios e peremptórios, o art. 35 expressamente

\footnotetext{
${ }^{652}$ Portanto, a suposição de que a adoção do rito mais abreviado causa prejuízo à defesa não acarreta a automática anulação do processado, devendo haver efetiva comprovação do prejuízo sofrido pela adoção do rito inadequado (RT 745/372), especialmente porque a simples variação ritual não impõe imediata restrição no âmbito da cognição (YARSHELL, Flávio Luiz. Tutela jurisdicional, cit. p. 181).

${ }^{653}$ Por esta razão, conforme aponta Bedaque, "não é convincente a tese da relação necessária entre procedimento e interesse público, o que determinaria a observância rigorosa do rito, sob pena de nulidade do processo" (BEDAQUE, José Roberto dos Santos. Efetividade do processo e técnica processual: tentativa de compatibilização, cit., p. 63).
} 
permitia ao juiz abreviar ou prorrogar quaisquer destes prazos mediante requerimento de uma das partes e assentimento das demais (inclusive do Ministério Público), desde que ele ainda não houvesse se esgotado. Incólumes a esta regra só restavam os prazos para recursos. ${ }^{654}$

Em Portugal, a moderna legislação processual de 1995 assegura aos litigantes a possibilidade de prorrogação consensual de qualquer prazo (inclusive de recursos), desde que a ampliação não faça exceder o dobro do prazo legalmente previsto (art. 147), tudo sem prejuízo da já analisada flexibilizante judicial do prazo para apresentação de contestação (art. 486).

O sistema processual brasileiro vigente, à exceção das duas hipóteses acima lembradas, não dá espaço para que as partes possam negociar o prazo para a prática do ato processual. Ainda que estejam completamente de acordo com a operação, o prazo deve ser ater ao regime legal, no máximo ao regime judicial de dilação do prazo analisado no item 5.4.6. supra.

Seria interessante, de lege ferenda, ampliar a possibilidade das partes celebrarem negócio jurídico processual ${ }^{655}$ quanto ao prazo processual. Se aos litigantes interessa, precipuamente, a resolução do conflito, parece-me que devem ter eles autonomia, também, para consensualmente estabelecer o curso do procedimento ou de parcela dele, nos moldes do que já ocorre em sede arbitral (art. 21 da Lei de Arbitragem). ${ }^{656}$

\footnotetext{
${ }^{654}$ MIRANDA, Francisco Cavalcanti Pontes de. Comentários ao Código de Processo Civil (1939), cit., t. 1, p. 334.

${ }^{655}$ Certamente pelo ideário rígido do nosso procedimento, a doutrina nacional parece não se interessar muito pelos negócios jurídicos processuais (MOREIRA, José Carlos Barbosa. Convenção das partes sobre matéria processual. In: ___. Temas de direito processual: $3^{\mathrm{a}}$ série. São Paulo: Saraiva, 1984). Há forte tendência em negar-lhes a existência, sob o fundamento de que a vontade dos sujeitos processuais não determina os efeitos dos atos processuais que praticam, não havendo, por isto, discricionariedade para que elas possam convencionar a respeito (ROCHA, José Albuquerque. Teoria geral do processo. 3. ed. São Paulo: Malheiros Ed., 1996. p. 253 e ss.). Mesmo os que aceitam tal figura, aduzem que não se pode emprestar à vontade da parte no processo civil a mesma importância que tem no direito privado, eis que no processo "há sempre um elemento especial a considerar, e é a presença do órgão do Estado sobre a atividade do qual, se bem que estranho ao negócio, pode ele exercer influência mais ou menos direta" (CHIOVENDA, Giuseppe. Instituições de direito processual civil, cit., v. 3, p. 25-26).

${ }^{656} \mathrm{Não}$ é isto que pensa José Maria Espinosa. De acordo com o autor, se às partes for dado definir a forma a adotar em cada caso, inclusive os prazos, está aberto caminho para intermináveis dilações e desfigurações que põem em causa a realização do próprio interesse das partes no processo (MARTIN DE LA LEONA ESPINOSA, José Maria. La nulidad de actuaciones en proceso civil, cit., p. 83). O autor só se olvida que é possível que as partes convencionem a respeito (condição para que o prazo seja distinto do constante da regra legal), o que certamente afasta o risco de dilações e desfigurações, eis que são elas as maiores interessadas na adequada solução do conflito.
} 


\subsubsection{Eleição do ato processual na série}

A flexibilidade procedimental voluntária também pode ocorrer por conta de disposição legal normativa a permitir que a parte pratique, alternativamente, um ou outro ato processual na série, nos moldes do que acontece no modelo de flexibilização procedimental judicial alternativa (item 5.3).

De fato, há algumas disposições no CPC/73 valorizam a escolha da parte, entendendo que em muitas situações deve competir a ela, que tem como regra a disponibilidade do direito em debate, a opção pelo melhor tramitar do procedimento.

Assim, no âmbito recursal, o art. 523, $\S 3^{\circ}$, do CPC (com redação pela Lei n. 11.187/2005), permite que a parte opte pelo agravo retido na forma oral ou escrita, excetuados os interpostos contra decisões proferidas em audiência de instrução, quando, então, serão obrigatoriamente orais.

Em sede de execução, compete ao exeqüente eleger alternativamente entre a adjudicação do bem, a alienação por iniciativa particular, a alienação em hasta pública, ou o usufruto do bem móvel ou imóvel (art. 647 do CPC, com redação dada pela Lei n. 11.382/2006). Será com base na eleição do meio expropriativo pelo credor que o procedimento executivo seguirá seu trâmite.

Também no âmbito das obrigações de fazer, não fazer e entrega, competirá ao credor, frustrada a obrigação, optar pela conversão dela em perdas e danos (art. 461, § $1^{\circ}$, do CPC) ou pela execução específica da obrigação (art. 461, caput, do CPC). Conforme a medida eleita que o procedimento seguirá, no primeiro caso, pela via da liquidação de sentença, no outro, pela fixação de multa e de medidas de apoio a bem do adimplemento específico. 


\section{CONCLUSÕES}

É chegado o momento de concluir:

1. O modelo federalista brasileiro - se é que podemos, tecnicamente, dizer que há uma Federação brasileira - é marcadamente centralizador, com manifesta e absoluta concentração de poderes, rendas e competências legislativas no âmbito da União.

2. No âmbito da competência concorrente (repartição vertical de competências), o art. 24 da Constituição Federal estabelece que a União limitar-se-á à edição de normas gerais, prerrogativa esta que não exclui a competência complementar dos Estados e do Distrito Federal no estabelecimento também destas normas gerais. E mesmo que haja normas gerais sobre o assunto editadas pelo Poder Central, compete ao Estado e ao Distrito Federal a edição de normas específicas, detalhadas, minuciosas (competência suplementar), hábeis a particularizar e adaptar a matéria de sua competência à realidade regional.

3. As normas gerais referidas no art. $24, \S 1^{\circ}$, da Constituição Federal são leis de caráter e abrangência nacional, de natureza mais genérica e abstrata do que as normas locais; são disposições que determinam parâmetros mínimos, com maior nível de generalidade e abstração que as leis editadas fora dos limites da competência concorrente; são disposições já predispostas a serem desenvolvidas e complementadas pela ação normativa subseqüente dos demais entes federados (Estados e Distrito Federal), que se contenham no mínimo indispensável ao cumprimento dos preceitos fundamentais, abrindo espaço para que o legislador possa abordar aspectos diferentes, diversificados, sem desrespeito a seus comandos genéricos, básicos. Não são normas gerais, por isto, as que se ocupem de detalhamentos, que minudenciem condições específicas, que esgotem por completo o assunto, de modo que nada deixam à criação própria do legislador a quem se destinam (o legislador estadual ou distrital), exaurindo, assim, o assunto de que tratam.

4. À União compete legislar privativamente sobre processo (art. 22, I, da CF). São normas processuais - e, portanto, de competência privativa da União - todas aquelas relacionados à gênese da relação jurídica processual, como jurisdição, competência, ação, 
defesa e contraditório, entre as quais se inclui a definição da capacidade e legitimação das partes, a disciplina da prova, dos efeitos da sentença e da coisa julgada.

5. À União compete editar normas gerais em matéria de procedimento processual, e aos Estados e Distrito Federal compete editar as normas não gerais sobre este assunto (art. 24, XI, da CF). Normas procedimentais são as que definem o modo e prazo de manifestação dos atos processuais das partes, dos magistrados ou da secretaria (normas acidentalmente procedimentais), bem como o lugar que cada ato tem no conjunto do procedimento, ou seja, a ordenação formal dos atos (normas puramente procedimentais).

6. A edição pela União de normas não gerais em matéria de procedimento é inconstitucional por violação ao art. 24, XI e $\S \S$ da Constituição Federal e ao pacto federativo, tanto quanto o é a edição de normas gerais de procedimento pelos Estados e Distrito Federal na existência de normas desta natureza editadas pela União.

7. O Código de Processo Civil de 1973, apesar de conter inúmeras normas não gerais de procedimento, foi recepcionado pela Carta Constitucional de 1988, já que no regime pretérito (1967/1969) a competência para legislar sobre processo e procedimento era da União. Até que os Estados e o Distrito Federal tomem coragem para editar suas normas procedimentais específicas, valem as regras desta natureza do CPC/73.

8. Todas as normas procedimentais editadas pela União após 1988 que ultrapassam os limites da generalidade, excedendo a disciplina dos sujeitos, objeto ou forma mínima do rito, ou disciplinando por inteiro a maneira de ser praticado o ato processual - inclusive as incorporadas ao CPC por conta das tantas reformas legislativas operadas desde 1992 - não são gerais, e, como tais, inconstitucionais (art. 172, 176, 527 , II, todos do CPC).

9. Juizados especiais e juizados de pequenas causas são expressões utilizadas com equivalência na Constituição Federal, de modo que em sede de juizados especiais a competência para legislar sobre processo é concorrente entre União, Estados e Distrito Federal (art. 24, X, da CF), o que acarreta a inconstitucionalidade de uma série de dispositivos não gerais das Leis ns. 9.099/95 e 10.259/2001. O STF, todavia, entende de modo diverso. 
10. O CPC/1973 representou verdadeira evolução terminológica e conceitual no uso dos termos processo e procedimento, que até então eram empregados sem rigor técnico, muitas vezes como sinônimos. Pela legislação atual os processos são de conhecimento, execução e cautelar, cada qual como variados procedimentos préestabelecidos.

11. Quanto ao procedimento, conhecem-se dois modelos: a) sistema da legalidade das formas (onde todas as etapas do procedimento são fixadas em lei); e b) sistema da liberdade das formas (em que compete ao juiz e/ou às partes determinar o curso do procedimento). Nosso sistema se filiou quase que integralmente ao primeiro modelo, sendo vedado ao juiz ou às partes, a não ser que haja permissivo legal, variar o procedimento (elegendo, alterando, adequando ou mesclando-o).

12. As regras de forma devem ser moldadas judicialmente quando sua utilização torna estéril e dissipa os fins do processo. Não têm elas um fim próprio.

13. A Segurança e a previsibilidade do sistema são garantidas pelo conhecimento prévio das regras do jogo, e não pela rigidez do procedimento, eis que a flexibilização pode se dar com plena participação e ciência das partes, ainda que as regras não sejam cogentes e tampouco pré-estabelecidas.

14. São requisitos para que se opere a flexibilização judicial do procedimento: a) a finalidade (proteção ao direito material, à parte hipossuficiente ou à própria utilidade do procedimento); b) o contraditório prévio (desde que útil); e c) motivação. Fora destas circunstâncias o procedimento segue o regime legal padrão.

15. A flexibilização não é incompatível com o fator legitimante do procedimento, pelo contrário, até aumenta o poder de conformação das partes com a decisão proferida, eis que além delas participarem da formação da decisão via contraditório, também participam da formação dos meios que levaram à decisão.

16. O procedimento flexibilizado não viola a cláusula do devido processo legal, eis que se conservarão na operação todas as garantias constitucionais do processo, especialmente o contraditório. Aliás, o devido processo legal previsto na Carta Constitucional é potencializado com a adequação do procedimento às circunstâncias da causa (art. $5^{\circ}, \mathrm{LIV}$, da CF). 
17. Os modelos procedimentais estrangeiros não podem e não devem ser supervalorizados, tampouco simplesmente transplantados para o ordenamento jurídico interno sem uma série de aferições. Apesar disto, servem sim de parâmetro para aperfeiçoamento do sistema nacional.

18. A distinção dantes tão expressiva entre os sistemas da common law e da civil law acabou, com o passar dos anos, sendo atenuada pela influência recíproca das boas iniciativas adotadas em cada qual dos sistemas. Ora países adeptos do padrão continental implementaram medidas típicas do processo da common law, ora os sistemas anglosaxônicos se curvaram ao direito escrito, de modo que não mais se conservam, de maneira geral, modelos puros, resistentes à saudável influência recíproca dos outros sistemas. Daí porque já se reconhece certo ativismo ao juiz dos ordenamentos filiados ao sistema adversarial, enquanto que se introduzem nos ordenamentos inquisitoriais, ainda que no plano normativo, maior poder das partes no controle dos procedimentos.

19. Na Inglaterra, onde desde 1999 há um diploma semelhante a um Código de Processo Civil (CPR), o juiz tem liberdade na direção do procedimento: ele pode abreviar o procedimento julgando-o in limine, pode recombinar os atos processuais para a tutela das causas menores, pode prorrogar ou abreviar boa parte dos prazos legais, futuros ou já superados. Há, portanto, verdadeira atividade gerencial no âmbito do rito.

20. O modelo de gerenciamento de casos das cortes federais norte-americanas se inspira em duas premissas: a) busca da solução do conflito por via dos meios alternativos de resolução das controvérsias (ADR); e b) flexibilização judicial do procedimento permitindo ao juiz que, junto às partes, previamente estipule as etapas do desenvolvimento do feito, incluindo prazos e tarefas.

21. O sistema processual civil português conta com um princípio da adequação formal positivado (art. 265-A do CPC), que concede genericamente ao juiz, como ocorre no nosso poder geral de cautela do art. 798 do CPC, a possibilidade de adequar qualquer procedimento aos fins do processo. Continental como o nosso, possível que este sistema sirva de fonte inspiradora para que os intérpretes e legisladores pátrios se esforcem para uma releitura das regras procedimentais.

22. Dois princípios implícitos informam todo o sistema brasileiro de flexibilização do procedimento: o da adequação e da adaptabilidade. Fala-se em princípio 
da adequação para designar a imposição sistemática dirigida ao legislador federal e estadual para que construa modelos procedimentais aptos para a tutela especial de certas partes ou do direito material; e princípio da adaptabilidade (ou da elasticidade processual) - que é subsidiário ao primeiro - para designar a atividade do juiz de flexibilizar o procedimento legal inadequado ou de reduzida utilidade para melhor atendimento das peculiaridades da causa.

23. Quatro são os modelos de flexibilidade procedimental: a) legal genérica; b) legal alternativa; c) judicial; e d) voluntária.

24. A flexibilidade procedimental legal genérica se dá através de disposição, sob a forma de uma cláusula geral, que permite ao juiz o encaminhamento de casos singulares, adaptando o procedimento à situação das partes ou do direto material debatido. O permissivo legal, diversamente o regime da flexibilização alternativa, não pré-determina os atos possíveis de serem praticados, deixando a cargo do magistrado, com a constante colaboração das partes, o controle quase que integral do procedimento. No sistema pátrio este modelo é encontrado no art. 153 do ECA, art. 1.109 do CPC, Art. 21 e $\S 1^{\circ}$ da Lei de Arbitragem, art. $6^{\circ}$ da Lei n. 9.099/95, e art. 461, $\S 5^{\circ}$, do CPC.

25. A flexibilidade procedimental legal alternativa é o modelo padrão do sistema processual civil brasileiro. Por ele a lei permite a flexibilização, mas pré-determina os atos processuais possíveis de serem adequados à situação concreta. Várias são as ocorrências deste modelo: art. 277, § $4^{\circ}$ e $5^{\circ}$; art. 285-A; art. 330; art. 331, § 3º $518, \S 1^{\text {o }}$, 527, I e II; 544, $\S 3^{\circ} ; 557, \S 1^{\circ}$ e $\S 1^{\circ}$-A; todos do CPC.

26. A flexibilidade procedimental judicial, rigorosamente, seria o genuíno caso de flexibilização. Por este modelo, inexistente procedimento legal adequado para a tutela do direito ou da parte, compete ao juiz proceder a adaptação, ainda que, para isto, tenha que se afastar do regime normativo. A experiência prática tem moldado todas estas situações, entre elas a inversão da ordem de produção de provas em audiência, inúmeras hipóteses de fungibilidade procedimental, utilização de procedimento diverso do legal e abstratamente previsto, variantes no procedimento recursal, flexibilização de prazos e do rígido regime preclusivo.

27. Por fim, pelo modelo da flexibilidade procedimental voluntária, competiria às partes eleger o procedimento processual adequado, ou ao menos parte dos atos 
processuais da série. Neste regime, naturalmente excepcional, o papel do juiz seria mais passivo, eis que a deliberação sobre o encaminhamento do caso seria dos litigantes, inclusive no tocante a parcela dos prazos. 


\section{REFERÊNCIAS BIBLIOGRÁFICAS}

ABELHA, Marcelo. Manual de execução civil. Rio de Janeiro: Forense, 2006.

ABREU, Pedro Manoel. Juizados Especiais. Jurisprudência Catarinense, Florianópolis, ano 21, n. 72, p. 27-44, 1995.

ADAM, R. La cooperazione in materia di giustizia e affari interni tra comunitarizzazione e método intergovernativo. Il Diritto dell'Unione Europea, UE, fasc. 2-3, p. 481-509, 1998.

ALCALÁ-ZAMORA e CASTILlO, Niceto. Derecho procesal mexicano. México: Porruá, 1976. v. 1.

. Princípios técnicos y políticos de uma reforma procesal. Honduras: [s.n.], 1950.

_. Proceso, autocomposición y autodefensa. 2 . ed. México: Unam, 1970.

ALENCAR, Luiz Carlos Fontes de. Constituição Federal de 1988. Juizados de pequenas causas. Juizados especiais cíveis e criminais. Processo e direito processual. Revista do Centro de Estudos Judiciários do Conselho da Justiça Federal, Brasília, ano 2, n. 5, ago. 1998.

A federação brasileira e os procedimentos em matéria processual. Revista do Centro de Estudos Judiciários do Conselho da Justiça Federal, Brasília, ano 5, n. 13, p. 184-186, jan./abr. 2001.

. Procedimentos em matéria processual. Revista do Centro de Estudos Judiciários do Conselho da Justiça Federal, Brasília, ano 2, n 4, p. 91-95, abr. 1998.

ALMEIDA, Fernando Dias Menezes de. Considerações sobre os Municípios no Brasil. In: TAVARES, André Ramos; FERREIRA, Olavo A. V. Alves; LENZA, Pedro (Orgs.). Constituição Federal 15 anos: mutação e evolução. São Paulo: Método, 2003. p. 313-319.

ALMEIDA JÚNIOR, João Mendes. Direito judiciário brasileiro. Atualizada por João Mendes Neto. 6. ed. Rio de Janeiro: Freitas Bastos, 1960. 
ALPA, Guido. Interessi difusi. Revista de Processo, São Paulo, ano 21, n. 81, p. 146-159, jan./mar. 1996.

Trattato di diritto civile: storia, fonti, interpretazione. Milano: Giuffrè, 2000.

ALVES, Francisco Glauber Pessoa. O princípio jurídico da igualdade e o processo civil brasileiro. Rio de Janeiro: Forense, 2003.

ALVIM, J. Eduardo de Carreira. Juizados especiais cíveis estaduais. Curitiba: Juruá, 2003.

ALVIM NETTO, José Manoel de Arruda. Manual de direito processual civil. 8. ed. São Paulo: Ed. Revista dos Tribunais, 2003. v. 1 e 2.

AMARAL NETO, Francisco dos Santos. A equidade no Código Civil brasileiro. Revista do Centro de Estudos Judiciários, Brasília, n. 25, p. 16-23, abr./jun. 2004.

AMENDOEIRA JÚNIOR, Sidnei. A fungibilidade de meios: conversão do ato praticado no processo civil brasileiro e possibilidade de escolha dentre meios processuais postos à disposição das partes. Tese (Doutorado) - Faculdade de Direito, Universidade de São Paulo, São Paulo, 2006.

AMORIM FILHO, Agnelo. Critério científico para distinguir a prescrição da decadência e para identificar as ações imprescritíveis. Revista dos Tribunais, São Paulo, ano 86, n. 744, p. 725-750, out. 1997.

ANDREWS, Neil H. A new civil procedural code for England: party-control 'going, going, gone'. Civil Justice Quarterly, v. 19, p. 19-38, 2000.

ARAGÃO, E. D. Moniz de. Procedimento: formalismo e burocracia. Revista Forense, Rio de Janeiro, v. 358, p. 49-58, nov./dez. 2001.

ARANTES, Rogério Bastos; SADEK, Maria Teresa. A crise do Judiciário e a visão dos juízes. Revista da USP, São Paulo, n. 21, p. 34-45, mar./maio 1994.

ARISTÓTOLES. Ética a Nicômano. São Paulo: Abril Cultural, 1979. v. 2. (Os pensadores). 
ARMELIN, Donaldo. Apontamentos sobre as alterações ao Código de Processo Civil e à Lei n. 8.038/90, impostas pela Lei n. 9.756/98. In: WAMBIER, Teresa Arruda Alvim (Coord.). Aspectos polêmicos e atuais dos recursos cíveis de acordo com a Lei n. 9.756/98. São Paulo: Ed. Revista dos Tribunais, 1999. p. 193-220.

ASSIS, Araken de. Fungibilidade das medidas inominadas cautelares e satisfativas. Revista de Processo, São Paulo, Ano 25, n. 100, p. 33-60, out./dez. 2000.

. Procedimento sumário. São Paulo: Malheiros Ed., 1996.

ATALIBA, Geraldo. Regime constitucional e leis nacionais e federais. Revista de Direito Público, São Paulo, n. 53-54, p. 62-69, jan./jun. 1980.

AZEVEDO, Luiz Carlos; CRUZ E TUCCI, José Rogério. Lições de história do processo civil romano. São Paulo: Ed. Revista dos Tribunais, 2001.

; __ Lições de processo civil canônico: história e direito vigente. São Paulo: Ed. Revista dos Tribunais, 2001.

BALEEIRO, Jedor Pereira. Processo e procedimento. Revista do Curso de Direito da Universidade Federal de Uberlândia, Uberlândia, v. 2, p. 215-228, dez. 1991.

BAPTISTA, Luiz Olavo. Arbitragem: aspectos práticos. Revista Brasileira de Arbitragem, n. 0, São Paulo, p. 215-220, jul./out. 2003.

BARRAL, Welber. Arbitragem e jurisdição. In: CASELLA, Paulo Borba (Coord.). Arbitragem: lei brasileira e praxe internacional. 2. ed. São Paulo: LTr, 1999. p. 163-175.

BARROSO, Luis Roberto. Direito constitucional brasileiro: o problema da federação. Rio de Janeiro: Forense, 1982.

BASEDOW, Jürgen. The communitarization of the conflict of laws under the treaty of Amsterdam. Common Market law Review, Holanda, n. 37, p. 687-708, 2000.

BASTOS, Aureliano Cândido Tavares. A província: estudo sobre a descentralização no Brasil. 3. ed. São Paulo: Nacional, 1975.

BASTOS, Celso Ribeiro. Curso de direito constitucional. 11. ed. São Paulo: Saraiva, 1989. 
BASTOS, Celso Ribeiro; MARTINS, Ives Gandra da Silva. Comentários à Constituição do Brasil. São Paulo: Saraiva, 1993. v. 3, t. 3.

BATISTA, J. Pereira. Reforma do processo civil: princípios fundamentais. Lisboa: Lex, 1997.

BATISTA, Weber Martins; FUX, Luiz. Juizados especiais cíveis e criminais e suspensão condicional do processo penal. Rio de Janeiro: Forense, 1996. v. 2

BAUR, Fritz. Potere giudiziale e formalismo del diritto processuale. Rivista Trimestrale di Diritto e Procedura Civile, Milano, n. 2, p. 1689-1691, 1965.

BEDAQUE, José Roberto dos Santos. Direito e processo. 2. ed. São Paulo: Malheiros Ed, 2001.

- Efetividade do processo e técnica processual: tentativa de compatibilização. 2005.Tese (Titular de Direito Processual Civil) - Faculdade de Direito, Universidade de São Paulo, São Paulo, 2005.

. Nulidade processual e instrumentalidade do processo. Revista de Processo, São Paulo, v. 15, n. 60, p. 31-43, out./dez. 1990.

Poderes instrutórios do juiz. 3. ed. São Paulo: Ed. Revista dos Tribunais, 2001.

Tutela cautelar e tutela antecipada: tutelas sumárias e de urgência - tentativa de sistematização. 3. ed. São Paulo: Malheiros Ed., 2003.

BERMUDES, Sérgio. Procedimentos em matéria processual. Revista de Direito da Defensoria Pública, Rio de Janeiro, ano 4, n. 5, p. 161-167, fev. 1991.

. A reforma do Código de Processo Civil. 2. ed. São Paulo: Saraiva, 1996.

BETTI, Emílio. Diritto processuale civile italiano. 2 ed. Roma: Foro Italiano, 1936.

BIAVATI, Paolo. I procedimenti civili semplificati e accelerati: il quadro europeo e riflessi italiani. Rivista Trimestrale di Diritto e Procedura Civile, Milano, ano 56, n. 3, p. 751-775, sett. 2002. 
BIAVATI, Paolo. Processo comunitario e formazione di un processo comune europeo. Rivista Trimestrale di Diritto e Procedura Civile, Milano, ano 49, n. 3, p. 769-788, lugl./sett. 1994.

BOBBIO, Norberto. Estado, governo, sociedade. São Paulo: Paz e Terra, 1999.

BONAVIDES, Paulo. A Constituição aberta. 2. ed. São Paulo: Malheiros Ed., 1996.

BORGES, Alice Maria Gonzalez. Normas gerais nas licitações e contratos administrativos: contribuição para a elaboração de uma lei nacional. Revista de Direito Público, São Paulo, v. 24, n. 96, p. 81-93, out./dez. 1990.

BORGES NETTO, André Luiz. Competências legislativas dos Estados-Membros. São Paulo: Ed. Revista dos Tribunais, 1999.

BRITO, Pedro Madeira de. O novo princípio da adequação formal. In: SOUZA, Miguel Teixeira (Coord.) Aspectos do novo processo civil. Lisboa: Lex, 1997.

BUENO, Cássio Scarpinella. Amicus curiae no processo civil brasileiro. São Paulo: Saraiva, 2006.

. Curso sistematizado de direito processual civil. São Paulo: Saraiva, 2007. v. 1.

Tutela antecipada. 2. ed. São Paulo; Saraiva, 2007.

In: MARCATO, Antonio Carlos (Coord.). Código de Processo Civil interpretado. São Paulo: Atlas, 2004.

; MAGRI, Berenice Soubhie Nogueira. Tutela cautelar no sistema recursal do Código de Processo Civil modificado. Revista de Processo, São Paulo, v. 12, n. 83, p. 27 43, jul./set. 1996.

BÜLOW, Oskar von. La teoria de las excepciones procesales y los presupuestos procesales. Buenos Aires: Ejea, 1964.

BUZAID, Alfredo. Do ônus da prova. Estudos de direito. São Paulo: Saraiva, 1972. v. 1.

CALAMANDREI, Piero. Direito processual civil. Tradução de Luiz Abezia e Sandra Drina Fernandez Barbery. Campinhas: BookSeller, 1999. v. 1. 
CALAMANDREI, Piero. Instituciones de derecho procesal civil. Tradução de. Santiago Sentis Melendo. Buenos Aires: Depalma, 1943. v. 1.

Introdução ao estudo sistemático dos procedimentos cautelares. Tradução de Carla Roberta Andreasi Bassi. Campinas: Servada, 2000.

CAMBI, Eduardo. A prova civil: admissibilidade e relevância. São Paulo: Ed. Revista dos Tribunais, 2006.

CAPELLETTI, Mauro. Problemas de reforma do processo civil nas sociedades contemporâneas. In: MARINONI, Luiz Guilherme (Coord.) O processo civil contemporâneo. Curitiba: Juruá, 1994.

CAPEZ, Fernando; ROSA, Márcio F. Elias; SANTOS, Marisa F; CHIMENTI, Ricardo da Cunha. Curso de direito constitucional. 3. ed. São Paulo: Saraiva, 2006.

CARLIN, Marcelo. O julgamento por equidade nos juizados especiais cíveis: uma abordagem à luz da convergência entre os sistemas jurídicos da civil law e da common law e do movimento contemporâneo de acesso à justiça. 2004. Dissertação (Mestrado) Faculdade de Direito do Vale do Itajaí - SC (UNIVALI), 2004.

CARMINGNANI, Maria Cristina da Silva. O direito judicial como forma de resolução dos anseios por justiça. Revista do IASP, São Paulo, ano 8, n. 16, p. 253-263, jul./dez. 2005.

CARMONA, Carlos Alberto. Arbitragem internacional. Revista Forense, Rio de Janeiro, n. 329, p. 25-39, mar. 1995.

Arbitragem e jurisdição. Revista de Processo, São Paulo, v. 15, n. 58, p. 33-39, abr./jun. 1990.

A arbitragem no processo civil brasileiro. São Paulo: Malheiros Ed., 1993.

Arbitragem e processo: um comentário à Lei n. 9.307/96. 2. ed. São Paulo: Atlas, 2004.

O processo arbitral. Revista de Arbitragem e Mediação, São Paulo, v. 1, n. 1. p. 21-31. jan./abr. 2004.

CARNEIRO, Athos Gusmão. Considerações sobre o processo e os Juizados de Pequenas Causas. Revista de Processo, São Paulo, ano 13, n. 51, p. 23-31, jul./set. 1988. 
CARNEIRO, Athos Gusmão. Do rito sumário na reforma do CPC. São Paulo: Saraiva, 1996.

Tutelas e urgência. Medidas antecipatórias e cautelares. Esboço de reformulação legislativa. Revista de Processo, São Paulo, ano 31, n. 140, p. 72-85, out. 2006.

CARNEIRO, Paulo Cezar Pinheiro. Aspectos processuais da nova lei de arbitragem. In: Paulo Borba Casella (Coord.). Arbitragem: lei brasileira e praxe internacional. 2. ed. São Paulo: LTr, 1999. p. 291-315.

CARNEIRO, Rosa. Da desnecessidade de citação por edital nos pedidos de adoção de crianças e adolescentes cujos pais são desconhecidos. Ministério Público. Rio Grande do Sul. Disponível em: <www.mp.rs.gov.br/infancia/doutrina/id178.htm?impressao+1\&>. Acesso em: 23 ago. 2006.

CARNELUTTI, Francesco. Diritto e processo. Napoli: Morano Editore, 1958.

Instituições do processo civil. Tradução de Adrián Sotero de Witt Batista. Campinas: Servanda, 1999.

CAROCCA PÉREZ, Alex. Manual de derecho procesal. Santiago: LexisNexis, 2003.

CARRATA, Antonio. Funzione dimostrativa della prova: verità del fatto nel processo e sistema probatório. Rivista de Diritto Processuale, Padova, ano 56, n. 1, p. 73-103, genn./mar. 2001.

CARVALHO FILHO, Milton Paulo de. Processo cautelar. São Paulo: Atlas, 2005.

CASSEB, Paulo Adib. Federalismo: aspectos contemporâneos. São Paulo: Juarez de Oliveira, 1999.

CASTRO JUNIOR, Osvaldo Agripino de. A relevância do direito comparado e direito e desenvolvimento para a reforma do sistema judicial brasileiro. Revista de Informação Legislativa, Brasília, ano 41, n. 163, p. 51-68, jul./set. 2004.

CATHARINO, José Martins. Princípios do direito processual do trabalho. In: FRANÇA, Rubens Limongi (Org.). Enciclopédia Saraiva do Direito. São Paulo: Saraiva, 1977. v. 61. 
CAYMNI, Pedro Leonardo Summers. O papel da fundamentação das decisões judiciais na legitimação do sistema jurídico. Revista Dialética de Direito Processual, São Paulo, n. 17, p. 115-133, ago. 2004.

CENEVIVA, Walter. Falta que os Poderes se entendam: legisladores e os exercentes do Poder Executivo não chegam a entender os problemas do Judiciário. Folha de S. Paulo, São Paulo, 10 mar. 2007.2 Disponível em: $<$ http://www1.folha.uol.com.br/fsp/cotidian/ff1003200706.htm>. Acesso em: 02 mar. 2007.

CHAGAS, Magno Guedes. Federalismo no Brasil: poder constituinte decorrente na jurisprudência do Supremo Tribunal Federal. São Paulo: Sérgio Antonio Fabris, 2006.

CHIMENTI, Ricardo da Cunha; CAPEZ, Fernando; ROSA, Márcio F. Elias; SANTOS, Marisa F. Curso de direito constitucional. 3. ed. São Paulo: Saraiva, 2006.

; SANTOS, Marisa Ferreira. Juizados especiais cíveis e criminais - federais e estaduais. 2. ed. São Paulo: Saraiva, 2004.

CHIOVENDA, Giuseppe. Instituições de direito processual civil. Tradução de Paolo Capitanio. Campinas: Bookseller, 1998.v. 1, v. 3.

Princípios de derecho procesal civil. 3 ed. Madrid: Inst Ed. Reus, 2000.

CINTRA, Antonio Carlos; GRINOVER, Ada Pellegrini; DINAMARCO, Cândido Rangel. Teoria geral do processo. 21. ed. São Paulo: Malheiros Ed., 2005.

CLARK, Mary; MCKENA, Judith A.; HOOPER, Laural L. Case management procedures in the Federal Courts of Appeals. Washington: FJC, 2000. Federal Judicial Center. Disponível em: $<$ http://www.fjc.gov/public/pdf.nsf/lookup/caseman1.pdf/\$file/caseman1.pdf>. Acesso em: 23 jan. 2007.

CLARKE, Bruce M.; REAGAN, Robert Tiothy. Redistricting litigation: an overview of legal, statistical and case management issues. Washington: FJC, 2002. Federal Judicial Center. Disponível em: <http://www.fjc.gov/library/fjc_catalog.nsf>. Acesso em: 23 jan. 2007. 
CLAUS, Ben-Hur Silveira. A ordinarização do procedimento: uma herança do racionalismo sob interrogação. Revista da Ajuris, Porto Alegre, ano 27, n. 83, t. 1, p. 2032, set. 2001.

CLERMONT, Kevin; KAPLAN, Benjamin; FIELD, Richard H. Materials for a basic course in Civil Procedure. New York: The Foundation Press, 1990.

COELHO, Fábio Ulhoa. Curso de direito civil. São Paulo: Saraiva. 2003. v. 1.

COMOGLIO, L. Paolo. Direzione del processo e responsabilitá del giudice. In: Studi in Onore di Enrico Tulio Liebman. Milano: Giuffrè, 1979. v. 1.

. Il principio di economia processuale. Padova: Cedam, 1980. v. 1.

COSTA, Alfredo de Araújo Lopes da. A administração pública e a ordem jurídica privada. São Paulo: Ed. Bernardo Álvares, 1961.

- Manual elementar de direito processual. rev. e atual. por Sálvio de Figueiredo Teixeira. 3. ed. Rio de Janeiro: Forense, 1982.

COSTA, Moacyr Lobo da. Breve notícia histórica do direito processual civil brasileiro e de sua literatura. São Paulo: Ed. Revista dos Tribunais, 1970.

COUTORE, Eduardo J. Fundamentos del derecho procesal civil. 3. ed. Buenos Aires: Depalma, 1958.

Vocabulário jurídico. Buenos Aires: Depalma, 1976.

CRUZ E TUCCI, José Rogério. Precedente judicial como fonte do direito. São Paulo: Ed. Revista dos Tribunais, 2004.

. Tempo e processo. São Paulo: Ed. Revista dos Tribunais, 1998.

. Tutela processual do direito do executado. Revista da Ajuris, Porto Alegre, n. 61, p. 99-120, 1994.

; AZEVEDO, Luiz Carlos. Lições de história do processo civil romano. São Paulo: Ed. Revista dos Tribunais, 2001. 
CRUZ E TUCCI, José Rogério; AZEVEDO, Luiz Carlos. Lições de processo civil canônico: história e direito vigente. São Paulo: Ed. Revista dos Tribunais, 2001.

; TUCCI, Rogério Lauria. Constituição de 1988 e processo: regramentos e garantias constitucionais do processo. São Paulo: Saraiva, 1989.

; __ Devido processo legal e tutela jurisdicional. São Paulo: Ed. Revista dos Tribunais, 1993.

CUNHA, Rogério Sanches; PINTO, Ronaldo Batista. Violência doméstica. São Paulo: Ed. Revista dos Tribunais, 2007.

CUNHA, Sérgio Sérvulo da. O efeito vinculante e os poderes do juiz. São Paulo: Saraiva, 1999.

DALLARI, Dalmo de Abreu. O Estado federal. São Paulo: Ática, 1986.

DESTEFFENNI, Marcos. Curso de direito processual civil. São Paulo: Saraiva: 2006. v. 1.

DIDIER JÚNIOR, Fredie. Direito processual civil. 4. ed. Salvador: JusPodiVm, 2004. v. 1.

- Sobre dois importantes, e esquecidos, princípios do processo: adequação e adaptabilidade do procedimento. Revista Gênesis de Direito Processual Civil, Curitiba, n. 21, p. 530-541, jul./set. 2001.

; ZANETI JÚNIOR, Hermes. Curso de direito processual civil: processo coletivo. Salvador: JusPodvum, 2007. v. 4.

DINAMARCO, Cândido Rangel. Agravo inadmissível. In: Fundamentos do processo civil moderno. 3. ed. São Paulo: Malheiros Ed., 2000. v. 2, , p. 1.156-1.157.

. Das ações típicas. In: . Fundamentos do processo civil moderno. 3. ed. São Paulo: Malheiros Ed., 2000. v. 1, p. 324-352.

Os efeitos dos recursos. In: . A nova era do processo civil. São Paulo: Malheiros Ed., 2004. p. 104-153.

- Efetividade do processo e os poderes do juiz. In: Fundamentos do processo civil moderno. 3. ed. São Paulo: Malheiros Ed., 2000. v. 1, p. 591-609. 
DINAMARCO, Cândido Rangel. Os embargos de declaração como recurso. In: A nova era do processo civil. São Paulo: Malheiros Ed., 2004.

A execução na reforma do Código de Processo Civil. In: Fundamentos do processo civil moderno. 3. ed. São Paulo: Malheiros Ed., 2000. v. 2, p. 1.162-1171.

. Instituições de direito processual civil. 4. ed. São Paulo: Malheiros Ed., 2002. v. 1.

. Os institutos fundamentais do direito processual. In: Fundamentos do processo civil moderno. 3. ed. São Paulo: Malheiros Ed., 2000. v. 1, p. 71-123.

. A instrumentalidade do processo. 5. ed. São Paulo: Malheiros Ed., 1996.

. Julgamento antecipado da lide após a perícia. In: Fundamentos do processo civil moderno. 3. ed. São Paulo: Malheiros Ed., 2000. v. 1.

Julgamento antecipado do mérito. In: Fundamentos do processo civil moderno. 3. ed. São Paulo: Malheiros Ed., 2000. v. 2, p. 1.032-1.040.

. Manual dos juizados especiais cíveis. 2. ed. São Paulo: Malheiros Ed., 2001.

. Manual de pequenas causas. São Paulo: Ed. Revista dos Tribunais, 1986.

. O princípio do contraditório e sua dupla destinação. In: Fundamentos do processo civil moderno. 3. ed. São Paulo: Malheiros Ed., 2000. v. 1, p. 124-135.

. Procedimentos especiais de jurisdição voluntária. In: Fundamentos do processo civil moderno. 3. ed. São Paulo: Malheiros 2000. v. 1, p. 375-398.

. A reforma do Código de Processo Civil. 5. ed. São Paulo: Malheiros Ed., 2001. . A reforma da reforma. 4. ed. São Paulo: Malheiros Ed, 2003.

. Relativizar a coisa julgada material. In: . A nova era do processo civil. São Paulo: Malheiros Ed., 2004. p. 220-266.

O relator, a jurisprudência e os recursos. In: Fundamentos do processo civil moderno. 3. ed. São Paulo: Malheiros Ed., 2000. v. 2, p. 1.099-1.12. 
DINAMARCO, Cândido Rangel. Vocabulário de direito processual civil. In:

Fundamentos do processo civil moderno. 3. ed. São Paulo: Malheiros Ed., 2000. v. 1, p. 136-231.

; GRINOVER, Ada Pellegrini; CINTRA, Antonio Carlos de Araújo. Teoria geral do processo. 21. ed. São Paulo: Malheiros Ed., 2005.

DINIZ, Antônio Carlos de Almeida. Legitimação procedimental e modernidade - a problemática da legitimidade jurídica política em sociedades complexas. Revista de Informação Legislativa, Brasília, ano 38, n. 150, p. 99-120, abr./jun. 2001.

DOYLE, John. The judicial role in a new millennium. Journal of Judicial Administration, Austrália, LawBook, v. 10, n. 3, p. 133-148, 2001.

DUNWORTH, Terence; KAKALI. James S. Preliminary observations on implementation of the pilot program of the civil Justice Reform Act of 1990. Stanford Law Review, v. 46, n. 6, p. 1303-1337, jul. 1994. JSTOR. Disponível em: <http://links.jstor.org/sici?sici=00389765(199407)46\%3A6\%3C1303\%3APOOIOT\%3E2.0.CO\%3B2-I,com>. Acesso em: 23 jan. 2007.

DEVI ECHANDÍA, Hernando. Teoria general de la prueba judicial. 6 ed. Buenos Aires: Zavalia, 1988. v. 1.

ELIAS, Roberto João. Comentários ao Estatuto da Criança e do Adolescente. 2. ed. São Paulo: Saraiva, 2004.

ENCICLOPÉIDA Wikipédia <http://pt.wikipedia.org/wiki/Ordena\%C3\%A7\%C3\%B5es_Afonsinas>. Acesso em: 08 dez. 2006.

ENGISH, Karl. La idea de concreción em el derecho y em las ciencias jurídicas actuales. 2. ed. Pamplona: [s.n.], 1968.

FABRÍCIO, Adroaldo Furtado. Comentários ao Código de Processo Civil. 7. ed. Rio de Janeiro: Forense, 1995. v. 8, t. 3.

FAIRÉN GUILLÉN, Victor. El juidicio ordinário e los plenários rápidos. Barcelona: Bosch, 1953. 
FARIAS, Talden. O princípio do contraditório em face dos embargos declaratórios com efeito modificativo ou infringente. Revista Dialética de Direito Processual, São Paulo, n. 18, p. 108-112, set. 2004.

FAZZALARI, Elio. La giurisdizione volontaria: profilo sistemático. Padova: Cedam, 1953.

. Istituzioni di diritto processuale. 7. ed. Padova: Cedam, 1994.

. Per un processo comune europeo. Rivista Trimestrale di Diritto e Procedura Civile, Milano, p. 665-692, 1994.

. Proceso (teoria generale). In: Novissimo Digesto Italiano. Torino: UTET, 1966. v.

13.

FENECH, Miguel. El proceso penal. 3. ed. Madrid: Agesa, 1978.

FERNANDES, Antonio Scarance. Teoria geral do processo e do procedimento penal. São Paulo: Ed. Revista dos Tribunais, 2005.

FERNANDES, Luis Eduardo Simardi. Embargos de declaração: efeitos infringentes, prequestionamento e outros aspectos polêmicos, São Paulo: Ed. Revista dos Tribunais, 2003.

FERRARI, Regina Maria Nery. Efeitos da declaração de inconstitucionalidade. 4. ed. São Paulo: Ed. Revista dos Tribunais, 1999.

FERRAZ JÚNIOR, Tércio Sampaio. Normas gerais e competência concorrente: uma exegese do art. 24 da Constituição Federal. Revista da Faculdade de Direito da Universidade de São Paulo, São Paulo, v. 90, p. 245-251, 1995.

FERREIRA, Carlos. Os poderes dos juízes e das partes. Revista da Ordem dos Advogados, Lisboa, n. 3, 1990.

FERREIRA, Pinto. Comentários à Constituição brasileira. São Paulo: Saraiva, 1989. v. 2.

FERREIRA FILHO, Manoel Gonçalves. Curso de direito constitucional. 32. ed. São Paulo: Saraiva, 2006. 
FIELD, Richard H.; KAPLAN, Benjamin; CLERMONT, Kevin. Materials for a basic course in civil procedure. New York: The Foundation Press, 1990.

FIGUEIRA JÚNIOR, Joel Dias. Juizados especiais estaduais cíveis e criminais comentários à Lei n. 9.099/95. 4. ed. São Paulo: Ed. Revista dos Tribunais, 2005.

FONTES, André. Procedimento sumaríssimo trabalhista - a conversibilidade do rito em benefício da celeridade processual. Repertório de Jurisprudência IOB, São Paulo, n. 1, cad. 2, p. 17-19, 2002.

FOUCAULT, Michel. A verdade e as formas jurídicas. 3. ed. Rio de Janeiro: Ed. Nau, 2003.

FRANÇA, Rubens Limongi. Formas e aplicação do direito positivo. São Paulo: Ed. Revista dos Tribunais, 1969.

FREIRE, Florisberto. História constitucional da República dos Estados Unidos do Brasil. Brasília: Ed. da Unb, 1983.

FREIRE JÚNIOR, Américo Bedê. Pontos nervosos da tutela coletiva: legitimação, competência e coisa julgada. In: MAZZEI, Rodrigo; NOLASCO, Rita Dias. Processo civil coletivo. São Paulo: Quartier Latin, 2005. p. 66-81.

FREITAS, José Lebre de. Introdução ao processo civil: conceito e princípios gerais. 2. ed. Coimbra: Coimbra Ed., 2007.

FRIEDENTHAL, Jack H.; KANE, Marty Kay; MILLER, Arthur C. Civil procedure. 3. ed. St. Paul: West Group, 1999.

FUX, Luiz; BATISTA, Weber Martins. Juizados especiais cíveis e criminais e suspensão condicional do processo penal. Rio de Janeiro: Forense, 1996.

GAJARDONI, Fernando da Fonseca. Aspectos fundamentais de processo arbitral e pontos de contato com a Jurisdição estatal. Revista de Processo, São Paulo, n. 106, p. 190-192, abr./jun. 2002.

- Breve análise estatística de alguns pontos da primeira fase das reformas processuais civis no âmbito da justiça estadual paulista. Revista da Escola Paulista da Magistratura, São Paulo, v. 5, n. 1, p. 47-63, jan./jun. 2004. 
GAJARDONI, Fernando da Fonseca. Breve introdução aos procedimentos especiais de jurisdição contenciosa. In: ; SILVA, Márcio Henrique Mendes da (Coords.). Manual dos procedimentos especiais de legislação extravagante. São Paulo: Método, 2006. p. 15-24.

Direito processual civil: processo cautelar. São Paulo: Ed. Revista dos Tribunais, 2006. v. 4.

A nova sistemática do recurso de agravo introduzida pela Lei n. 11.187/2005 e os prejuízos à justiça de $1^{\circ}$ grau. In: HOFFMAN, Paulo; RIBEIRO, Leonardo Ferres da Silva (Coord.). O novo regime do agravo de instrumento e do agravo retido. São Paulo: Quartier Latin, 2006. p. 159-168.

- O princípio constitucional da tutela jurisdicional sem dilações indevidas e o julgamento antecipadíssimo da lide. Revista de Processo, São Paulo, ano 131, n. 141, p. 150-179, nov. 2006.

Reflexões sobre a nova liquidação de sentença. In: SANTOS, Ernane Fidélis dos; WAMBIER, Luiz Rodrigues; NERY JÚNIOR, Nelson; WAMBIER,Teresa Arruda Alvim Wambier (Coords.). Execução civil: estudos em homenagem a Humberto Theodoro Júnior. São Paulo: Ed. Revista dos Tribunais, 2007. p. 537-550.

. Técnicas de aceleração do processo. Franca: Lemos e Cruz, 2003.

; SILVA, Márcio Henrique Mendes da (Coords.). Manual dos procedimentos especiais de legislação extravagante. São Paulo: Método, 2006.

GARCIA, Maria. Sistemas constitucionais comparados: o sistema inglês (common law) e Constitucional e Ciência Política, São Paulo, ano 3, n. 9, p. 53-72, out./dez. 1994.

GERALDES, António Santos Abrantes. Temas da reforma do processo civil - processo cautelar comum. Coimbra: Almedina, 2000. v. 3.

GERLIS, Stephen; LOUGHLIN, Paula. Civil procedure. 2. ed. London: Cavendish, 2004.

GOMES, Mariângela Gama de Magalhães. Devido processo legal e direito ao procedimento adequado. Revista Brasileira de Ciências Criminais, São Paulo, ano 13, n. 55, p. 293-313, jul./ago, 2005. 
GOMES FILHO, Cyrilo Luciano. Separação judicial e divórcio (de acordo coma Lei n. 11.112/2005). In: GAJARDONI, Fernando da Fonseca; SILVA, Márcio Henrique Mendes da (Coords.). Manual dos procedimentos especiais de legislação extravagante. São Paulo: Método, 2006. p. 321-369.

GONÇALVES, Marcus Vinicius Rios. Novo curso de direito processual civil. 3. ed. São Paulo: Saraiva, 2006. v. 1.

GORGA, Érica; SZTAJN, Rachel. Tradições do direito. In: ZYLBERSZTAJN, Décio; SZTAJN, Rachel (Coords.). Direito e economia: análise econômica do direito e das organizações. Rio de Janeiro: Elsevier, 2005. p. 137-196.

GRASSI, Lúcio. Cognição processual civil: atividade dialética e cooperação intersubjetiva na busca da verdade real. Revista Dialética de Direito Processual. São Paulo, n. 6, p. 4759, set. 2003.

GRECO, Leonardo. O princípio do contraditório. Revista Dialética de Direito Processual, São Paulo, n. 24, p. 71-79, mar. 2005.

GRECO FILHO, Vicente. Direito processual civil brasileiro. 16. ed. São Paulo: Saraiva, 2003. v. 2.

Litigância de má-fé. In: TEIXEIRA, Sálvio de Figueiredo (Org.). Reforma do Código de Processo Civil. São Paulo: Saraiva, 1996. p. 577-580.

GRINOVER, Ada Pellegrini. O conteúdo da garantia do contraditório. In: Novas tendências do direito processual. Rio de Janeiro: Forense, 1990. p. 17-39.

Inconstitucionalidade de leis processuais estaduais. In: CALDEIRA, Adriano; FREIRE, Rodrigo da Cunha Lima (Coords.). Terceira etapa da reforma do Código de Processo Civil. Salvador: JusPodivm, 2007. p. 19-21.

Iniciativa instrutória do juiz no processo penal acusatório. Revista Brasileira de Ciências Criminais, São Paulo, v. 7, n. 27, p. 71-79, jul./set. 1999.

Invalidade dos atos processuais e ação rescisória. Revista IOB de Direito Civil e Processual Civil, Porto Alegre, n. 39 p. 63-79, jan./fev. 2006. 
GRINOVER, Ada Pellegrini. Princípio da proporcionalidade: coisa julgada e justa indenização. No prelo. Artigo cedido pela autora para o curso de pós-gradução do Instituto Brasileiro de Direito Processual Civil, Rede de Ensino Luiz Flávio Gomes e UNISUL.

Tutela jurisdicional nas obrigações de fazer e não fazer. In: TEIXEIRA, Sálvio de Figueiredo (Org.). Reforma do Código de Processo Civil. São Paulo: Saraiva, 1996. p. 251-269.

; CINTRA, Antonio Carlos de Araújo; DINAMARCO, Cândido Rangel. Teoria geral do processo. 21. ed. São Paulo: Malheiros Ed., 2005.

GUERRA, Marcelo Lima. Direitos fundamentais e a proteção do credor na execução civil. São Paulo: Ed. Revista dos Tribunais, 2003.

GUIMARÃES, Luiz Machado. Comentários ao Código de Processo Civil. Rio de Janeiro: Revista Forense, 1942. v. 4.

GUINCHARD, Serge et al. Droit processuel: droit commun et droit compare du procès. 2. ed. Paris: Dalloz, 2003.

GUTIÉRREZ, Cristina. Dever judicial de adequação do procedimento à pretensão deduzida em juízo. Revista da EMERJ, Rio de Janeiro, v. 4, n. 13, p. 107-116, 2001.

HABERMAS, Jürgen. Direito e democracia: entre facticidade e validade. Rio de Janeiro: Tempo Brasileiro, 1997.

HEERDT, Paulo. Sumarização do processo e do procedimento. Revista da Ajuris, Porto Alegre, n. 48, p. 80-109, mar. 1991.

HERKENHOFF FILHO, Helio Estellita. Suprimento judicial de autorização para viagem ao exterior. Jus Navegandi. Disponível em: <http://jus2.uol.com.br/doutrina/texto.asp?id+4743>. Acesso em: 22 ago. 2006.

HIRSCH, Allan; SCHWARZER, Willian W. The elements of case management: a pocket guide for judges. 2. ed. Washington: FJC, 2006. Federal Judicial Center. Disponível em: <http://www.fjc.gov/library/fjc_catalog.nsf>. Acesso em: 23 jan. 2007. 
HOOPER, Laural L; CLARK, Mary; MCKENA, Judith A. Case management procedures in the Federal Courts of Appeals. Washington: FJC, 2000. Federal Judicial Center. Disponível em: $<$ http://www.fjc.gov/public/pdf.nsf/lookup/caseman1.pdf/\$file/caseman1.pdf>. Acesso em: 23 jan. 2007.

HORTA, Raul Machado. Estudos de direito constitucional. Belo Horizonte: Del Rey, 1995.

. Unidade e dualidade da magistratura. Revista de Direito Público, São Paulo, v. 21, n. 87 , p. $35-42$, jul./set. 1988.

IHERING, Rudolf von. O espírito do direito romano. Tradução da Rafael Benaion. Rio de Janeiro: Calvino F., 1934. v. 1.

JACOB, Jack I. H. La giustizia civile in Inghilterra. Tradução italiana de Elisabetta Silvestrino.Bologna: Mulino, 1995.

JACQUES, Paulino. Da norma Jurídica (forma e matéria). 2. ed. Rio de Janeiro: Forense, 1963.

JAUERNIG, Othmar. Direito processual civil (Zivilprozessrecht). Tradução de F. Silveira Ramos. 25. ed. Coimbra: Almedina, 2002.

JESUS, Damásio Evangelista. A lei dos juizados especiais criminais anotada. São Paulo: Saraiva, 1995.

JOLOWICZ, J. A. Adversarial and inquisitorial models of civil procedure. Internacional and Comparative Law, Oxford, v. 52, n. 2, p. 281-295, 2003. Oxford Journals. Disponível em: <http://iclq.oxfordjournals.org/content/vol52/issue2/index.dtl>. Acesso em: 24 jan. 2007.

JORGE, Flávio Cheim. A nova disciplina do cabimento do agravo: Lei 11.187, de 19/10/2005, Revista do Advogado, São Paulo, ano 26, n. 85, maio 2006.

JUSTEN FILHO, Marçal. Comentários à lei de licitações e contratos administrativos. Rio de Janeiro: Aide, 1993. 
KAKALI, James S.; DUNWORTH, Terence. Preliminary observations on implementation of the pilot program of the civil Justice Reform Act of 1990. Stanford Law Review, v. 46, n. 6, p. 1303-1337, jul. 1994.

KANE, Marty Kay; FRIEDENTHAL, Jack H.; MILLER, Arthur C. Civil procedure. 3. ed. St. Paul: West Group, 1999.

KAPLAN,Benjamin; FIELD, Richard H.; CLERMONT, Kevin. Materials for a basic course in civil procedure. New York: The Foundation Press, 1990.

KOMATSU, Roque. Da invalidade no processo civil. São Paulo: Ed. Revista dos Tribunais, 1991.

KRAFKA, Carlo; LOMBARD, Patrícia. 2003-2004 District Court Case-Weighiting study: final report to the subcommittee on judicial statistics of the committee on judicial resources of the judicial conference of the United States. Washington: FJC, 2005. Federal Judicial Center. Disponível em: <http://www.fjc.gov/library/fjc_catalog.nsf>. Acesso em: 23 jan. 2007.

LACERDA, Galeno Velhinho de. O código como sistema legal de adequação do processo. Revista do Instituto dos Advogados do Rio Grande do Sul, Porto Alegre, p. 161-170, 1976. Comentários ao Código de Processo Civil. Rio de Janeiro: Forense, 1980.

LAMY, Eduardo de Avelar. Princípio da fungibilidade no processo civil. São Paulo: Dialética, 2007.

LEAL, Antonio Luiz da Câmara. Código de Processo Civil e Commercial do Estado de São Paulo comentado. São Paulo: Acadêmica, 1932. v. 4.

LEE, João Bosco. A especificidade da arbitragem comercial internacional. In: CASELLA, Paulo Borba (Coord.). Arbitragem: lei brasileira e praxe internacional. 2. ed. São Paulo: LTr, 1999. p. 176-204.

LEMES, Selma Maria Ferreira. Árbitro: o padrão de conduta ideal. In: CASELLA, Paulo Borba (Coord.). Arbitragem: lei brasileira e praxe internacional. 2. ed. São Paulo: LTr, 1999. p. 233-268.

. Árbitro: princípios da independência e da imparcialidade. São Paulo: LTr, 2001. 
LEONEL, Ricardo de Barros. Manual do processo coletivo. São Paulo: Ed. Revista dos Tribunais, 2002.

LETTERIELLO, Rêmolo. Considerações sobre os juizados de pequenas causa. Revista dos Juizados Especiais de Pequenas Causas, TJ/RS, n. 2, p. 8-16, ago. 1991.

Mato Grosso do Sul: onde nasceram os juizados especiais. Tribunal de Justiça.

Poder Judiciário. Mato Grosso do Sul. Disponível em: <http://www.tj.ms.gov.br/portal2005/juizados/doutrina/DTR_20050607181401.pdf>. Acesso em: 20 nov. 2006.

LIBERATI, Wilson Donizeti. Comentários ao Estatuto da Criança e do Adolescente. 9. ed. São Paulo: Malheiros Ed., 2006.

LIEBMAN, Enrico Tullio. L'opera scientifica di James Goldshimidt e la teoria del rapporto processuale. In: . Problemi del processo civile. Napoli: Morano, 1962.

Manual de direito processual civil. 2. ed. Tradução e notas de Cândido Rangel Dinamarco. Rio de Janeiro: Forense, 1985. v. 1.

LOBÃO, Manoel de Almeida e Souza de. Tractado prático compendiário de todas as acções summarias, sua índole, e natureza em geral, e em especial, Das Summarias, Summaríssimas, Preparatórias, Provisionaes, Incidentes, Preceitos Comminatorios, etc. Lisboa: Imprensa Nacional, 1847.

LOMBARD, Patrícia; KRAFKA, Carlo. 2003-2004 District Court Case-Weighiting study: final report to the subcommittee on judicial statistics of the committee on judicial resources of the judicial conference of the United States. Washington: FJC, 2005. Federal Judicial Center. Disponível em: <http://www.fjc.gov/library/fjc_catalog.nsf>. Acesso em: 23 jan. 2007.

LOPES, José Reinaldo de Lima. Uma introdução à história social e política do processo. In: WOLKMER, Antonio Carlos (Coord.). Fundamentos da história do direito. 2. ed. Belo Horizonte: Del Rey, 2001.

LOSANO, Mario G. Os grandes sistemas jurídicos. Lisboa: Editorial Presença, 1978.

LOUGHLIN, Paula; GERLIS, Stephen. Civil procedure. 2. ed. London: Cavendish, 2004. 
LUHMANN, Niklas. Legitimação pelo procedimento. Tradução de Maria da Conceição Corte Real. Brasília: Ed. da UnB, 1980.

MAGALHÃES, José Carlos de. Arbitragem internacional privada. In: BAPTISTA, Luiz Olavo (Coords.). Arbitragem comercial. Rio de Janeiro: Freitas Bastos, 1986. p. 17-30.

. Arbitragem e processo judicial. Revista do Advogado da AASP, São Paulo, ano 26, n. 87, p. 61-66, set. 2006.

MAGRI, Berenice Soubhie Nogueira; BUENO, Cássio Scarpinella. Tutela cautelar no sistema recursal do Código de Processo Civil modificado. Revista de Processo, São Paulo, v. 12, n. 83, p. 27-43, jul./set. 1996.

MALACHINI, Édson Ribas. A Constituição Federal e a legislação concorrente dos Estados e do Distrito Federal em matéria de procedimentos. Revista Forense, Rio de Janeiro, v. 89, n. 324, p. 49-54, out./dez. 1993.

MANCUSO, Rodolfo de Camargo. Divergência jurisprudencial e súmula vinculante. São Paulo: Ed. Revista dos Tribunais, 1998.

MANDRIOLI, Crisanto. Corso di diritto processuale civile. Torino: Giappichelli, 1993. v. 1.

MARCACINI, Augusto Tavares Rosa. Estudo sobre a efetividade do processo civil. 1999. Tese (Doutorado) - Faculdade de Direito, Universidade de São Paulo, São Paulo, 1999.

MARCATO, Antonio Carlos. Procedimentos especiais. 12. ed. São Paulo: Atlas, 2006.

MARINONI, Luiz Guilherme. Ações repetitivas e julgamento liminar. Site pessoal Prof. Luiz Guilherme Marinoni. Disponível em: <http://www.professormarinoni.com.br/admin/users/35.pdf>. Acesso em: 07 maio 2007. . Novas linhas do processo civil. 4. ed. São Paulo: Malheiros Ed., 2000.

Sobre a chamada relativização da coisa julgada material. Site pessoal Prof. Luiz Guilherme Marinoni. Disponível em: <http://www.professormarinoni.com.br/artigos.php>. Acesso em 08 jan. 2007.

Técnica processual e tutela dos direitos. São Paulo: Ed. Revista dos Tribunais, 2004. 
MARINONI, Luiz Guilherme. Tutela antecipatória, julgamento antecipado e execução imediata da sentença. 4. ed. São Paulo: Ed. Revista dos Tribunais, 2000.

MARINS, Victor A. A. Bomfim. Tutela cautelar: teoria geral e poder geral de cautela, Curitiba: Juruá, 1996.

MARKS, K. H. The interventionist Court and procedure. Monash University Law Review, Melbourne-Austrália, n. 18, p. 1-15, 1992.

MARQUES, José Frederico. Ensaio sobre a jurisdição voluntária. Campinas: Millenium, 2000. Instituições de direito processual civil. Campinas: Millenium, 2000. v. 1.

MARTIN DE LA LEONA ESPINOSA, José Maria. La nulidad de actuaciones en proceso civil: análisis constitucional de la nulidad en la Ley orgánica del poder judicial. 2. ed. Madrid: Colex, 1996.

MARTINS, Ives Gandra da Silva; BASTOS, Celso Ribeiro. Comentários à Constituição do Brasil. São Paulo: Saraiva, 1993. v. 3, t. 3.

MATOS, Cecília. O ônus da prova no Código de Defesa do Consumidor. Revista de Direito do Consumidor, São Paulo, v. 11, p. 161-169, jul./set. 1994.

MAZZILI, Hugo Nigro. A defesa dos interesses difusos em juízo. 11. ed. São Paulo: Saraiva, 1999.

MCKENA, Judith A.; HOOPER, Laural L.; CLARK, Mary. Case management procedures in the Federal Courts of Appeals. Washington: FJC, 2000. Federal Judicial Center. Disponível em: $<$ http://www.fjc.gov/public/pdf.nsf/lookup/caseman1.pdf/\$file/caseman1.pdf>. Acesso em: 23 jan. 2007.

MEDINA, José Miguel Garcia. Execução civil. 2. ed. São Paulo: Ed. Revista dos Tribunais, 2004.

Juízo de admissibilidade e juízo de mérito dos recursos na nova sistemática recursal e sua compreensão jurisprudencial de acordo com as leis n. 9.756/98 e 9.800/99. In: ALVIM, Eduardo Pellegrini de Arruda; NERY JÚNIOR, Nelson; WAMBIER, Teresa de Arruda Alvim (Coords.). Aspectos polêmicos e atuais dos recursos. São Paulo: Ed. Revista dos Tribunais, 2000. p. 341-374. 
MEDINA, José Miguel Garcia; WAMBIER, Luis Rodrigues; WAMBIER, Teresa Arruda Alvim. Breves comentários à nova sistemática processual civil 2. São Paulo: Ed. Revista dos Tribunais, 2006.

; WAMBIER, Teresa Arruda Alvim. O dogma da coisa julgada: hipóteses de relativização. São Paulo: Ed. Revista dos Tribunais, 2003.

MELLO, José Luiz de Anhaia. O Estado federal e suas novas perspectivas. São Paulo: Max Limonad, 1960.

MICHELI, Gian Antonio. L'onere della prova. 2. ed. Padova: Cedam, 1966.

MILLER, Arthur C.; KANE, Marty Kay; FRIEDENTHAL, Jack H. Civil procedure. 3. ed. St. Paul: West Group, 1999.

MINISTÉRIO DA JUSTIÇA. Reforma do Judiciário. Disponível em: $<w w w . m j . g o v . b r /$ reforma $>$.

MIRANDA, Francisco Cavalcanti Pontes de. Comentários ao Código de Processo Civil (1939). 2. ed. Rio de Janeiro: Revista Forense, 1958. t. 1.

Comentários ao Código de Processo Civil. Rio de Janeiro: Forense, 1977. v. 13.

. Comentários ao Código de Processo Civil. 2. ed. Rio de Janeiro: Forense, 1979. t. 3.

Comentários à Constituição de 1967 (com a emenda n. 1 de 1969). 2. ed. São Paulo: Ed. Revista dos Tribunais, 1970. v. 1.

Tratado das ações. São Paulo: Ed. Revista dos Tribunais, 1970. t. 1.

MONTESQUIEU. O espírito das leis. São Paulo: Abril Cultural, 1973.

MORAES, Alexandre de. Direito constitucional. 15. ed. São Paulo: Atlas, 2004.

MORBIDELLI, Janice Helena Ferreri. A federação. In: BASTOS, Celso Ribeiro. Por uma nova federação. São Paulo: Ed. Revista dos Tribunais, 1995.

Um novo pacto federativo para o Brasil. São Paulo: Celso Bastos, 1999. 
MOREIRA, José Carlos Barbosa. Algumas inovações da Lei n. 9.756 em matéria de recursos cíveis. In: Temas de direito processual: $7^{\mathrm{a}}$ série. São Paulo: Saraiva, 2001. p. 71-83.

Breve notícia sobre a reforma do processo civil alemão. In: Temas de direito processual: $8^{a}$ série. São Paulo: Saraiva, 2004. p. 119-210.

Convenção das partes sobre matéria processual. In: Temas de direito processual: $3^{\text {a }}$ série. São Paulo: Saraiva, 1984.

Duelo e processo. In: Temas de direito processual: $8^{\mathrm{a}}$ série. São Paulo: Saraiva, 2004. p. 211-221.

Efetividade do processo e técnica processual. In: Temas de direito processual: $6^{\text {a }}$ série. São Paulo: Saraiva, 1997. p. 17-29.

O futuro da justiça: alguns mitos. In: Temas de direito processual: $8^{\mathrm{a}}$ série. São Paulo: Saraiva, 2004. p. 1-13.

A importação de modelos jurídicos. In: Temas de direito processual civil: $8^{\text {a }}$ série. São Paulo: Saraiva, 2004. p. 255-266.

Julgamento e ônus da prova. In: . Temas de direito processual: $2^{\mathrm{a}}$ série. São Paulo: Saraiva, 1980. p. 73-82.

. Lei n. 9.756: uma inconstitucionalidade flagrante e uma decisão infeliz. In: . Temas de direito processual: $7^{\mathrm{a}}$ série. São Paulo: Saraiva, 2001. p. 83-86.

Notas sobre alguns aspectos do processo (civil e penal) nos países anglosaxônicos. In: . Temas de direito processual: $7^{\mathrm{a}}$ série. São Paulo: Saraiva, 2001. p. 145-178.

O processo cautelar. In: Estudos sobre o novo Código de Processo Civil. Rio de Janeiro: Líber Júris, 1974.

O processo civil brasileiro entre dois mundos. In: : Temas de direito processual: $8^{a}$ série. São Paulo: Saraiva, 2004. p. 41-52.

Uma novidade: o Código de Processo Civil inglês. Revista Gênesis de Direito Processual Civil, São Paulo, ano 4, n. 13, p. 551-559, jul./set. 1999. 
NALINI, José Renato. Processo e procedimento - distinção e a celeridade da prestação jurisdicional. Revista dos Tribunais, São Paulo, ano 85, v. 730, p. 673-688, ago. 1996.

NERY JÚNIOR, Nelson. Audiência preliminar e saneamento do processo. In: TEIXEIRA, Sálvio de Figueiredo (Org.). Reforma do Código de Processo Civil. São Paulo: Saraiva, 1996. p. 335-346.

Princípios fundamentais - teoria geral dos recursos. 5. ed. São Paulo: Ed. Revista dos Tribunais, 2000.

. Princípios do processo civil na Constituição Federal. 2. ed. São Paulo: Ed. Revista dos Tribunais, 1995.

; NERY, Rosa Maria de Andrade. Código de processo civil comentado e legislação extravagante. 1. ed. São Paulo: Ed. Revista dos Tribunais, 1994.

; __ Código de processo civil comentado e legislação extravagante. 7. ed. São Paulo: Ed. Revista dos Tribunais, 2003.

NETO, Abílio. Código de processo civil anotado. 18. ed. Lisboa: Ediforum, 2004.

NIEMIC, Robert J. et al. Guide to judicial management of cases in ADR. Washington: FJC, 2001. Federal Judicial Center. Disponível em: <http://www.fjc.gov/library/fjc_catalog.nsf>. Acesso em: 23 jan. 2007.

OLIVEIRA, Carlos Alberto Alvaro de. Do formalismo no processo civil. São Paulo: Saraiva, 1997.

Efetividade do processo de conhecimento. Revista de Processo, São Paulo, n. 96, p. 59-69, out./dez. 1999.

A garantia do contraditório. Revista Forense, Rio de Janeiro, ano 95, v. 346, p. 919, abr./jun. 1999.

. Poderes do juiz e visão cooperativa do processo. Revista da Ajuris, Porto Alegre, ano 30, n. 90, p. 55-84, jun. 2003.

. Por um novo paradigma processual. Revista Forense, Rio de Janeiro, ano 96, v. 350, p. 399-404, abr./jun. 2000. 
OLIVEIRA, James Eduardo. Código de Defesa do Consumidor: anotado e comentado. São Paulo: Atlas, 2004.

OLIVEIRA JÚNIOR, Waldemar Mariz. A Constituição da República e os procedimentos alternativos. Revista da Escola Paulista da Magistratura, São Paulo, v. 1, p. 67-81, 1993.

OVALLE FAVELA, José. Teoria general del proceso. México: Harla, 1991.

PACÍFICO, Luiz Eduardo Boaventura. O ônus da prova no direito processual civil brasileiro. São Paulo: Ed. Revista dos Tribunais, 2001.

PALERMO, Hertha Helena Rollemberg Padilha. Decisão por eqüidade nos Juizados Especiais Cíveis. 1998. Dissertação (Mestrado) - Faculdade de Direito, Universidade de São Paulo, São Paulo, 1998.

PALLARES, Eduardo. Diccionário de derecho procesal civil. 11. ed. México: Porrua, 1978.

PASSOS, J.J. Calmon de. Comentários ao Código de Processo Civil. 4. ed. Rio de Janeiro: Forense, 1983. v. 3.

PAULA, Jônatas Luiz Moreira de. Comentários ao Código de Processo Civil. Barueri: Manole, 2003. v. 2.

PEREZ RAGONE, Álvaro J. Actividad probatória transfronteriza dentro da la Unión Europea: perspectivas en la cooperación judicial comunitária. Revista de Processo, São Paulo, ano 31, n. 139, p. 105-101, set. 2006.

PEYSNER, John; SENEVIRATNE, Mary. The management of civil cases: the courts and the post Woolf landscape. Londres: DCA, 2005. (Research Series n. 9). DCA: Department for Constitutional Affairs: Justice, rights and democracy. Disponível em: <http://www.dca.gov.uk/research/2005/9_2005_full.pdf>. Acesso em: 23 jan. 2007.

PICARDI, Nicola. La sucessione processuale. Milano: Giufré, 1964.

PINTO, Ronaldo Batista; CUNHA, Rogério Sanches. Violência doméstica. São Paulo: Ed. Revista dos Tribunais, 2007. 
POLI, Roberto. Sulla sanabilitá della inosservanza di forme prescrite a pena de preclusione e decadenza. Rivista de diritto processuale, Padova, Cedam, n. 2, p. 447-470, abr.jun. 1996.

POLLOCK, Frederick. The genius of the common law. New York: Columbia University Press, 1912.

PORTANOVA, Rui. Princípios do processo civil. Porto Alegre: Livr. do Advogado, 1995.

PUOLI, José Carlos Baptista. Os poderes do juiz e as reformas do processo civil. São Paulo: Juarez de Oliveira, 2002.

RAMOS, Dirceo Torrecillas. O federalismo assimétrico. 2. ed. Rio de Janeiro: Forense, 2000.

RAMOZ MENDES, Francisco. Derecho procesal civil. 3. ed. Barcelona: Bosch, 1986.

REAGAN, Robert Tiothy; CLARKE, Bruce M. Redistricting litigation: an overview of legal, statistical and case management issues. Washington: FJC, 2002. Federal Judicial Center. Disponível em: <http://www.fjc.gov/library/fjc_catalog.nsf>. Acesso em: 23 jan. 2007.

REGO, Carlos Francisco de Oliveira Lopes do. Comentários ao Código de Processo Civil. 2. ed. Coimbra: Almedina, 2004. v. 1.

REIS, Élcio Fonseca. Competência concorrente e normas gerais de direito tributário. Belo Horizonte: Mandamentos, 2000.

REIS, José Alberto dos. Processos Especiais. Coimbra: Coimbra Ed., 1982. v. 1.

RIBAS, Antonio Joaquim. Consolidação das leis do processo civil. 3. ed. Rio de Janeiro: Jacintho Ribeiro dos Santos, 1915.

RIBEIRO, Antonio da Costa Neves. Processo civil da União Européia 1. Coimbra: Coimbra Ed., 2002.

RIVAS, Adolfo. El arbitraje según el derecho argentino. Revista de Processo, São Paulo, v. 12 , n. 45 , p. 70-93, jan./mar. 1987. 
ROCHA, Carmem Lúcia Antunes. República e federação no Brasil: traços constitucionais da organização política brasileira. Belo Horizonte: Del Rey, 1997.

ROCHA, José Albuquerque. Teoria geral do processo. 3. ed. São Paulo: Malheiros Ed., 1996.

ROCHA, José Moura. Sobre os procedimentos especiais. Revista de Processo, São Paulo, ano 14, n. 53, p. 23-30, jan./mar. 1989.

ROCHA, Silvio Luis Ferreira da. Responsabilidade civil do fornecedor pelo fato do produto no direito brasileiro. 2. ed. São Paulo: Ed. Revista dos Tribunais, 2000.

ROGERS, Andrew. The managerial or interventionist judge. Journal of Judicial Administration, Austrália, n. 3, p. 96-110, 1993.

ROSA, Márcio F. Elias; SANTOS, Marisa F.; CHIMENTI, Ricardo da Cunha; CAPEZ, Fernando. Curso de direito constitucional. 3. ed. São Paulo: Saraiva, 2006.

SADEK, Maria Teresa. Poder Judiciário: perspectivas de reforma. Opinião Pública, São Paulo, v. 10, n. 1, p. 1-62, maio 2004.

; ARANTES, Rogério Bastos. A crise do Judiciário e a visão dos juízes. Revista da USP, São Paulo, n. 21, p. 34-45, mar./maio 1994.

SANTOS, Altamiro J. Processo e procedimento à luz das Constituições Federais de 1967 e 1988 - competência para legislar. Revista de Processo, São Paulo, ano 16, n. 64, p. 217 246, out./dez. 1991.

SANTOS, Ernane Fidélis dos. Manual de direito processual civil. 10. ed. São Paulo: Saraiva, 2006. v. 3.

. Manual de direito processual civil. 11. ed. São Paulo: Saraiva, 2006. v. 1.

SANTOS, Francisco Cláudio Almeida. As provas no procedimento arbitral. Revista de Processo, São Paulo, ano 22, n. 88, p. 83-90, out./dez. 1997.

SANTOS, Marisa Ferreira; CHIMENTI, Ricardo da Cunha. Juizados especiais cíveis e criminais -federais e estaduais. 2. ed. São Paulo: Saraiva, 2004. 
SANTOS, Marisa Ferreira; CHIMENTI, Ricardo da Cunha; CAPEZ, Fernando; ROSA, Márcio F. Elias. Curso de direito constitucional. 3. ed. São Paulo: Saraiva, 2006.

SANTOS, Moacyr Amaral dos. Ações cominatórias no direito brasileiro. São Paulo: Max Limonad, 1969. v. 1.

Primeiras linhas do direito processual civil. Atualizada por Aricê Moacyr Amaral dos Santos. 23. ed. São Paulo: Saraiva, 2004. v. 1.

SARMENTO, Daniel. A vinculação dos particulares aos direitos fundamentais no direito comparado e no Brasil. In: BARROSO, Luis Roberto (Orgs.). A nova interpretação constitucional: ponderação, direitos fundamentais e relações privadas. 2 ed. Rio de Janeiro: Renovar, 2006. p. 193-284.

SATTA, Salvatore. Dalla procedura al diritto processuale civile. Rivista Trimestrale di Diritto e Procedura Civile, Milano, ano 18, p. 28-43, mar. 1964.

SCHWARZER, Willian W.; HIRSCH, Allan. The elements of case management: a pocket guide for judges. 2. ed. Washington: FJC, 2006. Federal Judicial Center. Disponível em: <http://www.fjc.gov/library/fjc_catalog.nsf>. Acesso em: 23 jan. 2007.

SENEVIRATNE, Mary; PEYSNER, John. The management of civil cases: the courts and the post Woolf landscape. Londres: DCA, 2005. (Research Series n. 9). DCA: Department for Constitutional Affairs: Justice, rights and democracy. Disponível em: <http://www.dca.gov.uk/research/2005/9_2005_full.pdf>. Acesso em: 23 jan. 2007.

SHIMURA, Sérgio Seiji. Arresto cautelar. São Paulo: Ed. Revista dos Tribunais, 1993.

. Execução provisória. In: et al. Nova reforma processual civil comentada.

São Paulo: Método, 2002.

. Título executivo. São Paulo: Saraiva, 1997.

SICA, Heitor Vitor Mendonça. Questões velhas e novas sobre inversão do ônus da prova. Revista de Processo, São Paulo, ano 32, n. 146, p. 49-68, abr. 2007.

SIDOU, J.M. Othon. A arbitragem no direito comparado e a lei n. 9.307/96. Revista da Academia Brasileira de Letras Jurídicas, Rio de Janeiro, ano 10, n. 10, p. 99-122, 2. sem. 1996. 
SILVA, Bruno Freire e. A inversão judicial do ônus da prova. Revista de Processo, São Paulo, ano 32, n. 146, p. 332-343, abr. 2007.

SILVA, De Plácido e. Vocabulário jurídico. 9. ed. Rio de Janeiro: Forense, 1986. v. 4.

SILVA, Jorge Alberto Quadros de Carvalho. Lei dos juizados especiais cíveis anotada. 2. ed. São Paulo: Saraiva, 2001.

SILVA, Ovídio A. Baptista. Antecipação de tutela - duas perspectivas de análise. Revista da Ajuris, Porto Alegre, n. 70, p. 84-94, jul. 1997.

. Comentários ao Código de Processo Civil. Porto Alegre: Lejur, 1985.

Curso de processo civil. 5. ed. São Paulo: Ed. Revista dos Tribunais, 2000. v. 1.

Do processo cautelar. Rio de Janeiro: Forense, 1996.

Processo e ideologia: o paradigma racionalista. Rio de Janeiro: Forense, 2004.

SILVA, Paulo Eduardo Alves. Condução planejada dos processos judiciais: a racionalidade do exercício jurisdicional entre o tempo e a forma do processo. 2006. Tese (Doutorado) - Faculdade de Direito, Universidade de São Paulo, São Paulo, 2006.

SILVA NETO, Orlando Celso. Princípios do processo e arbitragem. In: CASELLA, Paulo Borba (Coord.). Arbitragem: lei brasileira e praxe internacional. 2. ed. São Paulo: LTr, 1999. p. 335-370.

SIPES, Larry L. Reducing delay in State Courts - a march against folly. Rutgers Law Review, New York, n. 37, p. 299-317, 1985.

SOUZA, Miguel Teixeira de. Estudos sobre o novo processo civil. 2. ed. Lisboa: Lex, 1997.

SOUZA, Wilson Alves de. Princípios do direito processual do trabalho: o princípio da adequação e suas variantes. $L T r$ : revista legislação do trabalho, São Paulo, v. 50, n. 2, p. 166-179, fev. 1986. 
STAMFORDS, Artur. As audiências judiciais como processo de legitimação e justiça social: à luz da teoria da justiça de Rawls e da legitimação pelo procedimento de Luhman. Revista da Escola Superior da Magistratura do Estado de Pernambuco, Olinda, v. 3, n. 7, p. 43-65, jan./jun. 1998.

SUPERVISOR'S Roles in Case Management (Available from the Education Division). Federal Judicial Center. Disponível em: <http://www.fjc.gov/library/fjc_catalog.nsf>. Acesso em: 23 jan. 2007.

SZTAJN, Rachel; GORGA, Érica. Tradições do direito. In: ZYLBERSZTAJN, Décio; SZTAJN, Rachel (Coords.). Direito e economia: análise econômica do direito e das organizações. Rio de Janeiro: Elsevier, 2005. p. 137-196.

TALAMINI, Eduardo. Tutela monitória. 2. ed. São Paulo: Ed. Revista dos Tribunais, 1998.

TANIGUCHI, Yasuhei. O código de processo civil japonês de 1996: um processo para o próximo século? Revista de Processo, São Paulo, v. 25, n. 99, p. 50-73, jul./set. 2000.

TARUFFO, Michele. La giustizia civile in Itália dal'700 a oggi. Bologna: Il Mulino, 1980.

. Modelli di prova e di procedimento probatório. Rivista di Diritto Processuale, Padova, ano 45, n. 2, apr./giug. 1990.

La ricerca della veritá nel adversary system anglo-americano. Rivista di Diritto Processuale, Padova, ano 32, n. 4, p. 596-634, out./dez. 1977.

TARZIA, Giuseppe. L'ordine europeo del processo civile. Rivista di Diritto Processuale, Padova, ano 56, n. 4, p. 902-937, ott./dic. 2001.

La paritá delle armi tra le ter parti e poteri del giudice nel processo civile. Studi Parmensi, v. 18, p. 357-359, 1977.

TAVARES, André Ramos. Nova lei de súmula vinculante. São Paulo: Método, 2007.

TAYLOR, Stephen E. Case management: a fundamental concept for the 90's and beyond. Federal Washington, Litigation Guide, 1993. 
TEIXEIRA, Guilherme de Freira Barros. O princípio da fungibilidade no processo civil. 2005. Tese (Doutorado) - Faculdade de Direito, Universidade de São Paulo, São Paulo, 2005.

TEIXEIRA, Sálvio de Figueiredo. Revista de Crítica Universitária, São Paulo, v. 4, 1987.

Procedimento sumaríssimo: necessidade de sua reformulação. Revista da Faculdade de Direito, Curitiba, n. 21, ano 21, p. 91-99, 1983-1984.

TELLES, Gil Trotta. Propositura de ação declaratória negativa depois de ajuizada execução de título extrajudicial. Revista dos Tribunais, São Paulo, ano 81, n. 677, p. 28-33, mar. 1992.

THEODORO JÚNIOR, Humberto. Curso de direito processual civil. 44. ed. Rio de Janeiro: Forense, 2006. v. 1.

. Curso de direito processual civil. 36. ed. Rio de Janeiro: Forense, 2006. v. 2.

Curso de direito processual civil. .39. ed. Rio de Janeiro: Forense, 2006. v. 3.

Direitos do consumidor. Rio de Janeiro: Forense, 2001.

Opção do credor entre a ação executiva e a ação ordinária de cobrança. Revista Dialética de Direito Processual, São Paulo, n. 4, p. 80-92, jul. 2003.

. Processo cautelar. 19. ed. São Paulo: Leud, 2000.

TORNAGHI, Hélio. Comentários ao Código de Processo Civil. 2. ed. São Paulo: Ed. Revista dos Tribunais, 1974. v. 1.

Comentários ao Código de Processo Civil. 2. ed. São Paulo: Ed. Revista dos Tribunais, 1978. v. 2.

TROCKER, Nicolò. Il nuovo art. 111 della Constituzione e il giusto processo in matéria civile: profili generali. Rivista Trimestrale di Diritto e Procedura Civile, Milano, n. 2, giug. 2001.

. Processo civile e Constituzione. Milano: Giuffrè, 1974. 
TUCCI, Rogério Lauria. Direitos e garantias individuais no processo penal brasileiro. 1993. Tese (Titular de direito processual penal) - Faculdade de Direito da Universidade, São Paulo, São Paulo, 1993.

A nova fase saneadora do processo civil brasileiro. In: TEIXEIRA, Sálvio de Figueiredo (Org.). Reforma do Código de Processo Civil. São Paulo: Saraiva, 1996. p. 347-369.

. Processo e procedimentos penais. Revista dos Tribunais, São Paulo, ano 87, n. 749, p. 485-501, mar. 1998.

; CRUZ E TUCCI, José Rogério e. Constituição de 1988 e processo: regramentos e garantias constitucionais do processo. São Paulo: Saraiva, 1989.

; __ Devido processo legal e tutela jurisdicional. São Paulo: Ed. Revista dos Tribunais, 1993.

VALLADÃO, Haroldo. História do direito especialmente do direito brasileiro. Rio de Janeiro: Freitas de Bastos, 1973.

VASCONCELOS, Rita de Cássia Correia. Princípio da fungibilidade: hipóteses de incidência no processo civil contemporâneo. São Paulo: Ed. Revista dos Tribunais, 2007.

VELloso, Carlos Mario da Silva. Lei Complementar Tributária. Revista de Direito Administrativo, São Paulo, n. 235, p. 117-138, jan./mar. 2004.

. Temas de direito público. Belo Horizonte: Del Rey, 1994.

WAMBIER, Luiz Rodrigues. Apontamentos sobre os Juizados Especiais Cíveis. Juizados Especiais Cíveis e Criminais. Caxias do Sul: Ed. Plenum, v. 1, [s.n.]. CDROM.

. A reforma daqui por diante (artigo não publicado).

Sentença civil: liquidação e cumprimento. 3. ed. São Paulo: Ed. Revista dos Tribunais, 2006.

; WAMBIER, Teresa Arruda Alvim. Breves comentários à $2^{a}$ fase da reforma do

Código de Processo Civil. 2. ed. São Paulo: Ed. Revista dos Tribunais, 2002. 
WAMBIER, Luiz Rodrigues; WAMBIER, Teresa Arruda Alvim; MEDINA, José Miguel Garcia. Breves comentários à nova sistemática processual civil 2. São Paulo: Ed. Revista dos Tribunais, 2006.

WAMBIER, Teresa Arruda Alvim. Os agravos no CPC brasileiro. 4. ed. São Paulo: Ed. Revista dos Tribunais, 2005.

. Impossibilidade de decretação da pena de prisão como medida de apoio, com base no art. 461, para ensejar o cumprimento da obrigação in natura. Revista de Processo, São Paulo, n. 112, p. 196-221, out./dez. 2003.

. Nulidades do processo e da sentença. 5. ed. São Paulo: Ed. Revista dos Tribunais, 2004.

. Nulidades do processo e da sentença. 6. ed. São Paulo: Ed. Revista dos Tribunais, 2007.

O óbvio que não se vê: a nova forma do princípio da fungibilidade. Migalhas. Disponível em: <www.migalhas.com.br>. Acesso em: 22 maio 2006.

O princípio da fungibilidade sob a ótica da função instrumental do processo. Revista dos Tribunais, São Paulo, n. 821, p. 39-74, mar. 2004.

MEDINA, José Miguel Garcia. O dogma da coisa julgada: hipóteses de relativização. São Paulo: Ed. Revista dos Tribunais, 2003.

; ___ W WAMBIER, Luiz Rodrigues. Breves comentários à nova sistemática processual civil 2. São Paulo: Ed. Revista dos Tribunais, 2006.

WATANABE, Kazuo. Da cognição no processo civil. 2. ed. Campinas: Bookseller, 2000.

Tutela antecipatória e tutela específicas das obrigações de fazer e não fazer. In: TEIXEIRA, Sálvio de Figueiredo (Org.). Reforma do Código de Processo Civil. São Paulo: Saraiva, 1996. p. 18-51.

et al. Código Brasileiro de Defesa do Consumidor (comentado pelos autores do anteprojeto). 5. ed. Rio de Janeiro: Forense, 1997.

In: CURY, Munir (Coord.). Estatuto da Criança e do Adolescente comentado 6. ed. São Paulo: Malheiros Ed., 2003. 
WEBER, Max. Economia e sociedade. Brasília: Ed. da Unb, 1998.

YARSHELL, Flávio Luiz. Tutela jurisdicional. São Paulo: Atlas, 1999.

Tutela jurisdicional específica nas obrigações de declaração de vontade. São Paulo: Malheiros Ed., 1993.

ZANETI JÚNIOR, Hermes. O problema da verdade no processo civil: modelos de prova e de procedimento probatório. Revista de Processo, São Paulo, n. 116, p. 335-371, jul./ago. 2004.

; DIDIER JÚNIOR, Fredie. Curso de direito processual civil - processo coletivo. Salvador: JusPodivm, 2007. 